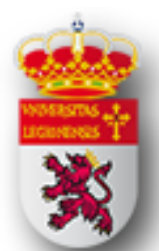

UNIVERSIDAD DE LEÓN

FACULTAD DE FILOSOFÍA Y LETRAS

DEPARTAMENTO DE FILOLOGÍA HISPÁNICA

\title{
ESTUDIO DEL LÉXICO EN LOS PROTOCOLOS NOTARIALES DEL PARTIDO JUDICIAL DE LA BAÑEZA
}

(SS. XVII-XIX) 

A mis padres que con su sacrificio y esfuerzo permitieron mi andadura por el camino de la Filología 



\section{ÍNDICE}

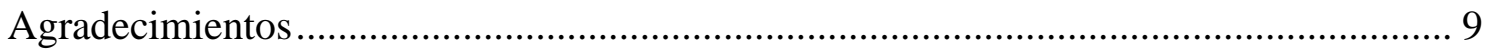

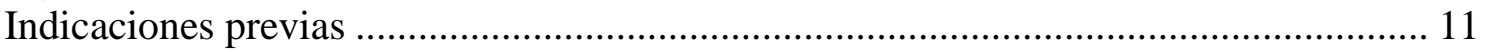

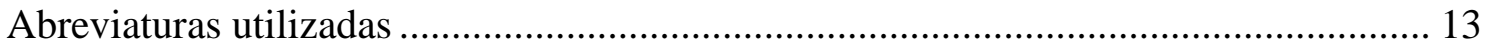

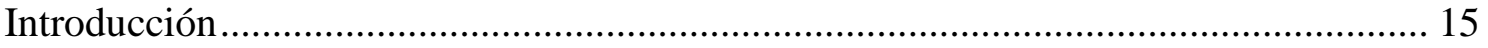

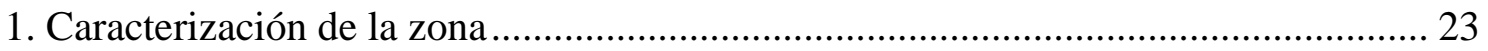

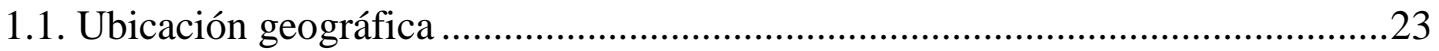

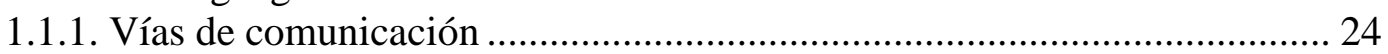

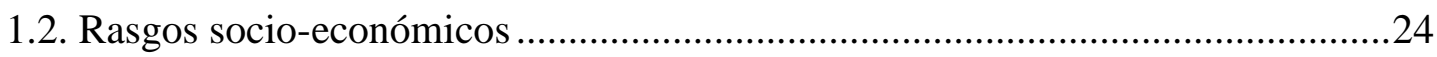

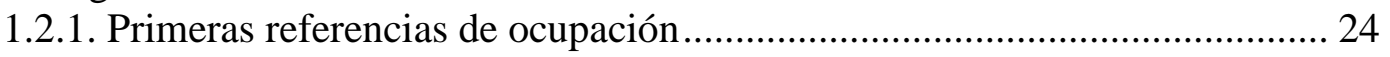

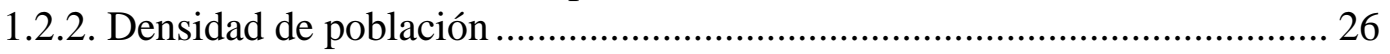

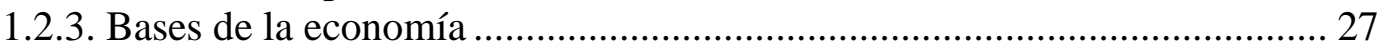

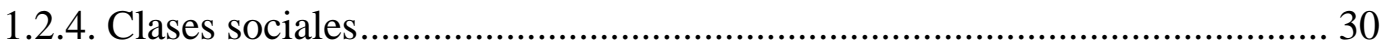

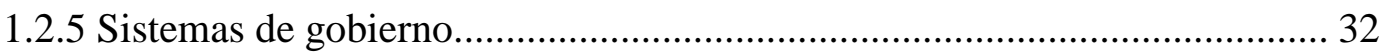

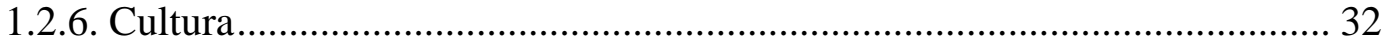

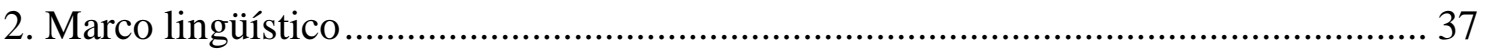

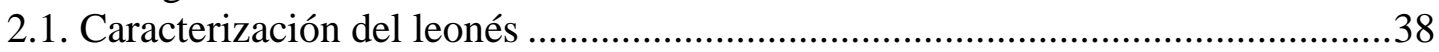

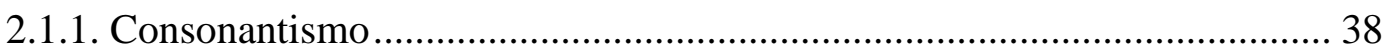

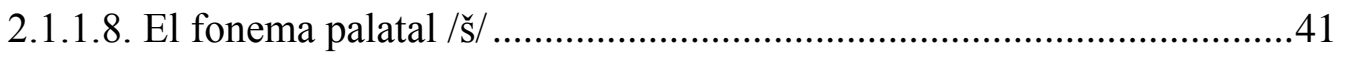

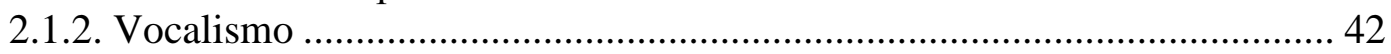

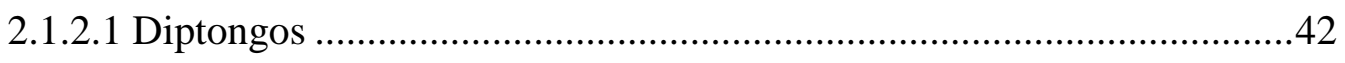

2.1.2.2. Conservación de los diptongos decrecientes ......................................42

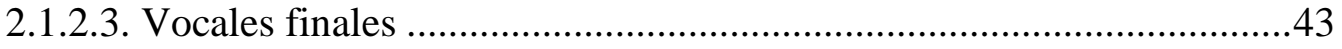

2.1.2.4. Epéntesis de yod en la terminación ....................................................44

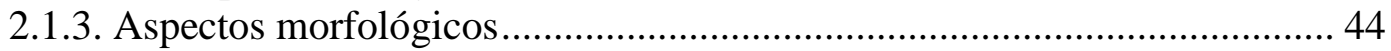

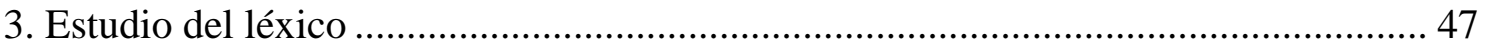

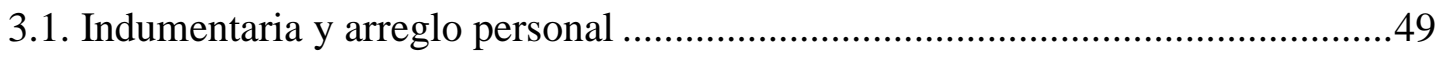

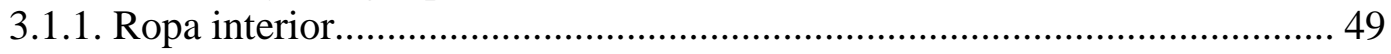

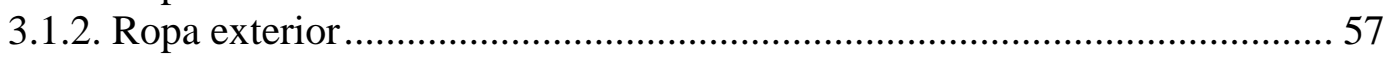

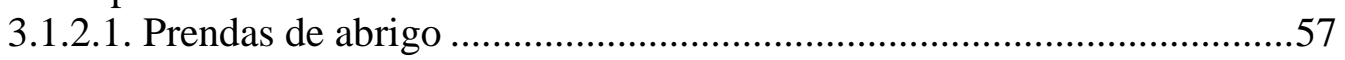

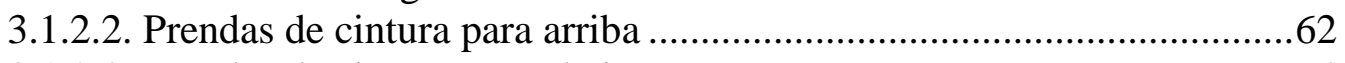

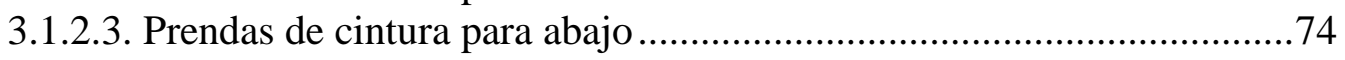

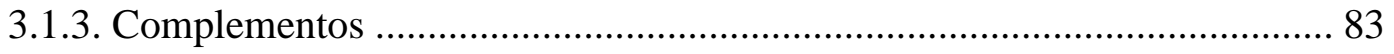

3.1.3.1. Complementos de cabeza y tocados ............................................. 83

3.1.3.2. Otros complementos .................................................................... 92

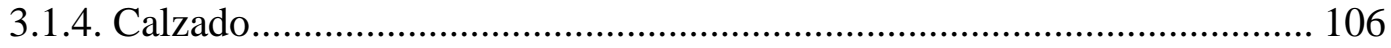

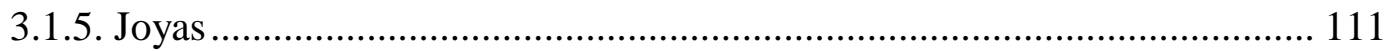

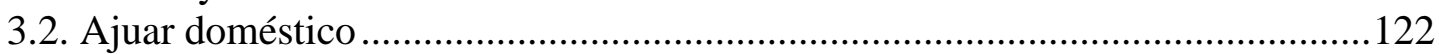

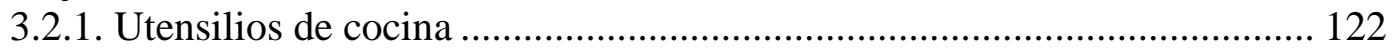

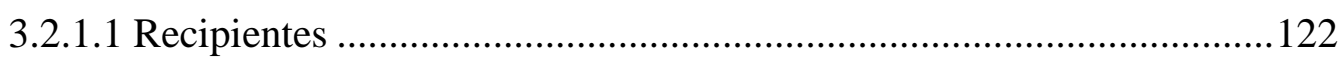

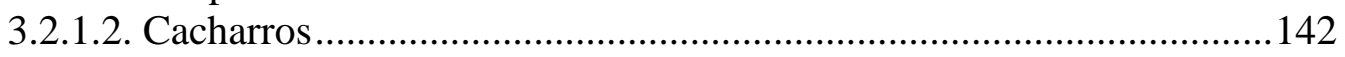

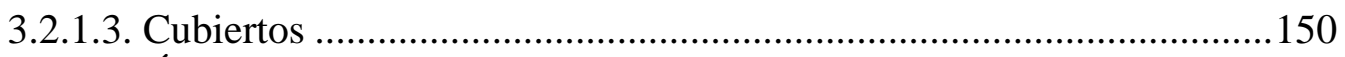

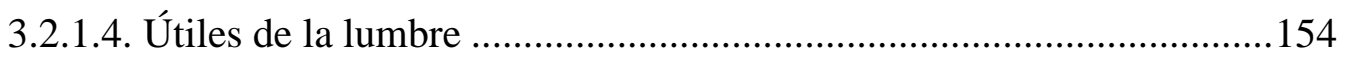

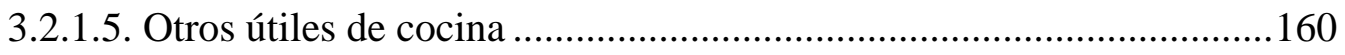

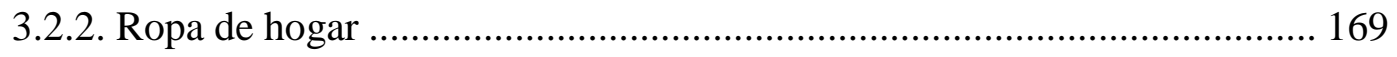

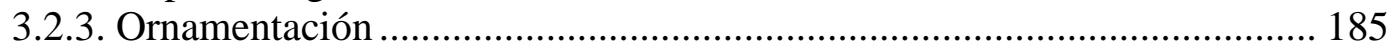

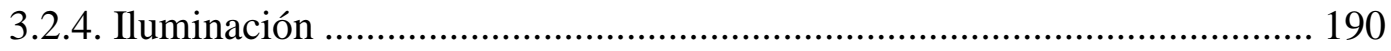

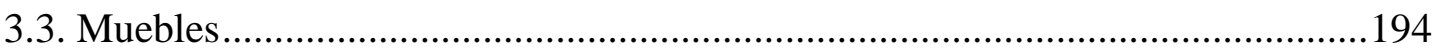




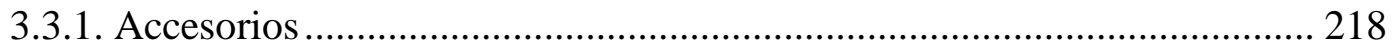

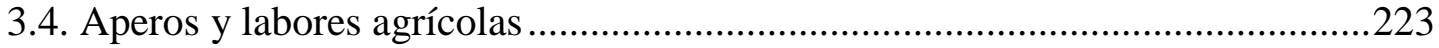

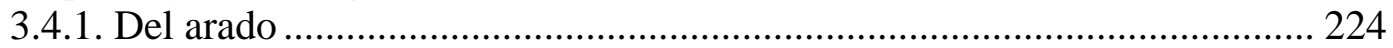

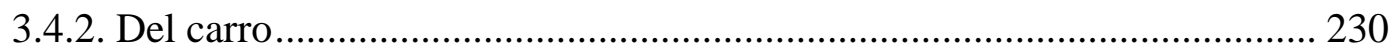

3.4.3. Del yugo y de uncir .......................................................................... 238

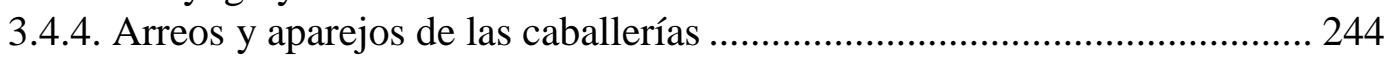

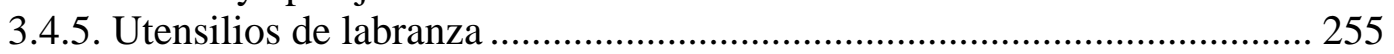

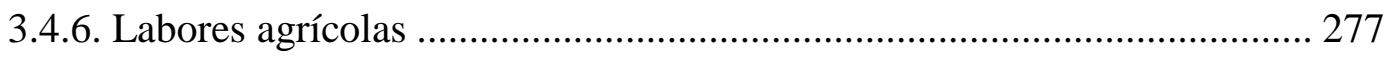

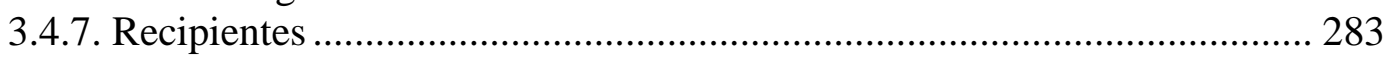

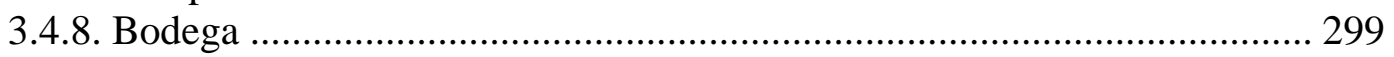

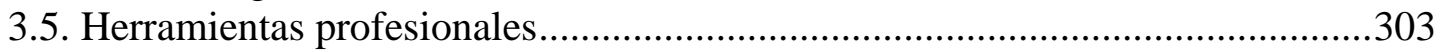

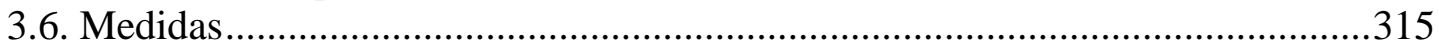

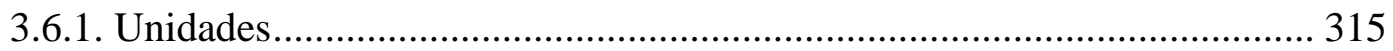

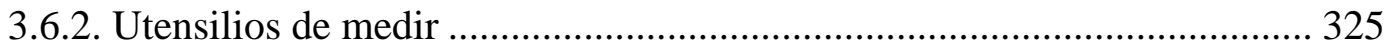

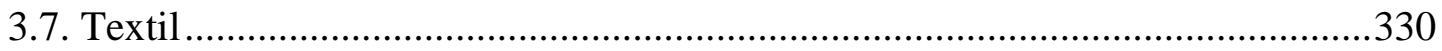

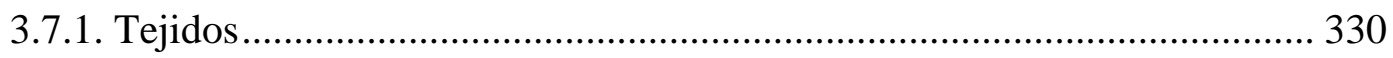

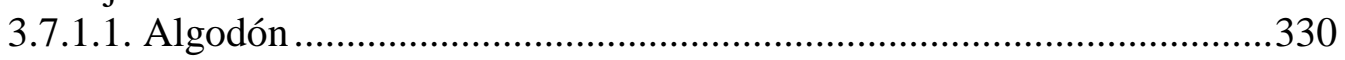

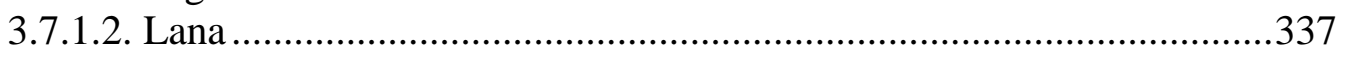

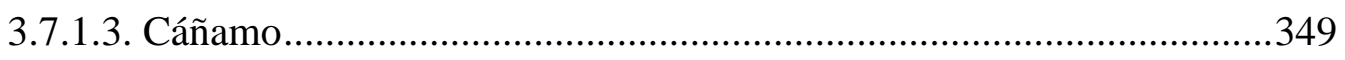

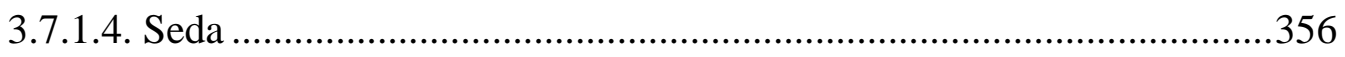

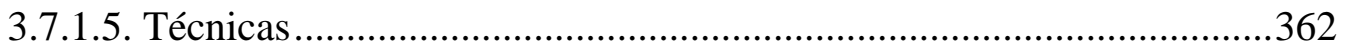

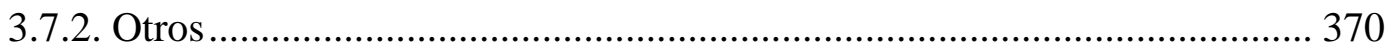

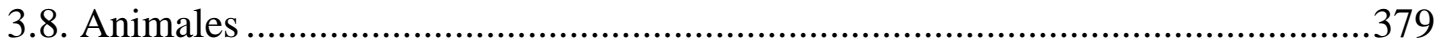

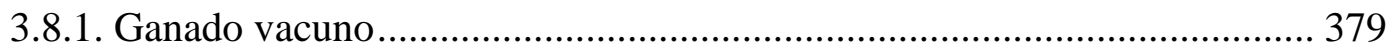

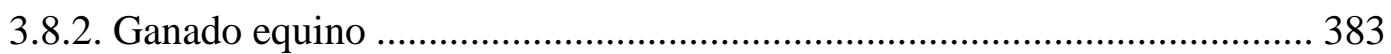

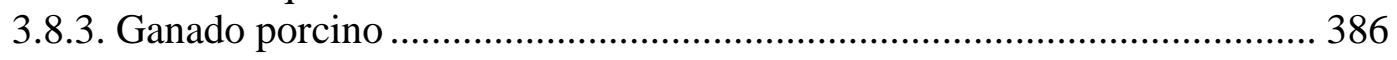

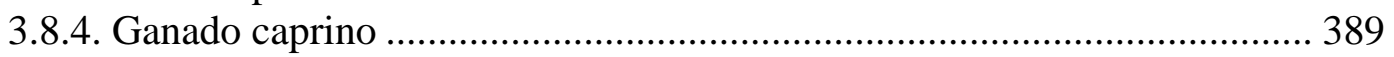

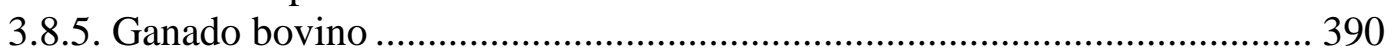

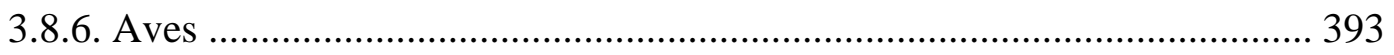

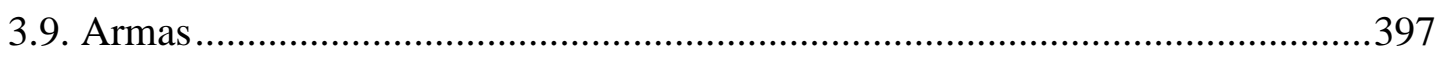

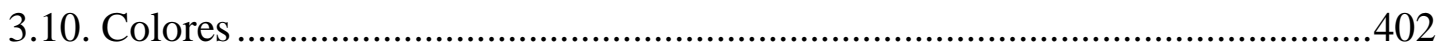

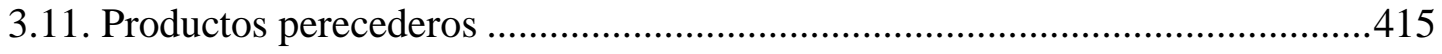

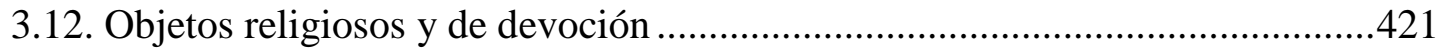

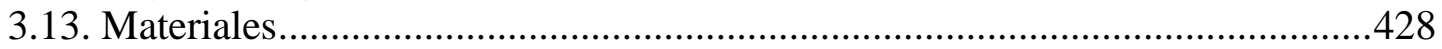

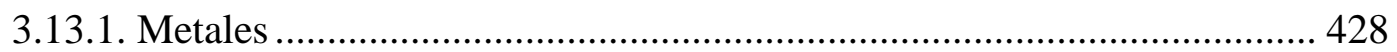

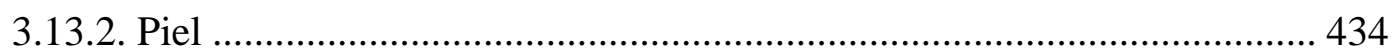

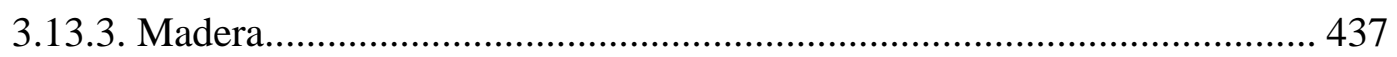

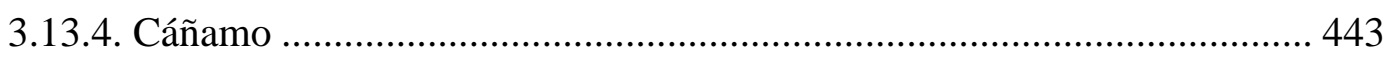

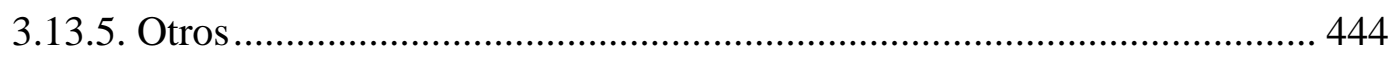

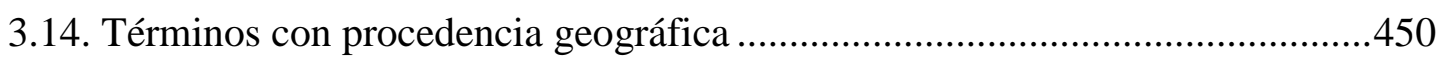

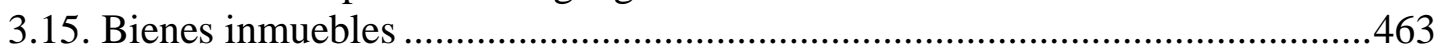

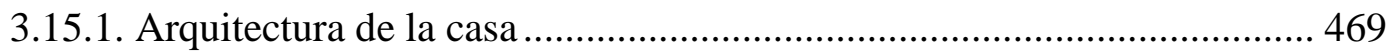

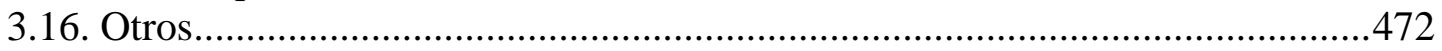

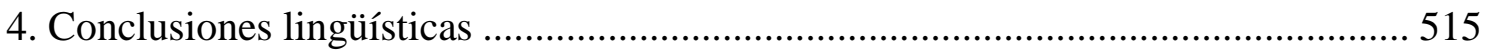

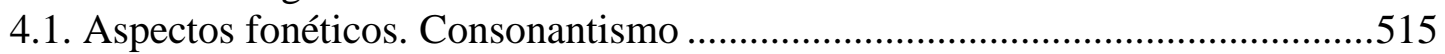

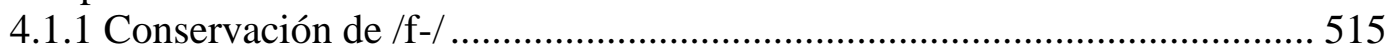

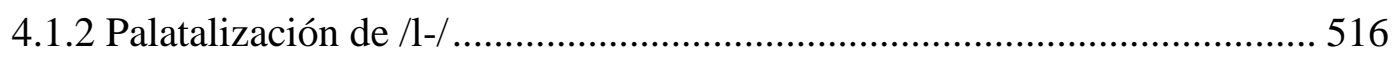

4.1.3 Mantenimiento de /-mb-/................................................................... 517

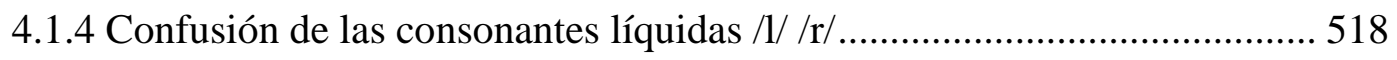

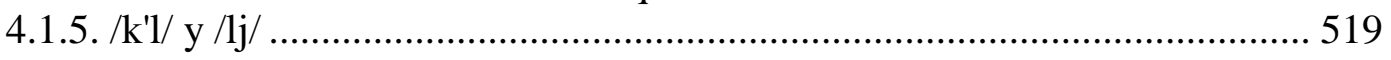




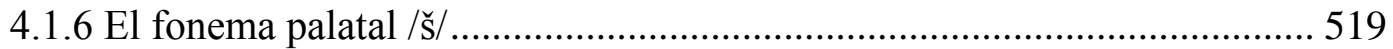

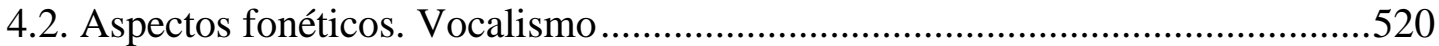

4.2.1 Vacilación en el timbre de las vocales átonas ......................................... 520

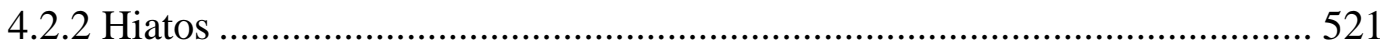

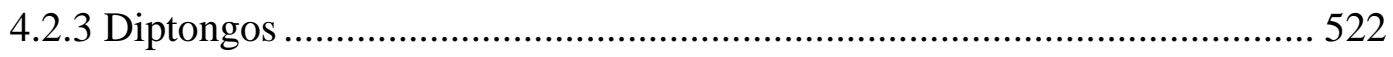

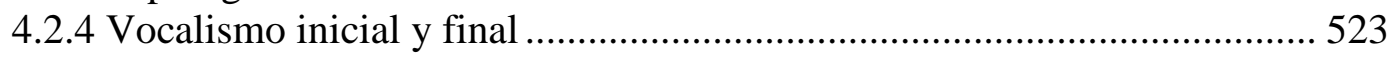

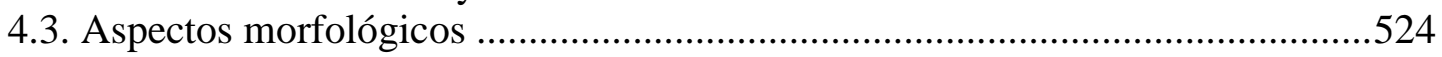

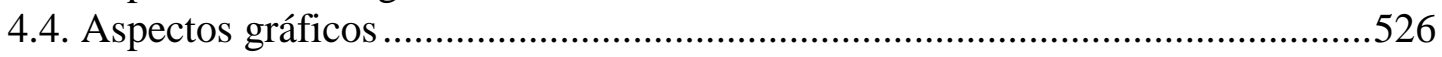

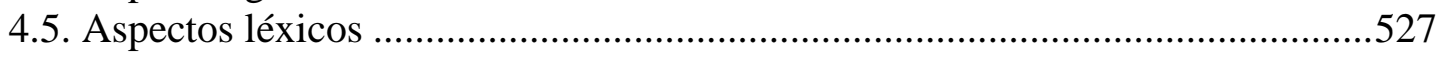

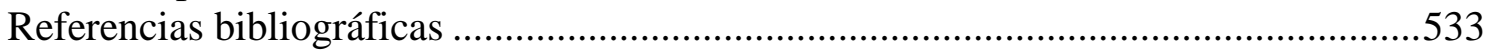

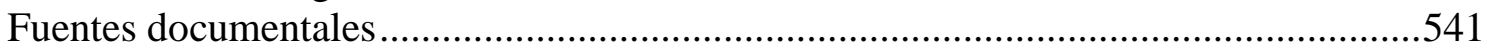

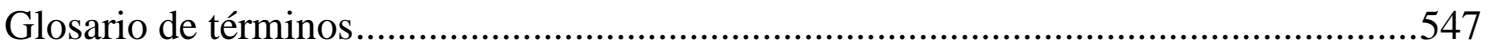

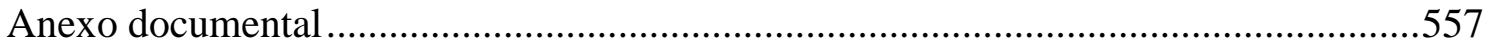




\section{AGRADECIMIENTOS}

Mi primer agradecimiento y reconocimiento ha de ser para el director de la tesis el Dr. José Ramón Morala Rodríguez, ya que fue quien me impulsó a adentrarme en el estudio del léxico cotidiano a partir del análisis de los protocolos notariales que constituyen una gran fuente en este ámbito.

Mi agradecimiento a todos los trabajadores del Archivo Histórico Provincial de León que se mostraron colaboradores en todo momento facilitándome así todo el trabajo de recopilación de fuentes.

Mi agradecimiento a la doctora profesora de esta Universidad Janick Le Men por toda su ayuda con la aportación bibliográfica.

Mi agradecimiento a los profesores del Departamento de Lengua de la Universidad de León por su colaboración en todo aquello que les solicité, así como la concesión de todas las facilidades para desarrollar mi trabajo tanto en materiales como en espacios.

Mi agradecimiento a la señora Encarna Fernández Las Cuevas y al señor Andrés Peñín Martínez, vecinos de Coomonte de la Vega que me han aportado información de campo sobre los nombres con los que se han conocido en la zona determinados objetos.

Mi agradecimiento a mi querido amigo José Luis Santos Cela por su ayuda incondicional tanto en temas relacionados con la metodología como en su apoyo y ánimo continuos compartiendo conmigo la ilusión desde el inicio de este trabajo.

Mi agradecimiento a mi estimado compañero y amigo Vicente García Pérez que ha contribuido desinteresadamente en el repertorio fotográfico.

Mi agradecimiento a María Gutiérrez Campelo, apreciada exalumna, por su ayuda en la traducción de artículos en lengua inglesa.

Mi agradecimiento a todos los compañeros que han formado parte del equipo directivo del IES Ordoño II que han facilitado que este proyecto se hiciera realidad eximiéndome de dedicación al centro en horario de tarde.

Finalmente quiero mostrar mi agradecimiento a mi familia, padres y hermano por su apoyo y comprensión en los momentos de agobio. 


\section{INDICACIONES PREVIAS}

- Las voces que encabezan los artículos aparecen en versalita y en negrita. Las variantes formales entre corchetes en minúscula y en negrita.

- Los étimos se trascriben en minúscula y en cursiva.

- Las acepciones aparecen entre comillas simples.

- Los términos aparecen dentro del cuerpo de tesis en cursiva.

- Los ejemplos aparecen en letra menor y a menor espacio, con la palabra concreta en cursiva, entre paréntesis el nombre del pueblo en el que se hizo el inventario y el año.

- Los términos que aparecen omitidos en el texto original porque se sobreentienden, se expresan en los ejemplos entre paréntesis.

- Los ejemplos extraídos del corpus que se incluyen en la microestructura aparecen entre «». Si son de otros corpus, por ejemplo el CORDE, entre comillas.

- Los fragmentos de los ejemplos, por ejemplo, pasamanos, etc. que se incluyen en la microestructura aparecen entre comillas.

- Los términos que se incluyen en la microestructura aparecen en cursiva.

- Las citas bibliográficas aparecen con el nombre del autor, la fecha y el año de publicación cuando se trata de un libro. En el caso de los diccionarios, se indica el nombre del autor, s.v. y la palabra en cuestión en cursiva.

\section{Transcripción de los anexos}

- Se mantienen los rasgos que corresponden al sistema medieval (c, ç, z, x, j, g, f, h, $\mathrm{u}, \mathrm{v}, \mathrm{b}, \mathrm{y},-\mathrm{ss}-)$.

- Las consonantes dobles se reducen (rr- al inicio, $\mathrm{tt}, \mathrm{ff}, \mathrm{ss}-$ ).

- Se regulariza la ñ.

- La acentuación se moderniza según la regla actual.

- Las mayúsculas se modernizan siguiendo la regla actual.

- La separación de palabras se moderniza según la regla actual a excepción de palabras del tipo (destos, dellos, destopa, destameña, etc.).

- Se utiliza el símbolo [...] para sustituir alguna palabra que no aparece expresada por dificultades en la lectura del original. 


\section{ABREVIATURAS UTILIZADAS}

En el documento se han utilizado muchas abreviaturas tomadas del DRAE y del DECH; aunque se ha reducido su uso con el fin de utilizar un lenguaje explícito que facilite la consulta del texto.

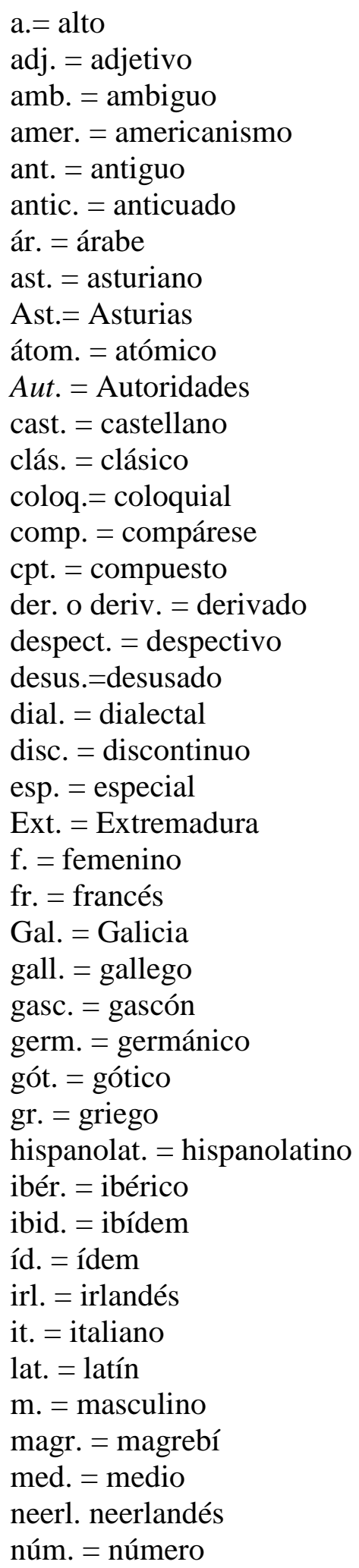


oc. u occ. $=$ occitano

occid. $=$ occidental

op. cit. $=$ obra citada

p.ej. = por ejemplo

P.J.= Partido Judicial

pl. = plural

port. $=$ portugués

port. $=$ portugués

probte. $=$ probablemente

propte. $=$ propiamente

S. = siglo

S.V.= sub voce

Sal. $=$ Salamanca

santand. $=$ santanderino

SS. $=$ siglos

sust. $=$ sustantivo

U. m. en pl. = úsase más en plural

verb. $=$ verbo

vg. o vulg. = vulgar

vid. $=$ véase

Zam. = Zamora

* = signo que precede a una forma hipotética en las etimologías

CORDE $=$ Corpus Diacrónico del Español

CORLEXIN= Corpus Léxico de Inventarios

DALLA $=$ Diccionario de la Llingua Asturiana

$\mathrm{DECH}=$ Diccionario Crítico Etimológico Castellano e Hispánico

DEEH $=$ Diccionario Etimológico Español e Histórico

DHL $=$ Diccionario Histórico de la Lengua Española

DHTT $=$ Diccionario Histórico de Telas y Tejidos

DRAE $=$ Diccionario de la Real Academia Española

NDHE $=$ Nuevo Diccionario Histórico del Español

NTLE $=$ Nuevo Tesoro Lexicográfico

NTLLE $=$ Nuevo Tesoro Lexicográfico de la Lengua Española

$\mathrm{RAH}=$ Real Academia de la Historia 


\section{INTRODUCCIÓN}

\section{Elección y justificación del tema}

El trabajo que he desarrollado es un estudio del léxico habitual de la vida cotidiana que aparece en los documentos notariales en los que se encuentran relaciones de bienes tales como inventarios, testamentos, cartas de dote, etc., pertenecientes al Partido Judicial de La Bañeza y al S. XVIII principalmente, pero también finales del S. XVII y primera mitad del S. XIX. Se trata, por tanto, de un estudio sobre el léxico cotidiano que normalmente no aparece recogido en la literatura de la época y, algunas veces, ni siquiera en los diccionarios normativos y que va a permitir hacer un estudio diatópico estableciendo relaciones con el léxico cotidiano que aparece en otros puntos geográficos. Además, puede ser una aportación al proyecto CorlexIn, corpus documental que aporta una amplia información léxica así como variada ya que incluye palabras de la época áurea procedentes de documentación notarial inédita tanto de España como de América, y cuyo grupo investigador está formado por investigadores de la Universidad de León como el Dr. D. José R. Morala, director de esta tesis y del proyecto; la Dra. María Cristina Egido y la Dra. Janick Le Men; también por investigadores de las universidades de Burgos, el Dr. D. Hermógenes Perdiguero Villarreal y de Oviedo, la Dra. Marta Pérez Toral. Los motivos de la elección de este tema se remontan al año 2007 cuando el Dr. D. José R. Morala Rodríguez me propuso estudiar el léxico que ofrecía la documentación del Archivo Provincial de León referente al S. XVIII y acotado a una zona geográfica concreta. En ese momento decidí emprender este proyecto centrándome en el Partido Judicial de La Bañeza, puesto que en el período cronológico que iba a estudiar el pueblo de Coomonte de la Vega, perteneciente a la provincia de Zamora, formaba parte de este Partido Judicial. Este hecho tuvo para mí una motivación personal ya que, por ser el lugar de origen de mi abuelo materno y lugar de mis vacaciones de la infancia y adolescencia, la lectura de los documentos ubicados allí me permitía un acercamiento a la vida de las personas del lugar a través de las relaciones de los bienes que estas poseían.

\section{El proceso de recogida de información}

La primera fase fue el proceso de recogida de información que ha sido sencillo, pero a la vez, lento. Sencillo porque todo el material de campo pertenece al Archivo Histórico Provincial de León. Inicialmente hice una selección de cajas del S. XVIII en las que legajo por legajo busqué todo tipo de documentos que contuvieran relaciones de bienes 
para poder recopilar el léxico con el que posteriormente iba a trabajar. En esa selección de cajas tuve en cuenta que pertenecieran a los distintos puntos geográficos significativos del P.J. de La Bañeza: La Bañeza, el Bajo Órbigo, La Valdería, la Valduerna o el Páramo. Después de consultar el S. XVIII, decidí ampliar el campo de estudio a la última mitad del S. XVII y primera del S. XIX para ver si existían diferencias significativas entre los siglos. Como he señalado, este trabajo fue lento ya que el horario de apertura del Archivo era incompatible con mi horario de trabajo como profesora de Educación Secundaria y solo disponía de dos tardes a la semana en horario reducido para recopilar la información. Posteriormente, organicé todo el material recopilado estableciendo listas de léxico con las referencias en cuanto a signatura, caja, documento, folios, etc. para, una vez finalizado, elaborar fichas con los distintos términos recogidos. La segunda fase consistió en el estudio de cada uno de los términos donde he tratado de establecer una relación entre el significado académico y las posibles acepciones que este término tiene en León, para determinar el significado que puede tener en el contexto en el que aparece. Para ello, he tomado como principal elemento de referencia $E l$ repertorio léxico del leonés de Janick Le Men, junto a otros repertorios léxicos leoneses, además de corpus más generales como el CorLexIn, específico de inventarios o el CORDE. Para el significado académico he tomado como referencia el DRAE y el NTLE.

\section{Exposición del cuerpo de la tesis}

El texto que forma el cuerpo de tesis se presenta a modo de diccionario. Por ello, consta de lo que Alvar Ezquerra denomina macroestructura (conjunto de las entradas) y microestructura (informaciones de cada artículo) (Alvar Ezquerra: 1983). En la macroestructura las entradas se organizan por campos semánticos. Inicialmente, pensé en organizarlas por orden alfabético, pero posteriormente consideré que era más idóneo por campos semánticos para poder así establecer relaciones entre los términos que presentan significados próximos, aunque tienen diferencias de uso o de frecuencia. Por ejemplo, aparecen las voces rojo, encarnado o colorado, que en principio son sinónimas, pero sin embargo, presentan diferencias en el contexto en el que aparece cada una de ellas. El establecimiento de los campos semánticos entrañó cierta dificultad. Para ello tomé como referencia las propuestas de clasificación de J.R. Carriazo y M. Quirós y a partir de ellas introduje modificaciones. En la mayoría de los casos he añadido subgrupos, por ejemplo en el campo de los animales he establecido divisiones entre los tipos de ganado. En algún caso he introducido un subgrupo denominado otros 
para aquellos términos que no tienen cabida en ninguno y por sí solos no constituyen un apartado diferente. Cada uno de los campos se inicia con una introducción en la que justifico el porqué lo he incluido y cuál es su desarrollo. Dentro de cada uno de los grupos las palabras se ordenan por orden alfabético. Finalmente, hay un gran apartado de otros en el que se incluyen de nuevo los términos que no tienen cabida en otros campos semánticos.

Las entradas siempre aparecen bajo la variante normativa, en el caso de que haya varias formas, por ejemplo arracada, y a continuación todas las variantes formales que aparecen en los ejemplos extraídos de la documentación, siempre teniendo en cuenta las normas seguidas en la trascripción ${ }^{1}$ que se detallan en las indicaciones previas. En el caso de los verbos, se expresa como lema el infinitivo; para el sustantivo, el singular, salvo en los casos en que el lema designa un conjunto de elementos, por ejemplo, arreos u ordenanzas o se trata de un término cuya forma siempre se expresa en plural, por ejemplo, puntas con el significado de 'adorno', abregancias o carpontes. En el caso del adjetivo, siempre se expresa el lema en masculino acompañado de la terminación en femenino. Cuando en la documentación un término tiene más de un significado y distinta categoría gramatical, aparece en cada caso con una entrada independiente, por ejemplo, la voz frutero que se usa como sustantivo y como adjetivo paño frutero. En otros casos, se especifican dentro de la microestructura las distintas acepciones pero en la macroestructura aparece la entrada en el campo semántico al que corresponda con la reseña que remite al campo semántico en el que está desarrollada toda la información. Por ejemplo, la voz cepillo tiene una referencia en los complementos que remite a las herramientas profesionales, apartado donde se desarrolla el término.

En cuanto a la microestructura, los artículos siguen en general el mismo esquema. Primeramente aparece la categoría gramatical, la acepción o acepciones que da el DRAE y que pueden ser aplicadas a los ejemplos. En los términos que no recoge el diccionario académico, figura la acepción recogida en otros corpus, especialmente en el repertorio léxico de Janick Le Men, a continuación figura la etimología de la palabra tomada en casi todos los casos del Diccionario Crítico Etimológico Castellano e Hispánico $(D E C H)$ de Corominas y Pascual. Después se reflejan los ejemplos del término concreto localizados en los inventarios estudiados. El término que se analiza se

\footnotetext{
${ }^{1}$ La alternancia entre las grafías "u", "v" se mantiene en la transcripción de los documentos pero no en los ejemplos ni en las entradas para evitar la confusión.
} 
representa en cursiva y siempre dentro del contexto en el que aparece en la relación de bienes. Los ejemplos se organizan por orden cronológico. A continuación se desarrolla el estudio del término, que en unos casos tiene más extensión que en otros. Ello es debido a que las palabras de uso general no ofrecen ninguna aportación y simplemente se reseñan como términos que aparecen en las relaciones de bienes indicando que mantienen el significado general. En otros casos, se explica el posible significado que puede tener el término de acuerdo con el contexto lingüístico en el que aparece y con la zona, atendiendo a los posibles significados con el que se usa esa voz en León. En algunos casos se hace referencia a las diferentes variantes fonéticas que presenta el término, especialmente si son significativas porque den muestra de algún rasgo occidental o propio del leonés.

\section{Otros capítulos}

El trabajo se inicia con dos capítulos, el primero dedicado al estudio de la zona de La Bañeza y su entorno y el segundo dedicado al estudio linguístico. En el denominado Caracterización de la zona, junto a la información sobre los primeros pobladores y la situación geográfica del territorio, hago un análisis socio-económico de la época centrándome fundamentalmente en las bases de la economía del momento así como en la composición social. Para ello he tomado como referencia el libro Apuntes para la historia del Partido Judicial de La Bañeza de Rubio Pérez. La información que se aporta se documenta con la extraída del corpus en cuanto a modos de vida, cultura, profesión, etc. de los habitantes de la zona.

El capítulo dedicado al estudio lingüístico parte de la consideración de La Bañeza como zona comprendida en territorio del leonés. Por ello, en este capítulo hago una exposición, tomando como referente El dialecto leonés de Menéndez Pidal, entre otros, de los rasgos leoneses más significativos que pueden encontrarse en el corpus. Dentro de los rasgos morfológicos hay que señalar que no se recogen todos los que son propios del leonés ya que, en ningún caso por el tipo de texto con el que se trabaja, se van a encontrar en la documentación.

Tras el cuerpo de la tesis se dedica un capítulo a las conclusiones. Puesto que el trabajo se inicia con una exposición de los rasgos del leonés y tras el estudio de las voces recogidas en la documentación, se concluye analizando en qué medida se han localizado dichos rasgos para poder así justificar el tipo de lengua que predomina en esta zona y en esta época, que es castellano con algún rasgo leonés. En el ámbito léxico 
he tratado de concluir atendiendo a tres aspectos: préstamos léxicos, leonesismos u occidentalismos léxicos, para lo que ha sido fundamental la consulta del CorLexIn ya que algunas palabras que se podían considerar occidentalismos ha resultado que no lo son, puesto que se encuentran documentadas en zonas del centro y sur peninsular y términos derivados con repercusiones en el significado.

El trabajo se concluye con un bloque de bibliografía en el que junto a la consultada y citada en el texto aparecen las fuentes documentales y un bloque de anexos con una selección de documentos trascritos. Esta selección se ha realizado desde un criterio cronológico (inventarios de los distintos siglos), un criterio geográfico (distintos puntos geográficos comprendidos en el P.J. de La Bañeza) y sociológico (inventarios significativos por su contenido, por la profesión a la que pertenecía el propietario de los bienes, etc.). Finalmente, el trabajo se ilustra con un anexo fotográfico de inventarios, algunos de ellos trascritos en el bloque de anexos que figura en el índice. 


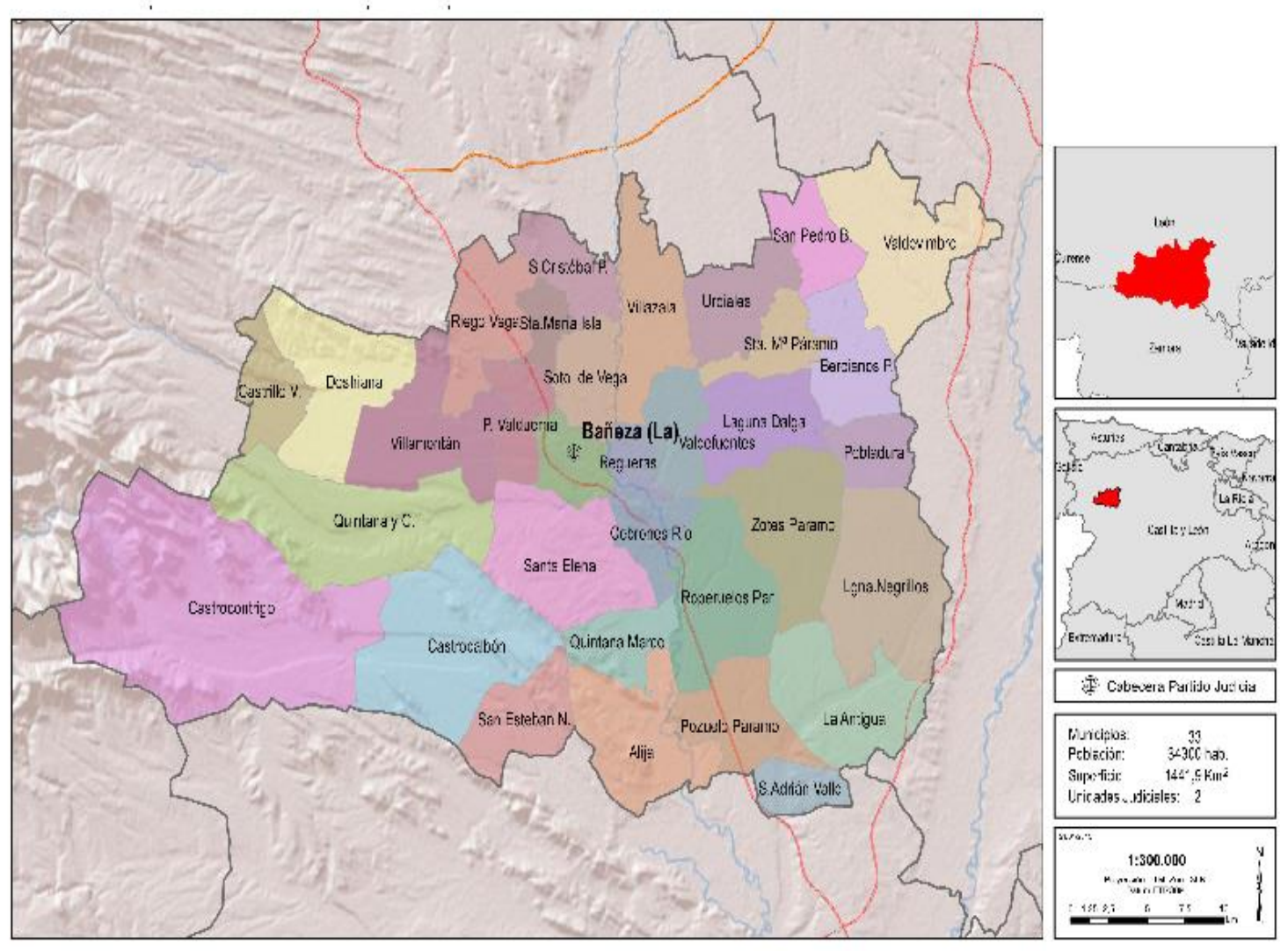

Mapa de partido judicial y municipios de su ámbito territorial. Ministerio de Justicia 


\section{CARACTERIZACIÓN DE LA ZONA}

Previo al análisis lingüístico del léxico es importante contextualizar la zona en la que se localiza este estudio tratando de reflejar una panorámica a nivel social, económico y cultural que nos permita enmarcar este corpus que tiene como campo de acción las relaciones de bienes (cartas de dote, testamentos, relaciones de bienes) que, en definitiva, son el documento con el que contamos para conocer la sociedad del momento. En mi caso, el objetivo de este punto no puede ser pretencioso, ya que solo busca contextualizar el objeto de mi investigación. Para ello, intentaré seguir la secuencia de la historia recogida en documentos y libros, de los que destaco los titulados La Bañeza y su tierra (1650-1850) (Rubio Pérez, L., 1987) y Apuntes para la historia del Partido Judicial de la Bañeza (Fernández Nuñez, M.F., 1988, $2^{\text {a }}$ edición)

\subsection{UBICACIÓN GEOGRÁFICA}

El Partido Judicial de La Bañeza tiene como centro la ciudad de La Bañeza, núcleo urbano debido al desarrollo de su actividad comercial. Geográficamente se encuentra situado al sur de la provincia de León entre las poblaciones de Benavente y Astorga. Está formado en su vertiente norte por los pueblos que forman parte de la Ribera del Órbigo, al oeste y noroeste por el Valle de la Valduerna, que se encuentra encajonado entre la comarca de la Cepeda y la Maragatería, y, al este, se sitúa el Páramo y el Valle de Valdejamuz. Su extensión es de unos 1328 kilómetros limitando con los Partidos Judiciales de Astorga y León por el norte, Valencia de Don Juan por el este, Benavente por el sur y parte del de Benavente y parte del de Astorga por el oeste y entre tres vegas fértiles que dan nombre a tres valles: El río Eria a la Valdería, el río Jamuz a Valdejamuz y el río Duerna al Valle de la Valduerna, junto a otros dos que forman las riberas del Órbigo y el Tuerto. Además, la comarca de La Bañeza queda limitada por otros accidentes geográficos, al sur una cordillera de mediana altitud que supone un límite con la provincia de Zamora, al oeste las montañas del Teleno que separan las tierras bañezanas con la comarca de La Cabrera y hacia el este no existen accidentes geográficos que sirvan de límite pero señala Rubio Pérez que encontramos dos elementos que marcan la diferencia, la medida de la tierra y áridos lo que para el autor supondría una diferenciación en cuanto a la extensión de la superficie parcelaria (Rubio Pérez, 1987: 53). En este entorno se asientan sesenta y un pueblos agrupados en dieciséis municipios, aunque a partir de la reforma administrativa del S. XIX algunos 
quedaron encuadrados en cabezas de municipio que no corresponden a la comarca de La Bañeza (op. cit: 53).

\subsubsection{Vías de comunicación}

Hasta bien avanzado el S. XX, La Bañeza tenía como principales vías de comunicación el ferrocarril de Plasencia a Astorga que fue inaugurado en 1898 permitiendo así las comunicaciones ferroviarias entre la comarca y el resto de España. Este tuvo que ser ampliado en las primeras décadas del siglo XX para adaptarse a las necesidades del tráfico comercial. La importancia de la línea creció al prolongarse en la llamada Ruta de la Plata que unía Gijón y Sevilla. En cuanto a las carreteras, la principal vía de comunicación era la carretera Nacional VI de Madrid-La Coruña, aunque importantes fueron a comienzos del S. XX las carreteras de La Bañeza-Alija, Camarzana y la carretera de La Coruña. Otra vía importante de comunicación es la carretera de Castrocontrigo a Truchas que habría de pasar por Torneros y Morla con una longitud de $26 \mathrm{~km}$.

\subsection{RASGOS SOCIO-ECONÓMICOS}

\subsubsection{Primeras referencias de ocupación}

Intentar situar a los primeros pobladores del término La Bañeza supone seguir su historia que resulta tan compleja como interesante.

Las primeras referencias históricas existentes para el territorio bañezano conciernen al emplazamiento, en la cercana localidad de San Martín de Torres, de la población astur-romana de Bedunia, mencionada por diversas fuentes como el Itinerario de Antonino. Conquistado por Roma entre los años 29 a.C. y 19 a.C., el espacio que ocupa actualmente La Bañeza formó parte del Conventus Asturum, primero dentro de la provincia Tarraconense y, desde finales del siglo III, de la Gallaecia. Claudio Tolomeo, geógrafo alejandrino, incluye entre los astures a los brigecinos, cuya capital es Brigencium, a los bedunensios, que tienen por capital, Bedunia, a los orniacos, con capital en Intercatia, y a los zungonos, zeolínos, superatios, amacos, tiburos y zígurros o egurros, con sus capitales respectivas. Sin entrar en esta diversidad de pueblos, sí parece ser que la provincia de León se componía, en su primitivo origen, de indígenas que recibieron diferentes nombres según el territorio que ocupaban. Todos pertenecieron, siguiendo las investigaciones del autor Fernández Núñez a los astures que más tarde se designaron con el calificativo de opídanos augustanos. Tal como se 
desprende de las investigaciones del maestro e historiador D. Matías Rodríguez, los egurros correspondían a los límites del partido bañezano. Cean Bermúdez sostiene que la Bañeza perteneció a la región de los egurros (Fernández Núñez, 1988: 51). Sigue diciendo este autor, siguiendo al P. Flórez que "correspondía al territorio de los Gígurros, colocados en los astures augustanos, el actual partido de la Bañeza y que comenzaba la población de estas gentes en el Norte de Astorga, extendiéndose hacia las regiones bañadas por los ríos Ornia y Urbico, del que nos hablan los antiguos cronicones" (op. cit, 1988: 53).

Por lo que respecta a la ubicación del actual término de la Bañeza existen distintas versiones. Algunos tratadistas P. Fidel Fita, Madoz, Torres Villegas, Aureliano Fernández Guerra y P. Tirso López reducen la antigua Bedunia al actual pueblo de la Bañeza, mientras Matías Rodríguez y García Foz colocan a Vertania o Vetania en la Bañeza. El autor del libro de referencia concluye que parece admisible la posibilidad de que Bedunia correspondiera a la Bañeza. Por otra parte, la tradición popular, como este autor recoge, siempre refirió La Bañeza a Bedunia, Por ello, y concluyendo en esta aproximación a los primeros pobladores, se inclina Fernández Núñez a considerar que la primitiva Bañeza fue un tiempo habitada por tribus indígenas, pertenientes a los Gígurros, Egurros o Cígurros, de cuyas gentes nos habla Plinio en su Historia Natural, refiriéndose a los astures augustanos (op. cit, 1988: 63).

Fernández Nuñez, en el libro al que me refiero, hace una detallada descripción de las costumbres de estas gentes, destacando que la Bañeza, antigua capital de los bedunienses astures, se distinguían sus gentes por su laboriosidad, su espíritu comercial y su fidelidad a los pactos y contratos que con los vecinos firmaban, dato que nos puede hacer pensar que este espíritu comercial podría ser la semilla de uno de los rasgos de la actual población de esta tierra

Dando un salto en el tiempo, la Bañeza, como otros pueblos, sería un mosaico de distintas culturas con la sucesión de guerras y asentamientos por parte de romanos, visigodos y suevos, siendo, según los historiadores, los godos quienes, posiblemente, entre los siglos V y VIII, tras su victoria, se establecieran con más estabilidad en estas tierras.

Posteriormente, estas tierras se vieron arrasadas por la invasión musulmana de 711, ya que la llamada Vía de la Plata fue una de las arterias de penetración utilizadas por el pueblo árabe. 
Es, a mediados del S. IX, por orden del Conde Gatón de El Bierzo, cuando nace el actual emplazamiento bañezano, formado a partir de dos núcleos diferentes: uno, con población de Pereje (Bierzo), funda San Pedro de Périx, otro, con mozárabes llegados desde Córdoba se asienta en torno a San Salvador. De la fusión de los mozárabes cordobeses y de bercianos nacerá la esencia aperturista y cosmopolita de la Bañeza, este nuevo elemento pudo también ayudar a consolidar el espíritu comercial que ya se definía en los primeros pobladores. Según los investigadores de estas tierras, fue la historia medieval de la Bañeza la que forjó el carácter comercial de sus gentes y por ello la cabecera económica de un territorio.

Durante la Edad Moderna, La Bañeza, cabeza del Marquesado de Bazán, recibió mercaderes, artesanos y comerciantes llegados desde las lejanas tierras de Europa, fundamentalmente flamencos y franceses, especializados en tejidos, uno de los gremios más importantes de la ciudad.

Es aquí, por tanto, donde queda emplazado este término territorial de la Bañeza.

\subsubsection{Densidad de población}

La población bañezana se estructura, en el período que comprende este corpus, en un porcentaje mayor de hombres que de mujeres en los primeros años de edad que va descendiendo en edades más avanzadas debido a un mayor índice de mortalidad entre los hombres y al fenómeno de la emigración. En cuanto al estado civil de la población, hay un tanto por ciento más o menos equivalente entre hombres y mujeres que ronda el $50 \%$ de casados entre 25 y 40 años, aunque a partir de esta edad aumenta el número de viudas que es mayor a partir de los 50 años. No obstante hay alguna variación de estos datos respecto al núcleo urbano en el que el número de casadas es menor debido a la inmigración y al servicio doméstico.

Por lo que respecta a la evolución de la población, en la última parte del S. XVI se produce un descenso de la misma que se acelera con la epidemia de finales de siglo. Sin embargo, a finales del S. XVII hay un crecimiento en la población bañezana que se diferenciará del área rural. En la segunda mitad del S. XVIII hay un incremento demográfico en toda la comarca que vuelve a ser interrumpido durante la primera década del S. XIX volviendo a recuperarse en la segunda década (Rubio Pérez, 1987: 76 y ss.) 


\subsubsection{Bases de la economía}

La agricultura constituye la actividad económica principal de la comarca de La Bañeza, como se refleja en este estudio en el que gran parte del léxico aquí recogido pertenece a la actividad agraria. Entre las medidas de superficie que se utilizan se encuentra la hemina como unidad que supone en superficie unos $626,26 \mathrm{~m} / 2$ para el regadío y más de 900 m/2 para el secano. Señala Rubio Pérez que según el Catastro de la Ensenada a mediados del S. XVIII el $94,3 \%$ de la superficie total se considera productiva mientras que hay un 5,7\% de tierra ocupada por caminos, ríos, montes, y cascos de pueblos que no produce nada. A su vez dentro de la tierra productiva, hay un amplio porcentaje de tierra de secano frente a un 20\% más o menos de regadío (Rubio Pérez, 1987: 189).

Entre los cultivos de regadío más frecuentes se encuentra el lino que se utilizaba como materia prima para la industria artesanal y para el que se empleaban en su proceso de transformación utensilios que aparecen con frecuencia en estos inventarios: rastrillos, fiteras o espadillas. Además, como se refleja en las relaciones de bienes analizadas para este estudio, es muy frecuente encontrar lino tanto como materia prima, que aparece en manizos, varas, copos; como en el ámbito textil señalando el tipo de tejido del que están confeccionadas algunas prendas que aparecen en estas relaciones, especialmente sábanas o almohadas. Junto al lino, se encuentra el cultivo del trigo ya que constituía un elemento básico para la alimentación del hombre. Fundamentalmente se cultivaba trigo y centeno, como lo demuestra el hecho de que encontramos en los inventarios tierras trigales y centenales, concretamente el centeno es además un cereal que se caracteriza por su resistencia y adaptación al frío y las heladas propias del invierno. Señala Rubio Pérez (Rubio Pérez, 1987: 269) que en el S. XVIII se introducen nuevas especies de trigo que resistían mejor al clima invernal de la zona como el morcajo y la barbilla. Los casos documentados pertenecen al S. XIX y son muy escasos, aunque tampoco resulta significativo ya que puede tratarse de una casualidad. Es probable que en la zona el término morcajo denomine a la mezcla de trigo y centeno, aunque también puede tratarse de un cereal de peor calidad. Importante también en esta comarca es el viñedo, fundamentalmente a partir de la segunda mitad del S. XIX, por ello he decidido marcar todos los términos que tienen que ver con la elaboración y conservación del vino dentro de un apartado independiente que se incluye en el denominado aperos y labores agrícolas.

Para desarrollar la actividad agraria es importante disponer de utensilios que faciliten el rendimiento. De ellos encontramos importantes testimonios en las relaciones 
de bienes, base del léxico aquí estudiado, que dan cuenta de cómo estos instrumentos pasaban de padres a hijos, no en vano gran parte del léxico que se documenta son los aperos de labranza y aparecen en testamentos y partijas, entre otros documentos. Dentro de estos, Rubio Pérez establece una diferenciación entre los que se consideran imprescindibles y los considerados menores ya que se emplean para tareas secundarias o menores (Rubio Pérez, 1987: 280). Entre los primeros se encuentran el arado o ativa, ampliamente recogidos en los inventarios analizados, que dan cuenta del nivel económico de sus propietarios ya que el número de ellos estaba en función del número de cabezas de ganado que tuvieran. Junto a ellos aparecen tanto los elementos del arado (mullidas, cornales, sobeo), como del carro o el trillo. Entre los considerados menores se emplean azadas, garabitas, palas, guadañas, etc., para segar; o cerandas, cribos, bieldos, etc. para aventar el grano.

Junto a la agricultura, la ganadería constituye el elemento esencial como fuerza de trabajo y como materia prima empleada para el cultivo y para el consumo humano. Dentro del conjunto de la ganadería, es el ganado bovino el que constituye el peso de la agricultura, en especial el buey, aunque en las relaciones de bienes abundan también las vacas, estas probablemente más para la obtención de la leche y la crianza. Significativo también era el ganado porcino ya que constituía la base de la alimentación con productos como el tocino o la manteca, entre otros. Es muy poco frecuente encontrar inventarios en los que, si se relacionan animales, no aparezca ganado porcino en cualquiera de sus denominaciones: cerdo, marrano, lechón; ya que normalmente se criaba y se sacrificaba al menos un cerdo para el mantenimiento del año. También son un elemento importante de la alimentación las aves de corral. Señala Rubio Pérez que solamente se documentan en los inventarios de los SS. XVII y XIX ya que su catalogación variaba según la opinión del escribano (Rubio Pérez, 1987: 301), sin embargo, en los inventarios analizados las aves, en especial las gallinas, aparecen con frecuencia también en el S. XVIII: «seis gallinas (Coomonte de la Vega, 1719) », «zinco gallinas y un gallo (Genestacio de la Vega, 1721)». Explica Rubio Pérez que la posesión de la ganadería y el tipo constituyen una radiografía de la estructura social de la zona y del momento. Así señala este autor que en el caso del clero su mayor presencia se encuentra en el ganado equino que lo empleaba como medio de transporte, mientras que el ganado vacuno se localiza en las cofradías que entregan arrendadas estas cabezas a los campesinos que trabajan sus tierras, o en los curas rurales que poseen una o dos vacas (Rubio Pérez, 1987: 302). De este dato encontramos ejemplos en nuestros inventarios 
puesto que en tres de ellos, pertenecientes al clero, aparecen objetos que indican que su medio de transporte eran los caballos, a modo de ejemplo, encontramos «una silla de cabalgadura vieja sin cinchas» en un inventario de Coomonte de la Vega de 1643, «una calesa vieja con dos almoadones» en un inventario de Robledo de la Valduerna de 1726 o «una silla de montar con todos sus talages, estrivos de yerro» en un inventario de Destriana de 1843, todos ellos pertenecientes a los curas del lugar. Además no se suelen encontrar otro tipo de animales en estos inventarios a excepción de cerdos, que probablemente usan para su consumo.

La mayor parte del ganado es propiedad de cada campesino que tiene que ajustarse a las normas del concejo que limitará generalmente el número de cabezas que pueden tener en las diferentes especies para distribuir equitativamente los recursos comunes, aunque los campesinos con más poder podían aumentar sus cabezas a través del pago a los concejos. Los campesinos que no tenían posibilidades de tener ganado en propiedad podían arrendarlo o tenerlo en la modalidad de "a medias", aunque para esta última modalidad necesitaba disponer de tierras que le permitieran alimentar al animal para poder participar de sus beneficios.

Junto a la actividad agrícola, encontramos también como base de la economía la actividad artesanal, especialmente en lo que se refiere a lienzos, curtidos y aceite, cuya comercialización convertirá a La Bañeza en un centro importante. El sector textil es durante el S. XVIII y parte del XIX la actividad fundamental. Se elaboraban lienzos finos para las prendas y bastos para la elaboración de fardos o quilmas. El lienzo aparece frecuentemente y se recogen varios casos del denominado lienzo casero, es decir, lienzo propio del lugar, se localizan también inventarios en los que se relacionan los objetos que había en la tienda que regentaba el propietario de la relación de bienes, que era una tienda de textil donde se hallaban tanto telas como otros utensilios relacionados con este ámbito.

Otra actividad artesanal importante es la que tiene que ver con el cuero y la elaboración de curtidos cuyo principal demandante es el campesino que los emplea para su actividad agraria en el uso de sobeos, collares, etc. Eran los zapateros quienes se encargaban de transformar el cuero una vez preparado. Resulta difícil conocer la profesión de los propietarios de los bienes ya que a excepción de los curas, no suele aparecer. Sin embargo, se localizan inventarios en los que por el tipo y cantidad de objetos que aparecen se puede deducir la profesión a la que se dedicaba el propietario, que tiene que ver con la actividad artesanal, especialmente zapateros. Por ejemplo, en 
un inventario de Viforcos del año 1729 encontramos: «seis taladros», «un taladro de galochas», «un cuchillo de galochas», «un serrete», etc., que reflejan que probablemente su propietario fuera un zapatero o carpintero por los objetos que en él aparecen. En relación con el lino, en La Bañeza tiene lugar la producción de aceite de linaza de cuya actividad se ocupaba la alta burguesía e hidalguía ya que eran quienes poseían los molinos de linaza. Se documenta con frecuencia en los inventarios el término linaza tanto como materia prima «tres eminas de linaza», como haciendo referencia al aceite que se obtenía de estas semillas donde junto a la voz linaza aparecen los objetos que sirven de continente, como la botija.

\subsubsection{Clases sociales}

La sociedad bañezana de esta época está marcada por relaciones socio-económicas. Pérez Rubio establece dentro del medio rural cinco clases sociales cuya división viene determinada por la posesión de los principales medios de producción, estos son: ricos campesinos, medianos campesinos, campesinos deficientes, precarios campesinos y pobres de solemnidad (Rubio Pérez, 1987: 347-348). Dentro del primer grupo, formado aproximadamente por un $10 \%$ de la población, se encuentran aquellos que disfrutan de grandes explotaciones de tierra así como del número necesario de cabezas de ganado para sus explotaciones agrarias. Estas condiciones hacen que tengan excedentes agrarios en su producción que les permitan aumentar sus riquezas, como se refleja en los inventarios donde se pueden encontrar todo tipo de enseres, joyas, etc. Por ejemplo, en algunos inventarios encontramos gran número de animales, todo tipo de aperos de labranza, bastantes prendas de ropa, joyas, cuadros que evidencian que se trata de una persona con recursos económicos.

Los medianos campesinos disfrutan de una solvencia económica ya que disponen del suficiente terreno y ganado para la explotación agraria, aunque a veces este ganado lo tienen arrendado o "a medias" con las instituciones eclesiásticas. Los pequeños y deficientes campesinos suponen algo más del $50 \%$ de la población. Estos campesinos disponen de una extensión de tierra mínima de manera que no todos los años obtienen la producción suficiente que les permita autoabastecerse, además necesitan alquilar el ganado. De ellos los deficientes campesinos se encuentran en peor situación y malviven de los escasos recursos que obtienen de sus tierras. Finalmente los pobres de solemnidad constituyen el grupo más bajo y carecen de recursos, aunque el porcentaje en esta época es mínimo. 
En el ámbito urbano Rubio Pérez distingue entre el sector artesanal, que es el más numeroso y cuya actividad se centra en el sector textil, y los curtidos (Rubio Pérez, 1987: 352). En algunos inventarios, como el señalado de Requejo de 1839, podemos evidenciar por la cantidad y el tipo de objetos que se encuentran así como por la estructura de la vivienda, ya que se va haciendo inventario de cada una de las dependencias de la casa, que pertenece a personas con grandes posibilidades económicas puesto que encontramos telas de calidad, joyas, cuadros y otros objetos de adorno. En otros se puede apreciar cómo, al oficio de tejedor, se alternan otros recursos. Así en un inventario de La Bañeza del año 1758 se observa que el propietario era tejedor por los utensilios que en él aparecen pero al final del inventario se referencian «onze libras de ylaza que está a cura»y «Más tres cargas de trigo en ser que está debiendo Melchor García vezino de esta villa por la compostura que se hizo entre dicho Melchor y el difunto del pleito sobre la renta de los molinos de la capellanía de misa de alba», lo que puede indicar el doble oficio.

Por otra parte se situarían los oficios liberales entre los que se encuentran escribanos, tratantes, maestros, administradores y boticarios. Según se puede apreciar en los inventarios disponen de solvencia económica ya que entre sus bienes hay importantes objetos de valor, abundantes utensilios para el hogar, incluso algún libro. En ellos, sin embargo, no suele aparecer ganado ni enseres relacionados con la agricultura. Por ejemplo en un inventario de La Bañeza perteneciente a "la viuda del administrador que fue de la renta de tabaco de la dicha villa" aparecen gran cantidad de objetos de plata, cono cucharas, tenedores, relicarios, incluso «dos pares de chinelas de moda franzesa» que muestran el nivel económico de estas personas.

La burguesía y el clero son los perceptores de los excedentes y la riqueza agraria. A través de los inventarios podemos conocer su nivel de vida. Señala Rubio Pérez que la mayor muestra de su nivel es la vivienda, grandes mansiones que se sitúan en las calles principales de la villa (Rubio Pérez, 1987: 359). En este sentido, se puede afirmar que algunos de los inventarios más ricos de los analizados pertenecen al sector del clero, en el que incluso en algún caso, hasta se recogen los bienes hallados en el cuarto de las criadas, junto a objetos de valor, abundantes libros, muebles elaborados con maderas de calidad, etc., así como sus deseos en cuanto al número de misas y lugar de su entierro cuando fallezcan: "mando que [...] para dicho entierro se traygan y compren dos velandones a dos livras y media cada uno y la demás cera siempre que sea necesaria...”. Además el clero poseía un gran prestigio social y nivel cultural, como se 
refleja en los inventarios con el gran número de libros que poseían entre sus pertenencias y objetos como escribanías, escritorios, estanterías que evidencian su dedicación al trabajo intelectual.

\subsubsection{Sistemas de gobierno}

Existen dos tipos de administración, la que procede de los órganos superiores del señorío que incide en todos los pueblos adscritos y que tiene como figuras más relevantes el corregidor y el alcalde mayor del señorío y los gobiernos locales. El corregidor pertenece a la baja y media nobleza y ha de caracterizarse por haber nacido en el reino y ser hombre bueno. Sus funciones son administrar justicia y dirigir los órganos de la administración territorial. Señala Rubio Pérez (Rubio Pérez, 1987: 343) que a excepción de la propia villa de La Bañeza en el resto de la comarca existió un concejo abierto de vecinos que nombraba cada año a los alcaldes pedáneos quienes ejercían funciones administrativas y eran supervisados por el corregidor. En la Villa de La Bañeza a partir del s. XVII existió lo que se denominaba regimiento que formaba junto con el corregidor el ayuntamiento. El procurador general debía pertenecer a la alta burguesía y debía tener conocimientos en leyes ya que entre sus funciones estaba resolver los problemas entre los vecinos y entre estos y la administración local.

\subsubsection{Cultura}

El nivel de alfabetización de la población en esta época es escaso. Rubio Pérez señala que en el S. XVII podemos hablar de un $15-20 \%$ de personas que tienen un nivel mínimo de cultura a juzgar por su firma, incrementándose un poco en la primera mitad del S. XVIII y algo más en la segunda mitad, siendo menor en las mujeres, puesto que la sociedad del momento no lo considera importante para las labores que debe realizar (Rubio Pérez, 1987: 483). Añade este autor que los motivos de la escasa alfabetización son fundamentalmente la ocupación de las faenas agrícolas, así como la falta de recursos de los concejos para contratar maestros. Señala, además, que uno de los elementos que definen la cultura de un pueblo es el libro. Demuestran los inventarios analizados que la presencia de este se encuentra fundamentalmente en el clero donde aparecen abundantes libros, fundamentalmente de temática religiosa, aunque también de otras disciplinas como Literatura, Filosofía o Historia. En algún caso también se ha encontrado algún libro en inventarios de personas de cierto nivel económico, quizá 
como elemento diferenciador de su nivel socio-cultural y una ausencia casi total entre el campesinado.

\section{Muestra de libros recogidos en los inventarios analizados:}

El mayor número, como se ha indicado, lo encontramos entre el clero. No obstante, dentro de este sector también hay diferencias puesto que encontramos dos inventarios muy nutridos, en uno de ellos quizá por el grado jerárquico del cura (prior), mientras que en otras relaciones de bienes pertenecientes al clero, más pobres en general, el número de libros se reduce a los breviarios necesarios para las funciones religiosas. Entre los más nutridos está el de Jerónimo Natera, cura que fue del lugar de Robledo de la Valduerna del año 1726:

Siete tomos de a folio y Historia de los anales de Aragón con su ýndice

Otro tomo de las guerras zíuiles de Francia

Otro tomo de a folio espejo de las cristalinas aguas

Istoria de Mariana en un tomo

Istoria de Méjico

Agricultura de Herrera

Escripturas de millones

Bocavulario eclesiástico

Corella Practica de confesores, tres tomos, uno de folio y los dos de quarto

Moncada comunión spiritual

Opúsculos de oro birtudes morales y cristianas de Calderón

Cartilla moral

Fuero de la conzienzia

Corona gótica

Obras de Góngora

Parnaso de Quebedo un tomo en pasta

Ignozenzia mendicada un tomo

Dos tomecillos Nobleza española y genealogía de la casa Leiba

Canto llano

Los quinze cantos de la Numantina

Autos de Calderón

D. Alejo de Piamontes

Garcilaso de La Vega

Manual de confesores de Villalobos

Conjuros de Remijio

Antorcha moral

Santo Tomás

Salazar dos tomos

Ordenantes

Bustamante de V/Rubricas

Entremeses

Floresta española

El diablo cojuelo

Doctrina cristiana

Secreto de Naturaleza

Especulum Granati forum

Barias cuestiones morales dos tomos

Dos conzilios 
Quatro cuerpos de brebiarios buenos

Un brebiario pequeño de todo el año

Dos divinos

Dos semanas santas

Nutrido también es el de Felipe Cordiado, presbítero cura prior de Destriana, perteneciente al año 1843, en el que se recogen los siguientes:

Tres tomos de la orden militar de Santiago

Un tomo Constitución del año doce

Un Misal nuevo con sus broches de metal sin perjuicio que corresponda o no a la Yglesia

Un tomo de sermones

Siete cuadernos oraciones fúnebres, cartas pastorales y esposiciones

Cinco reglamentos y órdenes para diferentes cosas

Tres tomos teología moral

Un tomo de elementos mecánicos en francés con láminas

Dos tomos de la curia filípica

Tres tomos conquista de Méjico

Dos tomos instrucciones doctrinales

Un tomo breviario particular

Dos tomos indiferentes

Sin embargo, tanto en el inventario de Alonso Hurtado, cura de Coomonte del año 1643, como en el de Joaquín González, párroco de la villa de Quintana del Marco de 1823 encontramos lo siguiente:

Dos breviarios (Coomonte de la Vega, 1643)

Un juego de breviarios (La Nora del Río, 1823)

Otro juego de breviarios en dos tomos (La Nora del Río, 1823)

Además de estas listas de libros, en los inventarios analizados se han recogido algunas muestras más, pero muy escasas en relación a las anteriores. Se hallan libros entre la población urbana, artesanos o profesiones liberales. Por ejemplo entre los bienes de, probablemente, un zapatero de La Bañeza encontramos:

Un libro de octavo devoción de las ánimas del purgatorio (La Bañeza, 1721)

Un libro de octavo en latín (La Bañeza, 1721)

Igualmente, entre los bienes de la viuda de un administrador de la villa de La Bañeza, entre los que se halla: «Un libro de filosofía de la conzienzia».

Entre el campesinado es mucho más atípico encontrar este tipo de objetos entre sus pertenencias y podemos afirmar que en los casos en los que aparecen siempre se da una particularidad, se trata de campesinos con posibilidades económicas cuyos inventarios suelen estar formados por todo tipo de objetos. Por ejemplo en un inventario de Huerga de Garaballes de 1723 encontramos: «zinco libros», o en otros dos de Destriana de 1843 y de Felechares de 1836 respectivamente encontramos: «tres libros 
grandes», «un libro». En estos casos se da una particularidad, no se referencia el título sino que solo se cita el nombre genérico junto al número de objetos que se hayan encontrado.

Finalmente, en este apartado referido a libros hay que citar los que son propiedad de una institución, como los recogidos en el inventario del concejo de la villa de Pobladura del Valle del año 1733, de temática administrativa, entre los que se encuentran:

Dos libros de la nueva recopilación, el uno sin prinzipio y ambos en pergamino Las ordenanzas de esta villa

Un legajo de cuentas de concejo

Dos legajillos de cartas de pago

Una ejecutoria sin prinzipio ni fin

Otra ejecutoria con pergamino y sin prinzipio 


\section{MARCO LINGÜÍSTICO}

Los protocolos analizados para la realización de este corpus pertenecen al Partido Judicial de La Bañeza y están fechados entre la segunda mitad del S. XVII, S. XVIII y primera mitad del S. XIX. Se localiza en la zona suroccidental de la provincia de León y norte de la actual provincia de Zamora. Nos encontramos, por tanto, en zona del leonés.

Cuando se produce la fragmentación del latín que trajeron los romanos a la Península, surgen una serie de lenguas entre las que se encuentra el castellano y el leonés. En la zona comprendida actualmente por Asturias y las provincias de León y Zamora se desarrollaron un conjunto de hablas que presentaban unas características comunes, aunque sus hablantes no tuvieran conciencia de estar hablando una lengua distinta del latín. En este momento, en torno al S. X, existen una serie de documentos oficiales del reino de Oviedo, el fuero de Avilés, de León, Zamora y de otras ciudades que presentan rasgos que evidencian la diferencia con respecto al latín y que constituyen lo que se llamará leonés. Será en el S. XIII cuando estas lenguas romances adquieran la categoría de lengua apta para la administración y es a partir de entonces cuando contamos con gran cantidad de documentos administrativos que dan muestra del leonés, así como textos literarios como El Libro de Aleixandre, sobre la vida de Alejandro Magno. A partir del S. XIII, el leonés se va poco a poco acercando al castellano y en consecuencia perdiendo progresivamente sus rasgos, debido tal vez a la cercanía de la franja más oriental del leonés con la zona del castellano. Este proceso duró varios siglos llegando hasta el S. XV, especialmente en la lengua escrita mientras que en la lengua hablada durará más tiempo. Aún así, el leonés siguió siendo un conjunto de hablas con sus características concretas que se mantenía en la lengua oral, especialmente en las zonas más occidentales, aunque poco a poco fue convirtiéndose en una lengua estigmatizada, hecho al que contribuyeron los literatos del Siglo de Oro que la consideraron como lengua propia del hombre que carece de cultura. No obstante, tanto sus rasgos fonéticos y morfológicos como sus características léxicas se han mantenido a comienzos del S. XX especialmente en zonas de León y Zamora, aunque poco a poco hayan perdido vigencia debido a factores diversos como la emigración, la enseñanza o los medios de comunicación, entre otros. Conviene por tanto, a modo de introducción, hacer un recorrido lingüístico por los rasgos más característicos del leonés tanto en sus aspectos fonéticos (vocalismo y consonantismo) como morfológicos, obviando los 
rasgos léxicos puesto que constituyen el objeto final del cuerpo de esta tesis. Este análisis lingüístico permitirá llegar a conclusiones sobre el tipo de lengua que caracteriza la zona comprendida en el Partido Judicial de La Bañeza en la época estudiada

\subsection{Caracterización del LeONÉS}

El leonés presenta unos rasgos característicos que, a pesar de la influencia del castellano, aún hoy perviven con mayor o menor grado de presencia según la zona en la que nos encontremos.

Menéndez Pidal señala que los límites del dialecto leonés no coinciden con los del antiguo reino de León, ni con los de las provincias gallegas y el reino de Portugal (M. Pidal, 1906: 30-33 [2006]). En León, las fronteras entre el gallego y el leonés quedan establecidas por las divisorias de los ríos Cúa y Sil, como se aprecia en la toponimia. En la provincia de Zamora el pueblo de Ermisende habla gallego, mientras que la tierra de Miranda en Portugal es de rasgos leoneses. Por tanto, de acuerdo con la pervivencia y vitalidad de los rasgos lingüísticos, Menéndez Pidal estableció tres zonas: occidental, central y oriental, aunque matiza el propio autor que estos límites no van a ser exactos en todos los rasgos característicos. La zona occidental se caracteriza por dos rasgos: la diptongación de la / $/$ / tónica y /ě/ tónica como el leonés oriental y la conservación de los diptongos decrecientes como el gallego. A esta zona correspondería el occidente de Asturias, León, Zamora y Miranda en Portugal. La zona central abarca hoy solo Asturias y la oriental se extiende por el oriente de Asturias, de León y de Zamora, por todo Santander, Salamanca y Extremadura. Añade además este autor que en León el Partido Judicial de La Bañeza representa probablemente el dialecto central con conservación de /f-/ latina (M. Pidal, 1906: 41 [2006]).

El leonés se caracteriza por unos rasgos que han sido recogidos ya por estudios clásicos realizados por Menéndez Pidal en El dialecto leonés (M. Pidal, 1906 [2006]) y en el manual de dialectología Dialectología española (A. Zamora Vicente, 1974), entre otros.

\subsubsection{Consonantismo}

\subsubsection{Conservación de /f-/}

La conservación de la /f-/ es uno de los rasgos más característicos del leonés, aunque señala Morala que este fenómeno singulariza al castellano frente al resto de las lenguas 
modernas procedentes del latín ya que lo regular en todas ellas es el mantenimiento, no la supresión (Morala y Gancedo, 2009: 89). Centrándonos en el leonés, la /f-/ se conserva en el occidente y centro de Asturias y en el occidente de León. En la zona oriental asturiana se produce una aspiración de la /f-/ cuyo límite se encuentra en el río Sella. Señala Morala que este proceso es similar a lo que ocurrió en castellano ya que en época medieval se generalizó y hoy todavía se conserva en el español meridional (Morala y Gancedo, 2009: 89). En León encontramos este rasgo en todo el occidente en palabras como farina, figo, facer, etc; mientras que hacia el este la pérdida es significativa. Este hecho es paralelo a lo que ocurre en otras provincias como Zamora donde se aprecia fundamentalmente en la mitad occidental y se va estrechando cada vez más a medida que avanzamos hacia el sur de la Península, siendo por ejemplo, en Extremadura generalizada la aspiración de la /f-/ llegándose incluso a confundir con la /x/ castellana. En las zonas donde se produce aspiración el resultado generalmente es sordo, aunque en la comarca de Mérida es claramente sonoro (Zamora Vicente, 1974: 119-121).

\subsubsection{Palatatalización de /I-/}

La solución frecuente del leonés a la /l-/ fue la palatalización en /l/, rasgo que encontramos ya en textos literarios medievales como El libro de Aleixandre y posteriormente en autores como Juan del Encina o Lucas Fernández (Zamora Vicente, 1974:122). Actualmente los resultados son diversos. Así en Asturias, la palatalización se extiende por el noroeste pero desde el Eo al Porcia se conserva la /1-/. En León la palatalización de /1-/ es generalizada en el occidente, aunque en la zona oriental quedan restos especialmente en la toponimia donde es frecuente encontrar Llama, Llamas, etc. En Zamora, Salamanca y Extremadura es menos frecuente, aunque sí se localiza en la toponimia (Zamora Vicente, 1974:124). Señala Menéndez Pidal que paralelamente a la palatalización de /l-/ encontramos la de /n-/, aunque tiene menor extensión (M. Pidal, 1906: 59 [2006]).

\subsubsection{3. /g-/ y /j-/ latinas}

En el habla antigua estas dos consonantes fueron consideradas fricativas mediopalatales independientemente que estuvieran ante vocal anterior o posterior. Actualmente la solución sorda/š/ aparece en todo el asturiano. En León se conserva con 
gran vitalidad en las comarcas de Babia y Laciana; en otras zonas de León junto a la conservación encontramos la solución castellana con la consonante dialectal confundida con la /x/ castellana, por ejemplo en jugo 'yugo'. En Zamora encontramos zonas en las que persiste ante vocal palatal mientras que se conserva ante vocal velar. En otras zonas como Sanabria, el fenómeno se produce de forma generalizada pero con resultados diversos: /š/, /x/, /ŷ/ o /ž/ (Zamora Vicente, 1974:134).

\subsubsection{4. /pl-, kl-, fl-/}

La solución que el castellano dio a los grupos /pl-, kl- y fl-/ fue /l/, mientras que el leonés occidental dio como resultado / $\mathrm{c} /$. Hoy esta solución es frecuente en el occidente asturiano, en el occidente de León, especialmente en Babia y Laciana, aunque en la toponimia se extiende un poco más llegando hasta el límite oriental de Astorga, mientras que en el resto del leonés se adopta la solución castellana. En Sanabria se usa no solo en la parte gallega sino en Ribadelago, aunque según vamos acercándonos hasta San Ciprián nos encontramos con casos aislados. En Salamanca quedan restos en la toponimia y en el resto de las zonas lo normal es la solución castellana, a excepción del mirandés de Portugal donde siempre encontramos la solución / $\hat{c} /$ (Zamora Vicente, 1974:136).

\subsubsection{Confusión de las consonantes líquidas $/ \mathbf{l} / \mathbf{r} /$}

Otro rasgo que podemos señalar como característico del leonés es el paso de $/ 1 />/ \mathrm{r} /$ cuando aparece en segundo lugar de un grupo. Este rasgo lo encontramos ya en El Libro de Aleixandre (Zamora Vicente, 1974:137). Actualmente, es frecuente en León en la zona de Curueña y Astorga, Murias de Paredes y La Bañeza donde ya encontramos casos en el habla vulgar de Fray Gerundio de Campazas (M. Pidal, 1906: 67 [2006]). También aparece en la comarca de Sayago en Zamora, en Salamanca y en Extremadura y, aunque en Asturias no se produce, sí se pueden encontrar algunos casos aislados.

\subsubsection{6. /k'l/ y /lj/}

Las combinaciones $/ \mathrm{k}^{\prime} \mathrm{l} / \mathrm{y} / \mathrm{lj} /$ derivaron en la mayor parte de las lenguas romances en un resultado palatal. En leonés el resultado es /l/ ya desde los primeros textos (M. Pidal, 1906: 65 [2006]). Modernamente la solución /// la encontramos en Miranda (Portugal) o la solución /y/ en Asturias y oeste de León donde se documenta /obeya/ en lugar de 
/obexa/. Además es frecuente que, tanto en Asturias como en León, se produzca la pérdida de la /y/ tras /i/, dando resultados como /fio/ en lugar de /fiyo/, y en menor medida, tras /e/ en ejemplos como /urea/ en lugar de /orexa/. Al suroeste de Asturias se produce un ensordecimiento de la /y/ dando /ĉ/ como resultado (M. Pidal, 1906: 65 [2006]).

\subsubsection{Conservación de /-mb-/}

Otro de los rasgos diferenciales del castellano frente al leonés fue la conservación del grupo /-mb-/ que el castellano asimiló a /-m-/. Como en otros rasgos, ya se documenta en El Libro de Aleixandre en palabras como camba (cama). Actualmente es un rasgo que está relativamente bien conservado y que se localiza en Asturias, en el occidente de León en palabras como llombu, palumba; incluso en la toponimia en Lomba, Lombillo entre otros nombres. También en Zamora donde sí encontramos soluciones castellanas aunque se conserva el grupo /-mb-/ en la toponimia, aunque señala De Andrés Díaz que en el castellano de León, Zamora y Salamanca se conserva en series limitadas de palabras (De Andrés Díaz, 2013: 208). Muy conservado lo encontramos en Miranda (Portugal), y en Extremadura se reduce a casos aislados (M. Pidal, 1906: 66 [2006]). La conservación de este grupo hace coincidir al leonés con el gallego frente a la solución castellana.

\subsubsection{El fonema palatal $/ \check{\mathbf{s}} /$}

El origen de este sonido se encuentra en los grupos latinos /-sk-/ y /-ssj-/. Debido a la confusión en el fonema sordo de /ž/ y de /š/ el leonés dio como resultado /šs/, igual que el castellano en un primer momento, que evolucionó posteriormente a /x/. Lo encontramos en palabras como xato, xelada, entre otras (Morala y Gancedo, 2009:93). Este rasgo se mantiene con gran vigencia en las hablas asturianas y en el occidente de León: Babia, Laciana y La Cabrera. En Zamora se localiza en Sanabria mientras que en Aliste aparecen ya formas castellanizadas como enjambre o tejo (Zamora Vicente, 1974:140).

\subsubsection{Otros rasgos}

Dentro del consonantismo, existen otros rasgos que quizá sean menos significativos. La solución más frecuente que el leonés dio al grupo /-kt-/ fue el resultado palatal /ĉ/ 
común al castellano, aunque en zonas tanto del occidente de León como de Asturias y en puntos de Sanabria se documenta la solución /-it-/ en común con la lengua gallega.

El grupo /m'n/ ya desde antiguo dio como resultado en leonés la asimilación a $/ \mathrm{m} /$ o la conservación de las dos consonantes. Hoy es frecuente encontrar la evolución a $/ \mathrm{m} /$ en el asturiano occidental y central mientras que en el oriental lo más frecuente es encontrar el grupo /-mbr-/. En León la solución leonesa la encontramos fundamentalmente en la zona noroccidental en palabras como fema (hembra) o fame (hambre), entre otras. En Zamora quedan restos en la parte de Sanabria (M. Pidal, 1906: 69 [2006]).

\subsubsection{Vocalismo}

\subsubsection{Diptongos}

Uno de los rasgos que caracterizó al leonés y al castellano frente a otros romances fue la diptongación de las vocales breves tónicas /ě/ y /ŏ/, que se produce incluso ante yod. Menéndez Pidal afirma que ya desde los textos antiguos encontramos gran vacilación en este fenómeno con formas no diptongadas e incluso diptongadas de manera anómala (M. Pidal, 1906: 44 [2006]). Señala Zamora Vicente que este hecho hizo que algunos estudiosos llegaran incluso a considerar que la diptongación no era propia del leonés. Estas teorías fueron después desechadas ya que los casos de monoptongación se deben a la influencia del gallego, por una parte, y a casos de ultracorrección por otra (Zamora Vicente, 1974: 90). Además añade este autor que a ello hay que añadir la incapacidad de los escribanos para representar los sonidos nuevos que surgen de la diptongación. Las soluciones al diptongo procedente de /ŏ/ no son solo /ue/ sino también /uo/ e incluso /ua/. La /ŏ / también diptonga ante yod. Este es uno de los rasgos más característicos del habla viva, especialmente en Asturias central, occidental, en la zona de Sajambre y en Miranda (Portugal). En cuanto a la /ě/, encontramos en leonés las formas /ie/ /ia/ que incluso aparecen como resultado de la diptongación de las formas del verbo ser y de la conjunción latina ĕt que el castellano mantuvo sin diptongar puesto que las consideró átonas. A diferencia de la /ŏ/ seguida yod, en el caso de la /ě/ seguida de yod la diptongación tuvo menos vigencia ya que se encuentra prácticamente reducida a las formas verbales, por ejemplo en tiengo frente a tengo.

\subsubsection{Conservación de los diptongos decrecientes}


Se trata de un rasgo que delimita claramente el leonés occidental caracterizado por la conservación de los diptongos /ou/, /ei/ igual que el gallego, del resto del leonés que coincide con el castellano y los reduce a /o/, /e/. Por tanto, lo encontramos en el asturiano occidental, incluso en esta zona diptongos decrecientes no etimológicos, especialmente en posición inicial, por ejemplo en eidá < aetate (De Andrés Díaz, 2013: 98). En León señala Morala que lo podemos encontrar al occidente de la Ribera del Órbigo, por ejemplo en palabras como cousa y, más al norte, en la divisoria entre el Luna y el Bernesga (Morala y Gancedo, 2009: 78). En Zamora también se mantiene en zonas de Sanabria, Viñas o Villarino; y en Salamanca solo se localiza en ejemplos aislados. El diptongo decreciente /ei/ se localiza ampliamente en la toponimia asturiana y especialmente en el sufijo latino -ariu que dio el resultado -eiro y aparece ampliamente documentado en Asturias, en el occidente de León, en la comarca zamorana de Sanabria, en Miranda (Portugal) y en Salamanca, como en el diptongo /ou/, se recogen casos aislados (M. Pidal, 1906: 49 [2006]).

\subsubsection{Vocales finales}

Un rasgo característico del leonés es la tendencia al cierre de la /-o/ y /-e/ finales por /u/, /-i/, rasgo que ya aparece desde antiguo en la documentación tanto leonesa como asturiana. Señala Menéndez Pidal que actualmente en Asturias el fenómeno presenta una distribución compleja aunque en el caso de las vocales velares hay una tendencia generalizada al cierre en el masculino singular pero no en el plural buenu frente a buenos. Este mismo fenómeno se localiza en León, siendo más frecuente en la serie velar que en la palatal. Ejemplos de cierre de vocales finales encontramos también en la comarca de Sayago en Zamora, y en parte de Salamanca y Cáceres. Además, localizado en un territorio reducido del asturiano central, encontramos que las terminaciones -as, ais, -an cambian la /a/ por /e/, cambio que es desconocido en el occidente de Asturias y en León (M. Pidal, 1906: 53 [2006]).

Otro fenómeno significativo del leonés que atañe a las vocales finales es el paso de la terminación -ino del asturiano a -in en el singular ya que de nuevo en el plural no se produce tal fenómeno, encontramos molin frente a molinos. Este rasgo no se produce cuando se trata de nombres bisílabos. En la zona occidental de León se produce alternancia de los finales -in, -ino.

Finalmente, con respecto a las vocales finales, hay que señalar que ya desde los textos antiguos encontramos casos de conservación de una /-e/ final tras /-d/ romance, 
por ejemplo en palabras como necesidade o mezquindade. Este fenómeno también se produce en algunos partes tras /-1/, /-r/. En León lo encontramos en Babia, Laciana, Maragatería y La Cabrera en árbole, cuchare, entre otras palabras, y en los infinitivos. Incluso se localiza en puntos próximos a la ciudad de León ya que se trata de un fenómeno vivo especialmente en el habla popular. Además se localiza en otras zonas como Sanabria, Aliste en Zamora o en Miranda (Portugal) (M. Pidal, 1906: 55-56 [2006]).

\subsubsection{Epéntesis de yod en la terminación}

Ya desde los textos antiguos aparece en leonés una /i/ añadida que no tiene explicación etimológica, es la llamada yod epentética. Algunos autores señalan que existen varios factores que pudieron contribuir a este fenómeno como la confusión entre verbos en -ar y en -iar y la extensión analógica de la terminación de sustantivos deverbales formados sobre verbos en -iar (De Andrés Díaz, 2013: 102). Actualmente, se trata de un rasgo muy extendido por todo el territorio comprendido por el leonés. No obstante, señala Morala que es un fenómeno que también afecta al resto de los romances hispánicos, aunque sea más frecuente en leonés. Este dato ha llevado a veces a considerar leonesismos palabras que pertenecen al español general como congrio o andancio (Morala y Gancedo, 2009:83).

\subsubsection{Aspectos morfológicos}

En los rasgos morfológicos conviene reseñar aquello que afecta directamente a las palabras, fundamentalmente lo relacionado con la derivación de los sustantivos (sufijos) y no a su combinación puesto que se trata en la parte de trabajo de léxico.

El sufijo -ino ha evolucionado a -in fundamentalmente en el noroeste del dominio leonés y en Asturias, fuera de esta zona lo común es encontrar la forma -ino. No obstante, en leonés, especialmente en Asturias, es frecuente que se use este sufijo como diminutivo, por ejemplo zapatín, afectando no solo al sustantivo sino también a otras categorías gramaticales como el adjetivo e incluso el adverbio (despacín). En León este sufijo se localiza en el noroeste pero en La Cabrera alterna con -ico, -ica, sufijo también característico de Miranda (Portugal). En el resto de territorios del leonés lo usual es la forma -ino (Zamora Vicente, 1974: 164).

Otro sufijo característico es -al, -ar para la formación de nombres de árboles, especialmente frutales que suelen tener género femenino. Así en Asturias se localiza la 
cerezal o la castañal, entre otros. En León se documentan las terminaciones -al, -ar pero alternan entre el femenino y el masculino. Así en Babia y Laciana encontramos el cerezal mientras que en La Ribera del Órbigo la cerezal. En otras zonas es también frecuente la alternancia, por ejemplo en Salamanca el sufijo -al se usa para formar nombres de árboles femeninos, mientras que en Extremadura son siempre masculinos (Zamora Vicente, 1974: 165). 
3. ESTUDIO DEL LÉXICO 


\subsection{INDUMENTARIA Y ARREGLO PERSONAL}

Uno de los campos mejor representados en los inventarios de bienes es el de la vestimenta, que aquí aparece bajo el título indumentaria y arreglo personal ya que en este apartado se incluyen diversos tipos de objetos. La vestimenta tanto masculina como femenina que aquí se documenta, se divide en ropa interior y ropa exterior, siguiendo un criterio de agrupación, divido a su vez esta en ropa de abrigo y ropa de cintura para arriba y de cintura para abajo. Otro grupo de voces que son importantes, puesto que formaban parte de la vestimenta de estos siglos, es el que tiene que ver con las prendas que cubrían la cabeza, por ello se diferencia entre complementos de cabeza y otros. Finalmente dentro del apartado de indumentaria, he establecido un subgrupo para el calzado y otro para las joyas, importantes en los inventarios ya que servían de adorno pero también de símbolo religioso, aunque no abundan en los inventarios analizados.

\subsubsection{Ropa interior}

\section{BRAGA}

Sust. f. 'Prenda interior femenina e infantil, que cubre desde la parte inferior del tronco y tiene dos aberturas en las piernas'. 'Calzón' (DRAE). Término procedente del lat. braca y este a su vez del galo (DECH, s.v. braga).

Unas bragas de frisa buenas (Santibáñez de la Isla, 1844)

Unas bragas biejas (Santibáñez de la Isla, 1844)

El significado con el que se utiliza es el de 'calzón' ya que es un término que se empleaba para designar las prendas masculinas que se colocaban de la cintura para abajo. Además, la acepción que hoy conocemos del término no se recoge en el diccionario académico hasta la edición de 1950, por tanto, en la época a la que pertenecen estos inventarios, el significado más común era el de 'calzón'. Los términos braga y calzón son sinónimos pero se puede observar un uso diferenciado en cuanto a la cronología ya que en los siglos XVII y XVIII abunda el término calzón y en ningún caso aparece braga, y en el S. XIX ambos términos conviven aunque el término calzón tiene un uso mucho menor y no aparece en los inventarios en los que se han recogido los dos ejemplos de braga. No obstante, el término braga es sustituido por el de calzón en la zona de Alija del Infantado y la Ribera del Órbigo Bajo (Cavero y Alonso, 2002: 282), dato que explica la escasez de la voz braga en el corpus. Estas prendas suelen documentarse siempre haciendo referencia, bien al tipo de tela con la que están 
fabricadas, bien a su estado.

\section{CALCETAS [calzetas]}

Sust. f. 'Media. Prenda que cubre el pie y la pierna' (DRAE). Término procedente del latín vulgar calcěa 'media', derivado del latín calceus 'zapato' (DECH, s.v. calza).

Un par de calcetas (Coomonte de la Vega, 1643)

Seis pares de calzetas de ylo de pana (La Bañeza, 1643)

Sendos pares de calzetas finas de ylo (La Bañeza, 1643)

Unas calzetas viejas (La Bañeza, 1721)

Tres pares de calzetas (La Bañeza, 1721)

Seis pares de calzetas buenas (Robledo de la Valduerna, 1726)

Tres pares de calzetas (Laguna de Negrillos, 1734)

Cinco pares de calcetas (Grajal de la Ribera, 1806)

Siete pares de calzetas (Alija del Infantado, 1812)

Seis pares de calzetas de hombre (La Bañeza, 1829)

Seis pares de calzetas de ilo (Calzada, 1838)

Tres pares de calzetas (Requejo de la Vega, 1839)

Se trata de una palabra de uso general. El significado con el que aparece es el de 'calcetín' o 'media'. Estas medias se tejían a mano con hilo de lino o de la lana de las ovejas. El término aparece bajo la forma normativa, pero es más frecuente que aparezca con la grafía "z" debido a la vacilación gráfica.

\section{CALZÓN}

Sust. m. 'Prenda de vestir con dos perneras, que cubre el cuerpo desde la cintura hasta una altura variable de los muslos' (DRAE). Término derivado de calza, del latín vulgar *calcěa 'media', del latín calceus 'zapato' (DECH, s.v. calza).

Unos calzones usados también de paño negro (Laguna de Negrillos, 1722)

Unos calzones de paño (Coomonte de la Vega, 1722)

Unos calzones biexos (Grajal de la Ribera, 1723)

Unos calzones muy viejos (Coomonte de la Vega, 1724)

Unos calzones forrados en lienzo (Laguna de Negrillos, 1725)

Una casaca chupa y calzón de paño (Robledo de la Valduerna, 1726)

Unos calzones de paño de Segovia viejos (Robledo de la Valduerna, 1726)

Unos calzones viejos de nobleza (Robledo de la Valduerna, 1726)

Dos pares de calzones de ante biejos (Robledo de la Valduerna, 1726)

Quatro pares de calzones de frisa (Palacios de la Valduerna, 1727)

Una enguarina de estameña prensada y unos calzones de estameña casera (Grajal de la Ribera, 1730)

Dos ropillas de pardo y unos calzones de lo mismo (Destriana, 1730)

Unos calzones de estameña nuebos (Alija del Infantado, 1734)

Dos capas usadas de lana vieja y una casaca, chupa y calzón de paño ordinario (Laguna de Negrillos, 1734)

Una chupa y calzón azul de paño fardero (La Bañeza, 1743)

Unos calzones de camelote mui viejos (La Bañeza, 1754)

Unos calzones nuebos (Castrocalbón, 1814) 
Unos calzones de estudillo aforrados (Castrillo de la Valduerna, 1828)

Un par de calzones de estameña usados (Quintana del Marco, 1839)

El término es común a lo largo de todo el corpus estudiado. Puede aparecer tanto en singular como en plural, aunque es más frecuente su uso en masculino plural. El vocablo se utiliza siempre con el significado de 'pantalón de hombre', aunque en toda la zona leonesa este término tiene otros significados. Se trata de una prenda muy común en toda la zona comprendida por el P.J. de la Bañeza, como se refleja en los ejemplos. Esta prenda era de paño, podía ser de paño fuerte o basto (estameña, pardo, frisa, etc.) o de paño fino (de Segovia o de Astudillo). Como en otras ocasiones, el tipo de paño, así como el estado de la prenda se refleja siempre en los inventarios, ya que era una información válida para calcular el valor de la misma. Es un sinónimo de braga, aunque su uso es mayor.

\section{CALZONCILLO [canzoncillos, canconcillos, canzuncillos]}

Sust. m. 'Prenda de la ropa interior masculina, que cubre desde la cintura hasta parte de los muslos, cuyas perneras pueden ser de longitud variable' (DRAE). Término derivado de calzón, derivado a su vez de calza, del latín vulgar *calcěa 'media', derivado del latín calceus 'zapato' (DECH, s.v. calza).

Unos calzoncillos de lienzo ya viexos (Coomonte de la Vega, 1643)

Unos calzoncillos de estopa (Coomonte de la Vega, 1719)

Una camisa y unos calzoncillos viejos (Coomonte de la Vega, 1722)

Unos calzoncillos de lino (Laguna de Negrillos, 1725)

Dos pares de calzoncillos de morlés (Robledo de la Valduerna, 1726)

Otros tres pares de calzoncillos de lienzo nuebos (Robledo de la Valduerna, 1726)

Unos canconcillos de vayeta (Saludes de Castroponce, 1808)

Tres pares de calzoncillos vien usados (La Bañeza, 1829)

Dos pares de canzoncillos (Palacios de la Valduerna, 1831)

Quatro pares de canconcillos (Felechares, 1837)

Tres pares de canzoncillos de lienzo (Requejo de la Vega, 1839)

Tres pares de calzoncillos de lienzo finos (Destriana, 1843)

Otros tres pares de calzoncillos más usados (Destriana, 1843)

Unos canzuncillos usados (Santibáñez de la Isla, 1844)

Dos camisas y dos canconcillos (Destriana, 1870)

El término aparece bajo diferentes variantes formales. Junto a la forma normativa, encontramos con frecuencia la variante canzoncillos, donde se produce una asimilación de la /n/. Es una forma bastante frecuente en la zona, a pesar de que solo aparece en un caso en el CORDE donde se especifica que se oye en Salamanca. Por tanto, quizá se trate de una variante que se registra en zonas del dominio leonés. Con menos frecuencia se recoge en el corpus la forma canconcillos, donde además de la asimilación ya comentada, aparece la grafía "c" para representar la fricativa interdental. 
Probablemente, se trate de una "ç" donde se ha borrado el rasgo o se le ha olvidado al escribiente, es posible que se trate de un hecho gráfico. También encontramos otra variante canzuncillos en la que junto a la asimilación se produce una vacilación de las vocales átonas velares, vacilación muy común cuando la vocal tónica es una /i/. El significado con el que se utiliza el término en el corpus es el que da el DRAE, es decir, 'prenda interior masculina que solía ser de lienzo o lino'.

\section{CAMISA [camissa]}

Sust. f. 'Prenda interior femenina de lienzo blanco, larga hasta la rodilla sin mangas y algo escotada'. 'Prenda exterior masculina usada antiguamente, por lo común de tela blanca con rayas de otro color y el cuello formado por una tira estrecha'. 'Prenda de vestido hecha de lienzo, algodón u otra tela, de media largura que cubre el torso' (Le Men, 2000, s.v. camisa). Del lat. tardío camisia 'camisa' de or. galo (DECH, s.v. camisa).

Una camissa (Castrocalbón, 1643)

Una camisa de hombre de buen lienço nueba (Coomonte de la Vega, 1643)

Otra camisa de hombre con puntas (Coomonte de la Vega, 1643)

Una camisa de escusa de muger (Alija del Infantado, 1644)

Una camisa de lienço de muger buena (La Nora del Río, 1645)

Seis camisas cuatro de muger y dos de omvre (La Bañeza, 1649)

Seis camisas de lienzo usadas (Robledo de la Valduerna, 1726)

Seis camisas de morlés (Robledo de la Valduerna, 1726)

Una camisa de zerrón de muger (Palacios de la Valduerna, 1728)

Dos camisas lavradas de lienzo finos (Alija del Infantado, 1812)

Una camisa usada de mujer y otra vieja (Castrocalbón, 1814)

Ocho camisas de hombre muy vien tratadas (La Bañeza, 1829)

Seis camisas de mujer de lienzo grueso y maltratadas (La Bañeza, 1829)

Una camisa de mujer con guarnición (La Bañeza, 1829)

Una camisa abierta (Quintanilla de Somoza, 1831)

Dos camisas de fiesta (Destriana, 1843)

Cuatro camisas vuenas de lienzo fino (Destriana, 1843)

Otra camisa más vasta (Destriana, 1843)

Otra camisa vieja (Destriana, 1843)

Cinco camisas de la moza mayor dos buenas y dos medianas (Santibáñez de la Isla, 1844)

Cinco camisas de la moza pequeña dos buenas y dos medianas (Santibáñez de la Isla, 1844)

Se trata de un término muy común en los inventarios de esta zona. Designa una prenda que puede ser de hombre o de mujer. Normalmente eran de lienzo, a veces de lienzo gallego (cerrón), y estaban bordadas. En el caso de las camisas de hombre solían estar bordadas en blanco y en el caso de las camisas de mujer, bordadas en colores en el cuello y en las mangas (Casado, 1993: 240 y 260). Encontramos diferentes referencias a estos bordados en expresiones como: "labradas", “con guarnición” o “con puntas”. En el 
ejemplo de Destriana, aparece el complemento "de fiesta", donde se ha de suponer que al ser de fiesta llevaría también los bordados (op. cit. 241). Además es frecuente que el término aparezca con referencias al estado de la prenda.

\section{CORSÉ}

Sust. m. 'Prenda interior armada con ballenas usada por las mujeres para ceñirse el cuerpo desde debajo del pecho hasta las caderas' (DRAE). Del francés corset, diminutivo de corps (DECH, s.v. cuerpo).

Un corsé (Requejo de la Vega, 1839)

Es el único ejemplo encontrado. Se trata de un término que se utiliza en nuestra lengua especialmente a partir de la segunda mitad del siglo XVIII, abundando en el XIX, lo que explica que haya pocos ejemplos en el corpus ya que la muestra del XIX pertenece a la primera mitad. Probablemente en esta época no sea una prenda muy usual y además esté restringida a un tipo de personas de un nivel socio económico más bien elevado, lo que también explicaría la escasez de ejemplos. La Academia incorpora el término desde la edición de 1780, aunque especifica el uso de prenda interior de las mujeres a partir de la edición de 1884 .

\section{ENAGUAS [henaguas]}

Sust. f. 'Prenda interior femenina, similar a una falda y que se lleva debajo de esta' (DRAE). Del antiguo naguas, y este del taíno de Santo Domingo, donde designaba una especie de faldas de algodón que las indias llevaban hasta las rodillas; la /e-/ se introdujo por aglutinación en frases como estaba en naguas, evitando que pudiera entenderse en aguas (DECH, s.v. enagua).

Unas enaguas de damasco de lana (La Bañeza, 1643)

Unas enaguas de bayeta con galón (La Bañeza, 1643)

Dos pares de enaguas (La Bañeza, 1649)

Tres pares de henaguas usadas (La Bañeza, 1721)

Henaguas (Robledo de la Valduerna, 1726)

Dos henaguas de lienzo (Grajal de la Ribera, 1806)

Tres pares de enaguas (Saludes de Castroponce, 1808)

Unas enaguas buenas nuevas (Alija del Infantado, 1812)

Unas enaguas de guarnición (Alija del Infantado, 1812)

Tres pares de enaguas de mujer de lienzo ordinario (La Bañeza, 1829)

Unas enaguas de morsolina con guarnición (Requejo de la Vega, 1839)

Seis enaguas buenas (Santibáñez de la Isla, 1844)

Es un término que designa una prenda interior muy común en la vestimenta femenina. Se ponían debajo del zagalejo y sobre la camisa. Se hacían de diferentes 
tejidos, normalmente de lienzo, aunque también de otras telas más finas, como puede ser la muselina, y con puntillas especialmente para los días de fiesta.

\section{LIGA}

Sust. f. 'Cinta o banda de tejido elástico, a veces con hebilla, para asegurar las medias o los calcetines' (DRAE). Término derivado de ligar, del latín lĭgare 'atar', por vía semiculta (DECH, s.v. liga).

Sendos pares de ligas (La Bañeza, 1643)

Un par de ligas (La Bañeza, 1643)

Siete pares de ligas de seda (Requejo de la Vega, 1839)

Unas ligas maragatas (Destriana, 1843)

Es un término común que normalmente se documenta en plural y por pares y el significado es el que da el DRAE de 'cinta empleada para sujetar las medias'.

\section{MARAGATO/A}

Adj. f. 'Perteneciente o relativo a la Maragatería' (DRAE).

Unas ligas maragatas (Destriana, 1843)

Es el único ejemplo recogido. El término se encuentra en un inventario de una zona próxima a la Maragatería. Probablemente, se refiera a las ligas que se utilizaban para sujetar las medias del hombre y que eran de una gran labor de telar, algunas llevaban incluso letreros y solían ser de color encarnado con amarillo, azul y verde. En el caso de los hombres viudos las ligas eran de color oscuro con los letreros en blanco (Casado, 1993: 410).

\section{MEDIA}

Sust. f. 'Prenda de punto, seda, nailon, etc., que cubre el pie y la pierna hasta la rodilla o más arriba' (DRAE). Derivado de medio, del latín mĕdĭus íd. (DECH, s.v. media).

Dos pares de medias de lana (La Bañeza, 1641)

Dos pares de medias biexas de paño (Coomonte de la Vega, 1643)

Nuebe pares de medias de seda de muger (La Bañeza, 1643)

Sendos pares de medias de seda negras de onbre (La Bañeza, 1643)

Dos pares de medias finas de Ynglaterra (La Bañeza, 1643)

Unas medias moradas de punto biexas (Alija del Infantado, 1644)

Dos pares de zuecos y dos pares de medias (Coomonte de la Vega, 1719)

Un par de medias negras usadas (Coomonte de la Vega, 1722)

Un par de medias negras (Grajal de la Ribera, 1723)

Dos pares de medias blancas viejas (Coomonte de la Vega, 1724)

Tres pares de medias de seda viejas (Robledo de la Valduerna, 1726)

Unas medias blancas (Palacios de Jamuz, 1728)

Unas medias de mujer (La Bañeza, 1754) 
Quatro pares de medias de nylon (Grajal de la Ribera, 1806)

Unas medias de algodón (Alija del Infantado, 1812)

Cuatro pares de medias de lana negras muy repasadas (La Bañeza, 1829)

Tres pares de medias vlancas (Quintanilla de Somoza, 1831)

Dos pares de medias usadas (Felechares, 1837)

Un par de medias usadas de seda (Requejo de la Vega, 1839)

Un par de medias negras y otras blancas (Requejo de la Vega, 1839)

Tres pares de medias gris a lila (Requejo de la Vega, 1839)

Treinta pares de medias azules (Requejo de la Vega, 1839)

Un par de medias blancas caladas (Requejo de la Vega, 1839)

Unas medias nuebas (Santibáñez de la Isla, 1844)

Es un término muy frecuente en los inventarios puesto que designa una prenda común en la vestimenta diaria tanto de hombres como de mujeres. Las más comunes eran de lana, lino o algodón y las de color blanco y negro. Las medias de color blanco las solían usar las personas jóvenes y de mediana edad, mientras que las negras las solían usar las personas mayores. También, como reflejan los ejemplos, se encontraban medias de seda, estas solían tener mayor lujo o distinción.

\section{VALÓN [balón]}

Sust. m. El DRAE define el término en su $4^{\mathrm{a}}$ acepción como 'zaragüelles o greguescos al uso de los valones, que los introdujeron en España' (DRAE). Propiamente 'valones procedentes de Valonia', por haber sido introducidos por los cortesanos de esta procedencia, que acompañaron a Carlos V (DECH, s.v. valones).

Unos balones de paño buenos ya rotos de las entrepiernas con botones a los lados (Coomonte de la Vega, 1643)

Unos balones de estameña buenos (Alija del Infantado, 1644)

Unos balones de jerga negra buenos (Alija del Infantado, 1644)

Unos balones de pasamanos de estameña (Coomonte de la Vega, 1645)

Unos balones de estameña negra (Coomonte de la Vega, 1645)

Unos balones de frissa picarça ya viejos (Urdiales del Páramo, 1645)

Unos balones de frisa (La Antigua, 1648)

Dos valones (Villamor de Órbigo, 1648)

Unos balones de xerga usados (Coomonte de la Vega, 1650)

Unos balones biejos de Somonte (Coomonte de la Vega, 1719)

El término aparece con frecuencia en el corpus en los inventarios del S. XVII, apenas, salvo en un caso, en los del XVIII y no aparece ya en el S. XIX. Este mismo dato se constata en el CORDE donde se registran un número escaso de ejemplos del término, siete con esta acepción, todos ellos del S. XVII. La voz designa un tipo de calzones que se introdujeron en los SS. XVI y XVII y fue cuando más popularidad tuvieron, posteriormente quizá se usaron otro tipo de calzones o simplemente se generalizó este término puesto que en el corpus la palabra que abunda especialmente en el S. XVIII es la voz calzones que convive en el XIX con el término braga. En las relaciones encontradas 
siempre se citan haciendo referencia al tipo de tela y al estado y en todos los casos el término aparece usado en plural.

\section{VALONA [balona]}

Sust. f. El DRAE define el término en su $5^{\text {a }}$ acepción como 'cuello grande y vuelto sobre la espalda, hombros y pecho, que se usó especialmente en los siglos XVI y XVII'. Propiamente 'valones procedentes de Valonia', por haber sido introducidos por los cortesanos de esta procedencia, que acompañaron a Carlos V. La valona fue también prenda introducida por ellos (DECH, s.v. valones).

Quatro aderezos de balonas (Alija del Infantado, 1643)

Una cestita de prender balonas (Alija del Infantado, 1644)

Una cesta de paxas de espurrir balonas (Alija del Infantado, 1644)

Una balona de puntas buena (Alija del Infantado, 1644)

Tres valonas con sus puntas grandes finas (La Bañeza, 1649)

Una valona con sus vueltas de los caños de carmona con sus puntas (La Bañeza, 1649)

Una zesta de espurrir balonas (Alija del Infantado, 1650)

Dos balonas buenas (Alija del Infantado, 1650)

El término se asocia con una prenda de vestir, aunque en los ejemplos del corpus no hay referencias a si guarda relación con prendas masculinas, femeninas o ambas. En cualquier caso, siempre aparece con referencias al valor o a los adornos de la prenda "con puntas". Además, como se observa en los ejemplos del corpus, el término aparece en ocasiones asociado a la palabra cestas. Probablemente se esté refiriendo a una cesta que se emplea para el cuidado o bordado de esta prenda.

\section{ZAGALEJO [zagalexo]}

Sust. m. 'Refajo que usan las lugareñas' (DRAE). Término derivado de zagal, del árabe vulgar zaǵáll 'valiente, fuerte', que a veces toma el sentido de 'muchacho robusto' (DECH, s.v. zagal).

Un zagalejo de baeza blanco (La Bañeza, 1721)

Un zagalexo de bayeta paxiza (Saludes de Castroponce, 1808)

Un zagalexo de paño pardo tiñido (Saludes de Castroponce, 1808)

Son los únicos ejemplos recogidos en el corpus. El término zagalejo designa en León $y$, concretamente en este corpus, una 'prenda de vestir femenina que se ponía generalmente debajo del manteo, aunque en ocasiones podía quedar a la vista'. Su función era diversa, se utilizaba como ropa de abrigo, de trabajo o para armar el manteo (Cavero y Alonso, 2002: 70). Por ello no eran tan vistosos en telas y adornos como estos, solían ser de pardo o estameña y de colores blancos o pajizos, aunque también los 
había rojos y azules. Normalmente, no llevaban adornos. Es probable que no fuera una prenda tan común como otras de cintura para abajo pero vistas, porque no son muchos los ejemplos encontrados.

\subsubsection{Ropa exterior}

\subsubsection{Prendas de abrigo}

\section{ANGUARINA [anguariña, enguarina]}

Sust. f. 'Gabán rústico de paño burdo y sin mangas, que se pone sobre las demás prendas para protegerse del frío y de la lluvia' (DRAE). Se trata de un término procedente del ant. hungarina, der. ungarina, que se relaciona con la voz gallega angorina "capote de mangas perdidas que chegaba normalmente ás canelas.” (Estravís, 1986, s.v. angorina). Este término se ha recogido, en el corpus estudiado, bajo diferentes formas.

Una anguariña (La Bañeza, 1713)

Una anguariña de Baeza (La Bañeza 1713)

Una enguarina (Coomonte de la Vega, 1719)

Una anguariña (Laguna de Negrillos, 1722)

Una anguarina nueba (Castrocalbón, 1814)

Una enguariña de estameña (La Nora del Río, 1820)

Una enguariña de paño Astudillo (Quintana del Marco, 1839)

Una enguarina de paño pardo vieja (Quintana del Marco, 1839)

No se recogen ejemplos en los documentos analizados del siglo XVII, si bien, puede tratarse de una mera casualidad, aunque en el CORDE esta voz aparece fundamentalmente a partir del siglo XIX y solo se registra un ejemplo del S. XVII, lo que llevaría a pensar que es a partir de este momento cuando se usa con más frecuencia.

A la vista de los ejemplos, se puede observar que la forma estándar anguarina aparece en La Bañeza y en la zona más oriental (Laguna de Negrillos), mientras que la forma disimilada, aparece en las zonas más occidentales del área estudiada. Además, la alternancia entre /a/ y /e/ es frecuente en voces que comienzan por /an-/ y que en estos contextos sufren un proceso de indefinición en el timbre de la vocal inicial (Morala, 2011: 6). De nuevo, se encuentran documentados en el CORDE ejemplos con la disimilación /a e/ que aparecen en La Historia del famoso predicador Fray Gerundio de Campazas, obra de José Francisco de La Isla, escritor leonés. Sin embargo, en La Bañeza y en los pueblos próximos a esta localidad, encontramos además la terminación -iña, que podría justificarse por una influencia de la lengua gallega en esta zona. Con pequeñas matizaciones, en algunos diccionarios se dice que no tiene mangas (DRAE) y, en otros, que las mangas se llevan solo de adorno (Miguélez, 1993: 51). En el corpus 
analizado no se encuentran datos que nos permitan deducir si se trataba de una prenda con mangas o sin ellas, solo podemos saber que era una prenda de tejido más bien fosco, ya sea paño o estameña.

\section{CAPA}

Sust. f. 'Prenda de vestir larga y suelta, sin mangas, abierta por delante, que se lleva sobre los hombros encima del vestido' (DRAE). Término procedente del latín tardío cappa 'capucho' (DECH, s.v. capa).

Una capa de frechilla buena (Alija del Infantado, 1644)

Una capa de pardo nueba aforrado el quello en fustán (Coomonte de la Vega, 1645)

Una capa de estameña blanca (La Antigua, 1648)

Una capa de pardo grande casera (Laguna de Negrillos, 1722)

Una capa de paño usada (Coomonte de la Vega, 1722)

Una capa buena de paño negro de mujer con su buelta (Grajal de Ribera, 1723)

Una capa de paño de chinchón (Robledo de la Valduerna, 1726)

Una capa de frisa, otra de grechilla (Palacios de la Valduerna, 1727)

Una capa de pardo de capillo viejo (Palacios de la Valduerna, 1728)

Una capa de Somonte buena (Palacios de la Valduerna, 1730)

Una capa de brechilla viexa (Palacios de la Valduerna, 1730)

Dos capas usadas de lana vieja (Laguna de Negrillos, 1734)

Una capa de frechilla vieja (Requejo de la Vega, 1735)

Una capa de frechilla nueba (Santiago Millas, 1735)

Una capa de paño de Ávila (La Bañeza, 1743)

Una capa para homvre de paño con vueltas (Quintana del Marco, 1820)

Una capa de paño color de la lana apolillada (La Bañeza, 1829)

Una capa azul de buen uso (Requejo de la Vega, 1839)

Una capa de estudillo con sus bueltas (Destriana, 1843)

Una capa de paño husada (Santibáñez de la Isla, 1844)

Es un término muy frecuente en todo el corpus analizado ya que denomina una prenda muy común en el atuendo masculino de esta época. Así, según se observa en los ejemplos, el significado que tiene la voz en todos los casos es el reflejado por el DRAE. Las capas más comunes son las de pardo y las de paño. Como en otros términos referidos a prendas de vestir, es frecuente que en los inventarios se registre tanto el tipo de tela como el estado de la prenda, puesto que son datos importantes a la hora de valorar la misma. En la zona leonesa con este término se designan otros objetos como 'la sartén' o una 'parte de la manteca del cerdo' (Le Men, 2004, s.v. capa). Con estos dos significados no se ha encontrado ningún ejemplo. 


\section{CAPOTE [capotón]}

Sust. m. 'Capa de abrigo hecha con mangas y con menor vuelo que la capa común' (DRAE). Término derivado de capa, procedente del latín tardío cappa 'capucho' (DECH, s.v. capa).

Un capote de pardo biexo con sus pasamanos (Coomonte de la Vega, 1643)

Un capote de pardo cerrado bueno (Alija del Infantado, 1644)

Un capote de pardo ya viexo (Vidriales, 1645)

Un capote zerrado de parrilla y usado (Alija del Infantado, 1646)

Un capote de pardo zerrado bueno (Coomonte de la Vega, 1650)

Un capote mui usado con bueltas de nobleza (Robledo de la Valduerna, 1726)

Un cofre pequeño con su herraje, con zerradura y llave y en él un capote de camellón con su forro encarnado (Laguna de Negrillos, 1726)

Un capotón de ratina encarnado (Alija del Infantado, 1812)

Un capote viejo (La Nora del Río, 1823)

Un capote (Felechares, 1837)

Es un término común en la zona. Además del significado dado por el diccionario académico, en la parte noroccidental de León y de Zamora se denominaba también capote a una 'capa de los pastores' (Le Men, 2004, s.v. capote). En los ejemplos mostrados el término siempre se usa con el significado general de 'prenda de abrigo'. Sin embargo, en aquellos en los que se especifica "capote de pardo" se puede estar usando el término con la acepción de 'capa de pastores', ya que se trata de una tela basta de lana de oveja que se usaría para protegerse del frío. En aquellos ejemplos en los que se hace referencia a "pasamanos", "vueltas de nobleza", es decir, a elementos más lujosos, el significado probablemente es el ofrecido por el DRAE. La variante capotón, es un aumentativo de la voz capote.

\section{CAPOTILLO}

Sust. m. 'Prenda a manera de capote o capa que llegaba hasta la cintura' (DRAE). Derivado de capote, y este a su vez de capa, procedente del latín tardío cappa 'capucho' (DECH, s.v. capa).

Un capotillo de frechilla a medio traer (Alija del Infantado, 1644)

Un capotillo de pardo usado (Coomonte de la Vega, 1650)

Dos capotillos de bareta blanca (La Bañeza, 1754)

Son escasos los ejemplos que aparecen del término. Su significado es el de 'prenda de abrigo'. Se trata de un término procedente de la trashumancia, pero probablemente sea una voz muy general ya que, por ejemplo, en trabajos lexicográficos como el CORDE aparece en numerosas ocasiones y utilizado por autores muy diversos. 


\section{CERRADO/A [zerrado/a]}

Adj. m. y f. 'Estricto, rígido, terminante' (DRAE). Participio del verbo cerrar, del latín tardío serare, derivado de sera 'cerrojo', 'cerradura' (DECH, s.v. cerrar).

Un capote de pardo cerrado bueno (Alija del Infantado, 1644)

Un capote zerrado de parrilla y usado (Alija del Infantado, 1646)

Un capote de pardo zerrado bueno (Coomonte de la Vega, 1650)

En estos tres ejemplos, el término aparece junto a la voz capote, para designar un tipo de prenda de abrigo que generalmente solía ser de pardo.

\section{CHUPA}

Sust. y Adj. f. 'Chaqueta, chaquetilla' (DRAE). El término jubón es derivado del antiguo aljuba o juba, que a su vez procede del árabe ŷ́bba 'especie de gabán con mangas', en francés jupe, probablemente del francés se tomó el castellano chupa (DECH, s.v. jubón).

Una chupa de paño vieja y otra de estameña negra (Laguna de Negrillos, 1721)

Una casaca chupa y calzón de paño de limiste negro (Palacios de la Valduerna, 1726)

Una casaca de terciopelo negro chupa y calzón de lo mismo (Palacios de la Valduerna, 1726)

Una chupa de grana con botoncillos (Palacios de la Valduerna, 1726)

Dos capas usadas de lana vieja y una casaca, chupa y calzón de paño ordinario (Laguna de Negrillos, 1734)

Casaca chupa y calzón de pardo de hombre (La Bañeza, 1743)

Una chupa y calzón azul de paño fardero (La Bañeza, 1743)

Casaca y chupa del mismo paño (La Bañeza, 1743)

Una chupa de estudillo con botones de ballena (Castrillo de la Valduerna, 1828)

Se trata de una prenda que forma parte de la indumentaria masculina y que pertenece a los llamados sobretodos, es decir, prendas de abrigo. La chupa es una prenda frecuente en los inventarios de esta zona hasta el S. XVIII, ya que a lo largo del S. XIX es poco frecuente encontrarla (todos los ejemplos encontrados pertenecen al S. XVIII y tan solo uno al S. XIX). Además, como reflejan los ejemplos, es frecuente que a lo largo de esta época esta prenda que normalmente era de paño, hiciera juego con el calzón. Por ello, siempre aparecen juntos chupa y calzón. También es frecuente que esté en consonancia de color con la casaca (Casado, 1993: 264).

FRISA (vid. textil/tejidos) 


\section{GABARDINA}

Sust. f. 'Impermeable confeccionado de la tela que recibe el mismo nombre' (DRAE). Resultado de un cruce de gabán con gabardina, diminutivo del sinónimo tabardo (DECH, s.v. gabardina).

Una gabardina de pardo biexa (Alija del Infantado, 1644)

Una gabardina biexa (La Nora del Río, 1645)

El término designa una prenda de vestir que no se corresponde con el concepto actual de gabardina. El DRAE en su $4^{\text {a }}$ edición define la voz como 'ropón con mangas ajustadas, usado por los labradores en algunas comarcas'. Esta acepción, que señala como poco usada, aparece en las primeras ediciones como la acepción principal. Por tanto, es lógico pensar que es el significado que tiene el término en los ejemplos extraídos del inventario que son escasos, puesto que abundan más otro tipo de prendas como la anguarina, aunque esta no tiene mangas, o la casaca.

\section{PARLAMENTA [parlamentaria]}

El término como tal no aparece recogido en el DRAE, remite al verbo parlamentar.

Una parlamentaria de escarlatín (Alija del Infantado, 1812)

Es el único ejemplo del término que aparece en el corpus estudiado que, como se deduce del contexto en el que se encuentra, designa un tipo de prenda de vestir. La parlamentaria o parlamenta es 'una pequeña capa de paño o encaje con dos esclavinas que cae desde los hombros hasta la cintura y se abrocha en el cuello' (Casado, 1993: 511). Señala además esta autora que es una prenda elegante en Galicia. Por tanto, parece tratarse de una vestimenta de distinción, dato que viene corroborado por el tipo de tela del que está confeccionado. Tal vez por este hecho o porque quizá fuera más frecuente en Galicia, son escasos los ejemplos que se encuentran del término pues no solo no aparece recogido en diccionarios como el DRAE o el NTLLE, sino que además en corpus léxicos como el CORDE no se recoge ningún ejemplo del término con este significado, sino que la voz parlamenta siempre aparece relacionada con el verbo parlamentar.

\section{PELLIZA}

Sust. f. 'Prenda de abrigo hecha o forrada de pieles finas'. 'Chaqueta de abrigo con el cuello y las bocamangas reforzadas de otra tela' (DRAE). Término derivado de piel, del latín pĕllis (DECH, s.v. piel).

Una pelliza de Canbrai usada (Palacios de la Valduerna, 1726)

Una manga de punto para meter las pellizas (Palacios de la Valduerna, 1726) 
Son los únicos ejemplos encontrados, aunque es una palabra conocida en la zona. Concretamente la pelliza nombra una prenda de abrigo, 'un abrigo grueso con el cuello de pelo y semejante al tabardo, que usan los hombres en invierno' (Rivas, 1996: 178).

\subsubsection{Prendas de cintura para arriba}

\section{ALMILLA [almilla, armilla]}

Sust. f. 'Especie de jubón, con mangas o sin ellas, ajustado al cuerpo' (DRAE). Covarrubias explica el origen del término de la siguiente forma: "Es cierta vestidura militar con medias mangas que no llegan al codo. Llevábanse debajo de las armas de donde tomaron el nombre de armilla y de armilla "corrompidamente" surgiría almilla (Covarrubias, s.v. almilla). Sin embargo, en el $D E C H$ se dice que se trata de un vocablo procedente de alma, cuya etimología se encuentra en el término latino anima "aliento, alma”. Derivado de este término procede almilla, denominada así por su unión íntima al cuerpo (DECH, s.v. alma).

Una almilla de escarlatín (Palacios de la Valduerna, 1730)

Una almilla (La Bañeza, 1714)

Una almilla de felpa verde vieja (Robledo de la Valduerna, 1726)

Una almilla de felpa verde vieja (Robledo de la Valduerna, 1726)

Dos almillas de lienzo nuebas (Robledo de la Valduerna, 1726)

Dos pares de armillas (Laguna de Negrillos, 1734)

Una armilla de vayeta pajiza (La Nora del Río, 1823)

Se trata de una prenda que era usada tanto por hombres como por mujeres, aunque Covarrubias señala que es de uso masculino (Almeda Molina: 2013). Encontramos este término en inventarios de los siglos XVIII y XIX, no así en el siglo XVII. Los casos encontrados se localizan en la zona más occidental del entorno analizado. Como puede observarse, los ejemplos presentan la forma académica en todos los casos excepto en el de La Nora del Río. Es curioso, en este sentido, que la Academia remite la voz armilla a la entrada almilla en sus primeras ediciones, a partir de 1791 ya no hace esa referencia. En el CORDE aparecen muy pocos casos en los que se utilice la forma armilla con el significado de almilla, tres ejemplos anónimos tomados de inventarios del siglo XVII y un ejemplo del siglo XVIII de Antonio de Ulloa: "las que usan apretadorcillo o armilla lo abrochan ceñido al cuerpo". En la zona leonesa, entre otras, es frecuente la confusión /l/ /r/. 


\section{ARMADOR}

Sust. m. El DRAE da como $4^{\mathrm{a}}$ acepción la de 'jubón'. Término derivado de armar, del latín arma (DECH, s.v. arma).

Tres armadores (Castrocalbón, 1814)

Un armador de pana usado (Palacios de la Valduerna, 1831)

Un armador de pana azul (Palacios de la Valduerna, 1831)

Un armador de pana (San Feliz, 1838)

Un costal bueno y un armador de palmilla (San Feliz, 1838)

El término armador que aparece en los inventarios tiene un significado más preciso que el que da la Academia. A principios del S. XIX existían varios tipos de chalecos, uno de ellos eran los armadores, chalecos de escote cuadrado con doble fila de botones. Esta prenda era frecuente en la zona del Bajo Órbigo (Casado, 1993: 261), aunque los ejemplos encontrados pertenecen a otras zonas de las tierras bañezanas, es muy probable que el término se esté utilizando con este significado concreto. En el corpus es mucho más frecuente el término general chaleco, pero probablemente, en estos casos se utilice el término armador para denominar este chaleco que tiene unas características concretas.

\section{CASACA}

Sust. f. 'Vestidura ceñida al cuerpo, generalmente de uniforme, con mangas que llegan hasta la muñeca, y con faldones hasta las corvas' (DRAE). Término procedente, probablemente del fr. casaque, de origen incierto (DECH, s.v. casaca).

Una casaca de paño (La Bañeza, 1721)

Una casaca de paño forrada en estameña (Coomonte de la Vega, 1722)

Una casaca de paño de Segovia negro (Laguna de Negrillos, 1725)

Una casaca chupa y calzón de paño (Robledo de la Valduerna, 1726)

Una casaca de terziopelo negro chupa y calzón de lo mismo (Robledo de la Valduerna, 1726)

Una casaca de carro de oro vieja (Robledo de la Valduerna, 1726)

Una casaca de lamparilla vieja (Robledo de la Valduerna, 1726)

Casaca chupa y calzón de pardo de hombre (La Bañeza, 1743)

Una casaca negra cuyas alaxas las mandó Zenteno a su hermano (Laguna de Negrillos, 1740)

Una casaca de paño forrada en mitán dorado (Laguna de Negrillos, 1740)

Una casaca bieja de terziopelo (La Bañeza, 1754)

Una casaca antigua paño negro muy vieja (La Bañeza, 1829)

Es un término muy frecuente, especialmente en el S. XVIII, fecha en la que se recogen prácticamente todos los ejemplos. Se trata de una prenda exterior que, generalmente era de paño, aunque podía ser de otro tipo de tejido como terciopelo, lamparilla o estameña. Formaba parte del vestuario masculino aunque también la usaban 
las mujeres, pero era menos frecuente. Aparece fundamentalmente en los inventarios del S. XVIII, y es común que aparezca junto a otras dos prendas de hombre: chupa y calzón. Es probable que esta prenda se conociera también con el nombre de chamberga ya que Varela Merino señala que la chamberga que define Autoridades como 'casaca ancha cuya longitud pasaba de las rodillas', recibió el nombre de casaca chamberga y de forma más general el de casaca cuyo origen es de más de un siglo anterior al de chamberga (Varela Merino, 2000: 2415). En este corpus, si embargo, apenas se documenta la voz chamberga (un solo ejemplo) y todos los ejemplos de casaca son del S. XVIII en adelante.

\section{CHAMBERGA}

Adj. 'Se dice de ciertas prendas del uniforme del regimiento creado en Madrid durante la menor edad de Carlos II para su guardia. Casaca chamberga' (DRAE). Se aplicó primeramente en calidad de adjetivo, a la casaca chamberga que trajeron el General Schomberg y sus tropas cuando vinieron de Francia a la guerra de Cataluña; y de ahí pasó luego a un regimiento formado y finalmente al sombrero chambergo y a otras prendas llevadas por los militares que vestían chamberga. Del nombre del general que introdujo aquella casaca (DECH, s.v. chamberga).

En retazos de listones y chambergas (Requejo de la Vega, 1839)

El significado más común del término es el que aparece en el diccionario académico con el que se designa un tipo de casaca, término que por otra parte aparece de forma más generalizada en el corpus. El contexto en el que aparece la palabra junto al sustantivo retazos plantea dudas sobre la acepción que este puede tener e incluso se puede llegar a pensar que podría estar utilizándose con otro significado. La Academia define el término en la $7^{\mathrm{a}}$ acepción como 'género de cinta de seda muy estrecha', aunque matiza que es usada en Andalucía. Esta acepción no resulta ilógica en el contexto en el que aparece en este corpus, teniendo en cuenta además que la voz chamberga está en plural y que se documenta en la relación de bienes de una tienda que por su contenido, parece tratarse de una mercería. No obstante, solo aparece en este caso y no hay más datos que ayuden a precisar el significado exacto del término. 


\section{CHALECO}

Sust. m. 'Prenda de vestir sin mangas, que cubre el tronco hasta la cintura y se suele poner encima de la camisa o blusa' (DRAE). Del árabe $\hat{y} a l \hat{\imath} k a$, y este del turco ielek (DECH, s.v. chaleco).

Un chaleco de monfor azul (Castrocalbón, 1814)

Un chaleco de paño fino (La Nora del Río, 1823)

Dos chalecos vlancos viejos de Colonia (La Nora del Río, 1823)

Un chaleco de paño negro (La Nora del Río, 1823)

Un chaleco y una chaqueta (La Nora del Río, 1823)

Un chaleco de paño con botones de gueso (Castrillo de la Valduerna, 1828)

Cuatro chalecos vlancos interiores y pasados (La Bañeza, 1829)

Un chaleco de colonia de homvre viejo (La Bañeza, 1829)

Un chaleco paño negro muy lleno de manchas y viejo (La Bañeza, 1829)

Un chaleco rozado (Quintanilla de Somoza, 1831)

Tres chalecos viejos (Requejo de la Vega, 1839)

Un chaleco de seda nuevo (Requejo de la Vega, 1839)

Tres chalecos dos de paño (Felechares, 1843)

Un chaleco de paño (Destriana, 1843)

Un sayo, un chaleco y unos calzones (Destriana, 1843)

Un chaleco de seda negra (Destriana, 1843)

Un chaleco de sarga viejo (Destriana, 1843)

Otro (chaleco) de terciopelo viejo (Destriana, 1843)

Es un término muy común, aunque no se han recogido ejemplos en los siglos XVIII y XIX. Lo más destacado que se reseña en los inventarios acerca de esta prenda tiene que ver con la tela, normalmente de paño, y el color. Solamente cuando llevaban botones y estos tenían alguna singularidad, también se reflejaba en el inventario, como en el ejemplo de Castrillo de la Valduerna.

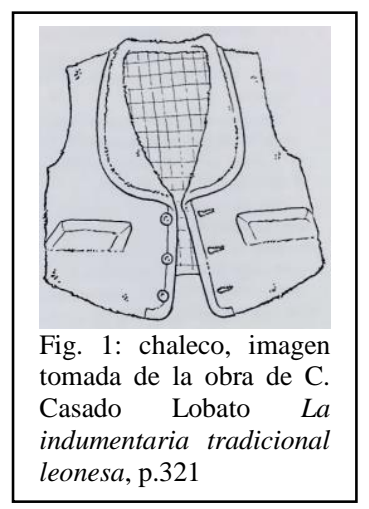

\section{CHAMBRA}

Sust. f. 'Vestidura corta, a modo de blusa con poco o ningún adorno, que usan las mujeres sobre la camisa' $(D R A E)$. Se trata de una abreviación del francés robe de chambre, porque sirve para permanecer en la chambre o cuarto, del latín caměra (DECH, s.v. chambra).

Dos chambras (Requejo de la Vega, 1839)

Una chambra bieja (Requejo de la Vega, 1839)

Solo se han recogido estos dos ejemplos, los dos pertenecientes al S. XIX. Se trata de un término que en los lugares donde se localiza, no solo en León, sino en otros lugares de la Península, tiene el significado de 'blusa'. En esta zona, próxima a La Bañeza se trata de una prenda que formaría parte de los sobretodos, es decir, su 
significado es el de 'prenda de vestir femenina de lana, con forma de chaqueta corta y con botones por delante que, colocada por encima de la ropa interior, se acompaña con una falda o saya' (Rivas, 1996: 67). Hay otros términos que aluden a palabras que denominan otras prendas que sirven de sobretodos cuya aparición es mucho más frecuente en los inventarios, quizá porque se refieren a prendas más comunes o propias de esta zona.

\section{CHAQUETA}

Sust. f. 'Prenda exterior de vestir, con mangas y abierta por delante, que cubre el tronco' (DRAE). Del francés jaquette 'chaqueta larga', especialmente la que llevaban antes los campesinos, derivado del francés antiguo jaque 'especie de jubón' (DECH, s.v. chaqueta).

Una chaqueta vieja (La Nora del Río, 1823)

Una chaqueta de punto vieja (La Nora del Río, 1823)

Una chaqueta de punto vlanca (La Nora del Río, 1823)

Un chaleco y chaqueta (La Nora del Río, 1823)

Unos calzones y una chaqueta de paño (La Nora del Río, 1823)

Una chaqueta bieja usada (Requejo de la Vega, 1839)

Una chaqueta interior de bambari (Destriana, 1843)

Se trata de un término que no se documenta hasta 1804. El DRAE lo recoge a partir de la edición de 1917. Originariamente el diccionario académico define el término a partir de la voz chaleco y hacia 1869 lo define como prenda independiente. Estos datos cronológicos explican que no aparezcan ejemplos en el corpus en fechas anteriores al S. XIX. Por otra parte, puesto que se trata de un término y una prenda moderna, el número de chaquetas que aparecían en los inventarios era escaso. Este dato se ve reflejado en el hecho de que prácticemente todos lo ejemplos encontrados pertenecen al mismo inventario.

CUERPO (vid. bienes inmuebles)

\section{CUERPO}

Sust. m. 'Parte del vestido, que cubre desde el cuello o los hombros hasta la cintura' (DRAE). Del latín cŏrpus, -бris (DECH, s.v. cuerpo).

Dos pares de cuerpos de lienço (La Bañeza, 1641)

Unos cuerpos de paño berde (La Bañeza, 1641)

Unos cuerpos colorados de media grana (Vidriales, 1645)

Unos cuerpos berdes nuebos con ribetes (Coomonte de la Vega, 1645)

Unos cuerpos de grana con ribetes de terciopelo (Coomonte de la Vega, 1645)

Unos cuerpos berdes digo azules biexos (Coomonte de la Vega, 1645) 
Unos cuerpos berdes biexos (Alija del Infantado, 1647)

Unos cuerpos con pasamanos (La Antigua, 1648)

Quatro cuerpos de breviarios buenos (Robledo de la Valduerna, 1726)

Unos cuerpos encarnados guarnezidos (Miñambres, 1727)

Unos cuerpos colorados (Palacios de Jamuz, 1728)

Unos cuerpos encarnados con galón de plata falsa (Toral, 1728)

Unos cuerpos nuebos de brechilla (Toral, 1728)

Unos cuerpos de escarlatín con guarnición (Palacios de la Valduerna, 1730)

Unos cuerpos de sempiterna (Grajal de la Ribera, 1730)

Unos cuerpos berdes barrados (Destriana, 1730)

Unos cuerpos de escarlatín (Miñambres, 1731)

Unos cuerpos de somonte (La Isla, 1735)

Unos cuerpos de palmilla con sus guarniciones (Grajal de la Ribera, 1750)

Unos cuerpos espolinaos (La Isla, 1829)

Es un término que aparece en casi todos los inventarios recogidos de los SS. XVII y XVIII. La voz designa una 'prenda femenina parecida al corpiño, pero guarnecida con pasamanería y terciopelo' (Casado, 1991: 505). Normalmente eran de lana y solían ser de colores vivos, rojos, verdes o azules. El término siempre se registra en plural, Egido Fernández señala que es poco probable que el uso del plural designe más de una prenda, ya que no es común tener dos vestimentas idénticas. Explica que tal vez el uso del plural se deba a que se trata de un resto de la forma del neutro latino de la tercera declinación corpus, o de una adaptación del francés corps (Egido Fernández, 2010: 99). Esta acepción no está registrada en el DRAE. No se recogen ejemplos de corpiño en ningún inventario, pero sí de otros términos que podrían considerarse sinónimos, como justillo. Este término no aparece en los inventarios analizados del S. XVII y apenas en los del S. XVIII, pero sí es frecuente en los del S. XIX, donde solo se registra un ejemplo de cuerpos. Además de la prenda de vestir, la voz cuerpos es utilizada en el ejemplo de Robledo de la Valduerna de 1726 con otro significado. Probablemente está usada con la acepción que contempla el DRAE de 'volumen, libro encuadernado'.

\section{CHUPÍN}

Sust. m. 'Chupa corta' (DRAE). El término jubón es derivado del antiguo aljuba o juba, que a su vez procede del árabe ŷúbba 'especie de gabán con mangas', en francés jupe, probablemente del francés se tomó el castellano chupa (DECH, s.v. jubón).

Un chupin de escarlatín encarnado bueno (La Bañeza, 1758)

Es el único ejemplo encontrado, dato que no es extraño pues se trata de un término poco frecuente. El diccionario académico lo recoge a partir de la edición de 1729 ya que se considera un sinónimo de jubón, que es el término que en general se utiliza con más frecuencia en los inventarios $\mathrm{y}$, por supuesto, en los analizados en este 
estudio en los que la voz jubón aparece ampliamente documentada. El hecho de que aparezca este único caso demuestra que el inventario en el que se recoge es un reflejo del nivel socioeconómico de su propietario ya que en él aparecen objetos poco frecuentes. Es importante destacar que, ni siquiera se ha recogido el término en inventarios del S. XIX, siglo en el que se empiezan a recoger términos nuevos, especialmente en lo que a textil se refiere, por las influencias del exterior. En el CORDE también aparece una muestra reducida del término, solo tres casos, y todos ellos pertenecientes al S. XIX.

\section{DENGUE}

Sust. m. 'Esclavina de paño, usada por las mujeres, que llega hasta la mitad de la espalda, se cruza por el pecho, y las puntas se sujetan detrás del talle' (DRAE). Probablemente de creación expresiva (DECH, s.v. dengue).

Un dengue de vayeta de Portugal encarnado (La Bañeza, 1743)

Un dengue encarnado con cinta (Grajal de la Ribera, 1806)

Un dengue de paño (Saludes de Castroponce, 1808)

Un dengue de paño encarnado (Alja del Infantado, 1812)

Un dengue de bayeta fino encarnado (Alija del Infantado 1812)

Otro de bayeta caterzena con cuita (Alija del Infantado 1812)

Un dengue de ratina nuebo (Jiménez de Jamuz, 1825)

Dos dengues encarnados viejos (Jiménez de Jamuz, 1825)

Un dengue de ratina algo usao (Alija del Infantado, 1827)

Un dengue de bayeta (Quintanilla de Somoza, 1831)

Un dengue de bayeta bueno (Quintana del Marco, 1839)

Un dengue de estameña (Santibáñez de la Isla, 1844)

Es un término común dentro del vestuario femenino de la zona comprendida en este estudio. Era una prenda que, como reflejan los ejemplos, solía ser de paño fino especialmente de bayeta y ratina. También los había de telas más gruesas como la estameña que aparece en el último ejemplo. Muchas veces iban adornados con cintas. Estos detalles siempre se reflejaban en los inventarios, así como el tipo de tela. El significado concreto del término presenta pequeñas variaciones, en algunas zonas como la Ribera del Órbigo se llama dengue a 'una especie de mantón de taparse las mujeres semejante a una toquilla' (Martínez García, 1985: 63). En el entorno de La Bañeza se define como una 'prenda que se parece a una mantilla en forma de toquilla pero con los extremos prolongados a modo de brazos que se unen por la espalda. Puede tener como adornos terciopelo o abalorios y se diferencia de la denga en que es 'una prenda femenina, a modo de mantilla, de paño fuerte negro, ancha en su parte posterior, que llega hasta la cintura, que se cruza por el pecho y se ata hacia la mitad de la espalda'. 
Generalmente no lleva adornos (Cavero-Alonso, 2002: 284). En el corpus estudiado no se ha recogido ningún ejemplo de denga. En cualquier caso, la voz dengue designa una prenda de busto femenina que se usa especialmente en las zonas rurales de Castilla y León, también en Asturias aunque en el DRAE figura de uso general castellano (Le Men, 2005, s.v. dengue).

ERMILLA (vid. almilla)

\section{FERRERUELO}

Sust. m. 'Capa corta con cuello y sin capilla' (DRAE). Del antiguo ferrehuelo, y este del ár. vulgar feriyûl 'especie de capa o blusa', el cual procede a su vez del latín palliŏlum 'manto pequeño', diminutivo de pallium 'manto, toga' (DECH, s.v. ferreruelo).

Un ferreruelo de paño negro usado (La Bañeza, 1641)

Un ferreruelo de veinte (Coomonte de la Vega, 1643)

Un bestido de honbre de bayeta con ferreruelo todo con pestaña de raso (La Bañeza, 1643)

Un ferreruelo de pardillo (La Antigua, 1647)

Un ferreruelo (Palacios de la Valduerna, 1730)

Un ferreruelo (Palacios de la Valduerna, 1730)

El término se usa con el significado de 'capa', prenda muy común en el S.XVII.

Todos los ejemplos recogidos aparecen bajo la forma ferreruelo, en ningún caso bajo la variante herreruelo.

\section{JUBóN [juvón, jubona]}

Sust. m. 'Vestidura que cubría desde los hombros hasta la cintura, ceñida y ajustada al cuerpo' (DRAE). Derivado del antiguo aljuba o juba, que a su vez procede del árabe ŷúbba 'especie de gabán con mangas' (DECH, s.v. jubón).

Un jubón de estameña con pasamanos (La Bañeza, 1641)

Un jubón de tela de oro (La Bañeza, 1643)

Un jubón de telilla ya usado (Alija del Infantado, 1644)

Un jubón bueno de birlinbau (Alija del Infantado, 1644)

Una jubona ya vieja (Vidriales, 1645)

Una vasquina y jubón de estameña parda (La Bañeza, 1649)

Un jubón de estameña prensada azul (Coomonte de la Vega, 1719)

Un jubón de sempiterna (Coomonte de la Vega, 1719)

Un jubón de sempiterna (Genestacio de la Vega, 1721)

Un jubón de droguete usado (Laguna de Negrillos, 1722)

Un jubón de estameña azul usado con mangas negras (Grajal de la Ribera, 1723)

Un jubón de estameña azul con mangas nuevo y botones (Grajal de la Ribera, 1723)

Un jubón de ante con galones de plata (Palacios de la Valduerna, 1726)

Un jubón de raso berde espolinado sin mangas (Palacios de la Valduerna, 1726)

Otro (jubón) de ormesí viejo (Palacios de la Valduerna, 1726) 
Un jubón azul con mangas coloradas (Jiménez de Jamuz, 1728)

Un jubón azul (Grajal de la Ribera, 1730)

Un jubón de sempiterna azul (Miñambres, 1731)

Un jubón de filoseda (Saludes de Castroponce, 1808)

Un jubón de tela de seda con mangas rizadas (Alija del Infantado, 1812)

Un juvón de moher negro (Alija del Infantado, 1812)

Un juvón de monfor berde usado (Alija del Infantado, 1812)

Un juvón de pana rayada negra nuevo (Alija del Infantado, 1812)

Un juvón de maón bueno (Alija del Infantado, 1812)

Dos jubones (Castrocalbón, 1814)

Un juvón viejo de estameña (La Bañeza, 1829)

Un juvón de estameña azul usado (Quintana del Marco, 1839)

Es un término muy común que aparece en prácticamente todos los inventarios.

El significado es el que da el DRAE, se trata de una prenda tanto masculina como femenina. Como se aprecia en los ejemplos, la tela de la que podía estar confeccionada es variada, aunque abundan los de estameña azul. Además del tipo de tela, algunos llevan diferentes tipos de adornos, datos importantes a la hora de valorar la prenda. En algunas

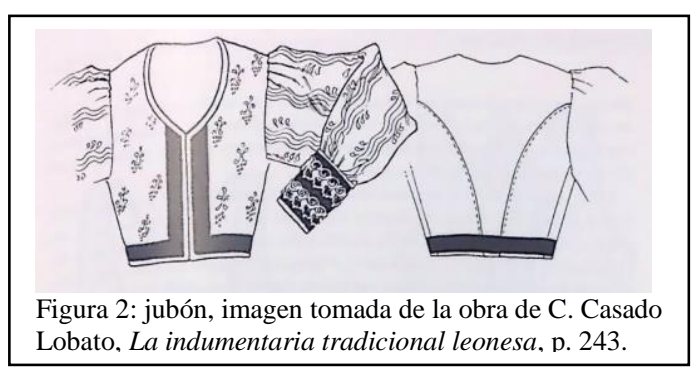
zonas también se le conoce con el término de jubona. Con esta denominación solo se ha encontrado un ejemplo, por lo que se trata de un término poco común en el área comprendida en este estudio.

\section{JUSTILLO}

Sust. m. 'Prenda interior sin mangas, que se ciñe al cuerpo y no baja de la cintura' (DRAE). Término derivado de justo, del latín jūstus 'justo, conforme a derecho' (DECH, s.v. justo).

Un justillo de damasco (La Bañeza, 1721)

Un justillo de estameña y de sempiterna bordado (Grajal de la Ribera, 1723)

Un justillo de estameña casera azul (Grajal de la Ribera, 1723)

Un justillo de monfor escarlatinado (Saludes de Castroponce, 1808)

Un justillo de seda viexo (Alija del Infantado, 1812)

Un justillo de seda vueno (Alija del Infantado, 1812)

Dos justillos de cotona buenos (Alija del Infantado, 1812)

Un justillo de estameña (Alija del Infantado, 1812)

Un justillo de seda (Quintana del Marco, 1820)

Un justillo usado de pana rayada azul (Quintana del Marco, 1820)

Otro justillo de estameña verde usado (Quintana del Marco, 1820)

Un justillo nuevo de monfor (Jiménez de Jamuz, 1825)

Tres justillos viejos (Jiménez de Jamuz, 1825)

Un justillo de escarlatín (Destriana, 1825)

Un justillo de cortes (Destriana, 1825)

Un justillo nuebo (Alija del Infantado, 1827) 
Un justillo de terciopelo (Castrocalbón, 1832)

Dos justillos de monfor berde y otro azul (Castrocalbón, 1832)

Dos justillos de cotonia (Castrocalbón, 1832)

Dos justillos de pana uno azul y otro blanco (Castrocalbón, 1832)

Un sobeo de carro y un justillo de monfor azul (Castrocalbón, 1832)

Un justillo encarnado (Castrocalbón, 1832)

Una marmota, un justillo, una gorra de camino y un cuello (Requejo de la Vega, 1839)

Un justillo de manchester (Santibáñez de la Isla, 1844)

Un mandil y un manteo azul, tres justillos azules (Santibáñez de la Isla, 1844)

Es un término muy común en los inventarios, ya que se trata de una prenda femenina de uso frecuente. No obstante, en el corpus analizado no se recogen ejemplos de justillo en el S. XVII y pocos en el S. XVIII. Abundan en el XIX, mientras que en los siglos anteriores el término que más se utiliza para designar una prenda similar es el de cuerpos. Los justillos eran una 'especie de chaleco que usaban las mujeres', se trataba de una prenda exterior. Como se observa en los ejemplos, los justillos podían estar confeccionados de diferentes telas, aunque los primeros fueron de estameña, sempiterna, monfor y seda, en el siglo XIX siguen apareciendo justillos de estas telas pero también de pana o de "Manchester", como el ejemplo de Santibáñez de la Isla. Se trata de un algodón que se fabricaba en esta ciudad, de ahí que se denominaran de Manchester (Cavero y Alonso, 2002: 93). También podían ser de diferentes colores aunque abundaban los de color verde o azul. Iban sujetos con cordones, que a veces podían señalarse en los inventarios, aunque no en este caso.

\section{LEVITA [lebita]}

Sust. m. y f. 'Vestidura masculina de etiqueta, más larga y amplia que el frac, y cuyos faldones llegan a cruzarse por delante' (DRAE). La acepción de 'chaqueta larga de hombre con faldones cruzados por delante' se tomó del francés lévite, íd., nombre aplicado a esta prenda por parecerse a la que llevaban los levitas en las representaciones teatrales (DECH, s.v. levita).

Una lebita de paño fino (La Nora del Río, 1823)

Una lebita de paño usado (La Nora del Río, 1823)

Dos lebitas viejas (La Nora del Río, 1823)

Un levita vuelto de paño azul muy deteriorado (La Bañeza, 1829)

Un levita nuevo (Felechares, 1837)

Un levita de paño fino negro en buen uso, votones de pasta con vueltas de tafetán, cuello de terciopelo (Destriana, 1843)

Los ejemplos recogidos pertenecen todos al S. XIX, dato que no es extraño puesto que, por ejemplo, el DRAE recoge el término por primera vez con esta acepción en la edición de 1837 y el CORDE presenta numerosos ejemplos a partir de la $2^{\mathrm{a}}$ mitad del $\mathrm{s}$. 
XIX. Además los casos encontrados en el corpus son poco numerosos y tres de ellos pertenecen al mismo inventario, y otro de ellos a La Bañeza, cabeza del Partido Judicial, donde era más frecuente encontrar aquellos objetos o prendas que comportaban cierto nivel socio-económico.

\section{MANTILLÍN}

Sust. m. y f. 'Especie de capa, de paño más o menos basto, que usan las mujeres como abrigo y como prenda de ceremonia en los actos religiosos', 'pañuelo para el cuello'. Término derivado de mantilla (Le Men, 2007, s.v. mantillín).

Un mantillín de paño de Segovia con blonda (Grajal de la Ribera, 1806)

Un mantillín enpeñado (Grajal de la Ribera, 1806)

Un mantillín (Alija del Infantado, 1812)

El término, que no recoge el DRAE, se documenta en León con las dos acepciones reseñadas anteriormente. Concretamente Le Men lo documenta en las zonas de Murias de Paredes y de Astorga (Le Men, 2007, s.v. mantillín). En el corpus, el término se usa con la $1^{\text {a }}$ acepción, quizá la más frecuente, teniendo en cuenta la información del primer ejemplo acerca del tipo de paño. En los casos encontrados, la voz solo aparece en masculino aunque es frecuente el uso de mantillín o mantillina. Se trata por tanto de una 'mantilla pequeña' que solía ser más valiosa, quizá porque normalmente eran de paño fino, podían llevar tejidos de seda junto a abalorios. Este dato podría explicar la escasez del término.

\section{MANTO}

Sust. m. 'Especie de mantilla grande sin guarnición, que usan las señoras' (DRAE). Del latín tardío mantum 'manto corto', que a su vez es de origen incierto; parece haberse extraído del lat. mantellum, que quizá fuese voz antigua en latín (DECH, s.v. manto).

Un manto de gurate (La Bañeza, 1643)

Un manto fino de Sebilla (La Bañeza, 1643)

Un manto de Sevilla usado (La Bañeza, 1649)

Un manto de pardillo (Fresno, 1726)

Un manto de estameña negra casera algo usado (Quintana del Marco, 1820)

Otro manto de estameña usado (Quintana del Marco, 1820)

Un manto de paño fino (Quintanilla de Somoza, 1831)

Un manto de estameña negra ya roto (Alija del Infantado, 1827)

Se trata de un término que designa una prenda de abrigo con la que las mujeres se cubrían, es una prenda generalmente rica, quizá lo que explica que tampoco abunde 
en los inventarios analizados. Como ocurre con otras prendas, es frecuente detallar el tipo de tela del que está confeccionada y el estado en el que se encuentra.

\section{MANTÓN}

Sust. m. 'Pañuelo grande que se echa generalmente sobre los hombros'. 'Pieza cuadrada o rectangular de abrigo, que se echa sobre los hombros' (DRAE). Término derivado de manto (DECH, s.v. manto).

Quatro mantones (Robledo de la Valduerna, 1726)

Una cama con su ropa compuesta de un mantón, una manta (Destriana, 1825)

Un mantón de pabilos (Valle de la Valduerna, 1829)

Un mantón de pabilos (Valle de la Valduerna, 1829)

Un mantón de lana (Quintanilla de Somoza, 1831)

Un mantón de pabilos biejo (Quintana del Marco, 1839)

Un mantón de pabilos bueno (Quintana del Marco, 1839)

Es un término que probablemente se está utilizando con dos significados. Por una parte con el significado de 'pañuelo que se echa sobre los hombros' y por otra como aumentativo de manta, puesto que en el ejemplo de Destriana lo cita como un elemento que forma, junto con otros, la ropa de cama, por lo que la otra acepción no resulta apropiada para este contexto. En cuanto al primer significado es el más común, dentro de las prendas femeninas de cintura para arriba abundaban los mantones, especialmente los de lana, aunque había otros de seda, etc. No obstante, este tipo de prendas se conocen también en toda la zona con el nombre de pañuelos y se documentan en muchas ocasiones con este término.

\section{ROPILLA}

Sust. f. 'Vestidura corta con mangas y brahones, de los cuales pendían regularmente otras mangas sueltas o perdidas, y se vestía ajustada al medio cuerpo sobre el jubón' (DRAE). Término derivado del verbo robar (DECH, s.v. robar).

Un calçón y una ropilla de terciopelo (La Bañeza, 1643)

Una ropilla de estameña (Coomonte de la Vega, 1719)

Una ropilla de estameña usada (La Nora del Río, 1724)

Una ropilla de paño (Laguna de Negrillos, 1725)

Una ropilla de paño con mangas (Robledo de la Valduerna, 1726)

Dos ropillas de frisa (Palacios de la Valduerna, 1727)

Dos calzones y una ropilla de frisa viejos (Palacios de la Valduerna, 1728)

Dos ropillas de pardo y unos calzones de lo mismo (Destriana, 1730)

Una ropilla sin mangas (Requejo de la Vega, 1735)

Una ropilla de frisa sin mangas nueva forrada en lienzo (La Isla, 1735) 
Son bastantes los ejemplos encontrados del término. Se trata de una prenda de busto fundamentalmente masculina, con mangas que se ponía sobre el jubón. Como en otros tipos de prendas, normalmente eran de frisa, paño o estameña.

\section{SAYUELO}

Sust. m. El DRAE recoge el término como diminutivo de sayo y lo localiza en León con la acepción de 'manga rajada que llevaban en su vestimenta las maragatas' (DRAE). Término derivado de saya, del latín vulgar *sagra , derivado del latín sagum 'especie de manto', 'casaca militar' (DECH, s.v. saya).

Un sayuelo de contray (Coomonte de la Vega, 1645)

Otro sayuelo de contray con ribetes de terciopelo (Coomonte de la Vega, 1645)

Un sayuelo (La Antigua, 1647)

Un sayuelo de paño negro (Genestacio de la Vega, 1721)

Un sayuelo viejo (Genestacio de la Vega, 1721)

Un sayuelo de Somonte (Fresno, 1726)

Un sayuelo negro viejo (Miñambres, 1729)

Un sayuelo de pardo usado (Santiago Millas, 1735)

Un sayuelo nuevo de paño de Prádanos de boquilla labrado con seda (Jiménez de Jamuz, 1825)

Otro sayuelo nuevo de lo mismo (Jiménez de Jamuz, 1825)

Otro sayuelo usado (Jiménez de Jamuz, 1825)

Un sayuelo de el mismo paño con bueltas de terciopelo (Destriana, 1825)

Un sayuelo nuevo de paño (Alija del Infantado, 1827)

Un sayuelo biejo de paño (Alija del Infantado, 1827)

Un sayuelo con sus dos abuyetas (Quintanilla de Somoza, 1831)

Un sayuelo de paño nuebo (Calzada, 1838)

Un sayuelo de pardo (Calzada, 1838)

En el Diccionario de Autoridades la voz se define como 'sayo pequeño' y 'especie de jubón que suelen usar las mugeres y se hacen de varias telas'. El significado más concreto que se le da al término en el corpus es el de 'prenda arcaizante femenina sustituida luego por el jubón, con amplio escote, manga rajada que se sujeta en el puño, y haldetas' (Casado, 1993: 512). No obstante, es un término frecuente en el corpus y los ejemplos se reparten por toda la zona comprendida por el P.J. de la Bañeza. A pesar de que la Academia lo incluye y localiza en León a partir de 1925 y antes lo define como diminutivo de sayo, son bastantes los ejemplos que recoge el CORDE del término.

\subsubsection{Prendas de cintura para abajo}

\section{BASQUIÑA [basquina, vasquiña, vasquina, vasciña]}

Sust. f. 'Saya que usaban las mujeres sobre la ropa para salir a la calle' (DRAE). Término 
procedente del port. anticuado vasquinha, diminutivo del gentilicio vasco (DECH, s.v. basquiña).

Una basquiña de piel de rata aforrada (La Bañeza, 1641)

Una basquina de tafetán doble negro (La Bañeza, 1643)

Una vasquina y jubón de estameña parda (La Bañeza, 1649)

Una basquiña de pelo de camello (La Bañeza, 1714)

Una basquina de lamparilla (La Bañeza, 1721)

Una basquiña azul de sempiterna (Grajal de Ribera, 1750)

Una basquiña de medio carro de oro negra (La Bañeza, 1754)

Una basquiña morada de tela (Alija del Infantado, 1812)

Una basquiña de estameña inglesa (Alija del Infantado, 1812)

Una vasquiña de estameña morada (Grajal de Ribera, 1806)

Un vasquiña de estameña de Guadalajara (Grajal de Ribera, 1806)

Una vasciña de estameña negra (Saludes de Castroponce, 1808)

El término solo se ha encontrado recogido en inventarios de la zona próxima a

la villa de La Bañeza y del Páramo, aunque es una voz muy común que ya aparece en el Tesoro de la Lengua Castellana, aunque no como entrada aparte, sino que se recoge vasquiña en la definición de falda (Almeda Molina: 2013). Asimismo el CORDE recoge numerosos ejemplos de todas las épocas.

\section{BRIAL}

Sust. m. 'Vestido de seda o tela rica que usaban las mujeres' (DRAE). Término del occ. ant. blial, de origen incierto, como el fr. ant. bliaut, quizá germánico (DECH, s.v. brial).

Un brial morado (Alija del Infantado, 1812)

Sebastián de Covarrubias señala que era una 'vestidura que usaban las reinas y grandes señoras' (Covarrubias, s.v. brial). Este dato, unido a la definición del DRAE, puede explicar que quizá se trate de una prenda de cierta categoría que solo poseían determinadas personas, hecho que justificaría la escasez de ejemplos en los inventarios.

\section{FRAC [fra]}

Sust. m. 'Vestidura de hombre, que por delante llega hasta la cintura y por detrás tiene dos faldones más o menos anchos y largos' (DRAE). Del francés frac, y este probablemente del inglés frock (DECH, s.v. frac).

Un fra nuevo (Requejo de la Vega, 1839)

Un fra de paño negro nuevo (Requejo de la Vega, 1839)

Un fra usado y una jardeta (Requejo de la Vega, 1839)

Son los únicos ejemplos recogidos del término. Resulta un poco confusa la lectura aunque, por comparación con las grafías que aparecen en el documento, el término que parece leerse es frac, la ausencia de la grafía final no es extraña puesto que 
es probable que se haya hecho una escritura fonética. Semánticamente, es un término poco usual en los inventarios ya que no es una prenda común, aunque lo que sí está claro es que se trata de una prenda de vestir ya que ambos ejemplos se encuentran en las relaciones de ropa que aparecen en este inventario, dato que permite considerar esta interpretación del término como la adecuada. El año en el que están fechados los ejemplos también están en consonancia con el hecho de que pueda tratarse de la voz frac, por ejemplo en el CORDE son varios los ejemplos de frac que se recogen en el s. XIX y, por supuesto, en los siguientes.

\section{GUARDAPIÉS [guardapié]}

Sust. m. El DRAE define el término como sinónimo de brial, vestido de las mujeres que llegaba hasta los pies. Término compuesto de guardar, del germánico wardôn y pie, del latín pēs, pědis (DECH, s.v. guardar y pie).

Un guardapié de sempiterna encarnada con guarniciones (La Bañeza, 1714)

Un guardapié de estameña azul con garapiñas (La Bañeza, 1714)

Un guardapié de estameña azul (Grajal de la Ribera, 1723)

Un guardapié de droguete usado (La Bañeza, 1754)

Un guardapiés de estameña verde (Grajal de la Ribera, 1806)

Un guardapiés de calamaco (Grajal de la Ribera, 1806)

Un guardapiés de tela verde (Grajal de la Ribera, 1806)

Un guardapiés de algodón (Grajal de la Ribera, 1806)

Un guardapié de estameña azul (Saludes de Castroponce, 1808)

Un guardapié de seda de colores (Alija del Infantado, 1812)

Un guardapiés de calamaco encarnado (Alija del Infantado, 1812)

Un guardapié de algodón (Alija del Infantado, 1812)

Un guardapié de barragán de aguas azul (Alija del Infantado, 1812)

Un guardapié de sempiterna azul (Alija del Infantado, 1812)

Un guardapiés de calamaco color de canela (Alija del Infantado, 1812)

Un guardapié de sarasa nueba (Alija del Infantado, 1812)

Un guardapié de algodón (Alija del Infantado, 1812)

Un guardapié azul (Alija del Infantado, 1812)

Es un término común que designa una prenda femenina de cintura para abajo. Se trata de una especie de saya que es frecuente, como se aprecia en los ejemplos, en la zona del Páramo. Este dato coincide con el de basquiña, que es una prenda similar que también aparece en los inventarios de esta zona, el guardapiés se solía colocar debajo de la basquiña. Normalmente suelen confeccionarse con telas y aderezos de cierta calidad. Los ejemplos en esta zona son numerosos y contrastan con los del CORDE que solo registra diez casos. Formalmente en el corpus estudiado, el término alterna indistintamente bajo las formas guardapiés y guardapié. Esta voz tiene como sinónimo tapapié, mucho menos utilizado en el corpus. 


\section{MANTEO}

Sust. m. 'Ropa de bayeta o paño que llevaban las mujeres, de la cintura abajo, ajustada y solapada por delante' (DRAE). Término derivado de manto, del lat. tardío mantum 'manto corto', que a su vez es de origen incierto; parece haberse extraído del lat. mantellum, que quizá fuese voz antigua en latín (DECH, s.v. manto).

Un manteo de frisa azul casero bueno (Villazala, 1722)

Un manteo de frisa negra (Fresno, 1726)

Un manteo de Baeza verde bordado de blanco y encarnado (La Bañeza, 1721)

Un manteo azul (Miñambres, 1731)

Un manteo verde (Miñambres, 1731)

Un manteo pajizo de rodadura encarnada (Grajal de la Ribera, 1806)

Un manteo de paño nuevo con rodapisa encarnada (Castrocalbón, 1814)

Un manteo nuevo de Astudillo (Jiménez de Jamuz, 1825)

Otro (manteo) nuevo de paño de pardo (Jiménez de Jamuz, 1825)

Otro (manteo) biejo negro (Jiménez de Jamuz, 1825)

Dos manteos azules buenos de estameña (Jiménez de Jamuz, 1825)

Un manteo de pardo (Destriana, 1825)

Un manteo nuevo con astudillos (Alija del Infantado, 1827)

Dos manteos antiguos de calamaco (La Bañeza, 1829)

Dos manteos de algodón antiguo de poco mérito (La Bañeza, 1829)

Un manteo de algodón antiguo (La Bañeza, 1829)

Un manteo pajizo biejo (Quintanilla de Somoza, 1831)

Un manteo usado paño de Segobia (Quintanilla de Somoza, 1831)

Un manteo de astudillo (Castrocalbón, 1832)

Otro (manteo) de estameña (Castrocalbón, 1832)

Otro manteo pajizo y otro azul (Castrocalbón, 1832)

Otro (manteo) de bayeta (Castrocalbón, 1832)

Otro manteo de color rosa con cortapisa de algodón (Castrocalbón, 1832)

Un manteo nuebo de pardo (Calzada, 1838)

Un manteo pajizo de estameña (Quintana del Marco, 1839)

Un manteo de Estudillo (Destriana, 1843)

Tres manteos de la biuda uno de paño y otro de frisa y otro de estameña (Santibáñez de la Isla, 1844)

Un mandil y un manteo azul (Santibáñez de la Isla, 1844)

Un vestido de la boda compuesto de manteo negro con terciopelo, jubón, mantilla y mandil (Destriana, 1870)

Es un término común ya que designa una prenda femenina de cintura para abajo que solía ser abierta por detrás o de vuelta, por tanto va a estar presente en muchos inventarios a partir del S. XVIII, puesto que en los inventarios recogidos en el S. XVII no se recogen casos de manteo, pero sí de saya. Como se muestra en los ejemplos, siempre se informaba sobre la tela, solían ser de estameña, paño, paño fino; si eran de fiesta, pardo, frisa, etc, aunque predominaban los de estameña y los de Astudillo. También es frecuente indicar el color, por esta zona eran comunes los amarillos pajizos, aunque también los había de otros colores, como el azul. Además en algunos ejemplos se detalla la presencia de adornos tales como cintas de terciopelo, rodaduras, etc. Se 
utiliza además el término rodao, que también aparece en el corpus designando este tipo de prenda femenina en otros inventarios, todos ellos del S. XIX. No obstante, su uso es menor.

\section{PANTALÓN}

Sust. m. 'Prenda de vestir que se ajusta a la cintura y llega generalmente hasta el pie, cubriendo cada pierna separadamente' (DRAE). Del francés pantalón (DECH, s.v. pantalón).

Un par de pantalones de paño azul todos rotos (La Bañeza, 1829)

Dos pantalones de berano muy usados (Requejo de la Vega, 1839)

Dos pantalones de berano pintados (Requejo de la Vega, 1839)

Un pantalón blanco de piqué (Requejo de la Vega, 1839)

Un pantalón paño azul obscuro fino en buen uso (Destriana, 1843)

Es un término que procede del francés y que no entra en nuestra lengua hasta el S. XVIII. Este dato explica que solo se recojan ejemplos en el corpus del S. XIX. Además la prenda denominada era menos común que otras prendas masculinas que tenían la misma función y que son más frecuentes en el corpus, como braga o calzón. Probablemente el término pantalón designa una vestimenta más "fina", lo que explicaría que incluso en el siglo XX los ejemplos sean poco numerosos.

\section{RODAO}

Sust. m. El DRAE señala, desde la edición de 1925, que en León se llama así a una 'especie de refajo que usan las mujeres'. Término derivado de rueda, del latín rŏta (DECH, s.v. rueda).

Un rodo (Santiago Millas, 1735)

Un rodao de estameña morao (Grajal de la Ribera, 1806)

Un rodao paxizo de estameña (Grajal de la Ribera, 1806)

Un rodao de bayeta pajiza nuevo (Alija del Infantado, 1812)

Otro (rodao) de estameña pajizo usao (Alija del Infantado, 1812)

Otro (rodao) encarnado (Alija del Infantado, 1812)

Un rodao de paño de damas (Castrocalbón, 1833)

Un rodao verde biejo (Requejo de la Vega, 1839)

Es un término que designa una prenda de vestir común, por tanto se trata de una voz conocida, aunque en el corpus aparecen más ejemplos del término manteo. Designa una prenda femenina de cintura para abajo, abierta por detrás o de vuelta. Suelen ser de paño o de estameña, de colores o pajizos. Desde el punto de vista formal, el término presenta las variantes ruedo, rodo, rodao; aunque en este corpus la más frecuente es rodao, con pérdida de la -d- intervocálica generalizada en toda la zona 
leonesa. Solo se recoge un ejemplo de rodo y ninguno de ruedo ni siquiera en las zonas próximas a la Cepeda o a Astorga donde Casado recoge este término (Casado, 1991: 388).

\section{SAYA [saia]}

Sust. f. El DRAE define el término como un sinónimo de falda. Del latín vulgar *sagĭa, derivado del latín sagum 'especie de manto', 'casaca militar' (DECH, s.v. saya).

Una saya azul usada (Alija del Infantado, 1644)

Una saya azul biexa (Coomonte de la Vega, 1645)

Una saya de blanqueta nueba (Coomonte de la Vega, 1645)

Una saya açul ussada (Urdiales del Páramo, 1645)

Una saya de blanqueta (Urdiales del Páramo, 1645)

Una saya de pardo (La Antigua, 1647)

Una saya de pardo y usada a medio serbir (Alija del Infantado, 1647)

Una saya de pardo fraylengo y negro lo negro biexo y lo fraylengo nuevo (Alija del Infantado, 1647)

Una saya azul biexa (Coomonte de la Vega, 1650)

Una saya clara buena (Coomonte de la Vega, 1650)

Una saya berde buena (Coomonte de la Vega, 1650)

Una saia de paño de Cuenca de color de yielo usada (Villanueva de Valdejamuz, 1704)

Una saya de palmilla verde (Genestacio de la Vega, 1721)

Una saya de paño azul (Genestacio de la Vega, 1721)

Una saya de palmera verde (Laguna de Negrillos, 1726)

Una saya de estameña azul casera (Laguna de Negrillos, 1726)

Una saya de mezcla buena (Miñambres, 1729)

Una saya negra de estameña (Grajal de la Ribera, 1750)

La saya era una de las prendas femeninas más frecuentes junto con el rodao o manteo, de ahí la cantidad de ejemplos que encontramos. La diferencia de estas con respecto al manteo está en que la saya tiene vuelo y es cerrada. Los ejemplos que aparecen en el corpus muestran el tipo de prenda más frecuente, las más comunes eran, sobre todo en el S. XVII las frailengas y las de blanqueta, también las de estameña que solían ser preferentemente azules, también negras. Estas sayas solían llevar rodadura. En el corpus no se hace referencia a la presencia de rodadura en estas prendas.

\section{SAYO}

Sust. m. 'Prenda de vestir holgada y sin botones que cubría el cuerpo hasta la rodilla' (DRAE). Del latín vulgar *sagĭa, derivado del latín sagum 'especie de manto', 'casaca militar' (DECH, s.v. saya).

Un sayo de frechilla (Alija del Infantado, 1644)

Un sayo y un xubón a medio serbir (Alija del Infantado, 1646)

Un sayo y un xubón de pardo usado (Coomonte de la Vega, 1650) 
Un sayo, un chaleco y unos calzones (Destriana, 1825)

Un sayo de paño usado (Santibáñez de la Isla, 1844)

El término alude a una prenda de las llamadas sobretodos. No son las más frecuentes ya que alternaban con las casacas, las chupas y sobre todo con las capas que eran las más típicas. En principio se trata de una prenda masculina, aunque en algunas zonas también los llevaban las mujeres (Casado, 1993: 512). En el corpus suele aparecer junto a otras prendas de hombre, por ejemplo, en el caso de Destriana, por lo que se puede suponer que era más bien una prenda masculina.

Se recoge un ejemplo del término en aumentativo

Un sayazo de pardo biexo (La Antigua, 1648)

El término sayazo como voz que denomina un objeto concreto no aparece documentado, siendo además el único ejemplo recogido, probablemente se trate de un derivado aumentativo del término, tal vez se trataba de una sayo grande y el escribano o la persona que iba cantando los objetos lo denominó así, aunque también es posible que se utilice con valor despectivo.

\section{DEVANTAL}

Sust. m. 'delantal' (DRAE).

Un abantal forrado con lana (Grajal de Ribera, 1806)

La Academia señala en su segunda edición que avantal es lo mismo que delantal y añade que es como hoy se dice. Por tanto, se trata de la misma palabra que tiene por significado el de 'delantal'. Es una voz poco usada en el corpus ya que solo se ha encontrado este ejemplo. Esta escasez aparece también en bases de datos como el CORDE donde solo aparecen tres casos de abantal, diez de avantal y nueve de delantal. En el corpus analizado son bastante más frecuentes otros términos como mandil.

\section{MANDIL}

Sust. m. 'Prenda de vestir que, atada a la cintura, usan las mujeres para cubrir la delantera de la falda y, por analogía, el que usan algunos artesanos, los criados, los camareros y los niños' (DRAE). De la misma etimología que mantel, del lat. mantēle 'toalla', pero llegado probablemente por conducto del árabe (DECH, s.v. mantel).

Un mandil camorano con listas, un cuerpo de camisa con sus mangas labradas en blanco (Coomonte de la Vega, 1645)

Un mandil de estameña (La Bañeza, 1641)

Un mandil açul (La Antigua, 1648)

Una saia de estameña mandilera usada (Grajal de la Ribera, 1723) 
Un mandil de frisa negro (Fresno, 1726)

Dos mandiles cardenos de lana (Palacios de Jamuz, 1728)

Un mandil de buriel con listas nuevo (Palacios de la Valduerna, 1728)

Un mandil con pasamanos (Requejo de la Vega, 1735)

Un mandil de frisa bendedera (Requejo de la Vega, 1735)

Dos mandiles de chalón (Grajal de la Ribera, 1806)

Otro mandil de chalón nuevo (Alija del Infantado, 1812)

Tres mandiles de estopa (La Nora del Río, 1823)

Un mandil de prado y una mantilla nueba de paño (San Feliz, 1838)

Un mandil de chalón (Requejo de la Vega, 1839)

Un mandil de sempiterna (Quintana del Marco, 1839)

Un mandil de bista (Santibáñez de la Isla, 1844)

Un mandil y un manteo azul (Santibáñez de la Isla, 1844)

Un vestido de la boda compuesto de manteo negro con terciopelo, jubón, mantilla y mandil (Destriana, 1870)

Es un término que aparece frecuentemente en los inventarios ya que se trata de una prenda común en la vestimenta de las mujeres. Como se aprecia en los ejemplos, los mandiles podían estar confeccionados de diferentes tipos de telas, las más comunes eran estameña, sempiterna, frisa y chalón; es decir, tejidos de lana. En algunas zonas del Alto Órbigo y alrededores de La Bañeza había mandiles traseros (Casado, 1993: 248). Sin embargo, en los inventarios analizados no hay muestras de este tipo de mandiles. Hay un ejemplo en el que se utiliza un derivado de mandil, el adjetivo mandilera, que tal vez esté caracterizando un tipo de estameña más apropiada para mandiles que para otro tipo de prendas, como puedan ser manteos.

\section{TAPAPIÉ}

Sust. m. El DRAE recoge el término como una voz en desuso y lo define como un brial (de las mujeres). Voz compuesta de tapar y pie.

Otro tapapié de sempiterna (La Bañeza, 1721)

Un tapapié de estameña berde (La Bañeza, 1743)

Solo se recogen estos ejemplos ya que el término que se utiliza con frecuencia en el corpus es el de guardapié. Como su sinónimo designa una 'saya que se solía colocar debajo de la basquiña'.

\section{VESTIDO [bestido]}

Sust. m. 'Prenda o conjunto de prendas exteriores con que se cubre el cuerpo'. 'Traje enterizo de la mujer' (DRAE). Del latín vestītus, -ūs (DECH, s.v. vestido).

Un bestido de honbre de bayeta con ferreruelo todo con pestaña de raso (La Bañeza, 1643)

Un vestido de tafetán (La Bañeza, 1643) 
Un bestido de mujer, ropa, jubón y basquiña de tafetán doble negro guarneçido de esparragón con botones de bidrio (La Bañeza, 1643)

Un vestido de damasco acabellado (La Bañeza, 1649)

Otro vestido de chamelote de aguas pardo (La Bañeza, 1649)

Un bestido (Castrocalbón, 1833)

Un bestido de cubica (Castrocalbón, 1833)

Un bestido negro nuevo (Requejo de la Vega, 1839)

Un bestido de seda (Requejo de la Vega, 1839)

Un bestido de seda (Requejo de la Vega, 1839)

Un vestido de la boda compuesto de manteo negro con terciopelo, jubón, mantilla y mandil (Destriana, 1870)

Es un término que puede utilizarse de dos formas diferentes, como se refleja en las acepciones del DRAE. En dos de los ejemplos de La Bañeza de 1643, el término vestido es un colectivo formado por casaca, chupa y calzón en el hombre; y basquiña y casaca en la mujer. Con este significado recoge el DRAE el término hasta 1843. También puede tener la acepción de 'prenda entera'. Probablemente, el resto de ejemplos tenga este uso aplicado a una prenda de mujer, puesto que de lo contrario aparecería la especificación ya comentada o la que aparece en el último ejemplo en el que de nuevo se refiere a un colectivo de prendas de mujer usadas para un fin.

\section{MANGAS}

Sust. f. 'Parte del vestido en que se mete el brazo' (DRAE). Del latín maňca íd., derivado de manus 'mano' (DECH, s.v. manga).

Tres pares de mangas de lana blanca (La Bañeza, 1641)

Unas mangas de damasco negro (La Bañeza, 1643)

Un xubón de damasquillo de lanas de colores con mangas negras biexas (Coomonte de la Vega, 1643)

Un cuerpo de camisa con sus mangas labradas de blanco (Coomonte de la Vega, 1645)

Unas mangas de lana de muger (Alija del Infantado, 1644)

Unas mangas de lana blanca (La Antigua, 1648)

Unas mangas de lamparilla (La Bañeza, 1721)

Un jubón de estameña azul usado con mangas negras (Grajal de la Ribera, 1723)

Un jubón de estameña azul con mangas nuevo y botones (Grajal de la Ribera, 1723)

Una ropilla de paño con mangas (Robledo de la Valduerna, 1726)

Otra de bareta vieja sin mangas (Robledo de la Valduerna, 1726)

Un jubón de raso verde espolinado sin mangas (Robledo de la Valduerna, 1726)

Una manga de punto para meter las pellizas (Robledo de la Valduerna, 1726)

Un jubón azul con mangas de estameña (Miñambres, 1727)

Un jubón azul con mangas coloradas (Palacios de Jamuz, 1728)

Unas mangas de lana (Palacios de Jamuz, 1728)

Un jubón de estameña azul con mangas de frisa (Requejo de la Vega, 1735)

Una ropilla sin mangas (Requejo de la Vega, 1735)

Una ropilla de frisa sin mangas nueva forrada en lienzo (La Isla, 1735)

Un jubón de tela de seda con mangas rizadas (Alija del Infantado, 1812)

Unas mangas de monja (Destriana, 1825) 
Unas mangas de lienzo (San Feliz, 1838)

Unas mangas buenas (Santibáñez de la Isla, 1844)

El término aparece con frecuencia y se utiliza con el significado que da el $D R A E$. En muchos ejemplos aparecen formando parte de una prenda de la que se destacan las mangas quizá por el tipo de tela o porque destacaban en la prenda, pero en otros aparecen solas, ello era debido a que se confeccionaban mangas solas. En los inventarios de esta zona es común encontrar mangas de monja, aquí solo hay un ejemplo, eran las mangas que se ponían a los cuerpos y podían ser de terciopelo, de lana o de estameña.

\subsubsection{Complementos}

\subsubsection{Complementos de cabeza y tocados}

\section{ALBANEGA [alvanega]}

Sust. f. 'Especie de cofia o red para recoger el pelo o para cubrir la cabeza'. 'Manga cónica, hecha de red y cerrada por el extremo más estrecho, que se utiliza para cazar conejos u otros animales cuando salen de la madriguera' (DRAE). Término procedente del ár. banîqa 'pieza triangular que se agrega a una prenda de vestir para ensancharla'. 'cofia', 'gorro de mujer' (DECH, s.v. albanega).

Una alvanega de lienzo labrada con seda vuena (Huerga de Garaballes, 1720)

Una albanega (Grajal de Ribera, 1750)

Solo se han recogido estos dos ejemplos del término. Se trata de una voz inusual dentro del corpus estudiado. Este hecho no es excepcional si tenemos en cuenta que en el CORDE solo se recogen quince casos, que en proporción, para el número de ejemplos del CORDE resultan escasos. No obstante, tanto el Diccionario de Autoridades como el DRAE en su edición de 1726 reflejan que se trata de una voz anticuada, dato que explicaría la escasez de ejemplos. En cuanto al significado, parece que el sentido más común del término es el que da la Academia como primera acepción. En el único caso encontrado, no hay datos suficientes que nos permitan deducir qué acepción se utiliza, ya que si recurrimos al lugar en el que aparece en la relación, vemos que se documenta junto a cántaros de barro, vueltas de corales o azuelas; por lo que no podemos afirmar si se trata de una prenda para cubrir la cabeza o de una red para cazar conejos. 


\section{CAPILLO}

Sust. m. 'Gorro de lienzo que se pone a los niños de pecho' (DRAE). Término procedente del latín * cappellus, diminutivo de cappa 'capa' (DECH, s.v. capa).

Un capillo de damasco azul (La Bañeza, 1641)

Un capillo de paño (Coomonte de la Vega, 1722)

Un capillo de espumilla (Palacios de la Valduerna, 1730)

Un capillo (La Bañeza, 1754)

Un capillo de niño blanco (Grajal de Ribera, 1806)

En León y en otras zonas de Castilla y León o de Asturias, este término se utiliza con otros significados que no aparecen recogidos en el DRAE. Así se llama capillo a la 'piel de oveja que los pastores se ponen cuando llueve', 'vaina que encierra el grano de trigo'; con este último significado se utilizaba el vocablo en Astorga, zona próxima a la estudiada. También se conocía por capillo a la 'caperuza que se ponía a la rueca para que no se saliera el lino en el hilado' (Le Men, 2004, s. v. capillo). Además de estas acepciones se usaba con el significado de 'gorro de niño'. En los ejemplos que se han extraído del corpus, parece claro pensar que el término se está utilizando con el significado académico, si tenemos en cuenta las especificaciones que acompañan a la palabra referidas al tipo de tela. Además, es una prenda frecuente dentro de la indumentaria infantil donde alterna con la palabra gorro. La diferencia parece estar en que el gorro presenta más colorido, mientras que el capillo suele ser una prenda de cabeza más sencilla y de tonos claros (Casado, 1993: 258).

\section{CHAMBERGO}

Adj. m. El DRAE en su $4^{\mathrm{a}}$ acepción cita la expresión sombrero chambergo. Término procedente del nombre del General Schomberg, quien introdujo la casaca denominada chamberga (DECH, s.v. chambergo).

Un sombrero de pastor y un chambergo (Robledo de la Valduerna, 1726)

Es un término poco común en el corpus estudiado, ya que hace referencia a un sombrero concreto que no era el más utilizado por la indumentaria tradicional de la zona. Se trata de un adjetivo que denomina tanto un tipo de chaquetilla como un tipo de sombrero. El hecho de que aparezca junto a otro sombrero del que se especifica "de pastor" y que aparezca en masculino, concordando con el sustantivo elidido sombrero, nos lleva a pensar que en el ejemplo concreto se está refiriendo a ese sombrero denominado así por ser parecido al que usaban los soldados de la chamberga, redondo y sin picos. 


\section{COFIA}

Sust. f. El DRAE en su $3^{\text {a }}$ acepción define el término como 'gorra que usaban las mujeres para abrigar y adornar la cabeza, hecha de encajes, blondas, cintas, etc.' Del latín tardío cofia íd., de origen incierto, acaso germánico (DECH, s.v. cofia).

Una cofia (La Antigua, 1648)

Una cofia bordada (Toral, 1728)

Una cofia de un niño y un pañuelo azul (San Feliz, 1838)

Son pocos los ejemplos encontrados. Es un término que designa un tipo de tocado de la época, pero menos usado que otros como el pañuelo. En el caso de los niños, a veces se les cubría la cabeza con una cofia, pero también era más común otro tipo de prenda como el gorro.

\section{GORRO}

Sust.m. 'Pieza redonda, de tela o de punto, para cubrir y abrigar la cabeza' (DRAE). Término de origen incierto (DECH, s.v. gorra).

Un gorro de punto negro y blanco (Robledo de la Valduerna, 1726)

Seis gorros de algodón vlancos (La Bañeza, 1829)

Dos gorros vlancos de dormir de lienzo y dos de punto dobles (La Nora del Río, 1823) Un gorro y una zinta (Calzada, 1838)

Tres gorros negros de estambre (Requejo de la Vega, 1839)

Dos gorros y una gorra de niño (Requejo de la Vega, 1839)

Una marmota, un justillo, una gorra de camino y un cuello (Requejo de la Vega, 1839)

Es una voz de uso general que aparece siempre en el corpus con el significado que hoy conocemos del término, aunque en algunas zonas de León tiene otras acepciones que no aparecen en los inventarios estudiados, 'pieza de hierro colocada en el extremo superior del árbol de rodezno y a la cual va fija la rueda volandera' (Le Men, 2007, s.v. gorro). El gorro o gorra es un elemento muy típico de la indumentaria infantil de toda la zona. Los había de diferentes telas, según fueran de fiesta o de diario. Los gorros que aquí aparecen probablemente fueran de diario puesto que son de telas más corrientes como algodón o punto. En cuanto al color los había de diferentes tonalidades y el color negro solía utilizarse en momentos de luto. Es probable que el ejemplo de La Nora del Río se refiera no a un gorro infantil, sino a un elemento que formaba parte del atuendo utilizado para dormir.

El término gorra aunque se utiliza indistintamente junto a gorro, aparece dentro del corpus en un contexto «dos gorros y una gorra de niño», que nos permite afirmar que el significado es distinto, puesto que los diferencia dentro de la misma 
relación. Probablemente la diferencia esté en la presencia de visera, para el caso de la gorra, tal y como hoy diferenciamos el término. En el segundo ejemplo, parece claro que se trata de una visera para cubrirse del sol, como se deduce de su complemento "de camino".

\section{MANTELLINA}

Sust. f. 'Mantilla de la cabeza' (DRAE). Término derivado de mantel, del latín mantēle 'toalla' (DECH, s.v. mantel).

Una mantellina (Castrillo de la Valduerna, 1828)

Es el único ejemplo encontrado en el corpus. El significado es el que da el $D R A E$, aunque se diferencia de la prenda denominada mantilla en que es de menor tamaño, además solía ser de paño fino y en la parte central solía tener sedas y rasos, también llevaba adornos de abalorios y pasamanerías. Es decir, en general, se trata de una prenda de más valor que la mantilla, dato que podría explicar su escasa presencia en los inventarios en contraste con la mantilla.

\section{MANTILLA}

Sust. f. 'Prenda de seda, blonda, lana u otro tejido, adornado a veces con tul o encaje, que usan las mujeres para cubrirse la cabeza y los hombros en fiestas o actos solemnes' (DRAE). Término derivado de manto, del lat. tardío mantum 'manto corto', que a su vez es de origen incierto; parece haberse extraído del lat. mantellum, que quizá fuese voz antigua en latín (DECH, s.v. manto).

Una mantilla de contray usada (Coomonte de la Vega, 1645)

Una mantilla de ceñir de lana negra (Coomonte de la Vega, 1645)

Una mantilla de cubrir de pardo (Coomonte de la Vega, 1645)

Una mantilla azul buena (Vidriales, 1645)

Otra mantilla de contray (Vidriales, 1645)

Una mantilla de pardo (La Antigua, 1647)

Una mantilla de contray biexa (Alija del Infantado, 1647)

Una mantilla de zeñir usada (Alija del Infantado, 1647)

Una mantilla berde en blanqueta (La Antigua, 1648)

Otra mantilla clara (La Antigua, 1648)

Una mantilla de contray buena con listas coloradas (Coomonte de la Vega, 1650)

Otra mantilla de contray buena (Coomonte de la Vega, 1650)

Otra mantilla de pardillo nueba (Coomonte de la Vega, 1650)

Una mantilla abinagrada buena (Alija del Infantado, 1650)

Una mantilla de paño negra (La Bañeza, 1714)

Una mantilla de paño azul (Genestacio de la Vega, 1721)

Una mantilla de paño negro (Grajal de la Ribera, 1723)

Una mantilla de palmilla azul (Fresno, 1726)

Una mantilla de frisa usada (Fresno, 1726) 
Una mantilla de contray nueba (Miñambres, 1727)

Una mantilla de somonte (Miñambres, 1727)

Una mantilla color de café (Palacios de Jamuz, 1728)

Una mantilla de buriel nueba (Palacios de la Valduerna, 1728)

Una mantilla de contray vieja (Palacios de la Valduerna, 1728)

Una mantilla redonda negra con su garapiña (Miñambres, 1729)

Una mantilla de cubrir de contray (Miñambres, 1729)

Una mantilla clara (Miñambres, 1731)

Una mantilla de mursulina (Grajal de la Ribera, 1806)

Una mantilla de vayeta blanca con cinta ancha (Grajal de la Ribera, 1806)

Una mantilla de franiela (Saludes de Castroponce, 1808)

Una mantilla de sarga negra de seda (Alija del Infantado, 1812)

Una mantilla de bayeta con galón (Alija del Infantado, 1812)

Una mantilla de tafetán dovlete de seda (Alija del Infantado, 1812)

Una mantilla de franela con cinta y terciopelo nueba (Alija del Infantado, 1812)

Una mantilla pajiza (Castrocalbón, 1814)

Otra (mantilla) de serafina (Castrocalbón, 1814)

Una mantilla de vistas (Huerga de Garaballes, 1820)

Una mantilla nueba de paño pardo (Jiménez de Jamuz, 1825)

Una mantilla negra de Segovia buena con cinta ancha de terciopelo (Jiménez de Jamuz, 1825)

Una mantilla de niño encarnada (Alija del Infantado, 1827)

Un mandil de pardo y una mantilla nueba de paño (San Feliz, 1838)

Una mantilla pajiza rodeada con zinta azul (Calzada, 1838)

Una mantilla con blonda de seda (Requejo de la Vega, 1839)

Dos mantillas de niño verdes cinta estrecha (Requejo de la Vega, 1839)

Un vestido de la boda compuesto de manteo negro con terciopelo, jubón, mantilla y mandil (Destriana, 1870)

Es un término muy frecuente por lo que los ejemplos mencionados son algunos

de los muchos que se han recogido. Se trata de una prenda habitual en las relaciones de bienes. Ya desde el S. XVII aparecen documentadas en esta zona mantillas de paño, de de frisa, entre otras; así como las de ceñir en la Ribera del Órbigo. Como en otras prendas, el objeto aparece detallado

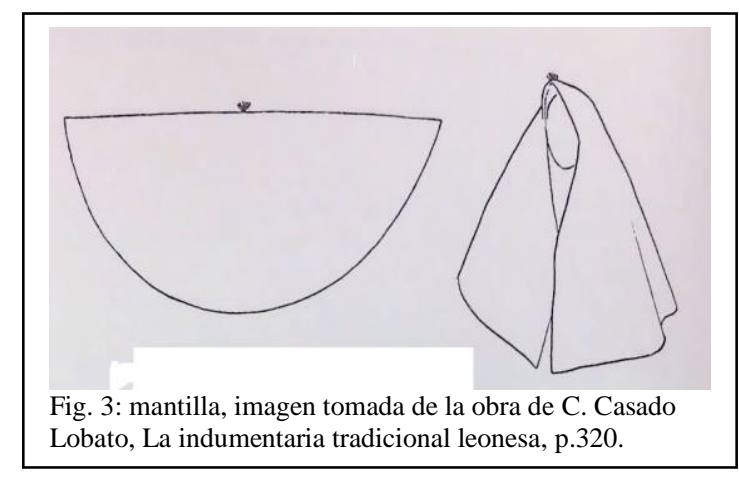
tanto en el tipo de tela, el color o si lleva o no alguna cinta de seda, galón, etc. Hay dos ejemplos en los que el término designa una prenda que normalmente se utilizaba para vestir a los niños que se iban a bautizar, a estas mantillas se las llamaba también mantillas de acristianar (Cavero y Alonso, 2002: 43).

\section{MARMOTA}

Sust. f. 'Gorra de abrigo, generalmente hecha de estambre, que usaban las mujeres y los niños' (DRAE). Del francés marmotte (DECH, s.v. marmota). 
Una marmota, un justillo, una gorra de camino y un cuello (Requejo de la Vega, 1839)

Un sombrerillo con dos pañuelos, una marmota (Requejo de la Vega, 1839)

Es un término poco usado en general, no solo en la zona analizada, puesto que el DRAE incorpora esta acepción al término marmota en la edición de 1899 y el CORDE no tiene ejemplos con estas acepciones. Por tanto, aunque los dos casos encontrados son tardíos, sin embargo aparecen documentados en fechas anteriores a las recogidas hasta ahora. Probablemente se trate de un término que nombra una prenda poco usual, aunque con la acepción de 'gorro de estambre de colores que usan los niños pequeños' sí se utiliza en Zamora (DECH, s.v. marmota). Esto explicaría que, aunque sea un término poco frecuente, encontremos algunos ejemplos por proximidad a esta provincia.

\section{MONTERA [monterilla]}

Sust. f. 'Prenda para abrigo de la cabeza, que generalmente se hace de paño y tiene varias hechuras, según el uso de cada provincia' (DRAE). Término derivado de monte (DECH, s.v. monte).

Una montera de dos picos usada (Coomonte de la Vega, 1643)

Un arca de nogal con su cerradura y llave y en ella cantoneras y sus aldabones y en ella se alló un sombrero nuevo aforado y una montera de paño negro, una almuada de lienzo con su lana, una colcha de tierra de Toledo de diferentes colores, una chupa de paño vieja, otra chupa de estameña negra (Laguna de Negrillos, 1721)

Una montera de pelo de camello (La Bañeza, 1721)

Una montera vieja (Laguna de Negrillos, 1722)

Una arca de castaño larga con todo erraxe en zing y en ella se alló una montera de somonte buena (Grajal de la Ribera, 1723)

Unos zapatos y montera de estameña (Grajal de la Ribera, 1730)

Una montera de somonte (La Isla, 1735)

Una monterilla con plumaje negro (La Bañeza, 1743)

Una montera de somonte (Grajal de la Ribera, 1750)

Una montera de paño (Castrocalbón, 1814)

Una montera de paño forrada en pana (Quintana del Marco, 1820)

Una montera de paño con pana (La Nora del Río, 1823)

Una montera negra con terciopelo (Castrillo de la Valduerna, 1828)

Una montera (San Feliz, 1838)

Una montera nueba de paño (Calzada, 1838)

Una montera usada (Quintana del Marco, 1839)

Una montera buena (Santibáñez de la Isla, 1844)

Es un término que aparece con frecuencia en los inventarios ya que era un tocado de cabeza utilizado en esta zona preferentemente por los hombres. Como reflejan los ejemplos, las más comunes eran las de paño. 


\section{PAÑUELO}

Sust. m. 'Trozo de tela, por lo general cuadrado y mayor que el de bolsillo, usado para abrigarse o como accesorio en la indumentaria femenina y masculina' (DRAE). Término derivado de paño, del latín pannus 'pedazo de paño', 'trapo', 'harapo' (DECH, s.v. pañuelo).

Dos pañuelos de Canbrai (Robledo de la Valduerna, 1726)

Un pañuelo y un mandil (Pobladura del Valle, 1734)

Un cofrecito pequeño clabeteado y en él se hallaron zintas y pañuelos de las niñas (Laguna de Negrillos, 1734)

Un pañuelo de mursulina (Grajal de la Ribera, 1806)

Otro pañuelo encarnado con cenefa blanca (Grajal de la Ribera, 1806)

Otro pañuelo de yerbas (Grajal de la Ribera, 1806)

Un pañuelo de seda de peso color de rosa (Grajal de la Ribera, 1806)

Otro pañuelo de seda de colores (Grajal de la Ribera, 1806)

Otro pañuelo de mursulina transparente (Grajal de la Ribera, 1806)

Otro pañuelo con cenefa de mursulina (Grajal de la Ribera, 1806)

Trece pañuelos de trece esquinas y cuadrados (Saludes de Castroponce, 1808)

Dos pañuelos grandes (Alija del Infantado, 1812)

Otro (pañuelo) fondo color de sapo (Alija del Infantado, 1812)

Un pañuelo nuevo de colores (Alija del Infantado, 1812)

Seis pañuelos blanco nuebos (Alija del Infantado, 1812)

Tres pañuelos más usados (Alija del Infantado, 1812)

Dos pañuelos de lienzo (Castrocalbón, 1814)

Un pañuelo encarnao con flores (Alija del Infantado, 1820)

Un pañuelo encarnado (Jiménez de Jamuz, 1825)

Un pañuelo de seda usado (Quintanilla de Somoza, 1831)

Una servilleta con listas encarnadas y un pañuelo encarnado todo biexo (Quintanilla de Somoza, 1831)

Un pañuelo blanco y pintado (Quintanilla de Somoza, 1831)

Un pañuelo de Casimiro (Castrocalbón, 1833)

Una cofia de un niño y un pañuelo azul (San Feliz, 1838)

Un pañuelo blanco con su fenefa grande (Requejo de la Vega, 1839)

Medio pañuelo de color de caña (Requejo de la Vega, 1839)

Medio pañuelo de paño de color (Requejo de la Vega, 1839)

Un pañuelo hárave ordinario (Requejo de la Vega, 1839)

Un pañuelo blanco (Requejo de la Vega, 1839)

Seis pañuelines (Requejo de la Vega, 1839)

Un pañuelo merino (Requejo de la Vega, 1839)

Un pañuelo de crespón (Requejo de la Vega, 1839)

Otro (pañuelo) de seda color de caña (Requejo de la Vega, 1839)

Un pañuelo de seda pequeño (Requejo de la Vega, 1839)

Un pañuelo con fondo pajizo (Requejo de la Vega, 1839)

Un sombrerillo con dos pañuelos y una marmota (Requejo de la Vega, 1839)

Un pañuelo blanco con flores encarnadas (Requejo de la Vega, 1839)

Dos pañuelos de seda (Requejo de la Vega, 1839)

Cuatro pañuelos muy ajados (Requejo de la Vega, 1839)

Dos pañuelos ajados también y un pechador blanco (Requejo de la Vega, 1839)

Cuatro pañuelos de seda de la mano (Requejo de la Vega, 1839)

Un pañuelo encarnado (Santibáñez de la Isla, 1844)

Un pañuelo de merino para la boda (Destriana, 1870) 
El pañuelo era una de las prendas femeninas más comunes que las mujeres se colocaban atándolos en la parte superior. Los ejemplos reflejan la realidad ya que fue a partir del S. XVIII y especialmente en el S. XIX cuando se extendieron los pañuelos de cabeza, aunque ya existieran anteriormente, sustituyendo a las tocas o a las monteras. Normalmente eran de seda, algodón o muselina como muestran los ejemplos que, como en otras prendas, se relacionan dando una información bastante precisa sobre la tela, el color o el estado de la prenda. No obstante, también se denominaban pañuelos a los que se usaban para colocar por encima de los hombros, concretamente se les denominaba pañuelos de hombros. En estos ejemplos no se hace referencia en ningún caso a si se trataba de uno $\mathrm{u}$ otro, aunque por las características de colores o adornos, probablemente se traten de pañuelos de cabeza.

\section{REBOCIÑO}

Sust. m. 'Mantilla o toca corta usada por las mujeres para rebozarse' (DRAE). Término derivado de bozo, de origen incierto, quizá de un *bŭcciu, derivado romance antiguo del latín bucca; pero es posible que este derivado se extrajera del verbo embozar, que entonces vendría de *imbucciare (DECH, s.v. bozo).

Un rebociño negro de bayeta (La Bañeza, 1643)

Un rebociño con tres pasamanos de oro (La Bañeza, 1643)

Se trata de un sinónimo de mantilla. La mantilla es una prenda muy común que utilizaban las mujeres para ir a la iglesia y este es un término del que se recogen numerosos ejemplos en el corpus. El rebociño es el nombre que se le da a la mantilla en

algunas zonas, especialmente a las que son de gran tamaño, es decir, más bien capas o mantos (Casado, 1993: 509). El hecho de que solo se recojan dos ejemplos, tratándose de una prenda tan común, puede deberse a que lo más frecuente eran mantillas de menor dimensión o a que era el término utilizado por el escribano o la persona que iba nombrando los objetos.

\section{SOMBRERO [sonbrero]}

Sust. f. 'Prenda de vestir que sirve para cubrir la cabeza y consta de copa y ala' (DRAE).Término derivado de sombra, del latín ümbra (DECH, s.v. sombra).

Un sonbrero nuevo fino de peso (Coomonte de la Vega, 1643)

Un sonbrero de lana biexo (Coomonte de la Vega, 1643)

Un sonbrero y toquilla nueba (La Bañeza, 1643)

Unos calçones de pardo y un sombrero bueno (Vidriales, 1645)

Un sombrero nuevo aforado y una montera de paño negro (Laguna de Negrillos, 1721) 
Un sombrero biejo (Laguna de Negrillos, 1722)

Dos sombreros (Grajal de la Ribera, 1723)

Un sombrero y un chambergo (Robledo de la Valduerna, 1726)

Un sombrero de copa alta (Destriana, 1843)

Un sombrero de teja fino (Destriana, 1843)

El sombrero es una prenda bastante común, normalmente eran de paño negro o marrón, en algunas ocasiones iban adornados con cintas de colores, aunque los que aparecen en los ejemplos no hacen referencia a este adorno. En toda la zona, los hombres también utilizaban la montera como prenda para cubrir la cabeza, quizá más frecuente que el sombrero.

\section{TOCA}

Sust. f. 'Prenda de tela con que se cubría la cabeza' (DRAE). Viene de una base tauca, muy antigua en tierras hispánicas, aunque no puede descartarse la posibilidad de que esta a su vez proceda del persa $t \bar{a} q$ 'velo, pañuelo, chal', transmitido en fecha temprana por el árabe (DECH, s.v. toca).

Quatro tocas con puntas (La Bañeza, 1643)

Dos tocas (Urdiales del Páramo, 1645)

Una toca de espumilla buena (Alija del Infantado, 1647)

Dos tocas (La Antigua, 1648)

Una toca de algodón nueba (Coomonte de la Vega, 1650)

Una toca (Alija del Infantado, 1720)

Una toca de algodón (Alija del Infantado, 1720)

Una toca de viatilla (Palacios de la Valduerna, 1728)

Una toca con encajes (Grajal de la Ribera, 1806)

Una toca de tela con encajes (Castrocalbón, 1814)

Dos tocas una de marsolina con encaje y otra de lienzo fino (Jiménez de Jamuz, 1825)

Una toca de morsolina (Destriana, 1843)

Una toca de lienzo ynglés (San Feliz, 1838)

Una toca de lienzo delgado (Calzada, 1838)

Entre los tocados que usaban las mujeres, uno de los más frecuentes eran las tocas, que solían ser de algodón o de lienzo, a veces también de beatilla. Era una de las prendas de uso general, los ejemplos reflejan tanto el tipo de tela como si tenían o no algún adorno. Posteriormente fueron sustituidas por los pañuelos de cabeza, por lo que estos serán mucho más abundantes en el siglo XIX.

\section{TOQUILLA}

Sust. f. 'Pañuelo pequeño, comúnmente triangular que se ponen algunas mujeres en la cabeza o al cuello'. 'Pañuelo de punto, generalmente de lana, que usan para abrigo las mujeres y los niños' (DRAE). Término derivado de toca, de una base tauca, muy antigua 
en tierras hispánicas, aunque no puede descartarse la posibilidad de que esta a su vez proceda del persa $t \bar{a} q$ 'velo, pañuelo, chal', trasmitido en fecha temprana por el árabe (DECH, s.v. toca).

Un sonbrero y toquilla nueba (La Bañeza, 1643)

Es el único ejemplo recogido del término, dato que no permite precisar con exactitud la acepción concreta con la que está utilizada la palabra. De acuerdo con el contexto del propio ejemplo, su adición al término sombrero hace pensar que puede tratarse de un pañuelo. Si se usa con este significado son más frecuentes en el corpus las tocas y posteriormente los pañuelos de cabeza. Si el término estuviera utilizado con la acepción de 'sobretodo', no es la prenda más habitual ya que abundaban más los mantones, entre otras prendas de abrigo.

\section{VISTAS}

Sust. f. El DRAE define el término en su $13^{\mathrm{a}}$ acepción como parte de una cosa que no se oculta a la vista; p.ej., los puños, cuello y pechera de una camisola. Término derivado de ver, del latín vidēre (DECH, s.v. ver).

Una mantilla de vistas (Huerga de Garaballes, 1720)

Es el único ejemplo encontrado por lo que no está clara la interpretación que se puede hacer del término. Siguiendo la definición recogida en el diccionario académico, se habla de vistas en prendas de vestir para referirse a la 'parte visible de una prenda interior'. Ahora bien, la mantilla es una prenda totalmente exterior en la que, cuando va adornada, siempre se especifica el adorno: cinta de terciopelo, lentejuelas, etc. Por tanto, es posible suponer que en este ejemplo el término vistas esté relacionado con otra acepción que se documenta en León y con variantes en otras zonas, y no recoge el DRAE. En la Cepeda se define el término como 'prendas que constituyen el equipo de la novia y que solían exponerse días antes de la boda' (Fuente García, 2000: 585). Tomando este sentido para el término vistas, podría en el ejemplo corresponde a 'una mantilla que forma parte del equipo de la novia'.

\subsubsection{Otros complementos}

\section{ABANICO}

Sust. m. 'Instrumento para hacer o hacerse aire' (DRAE). Es un diminutivo de abano derivado de abanar 'abanicar' del port. y gall. abanar 'aventar, cribar', 'agitar', 'abanicar', 
y este derivado del lat. vannus 'criba' (DECH, s.v. abanar).

Quatro abanicos finos (La Bañeza, 1643)

Un abanico (La Bañeza, 1839)

La palabra es muy poco común en el corpus estudiado, ya que tan solo se han encontrado dos casos. El mayor caudal léxico recogido procede del campo semántico de la agricultura y como puede observarse, los ejemplos encontrados se localizan en La Bañeza, es decir, en la capital del Partido Judicial. Este hecho muestra que estamos ante un objeto minoritario, que quizá solo poseían personas de cierto rango o nivel social o personas situadas en un entorno más urbano ya que, aunque es un objeto que se destina a darse aire, las mujeres lo utilizaban como un elemento de adorno y coquetería. A este respecto, Terreros señala que era símbolo de la coquetería, frivolidad y el capricho de la mujer por excelencia (Terreros, s.v. abanico). En este sentido, el adjetivo finos que acompaña al término en el primer ejemplo es significativo, ya que está indicando que se trata de un objeto destinado probablemente al adorno. La escasez de este término en los inventarios se muestra también en el CORDE donde el mayor número de ejemplos en los que aparece esta voz datan de los siglos XIX y XX. Aparecen algunos ejemplos tempranos del siglo XVII que se recogen en obras de autores destacados como Francisco de Quevedo o Juan de Zabaleta entre otros, o ejemplos tomados de autores como Jovellanos para el siglo XVIII.

\section{AGUJETA [abuyeta]}

Sust. f. 'Correa o cinta con un herrete en cada punta, que servía para sujetar algunas prendas de vestir' (DRAE). Término derivado de aguja, del latín vulgar acucŭla, diminutivo de acus 'aguja' (DECH, s.v. aguja).

Un sayuelo con sus dos abuyetas (Quintanilla de Somoza, 1831)

Es un término que se utiliza comúnmente en la zona de la Maragatería con el significado de 'cordones de seda, de varios colores, entretejidos en forma plana, terminados por cabos metálicos y unas esferillas de aquel tejido, pero más gruesas que los cordones. Sirven a los maragatos para atarse las bragas a la cintura' (Casado, 1993: 500-501). Aunque se trata de un término documentado en zonas próximas: la Maragatería y la Cepeda, solo se ha recogido en el corpus este ejemplo, que no presenta esta restricción tan precisa de significado sino que más bien se utiliza con el sentido amplio de 'cordón', en este caso, el utilizado para ceñir o abrochar el jubón o sayuelo. 
Formalmente, la variante más común es la que contiene la consonante palatal /y/ solución propia del leonés, que es la que presenta el ejemplo del corpus.

\section{ALZACUELLO [alzaquello]}

Sust. m. 'Tira de tela endurecida que, ceñida al cuello, obligaba a llevarlo erguido'. 'Tira suelta de tela endurecida o de material rígido que se ciñe al cuello, propia del traje eclesiástico' (DRAE). Palabra compuesta de alza y cuello. Alza palabra procedente del lat. vulg. *altiare íd., deriv. del lat. altus 'alto' (DECH, s.v. alzar) y cuello del lat. cŏllum (DECH, s.v. cuello).

Dos alzaquellos uno de damasco otro de tafetán (Robledo de la Valduerna, 1726)

Un alzacuello de paño de seda nuevo (Destriana, 1843)

En principio, teniendo en cuenta que solo se han recogido dos ejemplos aparecidos en inventarios de bienes pertenecientes a sacerdotes, podría pensarse que se trata de la tira rígida propia del traje eclesiástico. Sin embargo, si tenemos en cuenta la definición que da del término la edición del DRAE de 1726 junto a las especificaciones que aparecen en el inventario acerca de las telas de las que está elaborado el alzacuellos, telas de seda, podemos llegar a la conclusión de que el significado con el que aparece en el corpus analizado es el de 'adorno del pescuezo común a hombres y mujeres de que se ha usado en varios tiempos, de diversos modos y formas: en cuyo lugar ha sucedido hoy el cuello para los eclesiásticos, y la corbata y golilla para los seglares' (DRAE).

\section{ANTEOJO [antiojo]}

Sust. m. 'Instrumento óptico que acerca las imágenes de los objetos lejanos' (DRAE). Término derivado de ojo, del latín ǒcŭlus (DECH, s.v. ojo).

Una bolsa con antiojos y cartera (La Nora del Río, 1820)

Unos antiojos con caja de cartón (Destriana, 1843)

Otros (anteojos) sin caja descompuestos (Destriana, 1843)

Son pocos los ejemplos recogidos del término y todos pertenecen al S. XIX, dato que no es extraño puesto que en el CORDE la mayoría de los ejemplos pertenecen a los SS. XVIII y XIX y los pocos que hay del S. XVII están fechados en la última parte del siglo, ya que el NTLLE da como primeras documentaciones el S. XVIII. Desde el punto de vista del significado, el diccionario académico da varias acepciones del término, una es la de 'lunetas de vidrio', es decir, una especie de gafas, otra la de 'instrumento óptico para ver de lejos' y otra la de 'piezas de vaqueta que se ponen delante de los ojos a los caballos para que no se espanten', acepción que el DRAE, a partir de la edición de 1992, señala 
como sinónimo de anteojera. Observando los ejemplos encontrados en el corpus estudiado, la última acepción no es la utilizada puesto que en los casos de Destriana se trata de objetos localizados en el gabinete de la casa. Formalmente, en los tres ejemplos aparece el cambio del hiato /eo/>/io/, que no se registra en otras palabras del corpus que mantienen el hiato /eo/ como angeo, porque la /e/ es tónica (Morala y Egido, 2010: 425).

\section{BASTÓN [vastón]}

Sust. m. 'Vara, por lo común con puño y contera y más o menos pulimento, que sirve para apoyarse al andar' (DRAE). Término derivado del lat. tardío bastum (DECH, s.v. bastón).

Un vastón con su chuzo (La Nora del Río, 1823)

Un vastón con su empuñadura de plata (La Nora del Río, 1823)

Los dos ejemplos pertenecen al S. XIX. Según muestran algunos estudios, en esta época el término se definía más por su forma que por su función, destacando sus valiosas cañas o empuñaduras (Castañeda, 2003: 247). Este dato explicaría los complementos con los que aparece el término en los ejemplos recogidos e incluso que se trate de una palabra poco común, ya que probablemente era un objeto que solo poseían personas de cierto nivel social. Es significativo señalar que el término cacha o cachava con el significado de 'cayado' no aparece recogido en ningún caso a lo largo de todo el corpus estudiado y, sin embargo, se trata de un vocablo muy usado en toda la zona. Probablemente, el hecho de que se trate de un objeto muy vulgar, muy conocido, sea la explicación a que no se inventaríe, mientras que el bastón que entraña cierto valor sí aparezca en las relaciones de bienes.

\section{BLONDA}

Sust. f. 'Encaje de seda de que se hacen y guarnecen vestidos de mujer y otras ropas' $(D R A E)$. Del francés blonde, del adjetivo blond 'rubio', porque antiguamente se hacían del color de la seda cruda (DECH, s.v. blonda).

Un mantillín de paño de Segovia con blonda (Grajal de la Ribera, 1806)

Una mantilla con blonda de seda (Requejo de la Vega, 1839)

Corominas y Pascual documentan el término blonda en español en el S. XVIII, concretamente en los años 1770 y 1717 (DECH, s.v. blonda). Este dato explica la escasa presencia de ejemplos en el corpus y que los dos encontrados pertenezcan al S. XIX. Gramaticalmente el término puede usarse como sustantivo o como adjetivo con el 
significado de 'del color rojo parecido al del oro'. En los ejemplos aparece con un uso sustantivo con el significado de 'encaje', tal y como aparece en el DRAE.

\section{BOTón [votón]}

Sust. m. 'Pieza pequeña de metal, hueso, nácar u otra materia, forrada de tela o sin forrar; que se pone en los vestidos para que entrando en el ojal, los abroche y asegure' (DRAE). Del francés antiguo boton (hoy bouton) (DECH, s.v. botón).

Unos balones de paño buenos ya rotos de la entrepiernas con botones de serdas a los lados (Coomonte de la Vega, 1643)

Un bestido de muger, ropa, jubón y basquina de tafetán doble negro guarneçido de esparragón con botones de vidrio (La Bañeza, 1643)

Una colcha de votoncillos con su fleco y tres piernas (La Bañeza, 1714)

Dos votones de plata (Coomonte de la Vega, 1722)

Un jubón de estameña azul con mangas nuevo y botones (Grajal de la Ribera, 1723)

Una chupa de grana con botoncillos (Robledo de la Valduerna, 1726)

Un chaleco blanco con botones de gueso (Castrillo de la Valduerna, 1828)

Una ermilla de rizo con sus botones de espejuelo (Castrillo de la Valduerna, 1828)

Una chupa de estudillo con sus botones de ballena (Castrillo de la Valduerna, 1828)

Cuatro docenas de botones feligrana (Requejo de la Vega, 1839)

Unos pocos de botones negros diferentes calidades (Requejo de la Vega, 1839)

Dos pares de botones de plata (Requejo de la Vega, 1839)

Es un término común que aparece con frecuencia en algunas prendas de vestir.

El material del que están fabricados se suele reflejar ya que es un dato importante para el valor de la prenda.

\section{CARTERA}

Sust. f. 'Objeto rectangular hecho de piel u otro material, plegado por su mitad, con divisiones internas, que se lleva en el bolsillo y sirve para contener documentos, tarjetas, billetes de banco, etc' (DRAE). Término derivado de carta, del latín charta 'papel', y este del griego $\chi \alpha ́ \rho \tau \eta \varsigma ~ ' p a p i r o$, papel' (DECH, s.v. carta).

Dos carteras de seda (Castrocalbón, 1832)

Es el único ejemplo encontrado, dato que no es extraño ya que es inusual en la época y en el contexto social al que pertenecen estos inventarios. Probablemente, el uso que se le da al término es el de 'complemento o bolso de las mujeres', acepción que el $D R A E$ recoge con la especificación de uso en América.

\section{CEÑIDOR [ziñidero, ziñidor]}

Sust. m. 'Faja, cinta, correa o cordel con que se ciñe el cuerpo por la cintura' (DRAE). Término derivado de ceñir, del latín č̆ngěre (DECH, s.v. ceñir). 
Un ziñidero de seda con su caxica (Alija del Infantado, 1644)

Dos ziñidores de seda (Robledo de la Valduerna, 1726)

Un ziñidero plateado (Palacios de la Valduerna, 1728)

Los dos términos ceñidor y ceñidero son sinónimos y así aparecen en el DRAE desde el S. XVIII. No obstante, la voz ceñidor es en algunos corpus más frecuente e incluso el DRAE señala la forma ceñidero como poco usada. En el CORDE, solo aparecen diecisiete casos de ceñidero recogidos entres los SS. XIV y XVI, frente a los más de cien de ceñidor. En el corpus analizado son muy pocos los ejemplos encontrados tanto de un término como de otro, aunque predomina la variante ceñidero con cierre de la vocal /e/ en /i/, por ser un hecho frecuente en la zona occidental que se presenta en algunos términos con más frecuencia que en otros.

\section{CEPILLO (vid. herramientas profesionales)}

\section{COLONIA}

Sust. f. 'Cinta de seda, lisa, de dos dedos de ancha, poco más o menos' (DRAE). Se trata de una abreviación de cinta de colonia con referencia a la ciudad alemana de Colonia (DECH, s.v. colono).

Un par de chapines y colonia (La Bañeza, 1643)

Sendos pares de zapatos con colonias (La Bañeza, 1643)

Dos chalecos vlancos viejos de colonia (La Nora del Río, 1823)

Un chaleco de colonia de homvre viejo (La Bañeza, 1829)

Un poco de colonia nueva (La Bañeza, 1829)

Estamos ante un término que presenta en el corpus dos acepciones. Los primeros ejemplos nombran un tipo de cintas de seda de colores que destacaban por su vistosidad, que en algunos casos además podían llevar en los extremos algún adorno de abalorio, se usaban para adornar mantillas de acristianar, sombreros, etc. Además estas cintas designaban un objeto de adorno específico (las colonias), eran unas cintas que se sujetaban por medio de una cinturilla dejándola caer por detrás sobre el rodao o manteo. Estos son, probablemente, los significados de los dos primeros ejemplos. En los tres siguientes no se hace referencia a unas cintas, sino al tipo de tela del que están confeccionados los chalecos, o a una tela sin confeccionar en el último ejemplo, de seda específica de la ciudad alemana de Colonia. En este caso se trataría de un término que indica un producto con denominación de origen. 


\section{CUELLO}

Sust. m. El DRAE en su $6^{\text {a }}$ acepción define el término como 'pieza suelta de encaje, piel, etc., que, para adorno o abrigo, se pone alrededor del cuello (DRAE). Del lat. cŏllum (DECH, s.v. cuello).

Una docena de cuellos (Robledo de la Valduerna, 1726)

Un cuello (Requejo de la Vega, 1839)

Una marmoza, un justillo, una gorra de camino y un cuello (Requejo de la Vega, 1839)

Un cuello de lino (Requejo de la Vega, 1839)

Es un término poco común en el corpus estudiado ya que es un vocablo que nombra un objeto de valor y adorno, que, como en otros casos, no abundaba en las pertenencias de las personas. Así, tres de los ejemplos pertenecen al mismo inventario. En este caso el significado, probablemente, es el que da el DRAE, puesto que el término aparece relacionado junto a otras prendas de vestir del atuendo femenino. El primer ejemplo puede resultar más dudoso, ya que podría tener el significado de 'prenda de abrigo', pero también el que da el DRAE en su $5^{\text {a }}$ acepción que lo señala como sinónimo de 'alzacuellos del traje eclesiástico', puesto que el inventario en el que se encuentra este ejemplo pertenece a un sacerdote. Además, en esta relación también se documenta el término alzacuello, pero quizá con el significado de 'corbata'. Por todo ello, se puede concluir que aquí cuello se refiera a la pieza del traje eclesiástico.

\section{DIJE}

Sust. m. 'Adorno de los que se ponían a los niños al cuello o pendientes de la cintura'. 'Joya, relicario o alhaja pequeña con que se suelen adornar las mujeres e incluso los hombres' (DRAE). Quizá vino de la idea de 'friolera, menudencia' y esta de la de 'cuentecillo, patraña, enredo, bravata', formado con dije, pretérito del verbo decir (DECH, s.v. dije).

Cinco lazos de cinto, cinco gordones de seda, dos escapularios, una regla de S. Benito y otros dijes (Jiménez de Jamuz, 1825)

Es el único ejemplo recogido del término. Observando el contexto en el que aparece, es probable que se use la segunda acepción que recoge el diccionario académico ya que la voz dijes aparece como un término general al final de la enumeración que recoge otros adornos, relicarios, etc. La primera acepción es más concreta y sería más frecuente, en este caso, encontrar el término dentro de un objeto aparte en la relación. 


\section{ESCARPIDOR}

Sust. m. 'Peine de púas largas, gruesas y ralas que sirve para desenredar el cabello' (DRAE). Del catalán escarpidor, derivado de escarpir 'desenredar el cabello', y este de carpir, latín carpěre 'arrancar', 'desgarrar' (DECH, s.v. carpir).

Un escarpidor de media luna (Grajal de la Ribera, 1806)

Solo se ha recogido este ejemplo. En zonas de la montaña leonesa se ha registrado el término con el significado de 'cardador de la lana', acepción no recogida en el DRAE (Le Men, 2005, s.v. escarpidor). El significado que parece tomar el término en el único ejemplo encontrado parece ser el de 'peine', si tenemos en cuenta la matización de media luna y que aparece junto a otros objetos de aseo y atuendo femenino.

Un escarpidor de media luna

Un espejo y cinco pares de zapatos

\section{FACHA}

Sust. f. 'Traza, figura, aspecto' (DRAE). Del italiano faccia (DECH, s.v. faz).

Una facha de contray (Santiago Millas, 1735)

Una facha ancha, corta y bieja (Quintanilla de Somoza, 1831)

Solo se han recogido estos dos ejemplos pertenecientes ambos a la comarca de la Maragatería. En esta zona, así como en la Cabrera Baja, se utiliza esta voz con el significado de 'mandil' y de 'mantilla para cubrirse la mujer' (Casado, 1993: 506). Estas acepciones no están recogidas en el DRAE. Además, en la zona de la Maragatería facha designaba también una 'especie de mandil que se ataba a la cintura y caía por detrás, hasta el borde inferior de los perriellos, cubriendo el espacio vertical, de unos $40 \mathrm{~cm}$. de ancho, dejado entre las orillas traseras de estos manteos' (Alonso Garrote, 1947: 229). De los ejemplos extraídos no podemos deducir la acepción concreta, pero sí podemos concluir, atendiendo a las especificaciones que tiene el objeto, que el término se utiliza con cualquiera de estos significados relativos a una prenda de vestir.

\section{FAJA}

Sust. f. 'Tira de tela o tejido con que se rodea el cuerpo por la cintura, dándole una o varias vueltas'. 'Prenda interior elástica que ciñe la cintura o la cintura y las caderas' (DRAE). Del latín fasč̌a, derivado de fascis 'haz', de procedencia dialectal o tomado del romance ibérico (DECH, s.v. faja).

Una faja de paño (La Nora del Río, 1823)

Cuatro fajas (Requejo de la Vega, 1839)

Dos fajas encarnadas 10 palmos una de ellas manchada (Requejo de la Vega, 1839) 
Un faja del difunto (Santibáñez de la Isla, 1844)

En algunas zonas leonesas, entre las que se encuentra la comprendida en este estudio, el término faja se utiliza para denominar una 'prenda exterior masculina que forma parte del traje típico', acepción que no aparece recogida en el DRAE (Le Men, 2005, s.v. faja). En algunas comarcas, como la del Bajo Órbigo o la Valdería, eran muy frecuentes las fajas encarnadas, como se muestra en el ejemplo de Requejo de la Vega.

\section{FALTRIQUERA}

Sust. f. 'Bolsillo de las prendas de vestir'. 'Bolsillo que se atan las mujeres a la cintura y llevan colgando debajo del vestido o delantal' (DRAE). Es alteración de las formas antiguas y dialectales faldiquera y faldriquera, derivadas de faldita, forma diminutiva y amanerada de falda (DECH, s.v. faltriquera).

Dos pares de pistolas, unas de arrón y otras de faltriquera (Robledo de la Valduerna, 1726)

Solo se ha recogido este ejemplo del término que, según se puede deducir por el contexto, se utiliza con el significado de 'bolsillo'. Por tanto, se está refiriendo a unas pistolas de bolsillo. En diferentes zonas comprendidas en este corpus, como la Valdería o el Bajo Órbigo, son frecuentes las faltriqueras como complemento de la mujer, que en muchas ocasiones solían estar bordadas. Con este significado no se ha recogido ningún ejemplo en los inventarios analizados.

\section{GUANTE}

Sust. m. 'Prenda para cubrir la mano, que se hace, por lo común, de piel, tela o tejido de punto, y tiene una funda para cada dedo' (DRAE). Del germánico, probablemente del fráncico *want (DECH, s.v. guante).

Dos pares de escarpines, un par de guantes (Grajal de la Ribera, 1806)

Un par de guantes de cabritilla usados (Requejo de la Vega, 1839)

Dos pares de guantes de ante (Requejo de la Vega, 1839)

Solo se han recogido estos tres casos, todos ellos pertenecientes al S. XIX. Se trata de un complemento que, como se aprecia en los ejemplos por las referencias a los materiales, se utilizaba más como adorno que como prenda de abrigo. Por tanto, se trata de un elemento que imprimía cierta distinción, dato que explica la escasez de ejemplos. 


\section{GUARNICIÓN}

Sust. f. 'Adorno que se pone en los vestidos, ropas, colgaduras, etc.' (DRAE). Término derivado de guarnecer, del antiguo guarnir íd., y este del germ. occid. warnjan (DECH. s.v. guarnecer).

Unos cuerpos de escarlatín con guarnición (Palacios de la Valduerna, 1730)

Unos cuerpos de palmilla con sus guarniciones (Grajal de la Ribera, 1750)

Una almohada de lienzo inglés por estrenar con su guarnición (Jiménez de Jamuz, 1825)

Una almuada con guarnición (Castrillo de la Valduerna, 1828)

Una camisa de mujer con guarnición (La Bañeza, 1829)

Dos sabanas usadas, una de ellas con guarnición (Requejo de la Vega, 1839)

Unas enaguas de morsolina con su guarnición (Requejo de la Vega, 1839)

Es un término de uso general para indicar que la ropa $\mathrm{u}$ otro objeto tiene adornos. Fundamentalmente la voz aparece junto a prendas de vestir o ropa del hogar. En muchas ocasiones aparece el adjetivo guarnecido/a. Existe una diferencia contextual entre estas categorías gramaticales, ya que mientras el sustantivo solo aparece con prendas textiles, el adjetivo aparece con prendas, pero fundamentalmente con otros objetos, ya sean joyas o cualquier otro enser.

Tres cornalinas guarnezidas de plata (La Bañeza, 1641)

Un escritorio guarnecido de marfil mediano con otro escritorio de nogal (La Bañeza, 1643)

Un bestido de muger, ropa, jubón y basquina de tafetán doble negro guarneçido de esparragón con botones de bidrio (La Bañeza, 1643)

Unos cuerpos encarnados guarnezidos (Miñambres, 1727)

Un lignum crucis guarnecido en plata con vidrieras de cristal (La Bañeza, 1743)

Una toaya de morsolina bordada o guarnecida de encajes (Destriana 1825)

\section{HEBILLA [ebilla]}

Sust. f. 'Pieza de metal o de otra materia, generalmente con uno o varios clavos articulados en una varilla que la cierra por un lado, los cuales sujetan la correa, cinta, etc., que pasa por dicha pieza' (DRAE). Del latín vulgar *fíbělla, diminutivo del lat. fíbŭla íd.(DECH, s.v. hebilla).

Dos ebillas de metal (Requejo de la Vega, 1839)

Unas ebillas de plata (La Nora del Río, 1823)

Es un término que tiene en León, además del significado que hoy conocemos, el de 'pieza torneada que va por encima de la viga, donde encaja el huso y hace posible que suba el canto' (Le Men, 2007, s.v. hebilla). Sin embargo, en los ejemplos del corpus el término se utiliza con el significado del DRAE puesto que en el primer caso la voz aparece junto a otros términos como abanico o pañuelos de seda. En el segundo ejemplo se especifica al comienzo de la relación que son objetos encontrados en la sala 
principal y aparece junto a una caja de plata. Por tanto, no parece lógico que el término tenga otro significado relacionado con una pieza de la viga. Era frecuente que las hebillas aparecieran como adornos de zapatos, aunque en estos dos casos aparecen inventariadas de forma aislada y no sabemos si eran o no complemento de otro objeto o prenda. En ambos casos aparecen con la referencia al material del que estaban hechas, dato importante en los inventarios por el valor del objeto en función de su material.

\section{LISTA}

Sust. f. 'Tira'. 'Señal larga y estrecha o línea que, por combinación de un color con otro, se forma artificial o naturalmente en un cuerpo cualquiera, y con especialidad en telas o tejidos' (DRAE). Del germano occidental līsta (DECH, s.v. lista).

Otra manta de lana blanca nueba casera con tres listas negras (Coomonte de la Vega, 1643)

Un repostero de lana con listas negras usado (Coomonte de la Vega, 1645)

Un mandil camorano con listas (Coomonte de la Vega, 1645)

Un repostero de listas coloradas (La Antigua, 1648)

Una manta de lana con listas negras a cada punta buena (Coomonte de la Vega, 1650)

Una mantilla de contray buena con listas coloradas (Coomonte de la Vega, 1650)

Dos mantas nuevas con listas negras (Coomonte de la Vega, 1719)

Un mandil de buruel con listas nuevo (Palacios de la Valduerna, 1728)

Una mantilla de listas (Requejo de la Vega, 1735)

Una mesa de manteles con sus listas a las puntas (Quintanilla de Somoza, 1831)

Una servilleta con listas encarnadas y un pañuelo encarnado todo biexo (Quintanilla de Somoza, 1831)

Dos quilmas una con listas y otra sin listas (Palacios de la Valduerna, 1831)

Cuatro cortinas de morsolina con listas encarnadas (Requejo de la Vega, 1839)

Es una voz muy común que se utiliza con todo tipo de prendas con el significado de 'franja o tira', términos estos que con este uso nunca se localizan en los ejemplos del corpus. Hay un caso en el que se utiliza el adjetivo derivado, aunque lo más frecuente es encontrar el sintagma preposicional "con listas".

Un mantón de lana alistado (Requejo de la Vega, 1735)

\section{MANGUITO}

Sust. m. 'Manga sobrepuesta para preservar la ropa'. 'Rollo o bolsa, con aberturas en ambos lados, comúnmente de piel fina y peluda, y algodonado por dentro, que usaban las señoras para llevar abrigadas las manos'. 'Media manga de punto que usaban las mujeres ajustada desde el codo a la muñeca' (DRAE). Término derivado de manga.

Unos manguillos de estameña buenos (Alija del Infantado, 1644)

Un manguito de ombre (Robledo de la Valduerna, 1726) 
Solo se han recogido estos ejemplos que, probablemente, estén usados con el mismo significado aunque se usen con sufijos diferentes. Teniendo en cuenta el contexto del primer ejemplo, que es el que ofrece más información, tal vez tengan la acepción $3^{\text {a }}$ que ofrece el $D R A E$ que define el término como 'media manga que usaban las mujeres', aunque en el segundo ejemplo se especifica que es de hombre.

\section{OREJERA [orexera]}

Sust. f. 'Cada una de las dos piezas de piel o de tejido cálido, a modo de cascos, que se ajustan a las orejas para defenderlas del frío' (DRAE). Término derivado de oreja, del latín aurǐcŭla, diminutivo de auris 'oreja' (DECH, s.v. oreja).

Unas orexeras leonadas (La Bañeza, 1649)

Se trata de un término que puede tener otras acepciones, referidas al arado o a las caballerías; acepciones también recogidas por el DRAE, sin embargo, el término aparece junto a otras prendas de vestir, de ahí que la definición más precisa sea la de una 'prenda utilizada para abrigar las orejas'.

\section{PECHADOR}

Sust. m.

Dos pañuelos ajados también y un pechador blanco (Requejo de la Vega, 1839)

Es un término del que no se ha encontrado ninguna referencia como objeto ni en los vocabularios generales ni en los dialectales, sí como adjetivo con el significado de 'estafador'. Observando el ejemplo, es probable que se trate de un tipo de prenda o complemento que se ponía sobre el pecho, de ahí su nombre y que podría utilizarse para la higiene personal. Aparece junto a otro objeto de este campo semántico, el pañuelo, y dentro de una enumeración de los objetos encontrados en una tienda que, dadas las características de estos, parece ser una especie de mercería.

\section{PEINADOR}

Sust. m. 'Prenda o lienzo ajustada al cuello con que se protege el vestido de quien se peina o afeita' (DRAE). Término derivado de peine.

Dos peinadores de tela con sus encajes (Robledo de la Valduerna, 1726)

Un peinador de lienzo (Pobladura del Valle, 1734)

Son los únicos ejemplos encontrados y se utilizan en el corpus con el significado que da el DRAE. 


\section{PRETINA [petrina]}

Sust. f. 'Correa de cinta con hebilla o broche para sujetar en la cintura ciertas prendas de ropa'. 'Parte de los calzones, briales, basquiñas y otras ropas, que se ciñe y ajusta a la cintura' (DRAE). Del latín pectorina (DECH, s.v. pecho).

Una petrinilla de damasco con sus pasamano de Calabria (La Bañeza, 1641)

Dos pretinas de golilla (Robledo de la Valduerna, 1726)

El término también se usa con otras acepciones, aplicado a la ropa, con el significado de 'cinturón de cuero con hebilla con el que los hombres se sujetan los pantalones', sin embargo, las referencias a telas como el damasco o golilla en los ejemplos, justifican el uso del término con las acepciones que ofrece el diccionario académico. Formalmente, el primer ejemplo aparece sin metátesis, variante frecuente en toda el área leonesa ya que se documenta en León, Asturias, Santander, Salamanca, Zamora, entre otros lugares. Es, por otra parte, la forma etimológicamente correcta. El segundo ejemplo, presenta la forma castellana con metátesis.

\section{POLAINAS [polaynas]}

Sust. f. 'Especie de media calza, hecha regularmente de paño o cuero, que cubre la pierna hasta la rodilla y a veces se abotona o abrocha por la parte de afuera' (DRAE). Del francés antiguo polaine (DECH, s.v. polaina).

Dos polaynas de pardo biexas (Coomonte de la Vega, 1643)

Unas polainas de paño usadas (Coomonte de la Vega, 1722)

Unas polaynas nuebas (Castrocalbón, 1814)

Un par de polaynas de paño usadas (Quintana del Marco, 1839)

Es un término conocido en toda la zona que designa una 'especie de calza que protege la pierna hasta la rodilla', que podríamos incluir dentro del calzado, y que generalmente, como muestran los ejemplos, eran de paño pardo.

\section{QUITASOL}

Sust. m. 'Especie de paraguas o sombrilla usado para resguardarse del sol' (DRAE). Término compuesto de quitar, probablemente del verbo latino tardío quietare, derivado de quietus y de sol, del latín sōl, sōlis (DECH, s.v. quitar y sol).

Un quitasol biexo (Coomonte de la Vega, 1643)

El único término encontrado se utiliza con el significado que da el diccionario académico a lo largo de sus ediciones y que define como 'un instrumento algo más pequeño que el paraguas'. Castañeda Ordóñez afirma que en las primeras ediciones del 
diccionario, en torno a 1817, los términos quitasol, parasol, sombrilla e incluso sombrero eran sinónimos (Castañeda, 2003: 288). El uso que se le da en el corpus en el único ejemplo encontrado probablemente sea el de una especie de sombrilla, que no tiene que ver con el sombrero, aunque tengan el mismo uso, siendo este mucho más frecuente.

\section{ROCADERO}

Sust. m. 'Armazón en forma de piña, formada de tres o más varillas curvas, que en la parte superior de la rueca sirve para poner el copo que se ha de hilar' (DRAE). Derivado de rueca, voz de origen germánico, probablemente del germánico común *rŏkko, introducido en el latín vulgar desde fecha muy antigua y convertido en un femenino *rŏcca (DECH, s.v. rueca).

Un rocadero bordado, una bolsa y ebangelios (Grajal de la Ribera, 1806)

Es el único ejemplo encontrado. El contexto en el que se encuentra el término, complementado por el adjetivo bordado y coordinado con otros objetos que forman parte de los denominados complementos, hace suponer que el significado con el que se emplea esta palabra en el corpus no se corresponde con el que aparece en el DRAE. El diccionario académico remite para la voz rocador al término rocadero y da como acepción para este término, localizado en Salamanca a partir de la edición de 1925, la de 'mantilla semicircular que usan las charras. Se hace de terciopelo o veludillo y se adorna con abalorios'. Sin embargo, este término también se conoce en León con el significado de 'mantilla de cabeza adamascada que se empleaba en las comarcas leonesas para ir a la iglesia' (Cavero y Alonso, 2002: 289). Por tanto, esta será la acepción que aparece en el único ejemplo encontrado, tal vez porque se empleaban más, como se refleja en este corpus, otros términos como mantilla o dengue y denga; aunque estos tengan unas características específicas.

\section{VUELTA [buelta]}

Sust. f. El DRAE define el término en la $14^{\mathrm{a}}$ acepción como 'adorno que se sobrepone al puño de las camisas, camisolas, etc.' Derivado de volver, del latín vŏlvĕre (DECH, s.v. volver).

Tres valonas con sus puntas grandes y dos pares de vueltas de lo mismo (La Bañeza, 1649)

Una valona con sus puntas grandes y dos pares de vueltas de lo mismo (La Bañeza, 1649) 
Una capa buena de paño negro de mujer con su buelta (Grajal de la Ribera, 1723)

Un capote mui usado con bueltas de nobleza (Palacios de la Valduerna, 1726)

Un guardapié encarnado con tres vueltas de pasamanos (Grajal de la Ribera, 1730)

En los ejemplos mostrados, el término vueltas está usado con el significado que aparece en el diccionario académico. Sin embargo, al tratarse de una palabra polisémica, en el corpus se recogen otros ejemplos en los que la voz adquiere distinta acepción, así en:

Cinco bueltas de corales con veinte alconciles y dos sortixas de plata (Coomonte de la Vega, 1645)

Una vuelta de corales y una cruzica de plata (Coomonte de la Vega, 1719)

Una vuelta de sartas con dos avellanas, dos arconziles y cincuenta corales (Alija del Infantado, 1720)

Dos vueltas de corales (Huerga de Garaballes, 1720)

Dos bueltas de corales (Miñambres, 1727)

Una buelta de corales con tres alconziles de plata (Palacios de Jamuz, 1728)

Dos bueltas de sartas para el cuello (Palacios de Jamuz, 1728)

El término se usa con el significado primario de 'hilo del collar'. Ahora bien, el hecho de que se hable de una o más vueltas hace dudar acerca de la interpretación de este término. Cotera señala que en la comarca de Aliste en Zamora se denomina así a una forma de collar "una vuelta conlleva dos o más hiladas de cuentas que, hacia las puntas, tórnase un único hilo" (Cotera, 1999: 234), no a un hilo de cuentas y añade que esto puede ocurrir en otras regiones. Es posible que el uso de vueltas coincida con esta realidad, pero también que la vuelta se corresponda a cada hilo.

\subsubsection{Calzado}

\section{BOTA [vota]}

Sust. f. 'Calzado generalmente de cuero, que resguarda el pie y parte de la pierna' (DRAE). Palabra común con los demás romances de Francia y de la Península Ibérica, de origen incierto. Es probable que el término se tomara del galorrománico o del catalán, pero en realidad no se sabe cuál es el origen. Suele relacionarse con el francés pied bot, teniendo en cuenta que el francés botte designaba primitivamente un calzado grosero, forrado para proteger del frío, pero no está bien atestiguado (DECH, s.v. bota).

Unas botas de zapatos (La Nora del Río, 1823)

Unas votas de calzar (Destriana, 1843)

Son pocos los ejemplos de calzado que aparecen en los inventarios. De todos los términos utilizados para nombrar calzado abundan los escarpines. Solo aparecen estos ejemplos de bota, que se documentan en el S. XIX. Probablemente, se trate también 
de un término que no generalizó su uso hasta esta época ya que anteriormente se usaba otro tipo de calzado como las galochas o los escarpines. Para registrar de forma clara el objeto se especifica con el complemento "de zapatos" o el uso que se le da "de calzar".

\section{BOTín [votín]}

Sust. m. 'Calzado de cuero, paño o lienzo, que cubre la parte superior del pie y parte de la pierna, a la cual se ajusta con botones, hebillas o correas'. 'Calzado antiguo de cuero que cubría todo el pie y parte de la pierna' (DRAE). Derivado de bota.

Unos botines de paño negro (Robledo de la Valduerna, 1726)

Unos votines de Astudillo (La Nora del Río, 1823)

Unos botines biejos (Requejo de la Vega, 1839)

Unos botines buenos (Santibáñez de la Isla, 1844)

El significado con el que se utiliza el término es el señalado anteriormente. Los casos encontrados son de los siglos XVIII y XIX, dato que coincide con los ejemplos encontrados en el CORDE que se sitúan especialmente en los siglos XIX y XX.

\section{CHAPÍN}

Sust. m. 'Chanclo de corcho, forrado de cordobán, muy usado en algún tiempo por las mujeres' (DRAE).Término derivado de una onomatopeya chap-, imitativa del ruido que hacía la que andaba en chapines (DECH, s.v. chapín).

Un par de chapines y colonia (La Bañeza, 1643)

Un par de chapines con hevillas de plata (La Bañeza, 1643)

En algunas zonas de León este término tiene además otras acepciones. Concretamente, en la zona de la Valdería comprendida en este corpus, se denominan chapines a los 'calcetines tejidos con hilo de lana, hilada por la misma gente que los usa', 'calzado ligero, de una sola suela y una sola costura. Escarpines' (Rivas, 1996: 68). Solamente aparecen en este estudio estos dos ejemplos. La información que contienen es bastante escasa y no nos permite determinar cuál es la acepción concreta con la que se usa el término. Probablemente, en el segundo ejemplo se trate más bien de una denominación de calzado, si se tiene en cuenta el adorno que acompaña al objeto en el ejemplo. En las acepciones indicadas la voz escarpines aparece como sinónimo de este término, pero tanto uno como otro vocablo son escasos a lo largo del corpus estudiado. 


\section{CHINELA}

Sust. f. 'Calzado a modo de zapato, sin talón, de suela ligera, y que por lo común solo se usa dentro de casa'. 'Especie de chapín que usaban las mujeres sobre el calzado en tiempo de lodos' (DRAE). De cianella, variante dialectal del it. pianella, diminutivo de piano 'plano, llano' (lat. planus). Se explica este nombre porque las chinelas se distinguían de los chapines y demás calzado por su falta de tacón (DECH, s.v. chinela).

Dos pares de chinelas de moda franzesa (La Bañeza, 1758)

Se trata de un objeto poco usual en estos inventarios, dato que se justifica si se tiene en cuenta que aparece en un inventario que refleja un alto nivel económico por parte de su propietario, lo que explica que posea objetos singulares. Aunque Castañeda Ordóñez señala que eran muy frecuentes en el S. XIX (Castañeda Ordóñez, 2003: 297), solo se ha recogido este ejemplo, que podría ser un sinónimo de chapín y que aparece junto a otros objetos de distinción como «una casaca de nobleza» o «una esclabina de terciopelo», entre otros.

\section{ESCARPÍn}

Sust. m. 'Zapato de una sola suela y de una sola costura'. 'Calzado interior de estambre u otra materia, para abrigo del pie, y que se coloca encima de la media o del calcetín' (DRAE). Del italiano scarpino, diminutivo de scarpa 'zapato' (DECH, s.v. escarpín).

Dos pares de escarpines, un par de guantes (Grajal de la Ribera, 1806)

Es el único ejemplo encontrado a lo largo de todo el corpus estudiado, aunque es un término conocido en la zona. La voz designa una 'especie de calcetín que se ponía con las galochas'.

\section{GABUCHA}

Sust. f. 'Babucha, zapatilla' (Le Men, 2007, s.v. gabucha). Tomado del francés babouche, y este del árabe bābûs, que a su vez procede del persa pāpûs, compuesto de $p \bar{a}$ 'pie' y un verbo que significa 'cubrir' (DECH, babucha).

Unas gabuchas para los pies (Quintanilla de Somoza, 1831)

Es el único ejemplo encontrado. Se trata de una voz que el DRAE recoge bajo la forma babucha. La localidad a la que pertenece este ejemplo actualmente forma parte de la comarca de la Maragatería donde se ha recogido este término con el significado de 'babucha'. Solían ser unas 'zapatillas que se usaban dentro de las galochas' (Alonso Garrote, 1947: 242). En el CORDE no se recogen ejemplos del término gabucha, sí de 
babucha, por tanto, se trata de una variante de uso restringido a una zona geográfica concreta.

\section{GALOCHA}

Sust. f. 'Calzado de madera con refuerzos de hierro, usado en algunas provincias para andar por la nieve, por el lodo, o por suelo muy mojado' (DRAE). Probablemente del oc. ant. galocha 'calzado con suela de madera y empeine de cuero, para preservar de la humedad' o quizá del fr. galocha íd., de origen incierto; al parecer de un lat. vg. *calopěa, alteración de calopěda íd., y este del gr. kalópus, -ópodos, 'horma de madera para hacer zapatos', propte. 'pie de madera' (cpt. de gr. kâlon 'madera' y pûs 'pie') (DECH, s.v. galocha).

Un machado y un barreno de galochas y una azuela de galochas (Ribas de la Valduerna, 1726)

Un barreno de galochas (Miñambres, 1727)

Un taladro de galochas (Viforcos, 1729)

Un cuchillo de galochas (Viforcos, 1729)

Dos taladros de galochas (Miñambres, 1731)

Un barreno de hacer galochas (Calzada, 1838)

La voz tiene en León otras acepciones que no recoge el DRAE. Se llama así también a un 'envase para el vino', acepción poco usada; o a una 'pieza o especie de canal del molino por el que baja el grano hasta las piedras que lo muelen' (Le Men, 2007, s.v. galochas). No obstante, el significado más utilizado es el de 'calzado de madera o almadreña'. En concreto en la zona de La Bañeza es la acepción que se le da al término, de ahí que sea la que aparece en los ejemplos. Los casos recogidos en el corpus no son de los zapatos en sí, que no se recoge ningún ejemplo, sino de los utensilios que se utilizan para fabricarlos.

\section{ZAPATO [çapato]}

Sust. m. 'Calzado que no pasa del tobillo, con la parte inferior de suela y lo demás de piel, fieltro, paño u otro tejido, más o menos escotado por el empeine' (DRAE). De origen incierto (DECH, s.v. zapato).

Unos capatos de baqueta buenos (Coomonte de la Vega, 1643)

Dos pares de zapatos (La Bañeza, 1643)

Sendos pares de zapatos con colonias (La Bañeza, 1643)

Unos zuecos y unos zapatos (La Antigua, 1648)

Unos zapatos (La Nora del Río, 1724)

Unos zapatos viejos (La Nora del Río, 1724)

Unos zapatos y montera de estameña (Grajal de la Ribera, 1730)

Unos zapatos de baqueta (Alija del Infantado, 1737) 
Quatro pares de zapatos viejos de muger de diferentes colores (La Bañeza. 1754)

Otros dos pares (de zapatos) llanos (La Bañeza. 1754)

Un espejo y cinco pares de zapatos (Grajal de la Ribera, 1806)

Unos zapatos (Quintana del Marco, 1820)

Tres pares de zapatos vuenos (Jiménez de Jamuz, 1825)

Dos pares de zapatos de seda viejos (Jiménez de Jamuz, 1825)

Unos zapatos biejos (Alija del Infantado, 1827)

Dos pares de zapatos usados (Quintanilla de Somoza, 1831)

Unos zapatos buenos (Palacios de la Valduerna, 1831)

Unos zapatos biejos (Palacios de la Valduerna, 1831)

Cuatro pares de zapatos dos de seda y dos de cabra (Castrocalbón, 1833)

Unos zapatos medianos (Calzada, 1838)

Un par de zapatos de hombre usados (Quintana del Marco, 1839)

Unos zapatos buenos (Santibáñez de la Isla, 1844)

Dos pares de zapatos unos de la madre y otros de la hija (Santibáñez de la Isla, 1844)

Es una palabra de uso común, aunque probablemente no eran de uso tan frecuentes como en la actualidad. Es probable que la mayor parte de los que aparecen recogidos en estos inventarios pertenecieran a mujeres, ya que en el hombre eran frecuentes los chanclos y las galochas y, además, en algún caso se especificaba en el inventario que eran de hombre. Los de hombre solían ser abotinados en negro o en marrón. En el caso de las mujeres, a veces tenían adornos o, como reflejan los ejemplos, eran de seda.

\section{ZUECO [çueco]}

Sust. m. 'Zapato de madera de una pieza' (DRAE). Del latín sŏccus 'especie de pantufla empleada por las mujeres y los comediantes' (DECH, s.v. zueco).

Unos cuecos buenos (Coomonte de la Vega, 1645)

Unos zuecos de baca a medio serbir (Alija del Infantado, 1647)

Unos zuecos y unos zapatos (La Antigua, 1648)

Dos pares de zuecos y dos pares de medias (Coomonte de la Vega, 1719)

Unos zuecos usados (Laguna de Negrillos, 1726)

Se trata de una palabra que designa un tipo de calzado de madera y de cuero.

Cavero y Alonso señalan el término como sinónimo de chanclo, que es un tipo de calzado que se utiliza en invierno en las comarcas bañezanas (Cavero y Alonso, 2001: 291). Sin embargo, en los inventarios recogidos en este corpus son pocos los términos pertenecientes al campo semántico del calzado que se documentan. Así no se recoge la voz chanclo, pero tampoco la de otro calzado más o menos similar como las madreñas o las galochas, sí en cambio los instrumentos con los que se hacen estas últimas. Formalmente, encontramos un ejemplo del S. XVII en el que el sonido interdental aparece representado por la "ç" a la que le falta el rasgo y con un carácter más significativo desde el punto de vista formal, todos los ejemplos presentan la forma 
castellana de diptongación frente a la solución del mantenimiento de la vocal breve /ŏ/ zoco, que se encuentra en zonas del occidente de León por influencia del gallego.

\subsubsection{Joyas}

\section{ADEREZO [adrezo, adreço]}

Sust. m. El DRAE define este término en su quinta acepción como 'juego de joyas que se compone, por lo común, de collar, pendientes y pulseras'. Palabra derivada de la voz aderezar del ant. derezar y este del lat. vulgar *directiare 'dirigir, poner derecho' (DECH, s.v. aderezar).

Un macho color pardo con sus adreços (La Bañeza, 1643)

Quatro aderezos de balonas (La Bañeza, 1643)

Un aderezo de plata sobredorado (Grajal de la Ribera, 1806)

Un adrezo de cruz y pendientes sobredorado (Alija del Infantado, 1812)

Un aderezo de perlas finas vastante usado engarzado con seda (La Bañeza, 1829)

A excepción del primer ejemplo, el resto son del S. XIX, en el S. XVIII no se han encontrado ejemplos. Este dato no es inusual ya que, como en otros casos, las joyas no abundan en los inventarios. Por lo que respecta al significado, en los ejemplos del S. XIX se mantiene más o menos la definición que los diccionarios académicos dan al término 'juego de varias joyas con que se adornan las mujeres', sin embargo, en el ejemplo del s. XVII, la palabra toma el significado simple de 'adorno' y señala el tipo de adorno concreto del que se trata, la valona, 'pieza de tela para adornar el cuello'. Este dato coincide con los ejemplos reflejados en el CORDE donde, de los casos que aparecen, los que tienen el significado de juego de joyas pertenecen al S. XIX, "un aderezo de esmeraldas" (1862 Gustavo Adolfo Bécquer), mientras que en fechas anteriores el término se utiliza con el significado genérico de 'adorno'.

\section{ALCONCIL [arconcil]}

Sust. m. El DRAE recoge el término alcorcí que define como 'especie de joyel'.

Cinco vueltas de corales con veinte alconciles y dos sortijas de plata (Coomonte de La Vega, 1645)

Una vuelta de sartas con tres arconciles y cincuenta corales (Alija del Infantado, 1720)

Una vuelta de corales con tres alconciles de plata (Jiménez de Jamuz, 1728)

Once corales y dos avellanas y dos alconciles de plata (Genestacio de la Vega, 1738)

Dos vueltas con cuatro avellanas y cuatro alconciles y una cruceta (Saludes de Castroponce, 1808)

Una buelta de corales con quatro abellanas quatro alconciles y su cruceta de plata (Castrocalbón, 1814) 
El término aparece a lo largo de todo el corpus analizado, ya que es una pieza muy frecuente en los collares de corales de toda la zona de La Bañeza. Los alconciles son 'piezas de filigrana de plata, en forma alargada, que son parte de los collares y que suelen alternar con otras piezas esféricas llamadas avellanas' (Casado, 1991: 501). Estas piezas tenían además un símbolo de protección ya que daban a su dueña seguridad física y patrimonial (Rivero, 2006: 3). Formalmente, la variante alconciles aparece de forma generalizada, aunque aparecen algunos casos de confusión /l/ y /r/ que no son excepcionales ya que León es zona de confusión.

\section{ARRACADA [arrecada]}

Sust. f. El DRAE define el término como 'arete o pendiente con adorno colgante'. Se trata de un vocablo procedente del hispanoárabe *qarrat. (DRAE, s.v. arracada).

Tres arrecadas, dos sortixas y dos arconziles (Roperuelos del Páramo, 1724)

Unas arrecadas de plata (Coomonte de la Vega, 1719)

Unas arrecadas de plata (Palacios de Jamuz, 1728)

Unas arracadas y una sortija de plata (Castrocalbón, 1814)

Unas arrecadas con sus bincos (Alija del Infantado, 1827)

Unas arrecadas sin bincos (Alija del Infantado, 1827)

Aparece localizado en los documentos analizados de los siglos XVIII y XIX. No se ha encontrado en los inventarios del S. XVII, no necesariamente por falta de uso, puesto que en el CORDE se fija como primera fecha de aparición el año 1618, sino porque en las relaciones de enseres analizadas en el siglo XVII apenas se recogen joyas,

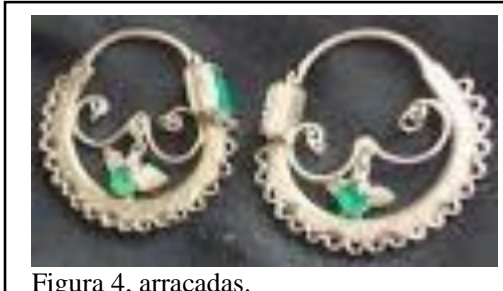

Figura 4, arracadas. abundan otros objetos como aperos de labranza, utensilios de cocina, etc. Desde el punto de vista geográfico, el término se encuentra repartido por todo el P.J. de La Bañeza. La voz aparece siempre bajo la forma disimilada arrecada, vacilación muy frecuente en la provincia de León (Morala, 2012: 559). Prueba de ello es que en el CORDE solo se recoge el término con esta variante en dos ocasiones, fechadas en el siglo XV y pertenecientes a Alfonso de Palencia. El significado con el que se utiliza es el de 'arete o pendiente', a este significado Covarrubias y Autoridades añaden otra matización "era uno de los bienes que daban los esposados a sus esposas con los anillos que se habían de poner en los dedos, este presente se llama arras, de ahí que tomaran el nombre de arracadas como cosa perteneciente a ellas." Como se puede observar en los ejemplos, es frecuente que el término aparezca acompañado del complemento "de plata" ya que era el metal más frecuente en esta zona en lo que a joyería se refiere. Los 
inventarios no suelen añadir más matizaciones, aunque aparecen dos ejemplos con la referencia a los vincos, que era el aro del pendiente o incluso el propio pendiente, ya que algunos se componían de un simple aro de plata.

\section{ALMENDRILLA}

Sust. f. El DRAE define este término, en la $4^{\text {a }}$ acepción como 'pendientes con diamantes de forma de almendra, que usaban las mujeres'. Se trata de una palabra que toma este nombre por su analogía formal con la almendra, de ahí que su origen sea idéntico al de esta palabra, es decir que proviene del latín amygdăla (DECH, s.v. almendra).

Unas almendrillas de plata pequeñas (La Antigua, 1647)

Unas almendrillas de cristal guarnecidas en plata (Palacios de la Valduerna, 1730)

El término toma esta denominación debido a la forma que tenían los colgantes de estos pendientes. Solo se han recogido dos ejemplos, ya que en los inventarios analizados no abundan las joyas $\mathrm{y}$, por otra parte, existían otros términos para denominar a los pendientes, con las características particulares de cada uno de los tipos: arracadas, zarzillos o simplemente pendientes. No obstante, el término aparece escasamente también en el CORDE que recoge un ejemplo con este significado.

\section{ANILLO}

Sust. m. 'Aro de metal u otra materia que se lleva, principalmente por adorno, en los dedos de la mano' (DRAE). Término procedente del lat. anéllus 'anillo pequeño' diminutivo de anülus 'anillo' (DECH, s.v. anillo).

Dos anillos de oro con sus piedras una blanca y otra verde (La Bañeza, 1641)

Unos zarzillos de oro y un anillo con piedras galias (La Bañeza, 1721)

Unos zarzillos de oro y un anillo con piedras galias (Robledo de la Valduerna, 1726)

Un anillo grande y dos mas chicos todo de plata (Robledo de la Valduerna, 1726)

Unas arrecadas y dos anillos de plata (Jiménez de Jamuz, 1825)

Dos pendientes con diamantes, dos anillos y un rosario de plata sobredorada (Destriana, 1844)

Se trata de una palabra común aunque, al tratarse de un elemento que no abunda en los inventarios, solo se han encontrado estos cuatro casos. El significado con el que se utiliza es el que da la Academia que desde su primera edición hasta 1884 mantiene el término como sinónimo de sortija, a partir de esta fecha utiliza la misma acepción para los dos términos, pero no se refiere explícitamente a la palabra sortija como sinónimo de anillo. En los inventarios estudiados se recogen los dos términos, por lo que tampoco se consideran sinónimos absolutos. Por otra parte, se puede observar 
cómo la referencia que se hace a este tipo de objetos en las relaciones de enseres suele ser lo más detallada posible, precisamente para indicar el valor ya que este difiere en función del material con el que esté hecho o el tipo de adornos que lleve.

\section{AVELLANA [abellana]}

Sust. f. 'Fruto del avellano'. 'Piezas redondas de filigrana de plata que se colocan entre los corales que forman un collar'. Este significado no aparece recogido en el DRAE ya que es una acepción creada a partir de una metáfora formal, que se deduce de la propia documentación. Además es bastante común en aquellos inventarios que contienen joyas. Término procedente del lat. avellana nux 'nuez de Abella' (DECH, s.v. avellana).

Una buelta de sartas con dos avellanas, dos arconciles y cincuenta corales (Alija del Infantado, 1720)

Quatro abellanas de plata (Toral, 1728)

Onze corales y dos avellanas y dos alconziles de plata (Genestacio de la Vega, 1738)

Dos vueltas con quatro avellanas, quatro alconziles y una cruzeta (Saludes de Castroponce, 1808)

Una buelta de corales con quatro abellanas quatro alconciles y su cruceta de plata (Castrocalbón, 1814)

Como en el caso de la voz alconciles, la palabra avellanas se documenta sobre todo en el S. XVIII y XIX, ya que en el S. XVII apenas se encuentran joyas en los inventarios analizados. Los collares de corales solían tener diferentes piezas de plata que eran los alconciles y las avellanas, llamadas así por su analogía formal con el fruto. Este significado no se recoge en el DRAE, y con esta acepción solo se ha encontrado un ejemplo en el CORDE: "todo unido por piezas de orfebrería: avellanas, argonciles, sueños, tablillas" (1939, Máximo Sanz). Este dato es significativo ya que solo hay un caso, frente al corpus reducido, base de este trabajo que presenta al menos cuatro ejemplos. Aunque lo más común es encontrar el término con este significado, también hay un ejemplo en el que aparece con el significado de fruto, es el único caso, fechado además en el S. XVII.

Tres medidas de avellanas (La Bañeza, 1641)

\section{AZABACHE}

Sust. m. 'Variedad de lignito, dura, compacta, de color negro y susceptible de pulimento, que se emplea como adorno en collares, pendientes, etc. y para hacer esculturas' (DRAE). Del árabe hispano zabáŷy (DECH, s.v. azabache).

Una gargantilla de azabache con siete pezezillas de plata (La Bañeza, 1641)

Un rosario de azabache (La Bañeza, 1641) 
Un rosario de azabache con una cruzezita de plata (La Bañeza, 1721)

No son muchos los ejemplos recogidos del término a pesar de que el azabache es un material que se ha empleado bastante en la joyería y en las piezas de adorno. Se consideraba además que tenía propiedades mágicas y curativas por lo que era muy apreciado. Además la joyería que contenía piezas de azabache era la que se usaba para guardar el luto. En general, el material de valor más empleado en joyería y que más aparece en el corpus es el coral.

\section{COLLAR}

Sust. m. ' Adorno que ciñe o rodea el cuello'. 'Aro, por lo común de cuero, que se ciñe al cuello de los animales domésticos para adorno, sujeción o defensa' (DRAE). Término derivado de cuello, del latín cŏllum (DECH, s.v. cuello).

Una cenzerrica pequeña con sus collar (Alija del Infantado, 1644)

Unos esquilones con collares de raposo (Coomonte de la Vega, 1645)

Unos esquilones con collares de perro (Coomonte de la Vega, 1645)

Dos esquilones con sus collares (Huerga de Garaballes, 1720)

Dos esquilones con sus collares (Genestacio de la Vega, 1721)

Unos esquilones con sus collares (Grajal de la Ribera, 1730)

Un esquilón con su collar (Palacios de la Valduerna, 1831)

El término utilizado como objeto que se pone a los animales es frecuente en el corpus puesto que formaban parte de los cencerros, esquilones, etc. Con menos frecuencia aparecen los ejemplos del término en su acepción de joya:

Unos collares (Palacios de la Valduerna, 1728)

Un collar de dos vueltas de granos de oro con un sacramento de oro (Requejo de la Vega, 1839)

Solo se recogen estos ejemplos del término. Ello es debido a que en las relaciones de bienes es más frecuente encontrar el nombre de la joya según su conformación: collaradas, gargantillas, joyeles o en el caso del corpus estudiado, también según el número de vueltas de corales que forman el collar en sentido genérico.

\section{CORAL}

Sust. m. ' Sartas de cuentas de coral, de que usan las mujeres por adorno' (DRAE). Del latín corallium o corallum, y este del griego korállion (DECH, s.v. coral).

Sendos rosarios el uno de coral fino (La Bañeza, 1643)

Cinco bueltas de corales con veinte alconciles y dos sortixas de plata (Coomonte de la Vega, 1645)

Una vuelta de corales y una cruzica de plata (Coomonte de la Vega, 1719)

Una buelta de sartas con dos avellanas, dos arconziles y cincuenta corales (Alija del Infantado, 1720) 
Dos bueltas de corales (Miñambres, 1719)

Dos vueltas de corales (Huerga de Garaballes, 1720)

Una buelta de corales con tres alconziles de plata (Palacios de Jamuz, 1728)

Onze corales y dos avellanas y dos alconziles de plata (Genestacio de la Vega, 1738)

Una buelta de corales con quatro abellanas quatro alconciles y su cruceta de plata (Castrocalbón, 1814)

Es un término que aparece con frecuencia en las relaciones de bienes estudiadas en este corpus ya que designa un tipo de joya que a menudo formaba parte de las collaradas y coraladas de las mujeres de esta zona y época. Parece ser que esto se debía a que se trataba de una piedra preciosa de gran aprecio pues se pensaba que tenía poderes curativos y protectores. En el S. XVI se creía que detenía las hemorragias, protegía en casos de tormenta, era bueno contra los males de estómago y potenciaba los sueños tranquilos (Guerrero y López 2009: 6). Además tenían un gran valor crematístico, por ello las grandes coraladas marcaban la posición social de quien las portaba (Cavero y Alonso, 2002: 218-219). Este dato explica que aparezcan como un bien en las relaciones marcando el número de corales tanto si van sueltos como si forman una vuelta.

\section{CORNALINA}

Sust. f. 'Ágata de color sangre o rojiza' (DRAE). Se trata de un término procedente del fr. cornaline (DECH, s.v. cuerno).

Tres cornalinas guarnecidas en plata (La Bañeza, 1641)

Dos cornalinas y una sarta (Roperuelos del Páramo, 1724)

Los diccionarios académicos y el CORDE señalan que es a partir del siglo XIX cuando aparece con el significado de 'ágata'. Sin embargo, los testimonios encontrados son muy anteriores.

\section{CRUZ}

Sust. f. 'Figura formada por dos líneas que se atraviesan o cortan perpendicularmente' (DRAE). Del lat. cruz, crŭcis (DECH, s.v. cruz).

Una cruz de S. Toribio guarnezida en plata (La Bañeza, 1641)

Una pintura de Nuestro Señor con la cruz a questas (La Bañeza, 1643)

Una cruz de cristal con sus remaches de oro (La Bañeza, 1649)

Una vuelta de corales y una cruzita de plata (Coomonte de la Vega, 1719)

Un rosario de azabache con una cruzezita de plata (La Bañeza, 1721)

Una cruz y dos relicarios de plata y un par de botones de lo mismo (Robledo de la Valduerna, 1726)

Seis alconciles y una cruz de plata (Miñambres, 1727)

Una cruz y una tablilla de plata (Toral, 1728) 
Una cruz pequeña con sus espejuelos pequeños (Grajal de la Ribera, 1730)

Una cruz encartonada de plata (Grajal de la Ribera, 1806)

Un adrezo de cruz y pendientes sovre dorado (Alija del Infantado, 1812)

Una gargantilla con quatro piezas y su cruz (Destriana, 1843)

Es un término común ya que designa un elemento que tiene un valor en sí mismo y por ello aparece con frecuencia en los inventarios, tanto si forma parte de una joya, de una pintura o constituye ella misma la joya o elemento de valor.

\section{CRUCETA [cruzeta]}

Sust. f. 'Cada una de las cruces o de las aspas que resultan de la intersección de dos series de líneas paralelas, especialmente en enrejados o en labores y adornos femeninos' (DRAE). Término derivado de cruz.

Una cruceta de plata con una figura de un Santo Cristo (Coomonte de la Vega, 1645)

Una cruceta de plata (Coomonte de la Vega, 1719)

Un pie blanco de plata, una tablilla, una cruceta, dos arecadas (Miñambres, 1727)

Dos vueltas con quatro avellanas y quatro alconziles y una cruzeta (Saludes de Castroponce, 1808)

Dos crucetas y dos medallas de plata (Alija del Infantado, 1812)

Una buelta de corales con quatro abellanas, quatro alconciles y su cruceta de plata (Castrocalbón, 1814)

Una vidriera y una cruzeta (La Nora del Río, 1820)

Es una palabra frecuente ya que es común que las gargantillas que llevaban las mujeres de adorno fueran de vueltas de corales con elementos de plata, entre ellos las avellanas $\mathrm{y}$, en medio, las crucetas.

\section{GARGANTILLA}

Sust. f. 'Adorno femenino que rodea el cuello' (DRAE). De la raíz onomatopéyica gargque imita el ruido del gargajeo y otros que se hacen con la garganta (DECH, s.v. gargajo).

Una gargantilla de azabache con siete pezezillas de plata (La Bañeza, 1641)

Una gargantilla con quatro piezas y su cruz (Destriana, 1843)

El término tiene el significado de 'objeto de adorno'. En esta zona comprendida en el corpus también recibían el nombre de ahogaderas (Cavero y Alonso, 2001: 213), aunque bajo este término no se ha recogido ningún ejemplo. Ello era debido a que estaban ajustadas al cuello. Estas gargantillas se confeccionaban con cuentas de diferentes materiales, el azabache era uno de los materiales comunes utilizado para los lutos. A veces, como en los ejemplos, llevaban colgantes de plata, uno de los más frecuentes era la cruz, que se resalta en el segundo ejemplo. 


\section{JOYA [xoya]}

Sust. f. 'Adorno de oro, plata o platino, con perlas o piedras preciosas o sin ellas, usado especialmente por las mujeres' (DRAE). Del fr. ant. joie, derivado regresivo de joiel, que a su vez procede del latín vulgar *jocale íd. derivado de jocus 'juego' (DECH, s.v. joya).

Una xoya de plata (La Antigua, 1648)

Es el único ejemplo encontrado. Probablemente, este hecho se deba a que es más frecuente inventariar estos elementos de adorno con el nombre concreto para especificar con detalle de qué objeto se trata en cada caso. Por ello, es más frecuente encontrar en las relaciones términos como joyeles, arrecadas, etc.

\section{JOYEL [joiel, joel, xoel, xoiel]}

Sust. m. 'Joya pequeña' (DRAE). Del francés antiguo joie, derivado regresivo de joyel, que a su vez procede del latín vulgar *jocale íd. (DECH, s.v. joya).

Un xoel de plata (La Antigua, 1647)

Un joel de plata con sus bidrieras (Grajal de la Ribera, 1723)

Un joel dorado (Miñambres, 1727)

Un joiel blanco de plata, una tablilla, una cruceta, dos arecadas (Miñambres, 1727)

Un joel de plata con la echura del Ángel y La Soledad (Palacios de la Valduerna, 1730)

Un joyel dorado afiligranado (Destriana, 1730)

Un xoiel, unas arrecadas con sus vincos (Requejo de la Vega, 1735)

Un joel de plata (Castrocalbón, 1814)

Es un término frecuente ya que se trata de una joya común en los inventarios leoneses y zamoranos. El significado que tiene no es el que da el DRAE, puesto que es una de las joyas de mayor tamaño que se encuentra en los inventarios. Se trata de un 'colgante'. Constan de dos superficies circulares y convexas, provistas una de ellas de un Cristo de bulto redondo y tres clavos, y la otra de una imagen de la Virgen (Cavero y Alonso, 2002: 238), aunque Casado señala que no eran joyas de carácter religioso, sino de adorno (Casado, 1993: 254). Normalmente eran de plata o sobredorados y podían llevar una ornamentación de filigrana, como se refleja en el ejemplo de Destriana.

\section{MEDALLA}

Sust. f. 'Pieza de metal batida o acuñada, comúnmente redonda, con alguna figura, inscripción, símbolo o emblema' (DRAE). Del italiano medaglia (DECH, s.v. medalla).

Tres medallas de plata y una piedra con el asa de plata y una cruz encartonada de plata (Grajal de la Ribera, 1806)

Dos crucetas y dos medallas de plata (Alija del Infantado, 1812) 
Es un término común aunque como en otros términos referidos a joyas, los ejemplos son, en general, escasos. En el caso de las medallas solían ser joyas apreciadas ya que en ellas se solían reproducir las imágenes de aquellas vírgenes, santos o símbolos religiosos hacia los que se tenía devoción o se consideraba que portarlos conllevaba cierta protección para la persona. A este respecto, el Diccionario de Autoridades dice que son 'la pieza de metal en que se ve la efigie de algún Santo o Santa o se representa algún misterio de nuestra sagrada religión, que suele bendecir el Sumo Pontífice, y conceder indulgencias a quien las trae'.

\section{PENDIENTE}

Sust. m. 'Joya que se lleva colgando' (DRAE). Término derivado de pender, del latín pĕndēre (DECH, s.v. pender).

Un adrezo de cruz y pendientes sovredorado (Alija del Infantado, 1812)

Dos pares de pendientes de oro (Castrocalbón, 1833)

Unos pendientes de oro con seis topacios cada uno (Requejo de la Vega, 1839)

Un par de pendientes de plata (Requejo de la Vega, 1839)

Unos pendientes de perlas (Requejo de la Vega, 1839)

Dos pendientes con diamantes, dos anillos y un rosario de plata sobredorada para el cuello (Destriana, 1870)

Se trata de un término común, aunque su uso queda restringido en el corpus al S. XIX. Probablemente esto es debido a que para designar este tipo de joya que cuelga, se utilizaban otros nombres específicos que designan cada tipo de pendiente de acuerdo con su forma y sus características, así encontramos por ejemplo el término arracadas. Sin embargo, quizá se pueda afirmar que el uso del término genérico pendientes se utiliza para referirse a otro tipo de joyas, probablemente más finas y que aparecen en fechas posteriores, por ello que los ejemplos se sitúen en el S. XIX. Además en este momento y con este nombre, los pendientes aparecen no solo en plata sino también en oro y con diferentes tipos de piedras preciosas como son diamantes, perlas, etc.

\section{SARTA}

Sust. f. 'Serie de cosas metidas por orden en un hilo, en una cuerda, etc.' (DRAE). Del latín serta 'guirnalda, corona', propiamente participio de serere 'trenzar, entrelazar'. En latín vulgar serta aparece cambiado en sarta por confusión con sarta 'remendada', participio de sarcire (DECH, s.v. sarta).

Una buelta de sartas con dos avellanas, dos arconziles y cincuenta corales (Alija del Infantado, 1720)

Dos bueltas de sartas para el cuello (Palacios de Jamuz, 1728) 
El término sarta es conocido como algo que se mete en un hilo. Sin embargo, aplicado a la joyería que aparece en los inventarios estudiados, la voz presenta un significado más concreto y probablemente al señalar en las gargantillas, collaradas, etc el número de corales, arconciles, etc. que conforman la joya (primer ejemplo), el término sarta se refiera a aquellas piezas populares que normalmente eran de pasta vítrea (Casado, 1993: 254).

\section{SORTIJA [sortixa]}

Sust. f. 'Anillo, especialmente el que se lleva por adorno en los dedos de la mano' (DRAE). Término derivado de suerte, del latín sors, sŏrtis (DECH, s.v. suerte).

Cinco bueltas de corales con veinte alconciles y dos sortixas de plata (Coomonte de la Vega, 1645)

Dos sortijas de oro la una de cuatro piedras y la otra de una flor de lis (La Bañeza, 1649)

Una sortija de plata (Palacios de Jamuz, 1728)

Unas arracadas y una sortija de plata (Castrocalbón, 1814)

Dos sortijas de oro con chispas de deamantes (Castrocalbón, 1833)

Como ocurre con el término anillo, los ejemplos que se encuentran en el corpus son escasos. Las sortijas solían formar parte de la dote y las donas que el novio regalaba a la novia con motivo de su compromiso, por lo que su presencia es escasa. Fundamentalmente eran de plata, también las había de oro y como material de adorno se empleaba sobre todo el vidrio y el coral.

\section{TABLILLA}

Sust. f. El Diccionario de Autoridades define tablilla como 'medalla grande en que está esculpida alguna imagen que se pone al pecho y la usan por adorno las labradoras'.

Seis honzas de corales con una tablilla y un empañado y una reliquia y quatro almendrillas, seis avellanas (Huerga de Garaballes, 1720)

Un joiel de plata, una tablilla, una cruceta, dos arecadas (Miñambres, 1727)

Una cruz y una tablilla de plata (Toral, 1728)

Son los únicos ejemplos encontrados del término ya que dentro de las joyas de colgar abundan otras como los joyeles o las cruces. Normalmente suelen ser rectangulares y de plata, como en los ejemplos, aunque también pueden ser de oro o plata sobredorada. 


\section{VINCO [binco]}

Sust. m. El DRAE define el término en singular como 'anillo de alambre que se pone en el hocico a los cerdos para evitar que hocen' y en plural como 'pendientes que usan las mujeres formados por un aro de plata'. En ambos casos localiza estos usos en León. Del latín *vincum atadura, regresión de vincŭlum (DEEH, s.v.vincum).

Dos pares de bincos de plata (Palacios de Jamuz, 1728)

Un xoiel, unas arrecadas con sus vincos (Requejo de la Vega, 1735)

Unas arrecadas sin bincos (Alija del Infantado, 1827)

En los tres ejemplos recogidos en el corpus, el término utilizado en plural tiene el significado de 'pendientes', aunque hay diferencias en cada uno de los casos. En los dos últimos ejemplos, la voz aparece junto al término arrecadas en las que se matiza la presencia o ausencia de vincos, que son en este caso el aro del pendiente. Mientras que en el primer ejemplo el propio término vinco designa la joya. Se trata en este caso de un tipo de pendientes de la época que se encuentran documentados en León desde el S. XVII. Normalmente eran de plata, como en el ejemplo o sobredorados y estaban formados por un gran aro al que se podía añadir un colgante. No obstante, quizá en el corpus son más frecuentes otros términos como arrecadas.

Además el término vinco se utiliza en singular con la acepción que da el diccionario académico localizada en León e incorporada a partir de la edición de 1925 pero también como 'gancho que se pone en las narices del ganado vacuno para dominarlo mejor' (Le Men, 2011, s.v. vinco). Con estas acepciones no se recoge ningún ejemplo.

VUELTA [buelta] (vid. indumentaria y arreglo personal/ complementos/otros).

\section{ZARCILLO}

Sust. m. 'Pendiente, arete' (DRAE). Del latín currcĕllus 'circulito', diminutivo de circus (DECH, s.v. zarcillo).

Unos zarcillos de oro y un anillo con piedras galias (La Bañeza, 1721)

Es el único ejemplo encontrado. No es un término frecuente en el inventario. Si remitimos a las acepciones que la Academia ha dado en sus respectivas ediciones para el término, se define como 'arillo de oro o plata'. Para esta acepción en el corpus aparecen otros términos más comunes como son vincos y sobre todo la voz arracadas que, en definitiva, son pendientes de aros, independientemente de que después lleven o no piedras. 


\subsection{AJUAR DOMÉSTICO}

El ajuar doméstico incluye gran cantidad de objetos que formaban parte de la vida diaria de las personas a quienes pertenecían estos inventarios. Tratando de organizar este material, se han establecido cuatro subapartados. El primero, de utensilios de cocina, incluye a su vez los siguientes subgrupos: recipientes, en el que se incluyen todo tipo de vasijas e incluso vajilla y cristalería; cacharros, grupo al que pertenecen todos aquellos recipientes que sirven para cocinar; cubiertos; objetos relacionados con la lumbre y un subgrupo de otros utensilios en el que se incluyen todos aquellos objetos relacionados con las tareas culinarias que no se ajustan propiamente a ninguno de los subapartados anteriores. Otro subapartado lo forman las voces que se incluyen en la denominación de ropa de hogar que han sido agrupadas por criterios de proximidad (la cama, la mesa, etc.). El tercer subapartado denominado ornamentación incluye términos que designan objetos que forman parte de la decoración de la casa. Finalmente hay un cuarto subapartado que se incluye en el ajuar doméstico y que está formado por los objetos destinados a la iluminación del hogar.

\subsubsection{Utensilios de cocina}

\subsubsection{Recipientes}

\section{ACEITERA}

Sust. f. El DRAE define la palabra en su $6^{\text {a }}$ acepción como 'alcuza'. Voz derivada de aceite, término procedente del ár. zéit (DECH, s.v. aceite).

Una aceitera y un canastillo (Grajal de la Ribera, 1806)

Una aceitera grande de ojadelata con su coladera (Destriana, 1843)

Aunque en León la palabra tiene también la acepción de 'candil casero' (Le Men, 2002, s.v. aceitera) los ejemplos encontrados utilizan el término con la acepción académica de 'recipiente para guardar aceite', ya que aparecen junto a otros enseres de cocina: ollas, platos, cubiertos.

\section{ALBORNÍA [albernía, alborma]}

Sust. f. 'Vasija grande de barro vidriado, de forma de taza' (DRAE). Se trata de un término procedente del árabe burniya (DECH, s.v. albornía). Se documenta por primera vez bajo la forma albornía en 1617.

Una albornía de medio baño (Alija del Infantado, 1644)

Una albernía (La Antigua, 1648) 
Una alborma blanca (Laguna de Negrillos, 1725)

El término aparece solo en tres casos de los cuales, dos pertenecen al siglo XVII y uno al siglo XVIII, pero a los primeros años. Este hecho coincide con los datos que se recogen en el CORDE donde los ejemplos que allí se registran pertenecen todos al S. XVII y se habla de una especie de vasija que no siempre es de barro, sino que puede ser de otros materiales: porcelana, etc. En este caso, con la información obtenida no se puede deducir el material del que estaba fabricada, incluso podría pensarse con los pocos datos que tenemos, que era de barro. Los tres casos encontrados se sitúan en la zona sur del ámbito estudiado. En el ejemplo de La Antigua aparece un caso de vacilación en el timbre de las átonas, que es frecuente en leonés y que precisamente, como en casos anteriores, se encuentra en la zona más occidental de los tres ejemplos.

\section{ALCUZA}

Sust. f. 'Vasija de barro, de hojalata o de otros materiales, generalmente de forma cónica, en que se guarda el aceite para diversos usos' (DRAE). Término procedente del ár. marroquí y egipcio kûza 'jarrito' (DECH, s.v. alcuza).

Dos alcuzas con su embudo para aceite (Quintanilla de Somoza, 1831)

Solo se ha recogido este ejemplo. En el CORDE aparecen abundantes ejemplos del término correspondientes a los siglos XVI y siguientes. En cambio, en los diccionarios leoneses consultados, no se recoge este término. Este dato, unido al único ejemplo encontrado en el corpus analizado, nos lleva a pensar que se trata de un caso aislado y, por tanto, no es una palabra de uso común en esta zona. Se utilizaría como sinónimo de aceitera, aunque el número de ejemplos en ambos términos es escaso a lo largo del corpus.

\section{ALMOFÍA}

Sust. f. 'Jofaina' (DRAE). Término procedente del ár. español y magr. múhfiya. (DECH, s.v. almofía).

Una almofía de Talavera (Grajal de Rivera, 1806)

Es el único ejemplo recogido en el corpus. Como en el caso anterior, se trata de un término que no aparece en los diccionarios leoneses consultados. Solo se ha recogido un caso, probablemente se trate de un caso aislado que indica que no es una palabra de uso común en esta zona, aunque sí aparece en zonas próximas como en Galicia o Portugal y, sobre todo, parece que sí es frecuente encontrarla en inventarios del centro 
occidental de la Península (Morala, 2012b: 89).

\section{ALTAMíA [altamía]}

Sust. f. El DRAE define el término como 'especie de taza'. Probablemente, procede de la palabra árabe t $a^{c} a ́ m \hat{\imath} y a$ 'especie de jofaina', derivado de $t a^{\mathrm{c}} t a ̂ m$,'comida' (DECH, s.v. altamía).

Tres altamías (La Antigua, 1648)

Cinco altamías y un salero (La Antigua, 1648)

Dos altamías (Coomonte de la Vega, 1719)

Ocho altamías (Coomonte de la Vega, 1719)

Es una voz con poco uso y centrada en un período cronológico concreto. El diccionario de Autoridades recoge el término e indica que es una voz en desuso. A partir de la edición de 1770 se indica que es una voz viva en las montañas de León y Burgos, dato que desaparece en la edición de 1882. Esta información guarda relación con los casos recogidos en el CORDE que aparecen fechados mayoritariamente en el S. XVI, a excepción de un ejemplo del S. XIV y otro del S. XVII, lo que llevaría a pensar que se trata de una palabra que se utiliza fundamentalmente durante el S. XVI. Los ejemplos encontrados en el corpus muestran, sin embargo, que en fechas posteriores al S. XVI, la voz seguía usándose en el área occidental, como lo reflejan los ejemplos de Coomonte de la Vega recogidos en este corpus u otros que se han documentado en la misma zona (Morala 2012c: 82). Es significativo señalar que esta palabra presenta grandes similitudes con el término anteriormente estudiado, también procedente del árabe y con un significado próximo. En cuanto al significado, el DRAE define el término como 'taza en que se sirve la comida' y señala a partir de la edición de 1925 el significado de 'cazuela de barro vidriado' en León. A pesar de esta información ofrecida por el DRAE, este término no se recoge en los vocabularios dialectales modernos de la provincia de León. En los ejemplos recogidos en el corpus, no podemos precisar con los datos extraídos de los documentos, si se trata de una taza o de una cazuela de barro vidriado.

\section{ESCUDILLA [escodilla]}

Sust. f. 'Vasija ancha y de forma de una media esfera, que se usa comúnmente para servir en ella la sopa y el caldo' (DRAE). Del lat. scutella (DECH, s.v. escudilla). El término se encuentra recogido especialmente en la zona más próxima a la provincia de Zamora. Es de uso general en la época analizada.

Un plato de madero y dos escudillas de lo mismo. (Coomonte de la Vega, 1643)

Unas escudillas y platos. (Castrocalbón, 1643) 
Una escodilla de medio baño (Alija del Infantado, 1644)

Una escodilla de Talavera fina (Alija del Infantado, 1644)

Una fuente y un plato y una escodilla de medio baño (Coomonte de la Vega, 1650)

Dos escudillas (Coomonte de la Vega, 1719)

Dos escudillas de Talavera (La Bañeza, 1754)

Dos escudillas y dos cucharas de madera (Quintana del Marco, 1820)

Aparece siempre bajo la forma castellana, que presenta reducción del diptongo /ie/ a /i/. Encontramos ejemplos de vacilación vocálica, escodilla, donde la vocal velar es una vocal átona que presenta vacilación en el timbre, característica frecuente en la lengua del siglo XVII. Esta inestabilidad se produce especialmente cuando la vocal tónica de la palabra es una /i/ (Morala, 2009: 557). Los casos de vacilación se producen en el S.XVII, pero en los ejemplos posteriores aparece ya bajo la forma actual. El significado que toma es el de 'cazuela de madera o más frecuente de barro' -como se puede deducir de la especificación "de medio baño"-, en la que se comen las sopas.

\section{BACíA [vacía]}

Sust. f. 'Vasija para contener líquidos u otras cosas' (DRAE). Voz emparentada con bacín y con varias palabras del latín tardío quizá proceda del francés anticuado bassie que parece ser forma dialectal correspondiente a un latín vulgar *bacceata, derivado de baccea (este probablemente acentuado en la $a$ ), (DECH, s.v. bacía).

Ocho bacías (La Antigua, 1647)

Siete bacías (Villanueva de Valdejamuz, 1704)

Una caja de un brasero sin la vacía (Laguna de Negrillos, 1722)

Es un término que puede designar diferentes objetos diversos utilizados para contener líquidos, aunque en estos ejemplos, la voz se emplea con la acepción general de 'vasija'. En los dos primeros casos el número de objetos que se documenta es acorde con este uso, en el tercero hace clara referencia al brasero y por tanto al espacio cóncavo de este objeto.

\section{BARREÑO [barreña, barreno, varreña]}

Sust. m. y f. 'Vasija de barro, metal, plástico, etc., de bastante capacidad, generalmente más ancha por la boca que por el siento, que sirve para fregar la loza y para otros usos' (DRAE). Término derivado de barro de origen prerromano (DECH, s.v. barro).

Dos barreñas de barro colorado (Alija del Infantado, 1644)

Seis barreñas de barro colorado (Coomonte de la Vega, 1650)

Un barreño de madera (Laguna de Negrillos, 1721)

Seys barreñas y dos platos (Coomonte de la Vega, 1724)

Una varreña (Coomonte de la Vega, 1724)

Dos barreños uno de galochas y uno de carro (Robledo de la Valduerna, 1726) 
Un barreno de galochas (Miñambres, 1727)

Zinco barrenos yngleses (La Nora del Río, 1823)

Una trasga y un barreno de cabijales (Palacios de la Valduerna, 1831)

Un barreno grande y unas tinajas (Santibáñez de la Isla, 1844)

En el corpus estudiado, probablemente, las formas masculina y femenina noson sinónimas. Se utiliza la forma barreña para referirse a un 'objeto de cocina que se utiliza para comer, normalmente las sopas', como lo demuestran los ejemplos que aparecen siempre referidos junto a otros utensilios de cocina: platos, escudillas, etc. En este sentido Rivas señala como definición de barreña 'recipiente de barro cocido, con dos asas y con barniz total o parcial. Se usaba para comer platos o condimentos calientes en invierno, muy especialmente las sopas de ajo' (Rivas, 1996: 44). Con este significado, por tanto, se utiliza la forma barreña o mucho menos frecuente varreña, forma que en esta época no es más que una mera variante gráfica. La forma masculina se refiere a un 'recipiente generalmente grande que se utiliza para diversos usos, como pueden ser para llevar la ropa, entre otros'.

\section{BARREÑón [varreñón]}

Sust. m. 'Vasija de barro tosco, de mayor tamaño que el barreño con o sin asas', 'barreño pequeño' (Le Men, 2000, s. v. barreñón). Término derivado de barreño.

Un barreñón de barro (Coomonte de la Vega, 1643)

Un barreñón de barro (Alija del Infantado, 1647)

Dos barreñones (Robledo de la Valduerna, 1726)

Un barreñón (Grajal de Ribera, 1750)

Dos barreñones (Castrillo de la Valduerna, 1828)

Dos varreñones de madera (La Nora del Río, 1823)

Un barreñón de madera grande (Quintana del Marco, 1839)

Una barreñón grande para adovar (Destriana, 1843)

Es una palabra de uso bastante común en el corpus analizado, aunque en el DRAE no aparece registrada y en el CORDE son escasos los ejemplos que aparecen, tan solo se reflejan cinco. Los ejemplos del corpus analizado que se localizan en la zona situada más al sur, especifican el material con el que está elaborado el objeto, por tanto, quizá se utiliza con la segunda acepción señalada, mientras que en las zonas próximas a la Valdería, probablemente por la influencia de los alfareros de Jamuz, se trata de un objeto elaborado con barro, de ahí que en ningún caso se haga referencia al material de elaboración y probablemente en este caso se utilice con la primera acepción señalada. 


\section{BARRIL}

Sust. m. 'Vaso de barro, de gran vientre y cuello estrecho, en que ordinariamente tienen los segadores y gente del campo el agua para beber' (DRAE). Se trata de una voz emparentada con barrica, barriga. Barriga es la forma genuinamente esp. de barrica, tomado del gasc. barrique, íd. procedente de una base *barrīca, cuyo origen se desconoce, de la cual procede asimismo barril (DECH, s.v. barriga, barrica).

Tres barriles colorados (Coomonte de la Vega, 1643)

Otro barril colorado (Coomonte de la Vega, 1643)

Tres barriles de barro colorado quebrados (Alija del Infantado, 1644)

Una xarra de Talabera fina con el pie quebrado y un barril de barro colorado (Coomonte de la Vega, 1645)

Dos platos y dos barriles un jarro y un barreñón (Vidriales, 1645)

Dos barriles de barro colorado (Coomonte de la Vega, 1650)

Un barril de Talabera (La Bañeza, 1839)

Dos barriles de barro (Destriana, 1843)

Los ejemplos encontrados son fundamentalmente del S. XVI, aunque hay ejemplos de los siglos siguientes. En diccionarios del leonés, además del significado dado por el DRAE, se define como 'botijo para el agua o el vino'. Con esta acepción parece utilizarse en los inventarios estudiados, ya que es frecuente que aparezca relacionado con los enseres de cocina y no con los objetos que guardaban alguna relación con las tareas agrícolas. Así, el ejemplo de Vidriales es significativo puesto que aparece en una enumeración junto al término platos, por ejemplo. El ejemplo de la Bañeza es también significativo ya que especifica el tipo de cerámica o barro de Talavera, cerámica mucho más fina y elegante y por tanto, de uso más doméstico que agrícola. Entre las ediciones de 1770 y de 1803, época que comprende el estudio de estos archivos, el DRAE señala que a este objeto, según Covarrubias, se le llamaba botija. Por tanto, se están considerando ambos términos sinónimos. En los inventarios analizados no se consideran sinónimos puesto que aparecen como términos independientes y por otra parte, la botija es una vasija que contiene fundamentalmente aceite y el barril es un objeto para beber ya sea agua o vino, aunque los dos estén hechos de barro.

\section{BARRILA}

Sust. f. El DRAE define la palabra como 'botija' y especifica que se usa en Cantabria.

Término derivado de barril, cuyo origen se desconoce.

Una barrila biexa y otra buena y un cántaro todo de barro (Alija del Infantado, 1644)

Un cántaro y una barrila de barro colorado (Alija del Infantado, 1647)

Una barrila de tener bino de barro colorado (Coomonte de la Vega, 1650) 
Un cántaro y una barrila de barro colorado (Genestacio, 1650)

Un cántaro y una barrila (Castrocalbón, 1814)

Una barrila con cañamina (La Nora del Río, 1820)

Dos barrilas (Calzada, 1838)

Los ejemplos encontrados datan de inventarios del S. XVII y XIX. Es, probablemente, una casualidad ya que no hay motivos lingüísticos que justifiquen la ausencia de ejemplos en el S. XVIII. Se trata de una palabra que se documenta solo en la zona norte de la Península. En el DRAE aparece por primera vez en la edición de 1884 y la localiza en Cantabria; aunque en la edición de 1936, la sitúa además en Burgos y Logroño. Posteriormente, vuelve a localizar el término en Cantabria. Sin embargo, vemos que se documenta también en León y en Zamora. En el CORDE aparecen solo tres casos, todos ellos en la misma obra titulada Itinerarios por las cocinas y bodegas de Castilla, obra de 1965. En trabajos lexicográficos de la zona se define el término como 'recipiente de barro cocido, con forma de ánfora, dos asas y una sola boca, usada para transportar el agua a la era o a las fincas y también para conservarla a una temperatura más fresca en época estival' (Rivas, 1996: 44). Con este significado se utiliza en los materiales analizados aunque, como se refleja en el ejemplo de Coomonte de la Vega, también servía para contener el vino.

\section{BOTE}

Sust. m. 'Recipiente pequeño, comúnmente cilíndrico, que sirve para guardar medicinas, aceites, pomadas, tabaco, conservas, etc' (DRAE). Es forma alterada de pote, tomado del catalán pot 'bote, tarro'; de una base pŏttus, de origen incierto, probablemente prerromano (DECH, s.v. bote).

Un bote de oja de lata y una cinta manchega (Grajal de la Ribera, 1806)

Un bote de oja de lata (Requejo de la Vega, 1839)

Seis botes de oja de lata grandes y chicos de tabaco de tape (Destriana, 1843)

El término tiene el significado que da el diccionario académico de 'recipiente pequeño' y solo se han recogido estos ejemplos, todos ellos pertenecientes al S. XIX, aunque la voz se documenta anteriormente, en el $D E C H$ se indica la fecha de 1490. En el corpus abundan otros términos para este uso como botija, barrila, vasija, etc. El término bote se ha documentado en algunas zonas de la provincia con el significado de 'carro que lleva tableros en los laterales para poder transportar la paja después de trillada' (Le Men, 2002, s.v. bote), acepción que no recoge el DRAE, uso que no aparece en el corpus y que equivaldría al término costanas, que sí aparece en estas relaciones de bienes. 


\section{BOTELLA [votella]}

Sust. f. 'Vasija de cristal, vidrio, barro cocido u otro material, con el cuello estrecho, que sirve para contener líquidos' (DRAE). Del fr. bouteille y este de bŭttǐcula, diminutivo del lat. tardío buttis 'odre', 'tonel' (DECH, s.v. botella).

Siete votellas de licores (La Nora del Río, 1823)

Trece botellas (Requejo de la Vega, 1839)

Una botella de ojadelata (Requejo de la Vega, 1839)

Una botella de bidrio (Destriana, 1843)

Una botella de cristal de roca labrada con su tapa rota (Destriana, 1843)

Seis botellas de vidrio vasto (Destriana, 1843)

Los ejemplos encontrados son todos del S. XIX. Se trata de un término cuyo uso se extiende fundamentalmente a los siglos XIX y XX, como se ve reflejado en los numerosos ejemplos del CORDE y en los localizados en este estudio lexicográfico que pertenecen a inventarios del S. XIX.

\section{BOTIJA [botixa]}

Sust. f. 'Vasija de barro mediana, redonda y de cuello corto y estrecho' (DRAE). Término procedente del lat. tardío bŭttīcŭla, diminutivo de buttis 'tonel' (DECH, s.v. botija).

Dos botixas de barro (Coomonte de la Vega, 1643)

Una botixa de barro colorado grande desbocada (Coomonte de la Vega, 1643)

Una botixa melada que ará dos libras de aceyte (Coomonte de la Vega, 1645)

Una botixa de tener aceyte de barro (Coomonte de la Vega, 1650)

Dos jarros y una botija (Coomonte de la Vega, 1719)

Una olla de periguela, una botija y una fiambrera (Castrocalbón, 1814)

Una botija y un cribo de linaza (La Nora del Río, 1820)

Se trata de un término de uso general como puede apreciarse en corpus como el CORDE, donde son numerosos los ejemplos incluidos. El DRAE señala en todas sus ediciones que se trata de una 'vasija de barro', y en la edición de 1927 indica que en Cuba es una 'vasija de hojalata que se utiliza para contener leche'. En diccionarios de la zona estudiada se define este objeto como una 'vasija normalmente de hojalata en la que se contienen líquidos de uso culinario' (Rivas, 1996: 50). En los ejemplos encontrados en los inventarios pertenecientes fundamentalmente al S. XVII, y a la zona suroeste del P.J. de la Bañeza, se observa que en algunas ocasiones se especifica el material con el que está fabricada con el sintagma preposicional "de barro". Por tanto, podemos decir que en esta zona el término botija se emplea para designar una vasija que puede ser de barro o de otros materiales. También podemos deducir que se emplea para contener líquidos, especialmente aceite, como lo indican los ejemplos señalados. 


\section{CALABAZA}

Sust. f. Término sinónimo de calabacino 'calabaza seca y hueca, para tener vino u otro líquido'. Calabaza vinatera 'la que forma cintura en medio y es más ancha por la parte de la flor. Sirve después de seca para llevar vino u otro líquido' (DRAE). De origen prerrománico, probablemente ibérico cuya base es *calapaccia (DECH, s.v. calabaza).

Una calabaza bebedera (Alija del Infantado, 1647)

Se trata de un ejemplo aislado usado con el significado de 'recipiente para contener líquido' como puede deducirse del adjetivo bebedera que acompaña al término.

Además el término calabazas designa un tipo de pendientes frecuentes en León, Zamora y Salamanca. Se denominaban así por su forma redonda. Eran más lujosos que otros como las arrecadas, lo que puede explicar la ausencia del término con este significado en el corpus; aunque señala Casado Lobato que eran muy frecuentes en las riberas del Órbigo y tierras bañezanas (Casado Lobato, 1993: 503).

\section{CARVONERA}

Se documenta en el corpus el término carvonera con un único ejemplo:

Zien carvoneras de barro (La Bañeza, 1641)

Es una voz de la que no se ha encontrado ninguna referencia ni en los diccionarios académicos ni en ningún otro repertorio léxico. El sintagma "de barro" que aparece junto al término, hace pensar que se pueda tratar de algún tipo de recipiente, aunque el número no es lógico, teniendo en cuenta que se trata del inventario de un particular, por lo que no está claro cuál puede ser el referente del término carvonera.

\section{CHOCOLATERA}

Sust. f. 'Vasija en que se sirve el chocolate' (DRAE). Término derivado de chocolate, palabra de origen azteca, pero de formación incierta (DECH, s.v. chocolate).

Una chocolatera de cobre con su molinillo sin tapa (La Bañeza, 1721)

Dos chocolateras (Laguna de Negrillos, 1734)

Dos chocolateras (La Bañeza, 1754)

Una chocolatera de cobre (Grajal de la Ribera, 1806)

Una chocolatera de cobre (La Nora del Río, 1823)

Una chocolatera con su molinillo (Castrillo de la Valduerna, 1828)

Una chocolatera chiquita y bieja (Quintanilla de Somoza, 1831)

Una chocolatera usada (Quintanilla de Somoza, 1831)

Una chocolatera grande de cobre (Requejo de la Vega, 1839)

Una chocolatera de azófar regular con su molinillo y tapa (Destriana, 1843)

Es un término muy común. La mayor parte de los ejemplos se encuentran en 
los inventarios del S. XIX. En esta época el significado del término es el de 'vasija que sirve para hacer el chocolate' (DRAE), normalmente eran de cobre, como aparece especificado en algunos ejemplos.

\section{CUENCO}

Sust. m. 'Recipiente no muy grande de barro u otra materia, hondo y ancho, y sin borde o labio' (DRAE). Término derivado de cuenca, del latín cŏncha y este del griego kónkhē (DECH, s.v. cuenca).

Dos cuencos grandes de lo mismo (barro) (Destriana, 1843)

Es el único término recogido en el corpus, tanto en la forma masculina como en la femenina cuenca. Es una voz polisémica que se encuentra documentada en León con diferentes acepciones, la más común, probablemente la utilizada en este ejemplo, puesto que el término se encuentra en la relación de bienes de los objetos hallados en la cocina de lumbre, es la de 'recipiente de madera o de barro que se usaba para comer' (Le Men, 2004, s.v. cuenco). También se denomina cuenco a la 'escudilla usada en las bodegas para catar el vino' (op. cit. s.v. cuenco), acepción que también sería válida, aunque sería más lógico localizar el término en objetos de la bodega. Finalmente, se usa como sinónimo de mortero, aunque en este inventario se documenta tanto la palabra mortero como almirez. Además, en zonas próximas como la comarca de la Cepeda, el significado es el de 'escudilla', concretamente se define como 'cazuelo de barro para la lleichi' (Bardón, 1987: 218). Del término escudilla se recogen ejemplos en el corpus, pero todos pertenecientes a la zona sur de León, norte de la provincia de Zamora, no se recoge por ejemplo ningún caso en este inventario.

\section{FIAMBRERA}

Sust. f. 'Cestón o caja para llevar el repuesto de cosas fiambres'. 'Cacerola, ordinariamente cilíndrica y con tapa bien ajustada, que sirve para llevar la comida fuera de casa' (DRAE).Término derivado de frío, del latín frīgĭdus (DECH, s.v. frío).

Una olla de periguela, una botija y una fiambrera (Castrocalbón, 1814)

Una fiambrera de ojalata (La Nora del Río, 1823)

Una fiambrera (Castrillo de la Valduerna, 1828)

Una fiambrera (Destriana, 1843)

Una fiambrera rota de madera (Destriana, 1843)

Los ejemplos encontrados son del S. XIX, aunque el término aparece documentado en época anterior, concretamente en el S. XVI. Se trata de un objeto que se 
usaba para llevar alimentos, aunque tal vez podían ser de distintos materiales, de ahí que se especifique en un caso "de ojalata". Covarrubias define el término como un 'género de cestones que suelen llevar los señores de camino con cosas fiambres para poder comer y beber donde y cuando quisieran'.

\section{GARAPIÑERA [garapinera]}

Sust. f. 'Vasija que sirve para garapiñar o congelar los líquidos metiéndola ordinariamente en un cubo de corcho, más alto y ancho que ella, y rodeándola de nieve y hielo, con sal' (DRAE). Término derivado de garapiñar, procedente de un latín vulgar

*carpiniare, derivado de carpěre (DECH, s.v. garapiñar).

Una garapinera de estaño (Robledo de la Valduerna, 1726)

Es el único ejemplo encontrado. Probablemente se trata de una palabra poco usada ya que en el CORDE solo se recogen cuatro casos. En las primeras ediciones del $D R A E$ se define el término como 'vaso de estaño u otro metal que sirve para helar los licores y las bebidas'. Este es el significado que tiene el término recogido en el corpus.

\section{GUBILETE [gubiletera]}

Sust. m. El DRAE remite a cubilete 'recipiente de cobre u hojalata, redondo o abarquillado y más ancho por la boca que por el suelo, que usan como molde los cocineros y pasteleros para varios usos de sus oficios'. Del francés gobelet 'vaso de beber, sin pie y sin asa' (DECH, s.v. cubilete).

Un gubilete de cobre (La Bañeza, 1721)

Un gubilete de cobre (Alija del Infantado, 1737)

Una gubiletera de cobre con unas tijeras de espabilar (Laguna de Negrillos, 1734)

Es el único ejemplo encontrado. El DRAE hasta la edición de 1869 lo incluye como una entrada aparte y define como una 'especie de vaso'. Probablemente es el significado que tiene en los dos ejemplos encontrados. El término gubiletera no aparece en el DRAE, sí en cambio gubileta, que probablemente tenga el mismo significado 'caja o vaso grande donde se metían los gubiletes'.

\section{JARRA [xarra]}

Sust. f. 'Vasija de barro, porcelana, loza, cristal, etc., con cuello y boca anchos y una o dos asas' (DRAE). Del árabe ýárra, id. (DECH, s.v. jarra).

Docena y media de platos finos, una docena de escodillas y dos jarras (La Bañeza, 1641)

Una xarra de Talabera fina (Coomonte de la Vega, 1643) 
Una xarra de Talabera (Alija del Infantado, 1644)

Una xarra y un xarrico de barro colorado (Alija del Infantado, 1644)

Una xarra de Talabera fina con el pie quebrado (Coomonte de la Vega, 1645)

Dos xarras de Talabera pintadas (Alija del Infantado, 1646)

Una xarra de medio baño mediana (Alija del Infantado, 1647)

Una xarra de Talabera (Genestacio de la Vega, 1650)

Una jarra de Talabera y otra de León (Alija del Infantado, 1812)

Dos jarras meladas (Castrillo de la Valduerna, 1828)

Una jarra melada, una fuente de barro, una taza blanca, dos barriles y unas cazuelas

(Calzada, 1838)

Dos jarras blancas de piedra (Requejo de la Vega, 1839)

Una jarra de barro melao (Quintana del Marco, 1839)

Dos jarras vastas de Talavera (Destriana, 1843)

Es un término de uso general. Con el término jarra se denomina también al 'vaso grande de latón que se usa para ordeñar' (Le Men, 2007, s.v. jarra). Sin embargo, en los ejemplos encontrados, el significado es el de 'vasija que se utiliza para servir el agua o el vino, o para beber directamente de ella', ya que siempre aparece inventariada junto a otros objetos del menaje de cocina. Dentro de las jarras, se diferencian las de barro, o las de Talabera, cuyo valor está en el tipo de loza utilizada que las convierte en objetos más finos. Es frecuente que el término aparezca bajo la variante xarra, forma frecuente en toda la zona occidental, aunque tampoco es extraño encontrar la alternancia de las grafías “j” y "x" para representar el sonido /x/.

\section{JARRO [xarro]}

Sust. m. 'Vasija de barro, loza, vidrio o metal, a manera de jarra y con solo un asa' (DRAE). Término derivado de jarra.

Dos xarricos de barro colorados (Coomonte de la Vega, 1643)

Un jarro y un salero y un salpimentero y un azucarero y quatro cuchares todo de plata (La Bañeza, 1643)

Una xarra y un xarrico de barro colorado (Alija del Infantado, 1644)

Dos xarricos de barro colorado (Coomonte de la Vega, 1645)

Dos platos y dos barriles, un jarro y un barreñón (Vidriales, 1645)

Dos xarros de barro colorados nuebos (Alija del Infantado, 1646)

Quatro xarros pequeños biexos (Alija del Infantado, 1647)

Tres jarros, una olla y dos cántaras (Villamor de Órbigo, 1648)

Un xarro de barro colorado biexo (Coomonte de la Vega, 1650)

Otro xarrico pequeño (Coomonte de la Vega, 1650)

Un xarro grande de barro (Coomonte de la Vega, 1650)

Dos xarros de barro colorado (Genestacio de la Vega, 1650)

Dos jarros y una botija (Coomonte de la Vega, 1719)

Dos jarros y un candil (Castrocalbón, 1814)

Un zesto vlanco chico, un jarro de barro, un plato de Talabera, dos escudillas y dos cucharas de madera (Quintana del Marco, 1820) 
Es un término común. El significado general es el de 'vasija de barro'. Le Men en su diccionario señala como una de las acepciones del término la de 'vasija de barro para beber vino' (Le Men, 2007, s.v. jarro). Los ejemplos del término sí señalan, en su mayoría, que se trata de un recipiente de barro, pero no se indica nada relacionado con el uso o el contenido que solía tener el jarro. Si bien, muchos de los ejemplos del término se encuentran en relaciones en las que también aparece el término en femenino. Por tanto, se trata de objetos diferentes cuya diferencia puede estar en el número de asas, en el tamaño, en el uso, o en las tres cosas; aunque la matización en dos de los ejemplos de jarros pequeños, hace pensar que la diferencia es más bien relativa al número de asas. Además, Le Men señala otra acepción (op. cit. s.v. jarro) que no recoge el DRAE. Jarro es también la 'jofaina de metal que contiene el agua de lavarse las personas en la alcoba'. Probablemente, no se utiliza el término con esta acepción ya que siempre aparece en contextos en los que se relacionan útiles de cocina, de ahí que el significado más probable sea el anteriormente explicado.

\title{
JÍCARA
}

Sust. f. 'Vasija pequeña, generalmente de loza, que suele emplearse para tomar chocolate' (DRAE). Probablemente tomado del náhuatl sikálli 'vasija de calabaza, vasija de ombligo', cpt. de šikilli, 'ombligo' y kalli, 'receptáculo' (DECH, s.v. jícara).

\author{
Siete jícaras (La Bañeza, 1754) \\ Tres jicaras y dos tazas (La Nora del Río, 1823) \\ Nuebe jícaras de piedra (La Nora del Río, 1823) \\ Una pequeña porción de loza compuesta de platos, jícaras y demás (La Bañeza, 1829) \\ Seis jicaras de Talavera (Destriana, 1843) \\ Tres jícaras de uso común (Destriana, 1843) \\ El significado más común del término es el de 'taza que se utiliza para tomar
} chocolate'. No obstante, en León el término se utiliza también con otra acepción que no recoge el DRAE, se denomina jícara al 'aislador que se coloca en los mastes o postes de la luz y que por su color blanco y su forma semiesférica sirve como reclamo en el ponedero' (Le Men, 2007, s.v. jícara). Está claro que la acepción empleada en los ejemplos es la recogida en el DRAE.

ORZA

Sust. f. 'Vasija vidriada de barro, alta y sin asas, que sirve por lo común para guardar conserva' (DRAE). Del antiguo orço. Este viene del latín ŭrcěus 'jarro', 'olla' (DECH, s.v. orza). 
Una orza grande con dos asas vidriadas tambien de tener aceyte (Destriana, 1843)

Tres orzas de tener manteca (Destriana, 1843)

Son los únicos ejemplos recogidos en el corpus, ambos pertenecientes al mismo inventario, aunque es un término que se encuentra recogido en los estudios léxicos de la zona. En el primer caso se señala en el ejemplo que se emplea para tener aceite, aunque es frecuente en esta zona que se use para conservar la manteca de cerdo (Casado, 1979: 116), como en el segundo ejemplo y, a veces, la miel.

\section{PEIZA}

Sust. f. 'Vasija grande de paja, tinaja' (Le Men, 2009, s.v. peiza).

Un peiza grande que ará tres cargas (Huerga de Garaballes, 1720)

Una peiza de media carga (Huerga de Garaballes, 1720)

Se trata de un término que no aparece recogido en el DRAE y el CORDE tampoco registra ningún caso. En este corpus solo se han encontrado estos ejemplos que pertenecen al mismo inventario, parece ser que se trata de una voz poco usada. En algunos casos aparece documentado su uso, como por ejemplo, para guardar el saco de sal. En estos ejemplos solo se hace referencia a la capacidad, pero no al uso.

\section{REDOMA}

Sust. f. 'Vasija de vidrio ancha en su fondo que va estrechándose hacia la boca' (DRAE). Voz de origen incierto, quizá del árabe (DECH, s.v. redoma).

Un redoma de bidrio (Coomonte de la Vega, 1650)

Una canasta larguita con una redoma y una luneta (Laguna de Negrillos, 1725)

Es un término conocido del que solo se han recogido estos dos ejemplos, quizá porque se prefieran otros términos para designar un objeto con la misma función.

\section{TINAJA [tinaxa]}

Sust. f. 'Vasija grande de barro cocido, y a veces vidriado, mucho más ancha por el medio que por el fondo y por la boca, y que encajada en un pie o aro, o empotrada en el suelo, sirve ordinariamente para guardar agua, aceite u otros líquidos' (DRAE). Del latín tīna 'especie de botella de vino, de cuello largo, con tapadera' (DECH, s.v. tinaja).

Una tinaxa (La Antigua, 1646)

Una tinaxa (Grajal de la Ribera, 1730)

Dos tinajas pequeñas de barro que arán catorze cántaras (Laguna de Negrillos, 1734)

Una tinaja (Pobladura del Valle, 1738)

Una tinaja zamorana (La Nora del Río, 1823)

Una tinaja grande (La Nora del Río, 1823) 
Una tinaja de tener aceyte (Destriana, 1843)

Una tinaja rota de lo mismo (zamorana) (Destriana, 1843)

Un barreno grande y unas tinajas (Santibáñez de la Isla, 1844)

Es un término común, aunque es posible que con el significado genérico de recipiente tenga dos referentes distintos. Rivas en el diccionario de usos de la Valdería define tinaja como 'recipiente compuesto de tablas de madera, remachadas con aros de hierro y clavos, más pequeño que la cuba y sin barriga, semejante al tino, que se usa para contener diferentes conservas, pimientos, guindillas, etc'. 'Vasija de barro cocido con forma de ánfora y una o dos asas, para meter las monedas de oro y plata antiguas' (Rivas, 1996: 225). En los ejemplos en los que no se especifica si es o no de barro, el término puede estar utilizado con la primera acepción, mientras que en el ejemplo de Laguna e incluso en el que especifica una "tinaja zamorana", no hay duda de que se trata de una vasija de barro que se utiliza para meter líquido, coincidiendo así con el uso que el $D R A E$ da al objeto; aunque en un significado secundario derivado del uso que en algunos hogares podía hacerse, sirviera para meter monedas como señala Rivas.

\section{TINO}

Sust. m. 'Tina que sirve para el tinte'. 'Depósito de piedra adonde el agua hirviendo va desde la caldera, en los lavaderos de lana'. 'Lagar para uva o aceituna' (DRAE). Del latín tìna (DECH, s.v. tina).

Un tino de tener harina (La Antigua, 1646)

Un tino panero (La Antigua, 1647)

Dos tinos (Laguna de Negrillos, 1722)

Un tino de tener sal (Grajal de la Ribera, 1750)

Tres viendos y una vilda y un tino (La Nora del Río, 1820)

Un tino mediano (Palacios de la Valduerna, 1831)

Otro tino más grande (Palacios de la Valduerna, 1831)

Es un término de uso común. El significado general del término es el de 'recipiente', aunque si nos centramos en las características específicas de dicho recipiente se caracteriza porque está 'compuesto de tablas de madera, remachadas con aros de hierro y clavos, más pequeño que la cuba y el cubeto $\mathrm{y}$, normalmente, sin barriga, semejante a la tinaja, que suele usarse para conservas de escabeche, pimientos, etc' (Rivas, 1996: 225). El uso que más aparece en los vocabularios es el destinado a conserva de escabeche, pero teniendo en cuenta los ejemplos, parece que se trata de un recipiente usado para guardar diferentes productos alimentarios. 


\section{VASIJA [basija]}

Sust. f. 'Pieza cóncava y pequeña, de barro u otra materia y de forma común u ordinaria, que sirve para contener especialmente líquidos o cosas destinadas a la alimentación' (DRAE). Término derivado de vaso, del latín vas, -is 'vasija', vulgarmente vasum (DECH, S.v. vaso).

Toda la basija sin vino (Laguna de Negrillos, 1722)

Una vasija de barro melao (Quintana del Marco, 1820)

Es un término común, aunque solo se hayan recogido estos ejemplos. El segundo de ellos no ofrece ninguna particularidad semántica y mantiene el significado común del término. El primer ejemplo pertenece a la relación de bienes que se hallaron en la bodega, por lo que podría entenderse que su uso es el mismo que en el otro ejemplo, o que el término tiene un uso colectivo y, como señala el $D R A E$ en la $3^{\mathrm{a}}$ acepción, se refiere al 'conjunto de cubas y tinajas en las bodegas'.

\section{CORTADILLO}

Sust. m. 'Vaso pequeño para beber, tan ancho de arriba como de abajo'. 'Medida casera para líquidos que equivale a una copa poco más o menos' (DRAE).

Trece cortadillos de cristal (Requejo de la Vega, 1839)

Aunque es un término que se documenta en la zona suroeste, son pocos los casos recogidos ya que este es el único ejemplo encontrado. Esta escasez también la refleja el CORDE donde se recogen aproximadamente unos doce ejemplos con estas acepciones. Coinciden también en las fechas ya que tanto este ejemplo como los recogidos en el corpus académico pertenecen al S. XIX. De las dos acepciones que da el $D R A E$, probablemente la aplicada al término en este ejemplo sea la primera de acuerdo al número de objetos que aparecen en la relación.

\section{FRUTERO}

Sust. m. 'Plato hecho a propósito para servir la fruta' (DRAE). Término derivado de fruto, del latín frūctus, -us (DECH, s.v. fruto).

\section{Dos fruteros ya usados (La Bañeza, 1647)}

Se trata de una voz común, aunque como sustantivo solo se ha recogido este ejemplo. La falta de especificación no permite señalar con exactitud el significado concreto del término en el ejemplo, ya que se puede referir al plato para servir la fruta, pero también al 'lienzo labrado con que por higiene se cubre la fruta que se pone en la 
mesa' ( $4^{\mathrm{a}}$ acepción del $D R A E$ ), aunque en otro ejemplo se utilice la voz como adjetivo para indicar esta acepción y especifique un "paño frutero".

\section{FRUTERO/A}

Adj. 'Que sirve para llevar o contener fruta' (DRAE). Término derivado de fruto, del latín früctus, -us (DECH, s.v. fruto).

Una cestica frutera de binbre con cosa de medio celemín de garbanzos (Coomonte de la Vega, 1643)

Un paño frutero de cuadros (La Bañeza, 1643)

\section{FUENTE}

Sust. f. 'Plato grande, más o menos hondo, que se usa para servir los alimentos' (DRAE).

Del latín fŏns, -tis (DECH, s.v. fuente).

Docena y media de platos de Talavera finos y escudillas, una fuente grande y otra pequeña (La Bañeza, 1649)

Una fuente y un plato y una escodilla de medio baño (Coomonte de la Vega, 1650)

Una fuente pintada de medio baño (Coomonte de la Vega, 1650)

Dos fuentes grandes (Laguna de Negrillos, 1721)

Una fuente basta pintada (Toral, 1728)

Dos fuentes finas (Destriana, 1728)

Una fuente de madera con clabos (Palacios de la Valduerna, 1730)

Una media fuente, tres platos finos y dos saleros (Grajal de la Ribera, 1738)

Ocho platos y ocho medias fuentes de Talabera (Grajal de la Ribera, 1750)

Dos fuentes de madera (La Bañeza, 1754)

Seis platos de Talavera y una fuente fina (Grajal de la Ribera, 1806)

Dos fuentes finas (Castrillo de la Valduerna, 1828)

Tres fuentes de Talabera (Castrillo de la Valduerna, 1828)

Dos fuentes de Talabera (Requejo de la Vega, 1839)

Una jarra melada, una fuente de barro, una taza blanca, dos barrilas y unas cazuelas (Calzada, 1838)

Tres medias fuentes vastas (Destriana, 1843)

Una fuente de Talabera planchada (Destriana, 1843)

Es un término frecuente en las relaciones que contienen utensilios de cocina.

Este tipo de objetos siempre aparecen en los inventarios con especificaciones referentes a la calidad o al material con el que están fabricadas. Eran frecuentes las de loza procedente de Talavera, rasgo que imprimía al objeto cierto valor.

\section{MANCERINA [marcelinas]}

Sust. f. 'Plato con una abrazadera circular en el centro, donde se coloca y sujeta la jícara en que se sirve el chocolate'. El término toma el nombre del marqués de Mancera, toledano que vivió en el S. XVII y fue virrey del Perú (DRAE).

Dos marcelinas (La Bañeza, 1829) 
Es el único ejemplo encontrado. Este dato no es extraño puesto que designa un objeto que conlleva unas connotaciones de cierto valor, lo que restringe su aparición en las listas de enseres. Además, no es un término frecuente en ningún caso ya que el CORDE solo registra un ejemplo bajo la forma mancerina fechado en el S. XIX, y otro bajo la forma marcelina fechado en el S. XVIII. La variante marcelina es una deformación del término, que en ningún caso es específica de una zona concreta.

\section{PLATO}

Sust.m. 'Recipiente bajo y redondo, con una concavidad en medio y borde comúnmente plano alrededor, empleado en las mesas para servir los alimentos y comer en él y para otros usos' (DRAE). Del latín vulgar *plattus 'plano', 'chato, aplastado' (DECH, s.v. plato).

Docena y media de platos finos, una docena de escodillas y dos jarras (La Bañeza, 1641)

Unas escudillas y platos (Castrocalbón, 1643)

Doze platos de echura de plata de estaño (La Bañeza, 1643)

Un plato de madero y dos escudillas de lo mismo (Coomonte de la Vega, 1643)

Quatro platos de medio baño (Coomonte de la Vega, 1643)

Quatro platos y dos escudillas (La Nora del Río, 1645)

Dos platos y dos barriles, un jarro y un barreñón (Vidriales, 1645)

Tres platos pintados uno fino y los dos de medio baño (Alija del Infantado, 1646)

Dos caçetas de yerro y dos platos (La Antigua, 1647)

Docena y media de platos de Talavera finos y escudillas, una fuente grande y otra pequeña (La Bañeza, 1649)

Tres platos de medio baño (Coomonte de la Vega, 1650)

Una fuente, un plato y una escodilla de medio baño (Coomonte de la Vega, 1650)

Diez platos finos y dos bastos (Coomonte de la Vega, 1719)

Quatro platos finos y dos usados (Genestacio de la Vega, 1721)

Un plato quebrado de peltre (La Bañeza, 1721)

Dos platos de Talavera (Alija del Infantado, 1724)

Una olla nueva y un plato (Coomonte de la Vega, 1724)

Seys barreñas y dos platos (Coomonte de la Vega, 1724)

Tres dozenas de platos finos (Robledo de la Valduerna, 1726)

Dos platos y una escudilla basta (Toral, 1728)

Una media fuente, tres platos finos y dos saleros (Grajal de la Ribera, 1730)

Una docena de platos y escudillas media docena (Laguna de Negrillos, 1734)

Dos platos y escudillas (Laguna de Negrillos, 1740)

Ocho platos y ocho medias fuentes (Grajal de la Ribera, 1750)

Un plato de madera y quatro cubiertos de boga (Grajal de la Ribera, 1806)

Una cazeta de azófar y un plato de madera (Castrocalbón, 1814)

Dos picadores y dos platos (La Nora del Río, 1823)

Seis platos de loza fina de Valencia (La Nora del Río, 1823)

Tres platos de madera (Castrillo de la Valduerna, 1828)

Doce platos de postre tanvién usados muy sencillos (La Bañeza, 1829)

Dos platos de Talabera, cuatro cazuelas y un azadón (San Feliz, 1838)

Ocho platos regulares (Requejo de la Vega, 1839)

Un platillo de China (Requejo de la Vega, 1839)

Un plato de madera (Destriana, 1843)

Dos platos de listas y flores azules (Destriana, 1843) 
Es un término muy común ya que designa un objeto propio del menaje de una casa. Normalmente en las relaciones de enseres se documentan indicando el material del que están hechos, puesto que el valor es diferente si se trata de loza fina, de madera, etc. La palabra siempre aparece bajo la forma plato, nunca se registra la voz prato que sí está documentada en León.

\section{SALERO}

Sust. m. 'Recipiente en que sirve la sal en la mesa' (DRAE). Término derivado de sal, del latín sal, salis (DECH, s.v. sal).

Un jarro y un salero y salpimentero y un azucarero y quatro cuchares todo de plata (La Bañeza, 1643)

Un salero de Talabera fina (Coomonte de la Vega, 1643)

Un salero de madera grande (Alija del Infantado, 1647)

Cinco altamías y un salero (La Antigua, 1648)

Un salero de Talabera fino (Coomonte de la Vega, 1650)

Un salero de Talabera fina (Genestacio de la Vega, 1650)

Un salero de Talabera (La Bañeza, 1721)

Un salero de Talavera con tres cajas (Laguna de Negrillos, 1722)

Un salero (Palacios de Jamuz, 1728)

Una media fuente, tres platos finos y dos saleros (Grajal de la Ribera, 1750)

Un salero de Talavera y dos vinagreras de lo mismo (Grajal de la Ribera, 1806)

Un salero de madera (Felechares, 1837)

Dos saleros uno de cristal y otro de China (Requejo de la Vega, 1839)

Dos saleros de China floreados (Destriana, 1843)

Es un término común que se utiliza con el significado actual. Los saleros más comunes eran los fabricados con cerámica de Talavera. Por ello siempre se reseñaba en los inventarios. Lo mismo ocurría en el caso del salpimentero, que también mantiene el significado.

\section{SALSERA}

Sust. f. 'Vasija en que se sirve salsa' (DRAE). Derivado de sal, del latín sal, salis (DECH, s.v. sal).

Una salsera con su platillo (Destriana, 1843)

Es el único ejemplo recogido del término, aunque se trata de una voz conocida que ya se documenta desde el S.XVI como 'plato o escudilla para echar la salsa'. Es un objeto que connota cierta distinción ya que no es común dentro de la vajilla. En este sentido señala Castañeda que muestra de esta distinción es el cambio en el significado que le da la Academia al término ya que pasa a definir en 1884 como 'escudilla donde se sirve la salsa', donde la diferencia semántica de los verbos echar y servir muestran el 
cambio (Castañeda, 2003: 312). Este hecho explicaría que no sea un objeto común en los inventarios.

\section{VASO [baso]}

Sust. m. 'Recipiente de metal, vidrio u otra materia, por lo común de forma cilíndrica, que sirve para beber' (DRAE). Del latín vas, -is 'vasija', vulgarmente vasum (DECH, s.v. vaso).

Un baso de bidrio (Coomonte de la Vega, 1643)

Dos basos de bidrio (Coomonte de la Vega, 1643)

Una lámpara de latón pequeña con su baso (La Bañeza, 1721)

Una taza y dos vasos de plata (Coomonte de la Vega, 1738)

Dos basos de cristal (Alija del Infantado, 1812)

Nuebe vasos de cristal (Quintanilla de Somoza, 1831)

Dos vasos de vidrio y dos de cristal (Castrocalbón, 1832)

Diez basos labrados de cristal (Requejo de la Vega, 1839)

Seis vasos grandes de cristal labrados (Destriana, 1843)

Una docena de basos finos (Destriana, 1870)

Es un término de uso común. El diccionario académico en sus primeras ediciones define la voz en su primera acepción de forma genérica como 'cualquier pieza cóncava de varias materias dispuesta para recoger y contener en sí alguna cosa, especialmente líquida', es decir, que el término tendría un uso hiperónimo en el que se englobarían distintos hipónimos. Sin embargo, en los ejemplos del corpus la voz vaso está utilizada con el significado que hoy conocemos y que da el DRAE actualmente de 'recipiente para beber'. Las referencias al material de cristal o la coordinación con otros términos de significado próximo, taza en algún caso, aclaran el uso del término en el corpus. En el ejemplo de La Bañeza de 1721, el término vaso aparece como sinónimo de la voz tulipa, en este caso por el parecido formal. En León, en la zona de la Maragatería y, por tanto, en una comarca próxima a la estudiada en el corpus, la voz vaso se define también como 'una de las clases de arado o tiba' (Madrid, 1985: 265), aunque con este significado no se han recogido ejemplos.

\section{TAZA [taça]}

Sust. f. 'Vasija pequeña, por lo común de loza o de metal y con asa, empleada generalmente para tomar líquidos' (DRAE). Del árabe tássa 'escudilla', 'tazón', 'caldero' (DECH, s.v. taza).

Una taza y media de lechón (Coomonte de la Vega, 1643)

Dos taçicas de Talabera pintadas (Alija del Infantado, 1644)

Una tazica de beber de Talabera (Coomonte de la Vega, 1645) 
Una taza y dos vasos de plata (Genestacio de la Vega, 1738)

Nueve ficas y una taza de loza (La Nora del Río, 1823)

Seis tazillas de dulce (La Nora del Río, 1823)

Tres fícaras y dos tazas (La Nora del Río, 1823)

Una jarra melada, una fuente de barro, una taza blanca, dos barrilas y unas cazuelas (Calzada, 1838)

Es una palabra común que se utiliza con el significado que aparece en el $D R A E$, aunque en León tiene otras acepciones no recogidas en el diccionario académico, como 'mimbre con el que se hacen los cestos' (Le Men, 2011, s.v. taza), que no se recogen en este corpus. El material del que está hecha la taza así como su procedencia eran importantes a la hora de hacer una relación de bienes porque de ello dependía su valor. Así se especifica si eran de plata, de loza, o si la cerámica era de Talavera.

\section{VINAGRERA}

Sust. f. 'Vasija destinada a contener vinagre para el uso diario' (DRAE). Derivado de vinagre, del latín vīnum (DECH, s.v. vino).

Un salero de Talavera y dos vinagreras de lo mismo (Grajal de la Ribera, 1806)

Unas vinagreras de cristal de roca con su caja de caova (Destriana, 1843)

Son los únicos ejemplos recogidos, aparecen con el significado que da el diccionario académico.

\subsubsection{Cacharros}

\section{CACHARRO}

Sust. m. El DRAE en su tercera acepción define el término como 'vasija o recipiente para usos culinarios'. Palabra derivada de cacho 'cacharro, cazo', del latín vulgar *caccŭlus, procedente del latín caccăbus 'olla' (DECH, s.v. cacho).

Las ollas, pucheros, cazuelas grandes y chicas y demás cacharros de cozina (La Nora del Río, 1823)

Se trata de un término común en toda la zona, aunque solo se haya recogido un ejemplo. La voz se utiliza como un término genérico para referirse a cualquier vasija u olla de cocina. Esta acepción puede explicar la escasez de ejemplos, ya que en los inventarios es frecuente que los objetos se inventaríen con detalle, de ahí que se suelan denominar con el nombre concreto y solo en algunas ocasiones se utilice un término genérico como en este caso. 


\section{CALDERA [calderita, calderica]}

Sust. f. 'Recipiente de metal, grande y semiesférico, que sirve comúnmente para poner a calentar o cocer algo dentro de él' (DRAE). Término derivado del latín caldaria, íd. derivado de caldus, variante de calidus (DECH, s.v. caldo).

Una caldera de cobre grande vuena (La Bañeza, 1641)

Una caldera grande biexa de cobre (Coomonte de la Vega, 1643)

Una calderica pequeña de cobre (Coomonte de la Vega, 1643)

Una caldera vieja (La Bañeza, 1643)

Una caldera de cobre mediana (Coomonte de la Vega, 1645)

Una caldera pequeña ya ussada que ará una ornada (Vidriales, 1645)

Una caldera de cobre que ará dos cántaros de agua buena (Alija del Infantado, 1646)

Una caldera herrada (La Antigua, 1647)

Una caldera grande de cobre (La Bañeza, 1721)

Un perol y una caldereta de azófar (Robledo de la Valduerna, 1726)

Una caldera de cobre que ará tres cántaros (Palacios de la Valduerna, 1728)

Una caldera pequeña de azófar (Miñambres, 1729)

Una caldera de azófar (Laguna de Negrillos, 1734)

Una caldera de cobre (Requejo de la Vega, 1735)

Una calderita pequeña y un caldero (La Bañeza, 1747)

Una caldera mayor otra más mediana y otra más pequeña (Santibáñez de la Isla, 1829)

Una caldera rota de hacer un cántaro de agua (Quintanilla de Somoza, 1831)

Una caldera la mayor buena (Palacios de la Valduerna, 1831)

Una caldera mediana (Palacios de la Valduerna, 1831)

Una caldera mediana (Quintana del Marco, 1839)

Una caldera grande usada y rota muy delgada (Destriana, 1843)

Una caldera bien grande vuena (Destriana, 1843)

Es una palabra muy común en toda el área estudiada. Se utiliza con el significado dado por el DRAE. Es frecuente que la palabra aparezca junto a otros utensilios de cocina, dato que hace suponer que se trata de un 'objeto que se utiliza para calentar o cocer algo'. En dos ejemplos aparece la voz en diminutivo. La forma en -ico, como en otras palabras, se encuentra en el ejemplo de la zona que actualmente forma parte de la provincia de Zamora. La variante caldereta presenta varios significados, pero en el ejemplo que aquí se documenta tiene el significado de 'recipiente más pequeño que la caldera', como se puede deducir del propio ejemplo ya que aparece junto a otro utensilio de cocina.

\section{CAZO [caço]}

Sust. m. 'Recipiente de cocina, de metal, porcelana, etc., generalmente más ancho por la boca que por el fondo, pero a veces cilíndrico, con mango y, por lo general, un pico para verter' (DRAE). Término de origen incierto, hay dificultades para partir del árabe o aceptar un origen griego (DECH, s.v. cazo).

Un caço de cobre ya usado (Vidriales, 1645) 
Un cazo de azófar (La Bañeza, 1712)

Una sartén, un cazo y un escañil (La Nora del Río, 1820)

Seis cazos pequeños viejos (La Nora del Río, 1823)

Un cazo chico remendado (Castrillo de la Valduerna, 1828)

Un cazo de azófar (Castrillo de la Valduerna, 1828)

Cuatro cazos regulares usados (La Bañeza, 1829)

Un cazo, un asador y un rallador (Quintanilla de Somoza, 1831)

Un cazo viejo y una sartén (Palacios de la Valduerna, 1831)

Dos cazos, una sartén espumadera y otros enredos de cozina (Calzada, 1838)

Dos cazos (Requejo de la Vega, 1839)

Un cazo de azófar (Destriana, 1843)

El término se usa con el significado que da el DRAE. Se trata de un vocablo común, aunque la mayoría de los ejemplos son del S. XIX. Como en la entrada anterior, el ejemplo más antiguo aparece con la grafía "ç" para representar la consonante fricativa interdental.

\section{CAZUELA [cacuelica]}

Sust. f. 'Vasija, por lo común redonda y de barro, más ancha que honda que sirve para guisar y otros usos' (DRAE). Término derivado de cazo, voz común a los romances ibéricos con la lengua de oc. y el italiano, de origen incierto (DECH, s.v. cazo).

Una cacuelica biexa (Coomonte de la Vega, 1643)

Una cazuela nueba (La Antigua, 1648)

Una cazuela mediana (Coomonte de la Vega, 1719)

Dos cazuelas y diferentes ollas (La Bañeza, 1721)

Siete cazuelas zamoranas (Coomonte de la Vega, 1734)

Las ollas, pucheros, cazuelas grandes y chicas y demás cacharros de cozina (La Nora del Río, 1823)

Una cazuela de dos asas (Castrillo de la Valduerna, 1828)

Cuatro cazuelas para asar (Quintanilla de Somoza, 1831)

Una docena de cazuelas (Felechares, 1837)

Dos platos de Talabera, cuatro cazuelas y un azadón (San Feliz, 1838)

Una jarra melada, una fuente de barro, una taza blanca, dos barrilas y unas cazuelas (Calzada, 1838)

Dos cazuelas, cántaros y otros trastos de cocina de poca consideración (Destriana, 1843)

Todas las ollas de piriyuela y barro, cántaros, cazuelas, barreñones (Santibáñez de la Isla, 1844)

Es un término bastante común en el corpus analizado. En toda la zona leonesa la voz aparece también con el significado de 'escudilla', es decir, de 'cazuela de barro que sirve normalmente para comer las sopas de ajo' (Le Men, 2004, s.v. cazuela). Esta acepción es común en zonas abarcadas en el estudio de este corpus, ya que la zona de Jamuz es de tradición alfarera. Probablemente, en muchos de los ejemplos citados aparezca con este significado, aunque no hay datos concretos que nos permitan confirmar esta afirmación. En cambio, en el ejemplo de Quintanilla de Somoza el 
término tomaría el significado dado en el diccionario académico, ya que el propio ejemplo especifica que se trata de una cazuela para asar. La denominación cazuela zamorana aparece en una ocasión. En zonas de Castilla y León, concretamente en Burgos, llaman así a 'un tipo de cazuela que tiene la propiedad de dar buen sabor a la comida' (González Ollé, 1964: 93). Es posible que en esta zona se mantenga la misma caracterización para la cazuela llamada zamorana. Desde el punto de vista formal, la voz aparece bajo la forma normativa. Hay un ejemplo donde aparece la variante en diminutivo con la terminación en -ico, que como en otros ejemplos, es frecuente encontrarla en los pueblos situados más al sur y próximos a la provincia de Zamora. Además, en este primer ejemplo la variante es cacuelica, donde probablemente el sonido interdental aparece representado por la grafía "ç" cuyo rasgo se ha borrado o simplemente no se ha representado.

\section{COBERTERA}

Sust. f. 'Pieza llana de metal o de barro, de forma generalmente circular, y con un asa o botón en medio, que sirve para tapar las ollas o para otros usos' (DRAE). Término derivado del verbo cubrir, del latín cooperire (DECH, s.v. cubrir).

Una cobertera de yerro (Alija del Infantado, 1644)

Una cobertera de yerro (Coomonte de la Vega, 1645)

Un azadón y una cobertera de yerro (La Bañeza, 1714)

Una sartén y una cobertera de yerro (La Bañeza, 1747)

Quatro coberteras de chapa (La Bañeza, 1754)

Un pote con cobertera de metal (Castrillo de la Valduerna, 1828)

Tres coberteras chiquitas (Quintanilla de Somoza, 1831)

Tres coberteras grandes (Quintanilla de Somoza, 1831)

Dos coberteras de yerro (Felechares, 1837)

Dos coberteras de yerro (Quintana del Marco, 1839)

Es un término común que se utiliza con el significado de 'tapadera de cualquier vasija de cocina'. En algunas zonas de León, en concreto en la Valdería o en la Cepeda, este término tiene además otra acepción 'cubierta de cuero que va sobre el yugo o la melena' (Le Men, 2004, s.v. cobertera). Con esta acepción no se ha encontrado ningún ejemplo en el corpus analizado. Formalmente, el término siempre se localiza bajo la forma cobertera. 
OLLA

Sust. f. 'Vasija redonda de barro o metal, que comúnmente forma barriga, con cuello y boca anchos y con una o dos asas, la cual sirve para cocer alimentos, calentar agua, etc.' (DRAE). Del latín ōlla (DECH, s.v. olla).

Tres ollas de miel llenas (Coomonte de la Vega, 1643)

Una olla grande negra de dos asas (Coomonte de la Vega, 1643)

Una olla de barro colorado (Coomonte de la Vega, 1643)

Una olla camorana (Coomonte de la Vega, 1645)

Una olla de barro zamorano quebrada con dos cuartillos de sal poco más o menos (Alija del Infantado, 1647)

Una olla de barro colorado mediana (Alija del Infantado, 1647)

Tres ollas de barro blanco (Coomonte de la Vega, 1650)

Una olla de manteca vacía (Villamor de Órbigo, 1648)

Tres jarros, una olla y dos cántaros (Villamor de Órbigo, 1648)

Una olla grande de barro colorado (Coomonte de la Vega, 1650)

Una olla grande de barro blanco digo zamorana (Coomonte de la Vega, 1650)

Una olla zamorana (Coomonte de la Vega, 1719)

Una olla bodal (Coomonte de la Vega, 1719)

Dos cazuelas y diferentes ollas (La Bañeza, 1721)

Dos ollas con un poco de manteca (Genestacio de la Vega, 1721)

Una olla nueva y un plato (Coomonte de la Vega, 1724)

Ocho ollas grandes y pequeñas (Robledo de la Valduerna, 1726)

Dos ollas de periguela (Grajal de la Ribera, 1806)

Una olla con un poco de miel (Grajal de la Ribera, 1806)

Una olla de periguela, una botija y una fiambrera (Castrocalbón, 1814)

Una olla de campania (La Nora del Río, 1823)

Una olla de periguela (Castrillo de la Valduerna, 1828)

Ollas y pucheros para el uso diario (La Bañeza, 1829)

Dos ollas grandes meladas (Quintanilla de Somoza, 1831)

Dos ollas de piriguela (Quintanilla de Somoza, 1831)

Una olla de campaña (Quintanilla de Somoza, 1831)

Una olla de periguela (Felechares, 1837)

Una olla grande zamorana con dos asas (Destriana, 1843)

Es un término muy común en el corpus. El significado que se le da en todos los ejemplo es el de 'vasija'. La palabra siempre aparece en los inventarios con alguna especificación. Las más comunes son las que se refieren al tamaño (grande, bodal, pequeña) o al material (de barro, perigüela, haciendo referencia al pueblo que lleva este nombre), pero también se hace referencia al uso, por ejemplo se dice en un caso para el uso diario, o en otros se hace referencia al contenido, lo que indica que en ese caso se suele utilizar esta olla para guardar manteca o miel, es significativo el ejemplo de Villamor de Órbigo que señala «una olla de manteca vacía», dato que indica claramente el uso que se le da a la vasija. Respecto al uso, en algunas zonas la olla es la 'vasija donde se maza la leche' (Le Men, 2009, s.v. olla). En este caso no hay referencias que justifiquen este dato. 
PEROL

Sust. m. 'Vasija de metal, de forma semejante a media esfera, que sirve para cocer diferentes cosas' (DRAE). Del catalán perol, diminutivo del catalán dialectal pér, que procede del galo *parion (DECH, s.v. perol).

Un perol de acófar mediano (La Bañeza, 1647)

Un perol y una caldereta de azófar (Robledo de la Valduerna, 1726)

Un perol viejo (La Nora del Río, 1823)

Un perol (Requejo de la Vega, 1839)

El término aparece en el corpus con el significado que da el diccionario académico y que es el actual. No son muchos los ejemplos recogidos para tratarse de un utensilio de cocina, y los que aparecen se encuentran en algunos inventarios significativos, bien por ser muy ricos en cuanto a sus objetos, es el caso del de Robledo de la Valduerna, o por tratarse de los objetos inventariados en una tienda, es el caso del ejemplo de Requejo de la Vega. Este dato quizá se deba a que se trata de un término que es importado en el siglo XVII del catalán para designar un objeto que es denominado con otros términos más afianzados como pote, y sobre todo olla.

\section{POTE}

Sust. m. 'Vasija redonda, generalmente de hierro, con barriga y boca ancha y con tres pies, que suele tener dos asas pequeñas, una a cada lado, y otra grande en forma de semicírculo. Sirve para guisar' (DRAE). Del catalán pot, 'bote, tarro', o del francés pot, 'bote, tarro, puchero', de origen desconocido (DECH, s.v. bote2)

Un pote de yerro (Miñambres, 1729)

Un pote con cobertera de metal (Castrillo de la Valduerna, 1828)

Un pote mediano y usado (Quintanilla de Somoza, 1831)

Un pote pequeño bien usado (Felechares, 1837)

Un pote de bronce con su cobertera (Quintana del Marco, 1839)

Un pote (Calzada, 1838)

Un pote de yerro con tres pies (Destriana, 1843)

Es un término común, que designa el tipo de vasija de metal con tres pies que se colocaba de las pregancias para cocinar. En el corpus se detalla el tamaño y el metal, ya que podía ser de hierro o de bronce.

\section{PUCHERO}

Sust. m. 'Vasija de barro o de otros materiales, con asiento pequeño, panza abultada, cuello ancho, una sola asa junto a la boca, y por extensión, otros tipos de vasija' (DRAE). Término derivado de puches, del latín pŭltes, plural de puls, -tis (DECH, s.v. puches). 
Un puchero (Coomonte de la Vega, 1719)

Un puchero zamorano (Coomonte de la Vega, 1724)

Las ollas, pucheros, cazuelas grandes, chicas y demás cacharros de cozina (La Nora del Río, 1823)

Ollas y pucheros para el uso diario (La Bañeza, 1829)

Dos pucheros (Felechares, 1837)

Un puchero con una libra (Felechares, 1837)

Es un término común, pero de uso menos frecuente que la voz olla. Aunque el diccionario académico señala que es una vasija de barro u otros materiales, en esta zona con el término puchero se nombra un 'recipiente de barro o cerámica cocida de barriga abultada y boca ancha, aunque con una sola asa' (Rivas, 1996: 190). Con esta acepción concreta se utiliza el término en toda la zona comprendida en el corpus, Valdería, Valduerna, Vidriales e incluso Benavente, zona muy próxima a las localidades en las que se han recogido los ejemplos. Formalmente, aunque en León se ha documentado la variante diptongada pucheiro, el término no se recoge con esta forma en el corpus.

\section{PUCHERA}

Sust. f. El DRAE define el término como sinónimo de olla (de carne, tocino, legumbres y hortalizas). Término derivado de puches, del latín pŭltes, plural de puls, -tis (DECH, s.v. puches).

Dos pucheras medianas (Destriana, 1843)

Es el único ejemplo recogido que aparece no con el significado que da el DRAE, sino con la acepción de 'puchero algo distinto al habitual', probablemente se diferencie del puchero en que tiene dos asas y barriga abultada y boca ancha (Rivas, 1996: 190). Como en el término anterior, la voz se recoge bajo la forma monoptongada.

\section{SARTÉN}

Sust. f. 'Recipiente de cocina, generalmente de metal, de forma circular, poco hondo y con mango largo que sirve para guisar' (DRAE). Del latín sartāgo, -agĭnis (DECH, s.v. sartén).

Dos sartenes (La Bañeza, 1641)

Una sartén y un caço (Castrocalbón, 1643)

Una sartén de yerro mediana (Castrocalbón, 1643)

Una sartén de yerro que anda al fuego (Alija del Infantado, 1644)

Una sartén de yerro buena (Coomonte de la Vega, 1645)

Dos sartenes de yerro pequeñas buenas (Alija del Infantado, 1646)

Otra sartén de yerro grande buena (Alija del Infantado, 1646)

Una sartén de yerro mediana y usada (Alija del Infantado, 1647)

Una sartén pequeña biexa (Alija del Infantado, 1647)

Una sartén y una cobertera de yerro (La Bañeza, 1647) 
Una sartén (La Antigua, 1647)

Una sartén (Villamor de Órbigo, 1648)

Una sartén (La Bañeza, 1714)

Dos sartenes uno grande y otro pequeño (Laguna de Negrillos, 1721)

Tres sartenes una buena y dos medianas (Laguna de Negrillos, 1722)

Dos sartenes (Palacios de Jamuz, 1728)

Una sartén nueba (Palacios de la Valduerna, 1728)

Una sartén vieja (Palacios de la Valduerna, 1728)

Dos sartenes (Pobladura del Valle, 1734)

Una sartén de yerro mediana (Laguna de Negrillos, 1740)

Una sartén de tres pies y otra sin ellos (Alija del Infantado, 1812)

Una sartén, un cazo y un escañil (La Nora del Río, 1820)

Una sartén grande (La Nora del Río, 1823)

Un caldero y una sartén biejos (Alija del Infantado, 1827)

Sartenes (La Bañeza, 1829)

Dos sartenes medianas (Quintanilla de Somoza, 1831)

Una sartén de tres pies (Quintanilla de Somoza, 1831)

Tres sartenes (Requejo de la Vega, 1839)

Una sartén (Santibáñez de la Isla, 1844)

Es un término muy común ya que se trata de uno de los enseres de cocina más habituales. Autoridades define sartén como 'una especie de vaso que abarcaría distintos enseres de cocina', aunque el uso que se le da en los ejemplos del corpus es el que actualmente conocemos. En esta época, el metal con el que se solían hacer estos objetos era el hierro, de ahí que en muchos casos aparezca esta especificación.

\section{SERVILLA [serbilla]}

Sust. f. 'Zapato ligero y de suela muy delgada' (DRAE).

Una serbilla de peltre buena (Coomonte de la Vega, 1643)

Una serbilla de estaño buena (La Bañeza, 1647)

Una serbilla pequeña (La Nora del Río, 1823)

Una servilla de peltre (Castrocalbón, 1832)

El término aparece en el corpus estudiado pero nunca con el significado que aparece en el DRAE o que registra el NTLLE en las sucesivas ediciones. Algunos de los ejemplos recogidos se encuentran dentro de la relación de bienes junto a otros utensilios de cocina (ollas, peroles). El ejemplo de Alija del Infantado aparece dentro de los objetos recogidos en la cocina. Además el material del que está elaborada es peltre o estaño, aleaciones que se empleaban, entre otras cosas, para los cacharros de cocina, por lo que probablemente se trate de un objeto de este tipo, aunque no se ha encontrado documentación que avale esta acepción, pero el CORDE recoge el siguiente ejemplo anónimo del S. XVII «Una serbilla de plata dorada a partes, con asa y tapador», en el que hay una similitud semántica. 


\section{TARTERA}

Sust. f. 'Recipiente cerrado herméticamente, que sirve para llevar los guisos fuera de casa o conservarlos en el frigorífico' (DRAE). Término derivado de torta, del latín tardío tōrta (DECH, s.v. torta).

Una tartera de cobre (La Bañeza, 1754)

Una tartera pequeña (La Nora del Río, 1823)

Dos tarteras (Castrillo de la Valduerna, 1828)

Una tartera de covre (La Bañeza, 1829)

Una tartera de cobre mediana (Quintanilla de Somoza, 1831)

Una tartera grande y de cobre (Quintanilla de Somoza, 1831)

Dos tarteras de cobre (Requejo de la Vega, 1839)

Una tartera de cobre grande (Destriana, 1843)

Tres tarteras de varro vidriadas regulares (Destriana, 1843)

El término designa un utensilio de cocina, concretamente una 'especie de olla que sirve para guisar', aunque originariamente la Academia señale en sus ediciones que servía para cocer y formar las tortadas, y también para otros usos; de ahí que se documente también la voz tortada, que no se registra en este corpus. En muchos de los ejemplos recogidos, aparece el sintagma "de cobre", pero en otros no, ya que podían ser también de barro. Todos los casos del corpus, a excepción del primero, pertenecen al s. XIX aunque el término ya se documenta en castellano en el S. XVII. Tal vez se trate de un hecho casual o quizá el término se alterne con el sinónimo cazuela, del que sí se recogen ejemplos en fechas anteriores.

\subsubsection{Cubiertos}

\section{CUBIERTO}

Sust. m. 'Juego compuesto de cuchara, tenedor y cuchillo' (DRAE). Término derivado de cubrir, de latín cooperire (DECH, s.v. cubrir).

Un plato de madera y cuatro cubiertos de boga (Grajal de la Ribera, 1806)

Una docena de cubiertos de yerro (Felechares, 1837)

Seis cubiertos de hierro (Requejo de la Vega, 1839)

Cuatro cubiertos de plata (Destriana, 1843)

Seis cubiertos de metal fino (Destriana, 1870)

Una docena de cubiertos de metal (Destriana, 1870)

Solo se han recogido ejemplos del S.XIX. El término tiene el significado que da el DRAE, pero en algunas zonas de León, y en concreto de La Bañeza, la voz cubierto tiene el significado de 'tenedor', excluyendo del término al cuchillo y a la cuchara (Rivas, 1996: 83) (Miguélez, 1998:143). A diferencia de la definición que da el DRAE que define el término como 'un conjunto', normalmente en los inventarios se relacionan 
los objetos por separado, de manera que la cuchara y el cuchillo se inventarían como tales y el término cubierto designa el 'tenedor'.

\section{CUCHARA [cuchar, cuchares, cucharitas]}

Sust. f. 'Utensilio que se compone de una parte cóncava prolongada en un mango, y que sirve, especialmente, para llevar a la boca los alimentos líquidos o blandos' (DRAE). Del antiguo y dialectal cuchar, femenino y este del latín cochlear, -āris (DECH, s.v. cuchara).

Tres cuchares de plata buenas (Coomonte de la Vega, 1643)

Un jarro y un salero y un salpimentero y un azucarero y quatro cuchares todo de plata (La Bañeza, 1643)

Siete cucharitas de madera curiosas y buenas (Coomonte de la Vega, 1643)

Tres cucharas de plata (Laguna de Negrillos, 1734)

Una cuchar de ierro de la olla (Laguna de Negrillos, 1734)

Una cuchar de yerro (La Bañeza, 1747)

Dos cucharas de madera (Quintana del Marco, 1820)

Una docena de cucharillas de plomo (Quintana del Marco, 1829)

Una cuchar de alquime y un tenedor (Palacios de la Valduerna, 1831)

El término presenta diferentes variantes. Bajo la forma normativa cuchara tiene el significado común del término. La forma cuchar es definida como 'cuchara' y la variante cuchares es definida en algunos diccionarios como 'piezas de madera del carro cantón que regulan la comprensión del eje o rodal' (Le Men, 2004, s.v. cuchara/cuchar). Según se puede deducir por los ejemplos, en lo inventarios analizados la forma cuchares presenta el mismo significado que cuchar y cuchara, puesto que llevan el complemento "de plata", más propio de un cubierto fino que de una pieza del carro. Miguélez en su trabajo de Santibáñez de la Isla señala que "uno de los encuestados me especificó que cuchares eran las de madera y cucharas las de metal. No he podido confirmar esa matización” (Miguélez, 1998: 143). Esta afirmación no se corresponde en este caso con los datos ya que la palabra cucharas aparece tanto para referirse a las de plata como a las de madera. Por tanto, cabe pensar que, al menos por lo que se puede deducir de los ejemplos encontrados, en la zona comprendida en este estudio se utiliza la forma cuchara, cuchar y cuchares en plural para denominar el útil de comer. Los diminutivos cucharitas y cucharillas probablemente denominen 'cucharas pequeñas', aunque la variante cucharitas además de hacer referencia al tamaño puede estar indicando a través del diminutivo un matiz de singularidad que acompaña con los adjetivos curiosas y buenas. 


\section{CUCHILLO}

Sust. m. 'Instrumento para cortar formado por una hoja de metal de un corte solo y con mango' (DRAE). Del latín cŭltěllus 'cuchillito', diminutivo de culter 'cuchillo' (DECH, s.v. cuchillo).

Una caja de siete cuchillos de Palermo (La Bañeza, 1643)

Otro candil con su grisuelo y otro cuchillo mediano (Laguna de Negrillos, 1722)

Dos cuchillos de monte (Robledo de la Valduerna, 1726)

Una caja de cuchillos con zinco y un tenedor (Robledo de la Valduerna, 1726)

Seis cuchillos con mangos de plata (La Nora del Río, 1823)

Un cuchillo de cozina (La Nora del Río, 1823)

Dos candiles, una linterna y dos cuchillos (Valle de la Valduerna, 1829)

Un cuchillo con mango de asta (Palacios de la Valduerna, 1831)

Un cuchillo mango de plata (Destriana, 1843)

Es un término de uso común. Es frecuente que en los inventarios se especifique el material del mango si tiene cierto valor. Formalmente, la palabra siempre aparece bajo la forma normativa.

\section{NAVAJA [nabaja]}

Sust. f. 'Cuchillo cuya hoja puede doblarse sobre el mango para que el filo quede guardado entre las dos cachas o en una hendidura a propósito' (DRAE). Del latín novacŭla, alterado vulgarmente en navacula (DECH, s.v. navaja).

Dos nabajas pintadas (Requejo de la Vega, 1839)

Es el único ejemplo recogido, aparece en un inventario que recoge objetos personales y otros que se encuentran en una tienda, dato que explica la presencia de objetos que no aparecen en otros inventarios. El significado del término es el actual y el que da el DRAE en su $1^{\text {a }}$ acepción.

\section{TENEDOR}

Sust. m. 'Instrumento de mesa en forma de horca, con dos o más púas y que sirve para comer alimentos sólidos' ( $D R A E$ ). Término derivado de tener, del latín těnēre 'tener asido u ocupado', 'mantener', 'retener' (DECH, s.v. tener).

Una caja de cuchillos con zinco y un tenedor (Robledo de la Valduerna, 1726)

Una cuchar de alquime y un tenedor (Palacios de la Valduerna, 1831)

Solo se han recogido estos ejemplos aunque se trata de un término común que junto a las cucharas y cuchillos aparece en los inventarios. 


\section{CACETA [caçeta, cazeta]}

Sust. f. 'Cazo con mango corto y fondo taladrado en diversos sitios, que usan los boticarios a modo de colador' (DRAE). Término derivado de cazo, del latín casseta (DECH, s.v. cazo).

Dos caçetas de yerro (La Antigua, 1647)

Una cazeta de azófar y un plato de madera (Castrocalbón, 1814)

Una cazeta y una espumadera (La Nora del Río, 1820)

Dos cazetas y una espumadera (La Nora del Río, 1823)

Una caceta regular (Destriana, 1843)

En la zona noroeste peninsular se documenta con el significado de 'cazo para repartir alimentos'. Con esta acepción se recoge en Asturias o Zamora. Así en Benavente, localidad próxima al área estudiada se define como 'cacillo con un mango largo que sirve para sacar comida de un recipiente, especialmente para apartar la comida' (Barrio, 1999: 170). En los ejemplos extraídos el significado con el que se usa es este, como lo demuestra el hecho de que aparece siempre junto a otros utensilios de cocina y, además, en los inventarios en los que se especifica el lugar en el que aparecen los objetos que se relacionan, las cacetas están siempre en la cocina.

En el ejemplo más antiguo, la palabra presenta la variante caçeta, es decir, con el mantenimiento de la grafía "ç" para la consonante fricativa interdental.

\section{ESPUMADERA}

Sust. f. 'Paleta ligeramente cóncava, y con agujeros, con que se espuma el caldo o cualquier otro líquido para purificarlo, o se saca de la sartén lo que se fríe en ella' (DRAE). Término derivado de espuma, del lat. spūma (DECH, s.v. espuma).

Una cazeta y una espumadera (La Nora del Río, 1820)

Una revolbedera y dos espumaderas (La Nora del Río, 1823)

Dos cazetas, una espumadera y un torzador (La Nora del Río, 1823)

Una espumadera (Destriana, 1825)

Una espumadera de azófar (Castrillo de la Valduerna, 1828)

Dos espumaderas (La Bañeza, 1829)

Tres cacetas y dos espumaderas (Quintanilla de Somoza, 1831)

Dos cazos, una sartén, espumadera y otros enredos de cozina (Calzada, 1838)

Una espumadera regular (Destriana, 1843)

Es un vocablo de uso generalizado, muy frecuente en las relaciones de enseres que aparecen en los inventarios notariales, ya que es un utensilio de cocina de uso común. 


\section{VOLVEDERA [bolvedera, revolbedera]}

Sust. f. El DRAE define el término como 'instrumento de madera para dar vuelta a la mies' y señala que es un coloquialismo rural en Segovia y Zamora. Probablemente de volver, del latín vŏlvěre ( $D E C H$, s.v. volver).

Dos asadores, una bolvedera (La Bañeza, 1641)

Una revolbedera y dos espumaderas (La Nora del Río, 1823)

Son los únicos ejemplos encontrados, aunque es probable que también se trate en estos casos de un término coloquial pero utilizado con una acepción diferente ya que aparece junto a asador y espumadera y otros utensilios de cocina (cazos, sartenes). Por tanto, probablemente haga referencia a algún objeto que se emplea para dar vueltas a los alimentos, de ahí el término coloquial volvedera.

\subsubsection{4. Útiles de la lumbre}

\section{ABREGANCIAS [brigancias, berganzas, berganças, berganzal, venganzas]}

Sust. f. 'Cadena de hierro que, en las cocinas antiguas, pende del centro de la campana y la chimenea y desciende sobre la lumbre del llar u hogar' (Le Men s.v. abrigancias). Término procedente de pregancias y este de pregar, forma leonesa de pregar, porque los llares se pliegan o recogen colgándolos de un gancho (DECH, s.v. abrigancias). Junto a este origen, otros estudiosos han explicado la etimología de la palabra partiendo de un fenómeno de fonética sintáctica, de manera que a partir de la pregancia se obtendría la forma *apregancia derivada de una confusión al establecer el corte de la secuencia. Así, el grupo /pr/ quedaría en posición intervocálica y sonorizaría en /br/ dando abregancia (Le Men, 1996, s.v. abrigancias).

Unas berganças (La Bañeza, 1641)

Unas brigancias de yerro medianas (Coomonte de la Vega, 1645)

Unas venganzas nuevas digo buenas (Huerga de Garaballes, 1720)

Unas berganzas de la lumbre pequeñas (La Bañeza, 1721)

Unas berganzas (Toral, 1728)

Un berganzal de ierro (Palacios de la Valduerna, 1728)

Unas verganzas de yerro (Destriana, 1728)

Unas verganzas (Miñambres, 1729)

Unas bregancias de yerro (Destriana, 1843)

Se trata de una palabra de uso dialectal, solo aparece en zonas de León y Asturias. Se recoge en el CORDE bajo la forma bregancias en ejemplos fechados en los SS. XIII y XIV; y en el DRAE aparece la forma abregancias como propia de León. Los ejemplos presentan la forma sonorizada, predominante en León, con aféresis de la /a/. 
Este fenómeno se explicaría por entenderse que existió el corte falso explicado anteriormente. Este término se documenta en la provincia de León con distintas variantes. Pérez Gómez recoge la forma abrigancia en Palacios de Jamuz, Destriana y Castrocalbón; abriganza en Villanueva de Jamuz, begrancia en la capital bañezana y señala que la variante pregancia aparece en la Ribera del Órbigo (Pérez Gómez, 1961: 536-541), sin embargo ninguna de esas variantes se ha recogido en este corpus.

\section{TRÉBEDE [trévede]}

Sust. f. 'Aro o triángulo con tres pies, que sirve para poner al fuego sartenes, peroles, etc.' (DRAE). Del latín trĭpĕdes, plural del adjetivo tripes,-edis, 'de tres pies', compuesto de tres y pes, pedis 'pie' (DECH, s.v. trébedes).

Unas trébedes de yerro (Coomonte de la Vega, 1643)

Unas trébedes de yerro grandes (La Bañeza, 1647)

Unas trébedes de yerro (La Bañeza, 1714)

Un badil, unas tenazas y unas trébedes pequeñas de yerro (La Bañeza, 1721)

Unas trébedes de pie y un calderito sin asa (Grajal de la Ribera, 1723)

Unas parrillas y dos pares de trévedes, las unas quebradas (Laguna de Negrillos, 1734)

Unas trévedes de yerro (Laguna de Negrillos, 1740)

Unas trébedes (Grajal de la Ribera, 1750)

Unas trévedes (La Bañeza, 1754)

Unas trébedes pequeñas de fierro (La Bañeza, 1758)

Unas trébedes pequeñas (La Nora del Río, 1823)

Unas trébedes usadas (Quintanilla de Somoza, 1831)

Dos trébedes (Requejo de la Vega, 1835)

Unas trévedes (Requejo de la Vega, 1835)

Unas trévedes chiquitas (Felechares, 1837)

Unas trévedes pequeñas triangulares de tres pies (Destriana, 1843)

Se trata de un término de uso común. Como se aprecia en los ejemplos, siempre aparece en plural lo que indica que se utiliza con el significado de 'caballete de hierro con tres patas que se utiliza para poner los potes' ya que en singular es un término que se documenta en León el trébede con otras acepciones, pero no se recoge ningún caso en el corpus. M. Descosido recoge también en la Valdería la forma estrébedes (M. Descosido, 1993: 189), con el mismo significado con el que se utiliza el término en el corpus, pero no se ha recogido ningún ejemplo con esta variante formal.

\section{ASADOR}

Sust. m. 'Varilla puntiaguda en que se clava y se pone al fuego lo que se quiera asar'. (DRAE). Término derivado de asar del lat. assare íd., derivado de assus, -a, -um, 'asado' (DECH, s.v. asar).

Un asador de yerro mediano (Coomonte de la Vega, 1643) 
Dos asadores de gaxos (Coomonte de la Vega, 1645)

Dos asadores pequeño sin gaxos de yerro (Alija del Infantado, 1647)

Ocho asadores de yerro llanos sin gaxos (Genestacio de la Vega, 1650)

Una sartén y un asador (La Bañeza, 1712)

Un asador de tres garfios (Genestacio de la Vega, 1721)

Un asador pequeño (Grajal de Ribera, 1730)

Quatro asadores de ierro (Santiago Millas, 1735)

Dos asadores de garfios (Grajal de Ribera, 1750)

Un asador de tres garfios (Castrillo de la Valduerna, 1828)

Un cazo, un asador y un rallador (Quintanilla de Somoza, 1831)

Es una palabra común tanto en este corpus como en otros más generales como el CORDE.

\section{ESCALFADOR}

Sust. m. 'Braserillo de hierro u otro metal, con tres pies, que se ponía sobre la mesa para calentar la comida' (DRAE). Término derivado de calfar, procedente del latín vulgar calfare, latín calefacĕre íd., compuesto de calēre 'estar caliente' y facĕre 'hacer' (DECH, S.v. escalfar).

Un escalfador de cobre bueno (Robledo de la Valduerna, 1726)

Es el único ejemplo recogido que se usa con el significado que el diccionario académico da en la $3^{a}$ acepción ya que también se llama escalfador a un 'aparato que usaban los pintores para quemar la pintura' y a un 'jarro de metal en el que los barberos calentaban el agua'. Por el contexto, el uso que el término tiene en el corpus es el de objeto para calentar la comida ya que aparece junto a otros utensilios de cocina.

\section{PARRILLA}

Sust. f. 'Utensilio de hierro en forma de rejilla para poner al fuego lo que se ha de asar o tostar' (DRAE). Probablemente del gótico *parra, -ans, 'cercado, enrejado'. Es probable que el sentido inicial de parra fuese 'glorieta', 'emparrado', 'enrejado' de ahí parrilla 'rejilla' (DECH, s.v. parra).

Un capote zerrado de parrilla y usado (Alija del Infantado, 1646)

Unas parrillas buenas (La Bañeza, 1721)

Unas parrillas viejas (Robledo de la Valduerna, 1726)

Unas parrillas y dos pares de trévedes las unas quebradas (Laguna de Negrillos, 1734)

Unas parrillas viejas (La Bañeza, 1829)

Unas parrillas usadas (Quintanilla de Somoza, 1831)

El término aparece utilizado en el corpus con dos acepciones. La más común se corresponde con la acepción del DRAE, es decir se trata de una especie de 'plancha para asar'. Sin embargo, en el primer ejemplo la palabra parece designar un tipo de tejido. 


\section{BADIL [vadil]}

Sust. m. 'Paleta de hierro o de otro metal, para mover y recoger la lumbre en las chimeneas y braseros' (DRAE). Término procedente del lat. vulg. *batīle, clás. batillum (DECH, s.v. badil).

Un badil, unas tenazas y unas trébedes pequeñas de yerro (La Bañeza, 1721)

Un badil pequeño (La Bañeza, 1754)

Dos vadiles y unas tenazas (La Nora del Río, 1823)

Dos vadiles grande y chico (La Bañeza, 1829)

Una paleta, vadil y tenaces (Quintanilla de Somoza, 1831)

Es un término que se usa con el mismo significado que aparece en el diccionario académico. Formalmente, en la mayoría de los casos el vocablo se recoge escrito con la grafía "v", que sigue alternando con la grafía "b", todavía en el S. XIX. Sin embargo, en el CORDE bajo esta forma solo se recoge un caso que data del S. XVII.

\section{PALETA}

Sust. f. 'Badil u otro instrumento semejante con que se remueve la lumbre'. 'Utensilio de palastro, de forma triangular y mango de madera que usan los albañiles para manejar la mezcla o mortero' (DRAE). Término derivado de pala, del latín pala (DECH, s.v. pala).

Una sierra y un machado y una paleta de enbarrar y un martillo (La Bañeza, 1641)

Dos paletas de enbarrar (Coomonte de la Vega, 1719)

Un vrasero de cobre con su caja, paleta (La Nora del Río, 1823)

Una paleta, vadil y tenaces (Quintanilla de Somoza, 1831)

Unas tenazas y su paleta (Requejo de la Vega, 1839)

Se trata de un término polisémico, aunque en el corpus solo está utilizado con dos significados. Por una parte, en aquellos ejemplos en los que se señala una "paleta de enbarrar", el término se emplea con la acepción de 'utensilio que se utiliza para extender una mezcla', es decir, lo que se conoce por pala de albañil. En el resto de casos el significado es el de 'utensilio que se usa para mover la lumbre'. La voz paleta también aparece documentada en León y otras zonas, y es recogida en el DRAE con el significado de 'utensilio de cocina que sirve para sacar los fritos de la sartén'. Con esta acepción no se recoge el término en el corpus, se emplean otras voces como espumadera, muy frecuente, o si empleamos el significado de 'cuchara grande', en el corpus aparecen términos como revolvedera. 


\section{MORILLO [morrillo]}

Sust. m. 'Cada uno de los caballetes de hierro que se ponen en el hogar para sujetar la leña' (DRAE). Del latín maurus 'moro', por las cabezas humanas con que suelen adornarse, tiznadas por el fuego (DECH, s.v. moro).

Unos morillos pequeños de yerro de la lumbre (La Bañeza, 1641)

Unos morrillos de yerro con sus tenaçes (La Bañeza, 1643)

Los morillos de la lumbre (La Bañeza, 1721)

Un morrillo de yerro (Laguna de Negrillos, 1722)

Unos morrillos pequeños de yerro (Palacios de la Valduerna, 1726)

Dos morrillos grandes de yerro (Laguna de Negrillos, 1734)

Un morillo de la lumbre (Quintanilla de Somoza, 1831)

Un morrillo de los de la lumbre (Quintanilla de Somoza, 1831)

Dos morillos (Requejo de la Vega, 1839)

Es un término que se usa generalmente con el significado de 'caballete que se utiliza para sujetar la leña'. En todos los casos recogidos, esta es la acepción utilizada, puesto que es frecuente que el término aparezca con la especificación "de hierro" y "de la lumbre". En el ejemplo de Requejo de la Vega no se especifica nada, pero se deduce ese significado por el contexto ya que se trata de un inventario en el que se iba haciendo la relación de objetos parte por parte de la casa y los morillos se encuentran en la cocina. Además de esta acepción, en algunas zonas de León próximas, por ejemplo en la zona de Valdevimbre, (González Prieto, 1986: 147) también se llama morillo a las 'piezas de madera que sujetan el canto al uso en las bodegas', pero con esta acepción en este corpus no se recogen casos.

\section{BRASERO}

Sust. m. 'Pieza de metal, honda, ordinariamente circular, con borde, y en la cual se echa o se hace lumbre' (DRAE). Palabra derivada de brasa, de origen incierto, latino o prerromano (DECH, s.v. brasa).

Un brasero con su caja (La Bañeza, 1643)

Una caja de brasero sin la vacía (Laguna de Negrillos, 1722)

Un braserico de cobre (Grajal de la Ribera, 1723)

Un brasero de cobre con caja de nogal (Robledo de la Valduerna, 1726)

Un brasero de cobre (Pobladura del Valle, 1734)

Un brasero con su caja (Felechares, 1837)

Un brasero de yerro y paleta de lo mismo (Destriana, 1843)

El término se inventariaba atendiendo a las partes que componen el objeto y al material del que estaban elaboradas. Los datos que ofrecen estos ejemplos no se corresponden con la información que aporta el Diccionario de Autoridades que señala que era "para el uso de la gente pobre". Este dato no coincide con la información que 
aparece en ejemplos como el de Palacios de la Valduerna, ya que el hecho de especificar el tipo de madera de la caja indica el valor del brasero.

\section{CALENTADOR}

Sust. m. 'Recipiente con lumbre, agua, vapor o corriente eléctrica, que sirve para calentar, la cama, el baño, etc.' (DRAE). Término derivado de caliente, del latín calens, ěntis (DECH, s.v. caliente).

Un calentador biejo (La Bañeza, 1643)

Un calentador nuevo de cobre con una campanilla de bronze (La Bañeza, 1643)

Un calentador de azófar con el mango de yerro (La Bañeza, 1721)

Un calentador mediano (Laguna de Negrillos, 1734)

Un calentador (La Nora del Río, 1823)

Un calentador (Requejo de la Vega, 1839)

Solo aparecen estos ejemplos a lo largo del corpus estudiado. Por tanto, no es un término muy común. El significado con el que se utiliza es el actual, es decir, 'objeto para calentar'. En esta época eran una especie de braseros con tapa y caja, de ahí la especificación "de cobre” que aparece en el ejemplo de La Bañeza.

\section{ESTUFA [stufa]}

Sust. f. 'Aparato destinado a calentar un recinto por electricidad o combustión de madera, gas, etc.' (DRAE). Del verbo estufar 'calderar un aposento cerrado', y este probablemente de un verbo del latín vulgar *extūphare 'caldear con vapores'.

Una stufa (Pobladura del Valle, 1734)

Solo se ha recogido este ejemplo. El significado con el que se utiliza es el de 'objeto destinado a calentar'.

\section{FUELLE}

Sust. m. 'Instrumento para recoger aire y lanzarlo con una dirección determinada, que esencialmente se reduce a una caja con tapa y fondo de madera, costados de piel flexible, una válvula por donde entra el aire y un cañón por donde sale cuando, plegándose los costados, se reduce el volumen del aparato' (DRAE). Del lat. fŏllis 'fuelle para el fuego', 'odre hinchado', 'bolsa de cuero' (DECH, s.v. fuelle).

Una fragua con su yunque y fuelles (Coomonte de la Vega, 1645)

Un tablón de fuelles (Palacios de la Valduerna, 1728)

Unos fuelles (La Bañeza, 1754)

Unos fuelles viejos (La Bañeza, 1829)

Unos fuelles para la lumbre (Quintanilla de Somoza, 1831)

Unos fuelles (Felechares, 1837) 
Un fuelle de la lumbre en buen uso (Destriana, 1843)

El término tiene en León varias acepciones, algunas de ellas probablemente recogidas en este corpus. Por una parte la voz aparece con el significado que da el DRAE de 'instrumento utilizado para avivar el fuego', como se refleja en el ejemplo de Coomonte de la Vega o el de Quintanilla de Somoza en los que se hace referencia a la fragua o se especifica su uso: "para la lumbre”. Además de esta acepción, el término tiene en León los significados de 'recipiente hecho con piel de cabra vaciada, curtida y cosida' y de 'saco usado para envasar la harina, el grano, etc.' (Le Men, 2005, s.v. fuelle). En los ejemplos de La Bañeza o de Felechares en los que no se especificada nada, el término podría estar usándose con cualquiera de los significados.

\section{FRAGUA}

Sust. f. 'Fogón en que se caldean los metales para forjarlos, avivando el fuego mediante una corriente horizontal de aire producida por un fuelle o por otro aparato análogo' (DRAE). De *fravga, *frabǐca, procedente del latín fabrica 'arte del herrero', 'fragua' (DECH, s.v.fragua).

Una fragua con sus yunque fuelles (Coomonte de la Vega, 1645)

Una fragua con sus aparejos (Grajal de la Ribera, 1750)

El término se utiliza con su significado propio. Formalmente, no se ha recogido ningún ejemplo con otras variantes formales que son frecuentes en León: fraugua, frauga (Le Men, 2007, s.v. fraugua).

\subsubsection{Otros útiles de cocina}

\section{ALMIREZ [almidez]}

Sust. m. 'Mortero de metal, pequeño y portátil que sirve para machacar o moler en él' (DRAE). Término que procede del árabe mihrâs id., de háras 'machacar' (DECH, s.v. almirez).

Un almirez pequeño con su mano (Coomonte de la Vega, 1643)

Un almidez con su mano bueno (Genestacio de la Vega, 1650)

Otra mano de almidez (Genestacio de la Vega, 1650)

Un almirez mediano (La Bañeza, 1721)

Un almirez de alquima (Palacios de la Valduerna, 1727)

Un almirez (Alija del Infantado, 1737)

Un almirez con su mano (La Bañeza, 1754)

Un almirez pequeña con su mano (La Bañeza, 1758)

Un almirez con una mano (Alija del Infantado, 1812)

Un almirez con su manilla (Quintanilla de Somoza, 1831) 
Un almirez con su mano vuena (Destriana, 1843)

Se trata de una voz de uso general ya que se recoge en todo el corpus analizado. El término almirez aparece recogido en el CORDE en ejemplos que son del S. XVI en adelante, no se registra ningún ejemplo bajo la forma almidez, que Menéndez Pidal explica como un caso de "liquidación", debida a la equivalencia entre /d/ y /1/ o /r/ (Menéndez Pidal, 1987: 199). Bajo esta forma, en el inventario estudiado solo se han encontrado dos casos que pertenecen a la misma relación, por lo que pueden considerarse casos aislados y no especialmente significativos. La descripción que se hace en el inventario del objeto alude en la mayor parte de los casos a las dos partes que componen el almirez, referencias lógicas en los listados de enseres donde la información que se da de los bienes ha de ser lo más detallada posible. Es importante señalar que en el corpus analizado solo se ha recogido un ejemplo de la palabra mortero, término muy común dentro de los objetos de cocina que aparece tanto en diccionarios generales, como en trabajos lexicográficos leoneses.

\section{MORTERO}

Sust. m. 'Utensilio de madera, piedra o metal, a manera de vaso, que sirve para machacar en él especias, semillas, drogas, etc' (DRAE). Del latín mortarium (DECH, s.v. mortero).

Un mortero con su mano (Destriana, 1843)

Es el único ejemplo encontrado. Su significado coincide con el que da el diccionario académico. En el corpus se registran bastantes ejemplos de la voz almidez, que parece sinónimo, pero que presenta alguna diferencia. Concretamente en este inventario aparecen ambos términos seguidos en la relación. Es probable que la diferencia se encuentre en el material del que está hecho, siendo el metal para el almidez. y la madera para el mortero.

\section{BANDEJA [vandeja]}

Sust. f. 'Pieza de metal, o de otra materia plana o algo cóncava, para servir, presentar o depositar cosas' (DRAE). Término procedente del port. (DECH, s.v. bandeja).

Una vandeja de charol chica vien usada (La Bañeza, 1829)

Dos bandejas pequeñas (Requejo de la Vega, 1839)

Dos canastillos y una bandeja de cristal (Requejo de la Vega, 1839)

Una bandeja de estaño (Requejo de la Vega, 1839)

No son muchos los ejemplos encontrados, todos pertenecen al S. XIX y tres de 
ellos al mismo inventario. Este dato coincide con los extraídos del CORDE, donde la mayoría de los ejemplos que aparecen pertenecen a los siglos XIX y XX.

\section{FUSTERA}

Adj. f. 'Perteneciente o realtivo al fuste' (DRAE). Derivado de fuste, del latín fūstis, 'bastón', 'garrote' (DECH, s.v. fuste).

Una fustera de piedra (Destriana, 1843)

Es el único caso recogido en el corpus. Como se aprecia en el ejemplo, el término aparece con uso sustantivo y, en principio, observando el contexto no guarda relación semántica con las acepciones que da el diccionario académico para el término fuste que define como 'vara o palo en que está fijado el hierro de la lanza', ni para su derivado fustera. En el inventario en el que se ha recogido este ejemplo, el término se encuentra en la relación de objetos del cuarto de la cocina y aparece junto a platos y otros objetos de menaje. Además lo que aparece inventariado inmediatamente después es «una fuente de lo mismo buena», por lo que cabe pensar que se trata de algún tipo de objeto utilizado en la cocina para servir los alimentos. No obstante parece tratarse de un objeto singular puesto que no se recoge ningún ejemplo en ningún corpus y en el CORDE se registran dos casos de fustera pertenecientes al S. XVI con un significado que nada tiene que ver con el utilizado en este corpus.

\section{BATIDORA}

Sust. f. 'Instrumento para batir' (DRAE). Palabra derivada de batir, del latín battuěre (DECH, s.v. batir).

Dos batidoras biejas (Quintanilla de Somoza, 1831)

Es una palabra poco común en el corpus analizado. Este dato no debe resultar extraño si tenemos en cuenta que corpus como el CORDE recoge ochenta casos de los que todos excepto uno pertenecen al S. XX y uno al S. XVI. Es decir, en la franja de años que comprende este estudio no se recoge ni un solo caso. Asimismo, el DRAE no introduce el vocablo hasta la $1^{\text {a }}$ edición del s. XX.

Se trata de un término polisémico, ya que es un instrumento que sirve para hacer la mezcla de arena y agua, acepción que recoge el DRAE, pero en la zona leonesa se ha documentado con otros significados: 'instrumento para hacer surcos en los prados', o 'especie de azada' (Le Men, 2002, s.v. batidera). Además, el término también tiene el significado que comúnmente se conoce 'instrumento para batir alimentos'. El hecho de 
encontrar un solo ejemplo que, además, no contiene mucha información, no nos permite ninguna conclusión acerca del significado con el que está utilizado en el corpus. Por otra parte, el lugar que ocupa en la relación tampoco es determinante ya que aparece junto a un arca, un carro o una cántara de agua.

\section{COLADERA}

Sust. f. 'Cedazo pequeño para licores' (DRAE). Término derivado de colar, del latín cōlāre, derivado de colum (DECH, s.v. colar).

Una coladera biexa (Alija del Infantado, 1650)

En León el término se documenta con acepciones distintas a las que recoge el DRAE. Se denomina así al 'colador', también a un 'cedacillo para la leche del ordeño' o incluso a un 'fregadero con un hueco circular en el centro, con un canal de desagüe en el que se hacía la colada' (Le Men, 2004, s.v. coladera). En el corpus estudiado, solo se ha recogido este ejemplo del que no se dan muchos datos para saber con exactitud cuál es la acepción empleada, probablemente basándose en el contexto, se use con el significado de 'colador' por aproximación ya que el objeto inmediatamente anterior en la relación es una caceta, es decir, otro elemento de cocina. No obstante, la voz colador tampoco se ha recogido en este corpus.

\section{EMBUDO [enbudo]}

Sust. m. 'Instrumento hueco ancho por arriba y estrecho por abajo, en forma de cono y rematado en un canuto, que sirve para transvasar líquidos' (DRAE). Del latín tardío ̌̌mbūtum, abreviación de trajectorium imbutum (trajectorium 'embudo' + el participio de imbǔĕre 'mojar' [en algo], meter [en un líquido] (DECH, s.v. embudo).

Una espita y un enbudo de estaño (Villamor de Órbigo, 1648)

Un enbudo de estaño (Coomonte de la Vega, 1650)

Un enbudo de madera (La Bañeza, 1721)

Un enbudo quebrado (Palacios de la Valduerna, 1730)

Dos alcuzas con su embudo para aceite (Quintanilla de Somoza, 1831)

Quatro embudos de ojadelata (La Nora del Río, 1823)

Dos embudos de ojadelata uno grande y otro chico (Destriana, 1843)

Es una voz común, de uso general. Aparece con el significado académico, que coincide con el actual. En algunas zonas de León, concretamente en Astorga, zona próxima a la estudiada, se recoge la variante femenina embuda con este mismo significado (Le Men, 2005, s.v. embuda). En el corpus estudiado no se ha recogido ningún ejemplo con esta variante. 


\section{RALLADOR}

Sust. m. 'Utensilio de cocina, compuesto principalmente de una chapa de metal, curva y llena de agujerillos de borde saliente, que sirve para desmenuzar el pan, el queso, etc., restregándolos con él' (DRAE). Término derivado de rallo, del latín rallum derivado de radĕre (DECH, s.v. rallo).

Un cazo, un asador y un rallador (Quintanilla de Somoza, 1831)

Un cazo, un asador y un rallador (Quintanilla de Somoza, 1831)

Solo se han recogido dos ejemplos pertenecientes al mismo inventario. El significado es el que aparece en el diccionario académico y se trata de un término común.

\section{ESPETERA [espitera]}

Sust. f. 'Tabla con garfios en que se cuelgan carnes, aves y utensilios de cocina' (DRAE).

Término derivado de espeto, el gót. *spǔtus (DECH, s.v. espeto).

Una espetera con sus escarpias (Fresno, 1726)

Una espetera (Miñambres, 1727)

Una espetera con sus escarpias (Toral, 1728)

Una espetera viexa (Palacios de la Valduerna, 1728)

Una espetera con una sartén (Palacios de la Valduerna, 1728)

Una espetera nueba (Destriana, 1730)

Un facerón de tabla, una espetera y un poco de teja (La Isla, 1829)

Una espetera vieja con su clavera (La Bañeza, 1829)

Una espitera con sus escarpias (Quintanilla de Somoza, 1831)

Con este término también se denomina a una 'percha en la cocina o en las bodegas', aunque en esta zona estudiada el significado con el que se utiliza la voz es el de 'tabla con unos ganchos de los que se cuelgan los útiles de cocina' (Rivas, 1996: 119). Desde el punto de vista formal, se registra un caso con la variante /i/ debido a que la palabra de la que procede *spitus ha dado descendientes con /e/ y con /i/.

\section{ARTESA}

Sust. f. 'Cajón cuadrilongo, normalmente de madera, que sirve para amasar el pan y para otros usos' (DRAE). Se trata de un término cuyo origen es incierto aunque probablemente tenga un origen prerromano, quizá íbero o protovasco: artesia (DECH, s.v. artesa).

Una artesa de masar nueva (La Bañeza, 1641)

Otra artesica pequeña (La Bañeza, 1641)

Una artesa de masar con sus varillas (Robledo de la Valduerna, 1726)

Una artesa (Santibáñez de la Isla, 1735)

Una artesa de Talavera (La Bañeza, 1754)

Una artesa (La Bañeza, 1758)

Una artesa mediana (Quintanilla de Somoza, 1831) 
Una artesa nueva (La Bañeza, 1839)

La palabra aparece a lo largo de todo el período analizado y los ejemplos encontrados se sitúan en La Bañeza, en localidades muy próximas a esta o situadas hacia el oeste. La definición académica señala que 'sirve fundamentalmente para amasar el pan', aunque tiene otros usos, en el $D E C H$ se especifica que, concretamente en La Bañeza, se utiliza el término masera (DECH, 2002, s.v. artesa/arteso). De los datos recogidos en los vocabularios leoneses se deduce que artesa y masera son objetos con distintos usos, así la masera sirve para amasar el pan, mientras que la artesa tiene otras utilidades (recoger el vino, hacer el mondongo) (Le Men 2002, s.v. artesa/arteso). Sin embargo, de los datos que aportan los inventarios estudiados, se puede observar que se hace una diferencia en el uso del objeto, así nos habla de una artesa de amasar o simplemente de una artesa, sin más apreciaciones que las propias del tamaño o estado. De este dato, se puede deducir, que en este caso, la artesa tiene indistintamente los dos usos.

\section{MASERA}

Sust. f. 'Artesa grande que sirve para amasar' (DRAE). Término derivado de masa, del latín massa (DECH, s.v. masa).

Una masera con sus barandas (Fresno, 1726)

Una masera con sus varandillas (Miñambres, 1729)

Una masera con barandas, piñeras, palas de orno (Santibáñez de la Isla, 1844)

No son muchos los ejemplos encontrados. Este dato junto al hecho de que la voz masera es muy usada en León y Asturias (Le Men, 2007, s.v. masera), nos hace suponer que en esta zona ha prevalecido el término genérico artesa frente a masera, más propiamente dialectal, aunque se documenta en otras zonas de la Península. Además, son más numerosos los ejemplos encontrados de la voz artesa.

\section{BARANDA [varandillas]}

Sust. f. 'Cada uno de los palos que se colocan atravesados por encima de la masera, con el fin de hacer de soporte a las piñeras con las que se cierne la harina' (Rivas, 1996: 43).

Del lat. vara (DHL, s.v. barándanas).

Una masera con sus barandas (Fresno, 1726)

Una masera con sus varandillas (Miñambres, 1729)

Unas varandillas de masar (Miñambres, 1731)

Una masera con barandas piñeras palas de orno (Santibáñez de la Isla, 1844)

Los casos encontrados son escasos y todos ellos se localizan en la zona de la 
Valduerna, es decir, la parte más occidental del área estudiada. Este dato coincide con los aportados por estudios del leonés que señalan que se trata de una voz que solo se conoce en el occidente de León (Le Men, 2000, s.v. baranda). El término se localiza en zonas como La Cabrera y la Maragatería, zonas próximas a las que presentan los ejemplos localizados en el corpus estudiado. La Academia no recoge esta acepción en ninguna de sus ediciones y en corpus como el CORDE tampoco se recoge ningún ejemplo con este significado. En cuanto a la forma, en los dos casos de Miñambres aparece la variante con el sufijo -illa.

\section{MASERÓN}

El DRAE define la voz masera como 'artesa grande que sirve para amasar' y no registra el término maserón.Término derivado de masa, del latín massa (DECH, s.v. masa).

Un maserón de roble (Calzada, 1838)

Es el único ejemplo recogido del término maserón que no registra el diccionario académico ni aparece como entrada independiente en los vocabularios dialectales. Probablemente, se trate simplemente de un aumentativo del término masera.

\section{MOLINILLO}

Sust. m. 'Instrumento pequeño para moler'. 'Palillo cilíndrico con una rueda gruesa y dentada en su extremo inferior, que se hace girar a un lado y otro entre las manos extendidas, para batir el chocolate u otras cosas' (DRAE). Término derivado de moler, del latín mŏlěre (DECH, s.v. moler).

Quatro dozenas de molinillos (La Bañeza, 1721)

Una chocolatera de cobre con su molinillo sin tapa (La Bañeza, 1721)

Una chocolatera con su molinillo (Castrillo de la Valduerna, 1828)

Una chocolatera de azófar regular con su molinillo y tapa (Destriana, 1843)

Es un término común que en este caso acompaña al sustantivo chocolatera para designar el recipiente donde se hacía el chocolate y el molinillo que batía ese chocolate.

\section{PICADOR}

Sust. m. El DRAE define el término en la $3^{\text {a }}$ acepción como 'tajo de cocina'. Término derivado de picar, voz común a todas las lenguas romances de Occidente; de creación expresiva; primero significó 'golpear con algo puntiagudo', de donde 'comer a picotazos', 'golpear', 'desmenuzar' (DECH, s.v. picar).

Dos picadores y dos platos (La Nora del Río, 1823) 
Es el único ejemplo encontrado del término. La voz picador se encuentra documentada en la zona de La Bañeza con el significado de 'cepo o tronco grueso en el que se apoya la leña para picarla con ayuda de macheta o machao' (Rivas, 1996: 181). Sin embargo, teniendo en cuenta el contexto en el que aparece, está claro que no es el significado que se le da al término en este ejemplo, ya que de ser así no sería lógico que apareciera coordinado con la voz plato y que los objetos que le siguen en la relación sean utensilios de cocina. Parece más lógico pensar que su significado puede estar relacionado con la llamada picadera 'vasija redonda y de madera, más ancha que honda, en el interior de la cual lleva una pieza cilíndrica sobre la que se pica la carne para hacer embutidos durante la faena de matar los cerdos' (Martínez Martínez, 1985: 187) o picadero 'útil para triturar o picar la comida' (Nuevo, 1997: 278). Quizá se trate de un sinónimo de tajador o tajadero, términos de mayor presencia en el corpus.

\section{TAJADERA [talladera]}

Sust. f. 'Cuchilla, a modo de media luna, con que se taja una cosa; como el queso, el turrón, etc.' (DRAE). Término derivado de tajar, del latín vulgar taleare 'cortar', 'rajar' derivado del latín talěa 'retoño, hijuelo que se trasplanta ' (DECH, s.v. tajar).

Una masera con su talladera (Priaranza, 1732)

Es el único ejemplo en el que la voz aparece bajo la forma talladera, no así tajador del que aparecen más ejemplos. El significado con el que se conoce el término es el de 'herramienta para cortar', y concretamente es el nombre que se le da a la que utilizan los herreros para cortar el hierro. Sin embargo, en el ejemplo, la voz aparece junto a la palabra masera, por lo que tal vez se trate de un tipo de cuchilla que lleva incorporada la masera y que sirve para cortar la masa ya preparada. Formalmente, en León es frecuente encontrar el término bajo la forma que aparece en el corpus pero con diptongo decreciente, talladeira.

\section{TAJADOR [taxador, tajadero]}

Sust. m. 'Tajo para partir la carne'. 'Cuchilla, semejante a un raspador, que se utiliza para cortar materias laminadas blandas, como el cuero, cartón, chapa de plomo, etc.' (DRAE). Término derivado de tajar, del latín vulgar taleare 'cortar, rajar', derivado del latín talěa (DECH, s.v. tajar).

Dos taxadores de madera grandes (Alija del Infantado, 1644)

Un taxador de madera (Alija del Infantado, 1644)

Un taxador de madera (Alija del Infantado, 1646) 
Dos tajadores de madera (Alija del Infantado, 1647)

Dos taxadores (La Antigua, 1648)

Un taxador de madera (Villamor de Órbigo, 1648)

Dos taxadores de madera buenos (Genestacio de la Vega, 1650)

Un tajadero (Huerga de Garaballes, 1720)

En el DRAE aparecen los términos tajador y tajadero bajo entradas diferentes, aunque los significados son próximos. En el corpus la palabra más usada es tajador, aunque también aparece tajadero, probablemente con el mismo uso, aunque es más frecuente la voz tajadero que recoge Covarrubias con el significado de 'plato sobre el que se corta la carne', definición que a partir de Autoridades se incluye en la entrada tajadero, sufijo usual en castellano (Puche Lorenzo, 2012: 350). Por tanto, en este corpus, el sufijo -dor prevalece sobre la forma castellana. En prácticamente todos los ejemplos, el término aparece acompañado del sintagma "de madera", por lo que es posible que ambos términos tengan el significado que se encuentra documentado en Salamanca para ambos términos que es el de 'el rollo de madera, plana en la superficie, que sale en medio de una fuente o plato, también de madera, y en el cual se coloca la carne que se ha de cortar' (Lamano, 1915: 637). Por tanto, en aquellos ejemplos en los que la voz aparece junto al complemento "de madera", probablemente este sea su significado, además, aunque no siempre se sigue un orden claro, estas voces se documentan en cada uno de los inventarios junto a otros enseres de cocina, así en el ejemplo de Villamor de Órbigo aparece junto a un embudo, una olla de manteca, platos y demás enseres. Sin embargo, utilizando el mismo argumento, el ejemplo de Huerga de Garaballes no presenta el complemento "de madera" y además aparece junto a otros objetos, algunos de hierro, que no son enseres de cocina; por ejemplo: tiraderos de yerro, un trillo, una garavita de yerro; por lo que tal vez en este caso, se trata más bien de un instrumento que se utiliza para cortar el hierro.

\section{TAJO [taxo]}

Sust. m. 'Pedazo de madera grueso, por lo regular afirmado sobre tres pies, que sirve para partir y picar la carne sobre él'. 'Tajuelo (banquillo)' (DRAE). Término derivado de tajar (DECH, s.v. tajar).

Tres tajos (Urdiales del Páramo, 1645)

Tres taxos (La Antigua, 1648)

Un tajo de enzina (La Bañeza, 1758)

Dos tajos de la carne (Palacios de la Valduerna, 1831)

Un tajo (Felechares, 1836)

Un tajo de yerro (Felechares, 1836)

Un tajo de escavar (Felechares, 1836) 
Es un término que, como en el caso anterior, probablemente se utilice con distintos significados. El término tajo tiene varias acepciones, se llama así a un 'asiento bajo de madera', también al 'tronco de árbol que sirve para picar leña o carne' la 'tabla de lavar', objeto que en este corpus también recibe el nombre de banca; o utilizado en plural puede significar 'tablones gruesos que se colocan sobre la masa de la uva contenida en la sartén del lagar para actuar como prensa' (Le Men, 2009, s.v. tajo). Los tres últimos ejemplos aparecen dentro de un contexto que permite deducir cuál puede ser el uso. En el caso del tajo de yerro, probablemente el término está usado como en el caso de tajador para nombrar un 'instrumento que sirve para cortar el hierro'; el segundo ejemplo de Felechares indica el uso que se le da, por tanto se tratará de una herramienta para escavar, quitar hierbas, etc. Finalmente, el último ejemplo, el complemento que aparece "de carne" indica que se trata del instrumento de madera que se usa para ese fin. En el resto de casos, la falta de referencias y la poca información que se puede extraer del contexto en el que aparecen los términos dentro de la relación impide conocer el significado exacto en cada caso.

Además existe un caso cuyo significado no tiene que ver con los anteriores:

Un tajo de guerta en dos reales (Palacios de la Valduerna, 1831)

Descosido Fuertes registra tajo en la comarca de la Valdería con la acepción de 'trabajo contratado o acordado' (Descosido Fuertes, 1993: 188), por lo que aplicado al ejemplo se puede estar refiriendo a un trozo de huerta, definido a través de la acotación del trabajo que en ella se realiza.

\section{TOCINERA}

Sust. f. 'Tablón ancho y algo cóncavo, con apoyos o pies, donde se sala el tocino en las casas'. Término derivado de tocino, probte. derivado del latín provincial tŭcca, al parecer de origen céltico ( $D E C H$, s.v. tocino).

Una tocinera (Felechares, 1837)

Es el único ejemplo recogido que probablemente mantenga el significado que da el diccionario académico.

\subsubsection{Ropa de hogar}

\section{ALMOHADA [almuhada, almoada, almuada]}

Sust. f. 'Colchoncillo que sirve para reclinar sobre él la cabeza en la cama' (DRAE). Esta 
palabra tiene su origen en el árabe hispánico y magrebí muhádda derivado de hadd 'mejilla' (DECH, s.v. almohada).

Una almoada buena con su lana con randa blanca (Coomonte de la Vega, 1643)

Dos almoadas de lienzo con deshilados blancos sin lana usados (Alija del Infantado, 1646)

Dos almuadas de lienço delgado (La Bañeza, 1641)

Una almoada (La Antigua, 1647)

Una almuada (La Antigua, 1648)

Dos almoadas con lana (La Bañeza, 1712)

Una almuada de lienzo con su lana (Laguna de Negrillos, 1721)

Siete almoadas de lienzo (Robledo de la Valduerna, 1726)

Diez y seis almoadas de lino viejas (Robledo de la Valduerna, 1726)

Una calesa vieja con dos almohadones de seda fina y otro de baqueta (Robledo de la

Valduerna, 1726)

Una almohada de lienzo inglés por estrenar con guarnición (Jiménez de Jamuz, 1825)

Una almuada con guarnición (Castrillo de la Valduerna, 1828)

Dos fundas de almuhadas (Felechares, 1837)

Una almoadilla de coser (Grajal de la Ribera, 1806)

Se trata de una voz de uso muy común en todas las épocas y lugares de ahí que los ejemplos recogidos sean numerosos. La palabra aparece casi siempre bajo las formas almoada, almuada, aunque en los diccionarios de la época se recoge la forma almohada, dato que llevaría a pensar que, la ausencia de la grafía "h", es un fenómeno atribuible, más bien, a un problema de fijación gráfica. También es muy frecuente la confusión /o/ / $/$, que se localiza frecuentemente en esta palabra, incluso alternando las dos variantes (Morala y Egido, 2010: 428). Por lo que respecta al significado del término, el DRAE señala varias acepciones y todas ellas se recogen en el corpus. Se llama almohada no solo al cojín sobre el que se reposa la cabeza, sino también a la funda que recubre el relleno o incluso a la sobrefunda, lo que conocemos con el nombre de almohadón en un juego de sábanas, de ahí que en el corpus se especifique, por ejemplo, si tenía o no adornos. Observamos que hacia el S. XIX, se empieza a diferenciar, en algún caso, la funda, de la almohada en sí. En cuanto al término almohadón, además del significado ya comentado, se recoge con el de 'cojín', como puede apreciarse en el ejemplo de Palacios de la Valduerna de 1726. Finalmente, otro derivado recogido en una ocasión, es el de objeto pequeño parecido al cojín en el que se pinchan las agujas, una almohadilla de coser. En León se registra con frecuencia la voz acerico, sinónimo de almohadilla. Con este significado también la recoge el DRAE. Sin embargo, el término acerico no aparece en el corpus estudiado.

\section{ALMOHADÓN}

Sust. m. 'Colchón pequeño a manera de almohada que sirve para sentarse, recostarse o 
apoyar los pies en él'. 'Almohada (funda de tela para meter la almohada de la cama)' (DRAE). Término derivado de almohada, esta palabra tiene su origen en el árabe hispánico y magrebí muhádda derivado de hadd 'mejilla' (DECH, s.v. almohada).

Una calesa vieja con dos almohadones de seda fina y otro de baqueta (Robledo de la Valduerna, 1726)

Cuatro almuhadones usados (La Bañeza, 1839)

Un almoadón de tela con su guarnición de muselina (Destriana, 1843)

Otro (almohadón) igual (Destriana, 1843)

Cuatro almohadones nuevos de lienzo con guarnición de muselina (Destriana, 1843)

Probablemente, en los ejemplos recogidos aparezcan las dos acepciones que da el diccionario académico. En el primer caso, los datos tanto del material (seda fina) como la referencia a la calesa, permiten suponer que el significado del término almohadón es el de 'cojín'; mientras que en los tres ejemplos siguientes pertenecientes todos al mismo inventario es muy probable que el significado empleado sea el de 'funda', ya que aparecen en la alcoba (los dos primeros ejemplos de Destriana) o dentro de la relación introducida como ropa que contienen los dos baúles y el arca, dentro de la cual se integran otras prendas de la ropa de cama. En los tres casos se señala, además, que llevan adorno.

\section{PLUMA}

Sust. f. 'Conjunto de plumas. Un colchón de pluma' (DRAE). Del latín plūma (DECH, s.v. pluma).

Dos cabezales de terliz vuenos con su pluma (La Bañeza, 1641)

Dos cabezales de lana sin pluma (La Bañeza, 1641)

Otro cabezalito muy biexo y roto sin pluma más otra manta de lana blanca de tres piernas biexa remendada (Coomonte de la Vega, 1643)

Un cabeçalito çamorano con pluma ya biexo (Coomonte de la Vega, 1643)

Dos cabezales de terliz con sus fundas y plumas vuenos (La Bañeza, 1649)

Un cabezal de lana pintado con su pluma bueno (Coomonte de la Vega, 1650)

Un cavezal de lana viejo con pluma (Miñambres, 1727)

Como se observa en los ejemplos, el término pluma aparece acompañando al sustantivo cabezal, que es una especie de almohada, que probablemente está rellena de pluma, término usado con la acepción que aparece en el diccionario académico. Formalmente, solo se recoge el término con la variante normativa, aunque en León se documenta la forma pruma. 


\section{CABEZAL [cabeçal, cavezal, caveçal]}

Sust. m. 'Almohada' (DRAE). Término derivado de cabeza procedente de capǔtĭa, forma del latín vulgar que sustituyó a caput, -ritis (DECH, s.v. cabeza).

Dos cabezales de terliz vuenos con su pluma (La Bañeza, 1641)

Dos mantas y dos cabezales nuebos (Castrocalbón, 1643)

Un cabezal biexo de lana blanca y negra roto (Coomonte de la Vega, 1643)

Otro cabezalito muy biexo y roto sin pluma (Coomonte de la Vega, 1643)

Un cabeçalito çamorano con pluma ya viejo (Coomonte de la Vega, 1643)

Seis cabezales de pabilos (La Bañeza, 1643)

Un cabezalico pequeño biexo (Alija del Infantado, 1644)

Unos cabezales de lana buenos (Coomonte de la Vega, 1645)

Tres cabezales buenos pintados de lana blanca y negra (Alija del Infantado, 1646)

Un caveçal de blanco y negro (La Antigua, 1647)

Tres cabezales de lana pintados (Coomonte de la Vega, 1650)

Un cavezal de lana viejo con pluma (Miñambres, 1727)

Un cavezal de lana negro y blanco (Palacios de Jamuz, 1728)

Un cavezal de lana enfrontado (Destriana, 1728)

Tres cabeçales de terliz grandes (La Bañeza, 1747)

Un cabezal con su pluma (La Bañeza, 1758)

Se trata de un término muy común a lo largo de todo el corpus analizado. El significado con el que se usa el vocablo es el de 'almohada' que el DRAE señala como sinónimo del término. Este dato se pude deducir de los complementos con los que suele aparecer la palabra: "de lana", "de terliz”, es decir, siempre referidos a algún tipo de tela. Por tanto ha de tratarse de una almohada que, al parecer, se colocaba por debajo del yugo para evitar rozaduras en los animales. En diccionarios dialectales se indica que en León y en general en Castilla este término se utiliza con el significado de 'cada uno de los dos palos transversales que cruzan las partes del trillo', pero con esta acepción no se ha recogido ningún ejemplo en el corpus. Como en otras palabras, aparecen diferentes variantes formales. Es frecuente la vacilación de las grafías "b" "v" para representar el sonido fricativo bilabial así como la grafia "ç" para el sonido fricativo interdental. En varias ocasiones se usa el diminutivo en -ito, aunque hay un caso de uso del diminutivo en -ico, muy frecuente en esta zona del sur de León y norte de Zamora.

\section{COBERTOR}

Sust. m. 'Manta o cobertura de abrigo para la cama' (DRAE). Término derivado del verbo cubrir, del latín cooperire (DECH, s.v. cubrir).

Un cobertor blanco bueno (La Bañeza, 1641)

Un cobertor de lana (La Bañeza, 1641)

Tres cobertores nuebos de Palencia (La Bañeza, 1641)

Dos cobertores vlancos de Palencia (La Bañeza, 1641)

Un cobertor colorado (Castrocalbón, 1643)

Un cobertor colorado biexo (Coomonte de la Vega, 1643) 
Dos cobertores de pellexo de perro (Alija del Infantado, 1644)

Un cobertor colorado que es de blanqueta teñido bueno y doble (Alija del Infantado, 1646)

Un cobertor y una manta (La Bañeza, 1712)

Un cobertor blanco de Palencia (La Bañeza, 1721)

Un cobertor azul viejo (La Bañeza, 1721)

Un cobertor de Palencia encarnado (Genestacio de la Vega, 1721)

Un cobertor de Palencia blanco (Laguna de Negrillos, 1721)

Un cobertor azul con sus zintas (Laguna de Negrillos, 1722)

Un cobertor de tres lienzos de estameña verde con fleco (Grajal de la Ribera, 1723)

Un cobertor de estameña azul con fleco de dos lienzos (Grajal de la Ribera, 1723)

Un cobertor de paño verde biejo (Robledo de la Valduerna, 1726)

Un cobertor de Palencia (Alija del Infantado, 1734)

Un cobertor de Palenzia encarnado (Alija del Infantado, 1812)

Otro cobertor de estameña azul viejo (Alija del Infantado, 1812)

Un cobertor inglés vien maltratado (La Bañeza, 1829)

Unos cobertores para unas mollidas (Palacios de la Valduerna, 1831)

Dos cobertores de Palencia muy deteriorados (Felechares, 1837)

Dos cobertores encarnados (Requejo de la Vega, 1839)

Es un término muy generalizado en los inventarios. Lo más frecuente es el uso de la palabra con el significado de 'manta'. Cuando se utiliza el vocablo con esta acepción, se suele especificar el tipo de tela, el color, el estado y, como se refleja en los ejemplos, es frecuente que se especifique la procedencia cuando son de Palencia, puesto que todos estos datos son relevantes para el valor del objeto. No obstante, el término aparece al menos en dos ejemplos utilizado con el significado de 'cubierta de cuero que va sobre el yugo y la melena' (Le Men, 2004, s.v. cobertero). Estas cubiertas solían ser de pellejo de perro, de ahí que en el ejemplo de Alija del Infantado de 1644 y, por supuesto, en el de Palacios de la Valduerna en el que se especifica claramente "para unas mollidas", la voz tenga este significado. Esta acepción está recogida en el DRAE de forma más generalizada, ya que se habla de una cubierta o tapa, en León se concreta en una cubierta para el yugo. Sin embargo, es significativo que la voz que se utiliza con esta acepción, tal y como se recoge también en el DRAE, es la de cobertera, mientras que en los inventarios estudiados aparece la forma cobertor. Casado ha recogido en inventarios del S. XIX el término cobertor con el significado de 'ropa de abrigo que usaban las mujeres de la comarca de Omaña' (Casado, 1991: 128). En los ejemplos en los que solo se informa del tipo de tela se podría aplicar esta acepción, aunque el significado general que se aplica al término es el de 'manta'.

\section{COLCHA}

Sust. f. 'Cobertura de cama que sirve de adorno y abrigo' (DRAE). Del francés antiguo colche 'yacija, lecho', derivado de colchier 'acostar', latín collocare (DECH, s.v. colcha). 
Una colcha buena (La Bañeza, 1643)

Una colcha de lienço buena (La Bañeza, 1643)

Una colcha de damasco carmesí con flueco de seda (La Bañeza, 1643)

Una colcha (La Bañeza, 1712)

Una colcha de color (La Bañeza, 1712)

Una colcha de tierra de Toledo de diferentes colores (Laguna de Negrillos, 1721)

Una colcha blanca usada con sus colgaduras de alemanisco (Laguna de Negrillos, 1722)

Dos colchas de cotón mui biejas (Robledo de la Valduerna, 1726)

Una colcha de lienzo pintada (Laguna de Negrillos, 1734)

Una colcha de lana color azul manchega forrada con estameña azul (Laguna de Negrillos, 1734)

Una colcha (Santiago Millas, 1735)

Una colcha de olanda (La Bañeza, 1747)

Otra colcha de botonçillo (La Bañeza, 1747)

Una colcha afelpada de hilaza buena (Alija del Infantado, 1812)

Una colcha de votonillo blanca (Alija del Infantado, 1812)

Una colcha de colores portuguesa (Alija del Infantado, 1812)

Una colcha rellena de algodón con algunos avujeros (La Bañeza, 1829)

Una colcha de lana verde afelpada (Felechares, 1837)

Seis colchas de cotona (Requejo de la Vega, 1839)

Una colcha de ilo afelpada (Destriana, 1843)

Es un término muy frecuente en los inventarios. Normalmente el objeto se relaciona en las listas de enseres especificando el tipo de tela, el color, los adornos y el estado. La diferencia con respecto al cobertor es que la colcha es más de adorno que de abrigo.

\section{ENCUBRIDOR [cubridor]}

El DRAE lo define como adjetivo, aunque señala que puede usarse también como sustantivo 'que encubre'. Término derivado de cubrir, del latín cooperire (DECH, s.v.cubrir).

Un encubridor de tafetán encarnado con sus puntas de ylo (La Bañeza, 1721)

Un cubridor de almoadas de tafetán encarnado (La Bañeza, 1721)

En el corpus, los ejemplos encontrados aparecen con un uso sustantivo. No se recoge el término como tal ni en el diccionario académico, ni en vocabularios dialectales ni tampoco en el CORDE. Teniendo en cuenta las especificaciones que acompañan al término y partiendo de su raíz léxica cubrir, se puede afirmar que se trata de una voz que nombra un tipo de paño o similar cuya función es la de cubrir, probablemente adornar, puesto que está fabricado de un tejido no común, el tafetán, y además tiene adornos en sus puntas. El contexto en el que aparece en el corpus guarda relación con estas afirmaciones puesto que acompaña a toallas y a encajes, en general, ropa de casa. La base léxica es común a la de la voz cobertor, manta que cubre la cama, 
pero no se considerarían sinónimos ya que ambos términos se registran en el mismo inventario y el segundo ejemplo señala la función de cubridor de almohadas, es decir, una especie de almohadón. Por tanto se trata más bien de un término genérico que se emplea para todo aquello que tenga la función de cubrir.

\section{FUNDA}

Sust. f. 'Cubierta o bolsa de cuero, paño, lienzo u otro material con que se envuelve algo para conservarlo y resguardarlo' (DRAE). Tomado del latín tardío fünda 'bolsa' (DRAE, s.v. funda).

Dos cabezales de terliz con sus fundas y plumas vuenos (La Bañeza, 1649)

Fundas biejas de felpa (Robledo de la Valduerna, 1726)

Dos fundas con sus almuadas (La Nora del Río, 1823)

Una funda nueba de terliz (Jiménez de Jamuz, 1825)

Dos fundas de almuadas (Felechares, 1837)

Quatro fundas de almuadas (Felechares, 1837)

Una funda de lona vieja (Destriana, 1843)

Otra funda de lo mismo (Destriana, 1843)

Dos almuadas con sus fundas Destriana, 1870)

Es un término de uso general que mantiene el significado ordinario. No obstante, los ejemplos recogidos en el corpus del S. XIX aparecen con el término almohada, lo que indica que en esta época se diferencia la funda de la almohada en sí, mientras que anteriormente no es tan frecuente encontrar la diferenciación. Esta funda recibe también el nombre de almohadón, pero este término con esta acepción se recoge en muy pocos casos y dentro del mismo inventario en el que también se recoge la voz funda pero elaborada con una tela común y sin adorno.

\section{SOBRECAMA}

Sust. f. El DRAE señala el término como un sinónimo de colcha. Término compuesto de sobre, del latín süper (DECH, s.v. sobre) y cama del hispanolatino cama, de origen incierto, quizá prerromano (DECH, s.v. cama).

Una sobrecama de estameña (Alija del Infantado, 1737)

Es el único ejemplo recogido. En zonas próximas se denomina sobrecama a una 'colcha antigua de percal' (Fuente García, 2000: 530). Sin embargo no parece que este sea el significado que tiene en el ejemplo o al menos en parte, ya que el percal es una tela fina y, sin embargo, en este caso se trata de una tela de estameña que es gruesa. Tal vez se denomina sobrecama a una 'colcha' y quizá el término más utilizado sea el de 
colcha del que sí hay varios ejemplos. En el caso de esta, por tratarse más bien de un objeto de adorno, abundan telas más finas que la estameña.

\section{COLCHÓN}

Sust. m. 'Pieza cuadrilonga, rellena de lana u otro material blando o elástico, que se pone sobre la cama para dormir en ella' (DRAE). Término derivado de colcha.

Un colchón biexo con su lana (Coomonte de la Vega, 1643)

Otro colchón con su lana nuebo (Coomonte de la Vega, 1643)

Un colchón (La Bañeza, 1712)

Un colchón que era de la cama de dicho difunto que está en el corral al sopor causa de estar suzio y de la mala calidad (Laguna de Negrillos, 1722)

Diez colchones de terliz buenos (Robledo de la Valduerna, 1726)

Dos colchones usados con sábanas de estopa (Palacios de la Valduerna, 1734)

Quatro colchones nuebos (La Bañeza, 1747)

Cuatro colchones de lana y terliz (La Bañeza, 1829)

Dos colchones de terliz casero (La Bañeza, 1829)

Un colchón usado (Quintanilla de Somoza, 1831)

Un colchón de terliz usado (Requejo de la Vega, 1839)

Un colchón de terliz (Felechares, 1839)

Un colchón de terliz bastante deteriorado (Destriana, 1843)

Es una palabra muy frecuente en las relaciones de enseres domésticos. Normalmente el término aparece acompañado de la especificación "de lana" o "de terliz", que eran los materiales de los que estaban fabricados.

\section{JERGÓN [gergón]}

Sust. m. 'Colchón de paja, esparto o hierba y sin bastas' (DRAE). Término derivado de jerga, de origen incierto (DECH, s.v. jerga).

Una cama de cordeles con su jergón biejo (La Bañeza, 1641)

Un jergón de estopa nuevo (La Bañeza, 1649)

Dos jergones de estopa usados (La Bañeza, 1714)

Un jergón (La Bañeza, 1712)

Un jergón de estopa nuevo (Alija del Infantado, 1720)

Dos jergones el uno bueno y el otro usado (Laguna de Negrillos, 1721)

Tres colchones con tres jergones (Laguna de Negrillos, 1734)

Una cama con sus balaustres y jergón (Laguna de Negrillos, 1740)

Un jergón de estopa casera por estrenar (Jiménez de Jamuz, 1825)

Un gergón usado (Valle de la Valduerna, 1829)

Dos jergones o pageros de estopilla (La Bañeza, 1829)

Una tarima con su gergón (Felechares, 1837)

Dos jergones de estopa (Felechares, 1837)

Un jergón de terliz usado (Requejo de la Vega, 1839)

Un gergón usado de estopa (Destriana, 1843)

Un jergón biejo (Santibáñez de la Isla, 1844)

Es un término común cuyo significado es el de 'colchón de pajas'. Es frecuente encontrar la palabra con el adyacente "de estopa" puesto que es la tela con la que se 
fabricaba, que después se rellenaba con pajas o mazorcas de maíz. La voz aparece, prácticamente, con la misma frecuencia que colchón, la diferencia está en que uno es de lana y otro de pajas. En el ejemplo de La Bañeza de 1829, el colchón aparece inventariado bajo los términos sinónimos jergón o pajero. Este último término designa un 'colchón de paja larga de centeno esbalagada' (Le Men, 2007, s.v. pajero). En el ejemplo el término pajero puede referirse al colchón de paja en general, o a un colchón elaborado con esa paja concreta. No obstante, es el único ejemplo del término pajero.

\section{MANTA}

Sust. f. 'Prenda de lana o algodón, tupida y ordinariamente peluda, de forma rectangular, que sirve para abrigarse en la cama' (DRAE). Término derivado de manto, del latín tardío mantum 'manto corto', que a su vez es de origen incierto; parece haberse extraído del lat. mantellum, que quizá fuese voz antigua en latín (DECH, s.v. manto).

Seis mantas de sayal grandes (La Bañeza, 1641)

Una manta de lana torcida (La Bañeza, 1641)

Dos mantas y dos cabezales nuebos (Coomonte de la Vega, 1643)

Una manta de buriel blanca y negra pisada usada (Coomonte de la Vega, 1643)

Otra manta blanca de lana casera buena (Coomonte de la Vega, 1643)

Una mantica biexa y rota de xerga blanca y negra (Coomonte de la Vega, 1643)

Una manta de red de pescar sardas (Alija del Infantado, 1646)

Dos mantas buenas que andan a la cama ordinaria (Alija del Infantado, 1646)

Una manta de lana pequeña biexa (Alija del Infantado, 1647)

Una manta de saial vieja (La Bañeza, 1714)

Un cobertor y una manta (La Bañeza, 1712)

Una manta gallega vieja (La Bañeza, 1721)

Una manta de blanqueta (Fresno, 1726)

Dos mantas nuebas (Palacios de la Valduerna, 1727)

Dos mantas de paxa (Palacios de la Valduerna, 1727)

Una manta de blanqueta usada (Palacios de la Valduerna, 1728)

Una manta de frisa usada (Palacios de la Valduerna, 1728)

Dos mantas de meter paja (Palacios de la Valduerna, 1728)

Una manta de buriel usada (Destriana, 1728)

Quatro mantas de lana de Palenzia y las tres caseras (Laguna de Negrillos, 1734)

Un jergón y dos mantas la una pintada (Laguna de Negrillos, 1734)

Una manta de Palenzia (Alija del Infantado, 1734)

Una manta de buriel bieja (Requejo de la Vega, 1735)

Una manta con un remiendo (Grajal de la Ribera, 1750)

Una manta con lana negra (La Nora del Río, 1820)

Una cama con su ropa compuesta de un mantón, una manta (Destriana, 1825)

Una manta remendada (Castrillo de la Valduerna, 1828)

El lecho cutediano que se compone de tarima, jergón dos mantas y mantón (Santibáñez de la Isla, 1844)

La mantas con cuartaderos y costanas (Santibáñez de la Isla, 1844)

Es un término muy común que aparece en prácticamente todos los inventarios, ya que se trata de un objeto frecuente en la ropa de la casa. Como ocurre con otros 
objetos similares, se inventaría con la mayor precisión posible en cuanto al tipo de tela, si tenía o no dibujos, el color, el estado de la prenda, incluso la procedencia, si esta era de importancia para la calidad del objeto.

\section{ROPA}

Sust. f. 'Prenda de vestir' (DRAE). Término derivado del verbo robar, con el sentido primitivo de 'despojos, botín' y luego 'mercancías, ropa' (DECH, s.v. robar).

Un bestido de muger, ropa, jubón y basquina de tafetán doble negro guarneçido con esparragón con botones de bidrio (La Bañeza, 1643)

Una cama con su ropa (Destriana, 1825)

Una cama con su ropa compuesta de un mantón y una manta (Destriana, 1825)

El término presenta en estos ejemplos dos acepciones distintas. En el primero, probablemente nombra con este término al conjunto de prendas que va a relacionar. En los ejemplos segundo y tercero, el término ropa es conocido y corresponde a lo que designamos como ropa de cama, en un caso especifica de qué se compone mientras que en el otro simplemente identifica el mueble y el conjunto de prendas que lo visten.

\section{SÁBANA [sávana]}

Sust. f. 'Cada una de las dos piezas de lienzo, algodón u otro tejido, de tamaño suficiente para cubrir la cama y colocar el cuerpo entre ambas' (DRAE). Del latín sabăna, plural de sabănum, y este del griego sabañón 'toalla de baño', a su vez de origen semítico (DECH, s.v. sábana).

Una sábana de tres piernas con un remiendo (Coomonte de la Vega, 1643)

Una sábana de estopa biexa (Coomonte de la Vega, 1643)

Otra sábana buena de tres liencos (Coomonte de la Vega, 1643)

Una sábana buena de tres piernas de buen lienzo (Coomonte de la Vega, 1643)

Una sábana de cerrón usada (Urdiales del Páramo, 1645)

Dos sávanas de lienzo nuebas (La Bañeza, 1712)

Una sábana de tres lienzos buena (Grajal de la Ribera, 1723)

Catorze sábanas de lienzo buenas (Robledo de la Valduerna, 1726)

Doze sabanas de estopa bieja (Robledo de la Valduerna, 1726)

Quatro sábanas de lino biejas (Robledo de la Valduerna, 1726)

Una sábana de lienzo de dos piernas y un colchón (Viñas, 1726)

Una sábana de lienzo buena (Palacios de Jamuz, 1728)

Una sábana de cordelate (Toral, 1728)

Una sábana de zorrón vieja (Palacios de la Valduerna, 1728)

Una sábana de lienzo usada (Palacios de la Valduerna, 1728)

Otra sábana de lienzo buena (Laguna de Negrillos, 1734)

Dos sábanas y una colcha de gusanillo (Laguna de Negrillos, 1734)

Una sábana de estopilla casera (Jiménez de Jamuz, 1825)

Otra sábana de estopa casera (Jiménez de Jamuz, 1825)

Una sábana con sus buelos (Quintanilla de Somoza, 1831)

Once sábanas sin guarnición nuevas (Requejo de la Vega, 1839) 
Una savana vuena usada (Destriana, 1843)

Otra sávana deteriorada y rota (Destriana, 1843)

Una sábana rota (Santibáñez de la Isla, 1844)

Es una palabra muy común, que está presente en prácticamente todos los inventarios. Se utiliza con el mismo significado que tiene en la actualidad. Las sábanas, al igual que ocurre con otro tipo de ropa, se inventariaban siempre haciendo referencia al tejido del que estaban hechas, las más frecuentes eran de lienzo y de estopa.

\section{COLGADURA}

Sust. f. 'Cortinas, cenefas y cielo de la cama que sirven de abrigo y adorno de ella' (DRAE). Término derivado de colgar, del latín cŏllŏcare (DECH, s.v. colgar).

Una colcha blanca usada con sus colgaduras de alemanisco (Laguna de Negrillos, 1722)

Una colgadura de cama bratillarista (Robledo de la Valduerna, 1726)

Una colgadura de cama en jerguilla encarnada (Robledo de la Valduerna, 1726)

Una colgadura de cama acarpetada (Graj al de la Ribera, 1806)

Es un término común cuyo significado es el que da el DRAE tanto para la colgadura de cama como en el primer caso que tiene el significado general de 'adorno'.

\section{PABELLÓN}

Sust. m. 'Colgadura plegadiza que cobija y adorna una cama, un trono, un altar, etc.' (DRAE). Del fr. ant. paveillon 'tienda de campaña' que vino del lat. papillıo, -ōnis, 'mariposa'. Desde tienda se pasó a 'dosel que cubre una cama, un trono' (DECH, s.v. pabellón).

Un pabellón (La Bañeza, 1758)

Es el único ejemplo encontrado, dato que no es extraño si se tiene en cuenta que, aunque se trata de un término, que recoge el Diccionario de Autoridades y aparece en todas las ediciones del diccionario académico, en el CorLexIn, los ejemplos que se recogen en inventarios son del centro y sur de la Península, así como de América, lo que indicaría que no es un término que aparezca con frecuencia en los inventarios de esta zona.

\section{CORTINA}

Sust.f. 'Tela que por lo común cuelga de puertas y ventanas como adorno o para aislar de la luz y de miradas ajenas' (DRAE). Del latín tardío cortīna (derivado del latín cohors, -tis 'recinto') (DECH, s.v. cortina). 
Una cortina de palmilla (La Bañeza, 1721)

Seis cortinas con sus cenefas de tafetán (Robledo de la Valduerna, 1726)

Seis cortinas de bareta encarnada biejas con sus cenefas (Robledo de la Valduerna, 1726)

Quatro cortinas de jerguilla (Robledo de la Valduerna, 1726)

Dos cortinas azules con sus barillas de ierro (Laguna de Negrillos, 1734)

Nuebe cortinas de bareta verde (La Bañeza, 1754)

Unas cortinas con sus varillas (La Nora del Río, 1823)

Quatro cortinas con dos varillas (La Nora del Río, 1823)

Tres cortinas viejas de algodón (La Bañeza, 1829)

Una cortina de lana usada (La Bañeza, 1829)

Dos cortinas de algodón con sus varillas (La Bañeza, 1829)

Cuatro cortinas de esparragón de lana encarnadas viejas (La Bañeza, 1829)

Unas cortinas de percal encarnado (Castrocalbón, 1833)

Quatro cortinas viejas con sus guardapolvos y sus varillas (Felechares, 1837)

Cuatro cortinas de morsolina con listas encarnadas (Requejo de la Vega, 1839)

Cuatro cortinas de algodón con pintas y sus dos barillas (Requejo de la Vega, 1839)

Dos cortinas de algodón con flores y barilla azul (Requejo de la Vega, 1839)

Cuatro cortinas de algodón oscuro de buen uso (Requejo de la Vega, 1839)

Dos cortinas para el balcón (Requejo de la Vega, 1839)

Unas cortinas de lienzo pintadas usadas con sus varillas de yerro (Destriana, 1843)

Es un término común que se usa con el significado que tiene en la actualidad.

La mayoría de los ejemplos que aparecen en el corpus indican el tipo de tela del que está hecha la cortina que, probablemente sea un dato que repercuta en el valor económico de la prenda. Las más comunes eran las de algodón.

\section{GUARDAPOLVOS}

Sust. m. 'Protección de tela, tablas u otra materia, que se pone encima de algo para preservarlo del polvo' (DRAE). Término compuesto de guardar, del germánico wardôn y polvo del latín vulgar *pŭlvus, clásico pulvis, pulvěris (DECH, s.v. guardar y polvo)

Quatro cortinas viejas con sus guardapolvos y sus varillas (Felechares, 1837)

Es el único ejemplo encontrado, quizá porque se trata de una prenda cuyo uso se generalizó a partir del S. XIX y, por tanto, en fechas anteriores no era de uso común. Este dato coincide con los ejemplos que aparecen en el CORDE que, a excepción de dos casos aislados, todos pertenecen a los SS. XIX y XX.

\section{AZUFRADOR}

Sust. m. El DRAE define el término como 'enjugador'. Se trata de una voz derivada de azufre, del lat. sŭlphŭr (DECH, s.v. azufre).

Dos azufradores (La Bañeza, 1721)

Dos azufradores (Alija del Infantado, 1737)

Un azufrador (La Bañeza, 1743) 
El DRAE define esta palabra como sinónimo de 'enjugador', aunque a partir de la edición de 1884 incluye como $2^{a}$ acepción el dato de que se llama así porque se utiliza para sahumar la ropa y ponerla más blanca. No obstante, la Academia incluye otra acepción, que podría ser también aplicable a los ejemplos extraídos de los documentos analizados 'instrumento para azufrar las vides', sin embargo el significado con el que se utiliza en el corpus analizado es el señalado en primer lugar. Esta afirmación se puede concluir teniendo en cuenta la relación de enseres que se citan junto al término en cuestión, así se refieren objetos como enaguas, zagalejos, manteos; es decir, nombres de ropa, por lo que parece más lógico suponer que el significado sea el de 'objeto que se emplea para calentar la ropa' y no 'para azufrar las vides'. Además, como dato significativo, hay que señalar que en el CORDE, donde también aparecen muy pocos casos, en concreto tres fechados en el S. XVII, se utiliza con el significado de 'azufrador'.

\section{CERNADERO [zernadero]}

Sust. m. 'Lienzo grueso que se ponía en el cesto o coladero sobre toda la ropa, para que, echando sobre él la lejía, pasase a la ropa solo el agua con las sales que llevaba en disolución deteniéndose en él la cernada' (DRAE). Término derivado de cernada, y este a su vez de *cen(e)rada, derivado del lat. cinis, -ěris 'ceniza' (DECH, s.v. cernada).

\section{Un cernadero pequeño viexo (Coomonte de la Vega, 1643)}

Un cernadero de bara y media bueno (Coomonte de la Vega, 1650)

Dos zernaderos nuebos (La Bañeza, 1721)

Dos tablas de manteles usados y un zernadero de estopa (Laguna de Negrillos, 1734)

Dos zernaderos nuebos (Alija del Infantado, 1737)

Un zernadero de estopa (Saludes de Castroponce, 1808)

Una camastra bieja y un zernadero (Castrocalbón, 1814)

Los casos recogidos se sitúan todos en una zona próxima al sur del territorio comprendido por este Partido Judicial. Probablemente, se trate de una casualidad ya que nos encontramos ante un término que se usa en toda la provincia. El número de casos encontrados, aunque no son muchos, son significativos con respecto a los que aparecen en el CORDE ya que solo se recogen nueve ejemplos. En cuanto al significado con el que se utiliza, en algunos diccionarios leoneses se registran otras acepciones que no aparecen recogidas en el DRAE, algunas, como 'comprador de ceniza' se descartarían como significados utilizados en el corpus estudiado, ya que los complementos "de bara y media" o "de estopa" hacen suponer que se trata de un tipo de paño. Otras, sí podrían ser utilizadas en este corpus, por ejemplo 'paño para tapar el cesto de la comida campestre' (Le Men, 2000, s.v. cernadero). Sin embargo, de los datos que podemos 
extraer del texto original, no podemos determinar con qué significado se está utilizando el término, aunque parece ser que el significado más común es el que aparece en el DRAE en su $1^{a}$ acepción. Formalmente, el término se escribe con vacilación de la grafía que representa la consonante fricativa interdental, vacilación común en esta época.

\section{MANTEL}

Sust. 'Cubierta de lino, algodón u otra materia que se pone en la mesa para comer' (DRAE). Del latín mantēle 'toalla' (DECH, s.v. mantel).

Dos mesas de manteles (Castrocalbón, 1643)

Una mesa de manteles de gusanillo biexos y rotos (Coomonte de la Vega, 1643)

Una tabla de manteles de gusanillo de dos piernas de siete cuartas de largo (Coomonte de la Vega, 1643)

Unos medios manteles de alimanisco biexos (Alija del Infantado, 1644)

Unos manteles de lino buenos (Alija del Infantado, 1644)

Unos manteles de alimanisco (Coomonte de la Vega, 1645)

Otros manteles angostos de lo mismo (Coomonte de la Vega, 1645)

Unos manteles de torzillos usados (Coomonte de la Vega, 1645)

Unos manteles de cerrón usados (Vidriales, 1645)

Unos manteles de gusanillo de cosa de dos baras de largo buenos (Alija del Infantado, 1646)

Una tavla de manteles reales de figuras nuevas vuenas (La Bañeza, 1649)

Una tabla de manteles de gusanillo de tres varas de largo y dos lienzos (La Bañeza, 1714)

Unos manteles de alemanisco (Genestacio de la Vega, 1721)

Unos manteles con dos aujeros (Genestacio de la Vega, 1721)

Un vufete de nogal vueno con su caxón y en él unos manteles de torzal (Laguna de Negrillos, 1722)

Una tabla de manteles de gusanillo (Robledo de la Valduerna, 1726)

Unos manteles de alemanisco (Palacios de la Valduerna, 1727)

Unos manteles de tres baras de lienzo (Palacios de la Valduerna, 1728)

Unos manteles largos (Miñambres, 1731)

Unos mantelicos pequeños (Miñambres, 1731)

Tres tablas de manteles buenos y una docena de servilletas (Laguna de Negrillos, 1734)

Unos manteles de gusanillo (Genestacio de la Vega, 1738)

Una tabla de manteles vuena (Alija del Infantado, 1812)

Unos manteles de alemanisco (Castrillo de la Valduerna, 1828)

Un paño de manos que hace a mantel (Quintanilla de Somoza, 1831)

Una mesa de manteles finos (Quintanilla de Somoza, 1831)

Una mesa de manteles con sus listas a las puntas (Quintanilla de Somoza, 1831)

Una mesa de manteles de dos varas y un paño blanco con encajes (San Feliz, 1838)

Un mantel usado (Requejo de la Vega, 1839)

Una tabla de manteles grandes y finos de gusanillo muy usados (Destriana, 1843)

Es un término muy frecuente en los inventarios. La palabra aparece a menudo junto al término tabla o al término mesa formando así un compuesto. El término tabla designa una 'pieza ancha y plana', que unida a la voz mantel designa lo que hoy conocemos por mantel y el término aislado que se documenta desde el S. X como 
sinónimo de toalla, probablemente tenga el significado de 'paño' en general (Castañeda Ordóñez, 2003: 212). Teniendo en cuenta que la voz mesa es definida por Terreros como 'tabla en que se come' (Terreros, s.v. mesa), probablemente en el compuesto mesa de manteles tenga el significado de 'mantel'. No aparece en ningún caso el término mantelería como conjunto de mantel y servilletas, en ese caso encontramos el compuesto de tabla de manteles más las servilletas, dato que no resulta extraño al compararlo con corpus como el CORDE donde no aparecen muchos casos y se sitúan más bien en los siglos XIX y XX. Además es frecuente que en los inventarios se haga referencia al tejido con el que está hecho, abundan los de alemanisco, cuyo origen se sitúa en Alemania; o gusanillo.

\section{RODAPISA}

Un manteo de paño nuevo con rodapisa encarnada (Castrocalbón, 1814)

Cuatro rodapisas vlancas regulares (La Bañeza, 1829)

Un catre de chopo con rodapisa blanca (Requejo de la Vega, 1839)

Un catre biejo con rodapisa (Requejo de la Vega, 1839)

Un catre con su rodapisa blanca (Requejo de la Vega, 1839)

Una rodapisa vieja (Requejo de la Vega, 1839)

El término rodapisa aparece en el corpus únicamente en inventarios del S. XIX $\mathrm{y}$, a pesar de ser una fecha tardía, es un término que no aparece recogido ni en los diccionarios académicos ni en los dialectales, por tanto es difícil saber con exactitud cuál es su significado. Atendiendo a los ejemplos en los que se recoge la voz rodapisa, se observa que en tres de ellos aparece junto al término catre, pero además se hace una referencia al color de la rodapisa que es en todos los casos blanca. Estos datos unidos a que aparece junto a otros objetos como son sábanas, manteles o servilletas; permiten suponer que el término nombra un tipo de ropa de hogar que podría ser una especie de colcha o similar.

\section{SERVILLETA [serbilleta]}

Sust. f. 'Pieza de tela o papel que usa cada comensal para limpiarse los labios y las manos' (DRAE). Probablemente tomado del francés serviette (DECH, s.v. siervo).

Seis serbilletas buenas (Alija del Infantado, 1644)

Cuatro baras y media de servilletas nuebas de tres cuartas de ancho (Coomonte de la Vega, 1645)

Quatro servilletas de gusanillo pequeñas buenas (Alija del Infantado, 1646)

Seis servilletas de gusanillo nuebas (La Bañeza, 1647)

Seis servilletas de gusanillo nuevas (La Bañeza, 1649)

Seys servilletas (Coomonte de la Vega, 1719) 
Dos serbilletas (Alija el Infantado, 1720)

Quatro docenas de servilletas de gusanillo buenas (Robledo de la Valduerna, 1726)

Beinte y dos servilletas de alemanisco (Robledo de la Valduerna, 1726)

Tres dozenas de servilletas usadas (Robledo de la Valduerna, 1726)

Una serbilleta de alemanisco (Miñambres, 1727)

Una serbilleta (Palacios de la Valduerna, 1727)

Dos serbilleta (Palacios de la Valduerna, 1727)

Tres tablas de manteles buenos y una docena de servilletas (Laguna de Negrillos, 1734)

Trece servilletas en pieza (Alija del Infantado, 1812)

Una canasta y servilleta (La Nora del Río, 1820)

Una servilleta nueba (Jiménez de Jamuz, 1825)

Una servilleta bieja (Destriana, 1825)

Una serbilleta nueba (Alija del Infantado, 1827)

Veinte servilletas gordas y muy usadas (La Bañeza, 1829)

Una servilleta con listas encarnadas y un pañuelo encarnado todo biexo (Quintanilla de Somoza, 1831)

Cinco servilletas (Requejo de la Vega, 1839)

Una serbilleta y un paño de manos (Santibáñez de la Isla, 1844)

Es un término muy común que se usa con el significado que tiene la palabra en la actualidad. Como en otros términos, es frecuente que la palabra se relacione haciendo referencia o bien a su estado, o bien al tipo de tela o ambas cosas.

\section{SOBREMESA}

Sust. f. 'Tapete que se pone a la mesa por adorno, limpieza o comodidad' (DRAE). Término compuesto de de sobre, del latín süper (DECH, s.v. sobre) y mesa del latín mensa (DECH, s.v. mesa).

Una sobremesa de de terçiopelo de colores (La Bañeza, 1643)

Una sobremesa de damasco vieja (Robledo de la Valduerna, 1726)

Son los únicos ejemplos recogidos. Probablemente y, en relación con lo que ocurre con el término sobrecama, la palabra sobremesa sea sinónima de mantel. El mantel solía aparecer en los inventarios junto a los términos mesa y tabla para designar lo que hoy conocemos como mantel y aparece en ocasiones solo para designar un paño en general. Por tanto, probablemente sea un sinónimo de sobremesa en todas sus utilidades y además un término más utilizado que este.

\section{TOALLA [tualla]}

Sust. f. 'Pieza de felpa, algodón u otro material, por lo general rectangular, para secarse el cuerpo' (DRAE). Del germánico thwahljō, compuesto el alemán antiguo dwahila, alemán dialectal zwehle, anglosajón twehlce. La forma antigua y castiza en castellano fue toaja, la moderna hubo de tomarse del italiano o del catalán (DECH, s.v. toalla). 
Una toalla de lienço nueba labrada (La Bañeza, 1641)

Otra tualla de lienzo nueba (La Bañeza, 1641)

Una toalla labrada de caparrosa y zilestre (Alija del Infantado, 1646)

Otras dos toallas de caparrosaizilestre de cosa de bara y media de largo cada una que la una dellas tiene puntas de lo mismo todo alrededor y la otra tiene unos desylados que anbas son buenas (Alija del Infantado, 1646)

Una tualla de lienço delgado con su cadeneta y cuatro cuadros (La Bañeza, 1649)

Una tualla con sus puntas (Alija del Infantado, 1720)

Una tualla de lienzo con sus puntas vuena (Huerga de Garaballes, 1720)

Tuallas de tela con sus puntas antiguas (La Bañeza, 1721)

Otra tualla de lienzo con sus puntas (La Bañeza, 1721)

Una toalla con sus encajes (Fresno, 1726)

Una toalla labrada con caparrosa vuena (Miñambres, 1729)

Una toalla de tela con sus encaxes (Requejo de la Vega, 1735)

Una toalla y un paño de manos (Priaranza, 1732)

Es una palabra de uso común. Semánticamente es un término que tenía un significado polisémico ya que como señala el diccionario académico en sus distintas ediciones, toalla era el 'lienzo que se utilizaba para secarse la cara y las manos'; pero también era una 'cubierta que se tendía sobre la almohada para mayor decencia'. Es decir, venía a ser una especie de almohadón. Formalmente, alternan las variantes toalla y tualla, incluso en ocasiones dentro del mismo inventario, como ocurre con los dos primeros ejemplos. Es una alternancia común en la historia del romance convertir hiatos en diptongos y concretamente en el caso de toalla es muy frecuente esta solución en la documentación leonesa (Morala y Egido, 2010: 428).

\subsubsection{Ornamentación}

\section{ALFOMBRA [alonbra]}

Sust. f. 'Tejido de lana o de otras materias, y de varios dibujos y colores, con que se cubre el piso de las habitaciones y escaleras para abrigo y adorno' (DRAE). Del árabe húmra, íd. (DECH, s.v. alfombra).

Una alonbra (La Bañeza, 1643)

Es el único ejemplo recogido, aparece bajo la forma en desuso alonbra que sí es frecuente en este siglo, como se demuestra en los varios ejemplos del CorLexIn donde todos los casos que presentan esta variante son de este siglo. En este corpus no se recogen más ejemplos, tal vez porque se trata de un objeto que en esta época no era habitual que decorara las casas, tal vez por su valor económico. 


\section{BASTIDOR [vastidor]}

Sust. m. 'Armazón de listones o maderos, sobre la cual se extiende y fija un lienzo o papel pintados' (DRAE). Término derivado de bastir, del oc. bastir y este del germ.

*bastjan 'tejer, trenzar' (DECH, s.v. bastir).

Otro quadro de Ntra. Sra. del Populo y otro Sr. de Sanpedro con su bastidor (La Bañeza, 1649)

Dos cuadros de los reyes de la Casa de Austria con sus vastidores (La Bañeza, 1649)

Un quadro en bastidor de Ntra Sra del Carmen (La Bañeza, 1721)

Dos cuadros de dos retratos de sus suegros con sus vastidores (La Bañeza, 1747)

Es una palabra común en nuestra lengua, aunque no son muchos los ejemplos encontrados y tres de ellos pertenecen al mismo inventario.

\section{CUADRO [quadro]}

Sust. m. 'Lienzo, lámina, etc., de pintura' (DRAE). Del latín quadrum (DECH, s.v. cuadro).

Un quadro de la Madalena con su marco (La Bañeza, 1641)

Otro quadro de la Conçeçión (La Bañeza, 1641)

Un quadro de la Anunciación (La Bañeza, 1643)

Un quadro de San Antonio (La Bañeza, 1643)

Un quadro pequeño del descendimiento (La Bañeza, 1643)

Dos cuadros de los reyes de la Casa de Austria con sus vastidores (La Bañeza, 1649)

Otro quadro de Ntra. Sra. del Populo y otro Sr. de Sanpedro con su bastidor (La

Bañeza, 1649)

Un quadro con su marco con la pintura de un Santo Cristo (La Bañeza, 1721)

Un quadro con la pintura de Jesús Nazareno (La Bañeza, 1721)

Un quadro en bastidor de Ntra Sra del Carmen (La Bañeza, 1721)

Tres quadros de la calle de Santiago viejos (La Bañeza, 1721)

Un quadro viejo y una lámina (Genestacio de la Vega, 1721)

Zinco cuadros de la calle de Santiago (Laguna de Negrillos, 1722)

Un cuadro de Santiago, pintura hordinaria (Laguna de Negrillos, 1725)

Diez quadros de diferentes ymágenes, pintura de Valencia con marcos cortados (Robledo de la Valduerna, 1726)

Dos quadros el uno con la pintura de S. José y el marco dorado y el otro con la de San Bizente y el marco viejo (Robledo de la Valduerna, 1726)

Otro (quadro) de Nuestra Señora de Belén, pintura ordinaria (Robledo de la Valduerna, 1726)

Seis cuadros y dos láminas (Laguna de Negrillos, 1734)

Un cuadro de Nuestra Señora con el niño durmido (La Bañeza, 1747)

Dos cuadros de dos retratos de sus suegros con sus vastidores (La Bañeza, 1747)

Dos cuadros de los reyes de la Casa de Austria con sus vastidores (La Bañeza, 1747)

Dos quadros de balenzia medianos con el marco dorado (La Bañeza, 1758)

Otros quadros pequeños de la misma fábrica (La Bañeza, 1758)

Otro quadro de la echura de un crucifijo sin marco grande (La Bañeza, 1758)

Otro (cuadro) de la echura de Ntro padre de san Francisco con su marco (La Bañeza, 1758)

Otro (cuadro) con la pintura de ntra sra de la Conzepzión (La Bañeza, 1758)

Un cuadro de Concepción con marco dorado (La Bañeza, 1829)

Dos cuadros de nogal con imágenes (Requejo de la Vega, 1839)

Cuatro cuadros de chopo con clavos romanos (Requejo de la Vega, 1839)

Un cuadro marco dorado con el busto de Nuestro Obispo (Destriana, 1843) 
Es un término que aparece con mucha frecuencia en el corpus. Exceptuando los casos en los que la voz tiene el significado de 'cuadrado', cuando aparece en los contextos señalados en estos ejemplos el significado es el de 'representación de una imagen, que puede ser pintura o dibujo'. Podría considerarse que el término cuadro incluye el marco frente a la voz lámina, aunque en el caso de este término hay un ejemplo en el que se cita la presencia del marco, pero quizá este dato se generaliza en el caso de la voz cuadro donde las referencias al marco se hacen más bien para especificar el tipo y por tanto el valor del mismo. Formalmente, la Academia incluye en su diccionario la variante quadro hasta 1803 , lo que podría explicar que hasta el S. XIX alternen las dos formas.

\section{LÁMINA}

Sust. f. El DRAE define el término en la $3^{\text {a }}$ acepción como 'figura trasladada al papel u otra materia' y en la $5^{\text {a }}$ acepción como 'pintura hecha en cobre'. Tomado del latín lamĭna 'hoja o plancha de metal' (DECH, s.v. lámina).

Una pieza de cristal con sus estremos de oro y dos láminas de Nuestro Salvador y María (La Bañeza, 1649)

Un quadro viejo y una lámina (Genestacio de la Vega, 1721)

Dos láminas pequeñas (Laguna de Negrillos, 1722)

Una lámina de Nuestra Señora de las Angustias con marquito de ébano (Robledo de la Valduerna, 1726)

Seis cuadros y dos láminas (Laguna de Negrillos, 1734)

Otros dos quadros pequeños y tres láminas (Laguna de Negrillos, 1734)

Zinco láminas con sus marcos (La Bañeza, 1758)

Una lámina y unos espexos (Quintanilla de Somoza, 1831)

Cuatro láminas con marco negro con sus cristales que contiene la Historia del hijo pródigo (Destriana, 1843)

Se trata de un término polisémico que en estos casos, según se puede deducir por el contexto, el significado es más bien el de 'pintura trasladada al papel'.

\section{MARCO}

Sust. m. 'Pieza que rodea, ciñe o guarnece algunas cosas, y aquella donde se encaja una puerta, ventana, pintura, etc.' (DRAE). Término derivado de marcar, de origen germánico; probablemente del it. marcare (DECH, s.v. marcar).

Una pintura de Nuestra Señora de media bara con marco dorado (La Bañeza, 1643)

Un espexo con marco dorado (La Bañeza, 1643)

Un quadro de la Madalena con su marco (La Bañeza, 1643)

Una Verónica con su marco dorado (La Bañeza, 1643)

Otro quadro de San Nicolás con su marco vueno (Laguna de Negrillos, 1722) 
Diez quadros de diferentes ymágenes pintura de Valencia con marcos cortados (Robledo de la Valduerna, 1726)

Un quadro de San Antonio con su marco (Robledo de la Valduerna, 1726)

Una lámina de Nuestra Señora de las Angustias con marquito de ébano (Robledo de la Valduerna, 1726)

La pintura del nacimiento de San Juan pequeño con marco negro y el filete dorado (Robledo de la Valduerna, 1726)

Dos quadros el uno con la pintura de San José y marco dorado y el otro con la de San

Bizente y el marco viejo (Robledo de la Valduerna, 1726)

Otro quadro de San Antonio con su marco negro grande (Laguna de Negrillos, 1734)

Dos estampas de papel con sus marcos (La Bañeza, 1743)

Zinco láminas con sus marcos (La Bañeza, 1758)

Un espejo con su marco mediano (La Bañeza, 1758)

Un marco de una ventana de yerro (Palacio de la Valduerna, 1831)

Es una palabra común. La acepción que aparece con más frecuencia en los ejemplos es la de 'marco de una pintura o cuadro', y como es habitual en las relaciones de inventarios, se suele indicar el material del marco, porque en él está también el valor del cuadro. El último ejemplo se refiere a la pieza en la que se encaja la ventana.

\section{PINTURA}

Sust. f. 'Tabla, lámina o lienzo en que está pintado algo'. 'Color preparado para pintar' (DRAE). Término derivado de pintar, del latín vulgar *pünctare, derivado de *pinctus, participio vulgar del latín p̆ngĕre (DECH, s.v. pintar).

Una pintura de Nuestro Señor con la cruz a questas (La Bañeza, 1643)

Una pintura de Nuestra Señora de media bara con marco dorado (La Bañeza, 1643)

Otro quadro pintura de San Pedro (Laguna de Negrillos, 1722)

Un cuadro de Santiago pintura hordinaria (Laguna de Negrillos, 1725)

Diez quadros de diferentes ymágenes, pintura de Valencia con marcos cortados (Robledo de la Valduerna, 1726)

La pintura del nacimiento de San Juan pequeña con marco negro y el filete dorado (Robledo de la Valduerna, 1726)

Dos quadros el uno con la pintura de San José y marco dorado, el otro con la de San Bizente y el marco viejo (Robledo de la Valduerna, 1726)

Otro de Nuestra Señora de Belén pintura ordinaria (Robledo de la Valduerna, 1726)

Un lienzo con la pintura de Nuestra Señora de la Soledad (Robledo de la Valduerna, 1726)

Dos sillas con pintura azul medianas (La Bañeza, 1829)

Es un término común cuyo significado general en el corpus es de 'lienzo' que está presente en todos los ejemplos a excepción del último donde tiene el significado de 'color'. En el corpus se documenta también la voz cuadro con un significado próximo, aunque quizá cuando se utiliza el término pintura se refiera no tanto al conjunto, al cuadro en sí, sino al lienzo. 
TAPIZ

Sust. m. 'Paño grande, tejido con lana o seda, y algunas veces con oro y plata, en el que se copian cuadros y sirve de paramento' (DRAE). Del francés tapiz, propiamente 'tapete', 'alfombra', y este del griego bizantino tapíti, diminutivo del griego tápes, -ētos (DECH, s.v. tapiz).

Quatro tapices muy viejos (La Bañeza, 1643)

Quatro tapizes viejos (Robledo de la Valduerna, 1726)

Es un término poco frecuente en los inventarios estudiados. Se trata de un objeto de valor que no abundaba entre los enseres de las personas $\mathrm{y}$, por tanto, aparece en pocos inventarios. Es más frecuente encontrar la voz repostero, probablemente porque como objeto de decoración el más común era aquel que contenía motivos heráldicos.

\section{REPOSTERO}

Sust. m. 'Paño cuadrado o rectangular, con emblemas heráldicos' (DRAE). Del latín *repositarius (DECH, s.v. poner).

Un repostero de lana con listas negras usado (Coomonte de la Vega, 1645)

Un repostero de toscos (Vidriales, 1645)

Un repostero de pavilos biexo pequeño (Alija del Infantado, 1647)

Un respostero de listas coloradas (La Antigua, 1648)

Un respostero usado (La Antigua, 1648)

Cuatro resposteros de lana de colores (La Bañeza, 1649)

Un repostero de lana pintado bueno (Coomonte de la Vega, 1650)

Un repostero biexo de lana pintado (Coomonte de la Vega, 1650)

Un respostero de lana nuevo (Coomonte de la Vega, 1719)

Un respostero de lana torzida (Alija del Infantado, 1720)

Un repostero de pavilos usado (Fresno, 1726)

Un respostero doble viejo (Laguna de Negrillos, 1722)

Un respostero de pabilos viejo (Palacios de la Valduerna, 1728)

Un respostero de lana (Palacios de la Valduerna, 1728)

Un respostero (Requejo de la Vega, 1735)

Un respostero vueno (Quintana del Marco, 1820)

Un repostero nuebo (Alija del Infantado, 1827)

Un repostero (Felechares, 1837)

Es una voz común que se utiliza para nombrar un objeto de valor que se empleaba como una especie de tapiz para decorar. En diccionarios de la zona se denomina repostero a un 'paño o manta burda tejida con retales de tejido grueso de estopas o estopillas de lino y forma cuadrada o rectangular, que sirve de soporte de cereales o legumbres en la era o en el suelo, mientras se limpian antes de recogerlos en sacos y quilmas' (Rivas, 1996: 202). Probablemente, este sea un uso posterior que se les daba una vez que se habían estropeado. El término aparece en el corpus junto a 
referencias sobre el tipo de tela del que estaba hecho, si tenía o no alguna raya etc, de otro color y sobre su estado, datos que contribuían en el valor del mismo.

\subsubsection{Iluminación}

\section{BUJíA [buxía]}

Sust. f. 'Vela de cera blanca'. 'Candelero en que se pone' (DRAE). Término procedente del ár. vulg. buğîa, ár.clás. buğâya, nombre de la ciudad africana de Bujía, de donde se traía la cera (DECH, s.v. bujía).

Tres candeleros los dos de buxías y el otro alto (La Bañeza, 1649)

Una bujía de alquimia (Destriana, 1730)

El vocablo parece referirse tanto a la vela como al conjunto de pie y vela. Así en el primer caso se referiría a la vela, y en el segundo al conjunto, es decir, al candelero, de ahí que especifique "de alquimia". En otros corpus, esta voz tiene también poco uso, así en el CORDE solo aparecen dos casos bajo la forma bujía y tres con la variante buxía, que como en el corpus estudiado datan del S. XVII. La Academia no recoge el término en su diccionario hasta la edición de 1839.

\section{CANDELERO}

Sust. m. 'Utensilio que sirve para mantener derecha la vela o candela, y consiste en un cilindro hueco unido a un pie por una barreta o columnilla' (DRAE). Término derivado de candela, del lat. candēla 'vela de luz', derivado de candēre 'arder' (DECH, s.v. candela).

Dos candeleros de azófar buenos (Coomonte de la Vega, 1645)

Tres candeleros de azófar (Alija del Infantado, 1647)

Tres candeleros los dos de buxías y el otro alto (La Bañeza, 1649)

Un candelero de azófar pequeño (Coomonte de la Vega, 1650)

Un candelero de alquima bueno (Laguna de Negrillos, 1722)

Dos candeleros de alquima (Robledo de la Valduerna, 1726)

Tres candeleros de latón (La Bañeza, 1758)

Un candelero y una palmatoria (La Bañeza, 1829)

Dos candeleros de metal (Felechares, 1837)

Se trata de un objeto de metal, cuya referencia al material se hace con distintos términos: alquimia, azófar o simplemente metal.

\section{CANDIL}

Sust. m. 'Utensilio para alumbrar dotado de un recipiente de aceite y torcida y una varilla con gancho para colgarlo' (DRAE). Término procedente del ar. qandîl, 'lámpara' 
del lat. candèla 'vela' (DECH, s.v. vela).

Un candil con su grisuelo bueno (Alija del Infantado, 1647)

Un candil (Alija del Infantado, 1720)

Tres candiles de yerro (La Bañeza, 1721)

Un candil con su crisuelo (Laguna de Negrillos, 1722)

Un candil de yerro con su grisuelo (Laguna de Negrillos, 1722)

Un candil de hierro (La Nora del Río, 1724)

Un candil (Fresno, 1726)

Un candil bueno (Palacios de la Valduerna, 1728)

Dos candiles (Grajal de la Ribera, 1730)

Dos candiles con sus crisuelos (Laguna de Negrillos, 1734)

Dos jarros y un candil (Castrocalbón, 1814)

Un candil de hierro (Castrillo de la Valduerna, 1828)

Seis candiles de yerro (La Bañeza, 1829)

Un candil de cobre (Destriana, 1843)

Se trata de un objeto que suele ser de hierro. En algunos casos se hace referencia no solo al candil, sino también al crisuelo, que en el corpus siempre aparece en masculino, pero que nombra a lo que en el DRAE aparece como crisuela 'bandeja que lleva el candil a donde cae el aceite'. Como en otros casos, es frecuente que se documente el objeto haciendo referencia a los elementos que lo forman.

\section{CORNUCOPIA [cornicopia]}

Sust. f. El DRAE defie el término en su $2^{\text {a }}$ acepción como 'espejo de marco tallado y dorado, que suele tener en la parte inferior uno o más brazos para poner bujías cuya luz reverbere en el mismo espejo'.

Cuatro cornicopias (La Bañeza, 1829)

Solo se ha recogido este ejemplo. Se trata de un objeto de decoración recargado y fastuoso, por lo que no es muy común encontrarlo en este tipo de inventarios. Como en el caso de otros objetos que entrañan cierto valor o categoría, el único ejemplo es de La Bañeza, cabeza del Partido Judicial.

\section{FAROL}

Sust. m. 'Caja de vidrio u otra materia transparente, dentro de la cual se pone una luz' (DRAE). Término derivado de faro, lat. pharus, tomado del griego pháros (DECH, s.v. faro).

Un farol pequeño (La Nora del Río, 1823)

Un farol grande (La Nora del Río, 1823)

Dos faroles de yluminaciones (Requejo de la Vega, 1839)

En León se registran además otras acepciones del término que no recoge el DRAE. Así tiene el significado de 'diente de león' o de 'planta que da una semilla aérea 
llamada vilano' (Le Men, 2005, s.v. farol). Sin embargo, de acuerdo con la especificación del primer ejemplo y, teniendo en cuenta que estamos ante relaciones de bienes, es lógico pensar que el término aparezca en el corpus con el significado de 'candil'.

\section{LÁMPARA}

Sust. f. 'Utensilio o aparato que, colgado o sostenido sobre un pie, sirve de soporte a una o varias luces artificiales' (DRAE). Del latín lampăda, acusativo de lampas, -adis, propte. 'antorcha'; a su vez tomado del griego lampás derivado de lámpō 'yo resplandezco' (DECH, s.v. lámpara).

Una lámpara de latón pequeña con su baso (La Bañeza, 1721)

Es el único ejemplo recogido en el corpus. No presenta ninguna particularidad ni semántica ni formal.

\section{LINTERNA}

Sust. f. 'Farol portátil con una sola cara de vidrio y un asa en la opuesta'. 'Aparato eléctrico portátil con pila y bombilla, para proyectar luz' (DRAE). Tomado del latín lantěrna, con /-i-/ por influjo de interna (por estar la luz, en las linternas, encerrada) (DECH, s.v. linterna).

Una linterna pequeña (La Bañeza, 1721)

Una linterna de oxa de lata (Grajal de la Ribera, 1723)

Dos linternas (La Bañeza, 1754)

Una pelleja, un cerandón y linterna (La Nora del Río, 1820)

Una linterna de ojalata (La Nora del Río, 1823)

Dos candiles, una linterna y dos cuchillos (Valle de la Valduerna, 1829)

Una linterna sin cristal (Destriana, 1843)

Es un término común que tiene el significado que mantiene hoy en día de 'lámpara portátil'.

\section{PALMATORIA}

Sust. f. 'Especie de candelero bajo, con mango y pie, generalmente de forma de platillo' (DRAE). Derivado de palma, del latín palma. La acepción 'especie de candelero no se explica claramente, quizá por el mango largo de las antiguas palmatorias de altar, comparado con el de la palmatoria de castigo, derivado regresivo palmeta' (DECH, s.v. palma).

Tres candeleros y una palmatoria (Laguna de Negrillos, 1734)

Un cribo y una palmatoria (Castrocalbón, 1814) 
Una palmatoria (La Nora del Río, 1823)

Un candelero y una palmatoria (La Bañeza, 1829)

Se trata de un término que el DRAE recoge en su diccionario a partir de la edición de 1737, dato que explicaría que en el corpus no se recojan ejemplos anteriores a aproximadamente estas fechas. Corominas y Pascual lo recogen documentado en el S. XIV en refranes aragoneses pero con el significado de 'azote para castigar empleado en las escuelas'. El significado que se le da en el corpus es el de 'especie de candelero', aunque con características propias que le distinguen de otro tipo de candeleros, entre ellas, según señala el Diccionario de Autoridades era muy manual para alumbrar.

\section{VELADOR [belador]}

Sust. m. 'Candelero, regularmente de madera' (DRAE). Derivado de velar, del latín v̌ğlătare (DECH, s.v. velar).

Un belador (Palacios de la Valduerna, 1728)

Es el único ejemplo recogido en el corpus. El diccionario académico incorpora a partir de la edición de 1817 la acepción de 'mesita en que se coloca la luz para alumbrarse las personas que trabajan de noche'. Resulta difícil saber cuál es la acepción empleada en el corpus ya que solo hay un ejemplo que además no presenta ningún tipo de caracterización y aparece en la relación junto a objetos diversos, como pueden ser muebles: cama, banco; pero también un candil o una masera. Por tanto, cualquiera de las dos acepciones podría ser válida.

\section{VELÓN [belón]}

Sust. f. 'Lámpara de metal, para aceite común, compuesta de un vaso con uno o varios picos o mecheros, y de un eje, en que puede girar, subir y bajar, terminado por arriba en un asa y por abajo en un pie, por lo general de forma de platillo' (DRAE). Derivado de velar, del latín v̌gĭlāre (DECH, s.v. velar).

Un belón de latón con su pie (La Bañeza, 1721)

Un velón grande (La Nora del Río, 1823)

Un velón nuevo de metal regular (La Bañeza, 1829)

Un velón pequeño de metal (La Bañeza, 1829)

Un velón de metal (Quintanilla de Somoza, 1831)

Un velón (Castrocalbón, 1832)

Un belón usado (Requejo de la Vega, 1839)

El término aparece usado con el significado que da el diccionario académico. Prácticamente, todos los ejemplos son del S. XIX, dato que no es extraño ya que el término entra en el S. XVII y está generalizado fundamentalmente en el S. XIX, como se 
refleja también en el CORDE donde la mayor parte de los ejemplos pertenecen a los SS. XIX y XX.

\subsection{MUEBLES}

Aunque relacionado con el ajuar doméstico, por el número de entradas y porque constituyen un campo semántico bien diferenciado, los muebles configuran un apartado independiente. Las palabras se distribuyen por similitud del referente al que aluden, es decir, asientos, baúles, muebles de cama, armarios, diferenciando a su vez los que sirven para guardar objetos de los que se usan para guardar ropa. Se añade además un subapartado de accesorios donde se incluyen todos los objetos que forman parte de los diferentes muebles.

\section{ALACENA}

Sust. f. 'Armario, generalmente empotrado en la pared, con puertas y anaqueles, donde se guardan diversos objetos' (DRAE). Término procedente del árabe al-jazana (DECH, s.v. alacena).

Unas alacenas buenas con sus aldabillas (Laguna de Negrillos, 1721)

Una alacena de álamo con portinas (Robledo de la Valduerna, 1726)

Una alacena para platos (Pobladura del Valle, 1734)

Unas alacenas con sus llaves (Grajal de la Ribera, 1750)

Unas alacenas con sus divisiones (Valle de la Valduerna, 1829)

Unas alacenas usadas (Quintanilla de Somoza, 1831)

Unas alacenas de chopo con cuatro puertas y dos celosías con cerradura y llave (Destriana, 1843)

Unas alacenas chicas (Santibáñez de la Isla, 1844)

Es una voz muy común, por lo que se han encontrado numerosos ejemplos a lo largo de todo el corpus analizado. El término aparece ya documentado desde 1521, como muestra el ejemplo que aparece en el CORDE "tener en la alacena botecitos de medicinas", con el significado de 'armario'. Aunque se dice que generalmente estaba empotrado, las alacenas podían ser de diversos tipos, de ahí que casi siempre se inventariaban con la especificación correspondiente atendiendo a si tenían o no puertas, si tenían o no cerradura o al tipo de madera del que estaban hechas. Normalmente, teniendo en cuenta el lugar que ocupaban en los inventarios, se trataba de muebles de cocina. La palabra aparece en las relaciones de bienes indistintamente en singular o en plural, el uso de alacenas no significa que sean varios armarios ya que en ese caso y, dada la precisión con que se realizaban los inventarios, se especificaría el número exacto: dos, tres, etc. alacenas. 


\section{APARADOR}

Sust. m. 'Mueble donde se guarda o contiene lo necesario para el servicio de la mesa' (DRAE). Término derivado de parar, del latín parare 'preparar', 'disponer' (DECH, s.v. parar).

Un aparador viejo de nogal (La Bañeza, 1643)

Solo se ha recogido este ejemplo del término que tiene el significado de 'armario', aunque en esta época era un mueble destinado al servicio de mesa, no se trataba de un armario ropero (Castañeda, 2003: 286). Se trata de un término que puede considerarse sinónimo de escaparate, término también poco frecuente en este corpus.

\section{CANTARERA}

Sust. f. 'Poyo de fábrica o armazón de madera que sirve para poner los cántaros' (DRAE). Término derivado de cántaro, del latín canthărus 'especie de copa grande, de dos asas', y este del griego kántharos (DECH, s.v. cántaro).

Una cantarera de chopo (La Bañeza, 1829)

Una cantarera (Destriana, 1843)

Solo se han recogido estos ejemplos. Probablemente se trata de una casualidad ya que es un término usado en toda la zona leonesa con el significado de 'armazón de madera que sirve para poner los cántaros'. En efecto, el segundo ejemplo aparece dentro de los objetos localizados en la cocina de lumbre, donde están los utensilios de cocina.

\section{CAPERO}

Sust. m. 'Eclesiástico que en iglesias catedrales, colegiales y otras asiste al coro y al altar con capacidad pluvial, por días o semanas, conforme a los estatutos' (DRAE). Término derivado de capa procedente del latín tardío cappa 'capucho' (DECH, s.v. capa).

Un capero (La Nora del Río, 1823)

Un capero (Requejo de la Vega, 1839)

Solo se han encontrado estos ejemplos, aunque la voz es bastante común en la zona. En León y en zonas rurales de Castilla y León el término se utiliza con el significado de 'perchero de pared, con gancho, o el gancho simplemente, adosado a la pared, que, en la entrada de la casa, sirve para colgar perchas y abrigos' (Hernández Alonso, 2001: 816). Esta acepción no se recoge en el DRAE ni aparecen ejemplos en el CORDE. Es lógico pensar que en este corpus se utiliza el término con este significado, ya que siempre lo que se registra en un inventario son objetos. 


\section{COPERO}

Sust. m. El DRAE define el término en su $3^{\text {a }}$ acepción como 'mueble que se usa para contener las copas en que se sirven licores' y en la $5^{\mathrm{a}}$ como 'sitio donde se guardan o ponen las copas'. Término derivado de copa, del lat. cŭppa (DECH, s.v. copa).

Un copero bueno de madera (Alija del Infantado, 1644)

Un copero mediano (La Bañeza, 1647)

Un copero pequeño (Grajal de la Ribera, 1723)

Una romana de pesar moneda y un copero biexo (Palacios de la Valduerna, 1730)

Probablemente el término aparezca con el significado de 'mueble para guardar las copas'. Son bastantes los ejemplos encontrados, si tenemos en cuenta que en el CORDE aparecen un gran número de casos, pero con otras acepciones, mayoritariamente con el significado de 'persona que tiene por oficio traer la copa o despensero'. Por tanto, es significativo el dato de que encontremos documentado el término en el S. XVII y no en pocos ejemplos en relación con un corpus como el CORDE.

\section{ESCAPARATE}

Sust. m. 'Especie de alacena o armario, con puertas de vidrios o cristales y con anaqueles para poner imágenes, barros finos, etc.' (DRAE). Del neerlandés anticuado schaprade 'armario' (DECH, s.v. escaparate).

Dos escaparates pequeños forrados enteros con diferentes echuras (Robledo de la Valduerna, 1726)

Un escaparate con dos efigies y adornos (Requejo de la Vega, 1839)

Son muy escasos los ejemplos encontrados del término. El diccionario académico en las ediciones del S. XVIII define la palabra como 'alhaja hecha a manera de alacena'. Es decir, no se trata por tanto de un mueble común sino de un objeto de cierto valor en el que se guardaban también cosas de valor. Señala el Diccionario de Autoridades que es muy usado por las mujeres para "guardar sus dijes". El hecho de que no se trate de un mueble común podría explicar su escasa aparición en los inventarios.

\section{VASAR [vasal, basal]}

Sust. m. 'Poyo de anaquelería de ladrillo y yeso u otra materia que, sobresaliendo en la pared, especialmente en las cocinas, despensas y otros lugares semejantes, sirve para poner vasos, platos, etc.' (DRAE). Término derivado de vaso, del latín vas, -is 'vasija', vulgarmente vasum (DECH, s.v. vaso).

Un basal (La Bañeza, 1754)

Un vasal de tablas (La Nora del Río, 1823)

Un vasal vastante biejo (La Bañeza, 1829) 
Un basalico chico y unas tablas (Palacios de la Valduerna, 1831)

Un basal (Requejo de la Vega, 1839)

Un basal de cuatro separaciones de madera de castaño (Destriana, 1843)

El término se utiliza con el significado que da el diccionario académico, aunque no necesariamente se trata de un poyo que sobresalga en la pared, sino que puede ser también un armario de madera en el que se colocan platos y vasos. Con esta matización probablemente se utilice el término puesto que aparece inventariado como un objeto aislado e independiente. Formalmente, todos los ejemplos aparecen bajo la variante vasal, con cambio del sufijo -ar por -al, rasgo característico del leonés (Le Men, 2012, s.v. vasar).

\section{ARMARIO [almario]}

Sust. m. 'Mueble con puertas y anaqueles o perchas para guardar ropas y otros objetos' (DRAE). Término derivado de arma, tomado del lat. armarium (DECH, s.v. armario).

Un almario (Castrocalbón, 1643)

Un armario guardarropa del pasillo (La Bañeza, 1829)

Es un término general en castellano, tal y como puede observarse en el CORDE, donde son numerosos los ejemplos. En este caso solo se han encontrado dos casos. Con respecto a la variante almario, es bastante frecuente encontrar este término bajo esta forma. En el CORDE son bastantes los casos encontrados fechados en diferentes siglos, pero los más frecuentes se sitúan antes del S. XIX, dato que está en consonancia con los ejemplos encontrados. La Academia señala en su edición de 1726 y solo en esta que "algunos corrompidamente dicen almario". Asimismo el $D E C H$ señala que esta variante disimilada es común en los SS. XIII-XVIII. En conclusión, el ejemplo de Castrocalbón no sería, por tanto, extraño en cuanto a su variante formal. El siguiente ejemplo que ya pertenece al S. XIX, presenta ya la forma normativa.

\section{ROPERO}

Sust. m. El DRAE define el término en la $5^{\text {a }}$ acepción como 'armario o cuarto donde se guarda ropa'. Término derivado del verbo robar (DECH, s.v. robar).

Un ropero de nogal (La Nora del Río, 1823)

Es el único ejemplo recogido de este término. La matización "de nogal” deja clara la acepción de 'armario'. Tanto un término como otro son escasos en los inventarios, tal vez porque el objeto que se utilizaba con esta finalidad eran los baúles, más comunes y sobre todo, las arcas que aparecen con mucha frecuencia en el corpus. 
Además, tampoco resulta extraño que este ejemplo esté fechado en el S. XIX puesto que de los muchos ejemplos del término que presenta el CORDE, todos los que tienen este significado pertenecen a los siglos XVIII y XIX.

\section{ARCA [arquita, arquetón]}

Sust. m. y f. 'Caja, comúnmente de madera sin forrar y con tapa llana que aseguran varios goznes o bisagras por uno de los lados, y uno o más candados o cerraduras por el opuesto' (DRAE). Término procedente del lat. arca, íd. der. a su vez del lat. arcēre (DECH, s.v. arca).

Se trata de una voz muy común en el corpus analizado por lo que los ejemplos encontrados son numerosos, algunos de ellos son:

Una arca de madera con su llave (Castrocalbón, 1643)

Una arca grande con su cerradura, llave sin cantoneras (Coomonte de la Vega, 1643)

Una arca panera buena (Coomonte de la Vega, 1645)

Un arca de pies altos vieja (Alija del Infantado, 1646)

Otra arquita vieja de tener papeles (Alija del Infantado, 1646)

Una arca de castaño con su llave mediana vieja (Alija del Infantado, 1647)

Un arca mediana (La Bañeza, 1712)

Una arca nueba (La Bañeza, 1712)

Un arca de nogal con cerradura, aldabones y cantoneras (Robledo de la Valduerna, 1726)

Un arca de yerro (Miñambres, 1727)

Una arquita chica con cerradura y llave de castaño (Palacios de la Valduerna, 1728)

Una arca vieja (Castrocalbón, 1814)

Una arca mediana nueba con llaves, visagras y cantoneras (Jiménez de Jamuz, 1825)

Una arca grande vuena (Valle de la Valduerna, 1829)

Un arca grande y ancha (Quintanilla de Somoza, 1831)

Una arca grade con sus aldabones (Quintanilla de Somoza, 1831)

Un arca con cerradura y llave y en ella un azafate con tapadera (Requejo de la Vega, 1839)

El significado con el que se utiliza es el que da la Academia como primera acepción. Comúnmente se trata de una caja de madera, podríamos decir, de un mueble, de ahí que en algunos casos se especifique el tipo de madera con el que está fabricada. En el caso de que esté elaborada con otros materiales se especifica, como en el ejemplo de Miñambres. También se reseña el fin para el que se destina: panera o para guardar papeles. En general, se trata de un mueble que se utiliza normalmente para guardar objetos que se consideran de cierto valor y que puede llevar ciertos elementos como cantoneras, aldabones, etc. que frecuentemente se señalan. Una variante recogida es la forma con el diminutivo arquita, que hace referencia a un arca pequeña. Desde el punto de vista morfológico, se puede observar en los ejemplos que existe una gran vacilación 
en la forma del determinante que en ocasiones aparece en masculino y en otras en femenino, pero sin ninguna correspondencia, lo que lleva a pensar que hay vacilación por parte del escribiente y así incluso dentro de un mismo inventario, unas veces se presenta de una forma y otras de otra.

\section{ARQUETÓN}

Sust. m. El significado de esta palabra es similar al de arca, es decir, especie de mueble o cajón que se utiliza para guardar cosas. Sin embargo, las diferencias con el arca son más bien de tamaño. El DRAE señala a lo largo de sus ediciones que el arquetón es un aumentativo de arqueta, y la arqueta es un diminutivo de arca.

Un arquetón de nogal (Miñambres, 1729)

Un arquetón con sus pies (Miñambres, 1729)

Un arquetón de lo mismo sin cerradura (Destriana, 1843)

Se trata de un objeto que se sitúa, en cuanto al tamaño, entre el arca y la arqueta. Además, tiene un uso mucho más reducido que el arca, solo dos casos encontrados frente a los numerosos casos de arca. Este dato coincide con el que ofrece el CORDE donde se registran cinco mil quinientos noventa casos de arca y cuatro de arquetón. La voz arqueta no se ha recogido en ningún caso en el corpus analizado.

\section{BAÚL [vaúl]}

Sust. m. 'Mueble parecido al arca, frecuentemente de tapa convexa, cubierto por lo común de piel, tela u otra materia que sirve generalmente para guardar ropas' (DRAE). Término procedente del fr. antiguo bahur de origen incierto, quizá onomatopéyico (DECH, s.v. baúl).

Un vaúl negro atachonado con erraduras y llabe (La Bañeza, 1649)

Un baúl forrado en mitán (La Bañeza, 1721)

Un baúl de pellejo rojo (La Bañeza, 1743)

Un baúl forrado en pellejo (La Bañeza, 1743)

Un baúl biejo sin llave (Destriana, 1825)

Dos baúles grandes forrados de pellejo (Castrocalbón, 1832)

Un baúl biejo grande con cinco barras (Requejo de la Vega, 1839)

Un baúl viejo (Requejo de la Vega, 1839)

Un baúl de media usa con cinco barras (Requejo de la Vega, 1839)

Un baúl de cuatro varras grande con cerradura y llave cantoneras de yerro (Destriana, 1843)

Un baúl de lo mismo con una copera para descanso de un sombrero (Destriana, 1843)

El DRAE señala este término como un sinónimo de arca, aunque lo diferencia de esta en la forma de la tapa y en que el baúl, a diferencia del arca, normalmente va forrado. Este último dato se ve reflejado en los ejemplos donde son bastantes los casos 
en los que se dice "forrado de pellejo". En cuanto a la frecuencia de uso, donde más ejemplos se han encontrado es en el S. XIX, y es significativo señalar que los anteriores a esta fecha se localizan en La Bañeza, capital del Partido Judicial. Quizá se trata, por tanto, de un objeto de mayor valor que el arca, de ahí que su presencia sea menor y que aparezca fundamentalmente en los núcleos más urbanos.

\section{COPERA}

Sust. f. El DRAE da como $5^{\text {a }}$ acepción del término la de 'sitio donde se guardan o ponen las copas'. Término derivado de copa, del latín cŭppa (DECH, s.v. copa).

Un baúl de lo mismo con una copera para descanso de un sombrero (Destriana, 1843)

Solo se recoge este ejemplo que no se corresponde con ninguna de las acepciones del DRAE ni se recogen muestras con este significado en el CORDE. Parece tratarse de un ejemplo aislado que da nombre a un elemento del baúl, que probablemente por su analogía con la copa, ya sea por el parecido formal o porque el sombrero se cuelga de la copa, ha tomado este nombre, o al menos ha sido denominado así por la persona que iba cantando la relación de objetos.

\section{COFRE}

Sust. m. 'Caja resistente de metal o madera con tapa y cerradura para guardar objetos de valor' (DRAE). Del francés coffre íd., y este del latín cŭphĭnus 'cesta', tomado a su vez del griego kóphinos (DECH, s.v. cofre).

Un cofre encorado bueno (La Bañeza, 1643)

Un cofre grande negro encorado (La Bañeza, 1643)

Siete cofres (Robledo de la Valduerna, 1726)

Un cofre forrado en cuero de cavallo con zerradura (Miñambres, 1727)

Un cofre forrado por fuera en vadana (Pobladura del Valle, 1734)

Un cofre con su forro cerradura y llave (Laguna de Negrillos, 1734)

Un cofre pequeño con su herraje con zerradura y llave (Laguna de Negrillos, 1734)

Un cofrecito pequeño clabeteado (Laguna de Negrillos, 1734)

Un cofre encorado grande y bueno con su cerradura y llabe (La Bañeza, 1747)

Un cofre forrado en colorado con barretas de yerro cerraduras y llabe (Palacios de la Valduerna)

Es un término común que convive en los inventarios junto a otros términos sinónimos como arca o baúl. Quizá la voz cofre tiene mayor frecuencia que baúl, especialmente antes del S. XIX y, como en el caso de baúl, se utiliza para guardar objetos de valor frente al arca que también sirve para otros usos como guardar papeles o el pan. Es frecuente que el cofre esté recubierto normalmente de cuero, dato que se especifica 
en los inventarios junto a otras características como si tiene cerradura, el tipo de forro, etc.

\section{CÓMODA}

Sust. f. 'Mueble con tablero de mesa y tres o cuatro cajones que ocupan todo el frente y sirven para guardar ropa' (DRAE). Del francés commode, abreviación de armoire commode (DECH, s.v. cómodo).

Una cómoda madera de chopo pintada con guarniciones de metal dorado con tres cajones grandes dos con cerradura y llave y uno sin ella deteriorada (Destriana, 1843)

El único ejemplo encontrado pertenece al S. XIX, dato lógico puesto que aparece incorporado al diccionario académico en la edición de 1780. Probablemente en esta época tampoco era un mueble de uso común y solo aparece en inventarios muy completos, como es en este caso.

\section{BANCO}

Sust. m. 'Asiento con respaldo o sin él, en que pueden sentarse varias personas'. 'Madero grueso escuadrado que se coloca horizontalmente sobre cuatro pies y sirve como de mesa para muchas labores de los cerrajeros, herradores y otros artesanos' (DRAE). Término procedente del germ. bank (DECH, s.v. banco).

Un banco de respaldar nuevo de pino al parecer (Coomonte de la Vega, 1643)

Un banco largo tosco de quatro pies (Coomonte de la Vega, 1643)

Un banco de moyl de carro (Alija del Infantado, 1644)

Un banco de palero biexo (Coomonte de la Vega, 1645)

Un banco de respaldo de nogal (La Bañeza, 1714)

Un banco largo (La Bañeza, 1712)

Un banco de segundera (Coomonte de la Vega, 1719)

Un banco de moil grande (Laguna de Negrillos, 1722)

Un banco pequeño (Coomonte de la Vega, 1724)

Un banco de palera largo (Palacios de la Valduerna, 1728)

Un banco largo de la lumbre (Alija del Infantado, 1737)

Un zesto tablizo y un banco (Castrocalbón, 1814)

Una pala tornadera y un banquito (Castrocalbón, 1814)

Un banco de humero (Destriana, 1825)

Un banco de matar zerdos (Castrillo de la Valduerna, 1828)

Un banco de matar los cerdos (Destriana, 1843)

Un banco de trabajar (Santibáñez de la Isla, 1844)

El significado más común con el que se utiliza el término es el que aparece como primera acepción. Se trata de un banco, más bien tosco, hecho de madera de diferentes árboles. Normalmente en los inventarios se especifica de qué tipo de madera se trata: pino, palera o umero, términos que se utilizan en León para referirse a un tipo 
de sauce, en el caso de palera, o al aliso, en el caso de umero que sería la denominación occidental del término. Asimismo, también se especifica si tiene o no respaldo. Con la segunda acepción también aparecen ejemplos, aunque no se detalla el tipo de trabajo al que se destina. Un tipo de banco específico del que se han encontrado dos ejemplos es el utilizado para la matanza del cerdo. Es un banco destinado a tal fin y con unas características concretas, por ejemplo, debe tener una altura específica que no sobrepase la rodilla de la persona que ejerce de matarife.

\section{BANCA}

Sust. f. 'Asiento de madera sin respaldo' (DRAE). Vocablo derivado de banco, procedente del germ. bank (DECH, s.v. banco).

Una banca de una tabla (Grajal de Ribera, 1730)

Una banca de chopo (Palacios de la Valduerna, 1728)

Una banca (Castrillo de la Valduerna, 1828)

El DRAE da como $6^{\text {a }}$ acepción del término la siguiente 'cajón donde se colocan las lavanderas para lavar la ropa'. Este mismo significado aparece en diccionarios dialectales de la zona (Rivas, 1996: 43). Por tanto, el significado con el que se usa el término en los documentos estudiados puede ser cualquiera de las dos acepciones. No hay datos concretos que nos permitan decir con exactitud si se usa con uno, otro o con los dos. Ni siquiera podemos extraer conclusiones de la relación de enseres en la que aparecen, ya que se insertan entre objetos de muy diverso tipo: escriños, cesta, hoz, etc.

\section{CENADOR}

Sust. m. 'Espacio, comúnmente redondo, que suele haber en los jardines, cercado y vestido de plantas trepadoras, parras o árboles' (DRAE). Tomado del latín cenacŭlum (DECH, s.v. cena).

Un cenador (Destriana, 1828)

Es el único ejemplo encontrado. No hay, por tanto, muchos indicadores que ayuden a determinar cuál es el significado concreto del término, ya que como elemento que hay en una relación de bienes, parece evidente que no se trata del espacio. Teniendo en cuenta el contexto en el que apararece y que al inicio del inventario se señala que la casa tiene "un pedazo de corral", puede pensarse que con el término cenador, se designa algún tipo de asiento o banco que se encuentra en el corral, por semejanza con el significado de espacio que suele haber en los jardines, que es la acepción que se registra ampliamente en los diccionarios. En el fichero que recoge el $N D H E$ aparece la siguiente 
referencia: «un cenador de piedra», ejemplo de Lampérez fechado en el año 1922. Este sintagma alude probablemente a un asiento, por lo que podría haber cierta similitud entre ambos ejemplos.

\section{ESCAÑIL}

Sust. m. El DRAE define el término como 'banco pequeño' y matiza que se utiliza en León. Término derivado de escaño del latín scamnum 'escambel', 'banco' (DECH, s.v. escaño).

Un escañilico (Coomonte de la Vega, 1719)

Un escañil de castaño (Genestacio de la Vega, 1721)

Un escañil de una tabla con sus traveseros de yerro (Laguna de Negrillos, 1722)

Un escañil de nogal bueno (Laguna de Negrillos, 1722)

Un escañil de tres pies de largo con diez y ocho clabos (Grajal de La Ribera, 1723)

Un escañil desbaratado (Laguna de Negrillos, 1725)

Un escañil con su respaldo (Laguna de Negrillos, 1725)

Un escañil de álamo y otro de nogal (Robledo de la Valduerna, 1726)

Dos escañiles, uno de chopo y otro de álamo (Palacios de la Valduerna, 1727)

Un escañil de álamo (Palacios de la Valduerna, 1728)

Un escañil de roble mediano (Grajal de La Ribera, 1730)

Un escañil biejo quebrado (Destriana, 1730)

Un escañil de roble (Pobladura del Valle, 1734)

Un escañil de álamo con sus clavos (La Isla, 1735)

Un escañil bueno de encaje (Laguna de Negrillos, 1734)

Un escañil de tres pies (La Nora del Río, 1820)

Un escañil con clavos de concha (Quintanilla de Somoza, 1831)

Un escañil de chopo (Destriana, 1843)

Es un término muy frecuente en toda el área comprendida en este estudio. En efecto, se trata de una voz muy usada en toda la zona leonesa frente al uso que pueda tener en otras partes. De hecho, el CORDE solo recoge cinco casos. El significado es el que da la Academia de 'banco pequeño', aunque en algunos vocabularios dialectales se define como 'banco de madera, largo con respaldo y sin brazos, en el que pueden sentarse tres o cuatro personas' (Fuente García, 2000: 269). El DRAE no recoge el término hasta la edición de 1925, es decir, posterior a los ejemplos. Estos bancos eran de madera, por ello, como se aprecia en los ejemplos, es frecuente que aparezca el tipo de madera del que están hechos. También se señalan otras características como la presencia de respaldo o que tengan o no clavos. Formalmente, es significativo el primer ejemplo en el que hay un caso de derivación con la adición del sufijo -ico, que se añade a la propia palabra que ya lleva en sí el significado de pequeño, frente al término escaño. 


\section{ESCAÑO}

Sust. m. 'Banco con respaldo en el que pueden sentarse tres o más personas' ( $D E C H$, s.v.

escaño). Término derivado del latín scamnum 'escambel', 'banco' (DECH, s.v. escaño).

Un escaño de pino (la Bañeza, 1641)

Un escaño (Castrocalbón, 1643)

Un escaño de madera ya usado (Coomonte de la Vega, 1643)

Un escaño de álamo bueno (Alija del Infantado, 1646)

Un escaño grande (La Antigua, 1647)

Un escaño (la Antigua, 1648)

Un escaño de roble sin clavos usado (Laguna de Negrillos, 1722)

Un escaño de respaldo viejo (Coomonte de la Vega, 1724)

Un escaño de álamo usado (Laguna de Negrillos, 1725)

Un escaño de chopo (Palacios de la Valduerna, 1727)

Un escaño grande biexo (Grajal de La Ribera, 1730)

Un escaño de madera (Miñambres, 1731)

Un escaño de pequeño de álamo (Pobladura del Valle, 1734)

Un escaño de respaldo (Genestacio de la Vega, 1734)

Un escaño grande que está a la lumbre (Laguna de Negrillos, 1734)

Un escaño de respaldo viejo (Valle de la Valduerna, 1829)

Un escaño (Quintanilla de Somoza, 1831)

Un escaño de chopo grande con respaldo (Destriana, 1843)

Es un término muy utilizado en toda la zona. Aparece en prácticamente todos los inventarios analizados. El significado que tiene es el de 'banco de madera, largo, con respaldo y brazos que solía estar en las cocinas antiguas' (Le Men, 2005, s.v. escaño). En algunas zonas próximas se diferencia del escañil en que es más ancho (Fuente García, 2000: 269). Como en el caso anterior, podían ser de diferentes tipos de madera, dato que se solía consignar en el inventario porque de ello dependía el valor del objeto. Normalmente estaba en las cocinas pero no siempre ya que en algunos casos, cuando se van detallando los objetos por habitaciones de la casa, el escaño puede aparecer en una sala contigua a la cocina o en el portal.

\section{POLTRONA}

Adj. f. El DRAE señala en su segunda acepción la expresión silla poltrona, que define en la entrada silla como 'la más baja de brazos que la común, y de más amplitud y comodidad'. De potro, palabra de origen incierto (DECH, s.v. potro).

Dos sillas poltronas de vagueta (La Nora del Río, 1823)

Una silla poltrona (La Nora del Río, 1823)

Una silla poltrona (Felechares, 1837)

Otra silla del mismo asiento figura poltrona mas usada (Destriana, 1843)

Son los únicos ejemplos recogidos y se utilizan con el significado del DRAE que es el empleado en la actualidad. 
SILLA

Sust. f. 'Asiento con respaldo, por lo general con cuatro patas, y en que solo cabe una persona' (DRAE). Del latín sĕlla (DECH, s.v. silla).

Una silla de cabalgadura biexa sin cinchas con su caparacón clabado (Coomonte de la Vega, 1643)

Una silla de costillas buena (Alija del Infantado, 1646)

Una silla de costillas (La Antigua, 1648)

Una silla de madera biexa (Coomonte de la Vega, 1650)

Dis sillas de vaqueta negra (Laguna de Negrillos, 1722)

Seis sillas de baqueta (Robledo de la Valduerna, 1726)

Dos sillas de briza, dos albardones y dos frenos (Robledo de la Valduerna, 1726)

Una silla bieja (Alija del Infantado, 1734)

Quatro sillas de vaqueta viejas (Alija del Infantado, 1734)

Una silla de baqueta (Grajal de la Ribera, 1750)

Onze sillas grandes (La Nora del Río, 1823)

Otra silla vlanca (La Nora del Río, 1823)

Dos sillas poltronas de vaqueta (La Nora del Río, 1823)

Dos sillas pintadas (La Nora del Río, 1823)

Una silla poltrona (La Nora del Río, 1823)

Quatro sillas en vlanco (La Nora del Río, 1823)

Dos sillas con pintura azul medianas (La Bañeza, 1829)

Una silla de serbicio con su bañado (Quintanilla de Somoza, 1831)

Dos sillas forradas de vecerro (Quintanilla de Somoza, 1831)

Una silla poltrona (Felechares, 1837)

Ocho sillas altas (Requejo de la Vega, 1839)

Dos sillas pequeñas (Requejo de la Vega, 1839)

Tres sillas biejas (Requejo de la Vega, 1839)

Trece sillas asiento de paja en buen uso (Destrina, 1843)

Diez sillas asiento de paja en vuen uso (Destrina, 1843)

Una silla de montar con todos sus talegos, estrivos de yerro (Destriana, 1843)

Es un término que aparece en el corpus con dos acepciones, la más utilizada es la referida al mueble ya que designa un objeto muy común en cualquier casa. Con este significado abundan en los ejemplos del corpus las sillas poltronas, más bajas que las comunes y más cómodas; y las sillas de vaqueta, que no son un tipo sino que hacen referencia al material del que están hechas, de cuero en este caso. La otra acepción menos frecuente es la de las sillas de montar o de cabalgadura.

\section{SILLETA}

Sust. f. 'Recipiente para excretar en la cama los enfermos' (DRAE). Término derivado de silla, del latín sělla (DECH, s.v. silla).

Onze silletas grandes (La Nora del Río, 1823)

Otra silleta chica (La Nora del Río, 1823)

Dos silletas vlancas (La Nora del Río, 1823)

Son los únicos ejemplos recogidos a lo largo del corpus, por ello la escasez de información de campo impide saber con exactitud el significado con el que se emplea el 
término. Los dos ejemplos pertenecen a un corpus en el que se van relacionando los ejemplos por el espacio de la casa en el que se encuentran. El primer ejemplo se recoge en la sala principal y además se documenta un número de objetos que plantea dudas acerca de que el término se use con el significado que aparece en el DRAE y es más lógico pensar que la voz nombre un tipo de silla específico, que puede ser la que se documenta en el este de la provincia bajo la voz sillete, 'tipo de silla sin respaldo, algo más baja de lo normal con el asiento de paja' (Le Men, 2012, s.v. sillete). El segundo ejemplo se recoge en la sala trasera, lugar en el que podría ser más lógico el uso del término con la acepción del DRAE, aunque el hecho de que aparezca en el mismo inventario que el otro ejemplo, así como que se documenten dos en el mismo cuarto, permite concluir que al menos si no se corresponde con el sillete, se trata de un tipo de silla específica.

\section{TABURETE [tavurete, taurete, taborete]}

Sust. m. 'Asiento sin brazos ni respaldo, para una persona' (DRAE). Del francés tabouret, derivado del francés antiguo tabour 'tambor' por comparación de forma (DECH, s.v. tambor).

Quatro taburetes lo dos de ellos colorados y los dos negros (La Bañeza, 1647)

Quatro taburetes de madera (La Bañeza, 1712)

Seis taburetes de baqueta (La Bañeza, 1721)

Dos taburetes el uno quebrado y el otro sano (Laguna de Negrillos, 1722)

Un taburete quebrado (Laguna de Negrillos, 1725)

Dos taburetes chiquitos (Robledo de la Valduerna, 1726)

Un taburete (Palacios de la Valduerna, 1733)

Un taurete con sus tornillos (Laguna de Negrillos, 1734)

Dos tauretes torniados (Laguna de Negrillos, 1734)

Un taburete (Alija del Infantado, 1737)

Un taburete (Grajal de la Ribera, 1750)

Un taborete (La Bañeza, 1758)

Dos tavuretes de madera (Alija del Infantado, 1812)

Un taburete (Castrocalbón, 1814)

Un taburete viejo (La Nora del Río, 1823)

Un taburete de madera (Destriana, 1825)

Un taborete (Castrillo de la Valduerna, 1828)

Cuatro tavuretes antiguos (La Bañeza, 1829)

Es un término que aparece con frecuencia en los inventarios. Hasta la edición de 1884, la Academia define el término como 'una silla, con la diferencia de que es raso, y sin brazos, y el respaldo para reclinarse más estrecho' además solía ser tapizado, como se aprecia en el primer ejemplo. Por tanto, probablemente, el uso que se le da al término no es el actual, sino el que aparece en el diccionario académico hasta esa fecha. 
Formalmente, hay un ejemplo en que se produce un caso de vacilación vocálica de abertura que tal vez se trate de un ejemplo aislado puesto que es el único y no presenta un contexto fónico propicio para la vacilación vocálica (Morala, 2009: 557-558). Se documentan también dos casos de taurete, forma ocasional en León (Morala y Egido, 2010: 434).

\section{TRONA}

Sust. f. 'Silla de patas altas para dar de comer a los niños pequeños' (DRAE). Término derivado de trono, del latín thrŏnus, tomado del griego thrónos 'sillón alto', 'trono' (DECH, s.v. trono).

Una trona chiquita bieja (Alija del Infantado, 1812)

Tres tronas dos medianas y otra chica (Destriana, 1828)

El significado que recoge el DRAE del término es el de un tipo de silla que se utiliza para los niños, sin embargo, en los ejemplos recogidos podría tener esta acepción que es la usada actualmente, pero también podría estar nombrando un tipo de silla particular no específica de los niños. En este sentido, se recoge en el NDHE la referencia siguiente: «allí estaré en una trona», de Jiménez de Urrea fechada en el año 1878. El ejemplo da a entender que se trata de una silla utilizada por adultos, es probable que tenga unas características específicas, quizá con respaldo, alta; pero no se han encontrado más referencias del término. El CORDE recoge el término para designar una silla desde la cual predica el sacerdote, pero en los casos encontrados en el corpus los inventarios no pertenecen a sacerdotes, por tanto, es probable que el término esté en estos casos designando una silla de similares características.

\section{MESA [messa]}

Sust. f. 'Mueble, por lo común de madera, que se compone de una o de varias tablas lisas sostenidas por uno o varios pies, y que sirve para comer, escribir, jugar otros usos' (DRAE). Del latín mensa (DECH, s. v. mesa).

Una mesa de manteles de alemanisco (La Bañeza, 1641)

Dos mesas de manteles (Castrocalbón, 1643)

Una mesica de álamo de madera buena (Coomonte de la Vega, 1643)

Una mesa de manteles de gusanillo biexos y rotos (Coomonte de la Vega, 1643)

Otra mesa mediana de quatro pies (Coomonte de la Vega, 1643)

Una messa de roble ya ussado (Vidriales, 1645)

Una messa grande de una tavla de roble (La Antigua, 1647)

Una mesica biexa sin pies (Alija del Infantado, 1647)

Una mesica biexa de quatro pies (Alija del Infantado, 1647)

Una mesa redonda (La Antigua, 1648) 
Una mesa mediana de chopo (Coomonte de la Vega, 1650)

Una mesa con su cajón, cerradura y llave buena y en ella una bolsa con diferentes reliquias (Laguna de Negrillos, 1721)

Una mesa redonda de piel de nogal y una tabla con sus cuatro clavos (Laguna de Negrillos, 1722)

Una mesa larga sin pies (Laguna de Negrillos, 1722)

Una mesica pequeña de dos tablas (Grajal de la Ribera, 1723)

Una mesa de chopo larga (Fresno, 1726)

Una mesica de álamo (Palacios de la Valduerna, 1727)

Una mesa de mano (Palacios de Jamuz, 1728)

Una mesa larga de dos tablas vieja (Toral, 1728)

Una mesa de castaño (Palacios de la Valduerna, 1728)

Una messa corta de una tabla (Destriana 1730)

Una mesa de álamo (Pobladura del Valle, 1734)

Una mesica (Pobladura del Valle, 1734)

Una mesa nueva con su cajón (Genestacio de la Vega, 1734)

Un zesto de traer paja y una mesica (Requejo de la Vega, 1735)

Una mesa chica de negrillo (Santiago Millas, 1735)

Una mesa grande con su guardapolbo (Santiago Millas, 1735)

Una mesa de mano (Alija del Infantado, 1812)

Un vanco con su mesa ordinario (La Bañeza, 1829)

Una mesa con su cajón (Destriana, 1843)

Una mesa muy pequeña de nogal (Felechares, 1837)

Una mesa de manteles de dos varas y un paño blanco con encajes (San Feliz, 1838)

Una mesa de chopo pequeña sin cajón (Destriana, 1843)

Es un término muy utilizado que tiene gran cantidad de acepciones, algunas de las cuales encontramos en los ejemplos. En León y otras zonas noroccidentales de la Península el término tiene, además del significado que da el DRAE, otros no recogidos en el diccionario académico. Concretamente en León se denomina mesa, además del mueble a, 'piso del carro', 'maderos que refuerzan la caja del carro por su parte posterior y/o anterior', 'parte del arado donde se inserta la reja dental', 'pieza de madera con una talla en el centro en la que se encaja el yugo', 'banco con tres patas', entre otros significados (Le Men, 2007, s.v. mesa). Teniendo en cuenta los ejemplos registrados, podemos señalar al menos tres significados distintos. Por una parte aparecen casos en los que el sustantivo mesa aparece con el sintagma "de mantel". Probablemente el uso que tiene en esos ejemplos el término es sinónimo al de tabla entendido como 'pieza ancha y plana' que junto a la voz mantel, tabla de manteles equivale a lo que hoy conocemos como mantel (Castañeda, 2003: 212); en este caso se registra en lugar de tabla de manteles, mesa de manteles. Además hay otros ejemplos en los que el contexto claramente determina el significado de mesa como 'mueble', en algunos ejemplos se especifica el tipo de madera, si tiene o no cajón, etc. Hay otros ejemplos en los que no está tan clara la acepción del término pero, en cualquier caso, no es ninguna de las dos anteriores, por lo que probablemente tenga algunos de los significados que registra Le 
Men (op. cit. s.v. mesa). El ejemplo de «una mesa de mano», o el de Requejo de la Vega donde en la misma relación aparecen coordinados un cesto y una mesa, permite pensar que estamos o bien ante una especie de banco o cualquiera de las otras acepciones relacionadas con el yugo o el carro que se han señalado. La falta de más información impide precisar con exactitud el significado concreto de estos ejemplos.

\section{BUFETE [vufete, bufetillo]}

Sust. f. 'Mesa de escribir con cajones' (DRAE). Voz procedente del fr. ant. bufet 'especie de mesa' de origen incierto (DECH, s.v. bufete).

Un bufete con los pies de madera y un caxón debajo del sin llave (Coomonte de la Vega, 1643)

Un bufete de nogal pequeño bueno (Alija del Infantado, 1644)

Un bufete de castaño con su cajón sin zerradura ni llave (Laguna de Negrillos, 1721)

Un vufete de nogal vueno con su caxón y en él unos manteles de torzal (Laguna de Negrillos, 1722)

Dos bufetillos forrados en terciopelo (Robledo de la Valduerna, 1726)

Un bufete con dos cajones de castaño (Miñambres, 1727)

Un bufette con su cajón (Destriana, 1730)

Un bufetillo con su contador y un escritorio pequeño y un niño Jesús encima (Laguna de Negrillos, 1734)

Un bufete de nogal con sus balaustres (Laguna de Negrillos, 1734)

Se trata de un término de uso común a lo largo de los siglos XVII y XVIII, no se han encontrado ejemplos del S. XIX. El DECH señala que en torno a 1587, el significado de este término era el de 'tocador' y en los comienzos del S. XVI pasa a significar 'mesa de comer', pero a mediados de siglo toma la acepción de 'escritorio'. Estos datos coinciden con los que da el DRAE que en la edición de 1726 define el término como 'una mesa de uso general, que se utilizaba para escribir pero también para comer'. Por tanto, teniendo en cuenta las fechas de los inventarios estudiados, el significado que en ellos se da al término coincide con el que dan los diccionarios mencionados, ya que se trata de un tipo de mesa que se encuentra en espacios de la casa no utilizados para comer y además, como se aprecia en los ejemplos, tienen adornos encima. Este dato indica que tiene un uso más bien decorativo o propio de una tarea intelectual. Además, junto a este término aparece la palabra mesa para designar otro mueble con una finalidad más general. Por otra parte, los propietarios de estos inventarios son normalmente personas con un nivel socio cultural alto, por ejemplo sacerdotes (es el caso del primer ejemplo o el de Robledo de la Valduerna). En otros no se conoce el nivel o estatus del propietario, pero probablemente se trate de una persona de cierto rango, si tenemos en cuenta la relación de objetos que aparecen inventariados. Como en otras ocasiones, el término se 
refiere con una serie de descripciones que dan cuenta detallada de la dimensión, material, etc. del objeto.

La variante bufetillo indica el diminutivo del objeto. Aparece siempre bajo esta forma ya lexicalizada, que incluso durante esta época tiene en las ediciones del DRAE una entrada aparte. El resto de variantes formales son poco frecuentes, ya que se trata de variantes meramente gráficas.

\section{ESCRIBANÍA [escrivanía]}

Sust. f. El DRAE en su $5^{\text {a }}$ acepción define el término como 'recado de escribir, generalmente compuesto de tintero, salvadera y otras piezas, y colocado en un pie o platillo'. También define el término como sinónimo de escritorio 'mueble para guardar papeles'. Término procedente del bajo latín scrība, -ānis (DECH, s.v. escribir).

Dos escribanías con su tintero ya biexas (Alija del Infantado, 1644)

Una escribanía completa de metal (La Nora del Río, 1823)

Una media escrivanía de estaño (La Bañeza, 1829)

Una escrivanía de Talavera, tintero y salvadera (Destriana, 1843)

Es un término poco frecuente en los inventarios analizados. El significado con el que se utiliza el término en estos inventarios es el de 'conjunto de instrumentos para escribir', dato que se puede deducir de las especificaciones que aparecen junto a la voz: "completa", "con su tintero" o "media escribanía". Formalmente, la palabra aparece en una ocasión con la grafía "v" para representar el sonido fricativo, dato no significativo.

\section{POLVO [polbo]}

Sust. m. 'Parte más menuda y deshecha de la tierra muy seca' (DRAE). Del latín vulgar *pŭlvus, clásico pulvis, pulvěris (DECH, s.v. polvo).

Como una libra de polbos de salbadera (La Nora del Río, 1823)

Es el único ejemplo recogido. El DRAE define el sintagma polvo de salvadera con el sinónimo de 'arenilla', probablemente es esta la acepción empleada en el ejemplo, ya que la expresión polvo de salvadera hace referencia al recipiente agujereado que contenía arenilla y se empleaba para secar lo escrito.

\section{SALVADERA}

Sust. f. 'Vaso, por lo común cerrado y con agujeros en la parte superior, en que se tenía la arenilla para enjugar lo escrito recientemente' (DRAE). Término derivado de salvado 
por el empleo de esta materia para enjugar lo escrito recientemente, salvado derivado a su vez de salvo, del latín salvus (DECH, s.v. salvo).

Una escrivanía de Talavera, tintero y salvadera (Destriana, 1843)

Es el único ejemplo recogido. Se utiliza con el significado que aparece en el diccionario académico. La voz salvadera aparece también en el corpus bajo la expresión polvos de salvadera.

\section{TINTERO}

Sust. m. 'Recipiente en que se pone la tinta de escribir' (DRAE). Término derivado de teñir, del latín tĭngěre 'mojar, empapar' (DECH, s.v. teñir).

Dos escribanías con su tintero ya biexas (Alija del Infantado, 1644)

Un tintero grande de piedra (Destriana, 1843)

Una escrivanía de Talavera, tintero y salvadera (Destriana, 1843)

Otro (tintero) de asta pequeño (Destriana, 1843)

Es un término conocido, aunque no común en el corpus ya que prácticamente todos los ejemplos pertenecen al mismo inventario. Ello es debido a que la mayoría de los inventarios analizados pertenecen a personas dedicadas a las labores agrícolas y ganaderas en cuyos bienes no se hallaban objetos relacionados con la escritura.

\section{ESCRITORIO [scriptorio]}

Sust. m. 'Mueble cerrado, con divisiones en su parte interior para guardar papeles y, a veces, con un tablero sobre el cual se escribe' (DRAE). Término derivado de escribir, del latín scrīběre (DECH, s.v. escribir)

Un escritorico pequeño (La Bañeza, 1643)

Un escritorio guarnecido de marfil mediano con otro escritorio de nogal (La Bañeza, 1643)

Un escritorio con seis nabetas (Robledo de la Valduerna, 1726)

Un scriptorio fábrica de Salamanca con herraje y nabetas doradas (Robledo de la Valduerna, 1726)

Un bufete de nogal bueno con su escritorio encima, con sus nabetas, sin llave y un S. Antonio encima (Laguna de Negrillos, 1726)

Un bufetillo con su contador y un escritorio pequeño y un niño Jesús encima (Laguna de Negrillos, 1734)

Un escritorio de nogal bueno grande con sus pies y catorze nabetas (La Bañeza, 1747)

El DRAE da más de una acepción al término ya que junto al significado expresado define también escritorio como 'mueble de madera, comúnmente con embutidos de marfil, concha u otros adornos de taracea, y con gavetas o cajones para guardar joyas'. El significado más común es en el que aparece como sinónimo de mesa, bufete. No obstante, por la información que aportan los ejemplos no se puede deducir 
con exactitud si se trataba de un mueble para escribir y guardar papeles o para guardar joyas. Los ejemplos en los que el término se encuentra al lado de la voz bufete llevan a pensar que se estaría utilizando con la primera acepción.

\section{NAVETA [nabeta]}

Sust. f.. 'Gaveta de escritorio' (DRAE). Término derivado de nave, del latín navis (DECH, S.v. nave).

Un escritorio de nogal bueno grande con sus pies y catorze nabetas (La Bañeza, 1647) Un scriptorio fábrica de Salamanca con herraje y nabetas doradas (Robledo de la Valduerna, 1726)

Un escritorio con seis nabetas (Robledo de la Valduerna, 1726)

Otro con seis nabetas de concha viejo (Robledo de la Valduerna, 1726)

Un bufete de nogal bueno con su escritorio encima con sus nabetas sin llave y un S. Antonio encima del escriptorio (Laguna de Negrillos, 1734)

Es un término poco común que designa una parte del mueble escritorio, objeto que no abundaba en los inventarios de la gente común de esta época y zona. De los ejemplos encontrados, tres forman parte del mismo inventario, que pertenecía a un sacerdote, y el otro ejemplo pertenece a un inventario de La Bañeza donde, por ser cabeza de Partido Judicial, siempre es más fácil encontrar inventarios que contengan objetos menos comunes. El significado que se le da al término es el señalado por el DRAE.

\section{ESTANTE}

Sust. f. 'Mueble con anaqueles o entrepaños, y generalmente sin puertas, que sirve para colocar libros, papeles u otras cosas'. 'Anaquel' (DRAE). Del lat. statuere (DECH, s.v. estar).

La librería con sus estantes (La Nora del Río, 1823)

Un estante para libros (Quintanilla de Somoza, 1831)

Un estante de madera (Requejo de la Vega, 1839)

Un estante de nogal pequeño con tres tablas (Destriana, 1843)

El término no es muy frecuente y tiene los significados que da el DRAE, aunque la acepción más empleada en los ejemplos es la de 'mueble con baldas', probablemente solo en el ejemplo de La Nora del Río se esté utilizando con el significado de 'anaquel' o 'balda'. 


\title{
PAPELERA
}

Sust. f. El DRAE define el término en su $4^{\text {a }}$ acepción como 'escritorio, mueble para guardar papeles' y señala que es voz poco usada. Del catalán paper, y este, por vía semiculta, del latín papyrus 'papiro' (DECH, s.v. papel).

Una papelera con su zerradura y pie de pino (Robledo de la Valduerna, 1726)

Es el único ejemplo encontrado, se utiliza con el significado de 'mueble para guardar papeles'.

\section{CAMA}

Sust. f. 'Conjunto formado generalmente por un armazón de madera o metal con jergón o colchón, almohada, sábanas y otras ropas, destinado a que las personas se acuesten en él' (DRAE). Voz procedente del hispanolatino cama 'yacija, lecho en el suelo', de origen incierto, quizá prerromano (DECH, s.v. cama).

\author{
Una cama de cordeles con su jergón bueno (La Bañeza, 1641) \\ Una cama (Castrocalbón, 1643) \\ La madera de una cama nueba de nogal (Coomonte de la Vega, 1643) \\ Una cama de nogal entera con sus barillas (La Bañeza, 1647) \\ Una media cama de nogal grande nueba con sus tornillos (La Bañeza, 1649) \\ Una cama de nogal sin cordeles (Coomonte de la Vega, 1650) \\ Una cama de chopo buena (La Bañeza, 1714) \\ Una cama rasa (Alija del Infantado, 1720) \\ Una cama con sus balaustres de plata (Laguna de Negrillos, 1721) \\ Una cama de tablas (Fresno, 1726) \\ Seis camas zinco rasas y una de armar (Palacios de la Valduerna, 1726) \\ Una cama de tablas viejas (Miñambres, 1729) \\ Una cama pequeña con su jergón pequeño (Grajal de Ribera, 1730) \\ Otra cama con cordeles y valaustres enguarnizados (Pobladura del Valle, 1734) \\ La madera de una cama con cordeles (Alija del Infantado, 1812) \\ Una cama con su ropa compuesta de un mantón, una manta (Destriana, 1825) \\ Una cama de pino con sus cordeles (Alija del Infantado, 1827) \\ Una tarima de una cama (Valle de la Valduerna, 1829) \\ Otra tarima de otra cama nueba con cordeles de lino (Valle de la Valduerna, 1829) \\ Una cama de encordeladura (La Bañeza, 1829) \\ Una cama con su cordeladura (Quintana del Marco, 1839)
}

Es un término muy común en los inventarios ya que en todas las relaciones de bienes domésticos están las camas como un elemento básico. Su significado es el de 'lugar destinado para descansar', acepción que recoge el DRAE aunque en León se documenta con otras acepciones que no recoge el diccionario académico, como la de 'hueco que se hace a cada lado del carro de hierba para que encaje en él el cuerpo de la vaca' (Le Men, 2004, s.v. cama), significado que no aparece en este corpus. Como se aprecia en los ejemplos, es frecuente que se relacione el término haciendo referencia al tipo de madera y sobre todo con referencias a la presencia de cordeles o encordeladura, 
que es una especie de somier hecho de cordeles. El término encordeladura no lo recoge el DRAE pero se documenta en León, especialmente en el noreste de la provincia. En el corpus se recoge la forma encordeladura o cordeladura como cama con cordeles.

\section{CAMILLA}

Sust. f. 'Mesa, generalmente redonda, bajo la cual suele haber una tarima para colocar el brasero'. 'Cama estrecha y portátil, que se lleva sobre varas a mano o sobre ruedas para transportar enfermos, heridos o cadáveres (DRAE). Término derivado de cama, voz procedente del hispanolatino cama 'yacija, lecho en el suelo', de origen incierto, quizá prerromano (DECH, s.v. cama).

Una camilla (La Nora del Río, 1823)

Solo se ha encontrado un ejemplo del término. En la zona de Astorga, muy próxima al área estudiada, la palabra tiene el significado de 'cuna' (Le Men, 2004, s.v. camilla), acepción que no es recogida por el DRAE. No hay muchos datos para saber con precisión con qué acepción se está utilizando el término, aunque podría pensarse que el significado no es el de 'cuna', puesto que el término aparece en la relación de objetos recogidos en la despensilla.

\section{CATRE}

Sust. m. 'Cama ligera para una sola persona' (DRAE). Término tomado del portugués catre (DECH, s.v. catre).

Un catre de nogal (La Nora del Río, 1823)

Un catre de chopo pintado (La Nora del Río, 1823)

Dos catres de madera vlanca (La Nora del Río, 1823)

Un catre de testera dorada madera de pino (La Bañeza, 1829)

Un catre pintado madera de pino casi sin servicio (La Bañeza, 1829)

Dos catres viejos (Felechares, 1837)

Un catre de chopo con rodapisa blanca (Requejo de la Vega, 1839)

Un catre biejo con rodapisa (Requejo de la Vega, 1839)

Un catre con su rodapisa blanca (Requejo de la Vega, 1839)

Un catre de nogal antiguo con encordeladura (Destriana, 1843)

El significado del término es el que da el $D R A E$, aunque en la época en la que se sitúan los ejemplos tenía el matiz de 'cama portátil'. Solo se recogen en los inventarios analizados muestras del S. XIX, aunque es un término que se documenta a partir de 1578 . Sin embargo, este dato temporal que aporta el corpus analizado no es extraño, si se tiene en cuenta que recopilatorios como el CORDE recogen cuatrocientos setenta y dos casos del término de los cuales solo un número mínimo se sitúan en fechas anteriores al s. 
XIX.

\section{CAMASTRO [camastra]}

Sust. m. 'Lecho pobre y sin aliño' (DRAE). Término derivado de cama, voz peculiar del castellano y el portugués, procedente del hispanolatino cama 'yacija, lecho en el suelo', de origen incierto, quizá prerromano (DECH, s.v. cama).

Una camastra bieja y un zernadero (Castrocalbón, 1814)

Una camastra nueba (Castrocalbón, 1814)

Los únicos ejemplos encontrados pertenecen al mismo inventario, aunque es una palabra de uso común. Es significativo su uso en femenino ya que es una voz común en masculino, tal y como aparece en el DRAE, puesto que la forma en femenino que aparece recogida en alguna edición tiene un significado que no tiene nada que ver con lo esperable en una relación de bienes, teniendo en cuenta además que el diccionario añade que se emplea en Chile. El CORDE recoge varios ejemplos en masculino pero no documenta el término en femenino. Rivas en su léxico sobre la Valdería, comarca a la que pertenece este inventario, recoge la voz camastro que define como 'escaño ancho y grande que servía también, en un apuro, para dormir' (Rivas, 1996: 58). Por tanto, cabe la posibilidad de que el término se esté empleando como un despectivo de cama y haga referencia a una especie de cama pobre y de poca calidad. Además, ambos ejemplos aparecen en la relación junto a términos de ropa tanto de hombre como de mujer, por tanto y teniendo en cuenta que se seguía un orden lógico según los espacios de la casa, puede tratarse de un objeto que se encuentra en un dormitorio, es decir, una especie de cama.

\section{LECHO}

Sust. m. 'Cama, armazón para que las personas se acuesten' (DRAE). Del latín lěctus 'cama' (DECH, s.v. lecho).

El lecho cotidiano con toda su ropa (Castrocalbón, 1814)

El lecho cotidiano que se compone de dos mantas y una sábana y una almuada y la tarima (Palacios de la Valduerna, 1831)

Son los únicos ejemplos encontrados, ambos del S. XIX. El término aparece en ambos casos con el adjetivo cotidiano que se refiere precisamente al lecho común que comprende la cama junto con el colchón y todos los demás complementos para dormir, que en el caso del ejemplo de Palacios cita detalladamente. La escasez de ejemplos quizá se deba a que la voz que más comúnmente se usa en las relaciones de bienes es 
cama, mientras que la expresión lecho cotidiano se trata de un término común en el ámbito jurídico pero quizá no tan familiar para quien iba nombrando la relación de objetos.

\section{CORDEL}

Sust. m. 'Cuerda delgada' (DRAE). Término derivado de cuerda, del latín chürda 'soga, cordel' (DECH, s.v. cuerda).

Un cordel de cáñamo de lino para camas de veinte (Coomonte de la Vega, 1643)

Una cama de nogal sin cordeles (Coomonte de la Vega, 1650)

Una cama de cordeles con su jergón biejo (La Bañeza, 1641)

Una cama de cordel con su jergón (Grajal de la Ribera, 1723)

Otra cama con cordeles y balaustres enguarnizados (Pobladura del Valle, 1734)

La madera de una cama con sus cordeles (Alija del Infantado, 1737)

La madera de una cama con cordeles (Alija del Infantado, 1812)

Una cama con su jergón y cordeles (Alija del Infantado, 1827)

Una tarima de una cama nueba con cordeles de lino (Valle de la Valduerna, 1829)

Una cama de encordeladura (La Bañeza, 1829)

Una cama de cordeles (Santibáñez de la Isla, 1844)

Es un término que aparece frecuentemente unido al sustantivo cama, se habla de "cama de encordeladura" o "cama de cordeles". Se trata de 'una cuerda de grosor intermedio entre la soga y la cuerda'. En León este término restringe el significado general y se utiliza la voz cordel para nombrar 'la cuerda que sujeta la carga del carro' o 'una especie de rienda prendida a un anillo para domar la yunta' (Le Men, 2004, s.v. cordel). En los inventarios estudiados siempre aparece el término relacionado con la voz cama. Se trata de una cama que tenía un trenzado de cuerda entre sus barrotes sobre el que se ponía el colchón.

\section{ENCORDELADURA}

Sust. f. 'Especie de somier hecho de cordeles' (Le Men, 2005, s.v. encordeladura). Término derivado de cordel, y este de cuerda, del latín chŏrda (DECH, s.v. cuerda).

Una cama de encordeladura (La Bañeza, 1829)

Un catre de nogal antiguo con encordeladura (Destriana, 1843)

Solo se ha encontrado este ejemplo del término, ya que es más frecuente encontrar en el corpus "cama de cordeles", o "cama con cordeles". Este dato no es extraño puesto que se trata de un término que se documenta y localiza en la zona noreste de la provincia (Le Men, 2004, s.v. encordeladura), es decir, en la zona opuesta a la estudiada. Se trata de un término que no recoge el DRAE y del que tampoco se recogen ejemplos en el CORDE donde sí se recogen casos de cama de cordeles. 
RASA

Adj. m. y f. 'Plano, liso libre de estorbos' (DRAE). Término derivado de raer, del latín radĕre (DECH, s.v. raer).

Una cama rasa (Alija del Infantado, 1720)

Seis camas zinco rasas y una de armar (Palacios de la Valduerna, 1726)

Es un adjetivo que acompaña en los ejemplos en los que aparece al sustantivo cama, probablemente para diferenciar este tipo de camas de las de armar.

\section{TARIMA}

Sust. f. 'Zona del pavimento o entablado, superior en altura al resto' (DRAE). Del árabe hispánico tarîma, árabe târima 'estrado, tarima' ( $D E C H$, s.v. tarima).

Una tarima vieja (La Bañeza, 1721)

Tres tarimas (Robledo de la Valduerna, 1726)

Otra tarima que sirbe de antepara (Robledo de la Valduerna, 1726)

Una tarima nueba de pino (Jiménez de Jamuz, 1825)

Una tarima de una cama (Valle de la Valduerna, 1829)

Otra tarima de otra cama nueba con cordeles de lino (Valle de la Valduerna, 1829)

Una tarima con tablas de chopo (Quintanilla de Somoza, 1831)

Una tarima de una cama con tablas (Palacios de la Valduerna, 1831)

Una tarima de una cama (Palacios de la Valduerna, 1831)

Un catre con tarima de nogal (Felechares, 1837)

Una tarima con su gergón (Felechares, 1837)

El lecho cutediano que se compone de tarima, jergón, dos mantas y mantón (Santibáñez de la Isla, 1844)

Es un término común que se usa, probablemente, con dos usos. Las tarimas eran de madera, por tanto se trata de un tablado. En muchos casos era una especie de lecho, como se especifica en los ejemplos en los que aparece junto a cama, catre u otros elementos de la cama como la manta.

\section{MOSQUERA}

Sust. f. 'Fresquera, especie de jaula que se coloca en sito ventilado para conservar frescos algunos comestibles o líquidos', 'especie de flecos colgantes de la melena que sirven para espantar las moscas de los ojos de los bueyes o vacas cuando van uncidos' (Le Men, 2007, s.v. mosquera). Término derivado de mosca, del latín mŭsca (DECH, s.v. mosca)

Una mosquera de estopa grande (Pobladura del Valle, 1734)

El término no aparece recogido en el DRAE que recoge la voz mosquero con el significado de 'fleco de correas o cordones que se pone en las cabezadas y jáquimas para que las caballerías se espanten las moscas' y añade en Andalucía. Tomando como 
referencia el único ejemplo recogido, el complemento "de estopa" que acompaña a la palabra permite pensar que el significado con el que se utiliza, puesto que la estopa es una tela gruesa, es el de 'fresquera', ya que de tratarse de la otra acepción no solo espantaría a las moscas sino que permitiría ver al animal. Probablemente, entonces, se trate de un mueble para conservar los alimentos forrado de este tipo de tela. Además aparece en un inventario muy pequeño en el que solo se registran objetos del hogar, no aparecen elementos relativos a la ganadería.

\subsubsection{Accesorios}

\section{CAJÓN [caxón]}

Sust.m. 'Receptáculo que se puede sacar y meter en un hueco determinado, al cual se ajusta, de un armario, una mesa, una cómoda u otro mueble' (DRAE). Término derivado de caja, del latín capsa, probablemente por conducto del catalán caixa (DECH, s.v. caja).

Un bufete con los pies de madera y un caxón debajo del sin llave (Coomonte de la Vega, 1643)

Un bufete de castaño con su cajón sin zerradura ni llave (Laguna de Negrillos, 1721)

Una mesa con su cajón, cerradura y llave (Laguna de Negrillos, 1721)

Una mesa con dos cajones (Genestacio de la Vega, 1721)

Un vufete de nogal vueno con su caxón y en el unos manteles de torzal (Laguna de Negrillos, 1722)

Un bufete con dos cajones de castaño (Miñambres, 1727)

Un bufete con su cajón (Destriana, 1730)

Un cajonito (Miñambres, 1731)

Una mesa con su cajón (Genestacio de la Vega, 1734)

Un bufete con su cajón de una tabla de castaño (Santiago Millas, 1735)

Una mesa con su cajón, zerradura y llave (Laguna de Negrillos, 1737)

Una mesa con tres cajones de madera de nogal (Quintanilla de Somoza, 1831)

Una mesa de cajón para la cocina (Quintanilla de Somoza, 1831)

Un cajón con un sombrerillo (Requejo de la Vega, 1839)

Una mesa con su cajón (Destriana, 1843)

Un cajón de chopo (Destriana, 1843)

El término es muy común especialmente con el significado que da el DRAE, como puede apreciarse en los ejemplos en los que aparece como elemento que conforma un mueble, ya sea un bufete o una mesa. Además de esta acepción, el término se utiliza con otros significados como los de 'caja grande', 'armazón de madera donde se arrodillaban las lavanderas para lavar' o 'armazón de madera que cubre la parte que recubre la piedra de arriba del molino' (Le Men, 2004, s.v. cajón). El último ejemplo que aparece como un objeto independiente podría tener el significado de 'caja grande', puesto que localizado en la panera, de todas es la acepción más lógica. 


\section{CARPETA}

Sust. f. El DRAE en la acepción del término define este como 'cubierta de badana o de tela que se ponía sobre las mesas y arcas para aseo y limpieza. Voz tomada del francés carpette, y este del inglés carpet 'alfombra', que a su vez viene del it.antic. carpita, derivado de carpire, latín carpěre (DECH, s.v. carpeta).

Una carpeta biexa pintada (Coomonte de la Vega, 1645)

Una carpeta (Palacios de la Valduerna, 1728)

Una carpeta de colores buena (Palacios de la Valduerna, 1728)

Una carpeta de lana (Miñambres, 1731)

Una colgadura de cama acarpetada (Grajal de Ribera, 1806)

Una carpeta de ilo y lana bastante usada (La Bañeza, 1829)

Una carpeta de damasco de lana encarnada (La Bañeza, 1829)

Una mesa ordinaria con su carpeta (Requejo de la Vega, 1839)

Una mesa bieja con su carpeta de bayeta (Requejo de la Vega, 1839)

Es una palabra bastante común desde el S.XVII. El significado que tiene entonces, que es el utilizado en el corpus, es el de 'cubierta de tela que se utilizaba para proteger muebles, especialmente las mesas'. A partir del S.XIX toma también el significado de 'útil de escritorio donde se guardan documentos'. Sin embargo, en los ejemplos extraídos del estudio pertenecientes al S.XIX el significado sigue siendo el de 'cubierta', como se puede deducir de las referencias al tejido con el que estaban fabricadas.

\section{ESPEJO [espexo]}

Sust. m. 'Tabla de cristal azogado por la parte posterior, y también de hacer u otro material bruñido, para que se reflejen en él los objetos que tenga delante' (DRAE). Del latín spěcŭlum (DECH, s.v. espejo).

Un espexo de marco dorado (La Bañeza, 1643)

Un espexo grande con su caxa y figuras sobredorados (La Bañeza, 1649)

Un espejo pequeño (La Bañeza, 1714)

Otro tomo de espejo de las cristalinas aguas (Robledo de la Valduerna, 1726)

Una cruz pequeña con sus espejuelos pequeños (Grajal de la Ribera, 1730)

Un espejo grande bueno (Laguna de Negrillos, 1734)

Un espejo con su marco mediano (La Bañeza, 1758)

Un espejo y cinco pares de zapatos (Grajal de la Ribera, 1806)

Un espejo roto y de mal uso (La Bañeza, 1829)

Una lámina y unos espexos (Quintanilla de Somoza, 1831)

Una estanpa de Ntra. Sra. del Prado, un S. Jerónimo y un espejo (Quintanilla de Somoza, 1831)

Un espejo antiguo con labores de cascarilla de plata (Requejo de la Vega, 1839)

Doce espejitos de ojadelata (Requejo de la Vega, 1839)

Es un vocablo de uso general. Formalmente presenta dos variantes espejo, espexo que no son significativas. Es interesante destacar el uso del término espejuelo, ya 
que no se trata de una voz diferente utilizada con las acepciones propias del término, sino de un diminutivo que aparece en el ejemplo con el significado de 'adornos'.

\section{RESPALDO}

Sust. 'Parte de un asiento en que descansa la espalda' (DRAE). Término derivado de espalda, del latín tardío spatǔla (DECH, s.v. espalda).

Un banco de respaldar nuevo de pino al parezer (Coomonte de la Vega, 1643)

Un escañil de respaldo (La Bañeza, 1641)

Un escaño de respaldo (Genestacio, 1721)

Un escaño de respaldo viejo (Coomonte de la Vega, 1724)

Un escañil con su respaldo (Laguna de Negrillos, 1725)

Un cuvo y un escaño de respaldo (Felechares, 1837)

El término aparece fundamentalmente con las voces banco y escaño para diferenciarlos de aquellos que no tenían para descansar la espalda. El primer ejemplo puede tomarse como un verbo, con el significado de 'apoyar la espalda', pero también como un sustantivo ya que el DRAE en la primera entrada del término lo define como un sustantivo. El hecho de que en el corpus se utilice habitualmente el término respaldo para el sustantivo, permite pensar que respaldar se usa como verbo en ese contexto.

\section{TRAVESERO [trabesero]}

Adj. m. 'Dicho de una cosa que se pone de través' (DRAE). Del lat. transvĕrsārius 'que atraviesa' (DEEH, s.v. transvěrsārius).

Un escañil de una tabla con sus traveseros de yerro (Laguna de Negrillos, 1722)

Un bufete de una tabla de nogal hendido por el medio con sus pies y traveseros de yerro (Grajal de la Ribera, 1730)

Tres trabeseros de yerro chiquitos (Quintanilla de Somoza, 1831)

Una mesa mediana de nogal con trabeseros (Felechares, 1837)

El término aparece utilizado como sinónimo de travesaño, por lo que se emplea como sustantivo. En León, la voz travesero presenta diferentes acepciones que no se recogen en el DRAE. Se utiliza con los siguientes significados: 'tizón, trozo grueso de leña que se coloca en la cabecera de la lumbre, sobre el que descansan las rachas'. 'Piedra del hogar'. 'Palo atravesado en las trébedes en el que se cuelgan los potes'. 'Madera travesaña que soporta los dos pinchos de madera (delante del lecho del carro)'. 'Travesaño que sujeta el dental a la cama del arado o al timón directamente. 'Maderas colocadas transversalmente en la cara superior del trillo que sirven para unir las tablas que lo componen'. 'Cargadero donde va fija la cuba' (Le Men, 2011, s.v. travesero). Si observamos los ejemplos que aparecen el corpus analizado, a excepción del ejemplo de 
Quintanilla de Somoza en el que el término aparece aislado y podría tratarse de la pieza que se coloca en la cocina para sujetar las cazuelas, en el resto de ejemplos aparece junto a muebles, por lo que el término se utiliza como una generalización de travesaño, es decir, pieza que atraviesa de una parte a otra de los diferentes muebles cuya función es de sujeción. Formalmente, tampoco se recogen ejemplos del término que presenten diptongo decreciente de la /e/ traveseiro, que sí aparece en las recopilaciones dialectales del S. XX del leonés occidental (op. cit. s.v. travesero).

\section{ALDABILLA [aldavillas]}

Sust. f. 'Pieza de hierro en forma de gancho, que, entrando en una hembrilla, sirve para cerrar puertas, ventanas, cofres, cajas, etc.' (DRAE). Término derivado de aldaba, del árabe daba 'barra de hierro para cerrar una puerta' (DECH, s.v. aldaba).

Unas alacenas con sus aldavillas (Laguna de Negrillos, 1721)

Un poco de yerro y una aldaba (Castrocalbón, 1814)

El significado del término es el que aparece en el DRAE.

\section{ALDABÓN}

Sust. m. 'Aldaba', 'asa grande de un cofre, un arca, etc.' (DRAE). Término derivado de aldaba, del árabe daba 'barra de hierro para cerrar una puerta' (DECH, s.v. aldaba).

Una arca de nogal con cerradura, aldabones y cantoneras (Robledo de la Valduerna, 1726)

Una arca grande con sus aldabones (Quintanilla de Somoza, 1831)

El significado del término es el que da el DRAE.

\section{CANTONERA}

Sust. f. 'Pieza que se pone en las esquinas de las tapas de los libros o de las carpetas, de los muebles o de otros objetos para protegerlos, adornarlos o fijarlos a una base' (DRAE). Del latín cantus (DECH, s.v. canto)

Una arca grande con su cerradura llave sin cantoneras (Coomonte de la Vega, 1643) Un vufete de nogal vueno de dos tavlas con su erraxe y cantoneras y su tapete de guadamaçil usado (La Bañeza, 1649)

Una arca grande de nogal con su llabe, cerradura y cantoneras (Coomonte de la Vega, 1650)

Un arca de nogal con zerradura, llave, cantoneras y aldabones (La Bañeza, 1714)

Un arca de nogal con su cerradura y llave y en ella cantoneras y sus aldabones y en ella se alló un sombrero nuevo aforado y una montera de paño negro, una almuada de lienzo con su lana, una colcha de tierra de Toledo de diferentes colores, una chupa de paño vieja, otra chupa de estameña negra (Laguna de Negrillos, 1721) 
Un arca de nogal con zerradura, llave con quatro cantoneras a la delantera (Laguna de Negrillos, 1725)

Una arca en la sala baja de nogal con zerradura, aldabones y cantoneras (Robledo de la Valduerna, 1726)

Un arca de castaño grande con sus cantoneras, cerradura y llave (Fresno, 1726)

Una arca mediana nueba con llaves, visagras y cantoneras (Jiménez de Jamuz, 1825)

Es un término frecuente en el corpus, especialmente junto a la voz arca, ya que estas eran las que solían llevar cantoneras. Se usa, por tanto, con el significado que da el diccionario académico.

\section{CERRADURA [zerradura]}

Sust. f. 'Mecanismo de metal que se fija en puertas, tapas de cofres, arcas, cajones, etc., y sirve para cerrarlos por medio de uno o más pestillos que se hacen jugar con la llave' (DRAE). Término derivado de cerrar, del latín tardío serare, derivado de sera 'cerrojo', 'cerradura'; la -rr- , que aparece ya en latín vulgar se debe a una confusión popular con serare 'aserrar' (DECH, s.v. cerradura).

Unas alazenas de castaño nuebas con su zerradura (La Bañeza, 1641)

Un arca vieja con su zerradura y llave (La Bañeza, 1641)

Una arca grande con su cerradura, llave sin cantoneras (Coomonte de la Vega, 1643)

Una arca mediana con su cerradura ya biexa (Coomonte de la Vega, 1645)

Una arquita pequeña de nogal con su zerradura y llabe (La Bañeza, 1647)

Un cofre encorado grande bueno con su cerradura y llabe (La Bañeza, 1647)

Una cerradura vieja con una llave vieja (Villamor de Órbigo, 1648)

Una arca grande de nogal con su llabe, cerradura y cantoneras (Coomonte de la Vega, 1650)

Un arca de castaño con zerradura y llave (Alija del Infantado, 1720)

Una arca con zerradura y sin llave (Genestacio de la Vega, 1721)

Una mesa con su caxón mediana con zerradura (Grajal de la Ribera, 1723)

Un arca de nogal con cerradura, aldabones y cantoneras (Robledo de la Valduerna, 1726)

Una rapetera con su zerradura y pie de pino (Robledo de la Valduerna, 1726)

Una arquita chica con cerradura y llave de castaño (Palacios de la Valduerna, 1728)

Quatro panales de zerradura (Destriana, 1728)

Una cerradura de puerta (La Nora del Río, 1823)

Un panal de cerradura sin llabe (Quintanilla de Somoza, 1831)

Una cerradura en sin llave (Palacios de la Valduerna, 1831)

Un arca con cerradura y llave y en ella un azafate con tapadera (Requejo de la Vega, 1839)

Es un término muy común que, como se aprecia en los ejemplos, aparece frecuentemente junto a aquellos objetos que tienen cerradura como son arcas, bufetes o mesas. 


\section{CERROJO}

Sust. m. 'Barreta cilíndrica de hierro, con manija, por lo común en forma de T, que está sostenida horizontalmente por dos armellas, y entrando en otra o en un agujero dispuesto al efecto, cierra y ajusta la puerta o ventana con el marco, o una con otra las hojas, si la puerta es de dos' (DRAE). Del antiguo cerrojo, alterado por influjo de cerrar, supone un latín vulgar verrŭcŭlum, de origen incierto, quizá modificación del clásico verūcŭlum (DECH, s.v. cerrojo).

Un bufete de nogal con sus zerrojos bueno (Robledo de la Valduerna, 1726)

\section{TAPETE}

Sust. m. 'Cubierta de hule, paño u otro tejido, que para ornato o resguardo se suele poner en las mesas y otros muebles' (DRAE). En castellano tapete se tomó del latín tapète, que a su vez viene del griego tápēs, -êtos (DECH, s.v. tapete).

Un tapete verde con su flueco ussado (La Bañeza, 1643)

Un vufete de nogal vueno de dos tavlas con su erraxe y cantoneras y su tapete de guadamaçil usado (La Bañeza, 1649)

Son los únicos ejemplos encontrados, mantienen el significado que aparece en el diccionario académico. Aplicado al objeto con el que aparece en el segundo caso, confiere cierta distinción al mismo.

\section{SOMBRERERA}

Sust. f. 'Caja para guardar el sombrero' (DRAE). Término derivado de sombra, del latín $\breve{u m b r a}$ (DECH, s.v. sombra).

Una sombrerera de baqueta buena (Coomonte de la Vega, 1643)

Es el único ejemplo encontrado que aparece con el significado que da el $D R A E$

\subsection{APEROS Y LABORES AGRÍCOLAS}

El apartado que he denominado "aperos y labores agrícolas" es el que más número de entradas incluye puesto que la zona a la que pertenecen estos inventarios ha basado su economía, aun todavía hoy, en la agricultura y la ganadería, esta especialmente como instrumento de trabajo de las labores agrícolas. Intentando establecer un orden lógico entre las palabras, se han delimitado varios subapartados. En primer lugar se encuentran los que incluyen términos de aperos e instrumentos agrícolas agrupándose por funciones: del arado, del carro, del arreo y otros utensilios de labranza, en este último se incluyen tanto los instrumentos que se usan para labores agrícolas como los 
relacionados con el cuidado y mantenimiento de los animales. Otro subapartado está dedicado a las acciones agrícolas para las que se emplean los objetos mencionados. Para muchas de estas tareas se usan objetos como cestos, etc. que se incluyen en otro subapartado, el de recipientes en el que los términos se agrupan por el material del que están hechos (mimbre, tela ordinaria, etc.). Finalmente y, puesto que se trata de una zona en la que hay viñas aunque no sea principalmente vinícola, se dedica un subapartado a los términos relacionados con la bodega.

\subsubsection{Del arado}

\section{ARADO}

Sust. m. 'Instrumento de agricultura que, movido por fuerza animal o mecánica, sirve para labrar la tierra abriendo surcos en ella' (DRAE). Término derivado de arar procedente del lat. arare (DECH, s.v. arar).

Dos arados con sus tiriyuelas (Alija del Infantado, 1644)

Un dentudo de arado con su manzera (Alija del Infantado, 1644)

Un arado con sus rejas y tiriyuelas de yerro (Alija del Infantado, 1646)

Tres canbas, dos arados (Grajal de la Ribera, 1723)

Un arado (Palacios de Jamuz, 1728)

Un arado con sus rexa (Castrocalbón, 1814)

Un arado con su reja (La Nora del Río, 1820)

Como puede observarse a través de los ejemplos, se trata de un término bastante común en el corpus analizado, sin embargo, aparece localizado en unas zonas muy concretas de toda el área geográfica estudiada. En concreto, el término se encuentra en la zona de Jamuz, Páramo y Bajo Órbigo, mientras que en las zonas de la Valduerna o del entorno de La Bañeza se

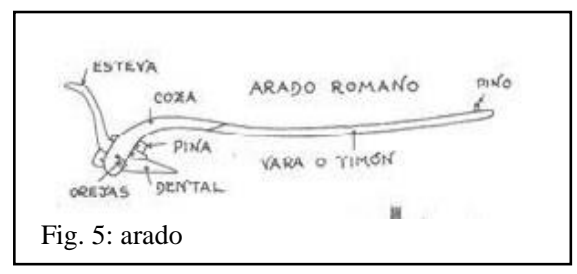
usa la voz ativa. En cuanto al significado del término, se puede deducir por los ejemplos que utiliza la acepción que da el $D R A E$, es decir, 'instrumento de labranza'. No parece que se utilice con el significado con el que se usa en otras partes de León de 'dental y/o cama del arado', ya que en las descripciones que aparecen en los ejemplos se reflejan las partes, si las hay, de las que consta el objeto; en cambio, si se trata solo del 'dental' también se especifica como un elemento aislado. 


\section{ATIVA [atiba]}

Sust. f. 'Arado común'. (Miguélez, 1998: 88). Del latín vulgar * stēva, que parece ser variante dialectal del latín stīva (DECH, s.v. esteva).

Tres atibas y seys rexas. (Bercianos del Páramo, 1647)

Una atiba con su reja (Ribas de la Valduerna, 1726)

Una atiba nueva (Ribas de la Valduerna, 1726)

Dos atibas con sus rejas (Palacios de la Valduerna, 1728)

Una atiba con su reja y clavija de yerro (Palacios de la Valduerna, 1728)

Dos atibas (Miñambres, 1729)

Una atiba con los cabijales cortos (Valle de la Valduerna, 1829)

Una garabita de acanterar y dos trillos con dos atibas (La Isla, 1829)

Una atiba nueba con su tiriyuela (Palacios de la Valduerna, 1831)

Una atiba buena con reja y tirijuelas (Palacios de la Valduerna, 1831)

Se trata de una voz bastante frecuente en los inventarios estudiados. Desde el punto de vista geográfico, se documenta fundamentalmente en el entorno de La Bañeza y en la zona de la Valduerna. El término aparece, normalmente, descrito con todos los elementos que lo forman: rejas, clavijas, cabijales. Por lo que respecta al uso, la entrada no aparece recogida ni en el CORDE ni en los diccionarios académicos. Tan solo se recoge en diccionarios dialectales, como el DALLA o en diccionarios leoneses donde se especifica que se trata de una voz recogida en Santander (op. cit: 88). En el corpus estudiado, los casos encontrados se delimitan a una zona muy concreta donde es significativo que no aparezca la voz arado, mientras que en otras zonas que componen el P.J. de la Bañeza, no se ha tomado ni un solo ejemplo de atiba pero sí aparece la voz arado. Es decir, se trata de dos términos que, siendo sinónimos en su significado, no parecen serlo en el uso que se hace de ellos, al menos desde el punto de vista diatópico.

\section{CLAVIJA [cabixa, cabia]}

Sust. f. 'Trozo cilíndrico o ligeramente cónico de madera, metal u otra materia apropiada, que se encaja en un taladro hecho al efecto en una pieza sólida' (DRAE). Término procedente del latín clavicŭla, mientras que la forma en $c a$ - procede de una variante del latín vulgar cavicla debida a una disimilación (DECH, s.v. cabilla).

Una cabixa de yerro grande (Alija del Infantado, 1647)

Una clavija de yerro (Palacios de Jamuz, 1728)

Una atiba con su reja y clavija de yerro (Palacios de la Valduerna, 1728)

Una reja y una clavija de yerro (Destriana, 1730)

Una tiba con su reja y tiriyuela la mejor y cabia de yerro (Santibáñez de la Isla, 1844)

El término aparece con bastante frecuencia a lo largo de todo el corpus. El significado con el que se utiliza está relacionado con los aperos de labranza, como se ve reflejado en la descripción que hace de la palabra o en el lugar en el que aparece en el 
corpus. En la zona de la Valdería, y probablemente por proximidad en la Valduerna y Bajo Órbigo, el término cabixa o clavija se usa con el significado de 'clavo grande de hierro o de madera que se coloca en los clavijales del timón del arado o del trillo con el fin de unirlos a la trasga del yugo' (Rivas, 1996: 64). En Santibáñez de la Isla, como se observa en el último ejemplo, se utiliza la forma cabia/cavia y su significado es el de 'palo resistente de madera o hierro que, al introducirse en los agujeros de la lanza del carro, trillo u otros aperos de labranza sirve de punto de apoyo a las fuerzas que arrastran tales objetos' (Miguélez, 1998: 139). En cualquier caso, se trata de acepciones parecidas. Dichas acepciones no están recogidas en el DRAE, pero han restringido su significado al campo semántico de la agricultura a partir del significado general que da el diccionario académico.

\section{CABIJAL}

Sust. m. En el DRAE aparece como entrada clavijero que define en su $3^{\mathrm{a}}$ acepción como 'parte del timón del arado en la cual están los agujeros para poner la clavija'. Término derivado de clavo, del latín clavus (DECH, s.v. clavo).

Una atiba con los cabijales cortos (Valle de la Valduerna, 1829)

Tres cabijales de palera (Valle de la Valduerna, 1829)

Una trasga y un barreno de cabijales (Palacios de la Valduerna, 1831)

En el DRAE la entrada cabijales no aparece, así como tampoco se encuentran ejemplos en corpus como el CORDE. En este recopilatorio sí se encuentra la voz clavijero pero en ningún caso con el significado de 'parte del timón del arado'. En el corpus estudiado son pocos los ejemplos encontrados, todos ellos pertenecen al S. XIX y a la zona de la Valduerna. El término siempre se utiliza en plural. En esta zona el plural de esta palabra no se refiere a una parte del timón sino al 'propio timón del arado o del trillo que sustenta los agujeros en los que se introduce la clavija con el fin de unirlos, mediante la trasga, al yugo'. (Rivas, 1996: 64).

\section{DENTUDO}

Sust. m. 'Pieza clave del arado formada por una canal en la que se mete el extremo alargado de la reja para asegurarla' (Le Men, 2005, s.v. dentudo). Término derivado de diente, del latín dens, děntis (DECH, s.v. diente).

Un dentudo de arado con su manzera (Alija del Infantado, 1644)

Se trata de un término que no recoge el DRAE ni aparecen ejemplos en el CORDE. Le Men lo localiza solo en la zona de La Bañeza (Le Men, 2005, s.v. dentudo), 
zona a la que pertenece este corpus, aunque del término dentudo solo se ha recogido este ejemplo. Este hecho puede tratarse de una casualidad ya que es un término común en la zona. La voz correspondiente dental, que recoge el DRAE, de la que se encuentran ejemplos en el CORDE y está documentada en diferentes puntos de la provincia de León y de otras limítrofes, tampoco aparece en este corpus.

\section{GARGANTA}

Sust. f. El DRAE en su $7^{\mathrm{a}}$ acepción define el término como 'ángulo que forma la cama del arado con el dental y la reja' (DRAE). De la raíz onomatopéyica garg- que imita el ruido del gargajeo y otros que se hacen con la garganta (DECH, s.v. gargajo).

Tres canbas, dos arados y una garganta de enzina (Grajal de la Ribera, 1723)

Con ese término se denomina en algunas zonas 'la cama del arado'. Este significado se utiliza especialmente en la zona occidental y central de León, zona en la que se encuentra el único ejemplo encontrado. En zonas más orientales se utiliza con este significado el término camba. El hecho de que en el ejemplo encontrado se documenten ambos términos permite pensar que se trata de palabras con distinto significado. Por tanto, la acepción sería la empleada en la zona más occidental de 'pieza del arado'.

\section{MANCERA [manzera, manxera]}

Sust. f. 'Esteva del arado' (DRAE). Podría ser un latín vulgar *maniciaria, derivado de un *manicia, que se hallaría en Cerdeña, o más bien *manuciaria, derivado de manucium, pero es más probable que resulte de un cambio de prefijo de manicella, 'manecilla, manija' (DECH, s.v. mano).

Un dentudo de arado con su manzera (Alija del Infantado, 1644)

Un arado con su manxera sin timón (Alija del Infantado, 1647)

Se trata de un término que se emplea con dos acepciones. En zonas comprendidas en este partido judicial presenta estos dos significados, así en Santibáñez de la Isla se llama manjera a la 'esteva del arado' (Miguélez, 1998: 162), mientras que en la zona de la Valdería manjera es 'agarradero del arado' (Rivas, 1996: 153-154). En Benavente, zona próxima al lugar en el que se documentan los ejemplos, es la 'pieza de madera curva por la que sujeta el arado el que lo conduce' (Barrio, 2000: 182). El significado exacto con el que se utiliza en los ejemplos no se conoce, aunque es probable que sea el de 'agarradero'. 


\section{REJA [rexa]}

Sust. f. 'Instrumento de hierro, que es parte del arado y sirve para romper y revolver la tierra' (DRAE). Del latín rēgǔla 'barra de metal o de madera' (DECH, s.v. reja).

Una tiba con su reja (Vidriales, 1645)

Una rexa de yerro de arar (Coomonte de la Vega, 1650)

Una tiriyuela, una reja (Alija del Infantado, 1720)

Un arado con su reja (Palacios de Jamuz, 1728)

Dos atibas con sus rejas (Palacios de la Valduerna, 1728)

Una atiba con su reja y clavija de yerro (Palacios de la Valduerna, 1728)

Dos atibas con sus rejas y clavijas de yerro (Palacios de la Valduerna, 1728)

Una reja y una clavija de yerro (Destriana, 1730)

Una ativa con su reja (Requejo de la Vega, 1735)

Una atiba con tres rejas (Requejo de la Vega, 1735)

Dos rexas (Requejo de la Vega, 1735)

Una reja vieja (Alija del Infantado, 1812)

Un arado con sus rexa (Castrocalbón, 1814)

Un arado con su reja (La Nora del Río, 1820)

Una reja (Castrillo de la Valduerna, 1828)

Una tiba con su reja y tiriyuela (Santibáñez de la Isla, 1844)

El significado más utilizado para el término en este corpus es el que señala el $D R A E$. En otras zonas, no solo de León, se utiliza el término en plural con la acepción de 'piezas de madera con las que se ensamblan y hacen más resistentes las piezas de las ruedas del carro' (Le Men, 2012, s.v. reja). En los ejemplos del corpus en los que aparece el término en plural, se sigue utilizando la palabra con la primera acepción puesto que siempre acompaña a arado o a tiva, dato que concreta el significado. Hay un ejemplo en el que solo se documentan dos rejas, donde la falta de más información no permite saber con exactitud con qué significado se está utilizando el término. Formalmente, todos los ejemplos presentan la variante castellana y no se recogen ejemplos de variantes dialectales como reya, reia, reixa, entre otras.

\section{TELERA [tiriyuela, tiriguela, tirigüela, tirijuela]}

Sust. f. 'Travesaño de hierro o de madera que sujeta el dental a la cama del arado o al timón mismo, y sirve para graduar la inclinación de la reja y la profundidad de la labor' (DRAE). Voz que designa varios objetos en forma de palo o de barra de hierro. Probablemente derivado del latín tēlum 'dardo' (DECH, s.v. telera).

Dos arados con sus tiriyuelas (Alija del Infantado, 1644)

Una tiriyuela de yerro (Alija del Infantado, 1644)

Dos tiriguelas de yerro (Coomonte de la Vega, 1645)

Un arado con sus rejas y tiriyuelas de yerro (Alija del Infantado, 1646)

Una gaza y una tirigüela (Grajal de la Ribera, 1750)

Una atiba nueba con su tiriyuela (Palacios de la Valduerna, 1831)

Una atiba buena con reja y tirijuelas (Palacios de la Valduerna, 1831) 
Es un término común, se utiliza con el significado que da el $D R A E$, aunque la telera 'es un travesaño de madera que une la cama y el dental, y no siempre es graduable' (Fernández Marcos, 1984: 66-69). Formalmente, es un término que presenta muchas variantes que responden a fenómenos de metátesis, asimilación o disimilación, siendo la variante tiriyuela la más común en el corpus y la más documentada en la provincia de León, aunque Fernández Marcos afirma que las variantes teregüela y tirigüela son las más frecuentes en la Ribera del Órbigo (op. cit. 66-69).

\section{TIMÓN}

Sust. m. 'Palo derecho que sale de la cama del arado y al que se fija el tiro' (DRAE). Del latín tèmo, -ōnis 'timón de carro o de arado', aunque casi todas las formas romances suponen una variante mal explicada *tìmo, ōnis, que debe de ser antigua y probablemente existente en latín vulgar (DECH, s.v. timón).

Un timón nuevo de bedul (Coomonte de la Vega, 1645)

Un arado con su manxera sin timón (Alija del Infantado, 1647)

Son los únicos ejemplos recogidos, aunque como parte del arado es un término común. El contexto del segundo ejemplo permite delimitar el significado que, en este caso, coincide con el que aparece en el diccionario académico. En el primer ejemplo no hay más datos que permitan saber con exactitud la acepción concreta ya que en León este término también se usa con el significado de 'palo que une el trillo al yugo', acepción que no recoge el DRAE; o 'lanza o pértiga del carro' (Le Men, 2011, s.v. timón).

\section{TIRADERO}

Sust. m.

Un tiradero bueno con sus yerros (La Nora del Río, 1645)

Un trillo con su tiradero (La Antigua, 1648)

Dos tiraderos con sus yerros (Coomonte de la Vega, 1650)

Unas sogas de cáñamo de meter paxa con sus tiraderos y usadas (Alija del Infantado, 1650)

Dos tiraderos de trillar con sus yerros buenos (Alija del Infantado, 1650)

Tiraderos de yerro (Huerga de Garaballes, 1720)

Un trillo de pino con su tiradero (Huerga de Garaballes, 1720)

Dos tiraderos con sus yerros (Genestacio de la Vega, 1721)

Un trillo nuevo con su tiradero (Grajal de la Ribera, 1723)

Es un término muy común que se utiliza con el significado de 'palo que une el trillo al yugo'. Se trata por tanto de un sinónimo de timón cuyo uso es mayor que el de este término ya que de él solo se recogen dos ejemplos, quizá con el significado de 'parte del arado de la que se sujeta la yunta'. El DRAE no recoge este término y en el 
CORDE tampoco se registran ejemplos con esta acepción. Sin embargo, en el corpus analizado es un término de uso frecuente que refleja que se trata de una voz usual para designar al timón en la acepción señalada, tanto en Zamora como en la provincia de León.

\subsubsection{Del carro}

\section{ANGARILLA}

Sust. f. El DRAE define el término en su $6^{\text {a }}$ acepción como 'armazón de cuatro palos clavados en cuadrote de los cuales penden unas como bolsas grandes de redes de esparto, cáñamo u otra materia flexible, que sirve para transportar en cabalgaduras cosas delicadas, como vidrios, loza, etc.' De *angariellae, diminutivo del latín angariae 'prestaciones de trasporte, trasporte obligado en caballería o en carro', 'la silla de caballo empleada para este efecto'. De angarillas o anguerillas por metátesis salió la variante arganillas, de donde se extrajo un seudo-primitivo árganas o árguenas (DECH, s.v. angarillas).

Un carro con sus ruedas, berbixones, angarillas, sogas (Grajal de la Ribera, 1723)

Solo se ha recogido este ejemplo que, de acuerdo con el contexto en el que aparece, tiene el significado de 'armazón que se coloca en la parte anterior y/o posterior del carro para sujetar la carga' (Rivas, 1996: 102) Este autor señala que la de la parte anterior está hecha con tablas de madera y la de la parte posterior con palos de mimbre, remitiendo así al término cañizo.

\section{BRAZUELO}

Sust. m. 'Pértigo de los carros en forma de $\mathrm{Y}^{\prime}$ (DRAE). Término procedente del lat. brachiǒlum 'brazuelo' (DECH, s.v. brachiŏlum).

Un brazuelo viexo (Miñambres, 1727)

Una bara de brazuelo (Destriana, 1730)

La escasez de ejemplos tal vez se deba a una casualidad ya que se trata de una palabra de uso general en esta zona, como se demuestra en los diccionarios dialectales. La Academia, a partir de la edición de 1950, incluye en sus acepciones la de 'pértigo de carro' señalando que con este significado se usa en León. Actualmente, da este significado en su $4^{\text {a }}$ acepción indicando que se usa en Asturias, León y Zamora. Estos datos, junto al lugar que ocupan los ejemplos en la lista de enseres inventariados, hacen 
suponer que el significado con el que se utiliza es el propio de la zona leonesa.

\section{CAMBA}

Sust. f. El DRAE señala que en Asturias, Cantabria y Salamanca este término tiene la acepción de 'pieza curva de la rueda de un carro'. Del céltico *cambos 'curvo' (DECH, s.v. cama II).

Dos cambas de madera (Alija del Infantado, 1644)

Unas cambas (Coomonte de la Vega, 1734)

Es una voz común en la zona, aunque solo se hayan registrado dos ejemplos a lo largo del corpus. En toda la zona leonesa, el término presenta otros significados que no recoge el DRAE y concretamente en el área comprendida por este estudio, el término presenta dos acepciones, la indicada por el DRAE 'pieza curva de madera de la rueda de un carro' y 'parte curva del tiradero

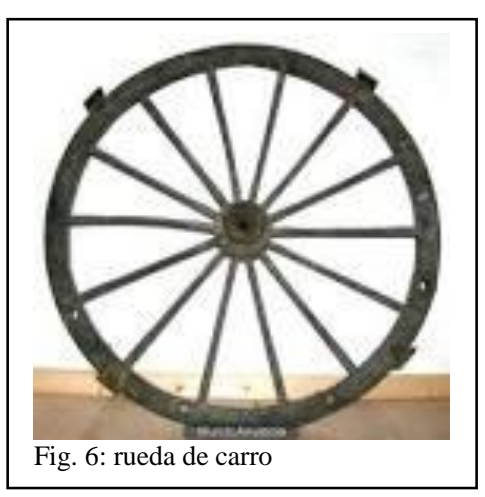
del arado en la que se inserta la reja y el dental', acepción que no contempla el diccionario académico (Le Men, 2004, s.v. camba). Los datos que aportan los ejemplos son escasos y no nos permiten indicar el significado concreto con el que se utiliza en cada caso. Formalmente, la conservación de /-mb-/ es regular en la zona leonesa, pero formas como cambio aparece en textos de Burgos del S. XIII. Por tanto debe suponerse que la forma cambiar se conservó ocasionalmente en Castilla.

\section{CAMBAR}

Verb. 'Formar las ruedas del carro con dos cambas'. Es derivado de camba.

Un maço de cambar carros (Alija del Infantado, 1644)

Es el único ejemplo recogido del término y no se documenta en los diccionarios de la zona. Covarrubias señala que la camba es el nombre que se le da a la pieza corvada del arado y a los trozos que reciben los rayos de la rueda que se se van torciendo para formar el redondo en ella (Covarrubias, s.v. camba). Por tanto, cambar podría interpretarse como un verbo que designa la acción de dar forma a la rueda. Teniendo en cuenta que en el ámbito rural el término camba aplicado al carro, como en el ejemplo, es la pieza curva de la rueda, forrada con un aro de hierro para evitar el desgaste (Le Men, 2004, s.v. camba), también incluso podría interpretarse como la 
acción de forrar con el aro de hierro la rueda del carro. Formalmente, el término mantiene uno de los rasgos típicos del leonés, la conservación de /-mb-/.

\section{CAÑIZO}

Sust. m. 'Tejido de cañas y bramante o tomiza que sirve para camas en la cría de gusanos de seda, armazón en los toldos de los carros, sostén del yeso en los cielos rasos, etc.' 'Timón del trillo' (DRAE). Término derivado de caña, del latín canna (DECH, s.v. caña).

Dos cañizos (La Antigua, 1648)

Quatro cañizos tres en el establo y uno en el corral (Laguna de Negrillos, 1725)

Un cañizo (Fresno, 1726)

Dos dozenas de cañizos (Destriana, 1730)

Se trata de un término propio del campo semántico de la ganadería y agricultura que alterna en el corpus con otras voces que podríamos considerar sinónimas, aunque con matizaciones. En la zona de La Bañeza se define el término como 'tejido o armazón de mimbre o de otro tipo de varas para los extremos anterior y posterior del carro' (Rivas, 1996: 60). Con un significado próximo encontramos en el corpus la voz costanas que define Rivas como 'cada uno de los dos cañizos de madera que se colocan a ambos lados del carro con el fin de que no se caigan los objetos menudos que se quieren transportar'. De estas definiciones podemos deducir que la diferencia está en que uno se coloca en los extremos y otro en los laterales del carro, aunque también podría haber diferencias en los materiales de los que están fabricados los objetos. En el CORDE no se recogen ejemplos con esta acepción.

\section{CARRETA}

Sust. f. 'Carro largo, estrecho y más bajo que el ordinario, cuyo plano se prolonga en una lanza en que se sujeta el yugo. Comúnmente tiene solo dos ruedas, sin herrar' (DRAE). Palabra derivada de carro, del latín carrus (DECH, s.v. carro).

Una carreta buena errada (Laguna de Negrillos, 1734)

Además del significado que da el DRAE, en León el término se utiliza con otras acepciones no recogidas por el diccionario académico. Por ejemplo se define también carreta como 'especie de carro, pero un poco mayor o más pesado' o 'plataforma hecha con una horquilla de madera cubierta de tablones, sobre la que se colocan piedras para hacer peso, con el fin de allanar la tierra (Le Men, 2004, s.v.carreta). La escasez de 
ejemplos del corpus estudiado no nos permite determinar el significado con el que se utiliza el término en estos inventarios.

\section{CARRO}

Sust. m. 'Carruaje de dos ruedas, con lanza o varas para enganchar el tiro, y cuya armazón consiste en un bastidor con listones o cuerdas para sostener la carga, y varales o tablas en los costados, y a veces en los frentes, para sujetarla' (DRAE). Del latín carrus (DECH, s.v. carro).

Un carro de yerba (Castrocalbón, 1643)

Un carro con todos sus aparexos, pernillas y borbixones (Alija del Infantado, 1644)

Dos carros de estacas (Coomonte de la Vega, 1645)

Un carro bueno con sus ruedas y armaduras y berbixones (Alija del Infantado, 1646)

Doçe carros de paxa (La Antigua, 1647)

Un carro con sus ruedas (La Antigua, 1647)

Un carrico de paxas (La Antigua, 1648)

Quinze carros de avena (Alija del Infantado, 1720)

Cosa de veinte carros de paxa, trigo y zenteno (Grajal de Ribera, 1723)

Un carro ya viejo (Ribas de la Valduerna, 1726)

Medio carro de yerva (Ribas de la Valduerna, 1726)

Dos carros con sus aparejos (Miñambres, 1727)

Un carro de zepas peladas (Palacios de la Valduerna, 1728)

Un carro de yerba buena (Palacios de la Valduerna, 1728)

Un carro bueno con sus aparejos (Palacios de la Valduerna, 1728)

Catorce carros de paja (Palacios de la Valduerna, 1728)

Un carro biejo con sus pernillas, costanas y bordigones (Palacios de la Valduerna, 1728)

Un carro con sus ruedas, berbixones y argarillas (Palacios de la Valduerna, 1730)

Un carro con todas sus armaduras (Genestacio de la Vega, 1734)

Un carro con sus aparejos (Santiago Millas, 1735)

Un carro usao (Alija del Infantado, 1812)

Un carro de paxa (La Nora del Río, 1820)

Un carro con sus perdiñas y bordigones (Castrillo de la Valduerna, 1828)

Un carro herrado vueno con sus aperios (Valle de la Valduerna, 1829)

Un carro usado (Quintanilla de Somoza, 1831)

Se trata de un término muy común, no solo en esta zona sino a lo largo de toda la Península. Por ello, puesto que estamos ante una zona agrícola, es lógico que los ejemplos encontrados sean numerosos. A lo largo del corpus la palabra tiene dos significados. Uno es el significado general de 'vehículo de dos ruedas de tiro animal'. Cuando el término se usa con esta acepción es frecuente que se documente haciendo referencia a los diferentes elementos que componen el vehículo. También se usa con el significado de 'medida', carros de hierba, de paja, etc. El carro de hierba equivale a once áreas y sesenta y ocho centiáreas, el resto se refiere a medida de tres cargas de grano, 
por ejemplo carro de paja, trigo, avena, etc. El DRAE solo hace referencia a "carro de tierra" referido a Santander.

\section{COLAÑO}

Sust. m. 'Tejido de varas rectas y delgadas, especie de zarzo, que sirve para cerrar por delante y por detrás la caja del carro' (Le Men, 2004, s.v. culaño).

Dos colaños de meter paja (Castrillo de la Valduerna, 1828)

Dos colaños (Santibáñez de la Isla, 1844)

Es un término que el DRAE recoge con la variante coloño con dos sentidos diferentes, como voz regional de Burgos con el valor de 'cesto' y como voz de Cantabria con el valor de 'haz de leña' y el CORDE solo presenta ejemplos también con esta forma, concretamente tres casos con el significado de 'haz de leña'. En León se documenta en el centro-oeste y suroeste, es decir, entre otras en la zona comprendida en este estudio. No obstante, solo se recogen dos ejemplos del término que por su significado es sinónimo de la voz cañizo. En algunos vocabularios de la zona la diferencia entre estas dos palabras está en que el cañizo es de mimbre y se coloca en la parte posterior del carro, mientras que el colaño está hecho con tablas de madera y se coloca en la parte posterior (Rivas, 1996: 85). Otros autores relacionan el término con la voz costanas y lo diferencian en que "mientras las costanas se apoyan en los estarojos, los culaños eran sostenidos por el palo del culaño, que iba de una costana a otra" (Miguélez, 1998: 144). Sin embargo, también parece claro que las costanas se colocan más bien en los laterales. No obstante, todos estos términos aparecen en distintos inventarios procedentes de distintos pueblos. Este dato no nos permite establecer con exactitud la diferencia en el empleo de uno u otro término.

\section{CORZA}

Sust. f. 'Hembra del corzo' (DRAE). Del lat. cŭrsāre, 'correr' (DEECH); del v. *corzar o acorzar, 'cercenar, dejar sin cola', der., a su vez, del lat. vulg. *curtiare íd., que viene de curtus, 'truncado' (por comparación con el deslizarse furtivo del corzo): "MeyerLübke, $R E W, 2419$, cree que la comparación es con la cornamenta del animal, pero las cuernas del corzo son demasiado pequeñas para poderse comparar con la entretejedura de la narria" (DECH, s.v. corzo).

Dos pares de corzas deshechas (Alija del Infantado, 1644) 
En León el término corza se usa con otros significados que no recoge el DRAE. Se llama corza al 'tablado de madera que sirve para arrastrar pesos grandes, especialmente piedras' y a 'cada una de las piezas que se acoplan al carro para transportar hierba' (Le Men, 2004, s.v. corza). Teniendo en cuenta el contexto en el que aparece el único ejemplo encontrado, parece lógico suponer que la voz en este caso se use con la acepción de 'pieza que se acopla al carro', ya que se encuentra en la relación entre «un carro con sus aparexos» y «un maço de cambar carros». Esta acepción es además más frecuente en la zona sur de la provincia, mientras que el otro significado se documenta más en la zona de la montaña.

\section{COSTANA}

Sust. f. El DRAE señala que en León, Palencia y Zamora este término tiene el significado de 'adral' voz que define el diccionario como 'cada uno de los zarzos o tablas que se ponen en los costados del carro para que no se caiga lo que va en él'. Término derivado de cuesta 'espalda' del lat. cŏsta 'costilla', 'costado, lado' (DECH, s.v. cuesta).

Dos costanas de meter paxa buenas (Coomonte de la Vega, 1645)

Dos costanas buenas (Vidriales, 1645)

Unas costanas de meter paja (Palacios de la Valduerna, 1730)

Unas costanas de tabla (Castrocalbón, 1814)

Un par de costanas de vimbre (Valle de la Valduerna, 1829)

Unas costanas para carro (Quintanilla de Somoza, 1831)

Las mantas con cuartaderos y costanas (Santibáñez de la Isla, 1844)

En algunas zonas de León el término tiene otro uso, no recogido en el DRAE 'tejido de mimbres que se coloca debajo de las tejas al cubrir la casa' (Le Men, 2004, s.v. costanas). Sin embargo, el significado de esta palabra en la zona estudiada es el de 'laterales del carro'. Por ello, es lógico pensar que con esta acepción se está utilizando el término en todos los ejemplos mostrados, aunque en algunos se especifique que son "para carro" o se diga "costanas de meter paja" o simplemente no se indique ninguna matización.

\section{MEÚL [moyl, moil]}

Sust. m. 'Pieza central de la rueda del carro en la que se introduce el eje' (Le Men, 2007, s.v. meúl). Probablemente se trata de un derivado de medius (DECH, s.v. medio).

Un banco de moyl de carro (Alija del Infantado, 1644)

Un moyl biexo que fue banco (Coomonte de la Vega, 1645)

Un banco de moyl pequeño (La Antigua, 1647)

Un vanco de moyl (La Antigua, 1647)

Un banco de moil grande (Laguna de Negrillos, 1722) 
Un banco de moyl (Ribas de la Valduerna, 1726)

Un banco de moyl (Fresno, 1726)

Un banco de moil (Palacios de la Valduerna, 1727)

Un banco de moil (Palacios de la Valduerna, 1728)

Un moil (Grajal de la Ribera, 1730)

Un banco de moil grande (Laguna de Negrillos, 1740)

Es un término que no aparece recogido en el DRAE, aunque es frecuente en toda la zona noroeste de la Península, dato que explicaría el número de casos de este corpus. Formalmente, solo se recogen las variantes moil, moyl que no aparecen en la documentación medieval, pero, sin embargo, en este corpus aparece de forma sistemática en todos los ejemplos.

\section{PERNILLA}

Sust. f. El DRAE recoge la entrada pernales que define como 'estacas largas que se ponen en los bordes del carro para sujetar y aumentar la altura de los cañizos y lograr que cargue mucha paja o heno', y localiza en León. Término derivado de pierna, del latín pĕrna (DECH, s.v. pierna).

Un carro con todos sus aparexos, pernillas y borbixones (Alija del Infantado, 1644)

Un carro biejo con sus pernillas, costanas y bordigones (Palacios de la Valduerna, 1728)

Un carro con sus pernillas, berbixones y ruedas (Grajal de la Ribera, 1750)

Unas pernillas grandes (Castrocalbón, 1814)

Un carro con sus pernillas y bordigones (Castrillo de la Valduerna, 1828)

Un carro con pernillas y bordigones y mantas de la paja y costanas del abono (Palacios de la Valduerna, 1831)

Es un término muy común en los inventarios que recogen aperos de labranza. Se usa siempre en plural puesto que siempre van dos, una a cada lado del carro. Forman parte de los aperos de labranza y son próximas a las costanas, también recogidas en estos inventarios, pero se diferencian de ellas en que son más altas y permiten así transportar hierba o paja. Aparecen en al carro sujetas por los bordigones, de ahí que se trate de términos que aparecen juntos en las relaciones de enseres.

\section{PINA}

Sust. f. 'Mojón terminado en punta'. 'Cada uno de los trozos curvos de madera que forman en círculo la rueda del coche o carro, donde encajan por la parte interior los rayos y por la exterior se asientan las llantas de hierro' (DRAE). De origen incierto, quizá prerromano, pero más bien parece procedente del germánico pinna (DECH, s.v. pina).

Una pina de yerro con la boca de acero de mas de tres libras (Coomonte de la Vega, 1643) 
Es un término muy común que se utiliza con varias acepciones, aunque en este corpus solo se recoja este ejemplo. Una de esas acepciones es la segunda que recoge el $D R A E$. La matización "de yerro" permite pensar que se trate o bien de 'cada pieza de hierro, de radio a radio y por debajo de la llanta, en la rueda del carro' (Rivas, 1996: 183); o bien de 'la pieza movible de hierro que se introduce en los extremos del eje del carro y que sirve en el mismo de tope a las ruedas' (Miguélez, 1998: 169). La falta de información en el propio ejemplo no permite precisar con más exactitud el significado empleado.

\section{SEGUNDERA}

Sust. f. El DRAE da la siguiente acepción del término empleado como sustantivo 'manecilla que señala los segundos en el reloj'. Derivado de segundo, del latín secŭndus (DECH, s.v. seguir).

Tres segunderas y dos palos de roble (Castrocalbón, 1814)

Empleado como sustantivo, es el único ejemplo recogido del término y se emplea con una acepción que no recoge el diccionario académico. Se denomina segundera a 'cada una de las piezas que van una a cada lado del eje o pieza central de la rueda del carro' (Rivas, 1996: 214). Se trata de un término que aparece documentado en la provincia de León, pero también en Zamora en la zona de Sanabria (Miguélez, 1993: 651). Puesto que se documenta en zona occidental, es frecuente recogerlo con presencia de diptongo decreciente segundeira, pero en el único ejemplo recogido aparece bajo la forma castellana.

\section{PALO}

Sust. m. 'Pieza de madera u otro material, mucho más larga que gruesa, generalmente cilíndrica y fácil de manejar' (DRAE). Del latín palus, -i (DECH, s.v. palo).

Un palo de roble y un pilón (Castrocalbón, 1814)

Un roldo y dos palos de chopo (Castrocalbón, 1814)

Tres segunderas y dos palos de roble (Castrocalbón, 1814)

Es un término polisémico, aunque en el corpus estudiado solo se usa con el uso que aparece en el DRAE como primera acepción. En los ejemplos encontrados siempre se trata de una pieza de madera y por ello suele aparecer especificando el tipo de madera del palo en cuestión. 


\section{VERBIÓN [borbixon, berbixon, bordigón]}

Sust. m. 'Cada uno de los dos maderos perpendiculares a la vara del carro que limitan la caja del carro por delante y por detrás. Llevan agujeros en los extremos en que se introducen las pernillas o palos verticales de la armadura del carro' (Le Men, 2012, s.v. verbión).

Un carro con todos sus aparexos, pernillas y borbixones (Alija del Infantado, 1644)

Un carro biejo con sus pernillas, costanas y bordigones (Palacios de la Valduerna, 1728)

Un carro con sus pernillas, berbixones y ruedas (Grajal de la Ribera, 1750)

Un carro con sus pernillas y bordigones (Castrillo de la Valduerna, 1828)

Un carro con pernillas y bordigones y mantas de la paja y costanas del abono (Palacios de la Valduerna, 1831)

Es una voz común en el corpus que se registra solo en la zona noroccidental de la Península, zona a la que pertenece la estudiada en este corpus, siempre se utiliza en plural. Se trata de un elemento que se incorpora al carro, como se refleja en los ejemplos, ya que siempre aparece con las voces carro y pernillas que son 'los palos que se sitúan en los laterales del carro y que contienen ciertos huecos en los que se introducen las pernillas' (Rivas, 1996: 49). El DRAE no recoge el término y el CORDE no presenta ningún caso en ninguna de sus variantes.

\subsubsection{Del yugo y de uncir}

COBERTOR (vid. ajuar doméstico/ropa de hogar)

\section{CORNAL}

Sust. m. y f. El DRAE define el término como 'correa para uncir los bueyes'. Se trata de un vocablo procedente del lat. cornu (DECH, s.v. cornal).

Un yugo con sus cornales (Castrocalbón, 1643)

Un yugo viejo con sus mullidas y una cornal y sobeyuelo y trasga (Alija del Infantado, 1644)

Un yugo con sus melenas y un cornal (Coomonte de la Vega, 1645)

Un yugo con sus cornales (Laguna de Negrillos, 1721)

Una cornal usada (Palacios de Jamuz, 1728)

Una cornalina de leche (Audanzas del Valle, 1736)

Unos cornales (Grajal de la Ribera, 1750)

Un yugo con cornales y mullidas (Castrocalbón, 1814)

Unas cornales nuevas (La Nora del Río, 1820)

Un yugo, cornales y sobeos con su trasga (Quintanilla de Somoza, 1831) 
La voz se encuentra recogida en todo el corpus analizado ya que se trata de un vocablo muy común. El término se usa fundamentalmente junto a la palabra yugo indicando los aparejos que componían este. Solo en algunos casos aparece inventariado de forma aislada. Se usa generalmente en femenino y plural porque, en realidad, se trata de dos correas largas, hechas de cuero, que van sujetando al yugo los cuernos de la pareja (Le Men, 2008, s.v. cornal). Se puede observar que encontramos casos en masculino, tanto singular como plural, y en femenino singular. En los ejemplos citados aparece un cornal y una cornal, en dos inventarios próximos en el año (1644 y 1645) y próximos en la zona, puesto que se trata de dos pueblos colindantes. Este dato puede indicar que se utilizaba el término en un género u otro indistintamente. En todo caso, se trata de una voz frecuente que, aunque la Academia no señala su uso dialectal, parece que es frecuente en la zona noroccidental (op. cit s.v. cornal). El CORDE prácticamente no refleja casos anteriores al S. XX.

Es significativo el uso del término cornalina, que en este caso no parece tener el significado de 'correa', si tenemos en cuenta el adyacente con el que aparece. Esta especificación parece estar más próxima al significado del término cornalina (vid. cornalina). Así se podría pensar que se trata de una piedra de color blanco, aunque el lugar en el que aparece en el corpus no es muy lógico, puesto que la palabra se encuentra después de referir a los animales y entre «dos candiles y un pozal». Solo se ha encontrado ese ejemplo tanto en el corpus analizado como en los casos recogidos en el CORDE.

\section{CUARTADERO}

Sust. m. 'Palo que une el trillo al yugo' (Le Men, 2004, s.v. cuartadero). El DECH señala el témino cuarta que en Asturias tiene un significado similar 'yunta de bovinos que engancha a la zaga del carro para moderar su movimiento en las bajadas', como palabra derivada de cuarto, del latín quartus, indicando que se ha empleado el ordinal partitivo cuarto para expresar una división de un objeto, aunque no se exactamente en cuatro partes. Probablemente, el término cuartadero derive de cuarto y su origen esté en el lat. quartus (DECH, s.v.cuarto).

El cuartadero de atropar las trillas con su dogal (Santibáñez de la Isla, 1844)

Un trillo usado con su tiradero y cuartadero de yerro (Santibáñez de la Isla, 1844)

Es un término que no aparece recogido en el DRAE. En el corpus solo se han recogido estos dos casos. Probablemente se trata de una casualidad ya que en esta zona 
de la Ribera del Órbigo y sureste de León es el nombre que se da a este objeto que en otras zonas leonesas recibe el nombre de camboneta, cambona, cambón, timón (op. cit. s.v. cuartadero), voces que no se registran en los inventarios analizados, aunque sí se registra con un mayor número de casos la voz tiradero, usada co el mismo significado. El significado del término en esta zona es el de 'palo grueso, rastrero del que tira la pareja de bueyes para juntar la trilla en la parva' (Miguélez, 1998: 213).

\section{MELENA}

Sust. f. 'Almohadilla o piel que se pone a los bueyes bajo el yugo' (DRAE). Término de origen dudoso, aunque ciertamente no latino, quizá viene del árabe melîna 'ablandada', participio pasivo del verbo lân 'ser blando', 'ablandar' (DECH, s.v. melena).

Un yugo con sus melenas y un cornal (Coomonte de la Vega, 1645)

Un yugo con sus melenas (Coomonte de la Vega, 1650)

Un yugo con cornales y melenas largas (Grajal de la Ribera, 1723)

Un yugo de arar con sus cornales y melenas (Palacios de la Valduerna, 1730)

Es un término de uso común en toda la provincia aunque presenta bastante confusión terminológica. Se entiende por melena la 'almohadilla que se pone para que que no dañe el yugo al animal', pero también se llama así a la 'cubierta de piel que se coloca encima de la mullida' y al 'fleco que se pone delante de la mullida para evitar que las moscas molesten al animal en la cara' (Le Men, 2007, s.v. melena). Analizando los ejemplos encontrados en el corpus y, teniendo en cuenta tanto el contexto en el que aparece este término como el contexto en el que aparece el término mullida, es lógico pensar que en esta zona se denomina melena a la 'almohadilla', puesto que en algunos ejemplos en los que se da una relación de objetos aparece o bien un término o bien el otro, pero en ningún caso aparecen juntos. Este dato prueba que son términos sinónimos. No obstante, el ejemplo de Grajal de la Ribera podría ofrecer dudas puesto que al determinar el objeto con el adjetivo largas, se podría pensar que se trata de los 'flecos', pero tampoco hay más datos que justifiquen esta acepción, mientras que sí hay bastantes ejemplos en los que se observa que mullidas y melenas nunca aparecen juntas. En algunas zonas se documenta una melena que viene a ser 'una almohadilla con flecos incorporados', acepción que también podría explicar el ejemplo de Grajal, aunque esta acepción se documenta en Ávila (op. cit s.v. melena). 


\section{MULLIDA [mollida]}

Sust. f. 'Especie de almohadilla que se coloca sobre el testuz de los bueyes o de las vacas debajo del yugo con el fin de que este no las lastime' (Le Men, 2007, s.v. mullidas).

Un par de mullidas (Palacios de la Valduerna, 1728)

Dos jugos con sus mullidas y cornales (Alija del Infantado, 1737)

Un yugo con cornales y mullidas (Castrocalbón, 1814)

Un yugo con sus cornales y mullidas (Destriana, 1825)

Unos cobertores para unas mollidas (Palacios de la Valduerna, 1831)

Un yugo de la arada con trasga y sobeyuelo cornales y mollidas (Palacios de la Valduerna, 1831)

Un yugo con sus mollidas y cornales dos trasgas subituelo (Santibáñez de la Isla, 1844)

Es una voz común en la zona, aunque probablemente con este significado también se usa el término melena. El DRAE no recoge este significado, sino que define mullida como 'montón de rozo, juncos, paja, etc., que suele haber en los corrales para la cama del ganado' y mullido como 'cosa blanda que se puede mullir y sirve para rellenar colchones, asientos, aparejos, etc.' El diccionario académico señala con este significado la voz melenera en su $2^{\text {a }}$ acepción o melena, en su $5^{\text {a }}$ acepción, término también recogido en este corpus. Con el significado que se le da en los inventarios analizados se documenta fundamentalmente en la zona noroeste de León, pero también en Asturias, noroeste de Zamora o suroeste de Orense, zonas bastante próximas a la comprendida en este estudio. Formalmente, alternan lan variantes mollidas, mullidas; ejemplo claro de vacilación de vocales átonas provocadas por la presencia de la vocal /i/ tónica causante de la inestabilidad (Morala, 2009: 557).

\section{SOBEO [subeo]}

Sust. m. 'Correa fuerte con que se ata al yugo la lanza del carro o el timón del arado' (DRAE). Probablemente de un latín vulgar *sŭbŭgĭum (DECH, s.v. sobeo).

Un subeo (Castrocalbón, 1643)

Un sobeo ya ussado (Urdiales del Páramo, 1645)

Un sobeo de carro bueno (Alija del Infantado, 1646)

Un sobeo (La Antigua, 1647)

Un sobeo a medio serbir (Alija del Infantado, 1650)

Un sobeo de carro biejo (Villamediana, 1723)

Un sobeo (Fresno, 1726)

Un sobeo bueno (Toral, 1728)

Un sobeo (Palacios de la Valduerna, 1728)

Un sobeo (Castrocalbón, 1814)

Un sobeo (La Nora del Río, 1823)

Un sobeo vueno (Valle de la Valduerna, 1829) 
Un yugo, cornales y sobeo con su trasga (Quintanilla de Somoza, 1831)

Un sobeo de carro (Calzada, 1838)

Es un término común en toda la zona leonesa. La acepción del término es la que figura en el DRAE. Es un término próximo semánticamente a las cornales, aunque es de más consistencia que estas y presentan diferente función ya que el sobeo sirve para atar el yugo al carro mientras que las cornales son para atarlo a los cuernos del animal. Formalmente, el término se documenta en León bajo muchas variantes, sin embargo, en el corpus se recoge fundamentalmente bajo la forma castellana sobeo, a excepción del primer ejemplo en el que se produce un cierre de la vocal /o/, sin embargo no se produce en la vocal final /o/, cierre que es frecuente encontrar en la zona leonesa.

\section{SOBEYUELO [subiyuelo]}

Sust. m. Se trata de un derivado de sobeo. Probablemente de un latín vulgar *sŭbı̆gŭum (DECH, s.v. sobeo).

Una trasga con su sobeyuelo ya usado (Alija del Infantado, 1644)

Un yugo biexo con sus mollidas y una cornal y sobeyuelo y trasga (Alija del Infantado, 1644)

Un sobeyuelo nuevo (Palacios de Jamuz, 1727)

Una trasga de yerro quebrada con su cacho de sobeyuelo y un dogal (Castrocalbón, 1814)

Un yugo de la arada con trasga y sobeyuelo, cornales y mollidas (Palacios de la Valduerna, 1831)

Un yugo con sus mollidas y cornales, dos trasgas y subiyuelo (Santibáñez de la Isla, 1844)

Se trata de un término también común que tiene el mismo significado que sobeo. Concretamente el sobeyuelo es un diminutivo de este, se trata de un 'cinto de cuero con el que une el yugo al arado' (Rivas, 1996: 217). Formalmente, como en el caso anterior, la variante más frecuente es con la vocal velar media aunque hay algún caso en que se produce el cierre de esta en $/ \mathrm{u} /$.

\section{TRASGA}

Sust. f. El DRAE define el término, con la anotación de Galicia, León y Zamora, como 'pértigo de la carreta de bueyes'. Probablemente de un latín vulgar *transǐca, derivado de transjičěre 'hacer pasar (por alguna parte)' porque el timón se introduce en la trasca (DECH, s.v. trasca).

Una trasga con su sobeyuelo ya usado (Alija del Infantado, 1644)

Un yugo biexo con sus mollidas y una cornal y sobeyuelo y trasga (Alija del Infantado, 1644)

Dos yugos con todos sus aparexos, trasgas y sobeyuelos (Huerga de Garaballes, 1720) 
Una trasga de yerro quebrada con su cacho de sobeyuelo y un dogal (Castrocalbón, 1814)

Un yugo, cornales y sobeo con su trasga (Quintanilla de Somoza, 1831)

Una trasga y un barreno de cabijales (Palacios de la Valduerna, 1831)

Un yugo de la arada con trasga y sobeyuelo, cornales y mollidas (Palacios de la Valduerna, 1831)

Una trasga de yerro que está abierta y una chapeta y otro poco de yerro (Palacios de la Valduerna, 1831)

Un yugo con todos sus arreos y trasga de yerro (Palacios de la Valduerna, 1831)

Un yugo con sus mollidas y cornales, dos trasgas y subiyuelo (Santibáñez de la Isla, 1844)

Es un término común del que se recogen bastantes ejemplos debido a que se trata de una voz usual en el occidente de León así como en algunas comarcas de Zamora, por tanto en la zona en la que se localizan estos ejemplos. En las comarcas del occidente de León se define como 'especie de estribo, sujeta con el subiyuelo al yugo y que sirve para enlazar el arado' (Álvarez Cabeza, 1994:159); o 'especie de argolla de hierro en forma de $\mathrm{U}$, con una trabilla de madera que, pendiente en medio del yugo y sujeta al sobiyuelo, sirve para encajar en ella el arado' (Fuente García, 2000: 562). Aunque en otros puntos de la provincia, de forma aislada, el término se use con otras acepciones, el significado más usual y, especialmente en esta zona, es el de 'barzón del yugo'. La mayor parte de los ejemplos encontrados aparecen con elementos del yugo o con el propio yugo que aclaran su significado, pero hay otros, como el tercer ejemplo de Palacios de la Valduerna, donde no se da esta circunstancia. El hecho de que en los demás ejemplos del mismo inventario tenga este significado lleva a suponer que en ese ejemplo también tiene ese uso y que la enumeración que hace se refiere a diferentes objetos de hierro. Observando los ejemplos, vemos que en algunos se especifica que es de hierro, lo que lleva a pensar que la anilla o el barzón pueden ser también de cuero o de madera. En otras zonas de León se documentan otros términos para nombrar este objeto que no se recogen en este corpus, voces como arcojo o barazón (Le Men, 2011, s.v trasga).

\section{YUGO [jugo, iugo]}

Sust. m. 'Instrumento de madera al cual, formando yunta, se uncen por el cuello las mulas, o por la cabeza o el cuello, los bueyes, y en el que va sujeta la lanza o pértigo del carro, el timón del arado, etc.' (DRAE). Del latín jŭgum (DECH, s.v. yugo).

Un yugo con sus cornales (Castrocalbón, 1643)

Un yugo biexo con sus mollidas y una cornal y sobeyuelo y trasga (Alija del Infantado, 1644)

Un yugo con sus melenas y un cornal (Coomonte de la Vega, 1645) 
Un iugo bueno (Urdiales de Páramo, 1645)

Un yugo con sus cornales (La Antigua, 1647)

Un yugo biexo (Alija del Infantado, 1647)

Un yugo de yeguas de madera (Coomonte de la Vega, 1650)

Un yugo de unir yegua (Alija del Infantado, 1650)

Una pala y un yugo biejo (Laguna de Negrillos, 1725)

Dos jugos (Palacios de la Valduerna, 1728)

Un yugo con sus aparejos (Santiago Millas, 1735)

Dos jugos con sus mullidas y cornales (Alija del Infantado, 1737)

Un yugo sin arreos (Castrocalbón, 1814)

Un yugo con cornales y mullidas (Castrocalbón, 1814)

Un yugo con sus cornales y mullidas (Destriana, 1825)

Un yugo vueno con sus aperios (Valle de la Valduerna, 1829)

Un yugo usado con sus aperios (Valle de la Valduerna, 1829)

Un yugo sin arreos (Quintanilla de Somoza, 1831)

Una tornadera de yerro y un yugo (Felechares, 1836)

Un yugo con todos sus arreos y trasga de yerro (Calzada, 1838)

Un yugo con sus mullidas y cornales dos trasgas y subituelo (Santibáñez de la Isla, 1844)

Es un término común ya que designa un apero de labranza básico. Semánticamente, la palabra no presenta ninguna particularidad. Formalmente, el mayor número de ejemplos aparecen bajo la variante normativa, muy pocos con la forma iugo o jugo, que muestran la pervivencia del leonés en algunos ejemplos ya que corresponde a la variante xugo, resultado del leonés para la yod inicial. Además en León se documentan otras variantes como llugo, yubo (Le Men, 2012, s.v. yugo), que no aparecen en este corpus.

\subsubsection{Arreos y aparejos de las caballerías}

\section{ALBARDA [albardón]}

Sust. f. 'Pieza principal del aparejo de las caballerías de carga' (DRAE). Término procedente del ár. al-barda'a (DECH, s.v. albarda).

Una albarda vieja (Alija del Infantado, 1647)

Una albarda (La Antigua, 1648)

Una albarda con su cincho (Grajal de la Ribera, 1750)

Un pollino con su albarda (Quintanilla de Somoza, 1831)

Se recoge a lo largo de todo el corpus ya que se trata de una voz de uso común en la época analizada. Se recoge también un término derivado de este, albardón. Se trata de un aumentativo ya que tiene un significado parecido, la diferencia es que es un aparejo más alto que la albarda (DRAE).

Un albardoncico con sus aziones y estribos de madera bueno (Coomonte de la Vega, 1643)

Dos sillas de briza, dos albardones y dos frenos (Robledo de la Valduerna, 1726) 
Un albardón con sus estribos (Miñambres, 1729)

\section{ALFORJAS [alforxas]}

Sust. f. 'Especie de talega abierta por el centro y cerrada por sus extremos, los cuales forman dos bolsas grandes y ordinariamente cuadradas, donde, repartiendo el peso para mayor comodidad, se guardan algunas cosas que han de llevarse de una parte a otra' (DRAE). Término procedente del ár. hurŷy (DECH, s.v. alforja).

Dos pares de alforjas (La Bañeza, 1641)

Unas alforxas (La Antigua, 1647)

Unas alforxas (La Antigua, 1648)

Unas alforjas de lana de colores con talegos de lienzo (Coomonte de la Vega, 1722)

Unas alforjas de lana usadas (Destriana, 1728)

Unas alforjas de pavilos usados (Miñambres, 1729)

Unas alforxas (Genestacio de la Vega, 1734)

Cuatro costales y unas alforxas biejas (Requejo de la Vega, 1735)

Unas alforjas viejas (Quintanilla de Somoza, 1831)

Unas alforjas viejas de estopa (Quintana del Marco, 1839)

Se trata de un término de uso común en todo el corpus analizado. Algunos trabajos lexicográficos señalan que en esta zona el término se refiere concretamente a 'las dos talegas que se colocaban encima de las caballerías para transportar cosas' (Rivas, 1996: 23). Este significado solo podemos corroborarlo en algunos de los ejemplos por el lugar que ocupa dentro del listado, como en el ejemplo de Destriana que se cita detrás de unas tijeras lanares, en otros casos, los datos que nos aporta el material son insuficientes para llegar a esta afirmación.

\section{ARREOS}

Sust. m. 'Guarniciones o jaeces de las caballerías de montar o de tiro' (DRAE). Término derivado de arrear, del latín vulgar *arredare, 'proveer', derivado del gótico * rêths, 'consejo', 'previsión', 'provisión' (DECH, s.v. arrear).

Un yugo sin arreos (Castrocalbón, 1814)

Un yugo sin arreos (Quintanilla de Somoza, 1831)

Un yugo con todos sus arreos y trasga de yerro (Calzada, 1838)

El término se define como 'conjunto de correas de una cabalgadura' (Rivas, 1996: 36), que aplicado al contexto en el que aparecen los ejemplos se refiere al conjunto de aperos necesarios para el ganado, ya sea ganado caballar o bovino que es el que se utilizaba con el yugo para las labores agrícolas. En definitiva, podría considerarse un sinónimo de aperos y de hecho esta voz también aparece en contextos 
similares: «un yugo con sus aperios», y por tanto del término aparejos, de uso más frecuente.

\section{BOCADO [vocado]}

Sust. m. 'Parte del freno que entra en la boca de la caballería' (DRAE). Derivado de boca, del lat. bŭcca 'mejilla' (DECH, s.v. boca).

Un bocado para una caballería (Miñambres, 1727)

Un vocado mular con su cabezada (La Bañeza, 1829)

Se trata de una palabra común, aunque solo aparezcan dos ejemplos a lo largo del corpus estudiado.

\section{CABEZADA [cavezada]}

Sust. f. El DRAE en su $6^{\text {a }}$ acepción define el término como 'correaje que ciñe y sujeta la cabeza de una caballería, al que está unido el ramal'. Término derivado de cabeza procedente de capǔtĭa, forma del latín vulgar que sustituyó a caput, -ĭtis (DECH, s.v. cabeza).

Un vocado mular con su cavezada (La Bañeza, 1829)

Otro caballar con cavezada muy despreciavle (La Bañeza, 1829)

Una cavezada (Palacios de la Valduerna, 1831)

Una albarda y una cabezada (Quintana del Marco, 1839)

No son muchos los ejemplos que aparecen, además todos pertenecen al S. XIX. Este dato coincide con los extraídos del CORDE donde los ejemplos del término que aparecen utilizados con esta acepción son de la $2^{\text {a }}$ mitad del S. XVIII y del S. XIX. El término siempre se utiliza con el significado de 'correa que se pone a las caballerías'.

\section{CINCHA [zincha]}

Sust. f. 'Faja de cáñamo, lana, cerda, cuero o esparto, con que se asegura la silla o albarda sobre la cabalgadura, ciñéndola ya por detrás de los codillos o ya por debajo de la barriga y apretándola con una o más hebillas' (DRAE). Del latín č̆ngŭlum 'cinturón', derivado de cingere 'ceñir' (DECH, s.v. cincho).

Dos zinchas y una cadena (La Bañeza, 1641)

Es una palabra conocida pero solo se ha recogido este ejemplo a lo largo del corpus estudiado. El significado con el que se utiliza es el que da la Academia. 


\section{COSCOJO $[\cos \operatorname{cox} 0]$}

Sust. m. 'Piezas de hierro, a modo de cuentas, que, ensartadas en unos alambres eslabonados y asidos por los extremos al bocado de los frenos de la brida, forman con la salivera los sabores' (DRAE). Del latín cŭscǔlium 'coscoja', que en latín parece ser de origen hispánico (DECH, s.v. coscojo).

Un freno con bocado de coscoxos y buenas riendas (Coomonte de la Vega, 1643)

Es el único ejemplo recogido del término cuyo contexto indica que aparece empleado con el significado que recoge el diccionario académico. Esta voz presenta en León otras acepciones que no se encuentran recogidas en el DRAE, como la de 'hierba mala nacida en los sembrados' (Le Men, 2004, s.v. coscojo), acepción que no tiene justificación de uso en el ejemplo.

\section{DOGAL}

Sust. m. 'Cuerda o soga de la cual con un nudo se forma un lazo para atar las caballerías por el cuello' (DRAE). Voz procedente del latín tardío dŭcāle 'ronzal para conducir las caballerías', derivado de dŭx,-cis, 'guía, el que conduce' (DECH, s.v. dogal).

Un dogal de zerdas grande (Coomonte de la Vega, 1650)

Un dogal de lino (Palacios de la Valduerna, 1727)

Un dogal de cáñamo (Palacios de la Valduerna, 1728)

Un dogal de zerdas (Miñambres, 1729)

Una rodadera con un dogal (Requejo de la Vega, 1735)

Un dogal nuevo (Castrocalbón, 1814)

Una trasga de yerro quebrada con su cacho de sobeyuelo y un dogal (Castrocalbón, 1814)

Un dogal (La Nora del Río, 1823)

Un par de dogales de lino vuenos (Valle de la Valduerna, 1829)

Un dogal de carro (San Feliz, 1838)

El cuartadero de atropar las trillas con su dogal (Santibáñez de la Isla, 1844)

Es una voz de uso general que se documenta desde Nebrija y así se refleja también en el CORDE y en las diferentes ediciones del DRAE. Su significado es el de 'cuerda' y es frecuente que en el corpus se señale el material del que está hecha.

\section{ESTRIBO [estrivo]}

Sust. m. 'Pieza de metal, madera o cuero, en que el jinete apoya el pie, la cual está pendiente de la ación' (DRAE). Término de origen incierto, quizá germánico ( $D E C H$, s.v. estribo).

Un albardoncico con sus aziones y estribos de madera bueno (Coomonte de la Vega, 1643)

Unos estribos (La Bañeza, 1643) 
Unos estribos de yerro (Grajal de Ribera, 1723)

Unos estribos (Palacios de la Valduerna, 1727)

Un albardón con sus estribos (Miñambres, 1729)

Unos estrivos de madera con corras de yerro (Destriana, 1843)

Una silla de montar con todos sus talegos, estrivos de yerro (Destriana, 1843)

Además del significado del DRAE, en algunas zonas de León el término tiene otras acepciones 'pieza de madera que, en la armadura de la techumbre va clavada de un tirante a otro' y 'pedal del telar' (Le Men, 2005, s.v. estribo). En los ejemplos encontrados en los inventarios analizados, cabe suponer que el significado con el que se usa el término es el académico. En algunos ejemplos está claro por sus referencias al albardón, en el de Grajal la referencia al material de hierro también hace suponer que se trata de la pieza en la que el jinete apoya el pie. No obstante, el hecho de usarse siempe en plural también permite suponer que se trata de esta acepción ya que se refiere a un objeto compuesto por dos elementos, como es el caso de los estribos del jinete.

\section{FRENO}

Sust. m. 'Instrumento de hierro que se compone de embocadura, camas y barbada, y sirve para sujetar y gobernar las caballerías' (DRAE). Del latín frēnum 'freno, bocado' (DECH, s.v.freno).

Un freno enbocado de coscoxos y buenas riendas (Coomonte de la Vega, 1643)

Un freno con su cabezada y petral (Huerga de Garaballes, 1720)

Unos estribos de yerro, un trocado de freno caballar y una argolla (Grajal de la Ribera, 1723)

Dos sillas de briza, dos albardones y dos frenos (Robledo de la Valduerna, 1726)

El término se utiliza con el significado del DRAE utilizado como elemento de guía de las caballerías.

\section{PETRAL}

Sust. m. 'Correa o faja que, asida por ambos lados a la parte delantera de la silla de montar, ciñe y rodea el pecho de la cabalgadura' (DRAE). Del latín pectorale 'que cubre el pecho' (DECH, s.v. pecho).

Un freno con su cabezada y petral (Huerga de Garaballes, 1720)

El ejemplo aparece usado con el significado que da el diccionario académico, aunque en León aparece utilizado con otro significado 'viga que horizontalmente y por lo común sin más apoyo que el de sus extremos, empotrados en los muros que forman el vano, sostiene el suelo de pajares y otros edificios' (Le Men, 2009, s.v. petral), que no aparece en este corpus. 
POTRO (vid. animales)

\section{RIENDA}

Sust. f. 'Cada una de las dos correas, cintas o cuerdas que, unidas por uno de sus extremos a las camas del freno, lleva asidas por el otro quien gobierna la caballería' (DRAE). Del latín vulgar *rětĭna, derivado de retīnēre (DECH, s.v. retener).

Un freno con bocado de coscoxos y buenas riendas (Coomonte de la Vega, 1643)

Es el único ejemplo recogido cuyo significado es el que aparece en el diccionario académico.

\subsubsection{Otros aparejos de animales}

\section{ENCAÑO}

Sust. m. 'Manojo de pajas al que se le sacude en grano y se coloca en manadas por la espiga' (Le Men, 2005, s.v. encaño). Derivado de caña, del latín canna (DECH, s.v. caña).

Un encaño de paxas de centeno (Alija del Infantado, 1644)

Se trata de un ejemplo que no recoge el DRAE, y este es el único ejemplo encontrado en el corpus. Además de esta acepción, el término también se utiliza en León con la acepción de 'vendaje'. Con el significado que aparece en el corpus también se usa en zonas próximas como en Zamora. Concretamente en Benavente la voz encaño tiene este significado pero con un uso concreto, así se llama encaño a 'hacecillo de pajas de centeno seco con las espigas juntas y sin grano que se utilizaba para chamuscar los cerdos en las matanzas y para relleno de jergones, de albardas y de colleras' (Barrio, 2000: 175).

GAZA

Sust. f. 'Lazo que se forma en el extremo de un cabo doblándolo y uniéndolo con costura o ligada, y que sirve para enganchar o ceñir algo o suspenderlo de alguna parte' (DRAE). De origen incierto (DECH, s.v. gaza).

Una gaza y una tirigüela (Grajal de la Ribera, 1750)

Solo se ha recogido este ejemplo del término gaza en el corpus. El significado general de la voz es de 'lazo que sirve para enganchar algo' y su uso es muy frecuente en el léxico marítimo, como se observa en la cantidad de ejemplos que el NDHE recoge en 
su fichero general. En el ejemplo de este corpus tiene el mismo significado general, no está tan claro el uso que el término pueda tener, puede tratarse de algún lazo que se utilice para atar el ganado al yugo y al arado o, aunque esté recogido junto a la voz tirigüela, puede tratarse de un objeto de labranza que se use de forma genérica para atar cualquier ganado (bueyes, caballería) a un carruaje. Con este uso se documenta el término en el $N D H E$ donde se especifica "la otra caballería quedó atada por dos fuertes tirantes de cuero adheridos por sus gazas a un balancín”.

\section{COMEDERA}

Sust. f. 'Vasija o cajón donde se echa la comida a las aves y otros animales' (DRAE). Término derivado de comer, del latín comĕdĕre (DECH, s.v. comer).

Dos comederas de dar de comer (Laguna de Negrillos, 1721)

Dos comederas (Castrocalbón, 1814)

Solo se recogen estos dos ejemplos del término comedera. El significado general es el que señala el DRAE, aunque en algunos casos se documenta la voz comedera como término sinónimo de pesebre y se define como 'lugar donde se echa de comer al ganado vacuno' (Fuente García, 2000: 174); y en otros casos como 'especie de cajón de madera, con forma rectangular y un palo horizontal de su misma longitud que hace de asa, que se sujeta a la pared y en el que se les echa la comida a las ovejas' (Rivas, 1996: 76). El uso concreto que se le da al término en estos ejemplos no está claro, no hay datos que confirmen si la comedera se usa para dar de comer solo a las ovejas, o si tiene el mismo fin que el pesebre siendo este término junto a pesebrera más frecuentes en la zona y por tanto de mayor presencia en el corpus. No obstante, se trata de un término académicamente poco documentado ya que no se recoge en el NTLLE y el CORDE tampoco recoge casos de comedera con uso sustantivo.

\section{PESEBRE}

Sust. m. 'Especie de cajón donde comen las bestias' (DRAE). Del latín praesēpe (DECH, s.v. pesebre).

Un pesebre y un pilonico (Castrocalbón, 1814)

Un pesebre de roble con su prisión (Palacios de la Valduerna 1831)

Otro pesebre de palera con su prisión (Palacios de la Valduerna, 1831)

Dos pesebres de madera (Felechares, 1837)

Es un término común en toda la zona. El pesebre era siempre de madera, como muestran los ejemplos y se define como una especie de 'cajón adosado a la pared de la 
cuadra donde comen el ganado vacuno y el caballar' (Fuente García, 2000: 468). Señala además esta autora que la voz pesebre viene a ser un sinónimo de comedera. En el corpus solo se ha recogido un ejemplo de comedera, lo que muestra que es una voz menos común. Además, tal y como aparece citado este término, es posible que haya alguna diferencia entre ambos términos ya sea aplicada al tipo de animal para el que se utiliza, Rivas señala que la comedera se emplea para las ovejas (vid. comedera), o referida incluso a la disposición en la cuadra en tanto que el pesebre aparece adosado a la pared. Formalmente, aunque son muchas las variantes con las que este término se documenta en León, solo se recoge en el corpus la forma actual, siendo también común la forma próxima a la latina presebre.

\section{PESEBRERA [peselvera]}

Sust. f. 'En las caballerizas, disposición u orden de los pesebres'. 'Conjunto de estos pesebres' (DRAE). Término derivado de pesebre.

Una pesebrera de palero (Alija del Infantado, 1644)

Ocho pesebreras de palero (Coomonte de la Vega, 1645)

Una pesebrera de palero buena (Coomonte de la Vega, 1650)

Unas pesebreras (Fresno, 1726)

Dos pesebreras (Miñambres, 1731)

Seys peselveras y un poco de madera viejo (Valle de la Valduerna, 1829)

Se suele definir la pesebrera como el 'conjunto de pesebres de una cuadra' (Miguélez, 1998: 169), aunque se caracterizan porque son 'un entramado de madera dispuesto sobre la pared, donde se echa la hierba para que coman los animales'. Formalmente, predomina la forma normativa pesebrera, aunque tardío todavía se encuentra algún caso de confusión /1//r/ y metátesis que da lugar a peselvera.

\section{PILÓN}

Sust. m. 'Receptáculo de piedra que se construye en las fuentes para que, cayendo el agua en él, sirva de abrevadero, de lavadero o para otros usos' (DRAE). Término derivado de pila.

Un pilón de madera (Laguna de Negrillos, 1740)

Dos pilones (La Bañeza, 1754)

Un pesebre y un pilonico (Castrocalbón, 1814)

Un pilón (Palacios de la Valduerna, 1831)

Un pilón de madera (Santibáñez de la Isla, 1844)

En estos ejemplos, se trata de un objeto de madera que se utiliza para echar la comida al ganado bovino y caballar, colocado en el establo. El término tiene otras 
acepciones que no aparecen en el corpus, por ejemplo el significado que da el DRAE es utilizado en la zona pero en pilones que son de cemento. El ejemplo de Palacios de la Valduerna no hace referencia al material de madera del que está hecho; pero, como en el término anterior, el contexto en el que aparece junto a «un pesebre de palera» y junto a «las prisiones de los bueyes», permite afirmar que se trate de la misma acepción que en los otros ejemplos.

\section{PRISIÓN}

El DRAE define el término en su $5^{\text {a }}$ acepción como DRAE 'cosa que ata o detiene físicamente'. Término derivado de prender, del latín prehĕnděre 'coger', 'atrapar' (DECH, s.v. prender).

Dos prisiones (Castrocalbón, 1814)

Una prisión (Castrocalbón, 1814)

Un pesebre de roble con su prisión (Palacios de la Valduerna, 1831)

Otro pesebre de palera con su prisión (Palacios de la Valduerna, 1831)

Una prisión de los jatos (Palacios de la Valduerna, 1831)

Las prisiones de los bueyes (Palacios de la Valduerna, 1831)

Dos prisiones de prender bueyes (Destriana, 1843)

Los ejemplos encontrados pertenecen todos a la zona de la Valduerna y uno a la Valdería, aunque el término se conoce en otras zonas de este Partido Judicial, por ejemplo en Santibáñez de la Isla (Miguélez, 1998: 171) aunque no se recojan casos en el corpus. El significado con el que se utiliza es el de 'cadena que sujeta el ganado al pesebre', acepción que no recoge el DRAE, al menos con esta concreción.

\section{CAMPANO}

Sust. m. 'Cencerro. Esquila. Campana pequeña de los conventos y otras casas' (DRAE). Término procedente del latín tardío campāna, abreviación de vasa Campana 'recipientes de Campania', región de la cual procedía el bronce de mejor calidad (DECH, s.v. campana).

Dos campanos con colleras pequeños (Alija del Infantado, 1644)

Como se puede deducir del único ejemplo encontrado, el significado del término es el de 'cencerro'. Al igual que ocurre con el término sinónimo cencerro, los ejemplos son poco numerosos. No obstante, a lo largo del corpus la voz cencerro es más frecuente que campano. Este mayor uso de uno de los términos coincide con los datos del CORDE donde los ejemplos de cencerro son muy numerosos, mientras que los de campano son escasos, en concreto con este significado solo se recoge uno. 


\section{CENCERRO/A [zenzerra]}

Sust. m. y f. 'Campana pequeña y cilíndrica, tosca por lo común, hecha con chapa de hierro o de cobre, que se usa para el ganado y suele atarse al pescuezo de las reses' (DRAE). Término de formación onomatopéyica; quizá tomado del vasco zinzerri que es también de origen imitativo (DECH, s.v. cencerro).

Dos cencerros grandes (Coomonte de la Vega, 1650)

Una zenzerra vieja (Miñambres, 1727)

Una zenzerra (Palacios de Jamuz, 1728)

Quinze zenzerras (Alija del Infantado, 1734)

Una quilma vieja y una cencerra (Castrocalbón, 1814)

No son muchos los casos encontrados. Se puede observar en los ejemplos que es más frecuente encontrar el término en femenino. En principio, parece que no existen diferencias en el significado de la palabra según esté usada en masculino o femenino. Sí parece que existen diferencias en la forma, así cuando la palabra está usada en femenino aparece escrita con la grafía "z", mientras que en masculino aparece bajo la forma actual. En corpus como el CORDE, el uso del femenino es mucho menor que el del masculino, ya que frente a los doscientos dieciocho casos de uno, aparecen siete del otro.

\section{ESQUILÓN}

Sust. m. 'Esquila grande' (DRAE). Término procedente del gót. *skilla, tomado probablemente por conducto del occitano antiguo esquila (DECH, s.v. esquila).

Unos esquilones con collares de raposo (Coomonte de la Vega, 1645)

Unos esquilones buenos con collares de perro (Coomonte de la Vega, 1645)

Dos esquilones (Vidriales, 1645)

Dos esquilones viejos (Villamor de Órbigo, 1648)

Un esquilón bueno (Coomonte de la Vega, 1650)

Dos esquilones con sus collares (Genestacio de la Vega, 1721)

Un par de esquilones de bueies (La Nora del Río, 1724)

Un esquilón (Palacios de Jamuz, 1728)

Dos esquilones (Miñambres, 1729)

Unos esquilones con sus collares (Palacios de la Valduerna, 1730)

Es un término frecuente en todo el corpus. Aparece en más ocasiones que otros términos sinónimos como cencerro o campano. El significado de la voz es el de 'esquila grande'. En León se trata de una 'esquila, generalmente de cobre, que se ataba al cuello del ganado vacuno' (Le Men, 2005, s.v. esquilón). En este corpus, solo en el ejemplo de La Nora del Río se especifica que sean de bueyes. En los demás casos, no se dice nada acerca del usuario. Es frecuente, como se observa en los ejemplos, que se indique si solo 
aparecen los esquilones o si estos van acompañados de los collares, que en algunos casos incluso se especifica el cuero del que están hechos: "de perro" o "de raposo".

\section{CARRANCA}

Sust. f. 'Collar de pinchos' (DRAE). Término de origen incierto, quizá del lat. tardío carcannum 'collar', cambiado por metátesis en *carcancu (DECH, s.v. carlanca o carranca).

Unas carrancas de yerro biexas (Coomonte de la Vega, 1650)

Se trata de un término muy escaso en los inventarios analizados, solo se ha encontrado este ejemplo del S. XVII. La Academia lo recoge por primera vez en su Diccionario en la edición de 1803 con el significado mencionado. Con esta misma acepción recoge otro término que aparece como sinónimo, carlanca. Este segundo vocablo en corpus como el CORDE aparece con más frecuencia que carranca, sin embargo en esta base de datos, la voz carlanca tampoco se registra. En cuanto al significado del término, en algunos vocabularios de la zona se define como 'cada una de las púas de hierro que constituyen el collar que llevan los perros para su defensa' (Rivas, 1996, s.v. carranca), acepción que el DRAE recoge con la entrada carranza. Sin embargo, es lógico pensar que en el inventario estudiado, el término se utilice con el significado de 'collar', ya que lo normal es que se inventaríe el collar y no cada una de las púas.

COLLAR (vid. collar en joyas)

\section{COLLERA}

Sust. f. 'Collar de cuero o lona, relleno de borra o paja, que se pone al cuello a las caballerías o a los bueyes para que no les haga daño el horcate' (DRAE). Término derivado de cuello, del latín cŏllum (DECH, s.v. cuello).

Dos campanos con sus colleras pequeños (Alija del Infantado, 1644)

Es el único ejemplo encontrado y como se observa en el texto, se trata de un collar que se pone a los animales, pero no para que no les haga daño el horcate sino que, en este caso, para sostener el campano. Es decir se trata de un sinónimo de collar, término más frecuente en el corpus. En algunas partes de León y más concretamente en la zona del Órbigo y La Bañeza, también se llama collera a 'collar de madera en forma 
de herradura que se pone a las vacas para atarlas al pesebre' (Le Men, 2004, s.v. collera), aunque con este significado no se recogen ejemplos en el corpus.

\section{MELA}

Sust. f. 'Mezcla de pintura roja u ocre, por lo general con un mordiente, que sirve para marcar el ganado lanar' (DRAE). Término derivado de miel, del latín mĕl, méllis (DECH, s.v. miel).

Una mela de melar ganado (Alija del Infantado, 1644)

Una mela de yerro (Alija del Infantado, 1650)

Son los únicos ejemplos encontrados, aunque probablemente se trate de un término conocido, al menos en la parte sur de la zona, de donde proceden estos ejemplos. La acepción concreta no es tanto la pintura sino el objeto que sirve para melar, para marcar a las ovejas. Con este sentido el DRAE define la voz mela marcándola como un término coloquial, rural y situándolo en Valladolid. Este dato del DRAE unido a la falta de ejemplos en el CORDE, permite concluir que probablemente se trate de un término localizado más bien en la zona limítrofe entre el leonés y el castellano, ya que también se documenta con este significado en Zamora, Salamanca o Ávila.

\subsubsection{Utensilios de labranza}

\section{APERO [aperio]}

Sust. m. 'Conjunto de instrumentos y demás cosas necesarias para la labranza' (DRAE). Término derivado de aperar, del latín vulgar *appariare 'emparejar', 'preparar', 'disponer', derivado de par, paris 'par' (DECH, s.v. aperar).

Un carro herrado con sus aperios (Valle de la Valduerna, 1829)

Un yugo bueno con sus aperios (Valle de la Valduerna, 1829)

Un yugo usado con sus aperios (Valle de la Valduerna, 1829)

El término es muy común, aunque solo se recoja en estos ejemplos, todos ellos pertenecientes al mismo inventario. La voz aperos usada en plural presenta un significado general de 'utensilios de labranza', aunque se extiende a utensilios empleados para cualquier oficio. Este significado general es el que aparece en el primer ejemplo, en los siguientes casos el término se ha concretado semánticamente y hace referencia a las 'cosas necesarias para uncir las vacas o los bueyes'. Esta concreción del término, que es usada en León, no la recoge el DRAE. No obstante, la escasez de ejemplos, pese a ser un término común, se debe a que con el mismo significado se 
emplea el término aparejo de mayor frecuencia en el corpus, que incluso se utiliza en los mismos contextos semánticos, aplicado al yugo, al carro, etc. Desde el punto de vista formal, la variante más común empleada es la que presenta yod epentética aperios, que también se usa mayormente en Asturias y alterna con aperos en Santander y Palencia (Le Men, 2002, s.v. aperos).

\section{AZADA [azado, azadín, azadica, zada,]}

Sust. f. 'Instrumento que consiste en una lámina o pala cuadrangular de hierro, sirve para cavar tierras roturadas o blandas' (DRAE). Término procedente del lat. vulgar *asciata 'herramienta provista de un ascia'. (DECH, s.v. azada).

Una azada cespedera buena (Alija del Infantado, 1644)

Una azada de cavar melones (La Nora del Río, 1645)

Una azada de cabar biñas buena (Alija del Infantado, 1646)

Una azada mocha buena (Coomonte de la Vega, 1650)

Una azada zespedera buena (Huerga de Garaballes, 1720)

Una azada cespedera husada (Huerga de Garaballes, 1720)

Una azadica (Genestacio de la Vega, 1721)

Quatro azadas tres de pala y una de dientes (Palacios de la Valduerna, 1728)

Dos marras y dos azadones y una azada (Laguna de Negrillos, 1734)

Una azada al estilo de Campos (Grajal de la Ribera, 1750)

Una azada de pino (Castrocalbón, 1814)

Una azada de rovle (Quintana del Marco, 1820)

Un azadín de hierro (Valle de la Valduerna, 1829)

Una azada de dientes (Valle de la Valduerna, 1829)

Dos azadas de pico para el abono (La Isla, 1829)

Una azada con peto y una tornadera de yerro (San Feliz, 1838)

Un azado con sus teriguelas (Calzada, 1838)

Una zada y un azadón y un machado (Santibáñez de la Isla, 1844)

Se trata de una palabra de uso generalizado en todo el corpus analizado. En cuanto a las variantes que presenta la palabra, lo más común es encontrarla bajo la forma azada, resultado propio del castellano. No se recoge ningún ejemplo con las variantes $\check{s} a d a$, variedades dialectales esperables en el leonés como resultado del grupo /-skj-/. Hay un caso en el que se presenta bajo la forma vulgar, con aféresis de la vocal inicial zada. Se recogen dos ejemplos con sufijos en diminutivo para designar una azada pequeña, en un caso el término aparece con el sufijo -ico que, como en otras ocasiones, corresponde a la zona más próxima a Zamora, mientras que la forma azadín aparece en una zona más noroccidental, próxima a la Maragatería. Esta variante formal, azadín, no se recoge en los diccionarios académicos, pero sí en diccionarios leoneses con el significado de 'azada pequeña' (Le Men, 2002, s.v. azado-a). Es frecuente que el término aparezca en los inventarios con diferentes matizaciones. Algunas veces esta 
información hace referencia al uso, azadas de cavar melones, etc.; otras veces señalan la existencia de distintas clases de azadas. Estas pueden ser de dientes o de pala. También se llaman azadas de peto. Se trata de una clase que tiene un pico opuesto a la pala y que no tienen las que se denominan mochas.

\section{AZADón [zadón]}

Sust. m. 'Instrumento que se distingue de la azada en que la pala cuadrangular es algo más curva y más larga que ancha' (DRAE). Su origen es el mismo que el de azada, del lat. vulgar *asciata.

Un azadón de peto (La Bañeza, 1641)

Un azadón zespedero (Alija del Infantado, 1644)

Un zadoncico mocho desmangado (Alija del Infantado, 1644)

Dos azadones de monte uno mediano y otro pequeño (Alija del Infantado, 1646)

Un azadón de monte grande bueno (Alija del Infantado, 1647)

Un zadón (Coomonte de la Vega, 1719)

Un azadón de peto bueno (Huerga de Garaballes, 1720)

Una pala de orno y un azadón (Laguna de Negrillos, 1721)

Un azadón de monte (La Nora del Río, 1724)

Dos marras y dos azadones y una azada (Laguna de Negrillos, 1734)

Un zadón de monte quebrado (Castrocalbón, 1814)

Es una palabra de uso común en el corpus analizado. El DRAE señala que la diferencia con el término anterior parece estar en el uso de un objeto y otro, así el azadón se utiliza para romper tierras duras, mientras que la se usaba para tierras suaves. Sin embargo, esta diferenciación no está clara en los ejemplos ya que en el primer caso se trata de un "azadón zespedero" y en la entrada anterior recogíamos el ejemplo "azada cespedera". Por tanto, la diferencia puede estar más en la forma del objeto que en la aplicación del mismo.

\section{MARRA}

Sust. f. El DRAE remite a la voz almádena que define como 'mazo de hierro con mango largo para romper piedras'. Del latín marra 'especie de azada o arpón' (DECH, s.v. marra).

Dos marras y dos azadones y una azada (Laguna de Negrillos, 1734)

Es el único ejemplo recogido, aunque se trata de una voz usada en la zona de La Bañeza y en zonas próximas. No obstante, podemos señalar que se trata de una palabra con varias acepciones incluso en lugares próximos. Así en algunas zonas del Órbigo se emplea con el significado de 'especie de bielda con los dientes de hierro; se utiliza fundamentalmente para mover y cargar el estiércol' (Le Men, 2007, s.v. marra); 
en otras como en Estébanez de la Calzada se emplea con el significado de 'especie de azadón con dos púas muy útil en la labranza' (Martínez Martínez, 1985: 182) y en zonas próximas como Benavente se emplea con el significado de 'piedra que divide dos fincas' (Barrio, 2000: 183). En el ejemplo está claro, tal y como se deduce del contexto, que se trata de una especie de azadón que se diferencia del azadón propiamente dicho y de la azada por las púas.

\section{BIELDO [bildo]}

Sust. m. El DRAE define el término como 'instrumento que sirve para beldar', es decir, 'aventar las mieses, legumbres, etc. trilladas para separar del grano la paja'. Término derivado de beldar.

Un bildo pequeño (Coomonte de la Vega, 1643)

Un bildo biejo (Alija del Infantado, 1647)

Dos bildos (La Antigua, 1647)

Un bildo (Palacios de la Valduerna, 1728)

Una pala y zinco bildos (Palacios de la Valduerna, 1730)

Una bilda y dos bildos (Quintanilla de Somoza, 1831)

Una talega y un bildo biejo (Felechares, 1837)

El término aparece siempre documentado bajo la variante bildo, con reducción del diptongo, no se recoge ningún caso que aparezca bajo la forma normativa. Sin embargo, parece ser bastante frecuente en el dominio leonés. En concreto, en la zona occidental, zona geográfica que comprende el dominio del P.J. de la Bañeza, la variante bildo es exclusiva (Le Men, 2000, s.v. bieldo). Además, hay que señalar que con esta variante no se recoge en el DRAE, ni aparece ningún ejemplo en corpus como el CORDE. El significado con el que se usa el término es el que da la Academia, aunque no solo se utiliza para beldar, sino que se trataba de un instrumento de madera, a diferencia de la bielda, que se utilizaba también para traspasar de un lugar a otro la paja (Rivas, 1996: 47).

\section{BIELDA [bilda, bienda, vienda]}

Sust. f. 'Instrumento agrícola que sirve para recoger cargar y encerrar la paja, y que sólo se diferencia del bieldo en tener seis o siete puntas y dos palos atravesados, que con las puntas o dientes forman una rejilla' (DRAE). Término derivado de bildar, verbo cuyo origen se encuentra en el término latino ventilare.

Una vienda de vendar paja (Santibáñez de Vidriales, 1645)

Dos bildas biejas de bildar paja (Alija del Infantado, 1647)

Dos biendas (Grajal de la Ribera, 1723) 
Una bilda y una tornadera (Fresno, 1726)

Una rastra y una bienda (Palacios de la Valduerna, 1730)

Una bienda (Laguna de Negrillos, 1740)

Una vilda (Castrocalbón, 1814)

Una bilda y una tornadera (Castrillo de la Valduerna, 1828)

Una bilda y dos bildos (Quintanilla de Somoza, 1831)

Una banastra y una bilda bieja (Felechares, 1837)

A diferencia del caso anterior, el término se presenta bajo la variante bilda, la más común, o bienda, con mantenimiento del diptongo pero con sustitución de /l/ por /n/. La forma bienda es la variante patrimonial de la franja occidental y por tanto, se localiza tanto en inventarios de León como de Zamora (Morala, 2012b: 323). No obstante, la variante bilda es la más común y aparece de nuevo en las zonas más occidentales.

Desde el punto de vista del significado, las diferencias con respecto al bildo no solo están en el número de puntas sino en el material, ya que el bildo es de madera y la bilda puede ser de madera o de hierro, este dato va a diferenciar los usos para los que se destina. Así, si es de madera se utiliza para recoger la hierba y si es de hierro se utiliza para recoger el estiércol (Rivas, 1996: 46). No obstante, de los datos extraídos de los inventarios, solo podemos decir que se trata de dos aperos diferenciados, pero no podemos obtener más información acerca de su significado o uso.

\section{CALABOZO [calabuzo, calavuzo]}

Sust. m. 'Instrumento de hoja acerada, ancha y fuerte, para podar y rozar árboles y matas' (DRAE). Probablemente compuesto de calar 'penetrar' y el leonés boza 'matorral' (DECH, s.v. calabozo).

Una podadera y un calabozo (La Bañeza 1641)

Un calabuzo desbocado biexo (Alija del Infantado, 1644)

Un calabuzo de yerro biexo (Coomonte de la Vega, 1650)

Un calavuzo y un martillo (Felechares, 1836)

Un calabozo bueno (Calzada, 1838)

Se trata de un término de uso general, aunque en el corpus no son muchos los ejemplos encontrados y estos se sitúan en el S. XVII o XIX. Presenta dos variantes, la normativa y la forma calabuzo o calavuzo con cierre de la vocal velar.

\section{CASTRADERA}

Sust. f. 'Instrumento de hierro que sirve para castrar las colmenas' (DRAE). Término derivado del latín castrare (DECH, s.v. castrar).

Dos castraderas de yerro buenas (Coomonte de la Vega, 1645) 
Una castradera de yerro (Genestacio de la Vega, 1650)

Son pocos los ejemplos encontrados del término, aunque el dato es significativo si tenemos en cuenta que en el CORDE solo aparece un ejemplo fechado también en una época temprana, siglo XVI.

\section{CEDAZO [cedaco, zedazo]}

Sust. m. 'Instrumento compuesto de un aro y de una tela, por lo común de cerdas, más o menos clara, que cierra la parte inferior. Sirve para separar las partes sutiles de las gruesas de algunas cosas, como la harina, el suero, etc.' (DRAE). Abreviación del latín vulgar cribrum setacěum 'criba hecha de cerdas', derivado del latín saeta 'cerda, crin' (DECH, s.v. cedazo).

Dos cedacos ussados (Vidriales, 1645)

Un zedazo (La Antigua, 1648)

Un cedazo (Fresno, 1726)

Un zedazo, un cribo y una Zelanda (Palacios de la Valduerna, 1730)

Es un término que designa un objeto que sirve para acerandar o cribar. Sin embargo, parece evidente que no se trata de un término sinónimo de ceranda o cribo, como lo demuestra el último ejemplo donde aparece una enumeración que contiene las tres voces. No obstante, existen diferencias en el material ya que el cedazo se compone de un aro y una tela. Las diferencias también se encuentran en el uso puesto que la ceranda sirve para limpiar la harina de impurezas, no hay que olvidar que en las paneras había incluso ratones que podían dejar en el producto allí guardado sus excrementos; y la ceranda y la criba se usaban para cribar los cereales y las legumbres. No obstante, en algunas zonas leonesas no comprendidas en este estudio, a las cerandas se las denomina cedazos. El número de ejemplos puede indicar que se trataba de un objeto menos usual que la ceranda o el cribo. Desde el punto de vista formal, es frecuente que en los ejemplos anteriores a la normalización académica aparezca la grafía "ç" para representar este sonido.

\section{VARILLA [barilla]}

Sust. f. Usado en plural el DRAE define el término en su $5^{\text {a }}$ acepción como 'bastidor rectangular en que se mueven los cedazos para cerner'. Diminutivo de vara.

Una cama de nogal entera con sus barillas (La Bañeza, 1647)

Dos cortinas azules con sus barillas de ierro (Laguna de Negrillos, 1722)

Una artesa de masar con sus barillas (Palacios de la Valduerna, 1726)

Unas barillas de zernir (Laguna de Negrillos, 1740)

Unas varillas de zerner (Grajal de la Ribera, 1750) 
Quatro cortinas con dos varillas (La Nora del Río, 1823)

Dos cortinas de algodón con sus varillas (La Bañeza, 1829)

Quatro cortinas viejas con sus guardapolvos y sus varillas (Felechares, 1837)

Cuatro cortinas de algodón con pintas y sus dos barillas (Requejo de la Vega, 1839)

Es un término polisémico que tiene varias acepciones, muchas de ellas no recogidas en el diccionario académico. En el corpus estudiado, el término se utiliza con dos significados. En los ejemplos en los que aparece junto al verbo cerner o junto al término artesa, la voz se define como 'cada uno de los palos que se ponen en la masera para cerner harina' (Le Men, 2011, s.v. varilla). En el resto de los ejemplos en los que aparece junto a la voz cortinas o cama, el significado empleado es más general pudiendo considerarse como sinónimo de 'barras'. Además se documentan otras acepciones en esta zona de las que no se recogen ejemplos en el corpus. Así también se llaman varillas a 'cada uno de los dos palos de madera que, en posición horizontal, unen los estadojos y los picos en las pernillas del carro' (Rivas, 1996: 235).

\section{CERANDA [zeranda, Zelanda]}

Sust. f. 'Cribo, criba' (DRAE). Probablemente se trata de una onomatopeya tsándara que expresaría el sonido rítmico de la criba y el grano al zarandearlos ( $D E C H$, s.v. zaranda).

Dos cribos ya usados y una ceranda de acerandar cebada buena (Coomonte de la Vega, 1643)

Dos cerandas (Alija del Infantado, 1644)

Una ceranda y dos descocaderos (Vidriales, 1645)

Cinco zerandas de cerandar trigo biexas (Alija del Infantado, (1647)

Dos zerandas y dos cribos (La Antigua, 1648)

Un cribo y una Zelanda (Coomonte de la Vega, 1719)

Una Zelanda (Genestacio de la Vega, 1721)

Una Zelanda y una criva (Laguna de Negrillos, 1721)

Una Zelanda (Fresno, 1726)

Un cribo, una zeranda y una pala (Palacios de la Valduerna, 1730)

Un zedazo, un cribo y una Zelanda (Palacios de la Valduerna, 1730)

Un crivo y una Zelanda (Requejo de la Vega, 1735)

Dos zerandas usadas (Grajal de Ribera, 1750)

Una zeranda (La Bañeza, 1758)

Un cribo y una ceranda (Quintanilla de Somoza, 1831)

Una ceranda de pasar (Destriana, 1843)

Una ceranda grande (Santibáñez de la Isla, 1844)

La voz aparece recogida en los inventarios bajo distintas formas. Durante los siglos XVII y XVIII es frecuente que alterne ceranda y zeranda, como en otros ejemplos ya vistos, se produce una vacilación en la grafía que representa la fricativa interdental. Esta vacilación se resuelve hacia la forma normativa en los ejemplos del S. XIX. Es significativo señalar la variante formal Zelanda, que solo aparece en los inventarios analizados del S. XVIII, y además aparece con una peculiaridad _ siempre se ha 
encontrado la palabra escrita con la letra inicial mayúscula _. Sin embargo, la forma que presenta en el DRAE y la mayoría de los ejemplos del CORDE, zaranda, no se ha registrado en ningún caso. En cuanto al significado con el que se utiliza el término, parece claro que en estos inventarios hay una diferenciación entre la ceranda y el cribo, ya que como se puede observar son bastantes los ejemplos en los que se citan los dos objetos, lo que muestra que no son sinónimos totales. La ceranda consta de un aro de madera con un fondo de piel con agujeros de distintos tamaños según el uso que tenga, de ahí la diferenciación entre ceranda de trigo, de cebada, etc. En cambio el cribo tiene el fondo metálico y por él no solo pasan semillas sino también pajas, etc.

\section{CERANDÓN [zerandón]}

Sust. m. 'Criba con los agujeros más grandes que la ceranda' (Le Men, 2004, s.v. cerandón). Se trata de un término aumentativo de ceranda por tanto tiene su misma raíz. Probablemente se trata de una onomatopeya tsándara que expresaría el sonido rítmico de la criba y el grano al zarandearlos (DECH, s.v. zaranda).

Un zerandón (Toral, 1728)

Una pelleja, un cerandón y linterna (La Nora del Río, 1820)

Un cerandón (Santibáñez de la Isla, 1844)

Aparece con mucha menos frecuencia que ceranda, voz mucho más usada en todas las regiones, ya que cerandón no se conoce en otras zonas. No la recoge el diccionario académico ni el CORDE. Como en el caso de ceranda, el término presenta alternancia en la grafía que representa la fricativa interdental.

\section{CESPEDERO/A [zespedero/a]}

Adj. m. y f. Derivado de césped, del latín caespes, -řtis (DECH, s.v. césped).

Un açadón cespedero biexo (Coomonte de la Vega, 1645)

Una azada cespedera buena (Coomonte de la Vega, 1645)

Un azadón zespedero biexo (Alija del Infantado, 1646)

Una azada zespedera buena (Huerga de Garaballes, 1720)

Una azada cespedera husada (Huerga de Garaballes, 1720)

Una azada cespedera (Huerga de Garaballes, 1720)

Una zespedera de yerro (Huerga de Garaballes, 1750)

El término aparece siempre acompañando a las voces azada y azadón, por tanto está señalando un tipo en concreto. Se trata de dos objetos que presentan una gran diversidad que refleja el tipo, el tamaño de la hoja e incluso la aplicación. Las cespederas suelen ser 'unas azadas y azadones que se utilizan para extraer tapines que 
cubrirán cierres de tapial, formadas por una hoja oval que es el extremo de un brazo de hierro que se prolonga desde el aro o engarce del mango' (J. Alonso, 2009: 100).

\section{CRIBO [crivo, criva]}

Sust. m. y f. 'Cuero ordenadamente agujereado y fijo en un aro de madera, que sirve para cribar. También se fabrica de plancha metálica con agujeros, o con red de malla de alambre' (DRAE). Del lat. crībum (DECH, s.v. cribo).

Dos cribos ya usados y una ceranda de acerandar cebada buena (Coomonte de la Vega, 1643)

Un cribo y una piñera (Castrocalbón, 1643)

Un cribo ya ha medio traer (Alija del Infantado, 1644)

Un cribo de acribar (Alija del Infantado, 1644)

Dos zerandas y dos cribos (La Antigua, 1648)

Un cribo y una Zelanda (Coomonte de la Vega, 1719)

Una Zelanda y una criva (Laguna de Negrillos, 1721)

Un cribo bueno de azer trigo (Destriana, 1728)

Un cribo, una zeranda y una pala (Palacios de la Valduerna, 1730)

Un zedazo, un cribo y una Zelanda (Palacios de la Valduerna, 1730)

Un crivo y una Zelanda (Requejo de la Vega, 1735)

Un crivo y una Zelanda (Requejo de la Vega, 1735)

Un cribo viejo de azer pan (Grajal de Ribera, 1750)

Dos cribos usados (La Bañeza, 1758)

Un cribo y una palmatoria (Castrocalbón, 1814)

Un cribo de linaza (La Nora del Río, 1820)

Un cribo de rajadillo (Castrillo de la Valduerna, 1828)

Un cribo y una ceranda (Quintanilla de Somoza, 1831)

Una quilma y un crivo (San Feliz, 1838)

El DRAE considera los términos cribo y ceranda como sinónimos. En cambio, en los ejemplos podemos apreciar cómo en numerosas ocasiones aparecen diferenciados dentro de un mismo inventario, este dato también lo constata el profesor Morala en inventarios de diferentes procedencias geográficas (Morala, 2012a: 319). La diferencia está en que el cribo es, generalmente, de madera y metal y además se emplea para separar las semillas pequeñas pero, además, la tierra, pajas o maleza. Asimismo, se puede observar en los ejemplos cómo se diferenciaban los distintos usos y así aparece la especificación "de linaza", “de hacer trigo" o "de hacer pan”. Por otra parte, el DRAE señala también como términos sinónimos cribo y criba, bajo la forma femenina solo se ha recogido un ejemplo. El hecho de que aparezca solo en un caso la forma femenina y en otros la masculina y no siendo significativos los datos geográficos puesto que estamos ante localidades colindantes, hace suponer que existe una diferenciación entre el masculino y el femenino que, probablemente, sea de tamaño. Así Le Men señala que generalmente el cribo es de menor tamaño que la criba (Le Men, 2000, s.v. cribo). 


\section{ESCOBA}

Sust. f. 'Utensilio compuesto por un haz de ramas flexibles o de filamentos de otro material sujetos normalmente al extremo de un palo o de un mango largo, que sirve para limpiar el suelo' (DRAE). Término procedente del latín scŭpa íd., primitivamente scŏpae 'briznas'. Secundariamente escoba se vuelve nombre de ciertas plantas empleadas para hacer escobas (DECH, s.v. escoba).

Una escobilla pequeña de mano (Coomonte de la Vega, 1643)

Una escoba de la hera (Palacios de la Valduerna, 1831)

Se trata de un término que se utiliza con el significado que hoy conocemos, aunque se tratara de escobas hechas con ramas.

\section{ESTERQUERA}

Adj. f. Como sustantivo esterquero 'estercolero', 'cesto pequeño de mimbre con dos asas' (Le Men, 2005, s.v. esterquiero). Derivado de estiércol, del latín stĕrcus, -ŏris (DECH, s.v. estiércol).

Una pala esterquera buena (Coomonte de la Vega, 1643)

Dos palas esterqueras biexas (Coomonte de la Vega, 1645)

Una pala esterquera biexa (Alija del Infantado, 1647)

Una pala esterquera biexa (Coomonte de la Vega, 1650)

En el corpus este término siempre aparece usado como adjetivo acompañando al sustantivo pala, especificando así que se trata de una pala que sirve para echar y esparcir el abono. Todos los ejemplos encontrados pertenecen al S. XVII y se sitúan en dos pueblos limítrofes situados en la zona del Bajo Órbigo. Para nombrar este tipo de palas aparecen en el corpus otras denominaciones que pertenecen a otras zonas dentro de este Partido Judicial; denominaciones como "pala de estercar", o "pala de echar avono".

\section{FORCA [horca, orca]}

Sust. f. El DRAE señala este término como sinónimo de 'horca', 'horquilla'; con la matización de ant. El DRAE define horca en la $4^{\text {a }}$ acepción como 'palo que remata en dos o más púas hechas del mismo palo o sobrepuestas de hierro, con el cual los labradores hacinan las mieses, las echan en el carro, levantan la paja y revuelven la parva'. Del latín fürca 'horca de labrador' (DECH, s.v. horca).

Cinco horcas de encina (La Antigua, 1647)

Una orca de peral (Coomonte de la Vega, 1719)

Una orca con pies (Coomonte de la Vega, 1719)

Una orca de negrillo (Laguna de Negrillos, 1725) 
Una forca de yierro para la yerba (Quintanilla de Somoza, 1831)

Zinzo orcas de cebollas (La Nora del Río, 1823)

En esta zona se denomina forca a 'una horca con mango de madera que se utiliza para mover la hierba, alfalfa, etc. Suele tener dos dientes que pueden ser de madera o de hierro'. Este dato explicaría la especificación del árbol del que procede la madera o la distinción "forca de yierro". El último ejemplo no tiene el significado de apero de labranza. Designa una 'ristra o soga de los tallos de cebollas, que se hace en dos ramales que se juntan por un lado' (DRAE). Se trata, por tanto, de un significado que adquiere por semejanza en la forma.

\section{FORCADA}

Sust. f. 'Horca de madera (a veces de hierro) que sirve para levantar la hierba o la paja, hacinar la mies, etc.' (Le Men, 2005, s.v. forcada).

Una forcada de yerro en dos (Quintanilla de Somoza, 1831)

Solo se ha encontrado este ejemplo que, por el contexto, parece ser sinónimo de horca. Podría estar usándose como sinónimo de forcón que define Rivas como 'apero de labranza que está formado por una parte de hierro, con solo dos gajos, unida a un mango de madera y que sirve para manejar mejor los haces de la hierba desde las fincas, el carro, etc.' (Rivas, 1996: 126-127). No obstante, es el único ejemplo encontrado y tampoco se recogen casos de forcón a lo largo del corpus. La matización "en dos", podría interpretarse como dos gajos, aunque es más lógico pensar que se trata de "dos reales" y que se ha suprimido el sustantivo.

\section{GUADAÑA [gadaña]}

Sust. f. 'Instrumento para segar que se maneja con ambas manos, formado por una hoja larga y curvilínea, puntiaguda por un lado y sujeta por el otro, más ancho, a un mango largo que forma ángulo con el plano de la hoja y lleva dos manijas, una en el extremo y otra en el segundo tercio del mango' (DRAE). De la raíz germánica waith-, probablemente como derivado (romance o germánico) del gótico *waithô, 'prado, pastizal' (DECH, s.v. guadaña).

Una gadaña biexa de segar (Coomonte de la Vega, 1645)

Una gadaña con mango (Vidriales, 1645)

Una guadaña armada (Destriana, 1730)

Todo el yerro menudo tasado con una cerradura, dos cachos de gadaña y otros chismes (Santibáñez de la Isla, 1844) 
Es un término muy común en el léxico de los aperos de labranza. Se trata de un instrumento que se utiliza para segar, generalmente la hierba. La variante que más aparece en el corpus es la de gadaña, forma frecuente en el noroccidente peninsular, aunque hay algún ejemplo de la variante normativa. Todos los casos que se han encontrado presentan el término en femenino, pero es frecuente encontrarlo en masculino, normalmente sin variación semántica, aunque en algunas zonas pertenecientes al P.J. de la Bañeza sí hay diferencias, así en Santibáñez de la Isla “el gadaño es la

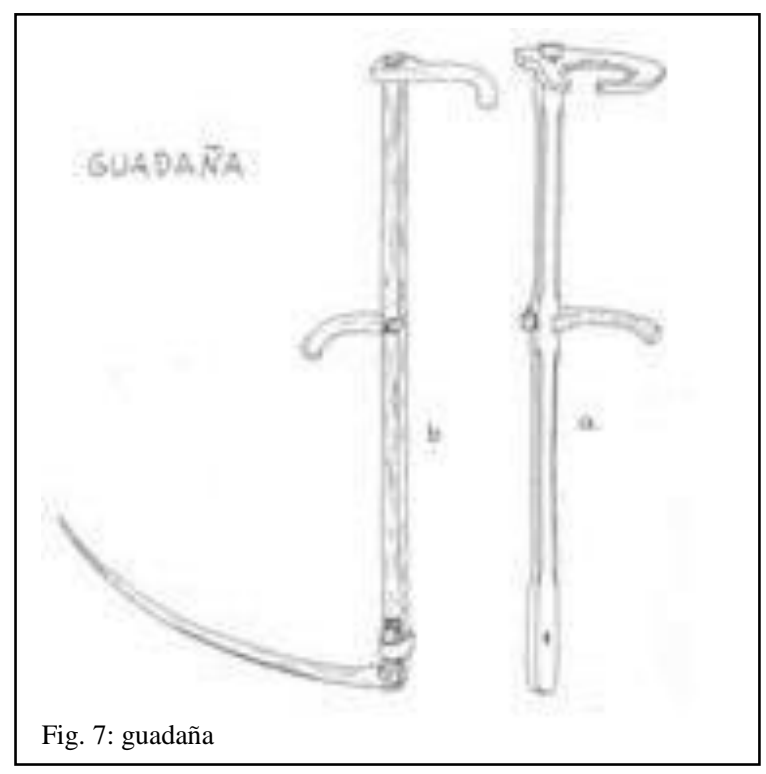
misma gadaña cuando ya está muy gastada y sirve solo para labores rudas. También se llaman gadaños los trozos rotos de la guadaña, que se guardan para raspar a los cerdos después de chamuscarlos en las matanzas" (Miguélez, 1998: 156). Sin embargo, en el ejemplo de Santibáñez de la Isla se habla de dos cachos de gadaña, por tanto de trozos y se utiliza el término en femenino. Puede ocurrir que cuando se trate de trozos de guadaña sea frecuente usar el término en masculino, aunque también se pueda encontrar con este matiz semántico en femenino.

\section{HOZ [oz $]$}

Sust. f. 'Instrumento que sirve para segar mieses y hierbas, compuesto de una hoja acerada, curva, con dientes muy agudos y cortantes o con filo por la parte cóncava, afianzada en un mango de madera' (DRAE). Del latín falx, falcis (DECH, s.v. hoz).

Dos ozes de segar una buena y la otra biexa (Alija del Infantado, 1646)

Cuatro ozes biexas las tres con mango y una sin él (Alija del Infantado, 1647)

Una $o z$ de segar buena (Coomonte de la Vega, 1650)

Dos ozes (Genestacio de la Vega, 1721)

Un par de ozes (La Nora del Río, 1724)

Dos ozes de segar (Ribas de la Valduerna, 1726)

Una $o z$ (Palacios de la Valduerna, 1727)

Media docena de ozes (Palacios de la Valduerna, 1728)

Dos ozes viexas (Miñambres, 1731)

Tres ozes (Castrocalbón, 1814)

Una hoz de monte (Castrillo de la Valduerna, 1828)

Dos hozes una buena y otra mediana (Palacios de la Valduerna, 1831) 
Es un término muy común. El significado con el que se utiliza es el que aparece en el DRAE. Formalmente, no se recoge ningún ejemplo con la variante foz, tal vez esta variante se utilizara en la lengua oral, como señala Miguélez: "solo existe la conciencia de haberlo oído" (Miguélez, 1998: 155); pero en los inventarios no se recoge.

\section{MAROMA}

Sust. f. 'Cuerda gruesa de esparto, cáñamo u otras fibras vegetales o sintéticas' (DRAE). Del árabe vulgar mabrûma íd., probablemente participio de báram 'trenzar', 'retorcer' (DECH, s.v. maroma).

Una maroma de atropar las trillas con su tiradero (Valle de la Valduerna, 1829)

Es un término de uso general cuyo significado es el de 'cuerda gruesa'. En este caso se refiere a una cuerda utilizada con un fin concreto.

\section{MAJADERA [maxadera]}

Sust. f. 'Mazo o pértiga para majar' (DRAE). Derivado de majar del arcaico majo 'mazo de hierro' que procede del latín mallĕus (DECH, s.v. majar).

Dos maxaderas de madero (Coomonte de la Vega, 1643)

En algunas zonas de León, se denomina majadero, majadera al 'palo con que se apalean los garbanzos y lentejas para que desprendan el grano' (Le Men, 2007, s.v. majadero). En zonas comprendidas en el P.J. de la Bañeza, como la Valdería, se denomina majadero a la 'losa para majar lino con dos o más metros de largo' (Rivas, 1996: 152). En los inventarios analizados es el único ejemplo encontrado. El complemento "de madero" que acompaña al término hace suponer que se trata del madero que se utiliza para majar, más que del instrumento que se utiliza para golpear los garbanzos y lentejas, que es un varal. No obstante, aunque el término aparece documentado en otras zonas de la Península, su uso es escaso, por ejemplo no se recoge con estos significados ningún ejemplo en el CORDE.

\section{MEDIANO}

Sust. m. El DRAE define el término en su $6^{\mathrm{a}}$ acepción como 'correa fuerte con que se ata el barzón al yugo de las yuntas'. Término derivado de medio, del latín mědĭus (DECH, s.v. medio).

Un mediano y un heje (Palacios de la Valduerna, 1831) 
Un mediano (Palacios de la Valduerna, 1831)

Es un término que está documentado en toda la provincia tanto en masculino como en femenino, aunque en este corpus solo se hayan recogido estos ejemplos en masculino. La voz mediano/a es polisémica por lo que se usa con otras acepciones además de la que recoge el diccionario académico. Algunas no son aplicables a estos ejemplos, como se puede deducir por el contexto. Entre las que se pueden aplicar está la reflejada en el DRAE, pero también se llama mediano a la 'correa que une los palos del manal', con este significado se recoge en la zona de La Bañeza, aunque en femenino (Mingote, 1990: 22-23). La escasez de ejemplos junto a la falta de más información impide llegar a una conclusión aunque en la relación de bienes se encuentra junto a términos relacionados con labores agrícolas como trillo, cerandas, mazos de desbagar, que podrían apuntar a un empleo de la segunda acepción aquí reseñada. Asimismo, son numerosos los ejemplos en lo que aparece con un uso adjetivo para designar el tamaño de un objeto, animal, etc.

\section{PALA}

Sust. f. 'Instrumento compuesto de una tabla de madera o una plancha de hierro, comúnmente de forma rectangular o redondeada, y un mango grueso, cilíndrico y más o menos largo, según los usos a los que se destina'. 'Hoja de hierro en forma de trapecio por lo común, con un filo por un lado y un ojo en el opuesto para enastarla, que forma parte de los azadones, azadas, hachas y otras herramientas' (DRAE). Del latín pala 'azada', 'pala' (DECH, s.v. pala).

Una pala esterquera buena (Coomonte de la Vega, 1643)

Una pala de orno a medio serbir (Coomonte de la Vega, 1645)

Dos palas esterqueras biexas (Coomonte de la Vega, 1645)

Una pala esterquera biexa (Alija del Infantado, 1647)

Una pala esterquera biexa (Coomonte de la Vega, 1650)

Una pala de orno nueba y otra biexa (Coomonte de la Vega, 1650)

Una pala de orno y un azadón (Laguna de Negrillos, 1721)

Dos palas de orno (Grajal de la Ribera, 1723)

Dos palas de pico (Grajal de la Ribera, 1723)

Una pala y un yugo biejo (Laguna de Negrillos, 1725)

Un azadón y una pala (Ribas de la Valduerna, 1726)

Una pala (Robledo de la Valduerna, 1726)

Quatro azadas tres de pala y una de dientes (Palacios de la Valduerna, 1727)

Una pala de orno (Palacios de Jamuz, 1728)

Una pala de desterrar (Palacios de la Valduerna, 1728)

Una pala de estercar (Palacios de la Valduerna, 1728)

Un cribo, una zeranda y una pala (Palacios de la Valduerna, 1730)

Una pala de orno (Palacios de la Valduerna, 1730)

Una pala y zinco bildos (Palacios de la Valduerna, 1730) 
Dos palas (Requejo de la Vega, 1735)

Una pala de echar avono (Requejo de la Vega, 1735)

Una pala tornadera y un banquito (Castrocalbón, 1814)

Una pala y una regla (La Nora del Río, 1823)

Una pala de yierro muy usada (Quintanilla de Somoza, 1831)

Dos palas de horno (Quintanilla de Somoza, 1831)

Una pala de madera (Quintanilla de Somoza, 1831)

Una pala grande de madera (Destriana, 1843)

Una masera con barandas, piñeras, palas de orno (Santibáñez de la Isla, 1844)

Es un término de uso común ya que se trata de un objeto muy frecuente en las labores agrícolas. Analizando los ejemplos recogidos, encontramos por una parte una diferenciación en el material, se cita "pala de hierro" y "pala de madera". Se trata en ambos casos de un instrumento agrícola cuya diferencia en el material conlleva una diferencia en el uso. Pala es 'un instrumento o apero agrícola formado por una plancha de hierro con forma redondeada y cóncava o por una tabla de madera de fresno o de haya de forma cuadrangular, y un mango de madera al que se ajusta. La de hierro tiene como uso primordial abrir el "cembo" de las fincas o hacer las "presas" en las labores de riego y la de madera se usa para dar vuelta a la trilla cuando ya es menuda o para remover cualesquiera otros objetos menudos, sobre todo grano o legumbres ya limpias' (Rivas, 1996: 171). Por otra parte, encontramos otra serie de ejemplos en los que se especifica el uso que se le da a la pala, así se citan "palas de horno", se trata de una pala de madera, plana y con el mango muy largo utilizada para meter y sacar el pan del horno, se citan también "palas esterqueras" o "de estercar" o en algún caso "de echar abono", es decir usadas para cargar y esparcir el abono, en algunas zonas a estas se las llama pala de dientes, no en este corpus donde el término con este uso siempre se recoge con las denominaciones indicadas anteriormente. Finalmente, el término también aparece junto a la voz azadón para designar la parte de hoja de hierro en forma rectangular de este apero, diferenciándola de la que tiene forma de dientes, no de hoja. Con este significado asociado a la voz azada se utiliza en el ejemplo de Grajal de la Ribera «dos palas de pico», donde en este caso la pala de la azada tiene forma triangular.

\section{PEÑERA [piñera]}

Sust. f. El DRAE localiza la voz en Asturias con el significado de 'cedazo fino'. Origen disc. quizá de un *pellinaria 'cedazo de piel agujereada' con cambio de *pelnaria en *pennaria y luego peñera (DECH, s.v. peñera).

Un cribo, una piñera (Castrocalbón, 1643) 
Dos piñeras la una buena y la otra biexa (Alija del Infantado, 1646)

Dos piñeras (La Antigua, 1647)

Dos piñeras biexas (La Antigua, 1648)

Dos piñeras de zirnir (Genestacio de la Vega, 1650)

Una piñera (Genestacio de la Vega, 1721)

Dos piñeras (Palacios de Jamuz, 1728)

Una piñera biexa (Palacios de la Valduerna, 1728)

Una clavera, dos piñeras biejas y un quadro (Requejo de la Vega, 1735)

Dos piñeras usadas (Laguna de Negrillos, 1740)

Quatro piñeras (La Nora del Río, 1823)

Una piñera (Requejo de la Vega, 1839)

Se trata de una voz común en todo el corpus estudiado. El significado del término es el de 'especie de ceranda para cerner la harina'. El $D E C H$ señala que la primera vez que la voz aparece documentada es en 1550 en Cristóbal de Villalón, quien tenía por voces de las montañas, propias de los que no saben castellano, las de masera por artesa o peñera por cedazo (DECH, s.v. peñera). En el corpus estudiado, se observa que incluso en los mismos inventarios aparecen las voces cedazo y piñera, o piñera y ceranda; esto hace suponer que se trata de objetos un poco distintos, tal vez la piñera es un cedazo que sirve para cerner materiales más finos. Así en algunos vocabularios de la zona se define como 'especie de zaranda o cribo de seda y tela fina para cerner la harina y quitarle el gorgojo. Se bate una contra otra encima de las barandas' (Rivas, 1996:184). Formalmente, nunca aparece bajo la variante peñera ni bajo otras formas que sí se documentan en otras zonas, por ejemplo la forma diptongada piñeira.

\section{PETO}

Sust. m. El DRAE en su $4^{\text {a }}$ acepción define el término como 'parte opuesta a la pala y en el otro lado del ojo, afilada o sin afilar, que tienen algunas herramientas, como el hacha, la podadera y el azadón'. Del italiano petto y de la variante onomatopéyica pet-, el portugués peto 'pico carpintero' y peta 'hacha pequeña' (DECH, s.v. pecho y picar).

Un azadón de peto (La Bañeza, 1641)

Una azuela de peto (Alija del Infantado, 1644)

Una azada con peto y una tornadera de yerro (San Feliz, 1838)

El término solo aparece en el corpus con los términos azada, azadón o azuela, es decir, que independientemente de que se conozca con las otras acepciones que tiene el término y que recoge el DRAE, en los ejemplos solo aparece para designar el tipo de herramienta que se caracteriza por ser una 'parte de la azada o el azadón que consiste en un pico puntiagudo en uno de sus extremos' (Rivas, 1996: 180). Parece ser que esta 
característica de estas azadas especializa su uso para determinadas funciones como desbrozar, escardar, etc.

\section{PODADERA}

Sust. f. 'Herramienta acerada, con corte curvo y mango de madera o hierro, que se usa para podar' (DRAE). Término derivado de podar, del latín pŭtare, propiamente 'limpiar' (DECH, s.v. podar).

Una podadera y un calabozo (La Bañeza, 1641)

Una podadera y un calabozo (La Bañeza, 1641)

Una podadera pequeña buena (Alija del Infantado, 1647)

Otra podadera biexa (Alija del Infantado, 1647)

Una podadera biexa (Grajal de la Ribera, 1730)

Una podadera (Grajal de la Ribera, 1730)

Un escriño y una podadera (Genestacio de la Vega, 1721)

Es un término de uso común que se encuentra dentro de los aperos de labranza que se utilizaban para podar los árboles o quitar la maleza. En algunas zonas de León se puede encontrar el término bajo la variante occidental podadeira, pero en este corpus todos los ejemplos aparecen bajo la forma castellana.

\section{RASTRA}

Sust. f. El DRAE lo define como femenino de rastro y remite a las voces rastro y rastrillo. Del latín rastrum 'rastrillo de labrador' (DECH, s.v. rastro).

Una rastra de apañar trillas (Alija del Infantado, 1644)

Una rastra biexa (Alija del Infantado, 1650)

Una rastra y una bienda (Grajal de la Ribera, 1730)

Probablemente se trate de un término que designa un apero de labranza próximo al rastro, pero con alguna diferencia. El ejemplo de Alija del Infantado que matiza el uso del apero tanto en el caso de la rastra como en el del rastro, lleva a pensar que la rastra quizá sea más ancha, y por tanto con mayor capacidad de recoger que el rastro. De ahí que una se utilice para la trilla y el otro para cosas menores como la hierba.

\section{RASTRILLO [restrillo]}

Sust. m. 'Instrumento compuesto de un mango largo y delgado cruzado en uno de sus extremos por un travesaño armado de púas a manera de dientes, y que sirve para recoger hierba, paja, broza, etc.' (DRAE). Del latín rastrum 'rastrillo de labrador' (DECH, s.v. rastro). 
Un rastrillo bueno (La Bañeza, 1641)

Un rastrillo (Castrocalbón, 1643)

Un rastrillo de rastrillar bueno (Castrocalbón, 1643)

Un restrillo de restrillar (Alija del Infantado, 1644)

Un restrillo de arrastrillar bueno (Coomonte de la Vega, 1644)

Un restrillo bueno (Coomonte de la Vega, 1645)

Un restrillo bueno (Alija del Infantado, 1646)

Un rastrillo bueno (La Antigua, 1648)

Dos restrillos de restrillar (Genestacio de la Vega, 1650)

Un restrillo bueno (Alija del Infantado, 1650)

Otro restrillo bueno (Alija del Infantado, 1650)

Un rastrillo quebrada la tabla (La Bañeza, 1721)

Un rastrillo con unas gatas en la tabla (Fresno, 1726)

Un rastrillo (Palacios de Jamuz, 1727)

Un rastrillo viejo (Palacios de Jamuz, 1728)

Otro restrillo viexo (Miñambres, 1729)

Un rastrillo (Grajal de la Ribera, 1730)

Un rastrillo biexo (Grajal de la Ribera, 1730)

Es un término que designa un apero de labranza común, concretamente se llama rastrillo al 'apero de labranza de hierro, con varios dientes o gajos y con mango de madera'. Es muy frecuente encontrar la voz bajo la variante restrillo, ya que en este término no es esporádica la alternancia de /a/ y /e/ donde el contexto de /i/ tónica junto al hecho de ir trabada por una /s/ facilita esta vacilación (Morala, 2009: 559). Esta variante, que es muy frecuente en este corpus, aparece en pocos casos en el CORDE, por lo que podemos hablar de una vacilación en el timbre de las átonas común en esta zona.

\section{RASTRO}

Sust. m. El DRAE remite a la voz rastrillo y define el término como 'instrumento que sirve para recoger hierba'. Del latín rastrum 'rastrillo de labrador' (DECH, s.v. rastro).

Dos rastros (Urdiales del Páramo, 1645)

Un rastro de apañar paxas (Alija del Infantado, 1646)

Son los únicos ejemplos recogidos, se trata de un término que aparece con el significado del DRAE, aunque tiene varios usos: recoger la hierba, la paja trillada, o incluso arrastrar el carro (Fuente García, 2000: 487).

\section{RAJADILLO}

Sust. m. 'Ceranda de cuero, en la cual este aparece horadado con dos tipos de orificios: unos de forma alargada, para que por ellos caiga el centeno indebidamente mezclado con el trigo que se pretende limpiar, y otros redondos y pequeños, por donde se cuelan las impurezas; de esta manera, el grano queda preparado para sembrarlo' (Le Men, 2012 s.v. rajadillo). Derivado de rajar, voz de origen incierto (DECH, s.v. rajar). 
Un cribo de rajadillo (Castrillo de la Valduerna, 1828)

Es el único ejemplo recogido del término y se localiza en la zona de la Valduerna, bastante próxima a la zona de la Cepeda Baja, donde también se ha documentado este término que no recoge el DRAE, tampoco el CORDE, ni se encuentra documentado en otras zonas.

\section{REGADERA}

Sust. f. 'Recipiente portátil a propósito para regar, compuesto por un depósito del que sale un tubo terminado en una boca con orificios por donde se esparce el agua' (DRAE). Término derivado de regar, del latín rĭgāre (DECH, s.v. regar).

Una regadera (Requejo de la Vega, 1839)

Una regadera de ojadelata vieja (Destriana, 1843)

Son los únicos ejemplos recogidos, aunque se trata de un término de uso común. Su significado es el que da el diccionario académico.

\section{RODADOR [arrodador, arrudadera]}

Sust. m. y f. La Academia define el término en la $3^{\text {a }}$ acepción como 'llaneador'. Se trata de una palabra derivada de arrodar, con la /a-/ protética, y a su vez del latín rŏta. (DECH, s.v. rueda).

Un arrodador de madera (Destriana, 1728)

Una arrudadera (Valle de la Valduerna, 1829)

Probablemente, se trate de una voz dialectal ya que no aparece ni en el CORDE ni en el DRAE, y sí en vocabularios dialectales donde se define como 'instrumento construido con barras de hierro, o de madera, fuerte y compacta, cruzadas unas en sentido horizontal y otras en sentido vertical, que se utiliza para aplanar el terreno cuando este todavía tiene terrones o es irregular en su superficie' (Rivas, 1996: 36-37). De nuevo, como en otros casos, encontramos el término con variantes que presentan vacilación de vocales átonas.

\section{SACHO [xaxo, sajo]}

Sust. m. 'Instrumento de hierro pequeño y manejable, en figura de azadón, que sirve para sachar' (DRAE). Derivado del latín sarculum, 'escardillo', der. de sarrire, 'escardar' (DECH, s.v. sacho).

Un xaxo de yerro pequeño (Coomonte de la Vega, 1645)

Dos sajos de guerta (Robledo de la Valduerna, 1726) 
Es el único ejemplo recogido, aunque se trata de una palabra muy conocida en la zona, y ampliamente documentada en toda la provincia. Aunque tiene otras acepciones en León como 'vástago de la vid con hojas' o 'hierba que nace en los sembrados y que hay que erradicar' (Le Men, 2012, s.v. sacho), la acepción utilizada en el corpus y en general en el partido judicial de La Bañeza es la de 'azada pequeña para cavar las malas hierbas' (Miguélez, 1998:159) 'azada pequeña para jejar' (Descosido, 1993: 182). Formalmente son muchas las variantes documentadas, en el corpus se recoge xaxo, sajo, forma frecuente en la zona del Órbigo como resultado de los grupos /pl-/, /kl-/, /fl-/; donde es frecuente encontrar la grafía " $\mathrm{x}$ " que podría representar el sonido /š/ que desembocaría en el resultado fricativo velar /x/ (Morala, 1987: 164-175), este resultado desembocaría más tarde en la grafía “ch", que es la que correspondería con la solución castellana. No obstante, la forma más empleada en la zona de La Bañeza es la variante jajo, forma en la que se produce una confusión $/ \check{\mathbf{s}} /=/ \mathrm{s} /$ por un fenómeno de asimilación.

\section{TORNADERA}

Sust. f. 'Horca de dos puntas usada para revolver la parva en las labores de la trilla' (DRAE). Término derivado de torno, del latín tornus y este del griego tópvos (DECH, s.v. torno).

Dos tornaderas de tornidar (Alija del Infantado, 1644)

Tres tornaderas de enzina (Coomonte de la Vega, 1645)

Un bildo y dos tornaderas grandes buenas (Alija del Infantado, 1646)

Un bildo y una tornadera biexos (Alija del Infantado, 1647)

Una tornadera de purrir manoxos grande (Coomonte de la Vega, 1650)

Una bilda y una tornadera (Fresno, 1726)

Dos tornaderas (Palacios de Jamuz, 1727)

Una tornadera (Requejo de la Vega, 1735)

Una tornadera de dos dientes (Huerga de Garaballes, 1720)

Una bilda y una tornadera (Castrillo de la Valduerna, 1828)

Una azada y dos tornaderas de yerro y una garabita (La Isla, 1829)

Un mazo de terrones y una tornadera (Palacios de la Valduerna, 1831)

Una tornadera de yerro y un yugo (Felechares, 1836)

Una azada con peto y una tornadera de yerro (San Feliz, 1838)

Es un término que aparece con frecuencia en los inventarios estudiados ya que designa un objeto muy común en las labores agrícolas. El significado básico es el que aparece en el DRAE, aunque convine matizar algunas cuestiones. En algunos vocabularios leoneses de la zona se define el término como 'apero de labranza, formado por una parte de madera a la que se unen dos o tres dientes o gajos también de madera $\mathrm{y}$, por último el mango; sirve para manejar, cargar y descargar hierba o mies en general, 
y para darle la vuelta a la trilla o a cualquier hatijo de hierba o manojo de cereal' (Rivas, 1996: 227), también encontramos la acepción de 'bilda de madera con varios ganchos, para volver al bálago en la trilla' (Descosido Fuertes, 1993: 189). Observando los ejemplos recogidos, se observa que aunque son términos muy próximos en el significado existen diferencias entre la bilda y la tornadera ya que en algún caso se relacionan dentro del mismo inventario como objetos diferentes. La diferencia se encuentra también en la forma, ya que la bilda es un objeto que tiene más puntas y además un palo atravesado que sirve de rejilla, mientras que la tornadera es un objeto más sencillo que, aunque frecuentemente sea de madera, también puede ser de yerro y, desde el criterio del uso, sirve fundamentalmente para dar vuelta en las labores de trilla. El DRAE no recoge ninguna referencia dialectal en su entrada, sin embargo el CORDE no registra ningún ejemplo, dato que está en consonancia con las referencias que del término hacen J. Corominas y J.A. Pascual que registran el término en un vocabulario zamorano y definen la tornadera con la matización de Zamora como 'instrumento de madera que usan los labradores para dar vuelta a la mies'. Formalmente, se recoge la variante tornadera, aunque en León es también frecuente encontrar las formas entornadera y con menor frecuencia tornadera (Le Men, 2011 s.v. tornadera).

\section{TRILLO}

Sust. m. 'Instrumento para trillar, que comúnmente consiste en un tablón con pedazos de pedernal o cuchillas de acero encajadas en una de sus caras' (DRAE). Del latín trībŭlum (DECH, s.v. trillo).

Un trillo (La Antigua, 1647)

Un trillo con su tiradero (La Antigua, 1648)

Dos trillos de pino (Huerga de Garaballes, 1720)

Un trillo de pino usado (Huerga de Garaballes, 1720)

Un trillo de pino con su tiradero (Huerga de Garaballes, 1720)

Un trillo nuevo con su tiradero sin alzabón (Grajal de la Ribera, 1723)

Un trillo mui biexo (Grajal de la Ribera, 1723)

Mas un trillo viejo (Ribas de la Valduerna, 1726)

Un trillo (Palacios de la Valduerna, 1727)

Un trillo usado (Palacios de Jamuz, 1728)

Un trillo bueno (Palacios de la Valduerna, 1728)

Dos trillos buenos (Palacios de la Valduerna, 1728)

Un trillo de pino (Palacios de la Valduerna, 1728)

Un trillo biexo (Grajal de la Ribera, 1730)

Un trillo (Santiago Millas, 1735)

Un trillo bueno (Genestacio de la Vega, 1738)

Un trillo (Laguna de Negrillos, 1742)

Dos trillos de chopo (Grajal de la Ribera, 1750)

Un trillo (Castrocalbón, 1814) 
Una garabita de acanterar y dos trillos con dos atibas (La Isla, 1829)

Un trillo que no tiene palo (Quintanilla de Somoza, 1831)

Un trillo para trillar (Quintanilla de Somoza, 1831)

Un trillo de Soria (Palacios de la Valduerna, 1831)

Un trillo usado con su tiradero y cuartadero de yerro (Santibáñez de la Isla, 1844)

Es un término común ya que denomina uno de los aperos de labranza más utilizados por lo que se encuentra en prácticamente todos los inventarios. Puesto que se trata de un instrumento formado por varias tablas, en los ejemplos es frecuente que se nombre el tipo de madera del que está hecho así como el estado del objeto. No se ha recogido en este corpus la variante femenina trilla, que sí se documenta en inventarios de Castilla. Ello puede ser debido a que en este caso el escribano, al igual que el DRAE considera el trillo y la trilla términos sinónimos o a que realmente no se recoge un apero que teniendo la misma función sea de menor tamaño o sea arrastrado en un caso por mulos y en otro por bueyes (Perdiguero, 2012b: 1553)

\section{TROSA}

Sust. f. El DRAE recoge el término en plural y con la información de usada en León, define el término como 'especie de angarillas usadas para transportar entre dos personas tierra, estiércol y otros materiales'. Etimología discutida (DECH, s.v. trousa y trojar).

Unas trosas de hechar estiércol (Alija del Infantado, 1644)

Las trosas biejas (Santibáñez de la Isla, 1844)

Son los únicos ejemplos encontrados. En toda la zona de La Bañeza la acepción que se le da al término coincide con la que da el DRAE por lo que es lógico pensar que es el significado con el que se emplea el témino en estos dos ejemplos, en el primero el propio contexto confirma esta afirmación, además en diferentes repertorios léxicos de la zona se recoge la voz trosa, trousa que se define como 'angarillas compuestas por dos palos largos que sirven de asideros y atraviesan una cavidad tejida de mimbre, que servía para transportar mies, hierba, abono, etc' (Rivas, 1996: 230), o en Santibáñez de la Isla, de donde procede uno de los ejemplos trosas, 'especie de angarillas, formadas por dos palos largos, en medio de los cuales cuelga una cesta de mimbres, más o menos honda, que sirve para trasladar entre dos personas, estiércol, tierra, etc. Ha sido desplazada por el carretillo y puede resultar problemático encontrar alguno' (Miguélez, 1998: 179). Datos, por tanto, que confirman el uso que el término puede tener en el corpus. Formalmente, la voz solo aparece bajo la forma trosa, forma ya monoptongada frente a la variante con diptongo decreciente que sería esperable en la zona occidental. 


\subsubsection{Labores agrícolas}

\section{ACERANDAR [cerandar]}

Verb. El DRAE define el término azarandar o zarandar como la acción de 'limpiar el grano o la uva, pasándolos por la zaranda'. Término derivado de zaranda, de origen incierto, probablemente se trate de una onomatopeya tsándara que expresaría el son rítmico de la criba y el grano al zarandearlos (DECH, s.v. zaranda).

Dos cribos ya usados y una ceranda de acerandar cebada buena (Coomonte de la Vega, 1643)

Cinco zerandas de cerandar trigo biexas (Alija del Infantado, (1647)

El significado que tiene el término en estos ejemplos es el de 'cribar con la ceranda el grano de cereal o de cualquier clase de legumbre'. La voz aparece siempre con la variante /e/, frecuente en las hablas leonesas que el $D E C H$ explica como variantes influenciadas por otro término como serondo.

\section{ACRIBAR}

Verb. 'Cribar, limpiar el trigo u otra semilla por medio de la criba, del polvo, tierra, neguilla y demás impurezas' (DRAE). Término derivado del latín crībrāre (DECH, s.v. cribo).

Un cribo de acribar bueno (Alija del Infantado, 1644)

El término se utiliza con el significado que aparece en el DRAE.

\section{APAÑN}

Verb. 'Coger, especialmente con la mano'. 'Recoger, coger con la mano frutos especialmente del suelo' (DRAE). Parece ser derivado de paño, procedente del latín pannus (DECH, s.v. apañar).

Una rastra de apañar trillas (Alija del Infantado, 1644)

Un rastro de apañar paxas (Alija del Infantado, 1646)

Un escriño y una cesta de apañar guebos (Villamor de Órbigo, 1648)

El verbo se emplea con el significado general de 'recoger algo del suelo', aunque en el primer caso el término adquiere un significado restrictivo del significado general ya que se hace referencia a la acción de 'recoger la trilla arrastrándola para reunirla en un montón' (Rivas, 1996: 28).

ASEMENTAR [assementar] (vid. sembrar)

Dos cubos de assementar (Coomonte de la Vega, 1734) 


\section{ATROPAR}

Verb. 'Juntar, reunir, especialmente la mies que se recoge en gavillas o el heno que antes se ha esparcido para que se seque' (DRAE). Término derivado de tropa, del francés troupe (DECH, s.v. tropa).

Una maroma de atropar las trillas con su tiradero (Valle de la Valduerna, 1829)

El cuartadero de atropar las trillas con su dogal (Santibáñez de la Isla, 1844)

El término es muy común en toda la provincia de León, aunque solo se hayan recogido estos dos ejemplos en el corpus. El significado general del término es el de 'recoger del suelo o reunir en él objetos caídos o dispersos' (Le Men, 2002, s.v. atropar). Se puede afirmar que se trata de un sinónimo del término apañar, aunque quizá el verbo atropar añada un matiz diferente que es el de 'reunir'. La distribución de los ejemplos es geográficamente diferente, aunque no es significativo puesto que el verbo atropar también es común en la zona del Bajo Órbigo.

\section{BELDAR [bildar, vendar]}

Verb. 'Aventar con el bieldo las mieses, legumbres, etc., trilladas para separar del grano la paja' (DRAE). Término procedente del latín ventilare 'agitar en el aire' (DECH, s.v. beldar).

Una vienda de vendar paja (Santibáñez de Vidriales, 1645)

Dos bildas biejas de bildar paja (Alija del Infantado, 1647)

\section{DESBAGAR}

Verb. 'Sacar de la baga la linaza' (DRAE). Término derivado de baga, del latín baca 'fruto (de cualquier planta)' (DECH, s.v. baga I).

Dos mazos de desbagar lino (Palacios de la Valduerna, 1831)

Es un término común que aparece en trabajos dialectales de la zona (Descosido, 1993: 178), aunque en este corpus solo se ha recogido este ejemplo cuyo significado deducible por el contexto es el de 'machacar el lino para sacar la linaza'. No obstante, se trata de una voz que no aparece en el CORDE ni bajo esta forma ni bajo las otras variantes con las que está documentada esbagar, devagar, formas que tampoco se han localizado en este corpus. El CORDE sí recoge el término baga con el significado de 'fruto', aunque los ejemplos son escasos. 


\section{ESTERCAR}

Verb. 'Desus. estercolar' (DRAE). Derivado de estiércol, del latín stěrcus, -ŏris (DECH, s.v. estiércol).

Una pala de estercar (Palacios de la Valduerna, 1728)

El término se usa con el significado que da el DRAE, es decir 'echar estiércol en las tierras para engrasarlas y beneficiarlas', aunque en los repertorios lexicográficos leoneses es más común encontrar el verbo estercar aplicado al animal, con el significado de 'echar el excremento', quizá para nombrar la acción de echar estiércol a las tierras, se utilice más el verbo abonar.

\section{ESPURRIR}

Verb. El DRAE da como $1^{\text {a }}$ acepción 'estirar, extender, especialmente las piernas y los brazos en Ast., Burg., Cantb., León, Pal. y Zam'. Término derivado de apurrir, del latín porrĭgĕre (DECH, s.v. apurrir).

Una cesta de paxas de espurrir balonas (Alija del Infantado, 1644)

Una zesta de espurrir balonas (Alija del Infantado, 1650)

Son los únicos ejemplos recogidos en el corpus. Ambos pertenecen a inventarios de la misma zona y aparecen junto al término cesta. Este dato permite afirmar que el significado es el de 'estirar', haciendo referencia a las cestas, probablemente se utilizan para estirar o extender este tipo de prendas que son las balonas, aunque el uso más extensivo que se hace del término es un uso pronominal, como indica el DRAE.

\section{LABRANZA}

Sust. f. 'Cultivo de campos' (DRAE). Derivado de labrar, del latín laborare 'trabajar' (DECH, s.v. labor).

Dos bueyes foscos de labranza de nuebe o diez años cada uno (Alija del Infantado, 1646)

Un buey de labranza pardo (Genestacio de la Vega, 1650)

Un buey color castaño de labranza (Coomonte de la Vega, 1719)

Dos tibas de labranza (Destriana, 1728)

Un lumbral de labranza (Destriana, 1728)

Dos bueies de labranza (Santiago Millas, 1735)

Un buey de labranza (Alija del Infantado, 1737)

Es un término que aparece como adyacente de otro que designa un objeto o un animal destinado a labores agrícolas. 


\section{MAJAR}

Verb. 'Golpear en la era el centeno, el trigo, el lino, los garbanzos, etc., con el manal o mayal para separar el grano de la paja' (DRAE). Derivado del arcaico majo 'mazo de hierro' que procede del latín mallěus (DECH, s.v. majar).

Dos mazos de majar lino (Palacios de la Valduerna, 1728)

Al tratarse de un verbo, los ejemplos encontrados del término son escasos, a excepción del que aparece señalado en el que se cita un objeto y se especifica el fin del mismo. El verbo majar es conocido en toda la zona con el significado genérico de 'machacar'. En la Valdería se usa majar para designar la acción de 'separar el grano de la paja en el caso de mies, y las vainas de su fruto respectivo en el caso de las legumbres, a base de golpear los tendidos en el suelo, mediante una tornadera de madera, una bilda de hierro u otros aperos. A este proceso se recurrió antes de descubrir el trillo en el caso de la mies y se siguió utilizando posteriormente para las legumbres a causa de que con el trillo se estropeaban algunas' (Rivas, 1996: 152). No obstante el proceso que se seguía para la mies y la legumbre era distinto, ya que esta última con majarla era suficiente para separar el fruto de la vaina. En Santibáñez de la Isla, comprendido también en este corpus, majar es también 'machacar el ajo' (Miguélez, 1998: 162). El participio del verbo majar aparece en un ejemplo de Coomonte de la Vega de 1643, «nuebe copos de lino maxado» y en otro de Palacios de la Valduerna de 1831, «diez y ocho mañizos de lino majado».

\section{PRENDER}

Verb. 'Asir, agarrar, sujetar algo' (DRAE). Del latín prehĕnděre 'coger', 'atrapar' (DECH, s.v. prender).

Una cadena de yerro de prender una cabalgadura (Coomonte de la Vega, 1643)

Una cestita de prender balonas (Alija del Infantado, 1644)

Dos prisiones de prender bueyes (Destriana, 1843)

El término se utiliza en León con varios significados, algunos de ellos no tienen justificación en el contexto en el que los ejemplos aparecen en el corpus. En estos casos concretos, fundamentalmente en el primero y en el tercero el verbo prender se usa con el significado de 'atar'. En este sentido es de suponer que la acepción 'uncir' que se registra en algunas zonas de León para el verbo prender (Krüger, 1991: 158), no se recoja en este corpus puesto que el verbo no aparece en ningún caso en los contextos en los que se recogen términos que sirven para uncir, mientras que sí en estos ejemplos con términos que designan objetos que se utilizan para atar. El ejemplo de Alija del 
Infantado presenta un contexto próximo al del verbo espurrir, dato que puede hacer pensar que se utiliza con el mismo significado. Álvarez Cabeza señala también para el término la acepción de 'sujetar con pinzas' (Álvarez Cabeza, 1994: 135), acepción que podría estar utilizándose en este ejemplo de acuerdo con su contexto.

\section{RASTRILLAR [restrillar, arrastrillar]}

Verb. 'Limpiar el lino o cáñamo de la arista y estopa'. 'Recoger con el rastro la parva en las eras o la hierba segada en los prados' (DRAE). Del latín rastrum 'rastrillo de labrador' (DECH, s.v. rastro).

Un rastrillo de rastrillar bueno (Castrocalbón, 1643)

Un restrillo de restrillar (Alija del Infantado, 1644)

Un restrillo de arrastrillar bueno (Coomonte de la Vega, 1644)

El término se utiliza con el mismo significado que da el DRAE, aunque en el corpus también es frecuente encontrar con este significado el verbo genérico apañar. Formalmente, la voz se encuentra bajo la variante normativa o con vacilación de las vocales /a/ /e/, como en el caso del término de la misma familia léxica rastrillo. También se encuentra la variante arrastrillar.

\section{SEMBRAR}

Verb. 'Arrojar y esparcir las semillas en la tierra preparada para este fin' (DRAE). Del latín sēmiñāre, deriv. de sēmen 'semilla' (DECH, s.v. sembrar).

Una cesta de sembrar (Ribas de la Valduerna, 1726)

Un zesto de sembrar (Palacios de la Valduerna, 1727)

Una zesta tabliza de sembrar (Miñambres, 1729)

Una zesta de sembrar (Miñambres, 1731)

Un cesto de sembrar y una cesta (Palacios de la Valduerna, 1831)

Una cesta de sembrar (Destriana, 1843)

El término se usa con la acepción del DRAE, aunque con un uso minoritario también se usa en el corpus el término asementar.

\section{TORNEAR}

Verb. 'Dar vuelta a la parva' (DRAE). Término derivado de torno, del latín tornus, y este del griego tórnos 'torno, instrumento de torneador o tornero' (DECH, s.v. torno).

Dos tornaderas de tornidar (Alija del Infantado, 1644)

Es el único ejemplo recogido que unido a la palabra tornadera y con la misma raíz léxica, hace suponer que probablemente se trate de un sinónimo de beldar o bildar, acto que se realiza con la bilda, o en este caso, con la tornadera. El término tornadera 
se registra solo en zonas de Castilla y León, este dato unido a que se usa menos el verbo, puesto que existen otros términos para designar la misma acción, explica que solo se registre un caso y que sea un término que apenas aparece documentado. Formalmente se registra bajo la forma tornidar, con presencia de la /-d-/ que puede explicarse como un caso de ultracorrección, ya que los escribanos trataban de distinguirse desde un punto de vista socio cultural y este hecho explicaría la presencia de este fenómeno en algunos casos. Concretamente en este ejemplo, puesto que la acción se realiza con la tornadera, se obtiene por similitud tornidar.

\section{TRASQUILAR [tresquilar, trisquilar]}

Verbo ' Cortar el pelo o la lana a algunos animales' (DRAE). Del antiguo y aragonés esquirar, y este del gótico *skaíran. De un cruce de esquirar con su sinónimo tondir resulta el dialectal tosquirar, cambiado por influjo del prefijo tras- en trasquilar (DECH, S.v. esquilar).

Unas tijeras de tresquilar ganado buenas (Urdiales del Páramo, 1645)

Dos pares de tixeras de trisquilar el ganado (Bercianos del Páramo, 1648)

El contexto en el que aparecen los términos muestra que el significado utilizado es el de 'esquilar'. Formalmente, se trata de un término que presenta muchas variantes, como lo demuestran los dos ejemplos encontrados en los que aparece de forma distinta en cada uno de ellos.

\section{TRILLA}

Sust. f. ' Acción y efecto de trillar' (DRAE). Derivado de trillo, del latín trībǔlum (DECH, s.v. trillo).

Una rastra de apañar trillas (Alija del Infantado, 1644)

Una trilla de trillar (La Nora del Río, 1645)

Una maroma de atrapar las trillas con su tiradero (Valle de la Valduerna, 1829)

El cuartadero de atrapar las trillas con su dogal (Santibáñez de la Isla, 1844)

El término aparece en estos ejemplos en los que se usa con acepciones diferentes. En todos los casos, excepto en el de La Nora del Río, el significado es el de 'la mies extendida en la era formando un gran círculo, dispuesta para ser trillada' (Fuente García, 2000: 564); mientras que en el segundo ejemplo el término nombra un apero de labranza. Comúnmente el objeto que se emplea para trillar es el trillo, no aparece la voz trilla con esta acepción. Solamente el DRAE en uno de los significados que da para trilla remite a la voz trillo y en sus primeras ediciones señala que es la 
misma voz que trillo, pero más usada. En el CORDE dentro de los numerosos ejemplos que aparecen del término en femenino, se encuentran tres del mismo autor y época: Pedro Ribadeneira, S. XVI, en los que se define como 'instrumento que aprieta y quebranta la trilla o que aparta la paja del grano'. Por tanto, es probable que se trate del mismo objeto y que no existan ni siquiera diferencias formales del mismo, siendo el término en masculino el empleado normalmente en esta zona, dato que explicaría que solo aparezca una vez en el corpus frente a los numerosos ejemplos que se documentan del término trillo.

\section{TRILLAR}

Verbo 'Quebrantar la mies tendida en la era, y separar el grano de la paja' (DRAE). Del latín trībŭlum (DECH, s.v. trillo).

Una trilla de trillar (La Nora del Río, 1645)

Dos tiraderos de trillar con sus yerros buenos (Alija del Infantado, 1650)

Un trillo para trillar (Quintanilla de Somoza, 1831)

El término tiene el significado que da el DRAE referido a una tarea agrícola. Concretamente en zonas del P.J. de la Bañeza y en otras áreas de León, este verbo tiene otras acepciones que no aparecen recogidas en el DRAE como la de 'ponerse reblandecidas las plantas de los pies por el sudor después de una larga caminata' o 'llevarse bien con alguien' (Miguélez, 1998: 178); aunque evidentemente no son los significados que tiene el término en estos ejemplos en los que el verbo aparece designando la acción que se lleva a cabo con el trillo, la trilla o el tiradero.

\subsubsection{Recipientes}

\section{AZAFATE}

Sust. m. 'Canastillo, bandeja o fuente con borde de poca altura, tejidos de mimbres o hechos de paja, oro, plata, latón, loza u otras materias' (DRAE). Término procedente del ár. sáfat (DECH, s.v. azafate).

Varios cestos azafates y cestas pichoneras (La Nora del Río, 1823)

Un arca con cerradura y llave y en ella un azafate con tapadera (Requejo de la Vega, 1839)

Solo se han recogido dos ejemplos. Es una voz bastante común en corpus léxicos como el CORDE, por tanto la escasez de ejemplos en este caso no tiene una explicación aparente. El DRAE lo define como una cesta de mimbre. Le Men especifica 
en su diccionario el fin para el que estos cestos se empleaban, se trataba de una cesta que se empleaba para guardar los útiles de la costura o para llevar la oblada en la misa en el momento del ofertorio (Le Men 2000, s.v. azafate). En estos dos ejemplos no tenemos más información, por tanto puede tener cualquiera de los significados señalados.

\section{BANASTA [banastra]}

Sust. m. 'Cesto grande formado de mimbres o listas de madera delgadas y entretejidas' (DRAE). Término cuyo origen es idéntico al de canasta, (y este de canastillo del lat. canistěllum, derivado de canı̌strum) cruzado con el galo benna 'cesto de mimbre' (DECH, S.v. banasta).

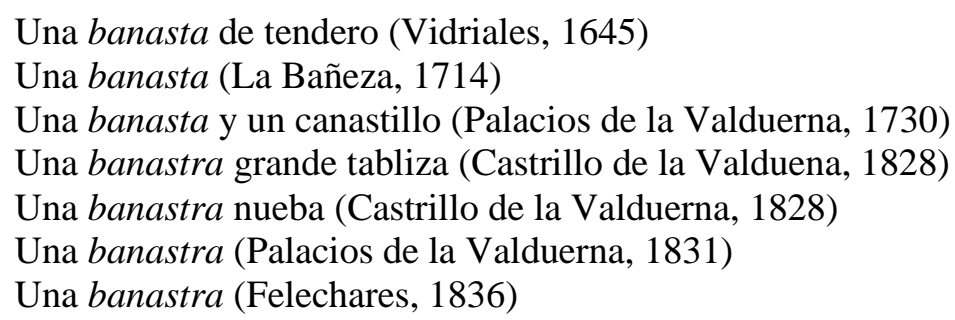

Una banasta de tendero (Vidriales, 1645)

Una banasta (La Bañeza, 1714)

Una banasta y un canastillo (Palacios de la Valduerna, 1730)

Una banastra grande tabliza (Castrillo de la Valduena, 1828)

Una banastra nueba (Castrillo de la Valduerna, 1828)

Una banastra (Palacios de la Valduerna, 1831)

Una banastra (Felechares, 1836)

Dos banastas (Santibáñez de la Isla, 1844)

El vocablo se localiza fundamentalmente en la zona de la Valduerna y la Valdería. Además en la Valduerna es donde predomina la forma banastra. Se trata de una cesta que en algunos casos está hecha de tablillas de madera, de ahí la presencia del adjetivo tabliza, en uno de los ejemplos. A partir de los datos, no se puede deducir el uso de esta cesta, probablemente tenía diferentes funciones y la que aparece en el primer ejemplo quizá pueda referirse a una cesta usada por un comerciante.

\section{CANASTA}

Sust. f. 'Cesto de mimbres, ancho de boca, que suele tener dos asas' (DRAE). Término derivado de canastillo, del lat. canistěllum, diminutivo de canı̌strum (DECH, s.v. canastillo).

Una canasta larguita con una redoma y una luneta (Laguna de Negrillos, 1725)

Una canasta y servilleta (La Nora del Río, 1820)

Una canasta de bidrio pequeña (Requejo de la Vega, 1839)

La canasta o canasto, aunque en el corpus solo se recoge el término en femenino, suele designar un 'cesto utilizado especialmente en la vendimia' (Le Men, 2004, s.v. canasta), acepción con la que es posible que se utilice también la voz talega. Quizá en algunos de los ejemplos, concretamente en el primero y último, el término 
hace referencia a una cesta que contiene objetos de vidrio, de ahí el sintagma "de bidrio" del ejemplo de Requejo de la Vega, que equivale a decir una cesta vidriada.

\section{CANASTILLO [canestillo, canastrillo]}

Sust. m. 'Azafate hecho con mimbres' (DRAE). Término derivado de canastillo, del lat. canistěllum, diminutivo de canistrum (DECH, s.v. canastillo).

Un canastillo (Castrocalbón, 1643)

Un canestillo (Alija del Infantado, 1644)

Un canastillo tablado biexo (Alija del Infantado, 1647)

Un canestillo grande, tablado, bueno (Alija del Infantado, 1647)

Un canestillo (Vidriales, 1645)

Un canestillo (La Antigua, 1647)

Un canestillo tablado (La Antigua, 1648)

Una banasta y un canastillo (Palacios de la Valduerna, 1730)

Una aceitera y un canastillo (Grajal de Ribera, 1806)

Un canastrillo para oferta y otro de paxa (Quintanilla de Somoza, 1831)

Dos canastillos y una bandeja de cristal (Requejo de la Vega, 1839)

La palabra se utiliza a lo largo de todo el corpus con el significado que da el DRAE. En algunos casos suele especificar el uso "para oferta" y en otros el tipo "tablado". El término aparece con bastante frecuencia con vacilación de /a e/ que se explicaría como un caso de vacilación en el timbre de las vocales átonas. Este cambio de /a/ por /e/ es bastante frecuente cuando la vocal va trabada por la consonante /s/. Bajo la forma normativa son numerosos los ejemplos encontrados en el CORDE, sin embargo, con la variante canestillo solo aparece un ejemplo del S. XIII. En el corpus estudiado, el término se recoge en una ocasión con la variante canastrillo que J. Corominas y J.A. Pascual explican como una forma secundaria debida al influjo del sufijo -astro. Esta variante se recoge en otras zonas del norte: Asturias, Zamora o Santander.

\section{CESTA [zesta]}

Sust. f. 'Recipiente tejido con mimbres, juncos, cañas, varillas de sauce u otra madera flexible, que sirve para recoger o llevar ropas, frutas y otros objetos' (DRAE). Término procedente del latín čsta (DECH, s.v. cesta).

Una cestica frutera de binbre con cosa de medio celemín de garbanzos (Coomonte de la Vega, 1643)

Una cestica de ofrecer pequeña (Coomonte de la Vega, 1643)

Una zestica tablada (Coomonte de la Vega, 1643)

Una cestita de prender balonas (Alija del Infantado, 1644)

Una cestica de estera con unas pocas de pepitas de melón (Alija del Infantado, 1644)

Una cesta de paxas de espurrir balonas (Alija del Infantado, 1644)

Una cestica de ofrecer de binbre blanca (Coomonte de la Vega, 1645)

Una cesta de binbre biexa (La Antigua, 1648) 
Otra cesta de quelmo biexa (La Antigua, 1648)

Una cesta de apañar guebos (Villamor de Órbigo, 1648)

Una zesta de ofrecer biexa (Genestacio de la Vega, 1650)

Una zesta tabliza (La Bañeza, 1721)

Una cesta de sembrar (Ribas de la Valduerna, 1726)

Dos zestillas de binbre (Destriana, 1728)

Dos zestas tablizas (Destriana, 1730)

Una zesta de sembrar (Miñambres, 1731)

Una cesta de costura y un cesto (Castrocalbón, 1814)

Varios cestos azafates y cestas pichoneras (La Nora del Río, 1823)

Una cestilla (Destriana, 1825)

Una cesta sembradera (Valle de la Valduerna, 1829)

Una cesta tabliza y otra de mimbres (Quintanilla de Somoza, 1831)

Una cesta y un facerón (San Feliz, 1838)

Una cesta de sembrar (Destriana, 1843)

El término es más frecuente que otras voces de significado similar como banasta o azafate. El término banasta aparece fundamentalmente en las zonas de la Valduerna y la Valdería mientras que la palabra cesta es más frecuente en la Ribera del Órbigo y el entorno de La Bañeza, aunque, en cualquier caso, se trata de una palabra que aparece en toda la zona comprendida por este estudio. De los ejemplos puede deducirse que se trata de un 'recipiente hecho con varillas entretejidas que pueden ser de mimbre, de madera (tabliza) o de pajas'. Los ejemplos también nos indican los diferentes usos para los que se destinaba este objeto. Podía ser para llevar frutas, realizar diversas tareas agrícolas o para usos religiosos. Formalmente, de nuevo alternan las grafías que representan el sonido fricativo interdental en posición inicial, aunque a diferencia de otros términos, la variante actual cesta, cestica, es bastante habitual ya desde el siglo XVII y aparece con más frecuencia que la forma zesta. Además, el término aparece frecuentemente en diminutivo, con diferentes sufijos: -ica, -ita, -illa. Como ya se ha señalado, el sufijo -ica es frecuente en la zona situada más al sur (Sur de León y Norte de Zamora). Curiosamente, todos los ejemplos recogidos en Coomonte de la Vega presentan este sufijo que no siempre añade el significado de 'pequeño'. En cambio, los dos ejemplos de cestilla se recogen en Destriana, zona situada más al occidente. El diminutivo -ita aparece solo en una ocasión, en este caso probablemente con el significado de 'cesta pequeña'.

\section{CESTO [zesto]}

Sust. m. 'Cesta grande y más alta que ancha, formada a veces con mimbres, tiras de caña o varas de sauce sin pulir' (DRAE). Término derivado de cesta, del latín č̆sta (DECH, s.v. cesta). 
Un zesto de binbre blanco con una asa (Coomonte de la Vega, 1643)

Un cestico de binbre pequeño (Alija del Infantado, 1644)

Un cestico pequeño biexo con unos pocos de clabos (Alija del Infantado, 1644)

Un cesto tablado bueno grande (Alija del Infantado, 1647)

Un zesto tablado grande nuevo (Genestacio de la Vega, 1650)

Dos zestos de binbre (La Bañeza, 1721)

Un cesto de vinbre (Ribas de la Valduerna, 1726)

Un zesto de mimvre (Laguna de Negrillos, 1726)

Ocho zestos de vendimiar (Coomonte de la Vega, 1734)

Un zesto de traer paja y una mesica (Requejo de la Vega, 1735)

Un cesto y un paño viejo de ofrecer (Castrocalbón, 1814)

Un zesto tablizo y un banco (Castrocalbón, 1814)

Un zesto vlanco chico, un jarro de varro, un plato de Talavera, dos escudillas y dos cucharas de madera (Quintana del Marco, 1820)

Un cesto trenzado (Valle de la Valduerna, 1829)

Una terijuela de yerro y un cesto pequeño (Calzada, 1838)

Una tabla de chopo y un cesto de binbre (Calzada, 1838)

Un cesto blanco con labores (Quintana del Marco, 1839)

Tres cestos chicos (Santibáñez de la Isla, 1844)

Es un término común en todo el corpus, como su variante femenina. La diferencia con el término anterior parece estar en el tamaño y en los usos, ya que el material con el que se fabrican es similar: varillas de mimbre o tablas de madera. En principio, el cesto es generalmente más grande que la cesta, aunque en algunas zonas como la Valdería, hay una diferencia de forma ya que el cesto tiene una sola asa y la cesta dos. No obstante, los ejemplos de la Valdería son escasos y en el primero que aparece en la muestra se especifica que tiene una sola asa, especificación que podría hacer pensar que hay cestos con dos. En cuanto a la función para la que se destina, también en la zona de la Valdería hay diferencias. El cesto se utiliza para transportar fruta, patatas, etc. y la cesta únicamente para la costura. Sin embargo, en otras zonas próximas esta diferencia no se mantiene ya que aparece un ejemplo en el que se especifica "cesto con labores". No obstante, el cesto parece emplearse en una función propia, la de vendimiar, quizá por el tamaño mayor con respecto a la cesta. Formalmente, aparece de nuevo la alternancia de grafías para representar el sonido fricativo interdental, vacilación meramente gráfica. De nuevo, nos encontramos con casos de derivación con la adición del sufijo -ico que, como en todos los casos que han aparecido, se encuentra en los ejemplos situados más al sur del área comprendida en este estudio. En este caso el sufijo añade el significado de tamaño pequeño que se refuerza con el adjetivo pequeño. 


\section{CUELMO}

Sust. m. El DRAE señala que en Asturias, León y Zamora tiene el significado de colmo, es decir, 'paja, generalmente de centeno, que se usa para cubrir cabañas', 'techo de paja'. Término derivado de colmena, probablemente de origen prerromano; quizá de un céltico *kolmēnā, derivado de kŏlmos 'paja' (DECH, s.v. colmena).

Quatro cestas de cuelmo y dos escrinos (Bercianos, 1648)

Es el único ejemplo encontrado. El significado del término es el de 'haz de paja larga, generalmente de centeno, desprovista de grano' (Le Men, 2004, s.v. cuelmo). El ejemplo del corpus indica el material con el que están fabricadas las cestas, es decir, se trata de cestas de paja. Sin embargo, los escrinos también son cestas de paja, por tanto cabe pensar que exiten diferencias entre ellas para inventariarlas de forma separada. Tales diferencias pueden estar en el tipo de paja y en el uso, ya que el escrino se usa para transportar el grano o dar de comer a los bueyes. Con este significado solo aparece un ejemplo en el CORDE del S. XX.

\section{ESCUSABARAJA [escusavaraja]}

Sust. f. 'Cesta de mimbre con tapa' (DRAE). Covarrubias la define como "cesta grande de sirge o mimbres blancas, con una asa por lo alto y una cubierta, de manera que se puede echar un candadito, para que vaya seguro lo que lleva dentro; y por ir cerrada excusa pesadumbres y cuestiones si falta o no falta algo de lo que iba dentro" (Covarrubias, s.v. excusabaraja).

Una escusavaraja sin asa (Destriana, 1843)

Una escusavaraja grande buena (Destriana, 1843)

Son los únicos ejemplos localizados en el corpus y pertenecientes al mismo inventario. Se trata de un término poco común que el NTLLE incorpora a partir de la edición de 1956, aunque el término se documenta ya en el S. XVII. En el CORDE también se localizan muy pocos ejemplos, solo tres, fechados incluso con anterioridad a los recogidos en este corpus, en concreto en los SS. XVII y XIX.

\section{ESCRIÑo [escrino, escriña]}

Sust. m. y f. 'Cesta o canasta fabricada de paja, cosida con mimbres o cáñamo, que se usa para recoger el salvado y las granzas de los granos, o para dar de comer a los bueyes cuando van de camino' (DRAE). Término procedente del lat. scrinium. Es de uso general en el corpus analizado. 
Una escriña pequeña (Alija del Infantado, 1643)

Un escriño grande viejo (Alija del Infantado, 1643)

Dos escriños medianos (Alija del Infantado, 1644)

Una escriñica pequeña con unos clavos viejos (Alija del Infantado, 1647)

Un escriño bueno (Laguna de Negrillos, 1740)

Un escriño y una poladera (Genestacio de la Vega, 1720)

Una escriñica pequeña (Coomonte de la Vega, 1724)

Un escriño (Palacios de la Valduerna, 1728)

Dos escrinos de comer los bueyes (Palacios de la Valduerna, 1728)

Dos escriños viejos (Destriana, 1730)

Un escriño chico (Castrillo de la Valduerna, 1828)

Una escriña mediana (Santibáñez de la Isla, 1829)

Un escriño usado (Destriana, 1825)

El término se usa en León con el significado de 'cesta fabricada en paja que se usa para guardar harina, legumbres o transportar el grano' (Le Men, 2005, s.v. escriño) aunque en algunos lugares, como es el caso de la zona leonesa de la Valdería, aparece también con la acepción de 'cesto que se usa para dar de comer a los bueyes'. En los ejemplos extraídos del corpus, podemos pensar que se usa de forma genérica con el primer significado y cuando aparece con esta última acepción se especifica, como se muestra en los ejemplos de 1728 de Palacios de la Valduerna. Se recoge bajo las formas masculina y femenina. La variante escriña, tiene el mismo significado que su correspondiente masculina, pero en este caso, la oposición masculino/femenino se debe a una diferencia de tamaño. Así hablamos de "escriña mediana" y "escriña pequeña", sin embargo no se conoce a partir de qué dimensiones se cambiaría el femenino por el masculino. Le Men señala que el escriño es ligeramente mayor que la escriña y algo menor que la grona (op. cit. s.v. escriño), término este último que no se ha recogido en el corpus. Como se puede observar en los ejemplos, es preciso señalar que en las relaciones pertenecientes a localidades que se encuentran en la zona próxima a Zamora, o que actualmente pertenecen a esta provincia, el concepto de tamaño aparece reforzado mediante un proceso de derivación con la adición del sufijo -ico -ica, muy frecuente en esta zona. En cambio, en la zona noroccidental, próxima a la Maragatería, la matización referente al tamaño se hace mediante la utilización del adjetivo chico, unido al sustantivo escriño.

\section{ORONA [urona]}

Sust. f. 'Receptáculo hecho de pajas de centeno, tejidas con zarzas o mimbres, que se emplea para guardar harina', 'cesta o canasta grande fabricada de paja y cosida con 
cáñamo o mimbres, de que se usa para recoger el pan' (Le Men, 2007, s.v. hurona). Del latín aero, -ōnis (DECH, s.v. horón).

Dos uronas (La Bañeza, 1641)

Dos oronas buenas que arán a dos cargas de pan (Alija del Infantado, 1646)

Una orona pequeña biexa (Alija del Infantado, 1646)

Una urona pequeña que ará quatro eminas de pan (Alija del Infantado, 1647)

Una hurona de paxa (La Antigua, 1647)

Una orona que ará seis cargas (Coomonte de la Vega, 1650)

Dos uronas grandes (Robledo de la Valduerna, 1726)

Una orona vieja que ará una carga de linaza (Miñambres, 1727)

Dos oronas medianas (Palacios de Jamuz, 1728)

Una orona vieja (Palacios de la Valduerna, 1728)

Otra orona más chica buena (Palacios de la Valduerna, 1728)

Dos uronas pajizas (Santiago Millas, 1735)

Una orona grande con tapa (Castrocalbón, 1814)

Una urona pequeña (La Nora del Río, 1823)

Dos oronas chicas (Castrillo de la Valduerna, 1828)

Una orona chiquita (Quintanilla de Somoza, 1831)

Una uronica sin ondón (Destriana, 1843)

Una orona (Santibáñez de la Isla, 1844)

Una orona chica (Santibáñez de la Isla, 1844)

Es un término que el DRAE no incorpora hasta la edición de 1989 bajo la forma horón y con el significado de 'serón grande y redondo'. Le Men lo recoge en su vocabulario y lo documenta en el Bierzo. Sin embargo, son muchos los casos extraídos del corpus, por lo que se trata de una voz común en la zona de La Bañeza. Observando los ejemplos, se puede afirmar que la voz se utiliza con el significado genérico de 'cesta' que se utiliza o bien para guardar el pan, o bien para guardar harina, linaza, etc. Es frecuente que el término aparezca en el corpus especificando el tamaño o estado de la cesta. Además solo se recogen formas en femenino tanto en este corpus como en léxicos dialectales (op.cit. s.v. hurona), mientras que tanto en el diccionario académico como en los escasos ejemplos del CORDE el término aparece bajo la forma masculina horón. Puede ser que este hecho se deba a que formalmente, alternan las variantes hurona, orona, con presencia o ausencia de la h-, fenómeno no significativo, presentando gran variabilidad, de manera que el uso del término en femenino evita la confusión con la voz hurón. Esta variación vocálica es una muestra más de la inestabilidad que algunas vocales tienen en determinados contextos sobre todo en el S. XVII y en menor medida en el XVIII. En este caso se trata de una palabra trisílaba en la que el acento está alejado de la vocal inicial, provocando así la confusión /o/ /u/ en la sílaba inicial (Morala, 2009: $558)$. 


\section{PICHONERA}

Adj. f. Probablemente derivado de pichón, 'pollo de la paloma casera' (DRAE). Del italiano piccione íd., que procede del latín tardío pīpio, -ōnis, íd., derivado de pipiare 'piar' (DECH, s.v. pichón).

Varios cestos azafates y cestas pichoneras (La Nora del Río, 1823)

Es el único ejemplo recogido del término. No está claro el significado que puede tener la palabra pichonera en este caso. Aparece acompañando al sustantivo cesta y, probablemente hace alusión a un tipo de cestas que se utilizan para llevar pichones.

\section{SACA}

Sust. f. 'Costal muy grande de tela fuerte, más largo que ancho' (DRAE). Término derivado de saco, del latín saccus (DECH, s.v. saco).

Una saca de lana blanca (Coomonte de la Vega, 1645)

Es el único ejemplo encontrado, probablemente no se trate de un término muy utilizado ya que con el mismo significado se emplea mayormente la voz costal o quilma, dato que se corresponde con las muestras del CORDE donde son más frecuentes los ejemplos de costal que los de saca. Del mismo modo, el derivado saco, que es una palabra frecuente, no se recoge en este corpus, sino que se emplean otros términos como pueden ser costal, fardela o fardel, quilma; en función del uso que se les dé.

\section{TALEGA}

Sust. f. 'Saco o bolsa ancha y corta, de lienzo basto u otra tela, que sirve para llevar o guardar las cosas' (DRAE). Término derivado del árabe taclîqa 'saco, bolsa, zurrón' (DECH, s. v. talega).

Una talega (Castrocalbón, 1643)

Dos talegas buenas de binbre (Coomonte de la Vega, 1645)

Una talega pequeña de binbre (Alija del Infantado, 1647)

Dos talegas de binbre pequeñas biexas (Alija del Infantado, 1647)

Una talega blanca biexa (Alija del Infantado, 1650)

Una talega de tapiar (Alija del Infantado, 1650)

Una talega (Laguna de Negrillos, 1740)

Una talega y un aro (Castrocalbón, 1814)

Dos talegas vlancas (La Nora del Río, 1823)

Una talega de mimbre (Castrillo de la Valduerna, 1828)

Dos talegas de mimbre negra (Quintana del Marco, 1829)

Una talega y un bildo biejo (Felechares, 1832)

Una talega blanca y otra desondonada (Santibáñez de la Isla, 1844) 
Es un término que aparece frecuentemente en el corpus estudiado. Se trata de una voz polisémica ya que en los ejemplos recogidos encontramos al menos tres acepciones del término. Por una parte se llama talega al 'saco para guardar algo', este significado general es el que podemos encontrar en aquellos ejemplos en los que no se especifica nada o que aparecen con el adjetivo blanca, que alude al mimbre pelado con el que está hecha. Con este significado más especificado se llama talega al 'zurrón en que los pastores llevan la comida al monte'. Por tanto, en los ejemplos en los que no se especifica nada, este también podría ser el uso que se le da al término en algunos casos. En aquellos ejemplos en los que se señala que es de mimbre, el significado es el de 'cesta'. El DRAE localiza esta acepción en León desde 1925. En la zona de la Valdería se define como 'especie de cesta grande, con forma cónica y dos asas, tejida de varas de mimbre o de salguera, para recoger y transportar cualquier fruto, especialmente en la vendimia' si aparece con la matización de talega de colgar se trata de 'talega de mimbre que se usa para escurrir los cadejos de lino que ya se han cocido con cernada para emblanquecerlos' (Rivas, 1996: 220 y 221); con esta matización no se han recogido ejemplos. Además, se puede señalar una tercera acepción en el ejemplo de Alija del Infantado de 1650, «una talega de tapiar» donde la voz se refiere probablemente en ese contexto a una cesta que se utiliza, en este caso, para transportar la tierra que se utiliza para hacer tapias.

\section{TALEGO}

Sust. m. 'Saco largo y estrecho, de lienzo basto o de lona, que sirve para guardar o llevar algo' (DRAE). Término derivado de talega.

Unas alforjas de lana de colores con talegos de lienzo (Coomonte de la Vega, 1722)

Una silla de montar con todos sus talegos, estrivos de yerro (Destriana, 1843)

Son los únicos ejemplos recogidos. Probablemente se trate de un término de uso menor que su derivado talega. En algunas zonas de León se utiliza con el significado de 'cesto', pero los ejemplos aquí recogidos reflejan claramente la acepción que da el diccionario académico.

\section{TALEGóN}

Sust. m. 'Cesto grande y fuerte hecho de mimbres. Suele llevar dos asas en el borde superior y se usa especialmente (pero no exclusivamente) para vendimiar' (Le Men, 2009, s.v. talegón). Término derivado de talega. 
Un talegón con unos añinos blancos y negros (Coomonte de la Vega, 1643)

Dos talegones buenos (Coomonte de la Vega, 1645)

Un talegón bueno (Alija del Infantado, 1650)

Un talegón de mimbre (Castrocalbón, 1814)

Un talegón (Palacios de la Valduerna, 1831)

El DRAE no recoge el término aunque se trata en esta zona y concretamente en el corpus estudiado de una voz de uso común próxima a la voz talega. En la Valdería se emplea con el significado de 'recipiente tejido con varas de mimbre o de salguera, de la misma forma que la talega, aunque mucho más alto, que se usa para transportar las uvas en el carro desde la viña hasta el pueblo o lugar de venta' (Rivas, 1996: 221). Sin embargo, en zonas del sur de León y del norte de Zamora se emplea con el significado genérico de 'cesto' y, en efecto, al menos en el primer ejemplo en el que encontramos más datos, el contexto permite suponer que este es el significado, aunque también se pueda usar para vendimiar, entre otros usos. En el CORDE, donde se registran bastantes usos del término, el significado del término es el de 'bolsa', vendría a ser un aumentativo de talega.

\section{COSTAL}

Sust. m. 'Saco grande de tela ordinaria, en que comúnmente se transportan granos, semillas u otras cosas' (DRAE). Del latín costalis (DECH, s.v.cuesta).

Un costal de pabilos nuevo (La Bañeza, 1641)

Cuatros costales (Castrocalbón, 1643)

Un costal roto y aumado (Coomonte de la Vega, 1643)

Un costal de tascos viejo (Vidriales, 1645)

Un costal de lana de cosa de media carga (La Nora del Río, 1645)

Un costal de lana nuebo (Coomonte de la Vega, 1645)

Tres costales de lana a medio serbir (Alija del Infantado, 1646)

Dos costales de pavilos biexos que arán media carga poco más o menos cada uno (Alija del Infantado, 1647)

Dos costalitos de lana biexa que ará media carga (Alija del Infantado, 1647)

Un costal de pavilos biexo pequeño (Alija del Infantado, 1647)

Un costal de pavilos muy biexo (Alija del Infantado, 1647)

Tres costales (La Antigua, 1648)

Tres costales de pabilos nuebos (Fresno, 1726)

Quatro costales buenos de pavilos (Palacios de la Valduerna, 1728)

Un costal con dos remiendos bueno (Palacios de la Valduerna, 1728)

Siete costales de pavilos y quatro quilmas (Destriana, 1730)

Un costal en que está la linaza (Priaranza, 1732)

Quatro costales y unas alforxas biejas (Requejo de la Vega, 1735)

Un costal usado (Castrocalbón, 1814)

Dos costales viejos (Castrocalbón, 1814)

Dos costales que hacen a quilmas (Santibáñez de la Isla, 1844)

Es una voz muy frecuente en el corpus. El término se define como 'saco o fardela, normalmente de tela de lino cultivado y tejido en la zona, para contener y 
transportar legumbres, cereales o harina. Equivale a seis heminas de peso' (Rivas, 1996: 81). Este autor señala las voces quilma y costal como sinónimos (op. cit. 81 y 193), aunque la frecuencia de ambos términos en el corpus es prácticamente igual, lo que explicaría que sea posible que exista alguna diferencia. En cuanto a la capacidad, ambos objetos equivalen aproximadamente a seis heminas. Es probable que la diferencia esté en el uso, así mientras que el costal sirve para transportar legumbres, harina, etc., la quilma guarda y transporta legumbres y cereales ya limpios (op. cit. 193).

\section{FARDEL}

Sust. m. 'Saco o talega que llevan regularmente los pobres, pastores y caminantes, para las cosas comestibles u otras de su uso' 'Fardo' (DRAE). De origen incierto, probablemente tomado del francés donde fardel 'fardo' y farde, íd. son muy antiguos y de etimología dudosa. Es posible que el francés antiguo fardel resulte de una metátesis *farcitellum (DECH, s.v. fardo).

Un fardelico de lienco bueno (Coomonte de la Vega, 1643)

Un fardelino de damasco azul (La Bañeza, 1643)

Dos fardeles de estopa (La Nora del Río, 1823)

Un fardel de estopa (Quintana del Marco, 1839)

Es un término común que en León tiene además otras acepciones distintas a las que da el DRAE. Se define como un 'saquito de tela para legumbres o harina', también 'bolsa pequeña para el pan' (Le Men, 2005, s.v. fardel). Los ejemplos del término se corresponden todos a la zona del Bajo Órbigo. El uso concreto para el que se destinaba este objeto no lo podemos deducir por los ejemplos, tan solo que era de tela gruesa como podía ser estopa o lienzo, entre otras.

\section{FARDELA}

Sust. f. 'Fardel'. 'Talega para llevar provisones' (Le Men, 2005, s.v. fardela). Término derivado de fardel.

Dos fardelas usadas (Ribas de la Valduerna, 1726)

Una fardela de lino (Palacios de la Valduerna, 1728)

Una fardela de zerrón (Palacios de la Valduerna, 1728)

Dos fardelas (Miñambres, 1729)

Dos fardelas de lana (Coomonte de la Vega, 1734)

Tres fardelas viejas (Alija del Infantado, 1812)

Ocho fardelas muy viejas (La Nora del Río, 1823)

Seis fardelas nuebas (La Nora del Río, 1823)

Seis fardelas viejas (Felechares, 1837)

Una fardela vieja (Requejo, 1839) 
Es un término común, del que incluso aparecen más ejemplos que del término fardel. El DRAE no recoge el término y en el CORDE solo se recoge un ejemplo. Sin embargo, es una voz bastante usada en León. En las comarcas que forman el P.J. de la Bañeza existen diferentes matizaciones semánticas del término. Así, por ejemplo, en la zona de la Valdería, donde se recoge algún ejemplo, fardela es 'saco o fardel grande, ancho y amplio, de tela gruesa, normalmente de esparto, que sirve para contener o transportar azúcar, alubias, harina, etc.' (Rivas, 1996: 124). En zonas del entorno de La Bañeza significa 'fardel de tamaño menor' (Miguélez, 1998: 154). De los ejemplos extraídos sí podemos deducir que fardel y fardela tienen ciertas diferencias de significado, que pueden ser de tamaño o uso, ya que en la zona del Sur, Bajo Órbigo, se han encontrado ejemplos tanto de uno como de otro término.

\section{PANERA}

Sust. f. 'Troje o cámara donde se guardan los cereales, el pan o la harina'. 'Cesta grande sin asa, generalmente de esparto, que sirve para transportar pan' (DRAE). Término derivado de pan, del latín panis (DECH, s.v. pan).

Una panera de madera (Castrocalbón, 1643)

Una caldera mediana que está en la panera (Palacios de la Valduerna, 1831)

Panera (Felechares, 1837)

En estos tres primeros ejemplos, el término está usado como sustantivo, pero con distinta acepción. En el primer caso puede estar empleado con el significado de 'arca muy grande donde se metía el grano y la hogaza', acepción no recogida en el DRAE, pero que se documenta en algunas zonas de León, por ejemplo en la Maragatería (Botas, 1993: 60). En los dos ejemplos siguientes el significado es el de 'habitación de la casa o de la cuadra destinada a guardar en ella la cosecha de cereales' o 'desván de la casa' (Le Men, 2009, s.v. panera), acepciones que tampoco recoge el DRAE, pero que son comunes en León. Concretamente en el ejemplo de Felechares, el término no aparece como un bien que se ponga en la relación, sino como una parte de la casa donde se sitúan una serie de objetos que se van a reseñar en la relación que aparece después.

Además es muy frecuente encontrar el término panera/o usado como adjetivo que determina a diferentes sustantivos, sobre todo al nombre arca.

Un arca panera buena (Coomonte de la Vega, 1645)

Un arca panera buena sin tapador que ará dos cargas y media de pan (Alija del Infantado, 1646)

Un tino panero (La Antigua, 1647)

Una cuva panera (La Antigua, 1647) 
Un arca panera y en ella como cosa de dos cargas de arina de centeno (Laguna de Negrillos, 1721)

Un arca panera (Genestacio de la Vega, 1721)

Una arca panera desarmada (Grajal de la Ribera, 1723)

Un cuarto panera y dentro del zinco cargas y media de zenteno (Palacios de la Valduerna, 1728)

Un arca panera (Palacios de la Valduerna, 1730)

Una arca panera (Genestacio de la Vega, 1738)

Una arca panera (Grajal de la Ribera, 1750)

Los significados del término adjetivo en estos casos son los mismos que en los ejemplos anteriores. Tanto el $a r c a$, como la $c u b a$ o el tino son recipientes que pueden tener diferentes usos, en este caso, el uso que se les da es para guardar el grano. En el ejemplo en el que se especifica "un cuarto panera", el significado es el de lugar en el que se guarda el grano, cereales, etc. Por tanto, se trata de las mismas acepciones, la diferencia es que en algunos se emplea como sustantivo y en otros, más frecuentes, como adjetivo.

\section{QUILMA}

Sust. f. 'Costal de tela gruesa' (DRAE). Voz emparentada con el árabe qírba 'odre', pero este vocablo en África era anterior a la invasión árabe, es probable que en España también fuese anterior a la conquista musulmana (DECH, s.v. quilma).

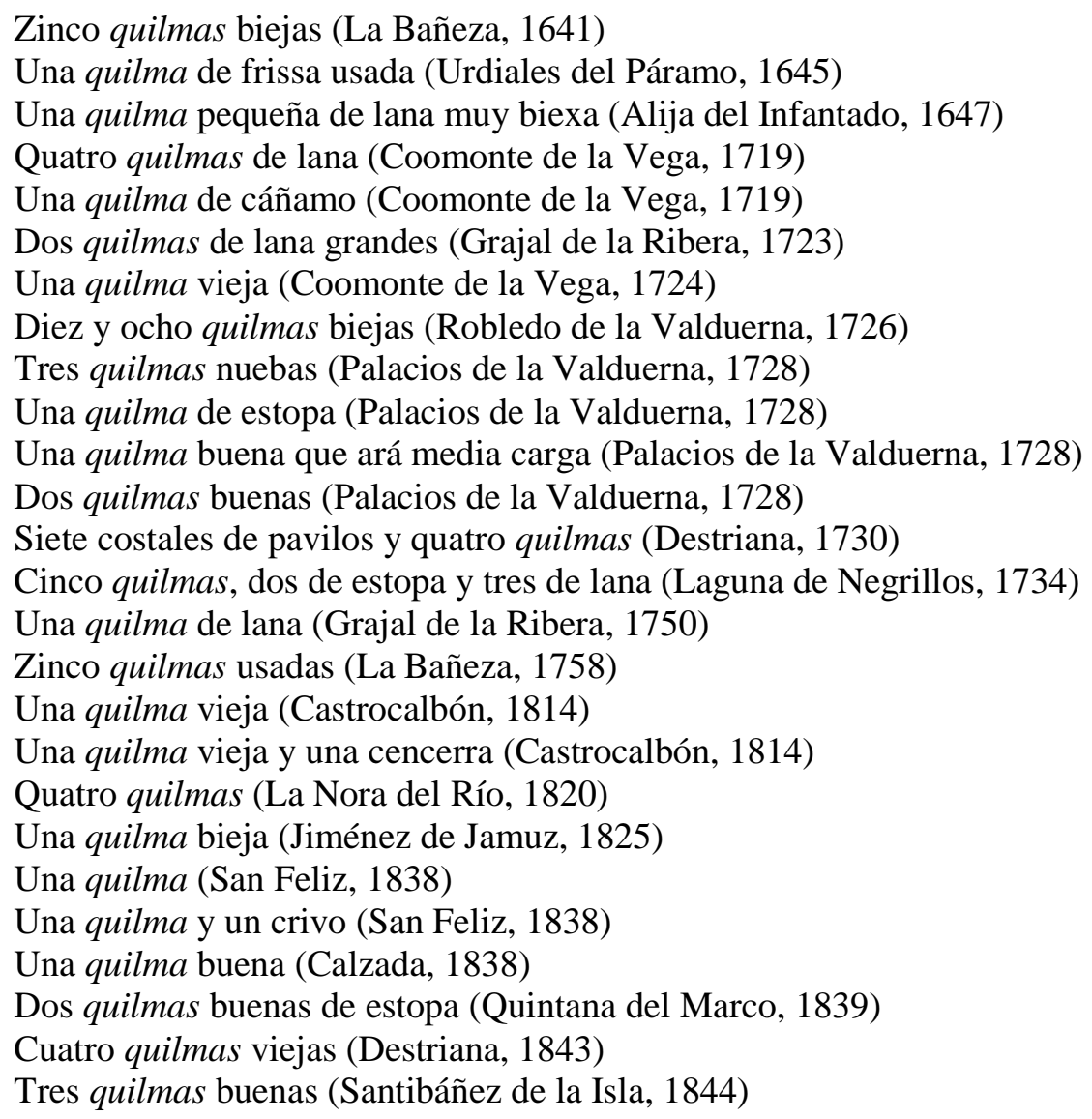


Dos costales que hacen a quilmas (Santibáñez de la Isla, 1844)

Es un término muy común en el corpus. El significado que tiene es el de 'especie de saco grande, confeccionado de lino o esparto, para guardar y transportar legumbres y cereales ya limpios' (Rivas, 1996:193). Los ejemplos del corpus solo dan información sobre el material del que estaba hecho (estopa o lana, generalmente) y el estado. Apenas hay referencias a la capacidad de estos sacos, a excepción del último ejemplo y uno de los de Palacios de la Valduerna del año 1728, en el que señala como capacidad media carga. Teniendo en cuenta que la carga son doce heminas, estaríamos hablando de seis heminas para la quilma. En este sentido Urdiales señala que la quilma hace por lo general seis heminas, aunque las hay de siete (Urdiales, 1966: 44-45). El término se documenta en distintas zonas del norte, en León es una voz muy común y también lo es en este corpus donde los ejemplos contrastan con los escasos ejemplos del CORDE, todos ellos a excepción de uno procedente de Cantabria, localizados en fechas tempranas SS. XIII y XVI, dato que indica que se trata claramente de una voz occidental.

\section{SERÓN}

Sust. m. 'Sera más larga que ancha que sirve regularmente para carga de una caballería' (DRAE). Término derivado de sera, voz de origen incierto aunque de todos modos europea (DECH, s.v. sera).

Dos serones de esparto (La Bañeza, 1721)

Es el único ejemplo encontrado. El término general con el que se usa el término es el de 'recipiente de paja trenzada', se trata de una especie de cesta que se emplea con diferentes usos.

CÁNTARA (vid. unidades de medida)

CÁNTARO (vid. unidades de medida)

\section{CALDERO}

Sust. m. 'Caldera pequeña de suelo casi semiesférico, y con asa sujeta a dos argollas en la boca' (DRAE). Término procedente del latín caldaria, íd. derivado de caldo, resultado de calidus. (DECH, s.v. caldo).

Un caldero de cobre usado (La Bañeza, 1641)

Un caldero de cobre que ará una errada (Vidriales, 1645)

Un caldero de yerro (La Bañeza, 1721) 
Un calderito sin asa (Grajal de Ribera, 1723)

Un caldero de cobre de sacar agua biejo (Laguna de Negrillos, 1722)

Una trona bieja y un caldero de yerro (Priaranza de la Valduerna, 1732)

Un calderico (Coomonte de la Vega, 1734)

Un caldero de cobre (Coomonte de la Vega, 1734)

Un caldero mediano (Castrocalbón, 1814)

Un calderico de azófar (La Nora del Río, 1823)

Un caldero remendado (Quintanilla de Somoza, 1831)

Un caldero chico de azófar (Quintana del Marco, 1839)

Un caldero de pozo de yerro (Quintana del Marco, 1839)

Un caldero de azófar usado (Destriana, 1843)

Es un término de uso común. Aparece con el significado que da el DRAE, que es el actual. Es frecuente que la palabra se documente haciendo referencia al material del que estaba hecho, que en esta época era siempre de cobre o de estaño. En dos ejemplos aparece la voz en diminutivo. Como en otras ocasiones es frecuente el uso del sufijo ico en la zona sur próxima a la actual provincia de Zamora.

\section{CUBO [cuvo]}

Sust. m. 'Recipiente de madera, metal u otra materia, por lo común de forma de cono truncado, con asa en la circunferencia mayor, que es la de encima, y fondo en la menor' (DRAE). Del lat. cŭbus, y éste del griego kýbos 'cubo', 'dado' (DECH, s.v. cubo).

Dos cubos de asementar (Coomonte de la Vega, 1734)

Un cuvo y un escaño de respaldo (Felechares, 1836)

Es un término que en la provincia de León presenta muchos significados, tales como 'pieza central de la rueda de un carro', 'tipo de reja', o algunos incluso documentados en la zona de La Bañeza como el de 'vaso de colmena formado por un trozo de tronco de árbol hueco' (Le Men, 2004, s.v. cubo). Sin embargo, en los escasos ejemplos encontrados el significado del término es el de 'caldero', aunque con un uso mucho menor que el del término sinónimo.

\section{POZAL [poçal]}

Sust. m. 'Cubo o zaque con que se saca el agua del pozo' (DRAE). Término derivado de pozo, del latín pŭtěus (DECH, s.v. pozo).

Trece tablas de un poçal (Villamor de Órbigo, 1648)

Un pozal (Palacios de la Valduerna, 1730)

Un pozal (Grajal de la Ribera, 1730)

Un pozal que ará seis cántaras (Laguna de Negrillos, 1734)

Un pozal grande para 40 cántaras (Grajal de la Ribera, 1750)

El significado más empleado del término es el de 'recipiente', aunque en León encontramos varias acepciones del término. Por ejemplo, se llama pozal a 'cubo grande, 
de forma cilíndrica, construido con tablas de madera bien unidas y remachadas con aros de hierro y clavos, en el que se echan las uvas nada más traerlas de las viñas, para pisarlas y hacerlas fermentar antes de hacer el vino' (Rivas, 1996: 188), probablemente esta sea la acepción utilizada en el ejemplo de la Valduerna y en el de Grajal, y probablemente también en el primero, puesto que las tablas a las que hace referencia el ejemplo, tal vez sean las que sirven para construir este objeto. También se denomina pozal a un 'tipo de vasija que se utiliza para contener agua' (Le Men, 2009, s.v. pozal). Las referencias a las cántaras para fijar la medida, pueden hacer pensar que el significado en los dos últimos ejemplos sea el de 'vasija de agua o cántaras de vino', aunque tampoco hay datos suficientes para decantarse por una u otra acepción. Con el significado que da el DRAE, aparece un ejemplo en el corpus en el que no se cita la palabra pozal sino que se recoge la expresión «un caldero de pozo de yerro (Quintana del Marco, 1839)».

\subsubsection{Bodega}

BOTA

Sust. f. 'Cuero pequeño destinado especialmente a contener vino'. 'Cuba para guardar líquidos' (DRAE). Término procedente del lat. tardío bŭttis 'odre' cuyo origen último se desconoce (DECH, s.v. bota).

Una bota que aze media azumbre (Coomonte de la Vega, 1645)

Solo se ha recogido este ejemplo. Probablemente, se trata de una coincidencia ya que es una palabra muy común, como puede verse en corpus como el CORDE donde son numerosos los ejemplos encontrados. El significado con el que se utiliza en este caso es el primero, ya que además aparece referido junto a otro elemento que se usa para contener vino. En trabajos lexicográficos del leonés (Le Men, 2000, s.v. bota) se señala que en esta zona próxima a La Bañeza, este término también toma la acepción de 'vaina seca del garbanzo, guisante, alubia u otras legumbres'. Sin embargo, la referencia a la medida "media azumbre", indica que se trata de un objeto que contiene líquidos.

\section{CUBA [cuva]}

Sust. f. 'Recipiente de madera, que sirve para contener agua, vino, aceite u otros líquidos. Se compone de duelas unidas y aseguradas con aros de hierro, madera, etc., y los extremos se cierran con tablas' (DRAE). Del latín cūpa (DECH, s.v. cuba). 
Una cuba que ará sesenta cantaras (Coomonte de la Vega, 1645)

Una cuva panera (La Antigua, 1647)

Una cuba (La Antigua, 1647)

Una cuba buena que ará ziento zinquenta cántaras (Laguna de Negrillos, 1722)

Otra cuba debajo del ventanario que ará zien cántaras (Laguna de Negrillos, 1722)

Una cuba de siete palmos (Coomonte de la Vega, 1734)

Una cuva para lienzo (Coomonte de la Vega, 1734)

Una cuba buena que ará 80 cántaras (Laguna de Negrillos, 1734)

Una cuba sin vino (Laguna de Negrillos, 1742)

Voz de uso general cuyo significado es el que da el DRAE.

\section{CUBETO}

Sust. m. 'Vasija de madera, más pequeña que la cubeta' (DRAE). Término derivado de cuba, del latín cūpa (DECH, s.v.cuba).

Un cubetico pequeño de tener salostrero (Coomonte de la Vega, 1643)

Un cubetico biexo (Coomonte de la Vega, 1645)

Un cubeto de seys cántaros (Vidriales, 1645)

Un cubeto mediano que ará diez y seis cántaras usado (Laguna de Negrillos, 1722)

Dos cubetos (Coomonte de la Vega, 1734)

Es una voz de uso común. En algunas comarcas pertenecientes a este Partido Judicial como la de la Valdería toma el significado de 'recipiente semejante a la cuba, aunque más pequeño, con forma cilíndrica, hecho de tablas de madera bien ajustadas y reforzadas, mediante aros metálicos de hierro colocados de forma horizontal y tapas de madera en los extremos superior e inferior, que sirve para guardar y conservar el vino' (Rivas, 1996: 83). Los ejemplos encontrados se sitúan en la zona del sur, próxima a Benavente donde se define como 'cuba pequeña para vino' (Le Men, 2004, s.v. cubeto). Independiente de su forma o tamaño, podemos deducir que se trata de una vasija empleada para el vino, probablemente de diferentes tamaños como muestran los ejemplos que hablan de cántaro y cántara como unidades de medida, referidas a ocho litros para el primer caso o dieciséis para el segundo. No aparece, sin embargo, ningún ejemplo de cubeta.

\section{ENARCAR}

Verb. 'Echar cercos o arcos a las cubas, toneles, etc.' (DRAE).

Un gato de ierro de enarcar (Vidriales, 1645)

Es el único ejemplo encontrado. Su significado coincide con el que aparece en el diccionario académico. 


\section{ESPITA}

Sust. f. 'Canuto que se mete en el agujero de la cuba u otra vasija, para que por él salga el licor que esta contiene' (DRAE). Del gót. *spŭtus (el germánico spĭtus ha dado descendientes con $e$ y con $i$ según la fecha en que se introdujo). El femenino espita no viene del sustantivo germánico directamente, sino como derivado del verbo espitar 'espetar, clavar'. (DECH, s.v. espita, espeto).

Una espita pequeña buena (Alija del Infantado, 1644)

Cuatro espitas y un taladrito desbocado todo de yerro (Coomonte de la Vega, 1645)

Una espita despuntada más un azadón zespedero biexo (Alija del Infantado, 1646)

Una espita y un enbudo de estaño (Villamor de Órbigo, 1648)

Una espita grande (Destriana, 1643)

Espitas (Coomonte de la Vega. 1719)

Un escoplo grande y una espita ynglesa (Castrocalbón, 1814)

Es un término muy común en todo el occidente peninsular con el significado de 'pincho o palo afilado' y con menos frecuencia en el norte de León donde se utiliza con otras acepciones que son restricciones del significado general (Le Men, 2005, s.v. espeta/espeto). Con algunos de estos significados se emplea la voz en el corpus estudiado. En algunos casos se utiliza el término con el significado reflejado en el diccionario académico de 'canuto por el que sale el vino o licor'. Este sería el caso del ejemplo de Villamor de Órbigo, como se puede deducir del lugar que ocupa en el corpus junto a enseres de cocina y del elemento con el que está inventariado embudo, o del ejemplo de Coomonte de la Vega. En otros casos en los que el término siempre aparece junto a objetos como taladro, azadón, etc. el significado parece ser el de 'barrena o taladro pequeño'.

En zonas próximas a la estudiada, la voz espita se utiliza para nombrar a las agujas de tejer. Por el lugar en el que aparece el término en los inventarios, no parece que haya ejemplos con este significado. Formalmente, la voz también se registra en León con la variante /e/ ya sea en femenino o en masculino espeta/espeto. En el corpus analizado solo se ha recogido bajo la forma espita.

\section{LAGAR}

Sust. m. 'Lugar donde se posa, pisa y prensa la uva para obtener el mosto' (DRAE).

Derivado de lacus en su acepción de 'balsa o depósito de líquidos' (DECH, s.v. lago).

Una cueva en el casco de esta villa con tres bentanos, su lagar y aparejos (Palacios de la Valduerna, 1730)

Quatro tablas que están enzima de los tirantes del lagar (Laguna de Negrillos, 1722)

Una bodega con su lagar y aparejos sin barriga (Laguna de Negrillos, 1734) 
El término tiene el significado que figura en el DRAE. Esta palabra en León aparece también bajo las variantes llagar y agar, pero en el corpus los pocos casos recogidos aparecen siempre bajo la forma normativa.

\section{PELLEJO [pellexo, pelexo, pillejo] (vid. materiales)}

\section{POÍNO [poýno]}

Sust. m. 'Codal que sirve de encaje y sustenta las cubas en las bodegas' (DRAE). Término derivado de poyo, del latín pŏdĭum 'repisa' (DECH, s.v. poyo).

Un poýno de encina (La Antigua, 1647)

Dos poýnos uno de enzina y otro de peral (La Antigua, 1648)

Son los únicos ejemplos encontrados $\mathrm{y}$, aunque forman parte de distintos inventarios, se documentan en la misma localidad. La voz poíno se registra en distintos puntos de la provincia de León con diferentes significados. Además de la que recoge el diccionario académico, se registran las siguientes acepciones: 'poyo que se coloca en los lados de las entradas y que sirve para sentarse o subir en las caballerías', 'tacón postizo de las galochas', 'cada uno de los salientes de madera donde encajan los estadonios o pernillas' (Le Men, 2009, s.v. poíno). En los ejemplos recogidos, no hay muchos datos para saber con exactitud el significado empleado, puesto que en ambos casos, el término aparece junto a objetos de diversa índole sin un orden lógico aparente. Quizá hay dos datos que pueden ayudar a discernir el uso que se hace del término en estos ejemplos. La última acepción que recoge Le Men no tiene razón de ser si se observa que las pernillas, junto a otros elementos del carro, siempre se citan juntas, por lo que no tendría sentido referir un elemento de las pernillas aparte. Además en Benavente, localidad zamorana próxima a La Antigua, también se documenta el término con la acepción que da el $D R A E$ (Barrio, 2000: 187), dato que apoya la idea de que puede ser este el significado empleado. Formalmente, aunque también se recogen otras variantes, en ambos casos el término aparece bajo la forma académica en el que la palatal/y/, al estar en contacto con la vocal /i/, se asimila a esta y se pierde. No obstante, es significativo señalar que en el NTLLE aparece recogido por primera vez en la edición de 1803, mientras que los ejemplos del corpus pertenecen a inventarios del S. XVII; y en el CORDE solo aparece una vez en el Fuero de Avilés y probablemente con otro sentido, lo que indicaría que estamos ante un occidentalismo léxico puesto que además en otras 
zonas donde sí se inventarían las bodegas no se documenta la voz poíno (Morala y Egido, 2010: 429).

\section{SALOSTRERO}

Se recoge en el corpus estudiado el término salostrero en un inventario:

Un cubetico pequeño de tener salostrero (Coomonte de la Vega, 1643)

Es una voz de la que no se ha encontrado ninguna referencia ni en los diccionarios académicos ni en ningún otro repertorio léxico. Atendiendo al contexto, aparece junto al término cubeto que designa un 'recipiente para contener el vino', por lo que es posible pensar que quizá la voz salostrero designe el vino en alguna de sus fases iniciales o bien haga referencia a los posos del mismo.

TONEL

Sust. m. 'Cuba grande' (DRAE). Del francés antiguo tonel, diminutivo de tonne 'tonel grande'. Este viene del latín tardío tŭnna y este del céltico tunna 'piel', de donde 'odre' y después 'cuba' (DECH, s.v. tonel).

Un tonel (Felechares, 1837)

Un tonel de cabida de dos y media cántaras (Requejo de la Vega, 1839)

Es una palabra de uso general, aunque solo se hayan recogido estos dos ejemplos.

VASIJA (vid. ajuar doméstico/ utensilios de cocina)

\subsection{HERRAMIENTAS PROFESIONALES}

En este apartado se incluyen términos que nombran herramientas propias de otras profesiones distintas a la agricultura como carpintero, herrero, etc. La mayor parte de los términos que aquí aparecen tienen que ver con el trabajo de la madera, pero también con el trabajo del hierro y otras que se pueden considerar generales ya que en algunos casos se empleaban para arreglos domésticos. Aunque no son muchas palabras, aparecen agrupadas según el uso que tenían.

\section{AZUELA [zuela]}

Sust. f. 'Herramienta de carpintero que sirve para desbastar' (DRAE). Término procedente del hispanolatino asciola, diminutivo del latín ascia 'azuela', 'hacha' (DECH, s.v. azuela). 
Una zuela de cabestro buena (Alija del Infantado, 1644)

Una zuela buena (Coomonte de la Vega, 1645)

Una azuela de peto (Alija del Infantado, 1646)

Una azuela de yerro biexa de cabestro (Alija del Infantado, 1646)

Una azuela (La Antigua, 1648)

Una azuela (Coomonte de la Vega, 1719)

Una zuela de peto con dos navaxas (Huerga de Garaballes, 1720)

Una zuela con un mango (Grajal de la Ribera, 1730)

Una azuela de martillo de yerro (Grajal de Ribera, 1750)

Una azuela de galochas (Ribas de la Valduerna, 1726)

Una azuela de martillo (Ribas de la Valduerna, 1726)

Una azuela (Miñambres, 1727)

Una azuela (Palacios de Jamuz, 1728)

Un machado y una azuela (Castrocalbón, 1814)

Una zuela (Destriana, 1843)

Desde el punto de vista del significado, se utiliza con el significado del DRAE, aunque como puede apreciarse por los ejemplos, se distinguen distintos tipos de azuelas, según la forma, por ejemplo azuela de peto, azuela de dos bocas una más ancha y otra más estrecha; o según la utilidad azuela de galochas, es decir un azuela que se utilizaba para la elaboración de las galochas. La escasez de ejemplos del S. XIX, se debe más bien a una casualidad ya que era un término común en esa época, como queda reflejado en corpus como el CORDE, y hoy es habitual. Formalmente, aparece en todos los casos bajo la forma castellana azuela y no la leonesa ašuela. Además, es frecuente encontrar en León, aunque también en otras provincias limítrofes la variante zuela con aféresis de la /a/ inicial, en los ejemplos se recogen las dos formas aunque con predominio de la variante normativa.

\section{CEPILLO [zepillo]}

Sust. m. 'Instrumento de carpintería formado por un prisma cuadrangular de madera dura, que lleva embutido, en una abertura transversal y sujeto por una cuña, un hierro acerado con filo, el cual sobresale un poco de la cara que ha de ludir con la medra cuya superficie se quiere alisar' (DRAE). Término derivado de cepo, del latín cĭppus (DECH, s.v. cepo).

Un zepillo con su yerro (Coomonte de la Vega, 1643)

Una garlopa y un cepillo (Coomonte de la Vega, 1645)

Un zepillo (Palacios de la Valduerna, 1728)

Un zepillo de madera (Palacios de la Valduerna, 1728)

Un zepillo (La Bañeza, 1754)

Un cepillo para limpiar la ropa (Destriana, 1843)

El término se utiliza a menudo con el significado de 'herramienta'. Este dato se deduce en algunos casos porque aparece con otros utensilios similares, como en el 
segundo ejemplo. Otras veces se especifica si es de madera, en cuyo caso tendría el significado expresado anteriormente; o si es de hierro. Este tipo de cepillo es semejante al de madera pero sirve para alisar metales. Únicamente, en el último ejemplo que especifica la función y en el primer ejemplo de Palacios de la Valduerna en el que no se especifica nada, se deduce que el significado con el que se está utilizando el término es el de 'objeto utilizado para el aseo y limpieza' (quizá como objeto para cepillar la ropa), ya que aparece inventariado junto a otros objetos de aseo y atuendo femenino, como ceñidero, collares, toca, etc.

\section{GARLOPA}

Sust. f. 'Cepillo largo y con puño que sirve para igualar las superficies de la madera ya cepillada, especialmente en las junturas de las tablas' (DRAE). De oc. garlopo, fem., y este del fr. dial. warlope íd., que a su vez resulta de un cruce de las denominaciones que este instrumento tiene en los dialectos flamencos: voorlooper, propte. 'precursor' y weerlucht, propte. 'relámpago'. Explicables ambas porque la garlopa precede a la labor del cepillo, como el relámpago al trueno (DECH, s.v. garlopa).

Una garlopa con su yerro de acepillar (Coomonte de la Vega, 1643)

Una garlopa con su cepillo (Coomonte de la Vega, 1645)

El término se utiliza con el significado académico que es el propio del término actualmente. Es un término de uso general, por lo que la escasez de ejemplos no responde a razones significativas ni cronológicas ni de uso de la palabra.

\section{GATO}

Sust. m. 'Instrumento de hierro que sirve para agarrar fuertemente la madera y traerla a donde se pretende. Se usa para echar aros a las cubas, y en el oficio de portaventero'. 'Trampa para cazar alimañas' (DRAE). Derivado del latín tardío cattus, íd., de origen incierto (DECH, s.v. gato).

Un gato de ierro de enarcar (Vidriales, 1645)

Un poco de yerro de un tiradero y un gato (Palacios de la Valduerna, 1831)

Son pocos los ejemplos encontrados, aunque se trata de un término polisémico de uso común. En León la voz también se utiliza con el significado de 'pieza que se coloca en la guadaña para evitar que se desgarre o abra', con esta acepción también se documenta el término en Zamora o en Asturias (Le Men, 2007, s.v. gato). Sin embargo, en los únicos ejemplos encontrados el significado del término es, más bien, el que da la Academia de 'instrumento que sirve para echar aros, etc', puesto que en el primer caso 
ya se detalla la función del objeto a través del verbo enarcar. El segundo ejemplo es más impreciso, puede tener ese significado, pero podría tener también el de 'pieza de la guadaña', puesto que se trata en ambos casos de instrumentos de hierro que guardan relación con tareas agrícolas y el ejemplo no nos aporta más información.

\section{GUBIA}

Sust. f. 'Formón de mediacaña, delgado, que usan los carpinteros y otros artífices para labrar las superficies curvas' (DRAE). Del latín tardío gŭlbĭa íd. (del cual ya en la Antigüedad existía una variante gubia), de origen céltico, emparentado con el irl. ant. gulba 'pico de ave' (DECH, s.v. gubia).

Una gubia desbocada (Coomonte de la Vega, 1643)

Dos escoplos, una gubia, todo de yerro (Coomonte de la Vega, 1645)

Se trata de un término de uso general que designa un instrumento de carpintería. En León el término aparece también bajo otras variantes formales, pero en el corpus solo se ha recogido bajo la variante normativa.

\section{MACHADO}

Sust. m. 'Hacha para cortar madera' (DRAE). Tal vez se explique del duplicado árabe de mazo (DECH, s.v. macho II).

Un machado de cortar leña mediano (Coomonte de la Vega, 1643)

Un machado biexo (Coomonte de la Vega, 1645)

Un machado (Coomonte de la Vega, 1719)

Una machadica y una media pala de yerro (La Bañeza, 1721)

Un machado grande (La Nora del Río, 1724)

Un machadico pequeño (La Nora del Río, 1724)

Un machado y un bareno de galochas y una azuela de galochas (Ribas de la Valduerna, 1726)

Un machado viejo (Fresno, 1726)

Un machado viejo (Miñambres, 1727)

Un machado (Palacios deJamuz, 1728)

Un machado viejo (Toral, 1728)

Un machado (Palacios de la Valduerna, 1728)

Dos machados (Miñambres, 1729)

Un machado viexo (Palacios de la Valduerna, 1730)

Un machado (Miñambres, 1731)

Un machado y una azuela (Castrocalbón, 1814)

Un machado grande (Castrillo de la Valduerna, 1828)

Un machado mediano (Quintanilla de Somoza, 1831)

Un machadica de picar carne (Quintanilla de Somoza, 1831)

Una azada y un azadón y un machado (Santibáñez de la Isla, 1844)

Es un término relativamente frecuente en los inventarios analizados, sobre todo si tenemos en cuenta que en corpus mucho más amplios, como el CORDE, el término con 
valor de sustantivo aparece en unos cuatro casos. El DRAE en sus numerosas ediciones define el término como 'hacha para cortar madera' y hasta la edición de 1791 lo señala como voz provincial de Galicia. Morala y Le Men, a partir de un inventario del Monasterio de Carrizo fechado en el S. XIII en el que el término aparece junto a otros objetos de hierro, sostienen la teoría de que el machado se trata del mismo objeto que hoy se conoce como machao, más que de macho 'especie de mazo de madera' (MoralaLe Men, 1996: 566). Volviendo a los ejemplos extraídos del corpus, objeto de este estudio, ocurre algo similar puesto que prácticamente todos los ejemplos del término van precedidos o seguidos en la relación de las voces azuela, fundamentalmente, o también de los términos azada y azadón, es decir, objetos de hierro. Además, en vocabularios dialectales de la zona se define el término como 'hacha' indicando que es más grande que la macheta y en algunos se indica que suele usarse para cortar los troncos de leña en el monte' (Rivas, 1996: 151). Por tanto, se puede definir la palabra como 'hacha' que entre otros usos tiene el de cortar leña, pero no es su uso exclusivo, afirmación que se puede apoyar en los ejemplos de Coomonte de la Vega, donde en unos de ellos especifica el uso de cortar leña, pero no en los demás. Significativo es el ejemplo de Quintanilla de Somoza donde la voz aparece en femenino y con una información sobre su uso, en este caso picar carne. Es el único ejemplo encontrado y es posible pensar que se trate de un hacha más pequeña, de ahí el uso del femenino junto al diminutivo -ica, que se usa para cortar la carne. Por tanto, incide en la idea anterior de que genéricamente tiene el significado de 'hacha' con diferentes usos.

\section{MACHETA}

Sust. f. 'Especie de cuchilla de hoja muy fuerte y ancha, usada especialmente para picar carne'. En Ast. Ext., Gal., León, Sal. y Zam. 'hacha pequeña' (DRAE). Probablemente derivado de macho 'mazo grande'. El sentido primitivo parece haber sido el de 'hacha', que conserva macheta en las provincias leonesas (DECH, s.v. machete).

Una macheta (La Nora del Río, 1823)

Una macheta (Quintanilla de Somoza, 1831)

Una macheta (Quintanilla de Somoza, 1831)

Es una voz general, aunque solo se hayan recogido estos ejemplos, y es significativo que el CORDE no la documente. El término se usa más bien con el significado de 'hacha pequeña', así lo definen algunos vocabularios de la zona 'hacha más pequeña que el machao que suele usarse para cortar leña menuda, huesos o cualquier otro material duro' (Rivas, 1996: 151). 


\section{REGLA}

Sust. f. 'Instrumento de madera, metal u otra materia rígida, por lo común de poco grueso y de forma rectangular, que sirve principalmente para trazar líneas rectas, o para medir la distancia entre dos puntos' (DRAE). Tomado del latín rēgǔla (DECH, s.v. regla).

Unos terziales con sus aparejos, un frontal, una regla, tres tablas, una biga de álamo (Coomonte de la Vega, 1719)

Una pala y una regla (La Nora del Río, 1823)

Un cuartal con su regla errado (Santibáñez de la Isla, 1844)

El DRAE da también la siguiente acepción para el término 'conjunto de preceptos fundamentales que debe observar una orden religiosa'. También aparece recogida en el corpus en los siguientes ejemplos:

Cinco lazos de cinto, cinco gordones de seda, dos escapularios, una regla de S. Benito y otros dijes (Jiménez de Jamuz, 1825)

Unas reglas de S. Benito con su zerna y dos escapularios (Calzada, 1838)

Se trata de un libro o una hoja de la regla de San Benito que se solía guardar en una bolsa adornada, de ahí el complemento "con su zerna", que llevaban las mujeres como amuleto u objeto de devoción. Se trataba de una costumbre frecuente en el Reino de León debida a la influencia de Cluny en el Camino de Santiago (Cavero y Alonso, 2001: 262).

\section{TERCIAL}

Sust. m.

Unos terziales con sus aparejos, un frontal, una regla, tres tablas, una biga de álamo (Coomonte de la Vega, 1719)

Es el único ejemplo recogido. Aparece junto a otros objetos considerados como herramientas de carpintero o utensilios para trabajar la madera, pero entre ellos se nombra la voz viga, por lo que es posible que con el término tercial se haga referencia a lo que en diferentes diccionarios dialectales se conoce con el nombre de tercia y que se define como 'cada una de las vigas horizontales que se colocan a la mitad aproximadamente de las agujas de las casas' (Le Men, 2012, s.v. tercia). Sin embargo, la voz tercia en este corpus solo se utiliza con el significado de 'unidad de medida'.

\section{CLAVERA [clabera]}

Sust. f. 'Agujero o molde en que se forman las cabezas de los clavos' (DRAE). Término derivado de clavo, del latín clavus (DECH, s.v. clavera).

Dos claberas grandes buenas (Alija del Infantado, 1644) 
Una clabera de once garabatos (Coomonte de la Vega, 1645)

Una clavera con dos órdenes de escarpias (La Bañeza, 1721)

Una clabera (Miñambres, 1729)

Un clabera con ocho garfios (Grajal de la Ribera, 1730)

Una espetera vieja con su clavera (La Bañeza, 1829)

Una clavera, dos piñeras biejas i un quadro (Requejo de la Vega, 1735)

Se trata de un término que en León presenta varios significados que no aparecen en el DRAE. Se llama clavera a 'madreña taruquera', 'yunque del zapatero', 'instrumento para agrandar los agujeros del callo de herrar', 'cerradura de los carrales', 'tabla provista de clavos en los que se cuelga la vajilla' (Le Men, 2004, s.v. clavera). De todas estas acepciones la más común en los ejemplos extraídos del corpus es la última. En el ejemplo de Coomonte de la Vega y en el de Grajal se deduce este significado de la especificación del número de garfios o garabatos que tiene la clavera, así como en el ejemplo de La Bañeza que aparece junto al término espetera que tiene este significado. En los demás casos no hay ningún dato concreto que nos permita llegar a ninguna conclusión, pero probablemente sea el mismo, ya que además es una acepción frecuente en la zona rural de Castilla y León (Hernández Alonso, 2001: 819), y geográficamente los ejemplos se sitúan en la zona sur de la provincia.

\section{CLAVO [clabo]}

Sust. m. 'Pieza metálica, larga y delgada, con cabeza y punta, que sirve para introducirla en alguna parte, o para asegurar una cosa a otra' (DRAE). Del latín clavus (DECH, s.v.clavo).

Cosa de dos libras de yerros y clabos biexos (Coomonte de la Vega, 1643)

Un cestico pequeño biexo con unos pocos de clabos (Alija del Infantado, 1644)

Una escriñica pequeña con unos clabos biexa (Alija del Infantado, 1647)

Un escanil vueno con sus clavos (La Bañeza, 1721)

Dos escaniles el uno con sus lavores y el otro llano con sus clavos (Laguna de Negrillos, 1721)

Un escaño de roble sin clavos usado (Laguna de Negrillos, 1722)

Una mesa redonda de pie de nogal y una tabla con sus cuatro clavos (Laguna de Negrillos, 1722)

Unas mordazas con sus clabos (Laguna de Negrillos, 1722)

Un escanil de tres pies de largo con diez y ocho clabos (Grajal de la Ribera, 1723)

Una fuente de madera con clabos (Grajal de la Ribera, 1730)

Un millar de clavo de zapato (La Bañeza, 1712)

Medio millar de clavo de errar (La Bañeza, 1712)

Medio ziento de clavo de media naranja (La Bañeza, 1712)

Medio ziento de clavo de escañil (La Bañeza, 1712)

Un escañil de álamo con sus clavos (La Isla, 1735)

Dos libras de clabos de carro (Castrocalbón, 1814)

Un escañil con clabos de concha (Quintanilla de Somoza, 1831)

Seis clavos romanos (Requejo de la Vega, 1839)

Cuatro cuadros de chopo con clavos romanos (Requejo de la Vega, 1839) 
Es una palabra común que se mantiene sin variación semántica. En los ejemplos que aparecen en el corpus, el término tiene siempre el mismo significado pero con diferencias contextuales. En los dos primeros casos y en el ejemplo de Castrocalbón, el término designa el objeto en sí, mientras que en la mayoría de los ejemplos en los que aparece con cofres, escañiles, escaños, etc., el término aparece designando una especie de adorno que presenta el objeto, es decir, está tachonado con clavos. En otros casos designa el uso, como en los ejemplos de La Bañeza, los que se usan para errar o para reforzar los zapatos.

\section{ROMANO}

Adj. m. El DRAE define el sintagma clavo romano como 'el de adorno, con cabeza grande de latón quebrado, que se atornilla en la extremidad de aquel después de clavado' (DRAE). Del latín romanus (DECH, s.v. romano).

Seis clavos romanos (Requejo de la Vega, 1839)

Cuatro cuadros de chopo con clavos romanos (Requejo de la Vega, 1839)

Son los únicos ejemplos recogidos y se refieren a este tipo de clavos definidos por el DRAE.

\section{CLAVETERO [clabetero]}

Sust. m. Término derivado de clavo, del latín clavus (DECH, s.v.clavo).

Un clabetero y un urdidor (La Bañeza, 1754)

El término clavetero no aparece recogido en el diccionario académico y se trata de una voz no frecuente en los inventarios, ya que en el CorLexIn no se recoge ningún caso, como tampoco se recogen en el CORDE. En este corpus solo se ha recogido este ejemplo de cuyo contexto resulta fácil extraer su significado. El término aparece coordinado a otro objeto textil, urdidor. Ambos presentan unos sufijos -ero y -dor que en español indican objeto que sirve para una determinada función. Por tanto, en este caso, la voz clavetero estará nombrando algún objeto que sirva para poner clavos, voz que sí tiene un uso frecuente en el corpus.

\section{CLAVETEADO [clabeteado]}

Adj. m. del sustantivo clavo.

Un cofrecito pequeño clabeteado (Laguna de Negrillos, 1734) 
En este ejemplo, aparece el adjetivo derivado del sustantivo clavo, que califica al cofre designando que está tachonado con clavos.

\section{ESCOPLO}

Sust. m. 'Herramienta de hierro acerado, con mango de madera, de unos tres decímetros de largo, sección de uno atres centímetros en cuadro, y boca formada por un bisel' (DRAE). Del antiguo escoplo, y este del latín scalprum 'escoplo', 'buril', 'podadera', 'escalpelo', derivado de scalpĕre 'rascar', 'grabar, esculpir'. Escopro se alteró en escoplo por influecia ultracorrecta leonesa, que convierte comúnmente el grupo /pl/ en /pr/ (DECH, s.v. escoplo).

Dos escoplos y una gubia, todo de yerro (Coomonte de la Vega, 1645)

Un escoplo (Coomonte de la Vega, 1719)

Un taladro, un escoplo (Genestacio de la Vega, 1721)

Un escoplo (Palacios de la Valduerna, 1728)

Un escoplo grande y una espita ynglesa (Castrocalbón, 1814)

Es una voz común que se utiliza con el significado de 'herramienta de carpintero'. Formalmente se registra siempre en el corpus bajo la forma normativa, no aparecen casos de conservación del diptongo decreciente, frecuente en el leonés occidental, ni de sustitución de $/$ / por /r/.

\section{CIGÜEÑAL [ciguñal]}

Sust. m. 'Eje con codos que transforma un movimiento rectilíneo en circular' (DRAE). Término derivado de cigüeña por su forma, del latín č̆cōnĭa (DECH, s.v. cigüeña).

Un ciguñal de una rueda de errero (Coomonte de la Vega, 1645)

Es el único ejemplo recogido del término. Se trata de una herramienta de uso general que mantiene el significado común del término, en este caso aplicado a una función concreta.

\section{GARABITO/A [jarabito]}

Sust. f. El DRAE define el término en su tercera acepción como 'gancho, garabato'. Garabato 'gancho retorcido' dialectalmente garabito. Parecen ser derivados del ast. y santand. gárabu, gáraba 'palito', de la misma familia prerromana que carba 'rama, matorral', 'rebollo' (DECH, s.v. garabito).

Dos garabitos de ierro (Vidriales, 1645)

Una garabita de hierro (Valle de la Valduerna, 1829)

Una azada y dos tornaderas de yerro y una garabita (La Isla, 1829)

Una garabita de acanterar y dos trillos con dos atibas (La Isla, 1829) 
Una garabita de yerro de sacar abono (Santibáñez de la Isla, 1844)

Un jarabito de yerro (Felechares, 1836)

El significado general del término es el de 'palo que termina en un ganchito y que se emplea para alcanzar una rama de árbol, sacar la hierba del pajar o el agua del pozo, colgar objetos, etc.' (Le Men, 2007, s.v. garabito). En algunas zonas incluidas en este corpus, la voz tiene acepciones concretas según se use el término en masculino o femenino. Así en Santibáñez de la Isla, a donde pertenecen los tres últimos ejemplos, garabito es un 'palo largo con un gancho de hierro o de madera (a veces, una herradura) en uno de los extremos, que se utilizaba para sostener el cubo con que se sacaba agua del pozo' y garabita 'rastrillo con dientes de hierro' (Miguélez, 1998:156, 157). Por tanto, la garabita es un rastrillo con diferentes usos, de ahí que en los ejemplos se especifique el fin para el que se utiliza. En los otros dos casos, probablemente tenga también el significado de 'rastrillo' en el caso de garabita; o de 'gancho' en el caso de garabito, pero a diferencia de los ejemplos siguientes se especifica que son de hierro, quizá porque también existan de madera.

\section{LEZNA [lesna]}

Sust. f. 'Instrumento que se compone de un hierro con punta muy fina y un mango de madera, que usan los zapateros y otros artesanos para agujerear, coser y pespuntear' (DRAE). Del germano occidental *alı̌sna (DECH, s.v. lezna).

Una lesna (Coomonte de la Vega, 1643)

Es el único ejemplo encontrado, aunque es una palabra documentada en toda la zona comprendida en el corpus. El significado con el que se utiliza es el que da el DRAE.

\section{MARTILLO}

Sust. m. 'Herramienta de percusión, compuesta de una cabeza, por lo común de hierro, y un mango' (DRAE). Del lat. vulgar martěllus, diminutivo del lat. martǔlus (DECH, s.v. martillo).

Una sierra y un machado y una paleta de enbarrar y un martillo (La Bañeza, 1641)

Dos martillitos pequeños con sus mangos (Coomonte de la Vega, 1643)

Unas bolsas de cuero de cacador con un martillico y un poco de plomo (Coomonte de la Vega, 1643)

Un martillo de rexas bueno (Alija del Infantado, 1644)

Un martillo de orexas de yerro (Coomonte de la Vega, 1645)

Un martillo de yerro pequeño y una espita despuntada mas un azadón zespedero biexo (Alija del Infantado, 1646)

Un martillo grande (Coomonte de la Vega, 1719)

Un martillo de orejas (La Nora del Río, 1724) 
Un martillo pequeño de herrar cavallerías (La Nora del Río, 1724)

Un martillo y un cacho de planchón (Castrocalbón, 1814)

Es un término de uso común, aunque no se hayan recogido ejemplos del S. XIX. El significado es el de 'martillo', tal y como hoy conocemos el término. También se denomina martillo a la 'parte superior de los hierros de picar la guadaña' (Le Men, 2007, s.v. martillo), pero por las descripciones que acompañan al término, es probable que el significado genérico sea el de 'martillo', con las diferencias en la forma y en la finalidad que aparecen en el inventario junto a la palabra. Formalmente, la voz aparece siempre bajo la forma castellana ya que no se recoge ningún caso de diptongación, que sí se documenta en León.

\section{MAZO [maço]}

Sust. m. 'Martillo grande de madera' (DRAE). Derivado de maza, del latín vulgar *mattěa, que parece ser derivado regresivo del latín mateola (DECH, s.v. maza).

Un maço de cambar carros (Alija del Infantado, 1644)

Un mazo (Coomonte de la Vega, 1719)

Dos mazos de majar lino (Palacios de la Valduerna, 1728)

Ocho mazos de desvagar lino (Valle de la Valduerna, 1829)

Un mazo de terrones y una tornadera (Palacios de la Valduerna, 1831)

El término se utiliza con el significado general de 'apero de labranza'. En la zona de la Valdería se define como 'apero de labranza, con forma de martillo, pero de madera y más pequeño que el mayo que sirve para diversos fines, desgranar un fruto a base de golpes, aunque más para aplastar o destripar un objeto' (Rivas, 1996: 156). De los ejemplos extraídos, se puede deducir que el término se emplea con dos acepciones, una con el significado de 'martillo', objeto que sirve para aplastar, sería el significado del primero y último ejemplos, incluso del de Coomonte de la Vega donde no se especifica nada; y el significado de 'instrumento agrícola consistente en un tablón de unos $50 \mathrm{~cm}$. de largo, 20 de ancho y 12 de altura; en el centro lleva un agujero para insertar el mango; se utiliza para machacar los garbanzos y el lino' (Le Men, 2007, s.v. mazo), que sería el utilizado en los ejemplos de la Valduerna en los que se indica la acción de majar lino. Además el término tiene el significado de 'matraca', pero no hay ejemplos en el corpus que recojan esta acepción.

\section{PLANCHÓN}

Sust. m. Término aumentativo de plancha 'lámina o pedazo de metal llano y delgado respecto de su tamaño' (DRAE). 
Un martillo y un cacho de planchón (Castrocalbón, 1814)

Es el único ejemplo encontrado, es probable que el significado sea el que aparece en el diccionario académico.

\section{PLOMADA}

Sust. f. 'Instrumento compuesto por una pesa cilíndrica o cónica de metal que se sujeta al extremo de una cuerda para que esta, tensada por la fuerza de la gravedad, señale la línea vertical' (DRAE). Término derivado de plomo, del latín plümbum (DECH, s.v. plomo).

Una plomada de yerro (Coomonte de la Vega, 1719)

De todas las acepciones que registra el diccionario académico, es probablemente la señalada aquí la que se usa en el único ejemplo recogido del término en este corpus.

\section{PUJAVANTE [pujabante]}

Sust. m. 'Instrumento que usan los herradores para cortar el casco a los animales de carga' (DRAE). Derivado de empujar, probablemente del latín tardío impǔlsare íd., frecuentativo de impellĕre impulsar, derivado de pellĕre poner en marcha ( $D E C H$, s.v. empujar).

Un pujabante (Quintanilla de Somoza, 1831)

Es el único ejemplo recogido. $\mathrm{Su}$ uso es el que aparece en el diccionario académico.

\section{SIERRA}

Sust. f. 'Herramienta para cortar madera u otros objetos duros, que generalmente consiste en una hoja de acero dentada sujeta a una empuñadura' (DRAE). Del latín sěrra (DECH, s.v. sierra).

Una sierra y un machado y una paleta de enbarrar y un martillo (La Bañeza, 1641)

Una sierra de mano pequeña (Coomonte de la Vega, 1645)

Una sierra mediana (Alija del Infantado, 1646)

Una sierra de monte (Miñambres, 1729)

Una sierra de mano (Destriana, 1730)

Es un término común que se utiliza con el significado que da el diccionario académico. 


\section{TENAZA [tenaçes, tenacas]}

Sust. f. 'Instrumento de metal, compuesto de dos brazos trabados por un clavillo o eje que permite abrirlos y volverlos a cerrar, que se usa para sujetar fuertemente una cosa, o arrancarla o cortarla' (DRAE). Término derivado de tener, del latín těnēre ' tener asido ' (DECH, s.v. tener).

Unas tenacas de arrancar buenas (Coomonte de la Vega, 1643)

Unos morrillos de yerro con sus tenaçes (La Bañeza, 1643)

Unas tenacicas de arrancar (Coomonte de la Vega, 1645)

Un badil, unas tenazas y unas trébedes pequeñas de yerro (La Bañeza, 1721)

Unas orquetas de tenaza (Miñambres, 1727)

Dos vadiles y unas tenazas (La Nora del Río, 1823)

Unas tenazas viejas (La Bañeza, 1829)

Una paleta, vadil y tenaçes (Quintanilla de Somoza, 1831)

Unas tenazas y su paleta (Requejo de la Vega, 1839)

El término se utiliza con el significado general que aparece en el DRAE, es una voz de uso común.

\subsection{MEDIDAS}

El hombre siempre ha tenido la necesidad de tomar como referencia unidades que le permitieran medir el espacio, para conocer la cantidad de terreno que poseía o que había cultivado; la masa, el volumen o la capacidad que había obtenido en sus cosechas o que poseía. Para delimitar esta realidad ha utilizado diferentes términos que, en ocasiones, incluso han variado según la época o el lugar en el que se han utilizado. Las palabras que constituyen este apartado denominado unidades de medida se agrupan atendiendo a criterios como líquidos, áridos, capacidad o superficie. Al final se añade un subapartado en el que se incluyen objetos de medir.

\subsubsection{Unidades}

\section{AZUMBRE}

Sust. Amb. 'Medida de capacidad para líquidos que equivale a unos dos litros' (DRAE). Del árabe tumn 'octava parte' (DECH, s.v. azumbre).

Una bota que ará media azumbre (Coomonte de la Vega, 1645)

Cinco azumbres de miel (Coomonte de la Vega, 1645)

Dos medias azumbres de lo mismo (Coomonte de la Vega, 1722)

Es un término que designa una medida que se utilizaba para los líquidos y que equivalía a la octava parte de la cántara. El azumbre y la cántara son las dos medidas que se utilizan en el corpus para líquidos, siendo más frecuente la cántara. 


\section{CARGA}

Sust. f. 'Cierta cantidad de granos que en una parte es de cuatro fanegas y en otras de tres' (DRAE). Del latín vulgar carrǐcare, íd., derivado de carrus 'carro', voz latina de origen céltico (DECH, s.v. carga).

Tres cargas de pan mediano (Castrocalbón, 1643)

Una carga melonera de binbre biexa (Coomonte de la Vega, 1643)

Un costal de lana de cosa de media carga (La Nora del Río, 1645)

Dos oronas buenas que arán a dos cargas de pan (Alija del Infantado, 1646)

Una arca panera buena sin tapador que ará dos cargas y media de pan (Alija del Infantado, 1646)

Dos costales de pavilos biexos que arán a media carga poco más o menos cada uno (Alija del Infantado, 1647)

Dos costalitos de lana biexa que ará media carga (Alija del Infantado, 1647)

Tres cargas de zestos (La Antigua, 1648)

Una orona que ará seis cargas (Coomonte de la Vega, 1650)

Dos quilmas de lana que arán media carga buenas (Alija del Infantado, 1650)

Dos cargas y media de trigo (Coomonte de la Vega, 1719)

Una carga de trigo (Genestacio de la Vega, 1721)

Nuebe cargas y media de sementera de trigo (Genestacio de la Vega, 1721)

Nuebe cargas de barbechos (Genestacio de la Vega, 1721)

Un arca panera y en ella como cosa de dos cargas de arina de centeno (Laguna de Negrillos, 1721)

Diez cargas de zestos buenos y usados (Laguna de Negrillos, 1722)

Una carga de zevada (La Nora del Río, 1724)

Una trona grande que ará tres cargas (Fresno, 1726)

Tres cargas y tres fanegas de trigo (Robledo de la Valduerna, 1726)

Una orona vieja que ará una carga de linaza (Miñambres, 1727)

Zinco cargas y diez eminas de trigo (Miñambres, 1727)

Tres cargas y media de trigo (Palacios de la Valduerna, 1728)

Seis cargas de zenteno (Palacios de la Valduerna, 1728)

Más un foro que se compone de tres cargas de tierras que se allaron en los términos de este lugar en cuio foro entran las casas de este ynbentario que se paga a las monxas de Villoria cada año de venta y foro (Palacios de la Valduerna, 1728)

Siete cargas y media de zestos (Grajal de la Ribera, 1730)

Una carga de zenteno y otra de trigo (Laguna de Negrillos, 1734)

Quatro cargas de trigo (Genestacio de la Vega, 1738)

Tres cargas de centeno (Genestacio de la Vega, 1738)

Una carga de zevada (Genestacio de la Vega, 1738)

Ocho cargas de trigo (Alija del Infantado, 1812)

Dos cargas de cebada (Alija del Infantado, 1812)

Carga y media de morcajo (Jiménez de Jamuz, 1825)

Dos cargas y tres eminas de trigo (Palacios de la Valduerna, 1831)

Tres cargas de barbilla (Santibáñez de la Isla, 1844)

Es un término muy común tanto en la zona estudiada como en las comarcas próximas a esta. La carga es el nombre que se le da a una unidad de medida tanto para áridos como de superficie, como se refleja en los ejemplos. Como medida de superficie la carga equivale en esta zona a doce héminas de tierra o a dos fardelas de grano como medida para áridos. Como muestran los ejemplos, también existe la media carga que corresponde a la mitad (Rivas, 1996: 62). Como unidades de medida para áridos se 
documentan, por tanto, tres: la fanega, la hemina y la carga. Los términos más frecuentes son hemina y carga, siendo este el más empleado como unidad de medida mientras que la voz hemina se emplea fundamentalmente para nombrar el medidor.

\section{CELEMÍn [zelemín]}

Sust. m. 'Medida de capacidad para áridos, que tiene cuatro cuartillos y equivale en Castilla a 4,6251 aproximadamente' (DRAE). Término derivado del árabe hispánico Oemēnî, plural de Aumnîya 'vaso de barro, cantarillo', cambiado en *cemenín y *cenemín, pasó luego a celemín por disimilación (DECH, s.v. celemín).

Una cestica frutera de binbre con cosa de medio celemín de garbanzos (Coomonte de la Vega, 1643)

Unas pocas de arbexas que será un celemín dellas poco más o menos (Coomonte de la Vega, 1643)

Un zelemín de cantudas (Quintana del Marco, 1820)

No son muchos los ejemplos recogidos, pero se trata de un término común para expresar una unidad de medida.

\section{CUARTA [quarta]}

Sust f. Una de las acepciones que da el DRAE como medida de longitud es la de 'palmo'. Derivado de cuarto, del latín quartus (DECH, s.v. cuarto).

Una pieza de lienzo o estopa que se midió por una bara y tubo catorce baras y una quarta (Coomonte de la Vega, 1643)

Una tabla de manteles de gusanillo de dos piernas de siete cuartas de largo (Coomonte de la Vega, 1643)

Tres cuartas de estameña canuza (Coomonte de la Vega, 1645)

Cuatro baras y media de servilletas nuebas de tres cuartas de ancho (Coomonte de la Vega, 1645)

Una quarta de vayeta (Genestacio de la Vega, 1721)

Una viña que ará quatro cuartas y media (Grajal de la Ribera, 1730)

Tres cuartas de estameña negra (Grajal de la Ribera, 1750)

Una quarta de monfor (Quintana del Marco, 1820)

Otro (pañuelo) de cinco cuartas (Jiménez de Jamuz, 1825)

Es un término muy común que aparece siempre en el corpus como medida de longitud. En todos los ejemplos se emplea con el significado de palmo, es decir, 'distancia desde el extremo del pulgar hasta el del meñique'. Solamente hay un ejemplo, el de Grajal del año 1730, en el que también se emplea como medida pero en este caso de superficie. Como unidad de medida textil, es un término mucho más frecuente que tercia, del que solo se recoge un ejemplo. Sin embargo, el significado más empleado en la provincia de León, incluso en el occidente peninsular, y más concretamente en el entorno de La Bañeza, es el de 'encuarte, yunta de refuerzo que se coloca delante de la 
que tira de un carro para ayudar a subir una cuesta o para salir de los malos pasos' (Le Men, 2004, s.v. cuarta), pero con esta acepción no se ha recogido ningún ejemplo en este corpus.

\section{CUARTAL [quartal]}

Sust. m. 'Duodécima parte de la cuartera, que se divide en cuatro picotines' (DRAE).

Término derivado de cuarto, del lat. quartus (DECH, s.v. cuarto).

Un cuartal con su regla errado (Santibáñez de la Isla, 1844)

Quince quartales de linaza (Santibáñez de la Isla, 1844)

Ocho quartales de cantudas (Santibáñez de la Isla, 1844)

Los ejemplos localizados pertenecen al mismo inventario. En esta zona, el término toma una acepción no recogida en el DRAE 'medida de capacidad para grano equivalente a 12 cuartillos' (Miguélez, 1998: 143). En el primer ejemplo es posible suponer que, de acuerdo con la especificación que tiene la voz, su significado sea el de 'recipiente de madera, especie de cajón con un asa pequeña en uno de los lados, que sirve para medir los áridos', acepción que se recoge en León, pero que no figura en el DRAE (Le Men, 2004, s.v. cuartal).

\section{CUARTILLO [quartillo]}

Sust. m. 'Medida de capacidad para áridos, cuarta parte de un celemín, equivalente a 1156 ml. aproximadamente' (DRAE). Término derivado de cuarto, del lat. quartus (DECH, s.v. cuarto).

Una emina y un cuartillo de sal blanca (Coomonte de la Vega, 1643)

Una olla de barro zamorano con dos cuartillos de sal poco más o menos (Alija del Infantado, 1647)

Un quartillo para herrar (Alija del Infantado, 1724)

Un quartillo para errar (Palacios de la Valduerna, 1831)

Un cuartillo por herrar tasado en rial (Santibáñez de la Isla, 1844)

El término se utiliza en los dos primeros ejemplos con el significado de 'medida de peso', concretamente se trata de una medida de peso equivalente a algo menos de un kilo (Rivas, 1996: 82). En los tres últimos ejemplos, la especificación "para herrar" hace pensar que se trata no de la medida, sino del medidor.

\section{FANEGA}

Sust. f. 'Medida de capacidad para áridos que, según el marco de Castilla, tiene 12 celemines y equivale a 55,5 1. pero es muy variable según las diversas regiones de 
España' (DRAE). Del árabe faníqa 'saco grande, costal', 'fanega, medida de capacidad equivalente al contenido de un saco' (DECH, s.v. fanega).

Una fanega de zevada (La Bañeza, 1712)

Una fanega de trigo (La Nora del Río, 1724)

Tres cargas y tres fanegas de trigo (Robledo de la Valduerna, 1726)

Una fanega (San Feliz, 1838)

El término tiene el significado de 'medida de capacidad', pero esta varía en función de las regiones. Así, por ejemplo, en la zona de la Valdería equivale a tres heminas de grano (Rivas, 1996: 123), en zonas del Órbigo próximas a Astorga equivale a siete cuartales (Martínez García, 1985: 68). En el último ejemplo, como ocurre con otros términos que designan una 'medida de capacidad', el hecho de no especificar el objeto que se mide, hace pensar que en este caso la voz designa el 'objeto que se utiliza para medir, el medidor'. En algunos puntos de la geografía española se ha documentado la fanega como una medida superficial para el cultivo de cereales denominándola fanega de tierra para evitar la confusión con la medida de capacidad (Torres Montes, 2000: 2403), en este corpus solo se recoge la fanega como medida de capacidad que es su primitivo valor

\section{HEMINA [emina]}

Sust. f. 'Medida antigua para líquidos, equivalente a medio sextario' (DRAE). El equivalente griego de $s e m i$ - es * $\eta \mu \iota$ que entra en la composición de varias palabras entre otras hemina (DECH, s.v. semi-).

Tres eminas de linaza (Castrocalbón, 1643)

Un escriño bueno nuevo que ará mas de una emina de trigo (Coomonte de la Vega, 1643)

Una emina y un cuartillo de sal blanca (Coomonte de la Vega, 1643)

Una emina biexa sin yerros (Alija del Infantado, 1646)

Un escriño que ará una emina de pan biexo (Alija del Infantado, 1647)

Una urona pequeña que ará cuatro eminas de pan (Alija del Infantado, 1647)

Una emina con su rasero buena (Coomonte de la Vega, 1650)

Una hemina de alquimia (La Bañeza, 1714)

Siete heminas de linaza (Genestacio de la Vega, 1721)

Una emina errada buena (Laguna de Negrillos, 1722)

Una emina de álamo errada (La Nora del Río, 1724)

Una emina errada (Robledo de la Valduerna, 1726)

Znco cargas y diez eminas de trigo (Miñambres, 1727)

Una emina bieja (Palacios de Jamuz, 1728)

Beinte y nuebe eminas de zenteno (Palacios de la Valduerna, 1728)

Una emina por herrar (Palacios de la Valduerna, 1728)

Dos heminas de garbanzos (Grajal de la Ribera, 1750)

Una emina de guisantes (Castrocalbón, 1814)

Ocho eminas de trigo (Castrocalbón, 1814)

Nuebe eminas de linaza (Castrocalbón, 1814) 
Una hemina de garbanzos (Jiménez de Jamuz, 1825)

Dos heminas de cantudas (Jiménez de Jamuz, 1825)

Diez y ocho heminas de trigo (La Nora del Río, 1820)

Diez y ocho heminas de morcajo (La Nora del Río, 1820)

Es un término muy frecuente en el corpus. El DRAE, además de la acepción ya señalada que aparece en primer lugar, señala las siguientes: 'En la provincia de León, medida de capacidad para frutos, equivalente a algo más de 181.'. 'Medida agraria usada en la misma provincia para la tierra de secano, que tiene 110 pies de lado, y equivale a 939 centiáreas y 41 decímetros cuadrados'. 'Medida para las tierras de regadío en la provincia de León, que tiene 90 pies de lado, y equivale a 628 centiáreas y 88 decímetros cuadrados' (DRAE). En ediciones anteriores, ya el Diccionario de Autoridades recogía la acepción de 'cierta medida de granos que tiene la tercera parte de una fanega', que localizaba en Castilla. El DRAE en su edición de 1803 define el término con la siguiente acepción 'medida de granos usada en algunos pueblos de Castilla y León y es la tercera parte de una fanega'. Analizando los ejemplos del corpus, se puede observar que el término está usado con dos significados. Por un lado aparece como 'medida de capacidad'. En este sentido, la voz tiene el significado que da el DRAE en su edición de 1803 y posteriores, así los ejemplos señalan heminas de garbanzos, linaza, trigo y demás granos. Además de este significado, en otros ejemplos como: «una emina por errar buena», «una emina herrada», «una hemina de alquimia»; el término tiene como referente un objeto, un medidor; no una medida. En algunos vocabularios de la zona se recoge además la acepción de 'apero o recipiente de forma piramidal y alargada, de madera y con una barra horizontal de hierro en medio que hace de asa, que sirve para tal medida y hace de 12 a 14 kg.' (Rivas, 1996: 137-138). Este será, probablemente, el significado que tiene el término en estos otros ejemplos del corpus. Se trata, por tanto, de un término muy usado que mantiene en el corpus dos acepciones localizadas geográficamente en la zona de Castilla y León y en la zona de la Valdería.

\section{ARROBA}

Sust. f. 'Peso equivalente a 11,502 kg.'. 'Medida de líquidos que varía de peso según las medidas y los mismos líquidos' (DRAE). De roba', pronunciación vulgar del árabe rub' (DECH, s.v. arroba).

Dos arrobas y media de manteca (La Bañeza, 1641)

Media arroba de lana de un colchón (La Bañeza, 1641)

Una arroba de lana negra (Coomonte de la Vega, 1645)

Arroba y media de añinos blancos y negros (Coomonte de la Vega, 1645)

Una @ de pez (La Bañeza, 1712) 
Una @ de almagre (La Bañeza, 1712)

Una arroba de lana negra (Alija del Infantado, 1720)

Quatro arrobas y cinco libras de tozino (Fresno, 1726)

Tres arrobas de lana negra (Robledo de la Valduerna, 1726)

Tres arrobas de lana blanca (Robledo de la Valduerna, 1726)

Treinta arrobas de lino fabricado (Robledo de la Valduerna, 1726)

Dos tozinos con sus menudos que pesaron dos arrobas (Palacios de Jamuz, 1728)

Dos arrobas y media de tozino (Palacios de la Valduerna, 1728)

Una pesa de una arroba, otra de media arroba (Pobladura del Valle, 1734)

Media arroba de lana blanca (Jiménez de Jamuz, 1825)

Tres arrobas de tozino (Castrillo de la Valduerna, 1828)

Una arroba de yierro biejo (Quintanilla de Somoza, 1831)

Es un término muy común. El significado es el que da el DRAE como 'peso equivalente a $11.502 \mathrm{~kg}$. Con esta acepción se utiliza en todos lo ejemplos. En el caso de Pobladura del Valle, el término toma la de 'pesa de veinticinco libras', acepción también recogida en el DRAE. Como medida de líquido, no se recoge ningún ejemplo.

\section{LIBRA [livra]}

Sust. f. 'Peso antiguo de Castilla dividido en 16 onzas y equivalente a 460g. En Aragón, Baleares, Cataluña y Valencia tenía 12 onzas, 17 en las Provincias Vascongadas y 20 en Galicia, y además las onzas eran desiguales según los pueblos'. 'Medida de capacidad que contiene una libra de un líquido' (DRAE). Del latín lībra 'libra de peso', 'balanza' (DECH, s.v libra).

Una pesa de yerro de una libra (Coomonte de la Vega, 1643)

Una pina de yerro con la boca de acero de más de tres libras (Coomonte de la Vega, 1643)

Cosa de dos libras de yerro y clabos biexos (Coomonte de la Vega, 1643)

Una botixa melada que ará dos libras de aceyte (Coomonte de la Vega, 1645)

Doçe libras de cera (Coomonte de la Vega, 1645)

Dos obillos de lino ylado que pesaron media libra poco más o menos (Alija del Infantado, 1647)

Dos ovillos de pavilos que pesarán una libra (Alija del Infantado, 1647)

Una pesa de yerro de una libra (Coomonte de la Vega, 1650)

Dos tozinos que pesarán zien libras (Coomonte de la Vega, 1650)

Una libra de azúcar y otras tres de arroz (Alija del Infantado, 1720)

Quatro libras de cáñamo (La Bañeza, 1721)

Tres libras de estopa (Fresno, 1726)

Quatro arrobas y cinco libras de tozino (Fresno, 1726)

Diez libras de alquima (Robledo de la Valduerna, 1726)

Setenta y zinco libras de ierro biejo (Robledo de la Valduerna, 1726)

Beinte y dos libras de plata labrada (Robledo de la Valduerna, 1726)

Nuebe libras y media de ilo calzetero (Robledo de la Valduerna, 1726)

Diez y ocho libras de ylaza casera (Robledo de la Valduerna, 1726)

Zinco libras de lino (Laguna de Negrillos, 1726)

Una pesa de dos libras (Palacios de Jamuz, 1728)

Veinte y quatro libras de ylaza cosida en obillos (Palacios de la Valduerna, 1728) 
Un peso de garfios con veinte y quatro libras y media de pesas de yerro (Miñambres, 1729)

Ocho libras de unto (Miñambres, 1729)

Veinte libras de unto de lechón (Destriana, 1750)

Dos libras de clabos de carro (Castrocalbón, 1814)

Veinte libras de lana negra y blanca (Castrocalbón, 1814)

Veinte libras de tocino (Castrocalbón, 1814)

Libra y media de manteca (Castrocalbón, 1814)

Libra y media de longaniza (Castrocalbón, 1814)

Veinte libras de lino (Castrocalbón, 1814)

Quatro libras de tozino (Jiménez de Jamuz, 1825)

Seis libras de pólbora (La Nora del Río, 1823)

Como una libra de polbos de salbadera (La Nora del Río, 1823)

Diez y seis libras de chocolate (La Nora del Río, 1823)

Trece libras y media de cera en velas (La Nora del Río, 1823)

Seis libras de hilo gallego calcetero (La Bañeza, 1829)

Diez y seis livras de pescado (La Bañeza, 1829)

Se trata de un término muy generalizado, como queda reflejado en los ejemplos. El significado es el de 'medida de capacidad', como indica el DRAE que da valores exactos diferenciados en cada zona. En la zona de La Bañeza una libra es exactamente 'medida de capacidad o peso equivalente a 16 onzas' (Rivas, 1996: 148). Además, el término aparece en León con otras acepciones que no recoge el DRAE y que pueden reflejarse en los ejemplos recogidos en el corpus, así se utiliza el término para designar la 'tableta de chocolate' (Le Men, 2007, s.v. libra), puede ser que en el ejemplo de La Nora del Río aplicado al término chocolate, la palabra libra se esté utilizando con esta acepción, que originariamente también tiene el significado de 'medida', puesto que se llamó así a la tableta de chocolate porque la libra era su medida.

\section{ONZA}

Sust. f. 'Peso que consta de 16 adarmes y equivale a 28,7g. Es una de las 16 partes iguales del peso de la libra y la del marco de la plata se divide en 8 ochavas' (DRAE). Del latín ünč̆a 'duodécima parte de la libra y de otras medidas' (DECH, s.v. onza).

Quatro onzas de tener aceyte (La Nora del Río, 1823)

Seis cuviertos de plata usados que pesan treinta y una onzas a razón de quince cada una (La Bañeza, 1829)

Dos onzas hilo blanco (Requejo de la Vega, 1839)

Dos onzas de lana (Requejo de la Vega, 1839)

Es un término común que tiene el significado de 'medida de peso equivalente a la cuarta parte del cuarterón o a la décimo-sexta parte de la libra'. No obstante su uso en el corpus es mucho menor que el de libra. 


\section{TERCIA}

Sust. f. El DRAE da en su $4^{\text {a }}$ acepción el significado de 'bulto', entendido como sinónimo de fardo. Término derivado de tres, del latín trēs (DECH, s.v. tres).

Una tercia de paño negro (Valle de la Valduerna, 1829)

El término se usa frecuentemente con otro significado distinto al que aparece en el ejemplo. Es frecuente utilizar tercia para nombrar a cada una de las vigas colocadas de forma horizontal hacia la mitad del techo de una casa, que sirven tanto para sujetar a otras, como para sujetar el tejado' (Rivas, 1996: 223). Sin embargo, las referencias al término paño indican que no es esa la acepción empleada y que probablemente el uso que se le da al término es el de 'medida', que el diccionario académico en sus sucesivas ediciones señala como 'la tercera parte de una vara', medida de longitud muy empleada en el ámbito textil.

\section{VARA [bara]}

Sust. f. 'Palo largo y delgado'. 'Medida de longitud que se usaba en distintas regiones de España con valores diferentes, que oscilaban entre 768 y 912 mm.' (DRAE). Del latín vara 'travesaño en forma de puente' (DECH, s.v. vara).

Es un término polisémico, aunque la mayor parte de los ejemplos encontrados son los que toman como acepción de la palabra la de 'medida de longitud' que fue muy utilizada como unidad de medida en telas. Algunos ejemplos encontrados son:

Dos baras y media de estameña parda (La Bañeza, 1641)

Veinte y dos baras y media de burato negro (La Bañeza, 1643)

Una pintura de Nuestra Señora de media bara con marco dorado (La Bañeza, 1643)

Unos manteles de torzillos de dos baras y media buenos (Alija del Infantado, 1644)

Una pieza de lienzo que se midió por una bara y tubo catorce baras y una quarta (Coomonte de la Vega, 1645)

Un poste de negrillo de dos baras de largo (Coomonte de la Vega, 1645)

Otras dos toallas de caparrosa i zilestre de cosa de bara y media de largo cada una (Alija del Infantado, 1646)

Un cernadero de bara y media bueno (Coomonte de la Vega, 1650)

Dos tablas de manteles de seis varas a tres cada uno buenos (Huerga de Garaballes, 1720)

Treinta baras de lienzo gallego ancho (Palacios de la Valduerna, 1726)

Diez y seis baras de zerrón (Palacios de la Valduerna, 1726)

Dos baras de pardo casero (Palacios de Jamuz, 1728)

Seis baras de estameña blanca (Requejo de la Vega, 1735)

Quatro varas de zinta (Genestacio de la Vega, 1738)

Cinco varas de galón (Grajal de la Ribera, 1806)

Tres baras de lienzo (Castrocalbón, 1814)

Diez varas cotonia de lino (La Nora del Río, 1823)

Una bara de algodón pintado (Jiménez de Jamuz, 1825)

Nueve varas de estopa (La Bañeza, 1829) 
Bara y media de percal blanco (La Bañeza, 1829)

Ocho varas de amantelado ordinario (La Bañeza, 1829)

Vara y media en un pedazo de angeo (Requejo de la Vega, 1835)

Dos varas de brocado (Requejo de la Vega, 1835)

Seis baras y media sayal negro doble (Requejo de la Vega, 1835)

Una mesa de manteles de dos varas y un paño blanco con encages (San Feliz, 1838)

En cuanto a la medida exacta a la que equivalía la vara, Rodríguez Bayo señala que en La Baña la vara equivale a cuatro cuartas (Rodríguez Bayo, 2007: 125). Es, por tanto, la medida aproximada que da el DRAE ya que señala que se trata de una longitud equivalente a $80 \mathrm{~cm}$. Además el término aparece en otros ejemplos en los que se utiliza con otras acepciones. En los ejemplos siguientes:

Una manada de baras (Palacios de Jamuz, 1727)

Una bara de brazuelo (Destriana, 1730)

Unas andas de santo con sus varas (Pobladura del Valle, 1733)

La acepción utilizada en el primer caso es la de 'palo largo y alargado'. El ejemplo se refiere a un conjunto de palos que tendrá diversos usos, aunque en esta zona, se emplean para sujetar las matas de habas. Los dos ejemplos siguientes, probablemente, utilicen el término con el significado de 'pértigo', en un caso referido al carro y en otro a los pértigos que se emplean para portar en hombros una imagen. Además Rivas señala que en la Valdería se denomina vara a 'cada uno de los pendientes con forma de aro que se colocaban en el lóbulo de las orejas de las niñas recién nacidas, en parte como símbolo de su sexo' (Rivas, 1996: 234), con este significado no se ha recogido en el corpus ningún ejemplo.

\section{MANADA}

Sust. f. 'Porción de hierba, trigo, lino, etc., que se puede coger de una vez con la mano' (DRAE). Término derivado de mano, del latín manus (DECH, s.v. mano).

Una manada de baras (Palacios de la Valduerna, 1727)

Es el único ejemplo recogido, aunque se trata de un término de uso general. Es una palabra que se utiliza con varios significados, aparte de utilizarse la voz manada para referirse a 'un conjunto de animales', tanto en esta zona de La Bañeza como en otras partes de León, también se llama manada a 'hozada, porción segada de cada golpe de la hoz' y a la 'cantidad de mies, hierba, trigo, centeno, etc., que, al segar, puede sostenerse con la mano' (Le Men, 2007, s.v. manada). Pero, volviendo al único ejemplo recogido, en este caso se utiliza el término con el significado de 'puñado o conjunto de baras', para indicar el número de objetos, es decir, más o menos las que caben en una mano. 


\section{PALMO}

Sust. m. 'Distancia que va desde el extremo del pulgar hasta el del meñique, estando la mano extendida y abierta'. 'Medida de longitud de unos $20 \mathrm{~cm}$, que equivalía a la cuarta parte de una vara y estaba dividida en doce partes iguales o dedos' (DRAE). Del latín palmus, derivado de palma de la mano (DECH, s.v. palma).

Una escopeta de cinco palmos (La Bañeza, 1643)

Una cuba de siete palmos (Coomonte de la Vega, 1738)

Dos fajas encarnadas 10 palmos una de ellas manchada (Requejo de la Vega, 1839)

Es un término sinónimo de cuarta, así lo refleja también el Boletín de la $R A H$ en su relación de antiguas medidas y pesos españoles. Sin embargo, a pesar de ser sinónimos, se trata de un término de menor frecuencia que cuarta, y además se puede hablar de una diferencia contextual ya que, a excepción del último ejemplo, aparece como medida de objetos que no son textiles, mientras que la voz cuarta como sinónimo de palmo aparece siempre con textiles.

\section{RESMA}

Sust. f. 'Conjunto de 20 manos de papel' (DRAE). Del ár. rízma íd., propte. 'paquete, haz', 'bala de paños', deriv. de rázam 'ató en forma de paquete' (DECH, s.v. resma).

Una resma de papel (La Bañeza, 1643)

Es el único ejemplo encontrado ya que no es fácil encontrar el término en un inventario común, salvo que se trate de una tienda, como en este caso. Su significado es el que aparece en el diccionario académico.

\subsubsection{Utensilios de medir}

\section{CÁNTARA}

Sust. f. 'Medida de capacidad para líquidos, que tiene ocho azumbres y equivale a 1613 centilitros aproximadamente'. 'Cántaro' (DRAE). Derivado de cántaro, del latín canthărus 'especie de copa grande, de dos asas', y este del griego kántharos (DECH, s.v. cántaro).

Un pellexo de tener bino que ara dos cántaras (Coomonte de la Vega, 1643)

Un guevo bueno que ace dos cántaras de vino (Coomonte de la Vega, 1645)

Una cuba que ara sesenta cántaras (Coomonte de la Vega, 1645)

Cuarenta cántaras de vino (Coomonte de la Vega, 1645)

Un pellexo de tener bino que ará tres cántaras (Coomonte de la Vega, 1650)

Un cuerón bueno de tener bino que ará tres cántaras buenas (Coomonte de la Vega, 1650)

Un cubeto mediano que ará diez y seis cántaras usado (Laguna de Negrillos, 1722)

Ziento y nobenta cántaras (Laguna de Negrillos, 1722) 
Media cántara de barro (Pobladura del Valle, 1722)

Dos tinajas pequeñas de barro que arán catorze cántaras (Laguna de Negrillos, 1734)

Un pozal que ará seis cántaras (Laguna de Negrillos, 1734)

Como diez cántaras de vino tinto (La Nora del Río, 1823)

Un tonel de cabida de dos y media cántaras (Requejo de la Vega, 1839)

Es un término muy común en toda la zona comprendida por el corpus estudiado. Fundamentalmente, se usa con la primera acepción que da el diccionario académico, es decir, 'medida para líquidos'. No obstante, diccionarios dialectales de la zona definen el término como 'vasija de barro cocido, con forma de ánfora, con o sin baño exterior que, a diferencia del cántaro, posee dos asas en lugar de una' (Rivas, 1996: 60). El ejemplo de Laguna de Negrillos del año 1722 «ziento y nobenta cántaras», probablemente usa el término con este significado ya que habla de un número de objetos, pero no hace referencia a ningún líquido cuya medida pueda estar en un número determinado de cántaras, como ocurre en los demás ejemplos. Con el significado de objeto probablemente también se esté empleando el término en el ejemplo siguiente de Pobladura del Valle, donde la indicación de "media cántara" está haciendo referencia a una cántara más pequeña, probablemente con la mitad de la capacidad, es decir, dieciséis litros.

\section{CÁNTARO}

Sust. m. Vasija grande de barro o metal, angosta de boca, ancha por la barriga y estrecha por el pie y por lo común con una o dos asas. Líquido que cabe en un cántaro (DRAE). Derivado de cántaro, del latín canthărus 'especie de copa grande, de dos asas', y este del griego kántharos (DECH, s.v. cántaro).

Un cántaro todo de barro (Alija del Infantado, 1644)

Una caldera de cobre que ará dos cántaros de agua buena (Alija del Infantado, 1646)

Un cántaro y una barrila de barro colorado (Alija del Infantado, 1647)

Una caldera de cobre que ará tres cántaros (Palacios de la Valduerna, 1728)

Una caldera de cobre que ara un cántaro de agua usada (Palacios de la Valduerna, 1728)

Cántaros de varro (Grajal de Ribera, 1750)

Un cántaro y una barrila (Castrocalbón, 1814)

Dos cántaros (Castrillo de la Valduerna, 1828)

Una caldera biexa de hacer dos cántaros y medio de agua (Quintanilla de Somoza, 1831)

Un cántaro de barro (Quintana del Marco, 1839)

Dos cazuelas, cántaros y otros trastos de cocina de poca consideración (Destriana, 1843)

Tres cántaros buenos (Destriana, 1843)

Todas las ollas de piriyuela y barro, cántaros, cazuelas y barreñones (Santibáñez de la Isla, 1844) 
Es una palabra frecuente a lo largo del corpus analizado. A partir de los ejemplos extraídos podemos concluir que el término tenía dos acepciones que más o menos coinciden con las que da el DRAE. Por una parte, en la zona leonesa se denominaba cántaro a 'vasija de barro o de metal, que con una capacidad de dieciséis litros, sirve de medida para el vino u otros líquidos'. Este sería el significado que, probablemente, tiene la palabra en los ejemplos en los que se especifica la capacidad de la caldera de cobre. Por otra parte, en esta zona el cántaro se diferenciaba de la cántara en que era 'una vasija de barro cocido, con o sin baño exterior, en forma de ánfora y con una sola asa' (Rivas, 1996: 60). Con este significado se utilizaría el término en el resto de los ejemplos. La voz, igual que en el caso de cántara, también designa una medida de capacidad, en esta zona igual que en otras zonas de la provincia de León, la cántara equivale a treinta y dos litros y el cántaro a dieciséis litros.

\section{CUARTERÓN [quarterón]}

Sust. m. 'Cuarta parte de una libra'. 'Postigo, puerta pequeña de algunas ventanas'. 'Cada uno de los cuadros que hay entre los peinazos de las puertas y las ventanas' (DRAE). Derivado de cuarto, del lat. quartus (DECH, s.v. cuarto).

Una viña en termino de esta villa aze cinco cuarterones ((Palacios de la Valduerna, 1730)

Un quarterón de ojalata (Pobladura del Valle, 1722)

Tres cuarterones de hilo negro de Córdova (Requejo de la Vega, 1839)

Un quarterón de ylo blanco (Grajal de la Ribera, 1806)

Es un término polisémico que, además de los significados que da el DRAE, se utiliza en la zona leonesa con otras acepciones. Los ejemplos encontrados dan muestra de esa variedad significativa. En el primer caso, teniendo en cuenta que el término se refiere a una parcela, hace suponer que el significado que toma aquí el término es el de 'cuadro de surcos compendido entre represas y canteras' (Le Men, 2004, s.v. cuarterón), acepción no recogida en el DRAE pero sí utilizada en zonas próximas pertenecientes a este Partido Judicial, como la zona de la Valdería (Descosido, 1993: 175). En el segundo ejemplo la voz toma otro significado. La especificación "de ojadelata" hace pensar que no se trata tanto de los cuadros de las puertas y ventanas, que eran de madera, sino más bien de 'parte superior de una puerta que se abre independientemente del resto, permitiendo la ventilación del interior aun con aquella cerrada', acepción que se documenta en Benavente (op.cit. s.v. cuarterón), zona muy próxima al lugar en el que se ha recogido el ejemplo. En este ejemplo la voz podría también tomar el 
significado de 'medidor', en este caso de hojalata. Finalmente, en los dos últimos ejemplos el término se utiliza con uno de los significados que da el DRAE, 'cuarta parte de una libra', es decir, equivalente a unos $115 \mathrm{~g}$.

\section{HERRADA [errada]}

Sust. f. 'Cubo de madera, con grandes aros de hierro o de latón, y más ancho por la boca que por la base' (DRAE). Término derivado de hierro, del latín fĕrrum (DECH, s.v. hierro).

Una errada de moral buena (Vidriales, 1645)

Un caldero de cobre que ará una errada (Vidriales, 1645)

Una caldera mediana que ará dos herradas de agua (Laguna de Negrillos, 1721)

Una errada de madera (Requejo de la Vega, 1735)

Una herrada buena (Laguna de Negrillos, 1740)

Una herrada (Grajal de la Ribera, 1750)

El significado del término es el de 'cubo de madera o de cinc para transportar el agua o para recoger la leche de las ovejas' (Le Men, 2005, s.v. ferrada). Sin embargo, en el corpus el término se utiliza, por extensión, con la acepción de 'medida'. Así en los ejemplos como «una caldera mediana que ará dos herradas de agua», el término herrada se refiere a la medida de la caldera en cuanto tiene la capacidad del contenido que cabe en una herrada, en este caso por dos. Formalmente, no se ha recogido ningún ejemplo con conservación de /f-/ latina.

\section{BALANZA [valanza]}

Sust. f. 'Instrumento que sirve para pesar' (DRAE). Término procedente del lat. vulg. bĭlancia. (DECH, s.v. balanza). Se trata de un vocablo de uso frecuente, aunque todos los ejemplos están localizados en el S. XVIII.

Un peso de balanzas de cobre (La Bañeza, 1714)

Un peso de valanzas bueno (La Bañeza, 1714)

Un peso de balanzas de cobre y una pesa (Palacios de la Valduerna, 1730)

Un peso de balanzas y dos libras (Alija del Infantado, 1737)

Como en otras palabras, la grafía "b" alterna con la grafía "v", aunque en este caso predomina la variante actual. En trabajos lexicográficos de la zona leonesa este término aparece con una acepción que no figura en el $D R A E$ 'columpio de una tabla sobre un caballete o viga' (Le Men, 2000, s.v. balanza). Con este significado no se ha recogido la voz en el corpus estudiado, siempre aparece con el significado más común del término. 


\section{ROMANA}

Sust. f. ' Instrumento que sirve para pesar, compuesto de una palanca de brazos muy desiguales, con el fiel sobre el punto de apoyo' (DRAE). Término de origen incierto, puede ser una abreviatura de balanza romana (DECH, s.v. romana).

Dos romanas una pequeña y otra grande (Robledo de la Valduerna, 1726)

Una romana de pesar monedas y un copero biexo (Palacios de la Valduerna, 1730)

Una romana inglesa (Alija del Infantado, 1812)

Una romana pequeña de plato (La Nora del Río, 1823)

Una romana grande (La Nora del Río, 1823)

Una romana chica de escarpias (Castrillo de la Valduerna, 1828)

Una romanilla vieja (Quintanilla de Somoza, 1831)

Una romana de platillo bieja (Palacios de la Valduerna, 1831)

Una romana chica con su platillo (Felechares, 1837)

Una romana de plato (Requejo de la Vega, 1839)

Una romana de plato (Destriana, 1843)

Una romana usada (Santibáñez de la Isla, 1844)

Es una palabra común que tiene el significado actual de 'balanza'. Las más comunes son las de plato en el que se ponía aquello que se quería pesar. La romana inglesa es bastante diferente, de ahí que, como en otros casos, se especifique con detalle el objeto en la relación.

PESA

Sust. f. 'Pieza metálica que se utiliza como término de comparación para determinar el peso de un cuerpo' (DRAE). Del latín pensum 'peso de lana por hilar' y vulgarmente 'peso' en general (DECH, s.v. pesar).

Dos pesas de valanças de cobre (La Bañeza, 1641)

Una pesa de yerro de una libra (Coomonte de la Vega, 1643)

Una pesa de yerro de una libra (Coomonte de la Vega, 1650)

Un peso de garfios con veinte y quatro libras y media de pesas de yerro (Miñambres, 1729)

Un peso con una pesa (Miñambres, 1731)

Una pesa de una arroba, otra de media arroba (Pobladura del Valle, 1734)

Un peso pequeño de garfios con una pesa de una libra en tres (Grajal de la Ribera, 1750)

Un pesito pequeño con pesas (Requejo de la Vega, 1839)

Es un término común que se utiliza con el significado actual. Es frecuente que se especifique el valor de la pesa así como, en algunos casos, también el material, si es de hierro o cobre.

PESO

Sust. m. 'Balanza u otro utensilio para pesar' (DRAE). Del latín pensum 'peso de lana por hilar' y vulgarmente 'peso' en general (DECH, s.v. pesar). 
Un peso de garfios con veinte y quatro libras y media de pesas de yerro (Miñambres, 1729)

Un peso con una pesa (Miñambres, 1731)

Un peso pequeño de garfios con una pesa de una libra en tres (Grajal de la Ribera, 1750)

Un peso de garfios (Castrocalbón, 1814)

Un pesito pequeño con pesas (Requejo de la Vega, 1839)

Es un término polisémico de uso común, aunque en los ejemplos recogidos del corpus únicamente tiene el significado de 'balanza', mientras que la voz en femenino designa los elementos que se emplean para equilibrar el peso, como se refleja en la entrada anterior.

\subsection{TEXTIL}

Si amplio es el apartado de la indumentaria, no es menor el número de voces que aparecen en los inventarios para designar el tipo de tejido del que están confeccionadas las prendas. Esta información es relevante ya que aporta un conocimiento acerca de los gustos y modas de la época, así como de los tejidos que eran más selectos por su calidad. Por ello he dedicado un apartado al textil en el que las voces se agrupan por fibras textiles (algodón, lana, cáñamo, seda). Las palabras que aparecen al final se agrupan en lo que se denominan técnicas ya que no mencionan un tejido en sí, sino más bien una forma de trabajar (DHTT, 2004: 264-288). Finalmente, aparece un subapartado bajo el nombre de otros en el que se incluyen las voces que guardan relación con el campo semántico del textil, generalmente máquinas y otros utensilios, pero que no son propiamente tejidos. Cabe destacar que muchos términos textiles remiten a términos de origen debido a la procedencia de la tela, por lo que se tratarán en el apartado denominado términos con procedencia geográfica.

\subsubsection{Tejidos}

\subsubsection{Algodón}

\section{ALGODÓN}

Sust. m. El DRAE en su $5^{\text {a }}$ acepción define el término como 'hilado o tejido hecho de borra de algodón'. Del árabe qutn íd., vulgarmente qotón (DECH, s.v. algodón).

Una toca de algodón nueba (Coomonte de la Vega, 1650)

Una toca de algodón (Alija del Infantado, 1720)

Un mandilete de algodón (La Bañeza, 1743)

Un guardapiés de algodon (Grajal de la Ribera, 1806)

Un retazo de algodón (Grajal de la Ribera, 1806) 
Un guardapié de algodón (Alija del Infantado, 1812)

Unas medias de algodón (Alija del Infantado, 1812)

Una colcha de algodón acolchonada (La Nora del Río, 1823)

Una bara de algodón pintado (Jiménez de Jamuz, 1825)

Tres cortinas viejas de algodón (La Bañeza, 1829)

Un guardapie de algodón (La Bañeza, 1829)

Una colcha de algodón (Felechares, 1837)

Cuatro cortinas de algodón con pintas y sus dos barillas (Requejo de la Vega, 1839)

Dos cortinas de algodón azul con flores y barilla de yerro (Requejo de la Vega, 1839)

Cuatro cortinas de algodón oscuro de buen uso (Requejo de la Vega, 1839)

Una cajita de algodón (Requejo de la Vega, 1839)

Otro manteo de color rosa con cortapisa de algodón (Destriana, 1843)

Es un término cuyo uso es mucho mayor que sus sinónimos cotón o cotonía, especialmente en el S. XIX. Esta mayor frecuencia de uso de un término sobre los otros no solo se da en este corpus, sino que en el CORDE el número de casos de algodón es muy superior al de los otros términos.

\section{COTón}

Sust. m. 'Tela de algodón estampada de varios colores' (DRAE). Del árabe qutn íd., vulgarmente qotón (DECH, s.v. algodón).

Dos colchas de cotón mui biejas (Robledo de la Valduerna, 1726)

Una bata de cotón (Robledo de la Valduerna, 1726)

Solo se han recogido estos ejemplos que presentan el significado que da el diccionario académico.

\section{COTONÍA [cotona]}

Sust. f. 'Tela blanca de algodón labrada comúnmente de cordoncillo' (DRAE). Quizá procedente del derivado árabe qutnîya (DECH, s.v. algodón).

Un jubón de cotonía (Saludes de Castroponce, 1808)

Cinco baras de cotona fina (Alija del Infantado, 1812)

Dos justillos de cotona finos (Alija del Infantado, 1812)

Diez varas de cotonía de lino (La Nora del Río, 1823)

Dos justillos de cotonía (Castrocalbón, 1832)

Seis colchas de cotona (Requejo de la Vega, 1839)

Es un término que designa un tipo de tela hecha de hilo de algodón. Se utilizaba tanto para prendas de vestir (jubones, justillos), como para ropa de casa (colchas). También aparece como tela en pieza que era medida en varas. Formalmente, aparece la variante cotona, que no guarda relación en este caso con el significado que toma en Méjico de 'chaqueta de gamuza', o en otras zonas de América 'camiseta fuerte de algodón' (DRAE). Como se puede ver reflejado en los ejemplos, el comportamiento tanto semántico como sintáctico del término es idéntico al de cotonía. Por tanto puede 
tratarse de una variante, quizá confundida con cotonada que designa también 'tela de algodón', en cuyo caso sería más bien cotoná, o de un fenómeno de ultracorrección de la llamada yod epentética.

\section{BEATILLA [viatilla]}

Sust. 'Especie de lienzo delgado y ralo' (DRAE). Término derivado de beato, del latín beatus (DECH, s.v. beato).

Una toca de viatilla (Palacios de la Valduerna, 1728)

Es el único ejemplo encontrado. La beatilla designa un 'tipo de tejido de lino delgado y ralo que se utilizaba para las tocas', aunque en los ejemplos de toca encontrados abundan tejidos como el lienzo o el algodón. Según Covarrubias su nombre se debe a que "debió ser invención del tipo de hilado y tela utilizada por las beatas para taparse la cabeza cuando iban a las funciones religiosas, o porque la usaban las mujeres recoletas que no se engalanaban”, aunque según señala Perdiguero no debió ser usado solo por beatas y monjas, sino también por moriscas (Perdiguero, 2012 Formalmente, en el único caso encontrado se produce la transformación del hiato en un diptongo por el cierre de la /e/ átona, solución que no es demasiado frecuente ya que los notarios la consideran vulgar (Morala y Egido, 2010: 427), pero al encontrarse en el registro oral, tal vez el escribano la recoja tal y como van enunciando las palabras.

\section{ENCAJE [encage, encaxe]}

Sust. m. 'Tejido de mallas, lazadas o calados, con flores, figuras u otras labores, que se hace con bolillos, aguja de coser o de gancho, etc., o bien a máquina' (DRAE). Término derivado de caja, probablemente del catalán caixa u occitano caissa, procedentes del latín capsa (DECH, s.v. caja).

Una colcha de gusanillo con encajes alrededor (La Bañeza, 1714)

Otra (toalla de lienzo con sus encages (La Bañeza, 1721)

Un encaje de manto (La Bañeza, 1721)

Otro encaje más angosto (La Bañeza, 1721)

Una toalla con sus encajes (Fresno, 1726)

Dos peinadores con sus encajes (Robledo de la Valduerna, 1726)

Una alba con su amito de encajes (Robledo de la Valduerna, 1726)

Un escañil bueno de encaje (Laguna de Negrillos, 1734)

Una toalla de tela con sus encaxes (Requejo de la Vega, 1735)

Una toca con encajes (Grajal, 1806)

Una toca de tela con encajes (Castrocalbón, 1814)

Una toalla de morsolina bordada o guarnecida de encajes (Destriana, 1825)

Dos tocas una de morsolina con encaje y otra de lienzo fino (Jiménez de Jamuz, 1825)

Una tualla de lienzo con sus encages (Castrillo de la Valduerna, 1828) 
Dos pedazos de encages con diez y seis baras (Requejo de la Vega, 1836)

Un paño blanco con encajes (San Feliz, 1838)

Es una palabra de uso común que sustituyó al término randa, que se utilizó hasta el S. XVII. A partir de 1680 comenzó a sustituirse por la voz encaje, con la acepción que recoge el diccionario académico. Posteriormente también se introdujo la voz blonda, con el significado de 'encaje' que, en cualquier caso, también tuvo una frecuencia menor en este corpus.

\section{FELPA}

Sust. f. 'Tejido de seda, algodón, etc., que tiene tejido por el haz' (DRAE). Voz común con el portugués, catalán e italano felpa, íd., oc. feupo, fr. ant. y dial. feupe 'harapo', de origen incierto; en castellano es probable que sea de procedencia galorrománica ( $D E C H$, s.v. felpa).

Una almilla de felpa verde bieja (Robledo de la Valduerna, 1726)

Una mantilla y tapa fundas biejas de felpa (Robledo de la Valduerna, 1726)

Solo se han recogido estos ejemplos ya que el sustantivo felpa alterna con el adjetivo afelpada, para especificar aquellas prendas que están hechas con este tipo de tejido. Es muy frecuente que en las relaciones de bienes se haga referencia a la tela con la que están confeccionadas las prendas.

\section{FRANELA [franiela]}

Sust.f. 'Tejido fino de lana o algodón, ligeramente cardado por una de sus caras' (DRAE).

Del francés flanelle y este del inglés flannel (DECH, s.v.franela).

Una mantilla de franiela (Saludes de Castroponce, 1808)

Una mantilla de franela con cinta y terciopelo nueba (Alija del Infantado, 1812)

Los dos ejemplos encontrados pertenecen al S. XIX ya que la voz designa un tejido que llega de Francia en este siglo. Se trataba de una lana fina y suave que, seguramente, encarecería la prenda confeccionada con este tejido. Este dato, junto al hecho de que se introdujera en el S. XIX, explicaría la escasez de ejemplos. Formalmente, el primer ejemplo aparece con diptongación que tal vez se produzca por un fenómeno de ultracorrección. 


\section{FUSTÁN}

Sust. m. 'Tela gruesa de algodón, con pelo por una de sus caras' (DRAE). Palabra común a las varias lenguas romances y al árabe hispánico y moderno, de origen incierto; quizá alteración del árabe fustâ 'tienda de campaña hecha de algodón' (DECH, s.v. fustán).

Una capa de pardo nueba aforrado el quello en fustán (Coomonte de la Vega, 1645)

Solo se ha recogido este ejemplo que toma el significado recogido en el DRAE.

\section{PANA}

Sust. f. 'Tela gruesa semejante al terciopelo, que puede ser lisa o con hendiduras generalmente verticales' (DRAE). Del francés panne (DECH, s.v. pana).

Seis pares de calzetas de ylo de pana (La Bañeza, 1643)

Un juvón de pana rayada negra nuebo (Alija del Infantado, 1812)

Un juvón de pana liso negra (Alija del Infantado, 1812)

Dos varas de pana negra (Castrocalbón, 1814)

Un justillo usado de pana rayada azul (Quintana del Marco, 1820)

Una montera de paño forrada en pana (Quintana del Marco, 1820)

Unos calzones de pana (La Nora del Río, 1823)

Otro (justillo) de pana nuevo (Jiménez de Jamuz, 1825)

Una montera de paño con pana (Alija del Infantado, 1827)

Un armazón de pana nuevo (Palacios de la Valduerna, 1831)

Dos jubones de pana (Castrocalbón, 1832)

Dos justillos de pana uno azul y otro blanco (Castrocalbón, 1832)

Un armador de pana (San Feliz, 1838)

Dos pedazos de pana de colores (Requejo de la Vega, 1839)

Es un término que aparece recogido en el diccionario académico en el año 1817, es decir es una voz tardía, lo que explica que prácticamente todos los ejemplos recogidos pertenecen a inventarios del S. XIX, coincidiendo así con el CORDE donde los numerosos ejemplos que aparecen del término con el significado de 'tejido' se sitúan en los SS. XVIII y XIX. Anteriormente, en los inventarios estudiados encontramos otros tejidos más frecuentes como por ejemplo, la estameña. El significado es el utilizado para este término en la actualidad.

\section{PERCAL}

Sust. m. 'Tela de algodón blanca o pintada más o menos fina, de escaso precio' (DRAE).

Del francés percale, procedente de la India; de origen incierto, allí quizá se tomó del persa pärgâlä (DECH, percal).

Otro (pañuelo) blanco de percal (Jiménez de Jamuz, 1825)

Bara y media de percal vlanco (La Bañeza, 1829)

Otros dos (vestidos) de percal (Castrocalbón, 1833)

Dos (pañuelos) de percal usados (Castrocalbón, 1833) 
Unas cortinas de percal encarnado (Castrocalbón, 1833)

Otro (vestido) blanco de percal (Requejo de la Vega, 1839)

Es un término que aparece solo en inventarios del S. XIX, no se documenta en España hasta este siglo. No es un tejido muy frecuente y los ejemplos se reducen bastante ya que tres pertenecen al mismo inventario y el ejemplo de Requejo de la Vega pertenece a un inventario de una tienda, lo que explica la posibilidad de encontrar cosas menos frecuentes que en relaciones de bienes personales.

\section{PIQUÉ}

Sust. m. 'Tela de algodón con diversos tipos de labor, que se emplea en prendas de vestir y otras cosas' (DRAE). Del francés piqué, participio de piquer 'hacer un pequeño agujero' (DECH, s.v. picar).

Un pantalón blanco de piqué (Requejo de la Vega, 1839)

Es el único ejemplo recogido, dato que no es extraño ya que se trata de un término procedente del francés que aparece documentado por primera vez en el diccionario académico en la edición de 1884 , por tanto las muestras del término no se van a encontrar hasta más o menos la segunda mitad del S. XIX ya no en corpus reducidos como este, sino en recopilaciones más bastas como en el CORDE.

RUAN (vid. términos con procedencia geográfica)

\section{TELA}

Sust. f. 'Obra hecha de muchos hilos, que, entrecruzados alternativa y regularmente en toda su longitud, forman como una lámina. Se usa especialmente hablando de la obra tejida en el telar' (DRAE). Del latín tēla (DECH, s.v. palma).

Tuallas de tela con sus puntas antiguas (La Bañeza, 1721)

Una tela de lienzo (Fresno, 1726)

Una toalla de tela con sus encaxes (Requejo de la Vega, 1735)

Un guardapiés de tela verde (Grajal de la Ribera, 1806)

Una basquiña morada de tela (Alija del Infantado, 1812)

El término tela se utiliza para designar la 'estructura hecha con hilos entrelazados, que tiene una longitud y una anchura considerable, y un grueso muy pequeño, especialmente la realizada con hilo o cáñamo; preferentemente se hace con ligamento de tafetán del cual es sinónimo tela'. No obstante, en algunas zonas, por ejemplo en catalán, también se utiliza como sinónimo de lienzo y sirve para nombrar la 
ropa fina de cáñamo, algodón o lino (DHTT, s.v. tela); uso que podría estar empleándose en los tres primeros ejemplos mostrados del corpus.

\section{TERLIZ}

Sust. m. 'Tela fuerte de lino o algodón, por lo común de rayas o cuadros, y tejida con tres lizos' (DRAE). Del latín trĭlix, -īcis 'de tres lizos', 'tela labrada con tres lizos' (DRAE, S.v terliz).

Dos cabezales de terliz vuenos con su pluma (La Bañeza, 1641)

Tres cabeçales de terliz grandes (La Bañeza, 1647)

Dos cabezales de terliz con sus fundas y pluma vuenos (La Bañeza, 1649)

Un colchón de terliz bueno (La Bañeza, 1721)

Diez colchones de terliz buenos (Robledo de la Valduerna, 1726)

Dos colchones de terliz (Alija del Infantado, 1812)

Una funda nueba de terliz (Jiménez de Jamuz, 1825)

Cuatro colchones de lana y terliz (La Bañeza, 1829)

Dos colchones de terliz casero (La Bañeza, 1829)

Un colchón de terliz (Felechares, 1837)

Un colchón de terliz usado (Requejo de la Vega, 1839)

Un jergón de terliz usado (Requejo de la Vega, 1839)

Un colchón de terliz bastante deteriorado (Destriana, 1843)

Es un término común ya que designa una tela cuyo uso era frecuente para fundas de colchones o, como reflejan los ejemplos, de los cabezales. Los ejemplos del corpus analizado contrastan con los del CORDE donde, estableciendo una comparación en lo que a volumen del mismo se refiere, solo se recogen veinticinco casos que se fechan a partir del S. XIII y cuyo uso va disminuyendo especialmente a partir del S. XVII donde no se recoge ningún ejemplo y muy pocos en los SS. XVIII y XIX, frente a los recogidos en este estudio donde el mayor número de ejemplos pertenecen al S. XIX.

\section{ZARAZA [sarasa]}

Sust. f. 'Tela de algodón estampada, ú. m. en América' (DRAE). De zarzahán que se convertiría en *zaraz(ah)án y de ahí zaraza (DECH, s.v. zarzahán).

Un guardapié de sarasa nueba (Alija del Infantado, 1812)

Otro (vestido) de sarasa oscura (Requejo de la Vega, 1839)

Otro (vestido) de sarasa clara (Requejo de la Vega, 1839)

Otro (vestido) de sarasa azul con flor biejo (Requejo de la Vega, 1839)

Otro (vestido) de sarasa bueno (Requejo de la Vega, 1839)

El DRAE recoge el término desde la edición de 1780 y lo define hasta la de 1992, en la que aparece la acepción señalada, como 'tela de algodón muy fina y ancha con listas de colores o con flores estampadas sobre fondo blanco, que se traía de Asia y era muy estimada en España'. En León, concretamente en la zona noroccidental, se 
documenta la voz zarazalla, sarasa y zaraza para denominar a un tipo de tejido distinto, concretamente un 'percal barato', (Fernández González, 1981: 409), es decir, de mala calidad. Atendiendo a los ejemplos encontrados, es probable que no se trate de un término frecuente, ya que se reducen a dos inventarios y aparece como tela de vestido, datos que indicarían que se trata de una tela de cierta calidad que se correspondería con la acepción del diccionario académico.

\subsubsection{Lana}

\section{ALEPÍN}

Sust. m. 'Tela muy fina de lana' (DRAE).

Otro (vestido) de alepín a media usa (Requejo de la Vega, 1839)

Es el único ejemplo recogido en el corpus y se trata de un tipo de tejido que se utilizaba, como se observa en el ejemplo, para vestidos pero también chalecos. Originariamente se fabricaba en Alepo (Siria) y después en diversas ciudades de Europa, entre ellas París e Inglaterra donde estaba el principal centro de producción, aunque el que comienza a llegar a partir de 1790 es el alepín francés (DHTT, s.v. alepín). Aunque en España se utilizó a principios del S. XIX, lo que explica que no haya ejemplos de épocas anteriores, en el corpus solo se ha recogido uno, tal vez porque se trataba de un tejido de alto valor económico.

\section{AÑINO}

Sust. m. El DRAE define el término como 'cordero de un año ', 'lana de corderos'. Del lat. agnīnus 'propio del cordero', derivado de agnus 'cordero' (DECH, s.v. añino).

Un talegón con unos añinos blancos y negros (Coomonte de la Vega, 1643)

Arroba y media de añinos blancos y negros (Coomonte de la Vega, 1645)

Media arroba de añinos negros (Robledo de la Valduerna, 1726)

Es una voz poco usada. En el CORDE se recoge tan solo un ejemplo anónimo del S. XVI "rendar los diezmos de los dichos corderos que son añino y lana...", hecho muy significativo que justificaría que estamos ante un término poco frecuente. La Academia incorpora el término a su diccionario en la edición de 1933 con los significados que aparecen al principio, este dato también indica que se trata de un término poco usual. Diccionarios dialectales señalan que en la zona de la Valdería, comarca que forma parte del P.J. de la Bañeza y muy próxima al lugar donde se han recogido los dos ejemplos, esta palabra tiene las siguientes acepciones 'primer corte dado a la lana de un cordero o 
cordera' y 'cada uno de los trozos de la primera lana que se esquila a los corderos que tienen menos de un año, y que no llega a ser un vellón sino un trozo pequeño' (Rivas,1996: 28), ( Le Men, 2000, s.v. añino). Sin embargo, en los ejemplos concretos recogidos, se da una información relativa tanto al color, como a una unidad de medida o a la cesta que se utiliza para transportarlos, datos que llevan a suponer que se estaría utilizando con el significado de 'lana de cordero'.

\section{BARRAGÁN}

Sust. m. 'Tela de lana impenetrable al agua' (DRAE). En árabe barrakân íd., pero no es seguro que venga de esta lengua (DECH, s.v. barragán).

Un capote de barragán forrado en cochinilla biejo (Robledo de la Valduerna, 1726)

Un guardapie de barragán de aguas azul (Alija del Infantado, 1812)

Es un término poco frecuente en el corpus, dato que no resulta extraño si tenemos en cuenta que en el CORDE la voz aparece con este significado solo en ocho ejemplos, prácticamente todos ellos pertenecientes al S. XIX. Por tanto, de estos datos se puede deducir que se trata de un tipo de tela no muy frecuente.

\section{BAYETA [vayeta]}

Sust. f. 'Tela de lana, floja y poco tupida' (DRAE). Probablemente del francés antiguo baiette que parece ser diminutivo de bai 'pardo' (DECH, s.v. bayeta).

Un bestido de honbre de bayeta con ferreruelo todo con pestaña de raso (La Bañeza, 1643)

Un rebociño negro de bayeta negra (La Bañeza, 1643)

Unas enaguas de bayeta con galón (La Bañeza, 1643)

Una quarta de vayeta (Genestacio de la Vega, 1721)

Un dengue de vayeta de Portugal encarnado (La Bañeza, 1743)

Una mantilla de vayeta blanca con cinta ancha (Grajal de la Ribera, 1806)

Unos canconcillos de vayeta (Saludes de Castroponce, 1808)

Un retazo de lienzo y otro de bayeta (Saludes de Castroponce, 1808)

Un rodao de bayeta pajiza nuevo (Alija del Infantado, 1812)

Un dengue de bayeta fino encarnado (Alija del Infantado, 1812)

Otro de bayeta caterzena con cuita (Alija del Infantado, 1812)

Una mantilla de bayeta negra con galón (Alija del Infantado, 1812)

Una cubierta de vayeta verde (La Nora del Río, 1823)

Una armilla de vayeta pajiza (La Nora del Río, 1823)

Unos calzones de paño forrados en vayeta (La Nora del Río, 1823)

Una mantilla de bayeta negra (Alija del Infantado, 1827)

Un denge encarnado de vayeta (Quintana del Marco, 1820)

Un dengue de bayeta (Quintanilla de Somoza, 1831)

Otro (manteo) de bayeta (Castrocalbón, 1832)

Una mesa bieja con su carpeta de bayeta (Requejo de la Vega, 1839) 
Es un término común que designa un tipo de paño que se utilizaba en algunas prendas de vestir, especialmente en mantillas y dengues, aunque también en sayas y rodaos; pero también, como reflejan los ejemplos, se utilizaba para cubrir la mesa. Incluso hay documentos que indican que se empleaba para cubrir el féretro, aunque con este uso no hay ejemplos. Formalmente siempre aparece la variante castellana, aunque en leonés es frecuente encontrar baeta, como consecuencia de la pérdida de /-y-/ en contacto con vocal palatal.

\section{BURATO}

Sust. m. 'Tejido de lana y seda que servía para alivio de lutos en verano y para manteos' (DRAE). Término derivado de buriel, del francés antiguo burel, buriau, de origen desconocido, quizá emparentado con el adjetivo romance *būrius (DECH, s.v. buriel).

Veynte y dos baras y media de burato negro (La Bañeza, 1643)

Es el único ejemplo recogido. El término alude a un tipo de tejido con el que se solían hacer capas y manteos sobre todo para el verano ya que se trata de tejido de lana delgado. No obstante las referencias al tejido de los manteos que aparecen en las relaciones son otras: estameña, paño, etc. lo que hace pensar que no se trata de un tejido tan común como puedan ser los anteriores.

\section{CALAMACO}

Sust. m. Tela de lana delgada y angosta, que tiene un torcidillo como jerga y se parece al droguete $(D R A E)$. Cierta tela de lana, amer. Propiamente poncho colorado: parece ser araucano kelü 'rojo' mákuñ 'poncho, manto de hombre con abertura en medio para pasar la cabeza' (DECH, s.v. calamaco).

Un guardapiés de calamaco (Grajal de la Ribera, 1806)

Dos manteos antiguos de calamaco (La Bañeza, 1829)

El término designa un tipo de tejido de lana que se podía fabricar de un solo color o de varios. En España el calamaco o lasting se recibía principalmente de Bradford (Inglaterra) donde se fabricaba con mucha perfección (DHTT, s.v. calamaco), aunque el NTLLE señala en la edición de 1729 que también venía de Portugal. El término se registra en nuestra lengua en el año 1729, pero los ejemplos recogidos en el corpus coinciden con los pocos aparecidos en el CORDE que pertenecen también al S. XIX. 


\section{CAMELOTE [chamelote]}

Sust. m. 'Tejido fuerte e impermeable generalmente de lana' (DRAE). Del francés antiguo camelot, forma dialectal de chamelot y este probablemente del francés antiguo chamel 'camello' porque el camelote se hacía con pelo de camello (DECH, s.v. camelote).

Otro vestido de chamelote de aguas pardo (La Bañeza, 1649)

Unos calzones de camelote mui viejos (La Bañeza, 1754)

Son los únicos ejemplos del término recogidos en el corpus. Se trata de un tejido del que existen distintas variedades. En el primer ejemplo encontrado se señala la variedad "de aguas", que indica que se trata de un 'tejido con seda que recibía un aderezo en el agua y se pasaba por la prensa caliente para darle lustre formando con ello figuras parecidas a las que usaban los pintores para expresar las ondas' (DHTT, s.v. camelote). Este dato indica que se trata de un tipo de tejido usado para prendas de uso no habitual y probablemente de cierto valor económico, lo que explicaría su escasez en el corpus así como que los ejemplos encontrados pertenezcan a dos inventarios de La Bañeza, cabeza del Partido Judicial, ya que en estos inventarios es más frecuente encontrar objetos de uso poco común.

\section{CARRO DE ORO}

Sust. m. 'Tela tornasolada, muy fina, de lana' (DRAE).

Una casaca de carro de oro vieja (Robledo de la Valduerna, 1726)

Una basquiña de medio carro de oro negra (La Bañeza, 1754)

Se trata de una tela que, al parecer se tejió en Flandes, aunque posteriormente en otros lugares. El origen del nombre tal vez se debe a que el Artífice tenía por insignia a la puerta de su tienda un carro de oro y de ahí surgió el nombre. Así se explica en el Diccionario de Autoridades que define el término de la siguiente manera "cierta tela muy fina hecha de lana que se teje en Flandes y otras partes: la cual siendo de toda ley y bondad despide las manchas. La más rica se fabricó en Bruselas y porque el Artífice tenía por insignia a la puerta de su tienda pintado un carro de oro, de ahí tomó el nombre esta tela uy se le dio a las que se fabricaban de este género en otras partes". Son escasos los ejemplos encontrados, ambos pertenecen al S. XVIII, tal vez por tratarse de una tela de calidad y valor y por tanto poco común. 


\section{CATALUFA}

Sust. f. 'Tejido de lana tupido y afelpado, con variedad de dibujos y colores, del cual se hacen alfombras'. 'Tafetán doble labrado' (DRAE). Del it. antic. cataluffa 'cierto paño fabricado en Venecia' (DECH, s.v. catalufa).

Cinco piezas de catalufa fina dobles (La Bañeza, 1643)

Dos piezas de catalufa de ylo y lana de colores (La Bañeza, 1643)

Son los únicos ejemplos encontrados en el corpus. La catalufa es un tejido italiano, parece ser que fabricado en Venecia y no es común encontrarlo en los inventarios de la zona. En el CorLexIn los casos recogidos del término pertenecen a la mitad sur de la Península, no se recogen en la zona norte. En este corpus los dos ejemplos aparecen en un mismo inventario que tal vez recoja los bienes encontrados en una tienda de la cabeza del P.J. de La Bañeza, lo que explicaría la presencia de estos ejemplos aislados, además en el DHTT se indica que se trata de una tela que tenía un uso escaso puesto que "se utilizaba para ornamentos sagrados y para forrar aposentos" (DHTT, s.v. catalufa).

\section{CHALÓN}

Sust. m. El DRAE en las ediciones de 1780 a 1822 define este término como 'tejido de lana llamado así por haber venido de la ciudad de Chalon en Francia'.

Dos mandiles de chalón (Grajal de la Ribera, 1806)

Otro mandil de chalón nuevo (Alija del Infantado, 1812)

Un mandil de chalón (Requejo de la Vega, 1839)

Solo se han recogido estos tres ejemplos fechados todos en el S. XIX. El término se utiliza con el significado que da la Academia en torno a esta época. Se trata de una tela utilizada en esta zona, junto con otras como la estameña, para los mandiles. El hecho de que sea un tejido procedente de Francia explicaría la escasez de ejemplos, puesto que los mandiles se confeccionaban también con otro tipo de telas, dato que además explicaría que los ejemplos sean todos del S. XIX, época en la que se produce una mayor influencia del país galo.

\section{CORDELLATE [cordelate]}

Sust. m. 'Tejido basto de lana cuya trama forma cordoncillo' (DRAE). Término derivado de cordel, de cuerda, del latín chürda 'soga, cordel' (DECH, s.v. cuerda).

Una sábana de cordelate (Toral, 1728)

Como cosa de una bara de cordelate (La Isla, 1735) 
Solo se han encontrado estos ejemplos del término. Abundan más otras voces que designan telas de lana, por ejemplo estameña, quizá porque tengan mayor uso en esta zona.

\section{DROGUETE}

Sust. m. 'Género de tela, comúnmente de lana, listada de varios colores y generalmente con flores entre las listas' (DRAE). Del francés droguet (DECH, s.v. droga).

Un jubón de droguete usado (Laguna de Negrillos, 1722)

Un guardapié de droguete usado (La Bañeza, 1754)

Solo se han recogido estos ejemplos. El droguete nombra un tipo de tejido de lana que en general no era de mucha calidad y formaba parte de la baja pañería (DHTT, s.v. droguete). No es muy común ya que los jubones solían confeccionarse con otro tipo de telas, especialmente la estameña.

\section{ESCARLATÍN}

Sust. m. 'Tela, especie de escarlata, de color más bajo y menos fino' (DRAE). Término derivado de escarlata, procedente del árabe hispánico iškirlâta (DECH, s.v. escarlata).

Otro (cobertor) de escarlatín (Robledo de la Valduerna, 1726)

Unos cuerpos de escarlatín con guarnición (Palacios de la Valduerna, 1730)

Una almilla de escarlatín (Palacios de la Valduerna, 1730)

Unos cuerpos de escarlatín (Miñambres, 1731)

Un justillo de monfor escarlatinado (Saludes de Castroponce, 1808)

Una parlamentaria de escarlatín (Alija del Infantado, 1812)

Un justillo de escarlatín (Destriana, 1825)

La voz designa un tipo de tela que aparece en determinadas prendas de vestir, por ejemplo en los cuerpos o justillos. Solo se han encontrado ejemplos del término en los SS. XVIII y XIX, tal vez porque a finales del S. XVIII aparecen los escarlatinas o escarlatones como un tejido de lana, a modo de sarga, que se exportaba a América (DHTT, s.v. escarlatín). No obstante, la frecuencia de uso es bastante alta si tenemos en cuenta que en trabajos lexicográficos como el CORDE solo aparece dos veces en dos documentos.

\section{ESTAMEÑA}

Sust. f. 'Tejido de lana, sencillo y ordinario, que tiene la urdimbre y la trama de estambre' (DRAE). Derivado de estambre, del lat. stamen, 'urdimbre' (DECH, s.v. estambre).

Dos baras y media de estameña parda (La Bañeza, 1641) 
Un mandil de estameña bueno (La Bañeza, 1641)

Tres cuartas de estameña canuza (Coomonte de la Vega, 1645)

Unos balones de pasamanos de estameña (Coomonte de la Vega, 1645)

Una ropilla de estameña (Coomonte de la Vega, 1719)

Un mandil de estameña (Alija del Infantado, 1720)

Una casaca de paño forrada con estameña (Coomonte de la Vega, 1722)

Un cobertor de tres herizos de estameña verde con fleco (Grajal de la Ribera, 1723)

Un guardapié de estameña azul (Grajal de la Ribera, 1723)

Una chupa de estameña (Laguna de Negrillos, 1725)

Una basquiña de estameña prensada (Palacios de la Valduerna, 1730)

Dos saias de estameña azul (Grajal de la Ribera, 1730)

Unos calzones de estameña nuebos (Alija del Infantado, 1734)

Seis baras de estameña blanca (Requejo de la Vega, 1735)

Una sobre cama de estameña (Alija del Infantado, 1737)

Un tapapié de estameña berde (La Bañeza, 1743)

Tres cuartas de estameña negra (Grajal de la Ribera, 1750)

Un rodao de estameña morado (Grajal de la Ribera, 1806)

Dos retazos de estameña azul (Castrocalbón, 1814)

Un manto de estameña negra casera algo usado (Quintana del Marco, 1820)

Dos pedazos de estameña fina (Requejo de la Vega, 1839)

Un juvón de estameña azul usado (Quintana del Marco, 1839)

Un ornador nuevo de estameña (Santibáñez de la Isla, 1844)

Es un término muy común en toda la zona puesto que denomina un tipo de tela de lana que se usaba mucho en diferentes tipos de prendas como jubones, colchas, manteos, etc. Antiguamente la estameña se usaba de diferentes colores, como se refleja en los ejemplos. En los inventarios, además de aparecer especificando a un sustantivo que señala un tipo de prenda, también aparece como objeto inventariable de forma aislada haciendo referencia a una cantidad concreta de tela "dos pedazos de estameña fina".

\section{FRISA [frissa]}

Sust. f. 'Tela ordinaria de lana, que sirve para forros y vestidos de las aldeanas' (DRAE). Probablemente del bajo latín tela frisia 'tela de Flandes', así llamada porque se importaba en barcos de Frisia (DECH, s.v. frisa).

Una quilma de frissa usada (Vidriales, 1645)

Unos balones de frissa picarça ya viejos (Vidriales, 1645)

Unos balones de frisa (La Antigua, 1648)

Un mandil de frisa negra (Fresno, 1726)

Una mantilla de frisa usada (Fresno, 1726)

Un manteo de frisa negra (Fresno, 1726)

Una mantilla de frisa (Palacios de la Valduerna, 1727)

Dos ropillas de frisa (Palacios de la Valduerna, 1727)

Una capa de frisa, otra de grechilla (Palacios de la Valduerna, 1727)

Quatro pares de calzones de frisa (Palacios de la Valduerna, 1727)

Un saiuelo de frisa remendado (Palacios de la Valduerna, 1727)

Una manta de frisa usada (Palacios de la Valduerna, 1727)

Un jubón de frisa (Palacios de la Valduerna, 1728) 
Un manteo bueno de frisa (Palacios de la Valduerna, 1728)

Un xubón de estameña azul con mangas de frisa (Requejo de la Vega, 1735)

Un xubón de frisa (Requejo de la Vega, 1735)

Una ropilla de frisa sin mangas nueva forrada en lienzo (La Isla, 1735)

Un mandil de frisa bendedera (La Isla, 1735)

Una mantilla de frisa casera (La Isla, 1735)

Una frisa usada (Quintanilla de Somoza, 1831)

Unas bragas de frisa buenas (Santibáñez de la Isla, 1844)

Un sayo biejo de frisa (Santibáñez de la Isla, 1844)

Tres manteos de la biuda, uno de paño y otro de frisa y otro de estameña (Santibáñez de la Isla, 1844)

Una frisa de cubrir (Santibáñez de la Isla, 1844)

Es un término muy común a lo largo de todo el corpus analizado. El significado más utilizado es el que aparece en el DRAE de 'tela de lana' con la que se confeccionaban todo tipo de prendas de abrigo: mantillas, mandiles, jubones, bragas, etc. Además, con el nombre de frisa se llama a una 'especie de manta de lana que usan las maragatas para cubrirse la cabeza y que les cuelga hasta más abajo de la cintura' (4 ${ }^{\mathrm{a}}$ acepción del $D R A E$ ). Además en León se recoge el término con el significado de 'especie de bufanda ancha' (Miguélez, 1998: 155). Con estas acepciones también se recogen casos en el corpus, ya que el último ejemplo probablemente toma este último significado, o más bien el que se utiliza en las zonas próximas a Astorga y a la Bañeza de 'prenda de abrigo', 'especie de mantón'. Como señala Concha Casado 'todavía se conservan en Maragatería estas frisas para cubrirse, que fueron tejidas en telares caseros. Son de lana fuerte y áspera, en color pardo oscuro, y llevan en los extremos un motivo floral, bordado en lanas de colores y, a veces, también el nombre de la dueña. La colocan sobre los hombros y la recogen con los brazos por delante. En inventarios del Alto Órbigo y alrededores de La Bañeza también aparece esta prenda femenina" (Casado, 1991: 507). Tanto, en el último ejemplo mostrado como en el de Quintanilla de Somoza, en los que el término no denomina un tipo de tela, probablemente se esté utilizando con estos significados.

\section{JERGA [xerga, gerga]}

Sust. f. 'Tela gruesa y tosca' (DRAE). De origen incierto (DECH, s.v. jerga).

Una mantica biexa y rota de xerga blanca y negra (Coomonte de la Vega, 1643)

Unos balones de jerga negra buenos (Alija del Infantado, 1644)

Unos balones de xerga usados (Coomonte de la Vega, 1650)

Una mantica de gerga (Grajal de la Ribera, 1750)

La voz aparece en el corpus con el significado que da el DRAE. 


\section{JERGUILLA [jerguilla, jergilla]}

Sust. f. 'Tela delgada de seda o lana, o mezcla de una y otra, que se parece en el tejido a la jerga'. Diminutivo de jerga.

Una colgadura de cama en jergilla encarnada (Robledo de la Valduerna, 1726)

Quatro cortinas de jerguilla (Robledo de la Valduerna, 1726)

La voz aparece en el corpus con el significado que da el DRAE.

\section{LAMPARILLA}

Sust. f. 'Tejido de lana delgado y ligero del que se solían hacer vestidos y capas de verano' (DRAE). Del fra. nompareille, íd. fabricado en Flandes (DECH, s.v. lámpara).

Una basquina de lamparilla (La Bañeza, 1721)

Unas mangas de lamparilla (La Bañeza, 1721)

Otra casaca de lamparilla vieja (Robledo de la Valduerna, 1726)

Probablemente, se trata de un tejido de lana poco común. En el corpus solo se han recogido estos ejemplos, todos ellos pertenecientes al S. XVIII, dato que resulta parejo a los ofrecidos por el CORDE, donde el término con este significado es poco frecuente y de los cuatro casos recogidos, tres pertenecen también al S. XVIII. En el corpus estudiado predominan otros tejidos como la estameña o el paño, como tejido más fino.

LANA

Sust f. 'Tejido de lana' (DRAE). Del latín lana (DECH, s.v. lana).

Un medio bellón de lana blanca (Coomonte de la Vega, 1643)

Otra manta de lana casera buena (Coomonte de la Vega, 1643)

Un cabezal biexo de lana blanca y negra roto (Coomonte de la Vega, 1643)

Un colchón biexo con su lana (Coomonte de la Vega, 1643)

Una almoada buena con su lana con randa blanca (Coomonte de la Vega, 1643)

Un xubón de damasquillo de lana de colores con mangas negras biexas (Coomonte de la Vega, 1643)

Un sonbrero de lana negro biexo (Coomonte de la Vega, 1643)

Unas mangas de lana de muger (Alija del Infantado, 1644)

Dos obillos de lana blanca (La Nora del Río, 1645)

Un repostero de lana con listas negras usado (Coomonte de la Vega, 1645)

Una mantilla de ceñir de lana negra (Coomonte de la Vega, 1645)

Una quilma pequeña de lana muy bieja (Alija del Infantado, 1647)

Media libra de lana negra (La Bañeza, 1721)

Diez y ocho pellexas de lana (Destriana, 1728)

Un bellón de lana (Palacios de la Valduerna, 1730)

Una carpeta de lana (Miñambres, 1731)

Un mantón de lana alistado (Requejo de la Vega, 1735)

Cuatro pares de medias de lana negras muy repasadas (La Bañeza, 1829)

Una cortina de lana usada (La Bañeza, 1829)

Una carpeta de ilo y lana bastante usada (La Bañeza, 1829) 
Un mantón de lana (Quintanilla de Somoza, 1831)

Una colcha de lana verde afelpada (Felechares, 1837)

Otro (pañuelo) de Casimiro de lana (Calzada 1838)

Dos onzas de lana (Requejo de la Vega, 1839)

Es un término muy común, por lo que se ofrece una pequeña muestra de la gran cantidad de ejemplos que aparecen en el corpus. En esta selección, la voz lana se usa con el significado de 'tipo de género', cuando se refiere a una prenda de vestir o a cualquier ropa de la casa; pero también como 'materia prima' con la que se fabrica el género y que proviene del pelo de las ovejas. Esta acepción es la que aparece cuando el término va acompañado de cualquier palabra que designa una unidad de medida, o con las palabras colchón o almohada, ya que se rellenan con la lana en basto.

\section{MERINO}

Adj. 'Tejido de cordoncillo fino, en que la trama y urdimbre son de lana escogida y peinada' (DRAE). Del latín majorīnus 'perteneciente a la especie mayor (en cualquier materia)', como nombre de una raza de ovejas y de la lana fina que producen, es verosímil, aunque no seguro, que merino venga del nombre de la tribu africana de los Benimerines, por la importación de ovejas berberiscas, practicada para mejorar la raza indígena española ( $D E C H$, s.v. merino).

Un pañuelo de merino para la boda (Destriana, 1870)

El pañuelo merino es común en la zona, concretamente en La Valduerna a donde pertenece este ejemplo, predominaron estos pañuelos lisos o estampados con fondos negros o de color vino.

\section{PALMiLla}

Sust. f. 'Cierto género de paño, que particularmente se labraba en Cuenca' (DRAE). "Pienso que se dijo palmilla, quasi palomilla, por tirar al color de la paloma; sin embargo de que hay palmillas verdes, o pudo ser que al principio se le pusiese en la orilla tejida una palma por señal" (Covarrubias, s.v. palmilla).

Una saya de palmilla verde (Genestacio de la Vega, 1721)

Una cortina de palmilla (La Bañeza, 1721)

Una mantilla de palmilla azul (Fresno, 1726)

Unos cuerpos de palmilla (La Isla, 1735)

Una cortina de palmilla (La Bañeza, 1721)

Un costal bueno y un armador de palmilla (San Feliz, 1838)

Se trata de un término que designa un tejido de paño que, como reflejan los ejemplos, se utilizaba para prendas diversas, aunque en estos casos solo hay un ejemplo 
en el que el color de la tela era azul, el de este color era el de mejor calidad (DHTT, s.v. palmilla). No se han recogido ejemplos anteriores al S. XVIII, aunque sí se documentan con fecha anterior en el CORDE.

\section{PAÑO}

Sust. m. 'Tela de lana muy tupida y con pelo tanto más corto cuanto más fino es el tejido' (DRAE). Del latín pannus 'pedazo de paño', 'trapo, harapo' (DECH, s.v. paño).

Unos balones de paño buenos ya rotos de las entrepiernas con botones de serdas a los lados (Coomonte de la Vega, 1643)

Dos pares de medias biexas de paño (Coomonte de la Vega, 1643)

Un paño de manos con puntas (La Bañeza, 1643)

Un paño frutero de quadros (La Bañeza, 1643)

Un paño labrado de cilestre y caparrosa (Alija del Infantado, 1644)

Un paño de manos de ruan labrado (Coomonte de la Vega, 1645)

Otro paño de ofrecer de cosa de una bara con randa blanca (Alija del Infantado, 1646)

Una montera de paño negro (Laguna de Negrillos, 1721)

Catorze pañitos de lino (Genestacio de la Vega, 1721)

Unas polainas de paño usadas (Coomonte de la Vega, 1722)

Una mantilla de paño azul usada (Grajal de la Ribera, 1723)

Un paño de ofrecer con puntas (Grajal de la Ribera, 1723)

Una ropilla de paño (Laguna de Negrillos, 1725)

Una casaca chupa y calzón de paño (Robledo de la Valduerna, 1726)

Una ropilla de paño con mangas (Robledo de la Valduerna, 1726)

Unos calzones de paño de Segovia viejos (Robledo de la Valduerna, 1726)

Unos botines de paño viejos (Robledo de la Valduerna, 1726)

Doze paños de manos de gusanillo (Robledo de la Valduerna, 1726)

Zinco paños de ofrecer buenos (Palacios de Jamuz, 1728)

Un paño de manos de lienzo (Alija del Infantado, 1737)

Una chupa y calzón azul de paño fardero (La Bañeza, 1743)

Un mantillín de paño de Segovia con blonda (Grajal de la Ribera, 1806)

Un dengue de paño (Saludes de Castroponce, 1808)

Un zagalexo de paño pardo tiñido (Saludes de Castroponce, 1808)

Una capa para homvre de paño con vueltas (Quintana del Marco, 1820)

Un chaleco de paño fino (La Nora del Río, 1823)

Una levita de paño fino (La Nora del Río, 1823)

Una tercia de paño negro (Castrillo de la Valduerna, 1828)

Una capa de paño color de la lana apolillada (La Bañeza, 1829)

Un paño de afeitar (La Bañeza, 1829)

Un paño de manos que hace a mantel (Quintanilla de Somoza, 1831)

Un paño para oferta pintado (Quintanilla de Somoza, 1831)

Una mesa de manteles de dos varas y un paño blanco con encages (San Feliz, 1838)

Un pantalón de paño viejo (Requejo de la Vega, 1839)

Medio pañuelo de paño de color (Requejo de la Vega, 1839)

Tre manteos de la biuda uno de paño y otro de frisa y otro de estameña (Santibáñez de la Isla, 1844)

Es una voz muy frecuente que aparece en prácticamente todos los inventarios recogidos. En el uso que se hace del término se pueden distinguir dos acepciones siempre dentro del campo semántico textil. Por una parte se utiliza paño para denominar 
un tipo de 'tejido de lana' con el que se hacían prendas de vestir de hombre y mujer de diferente tipo, tanto de busto como pantalones y zagalejos o prendas de cabeza. Además, el término también se utiliza para designar un trozo de tela ya elaborado con un fin concreto, así se habla de "paño de ofrecer", o de "paño de manos".

\section{RATINA}

Sust. f. Tela de lana, entrefina, delgada y con granillo (DRAE). Origen desconocido; en castellano parece ser de origen francés. El fr. ratine se documenta desde 1642, pero ya en el S. XIII aparece una voz rastin como nombre de una clase de lana (DECH, s.v. ratina).

Un capotón de ratina encarnado (Alija del Infantado, 1812)

Un juvón de la misma tela (ratina) (Alija del Infantado, 1812)

Otro dengue de ratina (Quintana del Marco, 1820)

Un dengue de ratina nuebo (Jiménez de Jamuz, 1825)

El término aparece con relativa frecuencia, especialmente si tenemos en cuenta que en el CORDE no se recoge ningún ejemplo. En los casos que aparecen en el corpus estudiado solo se cita la tela sin dar más detalles, a pesar de que había diversos tipos de ratina: apañadas, frisadas, de pelos largos, etc. (DHTT, s.v. ratina); aunque se empleaban para prendas de vestir de mujer, para cortinas y toallas, en el corpus solo se recoge como tejido de ciertas prendas, especialmente de las llamadas de busto. Además, el término ratina utilizado como adjetivo, se documenta en León para designar el pelo de los animales vacunos de pelo gris, semejante al de la rata. Con este uso no se recogen ejemplos, se documentan otros sinónimos como bardino.

\section{SEMPITERNA}

Sust. f. 'Tela de lana, basta y muy tupida, que se usaba para vestidos' (DRAE). Término derivado de siempre, sempiterno, tomado del latín sempütĕrnus (DECH, s.v. siempre).

Un jubón de sempiterna (Coomonte de la Vega, 1719)

Un jubón de sempiterna (Genestacio de la Vega, 1721)

Unos cuerpos de sempiterna (Genestacio de la Vega, 1721)

Otro tapapié de sempiterna (La Bañeza, 1721)

Un justillo de estameña y de sempiterna bordado (Grajal de la Ribera, 1723)

Una basquina azul de sempiterna (Grajal de la Ribera, 1723)

Dos saias de estameña azul y una de paño azul con pasamanos y unos cuerpos de sempiterna (Grajal de la Ribera, 1730)

Unos cuerpos de sempiterna (Miñambres, 1731)

Un jubón de sempiterna azul (Miñambres, 1731)

Un guardapié de sempiterna azul (Alija del Infantado, 1812)

Un mandil de sempiterna nuevo (Quintana del Marco, 1820)

Otro (mandil) de sempiterna (Jiménez de Jamuz, 1825) 
Es un término que aparece con frecuencia en el corpus a partir del S. XVIII, ya que nombra una tela muy popular en esta época que utilizaban las mujeres pobres para vestirse y hacer jubones y guardapiés (DHTT, s.v. sempiterna), aunque como se observa en los ejemplos también se utilizó para mandiles y otras prendas de cintura para arriba como basquinas o cuerpos.

\section{SERAFINA}

Sust. f. 'Tela de lana de un tejido muy semejante a la bayeta, aunque más tupido y abatanado, adornado con variedad de flores y otros dibujos' (DRAE). Término derivado de serafín, del latín bíblico seraphim 'serafines' (DECH, s.v. serafín).

Otra (mantilla) de serafina (Castrocalbón, 1814)

Es el único ejemplo recogido en el corpus, esta escasez no es extraña si se tiene en cuenta que en el CORDE solo se recoge un ejemplo del término que no tiene esta acepción que es la que aparece en el diccionario académico desde la edición de 1780.

\subsubsection{Cáñamo}

\section{CÁÑAMO}

Sust. m. 'Filamento textil de esta planta'. 'Lienzo de cáñamo' (DRAE). Del latín vulgar cannăbum, lat. cannăbis (DECH, s.v. cáñamo).

Un cordel de cáñamo de lino para camas de veynte (Coomonte de la Vega, 1643)

Una quilma de cáñamo (Coomonte de la Vega, 1719)

Un dogal de cáñamo (Palacios de la Valduerna, 1728)

La palabra aparece en el corpus para designar objetos hechos con este tipo de textil. Aunque solo se han recogido estos ejemplos, es un término común tanto en este corpus como en recopilaciones más extensas, como el CORDE, donde son numerosos los ejemplos que aparecen.

\section{CERRón [zerrón]}

Sust. m. 'Lienzo basto que se fabrica en Galicia, y es una especie de estopa algo mejor que la común' (DRAE).

Dosa baras de zerrón a medio curar (Coomonte de la Vega, 1643)

Unos manteles de cerrón ussados (Vidriales, 1645)

Una sábana de cerrón usada (Vidriales, 1645)

Dos zerrones (Palacios de Jamuz, 1728)

Una fardela de zerrón (Palacios de la Valduerna, 1728)

Un camisa de zerrón de muger (Palacios de la Valduerna, 1728) 
El término se utiliza de forma generalizada con el significado aportado por la Academia de 'lienzo'. En la mayoría de los ejemplos aparece junto a una prenda que se especifica que es de cerrón o junto a una unidad de medida utilizada para medir telas, como es el término baras o fardelas. Sin embargo, en varias comarcas del occidente de León, la Cepeda o la Ribera del Órbigo entre otras, el término se utiliza para nombrar a 'la bolsa en la que los pastores llevan la comida' (Le Men, 2004, s.v. cerrón), acepción no incluida en el DRAE. Probablemente, en el ejemplo de Palacios de Jamuz se esté utilizando con esta acepción puesto que habla de un número de cerrones y no de una medida concreta con la que se puedan medir las piezas de tela como en los otros casos. Además, la zona en la que aparece este ejemplo se encuentra en la parte occidental comprendida por el área estudiada. El término no es muy frecuente en el corpus estudiado, pero en cualquier caso, contrasta con la presencia de ejemplos en el CORDE donde solo aparece un caso, teniendo en cuenta que se trata de un corpus mucho más amplio. Este dato quizá pueda explicarse por la proximidad de León con Galicia.

\section{ESTERA}

Sust. f. 'Tejido grueso de esparto, juncos, palma, etc., o formado por varias pleitas cosidas, que sirve para cubrir el suelo de las habitaciones y para otros usos' (DRAE). Del latín storěa, de donde *estuera y luego estera (DECH, s.v. estera).

Una cestica de estera con unas pocas de pepitas de melón (Alija del Infantado, 1644)

Una estera de junco (La Bañeza, 1721)

Una estera grande de cinco paños que servía para la sala principal (Destriana, 1843)

El término estera se emplea con el mismo significado en los dos ejemplos, que coincide con el del diccionario académico, pero el uso que se hace de ellos es distinto. En el primer caso la voz estera remite al material del que está fabricada la cesta, mientras que en el segundo y el tercer caso, aunque tiene la misma acepción, el término aparece nominalizado nombrando así un objeto, una especie de alfombra; o de paño. Además en algunas zonas de León se utiliza la voz estera con el significado de 'tejido de paja para cubrir la colmena y evitar que las abejas piquen al que se acerca a ellas' (Le Men, 2005, s.v. estera). Con este uso no hay ejemplos en el corpus estudiado.

\section{ESTOPA}

Sust. f. 'Parte basta o gruesa del lino o del cáñamo, que queda en el rastrillo cuando se peina y rastrilla'. 'Tela gruesa que se teje y fabrica con la hilaza de la estopa' (DRAE). Término derivado del latín stüppa (DECH, s.v. estopa). 
Una sábana de estopa biexa (Coomonte de la Vega, 1643)

Una pieza de lienzo o estopa (Coomonte de la Vega, 1643)

Dos madexas de lino ylado y seis de estopa (Coomonte de la Vega, 1643)

Dos madejas de estopa (La Bañeza, 1643)

Dos peynes de peynar estopas (Alija del Infantado, 1644)

Un jergón de estopa nuevo (La Bañeza, 1649)

Unos calzoncillos de estopa (Alija del Infantado, 1720)

Nueve madexas, las siete de lino y dos de estopa (Grajal de la Ribera, 1723)

Tres libras de estopa (Fresno, 1726)

Dos sábanas de estopa (Robledo de la Valduerna, 1726)

Beinte y dos libras de estopa cozida en quarenta y quatro (Robledo de la Valduerna, 1726)

Una quilma de estopa (Palacios de la Valduerna, 1728)

Una mosquera de estopa grande (Pobladura del Valle, 1734)

Dos colchones usados con sávanas de estopa (Pobladura del Valle, 1734)

Dos tablas de manteles usados, un cernadero de estopa (Laguna de Negrillos, 1734)

Un rodapié de cama de estopa (Alija del Infantado, 1737)

Un jergón de estopa casera por estrenar (Jiménez de Jamuz, 1825)

Nueve varas de estopa (La Bañeza, 1829)

Dos jergones de estopa (Felechares, 1837)

Un fardel de estopa (Quintana del Marco, 1839)

Unas alforjas biejas de estopa (Quintana del Marco, 1839)

Un gergón usado de estopa (Destriana, 1843)

Es un término muy común en todo el corpus ya que se refiere a un tipo de tela gruesa muy utilizada. El significado más frecuente con el que aparece es el de 'tela gruesa fabricada con la hilaza'. Con esta acepción aparece siempre acompañando a algún sustantivo que designa un tipo de prenda. Con la primera acepción se utilizaría el término en algunos ejemplos como el de Coomonte de la Vega de 1643 o el ejemplo de Robledo de la Valduerna en el que se designa la cantidad de tela a granel y se indica que está cocida para después poder trabajarla.

\section{ESTOPILLA}

Sust. f. 'Parte más fina que la estopa, que queda en el rastrillo al pasar por él por segunda vez el lino o el cáñamo'. 'Tela que se ha fabricado con el hilado de estopilla' (DRAE). Diminutivo de estopa.

Una estopilla fyna (La Bañeza, 1643)

Tres sábanas, las dos de lienço delgado y una de estopilla todas nuebas (La Bañeza, 1649)

Una sábana de estopilla casera (Jiménez de jamuz, 1825)

Beinte y cinco baras y media de estopilla (Alija del Infantado, 1812)

Dos jergones o pageros de estopilla (La Bañeza, 1829)

Es un término que aparece con menos frecuencia que estopa. No obstante, su uso no es escaso si tenemos en cuenta que corpus como el CORDE solo presentan catorce 
casos frente a los siete encontrados en este breve trabajo. El significado con el que se utiliza la voz en todos los ejemplos es el de 'tela fina'.

\section{LIENZO [lienço]}

Sust. m. 'Tela que se fabrica de lino, cáñamo o algodón'. 'Pintura que está sobre lienzo'

(DRAE). Del latín lǐntěum 'tela de lino', 'lienzo' (DECH, s.v. lienzo).

Una toalla de lienço nueba labrada (La Bañeza, 1641)

Dos pares de cuerpos de lienço (La Bañeza, 1641)

Un camisa de hombre de buen lienco nueba (Coomonte de la Vega, 1643)

Otra sábana buena de tres liencos (Coomonte de la Vega, 1643)

Un fardelico de lienco bueno (Coomonte de la Vega, 1643)

Una sábana buena de tres piernas de buen lienzo (Coomonte de la Vega, 1643)

Una camisa biexa de lienzo (Coomonte de la Vega, 1643)

Unos calzoncillos de lienzo ya viexos (Coomonte de la Vega, 1643)

Una colcha de lienço colchada (La Bañeza, 1643)

Una camisa de lienço de muger buena (La Nora del Río, 1645)

Dos almoadas de lienzo con desylados blancos sin lana usados (Alija del Infantado, 1646)

Otra tabla de manteles de dos lienzos de gusanillo buenas (Alija del Infantado, 1646)

Nuebe baras de lienço casero en dos pieças (La Bañeza, 1647)

Unas alforjas de lana de colores con talegos de lienzo (Coomonte de la Vega, 1722)

Un cobertor de tres lienzos de estameña verde con fleco (Grajal de la Ribera, 1723)

Un sayuelo pardo nuevo forrado de lienzo (Fresno, 1726)

Una tela de lienzo (Fresno, 1726)

Dos almillas de lienzo nuebas (Fresno, 1726)

Treinta baras de lienzo gallego ancho (Robledo de la Valduerna, 1726)

Dieziocho baras de lienzo casero ordinario (Robledo de la Valduerna, 1726)

Un lienzo con la pintura de Nuestra Señora de la Soledad (Robledo de la Valduerna, 1726)

Un peinador de lienzo (Pobladura del Valle, 1734)

Una colcha de lienzo pintada (Laguna de Negrillos, 1734)

Una ropilla de frisa sin mangas nueva forrada en lienzo (La Isla, 1735)

Un paño de manos de lienzo (Alija del Infantado, 1737)

Una cuva para lienzo (Grajal de la Ribera, 1750)

Dos corbatas de mursulina y otra de lienzo (Grajal de la Ribera, 1806)

Dos henaguas de lienzo (Grajal de la Ribera, 1806)

Un retazo de lienzo y otro de bayeta (Saludes de Castroponce, 1808)

Nueve baras de lienzo por curar (Alija del Infantado, 1812)

Tres baras de lienzo (Castrocalbón, 1814)

Dos pañuelos de lienzo (Castrocalbón, 1814)

Una almohada de lienzo inglés por estrenar con guarnición (Jiménez de Jamuz, 1825)

Una toca de lienzo ynglés (San Feliz, 1838)

Unas mangas de lienzo (San Feliz, 1838)

Una toca de lienzo delgado (Calzada, 1838)

Dos tigeras con el lienzo roto (Requejo de la Vega, 1839)

Tres pares de calzoncillos de lienzo finos (Destriana, 1843)

Cuatro camisas vuenas de lienzo fino que se hallan en vuen uso (Destriana, 1843)

Es un término muy frecuente y son numerosos los ejemplos que se encuentran

de la palabra, por lo que los reflejados aquí son una muestra. El significado más común 
del término es el de 'tela de lino' de la que estaban confeccionadas diversas prendas de vestir o del hogar y que tenía diferentes calidades, de ahí la especificación "lienzo inglés" que tendría otra calidad o valor. También es posible encontrar el lienzo como pieza de tela. Solo hay un ejemplo en el que el término adquiere el significado de 'cuadro o pitura', pertenece al inventario de Robledo de la Valduerna de 1726, inventario que, por otra parte, tiene cierta riqueza en sus objetos, de ahí que aparezca este significado que no se documenta en el resto de inventarios en los que se ha recogido el término. Formalmente, la voz presenta formas totalmente castellanizadas, no hay ningún caso de palatización de /l/ o de reducción del diptongo, variantes que sí pueden encontrarse en otras zonas de León.

\section{LINO}

Sust. m. 'Materia textil que se saca del tallo de la planta del lino' (DRAE). Del latín lìnum íd. (DECH, s.v. lino).

Nuebe copos de lino maxado (Coomonte de la Vega, 1643)

Un cordel de cañamo de lino para camas de veynte (Coomonte de la Vega, 1643)

Dos madexas de lino ylado y seis de estopa (Coomonte de la Vega, 1643)

Unos manteles de lino buenos (Alija del Infantado, 1644)

Tres ovillos de lino (Vidriales, 1645)

Dos obillos de lino ylado que pesaron media libra poco más o menos (Alija del Infantado, 1647)

Dos manizos de lino (Coomonte de la Vega, 1650)

Cuatro madejas de estopa de lino (Coomonte de la Vega, 1719)

Un poco de lino con unas mazorcas (La Bañeza, 1721)

Catorze pañitos de lino (Genestacio de la Vega, 1721)

Nuebe madexas, las siete de lino y dos de estopa (Grajal de la Ribera, 1723)

Unos calzoncillos de lino (Laguna de Negrillos, 1725)

Quatro madejas de lino (Ribas de la Valduerna, 1726)

Veynte manizos de lino (Ribas de la Valduerna, 1726)

Quatro mañizos de lino (Ribas de la Valduerna, 1726)

Treinta arrobas de lino fabricado (Robledo de la Valduerna, 1726)

Quatro sábanas de lino biejas (Robledo de la Valduerna, 1726)

Diez y seis almoadas de lino biejas (Robledo de la Valduerna, 1726)

Dos arcas de lino (Robledo de la Valduerna, 1726)

Un dogal de lino (Palacios de Jamuz, 1728)

Diez mazorcas de lino (Palacios de Jamuz, 1728)

Una fardela de lino (Palacios de la Valduerna, 1728)

Una rodadera de lino (Palacios de la Valduerna, 1728)

Tres madexas de lino gordo (Miñambres, 1731)

Una sávana de lino (Miñambres, 1731)

Dos manizos de lino (Miñambres, 1731)

Ocho manizos de lino (Priaranza, 1732)

Seis manizos de lino (Castrocalbón, 1814)

Veinte nuebe manizos de lino (La Nora del Río, 1820)

Dos manizos de lino (Jiménez de Jamuz, 1825)

Un par de dogales de lino buenos (Valle de la Valduerna, 1829) 
Ciento cincuenta y cinco mañizos de lino (Valle de la Valduerna, 1829)

Otra tarima de otra cama nueba con cordeles de lino (Valle de la Valduerna, 1829)

Dos colchas de lino blanco (Felechares, 1837)

Ocho manizos de lino (San Feliz, 1838)

Una vara de lino (Requejo de la Vega, 1839)

Un cuello de lino (Requejo de la Vega, 1839)

Un peine de lino (Quintana del Marco, 1839)

Nobenta y dos mañizos de lino (Santibáñez de la Isla, 1844)

La voz es muy común, aunque podemos establecer tres usos distintos de la palabra dentro del conjunto de ejemplos extraídos del corpus. Por un lado, el término aparece con el uso de tipo de paño que se obtiene de esta planta tras un proceso de elaboración, así encontramos sábanas, pañitos, colchas, etc. de lino. Por otra parte, la voz aparece con el uso de tipo de hilo que se extrae de esta planta, se citan madejas, ovillos de lino. Finalmente el término también se usa para designar 'la materia prima previa a la elaboración de cualquier producto textil' y así se citan manizos, varas, copos de lino.

\section{MITÁN}

Sust. m.'Holandilla', 'lienzo para forros de vestidos' (DRAE). El mitán riojano sería una 'media holanda', comp. holandilla. De holán, puesto que se trata de un lienzo fino, quizá sea alteración islán 'especie de velo guarnecido de encajes, con que se cubrían la cabez las mujeres cuando no llevaban manto' (DECH, s.v. holanda).

Un baúl forrado en mitán (La Bañeza, 1721)

Una colcha de seda fondo verde forrada en mitán (La Bañeza, 1829)

Son los únicos ejemplos encontrados, dato que no es extraño puesto que se refiere a un tipo de tela no común y de cierta calidad, se trata de una colcha de seda, material no frecuente en la ropa. Este dato se corresponde con la información del CORDE donde solo se recoge un caso con este significado, no así del término holandilla del que se recoge algún caso más, concretamente siete. En el corpus la voz holandilla no aparece, solo mitán en este ejemplo, que como en otros casos referidos a objetos poco comunes, se registra en La Bañeza, cabeza del partido judicial.

\section{PABILO [pavilo]}

Sust. m. El DRAE localiza en Venezuela la acepción de 'hilo grueso, resistente, poco tramado, hecho de algodón, que se emplea, entre otras cosas, para tejer alpargatas, hamacas o cubrecamas'. Del latín papīlus 'papiro, planta' y este del griego $\pi \dot{x} \pi \nu \lambda o \varsigma$ (DECH, s.v. pabilo). 
Un costal de pabilos nuevo (La Bañeza, 1641)

Seis cabezales de pabilos (La Bañeza, 1643)

Dos costales de pavilos biexos que arán a media carga poco más o menos cada uno (Alija del Infantado, 1647)

Un repostero de pavilos biexo pequeño (Alija del Infantado, 1647)

Un costal de pavilos biexo pequeño (Alija del Infantado, 1647)

Un costal de pavilos muy biexo pequeño (Alija del Infantado, 1647)

Dos ovillos de pavilos que pesarán una libra (Alija del Infantado, 1647)

Ocho libras de pabilos hilados (Ribas de la Valduerna, 1726)

Tres costales de pabilos nuebos (Ribas de la Valduerna, 1726)

Un repostero de pabilos viejo (Palacios de la Valduerna, 1728)

Quatro costales buenos de pavilos (Palacios de la Valduerna, 1728)

Tres costales de pavilos (Palacios de la Valduerna, 1728)

Unas alforjas de pavilos usados (Miñambres, 1729)

Siete costales de pavilos y quatro quilmas (Destriana, 1730)

Diez y ocho libras de pavilos hilado (Destriana, 1825)

Un mantón de pabilos (Valle de la Valduerna, 1829)

Un mantón de pabilos biejo (Quintana del Marco, 1839)

Un mantón de pabilos bueno (Quintana del Marco, 1839)

Es un término común que, aunque tiene otras acepciones, en el corpus se utiliza en todos los casos con el significado de 'cada uno de los hilos gruesos y burdos que, de peor calidad y finura que el resto del hilo de lino, sacados de las estopas, servían para tejer alforjas, reposteros, y demás atuendos bastos' (Le Men, 2009, s.v. pabilo). Con este significado se utiliza la voz pabilo aplicada o bien al hilo sin tejer o bien al producto elaborado con este tipo de hilo que pueden ser reposteros, alforjas, mantones, etc.

PARDO (vid. colores).

\section{PARDILLO}

Adj. vid. pardo

Un ferreruelo de pardillo (La Antigua, 1647)

Otra mantilla de pardillo nueba (Genestacio de la Vega, 1650)

Un manto de pardillo (Fresno, 1726)

Una mantilla de pardillo (Requejo de la Vega, 1735)

Se trata de un término que se utiliza para denominar un tipo de paño, concretamente el Diccionario de Autoridades señala que 'se aplica al paño más tosco, grosero y basto, que se hace del color pardo y sin tinte, de que viste la gente humilde y pobre'.

\section{SOMONTE}

Adj. 'Basto, burdo, áspero, al natural y sin pulimento' (DRAE). Término derivado de monte, del latín mons, montis (DECH, s.v. monte). 
Una capa de paño de somonte (Coomonte de la Vega, 1719)

Unos balones biejos de somonte (Coomonte de la Vega, 1719)

Un jubón de somonte con sus mangas bueno (Huerga de Garaballes, 1720)

Una capa de somonte (Huerga de Garaballes, 1720)

Una ropilla de somonte (Huerga de Garaballes, 1720)

Una montera de somonte buena (Grajal de la Ribera, 1723)

Un sayuelo de somonte (Fresno, 1726)

Una mantilla de somonte (Miñambres, 1727)

Otro (saiuelo) de somonte usado (Palacios de la Valduerna, 1728)

Una capa de somonte buena (Grajal de la Ribera, 1730)

Un saiuelo de somonte (Miñambres, 1731)

Una montera de somonte (La Isla, 1735)

Unos cuerpos de somonte (La Isla, 1735)

Una capa de somonte usada (Laguna de Negrillos, 1740)

Una montera de somonte (Grajal de la Ribera, 1750)

Un manteo negro de somonte (Palacios de la Valduerna, 1831)

Es un término que aparece con frecuencia en el corpus estudiado, siempre precedido de la preposición de, dependiente de un nombre de tejido. En realidad, este sintagma alude al paño de somonte, que significa 'paño burdo, áspero', así aparece definido ya en Autoridades 'dícese del paño basto, burdo, al natural y sin pulimento', que como se observa en los ejemplos se utilizaba para todo tipo de prendas de vestir, ya sean de cintura para arriba, de cintura para abajo, de abrigo o de cabeza; aunque la frecuencia con la que aparece el término en el corpus contrasta con la escasez de casos que se recogen en el CORDE donde únicamente se recogen tres casos y solo en dos de ellos se aplica el adjetivo a un tejido.

\subsubsection{Seda}

\section{CRESPÓN}

Sust. m. 'Gasa en que la urdimbre está más retorcida que la trama' (DRAE). Término derivado de crespo, del latín crǔspus 'rizado, ondulado '(DECH, s.v. crespo).

Un pañuelo de crespón (Requejo de la Vega, 1839)

Dos pedazos de crespón (Requejo de la Vega, 1839)

Son los únicos ejemplos recogidos del término, dato que no es significativo puesto que se trata de un tipo de tejido de cierta calidad que no aparece con frecuencia en estos inventarios. Concretamente el crespón es una 'tela de seda clara, especie de gasa, con ligamento de tafetán, en la cual la urdimbre está más retorcida que la trama, confiriéndole un característico aspecto estriado; se tejía con seda cruda, que se crespaba después de hervida, de donde deriva el nombre de crespón. Había crespón todo de lana, de lana y seda, y totalmente de seda, que es el más común. Se usaba para adorno de 
sombreros de señora y trajes de baile cuando es de colores claros' (DHTT, crespón). El $D R A E$ incorpora el término en la edición de 1780 y la mayoría de los ejemplos que presenta el corpus académico pertenecen al S. XIX, dato que también explicaría la fecha de los ejemplos recogidos en este corpus.

\section{ESPARRAGÓN}

Sust. m. 'Tejido de seda que forma un cordoncillo más doble y fuerte que el de la tercianela' (DRAE).

Un bestido de mujer, ropa, jubón y basquiña de tafetán doble negro guarneçido de esparragón con botones de bidrio (La Bañeza, 1643)

Cuatro cortinas de esparragón de lana encarnadas viejas (La Bañeza, 1829)

Solo se han recogido estos dos ejemplos que presentan diferencias en el significado. El primero nombra un tipo de adorno que responde a la acepción indicada en el DRAE. El segundo caso no se refiere al cordoncillo de seda sino a un tejido antiguo que podía ser de lana, como en el ejemplo, pero también de barragán ordinario o paño de baja calidad que se fabricaba en Inglaterra (DHTT, s.v.esparragón). Es significativo que el CORDE no recoja ningún ejemplo del término, dato que contrasta con los encontrados en este reducido corpus que, sin abundar, al menos se documenta en dos ocasiones, en ambos casos en inventarios pertenecientes a la cabecera del Partido Judicial.

\section{ESPOLINADO}

Adj. m. 'Relativo al espolín'. Espolín es definido por el DRAE como 'tela de seda con flores esparcidas, como las del brocado de oro o de seda'. Espolín es definido por el DRAE como 'tela de seda con flores esparcidas, como las del brocado de oro o de seda'. Tomado del francés e(s)poulin u occitano espoulin canilla de tejedor, diminutivo del occitano antiguo espol íd. y este del gótico *spôla (DECH, s.v. espolín).

Un jubón de raso berde espolinado sin mangas (Robledo de la Valduerna, 1726) Unos cuerpos espolinaos (La Isla, 1829)

Se trata de un adjetivo que aparece en los dos ejemplos con prendas de vestir, lo que probablemente indica que guarda relación, como señala el diccionario académico, con el tipo de tela que se emplea para la prenda, que será una tela de espolín o parecida a este. En el CORDE no se registra ningún ejemplo de este término. Formalmente, es significativo señalar que, aunque se trata de un ejemplo tardío, todavía hay muestras de pérdida de la -d-, espolinaos. 


\section{ESPUMILLA}

Sust. f. 'Tejido muy ligero y delicado, semejante al crespón' (DRAE). Término derivado de espuma, del latín spüma (DECH, s.v. espuma).

Una toca de espumilla buena (Alija del Infantado, 1647)

Un capillo de espumilla (Grajal de la Ribera, 1730)

Son los únicos ejemplos recogidos, el significado es el que recoge el DRAE. Se trata de un tejido que solo se utiliza en el corpus para prendas de cabeza y es una tela de seda, muy delicada que se utilizaba en forma de pañuelos (DHTT, s.v. espumilla).

\section{FILOSEDA}

Sust. f. 'Tela de lana y seda' (DRAE). Término derivado de hilo, del latín fillum (DECH, s.v. hilo).

Un jubón de filoseda (Saludes de Castroponce, 1808)

Es el único ejemplo encontrado ya que se trata de un tipo de tejido que no era común en las prendas de vestir. Abundan otros términos referidos a la tela de los jubones como la estameña tal vez porque se trata de un tejido más económico.

\section{MOER [moher]}

Sust. m. 'Tela fuerte que hace aguas' (DRAE). Muaré, del francés moiré, participio de moirer 'labrar un paño de manera que forme aguas', derivado de moire 'muaré' (DECH, S.v. muaré).

Una basquiña de moher de seda (Alija del Infantado, 1812)

Un juvón de moher negro (Alija del Infantado, 1812)

Son los únicos ejemplos recogidos y pertenecen a un mismo inventario. Esta escasez no es extraña ya que se trata de un tipo de tejido, probablemente de cierta calidad, de origen francés. Eso explica que antes del S. XIX o finales del S. XVIII no se recojan ejemplos porque probablemente no se empezó a utilizar en España hasta esa época. Esta escasez se asemeja a la del CORDE que solo recoge un ejemplo del término de finales del S. XVIII, perteneciente a Ramón de la Cruz. El Diccionario académico recoge el término hasta la edición de 1970 como sinónimo de muaré.

\section{MUSELINA [morsolina, marsolina, mursulina, musulina]}

Sust. f. 'Tela de algodón, seda, lana, etc., fina y poco tupida' (DRAE). Del italiano mussolina, por conducto del francés mousseline, antes mussolino que, a su vez, se tomó del árabe mausîlî' hecho en Mosul, ciudad de Mesopotamia (DECH, s.v. muselina). 
Dos corbatas de mursulina y otra de lienzo (Grajal de la Ribera, 1806)

Una mantilla de mursulina (Grajal de la Ribera, 1806)

Un pañuelo de mursulina (Grajal de la Ribera, 1806)

Otro pañuelo de mursulina transparente (Grajal de la Ribera, 1806)

Una corvata de musulina (Saludes de Castroponce, 1808)

Una toalla de morsolina bordada o guarnecida de encajes (Destriana, 1825)

Dos tocas una de marsolina con encaje y otra de lienzo fino (Jiménez de Jamuz, 1825)

Cuatro cortinas de morsolina con listas encarnadas (Requejo de la Vega, 1839)

Unas enaguas de morsolina con su guarnición (Requejo de la Vega, 1839)

Una toca de morsolina (Destriana, 1843)

Otra tela vuena de dos piernas y media con guarnición de muselina (Destriana, 1843)

Es un término que nos ha llegado a través del francés, hecho que explica que los ejemplos encontrados pertezcan a fechas tardías, son todos del S. XIX, dato que coincide con los abundantes ejemplos que recoge el CORDE, fechados en su mayoría a finales del S. XVIII y durante el S. XIX. El diccionario académico no incorpora el término hasta la edición de 1803. Se trata de un tejido delicado, por lo que es una tela valiosa y no va a abundar en los inventarios. Formalmente, en los ejemplos encontrados el término presenta una gran variabilidad en la alternancia de /o/ / $/$ que, como ocurre con otras voces polisílabas, se explica por la presencia de una vocal palatal /i/ tónica que provoca la inestabilidad en la serie velar (Morala, 2009: 557). Además la mayoría de los ejemplos añaden una $/ \mathrm{r} /$ a la variante normativa, que probablemente se trate de una $/ \mathrm{r}$ / adventicia, epentética.

\section{ORMESÍ}

Sust. m. 'Tela fuerte de seda, muy tupida y prensada, que hace visos y aguas' (DRAE). Voz oriental de origen incierto; quizá del nombre de Ormuz, isla y puerto del Golfo Pérsico, gran factoría de los árabes y los portugueses en su comercio con el Océano Índico (DECH, s.v. ormesî).

Otro (jubón) de ormesí viejo (Robledo de la Valduerna, 1726)

Es el único ejemplo recogido, tal vez porque se trata de una tela de cierta calidad que no aparece, por tanto, en prendas de uso habitual. Esta escasez también se refleja en el CORDE donde no son muchos los ejemplos documentados, aparecen solo nueve, tres de ellos en el mismo documento. El ormesí es una tela parecida al camelote, término que también solo se documenta en un ejemplo del corpus, además la voz ormesí designa una tela antigua que modernamente se conoció con el nombre francés de moaré (DHTT, s.v. ormesí), que se documenta bajo la forma moer, voz que al igual que sus términos sinónimos aparece escasamente en el corpus. 


\section{PICOTE}

Sust. m. 'Cierta tela de seda muy lustrosa con la que se hacían vestidos' (DRAE). Probablemente derivado de picar porque es tan áspera que pica al tocarla (DECH, s.v. picote).

Tres piezas de picotes en seda y lana (La Bañeza, 1643)

Es el único ejemplo recogido en el corpus, tal vez porque se trata de un término que denomina una tela de cierta calidad que no abundaba entre las pertenencias de las personas.

\section{PIÑUELA}

Sust. f. 'Tela o estofa de seda' (DRAE). Término derivado de piña, del latín pīněa (DECH, s.v. pino).

Un saiuelo de piñuela usado (Grajal de la Ribera, 1723)

Es el único ejemplo recogido. La piñuela era un 'tipo de seda que tejían los indígenas de Filipinas con la fibra de la hoja de la piña americana. Se le dio este nombre porque tenía una especie de pequeñas piñas labradas en ella'. (DHTT, s.v. piñuela). Probablemente se trata de un tejido poco común puesto que la mayor parte de las prendas estaban hechas de estameña, paño fino, entre otros tejidos, aunque sí se conoce la existencia de sayuelos de este tejido en el S. XVIII en la zona de San Adrián del Valle.

\section{SEDA}

Sust. f. 'Tejido hecho de seda' (DRAE). De origen incierto. Quizá del latín saeta 'cerda de puerco, de caballo, etc.', 'sedal de pescar', que en la Edad Media debió de aplicarse al hilo de seda, porque entonces este género se importaba en hilo; de ahí pasaría al tejido de seda (DECH, s.v. seda).

Siete piezas de zintas de plata y seda (La Bañeza, 1643)

Nuebe pares de medias de seda de muger (La Bañeza, 1643)

Sendos pares de medias de seda negras de onbre (La Bañeza, 1643)

Una colcha de damasco carmesí con flueco de seda (La Bañeza, 1643)

Dos almoadas labradas con seda negra enfundadas con su lana buenas (Coomonte de la Vega, 1643)

Un ziñidero de seda con una caxica (Alija del Infantado, 1644)

Otro paño de ruan bueno labrado de caparrosa y seda (Coomonte de la Vega, 1645)

Dos ziñidores de seda (Robledo de la Valduerna, 1726)

Un zíngulo de seda encarnada (Robledo de la Valduerna, 1726)

Seis zintas de seda de color (Palacios de la Valduerna, 1728)

Siete pares de escapularios bordados en seda y plata (Grajal de la Ribera, 1806)

Otro pañuelo de seda de colores (Grajal de la Ribera, 1806)

Una basquiña de moher de seda (Alija del Infantado, 1812) 
Una mantilla de sarga negra de seda (Alija del Infantado, 1812)

Un guardapié de seda de colores (Alija del Infantado, 1812)

Un jubón de tela de seda con mangas rizadas (Alija del Infantado, 1812)

Un justillo de seda viexo (Alija del Infantado, 1812)

Una mantilla de tafetán dovlete de seda (Alija del Infantado, 1812)

Un justillo de seda vueno (Alija del Infantado, 1812)

Unas medias de seda (Alija del Infantado, 1812)

Un sayuelo nuevo de paño de Prádanos de boquilla labrado con seda (Jiménez de Jamuz, 1825)

Cinco lazos de cinto, cinco gordones de seda, dos escapularios, una regla de S. Benito y otros dijes (Jiménez de Jamuz, 1825)

Una colcha de seda fondo verde forrada en mitán (La Bañeza, 1829)

Un aderezo de perlas finas vastante usado engarzado con seda (La Bañeza, 1829)

Un pañuelo de seda usado (Quintanila de Somoza, 1831)

Dos carteras de seda (Castrocalbón, 1832)

Una mantilla con blonda de seda (Requejo de la Vega, 1839)

Otro (pañuelo) de seda cruda color de chocolate (Requejo de la Vega, 1839)

Dos pares de zapatos de seda viejos (Requejo de la Vega, 1839)

Otro paño de seda (Requejo de la Vega, 1839)

Un chaleco de seda nuebo (Requejo de la Vega, 1839)

Un bestido de seda (Requejo de la Vega, 1839)

Otro (pañuelo) de seda color de caña (Requejo de la Vega, 1839)

Siete pares de ligas de seda (Requejo de la Vega, 1839)

Cuatro pañuelos de seda de la mano (Requejo de la Vega, 1839)

Otro (justillo) de seda de fondo encarnado (Destriana, 1843)

El término se refiere en todos los casos a la tela que se obtiene de la secreción

del gusano. Se trata de un tipo de tejido de valor. Aunque son muchos los ejemplos recogidos, pertenecen a un escaso número de inventarios, tal vez se trataba de inventarios de cierto nivel económico en los que abundaban las prendas de seda.

\section{TAFETÁN}

Sust. m. 'Tela delgada de seda, muy tupida' (DRAE). Del persa tāftah 'paño de seda', 'vestido de hilo' (DECH, s.v. tafetán).

Un vestido de tafetán (La Bañeza, 1643)

Un tafetán verde (La Bañeza, 1643)

Un bestido de muger, ropa, jubón y basquina de tafetán doble negro guarneçido de esparragón con botones de bidrio (La Bañeza, 1643)

Otras dos almuadas grandes de olanda lavradas de ylo vlanco de cadeneta con su tafetán encarnado (Robledo de la Valduerna, 1726)

Seis cortinas con sus cenefas de tafetán (Robledo de la Valduerna, 1726)

Un ábito largo de tafetán (Robledo de la Valduerna, 1726)

Dos alzaquellos uno de Damasco y otro de tafetán (Robledo de la Valduerna, 1726)

Una bata de Damasco carmesí forrada en tafetán doble (Robledo de la Valduerna, 1726)

Una mantilla de tafetán dovlete de seda (Alija del Infantado, 1812)

Tres baras de tafetán de colores en retazos (Requejo de la Vega, 1839)

Una mantilla de tafetán con guarnición (Castrocalbón, 1833) 
A pesar de tratarse de una tela de valor, se recogen bastantes ejemplos, aunque se observa que pertenecen a los mismos inventarios.

\section{TERCIOPELO [terçiopelo, terziopelo]}

Sust. m. 'Tela de seda velluda y tupida, formada por dos urdimbres y una trama, o la de aspecto muy semejante' (DRAE). Término derivado de tres, del latín trēs (DECH, s.v. tres).

Un calçón y una ropilla de terciopelo (Coomonte de la Vega, 1643)

Una sobremesa de terçiopelo de colores (Coomonte de la Vega, 1643)

Un sayuelo de contray con ribetes de terciopelo (Coomonte de la Vega, 1645)

Unos cuerpos de grana con ribetes de terciopelo (Coomonte de la Vega, 1645)

Dos bufetillos forrados en terciopelo (Robledo de la Valduerna, 1726)

Una casaca de terziopelo negra, chupa y calzón de lo mismo (Robledo de la Valduerna, 1726)

Una casaca bieja de terziopelo (La Bañeza, 1754)

Una mantilla de franela con cinta y terciopelo nueba (Alija del Infantado, 1812)

Una capote con los voros de terziopelo (La Nora del Río, 1823)

Una mantilla negra de Segovia buena con cinta ancha de terciopelo (Jiménez de Jamuz, 1825)

Un sayuelo de el mismo paño con bueltas de terciopelo (Destriana, 1825)

Una montera negra con terciopelo (Castrillo de la Valduerna, 1828)

Un justillo de terciopelo (Castrocalbón, 1832)

Tres varas de terciopelo en tira (Requejo de la Vega, 1839)

Un vestido de la boda compuesto de manteo negro con terciopelo, jubón, mantilla y mandil (Destriana, 1870)

El terciopelo era una tela muy común que aparece como adorno en muchas prendas de vestir, fundamentalmente mantillas, justillos, como lo reflejan los ejemplos, pero también en otras prendas de las que no se recogen ejemplos, como los manteos que solían tener, especialmente los domingueros, una cinta de terciopelo alrededor que le servía de adorno. La presencia o no de este adorno encarecía la prenda, por ello siempre se reseñaba en el inventario ya que su valor no era el mismo.

\subsubsection{Técnicas}

\section{AFELPADA}

Adj. derivado de felpa 'tejido de seda, algodón, etc., que tiene tejido por el haz' (DRAE).Término derivado de felpa.

Una colcha afelpada de hilaza buena (Alija del Infantado, 1812)

Una colcha de ylaza afelpada (La Nora del Río, 1823)

Dos rodapinas afelpadas vien usadas (La Bañeza, 1829)

Una colcha afelpada usada (La Bañeza, 1829)

Una colcha de lana verde afelpada (Felechares, 1837) 
El adjetivo se utiliza para caracterizar a aquellas prendas que contienen tela de felpa.

\section{AMANTELADO}

Sust. m. 'Tejido, algunas veces de algodón' (DHTT, s.v. amantelado). Del francés antiguo mantel manto se tomó el castellano mantel como término heráldico, de donde mantelado (DECH, s.v. manto).

Ocho varas de amantelado ordinario (La Bañeza, 1829)

Es el único ejemplo recogido del término que se define en el DHTT, como tejido algunas veces de algodón mencionado en las telas vallisoletanas de 1780-1850. Este dato puede explicar la escasez de ejemplos en este corpus, no es un término común y aparece en un inventario completo en el que se encuentran objetos de cierta distinción y pertenece a esa franja de años. El carácter singular del término se refleja también en que no aparece recogido en el DRAE ni en el NTLLE, ni se recogen casos en el CORDE, aunque es posible encontrarlo en alguna documentación anterior.

\section{BORDADO/A}

Adj. m. y f. 'Participio del verbo bordar' (DRAE). De un aforma germánica como *bruzdôn, emparentada con el alemán antiguo gaprortôn, cambiado en brordar, se redujo a bordar y a sus variantes (DECH, s.v. bordar).

Un mantón de Baeza verde bordado de blanco y encarnado (La Bañeza, 1721)

Un justillo de estameña y de sempiterna bordado (Grajal de la Ribera, 1723)

Una cofia bordada (Toral, 1728)

Siete pares de escapularios bordados en seda y plata (Grajal de la Ribera, 1806)

Un rocadero bordado (Grajal de la Ribera, 1806)

El término se usa con el significado común de 'adornado con bordadura'. En el corpus se recogen otros adjetivos que pueden parecer sinónimos pero que tienen diferencias en su uso. El adjetivo bordado presenta muchos rasgos en común con el adjetivo labrado/a siendo este quizá más usual, especialmente en el S. XVII. Se recoge también el adjetivo guarnecido, que en algún caso se presenta como sinónimo coordinando ambos términos en el ejemplo «una toalla de morsolina bordada o guarnecida de encajes», aunque el uso de este término es el de adornada en general ya sea con bordadura o con otro tipo de adorno. 


\section{LABRADO/A}

Adj. m. y f. 'Dicho de una tela o de un género que tiene alguna labor' (DRAE). Término derivado de laborare 'trabajar', de labor, -ōris (DECH, s.v.labor).

Una toalla de lienço nueba labrada (La Bañeza, 1641)

Dos almoadas labradas con seda negras enfundadas con su lana buenas (Coomonte de la Vega, 1643)

Un paño labrado de cilestre y caparrosa (Alija del Infantado, 1644)

Un mandil camorano con listas, un cuerpo de camisa con sus mangas labradas de blanco (Coomonte de la Vega, 1645)

Un paño de manos de ruan labrado (Coomonte de la Vega, 1645)

Otro paño de de ruan bueno labrado de caparrosa y seda (Coomonte de la Vega, 1645)

Una toalla labrada de caparrosa y zilestre (Alija del Infantado, 1646)

Dos almuadas de olanda labradas de seda coloradas buenas (La Bañeza, 1647)

Tres pares de almuadas de lienço labradas de ylo açul y otro par de almuadas la una labrada de amarillo, la otra de azul (La Bañeza, 1647)

Dos paños de manos labrados de amarillo con sus puntas (La Bañeza, 1647)

Una alvanega de lienzo labrada con seda vuena (Huerga de Garaballes, 1720)

Un paño de manos labrado (Genestacio, 1721)

Beinte y dos libras de plata labrada (Robledo de la Valduerna, 1726)

Un paño de manos labrado (Miñambres, 1729)

Una tualla de lienzo labrada (Santiago Millas, 1735)

Un sayuelo nuevo de paño de prádanos de boquilla labrado con seda (Jiménez de Jamuz, 1825)

Seis vasos grandes de cristal labrados (Destriana, 1843)

Diez basos labrados de cristal (Requejo de la Vega, 1839)

Es un término muy frecuente y son muchos los ejemplos recogidos. El significado general de la palabra coincide con el que da el diccionario académico pero quizá es preciso hacer alguna matización. Castañeda señala que la voz se aplica a multitud de obras de tela, madera, piel, etc. con el significado de 'hecha a mano' (Castañeda, 2003: 231). Esta podría ser la acepción que aparece en los últimos ejemplos y en algún otro en los que el término acompaña a un objeto textil, por ejemplo un "paño de manos labrado". Sin embargo, en muchos de los casos recogidos, no hay duda de que la voz labrado/a es sinónimo de bordado/a puesto que se especifica el tipo o color del hilo con el que se hace la labor, siendo este término más frecuente especialmente en el S. XVII.

\section{BROCADO}

Adj. m. 'Dicho de una tela entretejida con oro o plata' (DRAE). Probablemente del italiano broccato (DECH, s.v. brocado).

Dos varas de brocado (Requejo de la Vega, 1839)

Solo se ha encontrado este ejemplo en el que aparece la tela a granel ya que forma parte de la relación de objetos recogidos en una tienda. Originariamente el 
término tenía el significado que aparece en el diccionario académico, sin embargo, a mediados del siglo XIX se llamaba brocado a 'todo tejido de tela sola, raso y aún tafetán, con tal que estuviese adornado de flores u otras figuras, usándose solamente por las altas dignidades eclesiásticas o la Corte' (DHTT, s.v. brocado), por tanto en este ejemplo podría estar utilizándose con esta acepción.

\section{CAPARROSA}

Sust. f. 'Nombre común a varios sulfatos nativos de cobre, hierro o cinc' (DRAE). Palabra de origen incierto, probablemente del árabe *qubrûsi 'vitriolo de Chipre', por la fama del cobre en esta isla (DECH, s.v. caparrosa).

Un paño labrado de cilestre y caparrosa (Alija del Infantado, 1644)

Otro paño de ruan bueno labrado de caparrosa y seda (Coomonte de la Vega, 1645)

Una toalla labrada de caparrosa y zilestre (Alija del Infantado, 1646)

Otras dos toallas de caparrosa y zilestre de cosa de bara y media de largo cada una (Alija del Infantado, 1646)

Como ocurre con el término anterior, la voz caparrosa remite a un color que, teniendo en cuenta el significado del término, probablemente se trate de un color verdoso.

\section{CELESTRE [cilestre, zilestre]}

Sust. m. 'Baño o calda que se daba a los paños' (DRAE). Del latín caelĕstis (DECH, s.v. cielo).

Un paño labrado de cilestre y caparrosa (Alija del Infantado, 1644)

Una toalla labrada de caparrosa y zilestre (Alija del Infantado, 1646)

Otras dos toallas de caparrosa y zilestre de cosa de bara y media de largo cada una (Alija del Infantado, 1646)

El término cilestre designa un tejido de lana teñido de azul (Martínez Meléndez, 1989: 64), y al menos con el significado de 'azul' es con el que se emplea en estos ejemplos recogidos, pertenecientes todos ellos al S. XVII puesto que, como señala el $D A$, en el S. XVIII se registra como palabra antigua, quizá sustituida por la voz celeste que después no aparece en el corpus. Formalmente en todos los casos se recoge la forma con /i/, vacilación que es frecuente en gran número de palabras.

\section{FILIGRANA [feligrana]}

Sust. f. 'Obra formada de hilos de oro y plata, unidos y soldados con mucha perfección y delicadeza' (DRAE). Tomado del italiano filigrana, compuesto con grano que en italiano 
se emplea como término de orfebrería para pequeñas partículas de metales ( $D E C H$, s.v. hilo)

Cuatro docenas botones feligrana (Requejo de la Vega, 1839)

Un corazón de feligrana (Saludes de Castroponce, 1808)

Es un término poco común en el corpus. Este dato no es extraño ya que, como ha ocurrido con otros términos semejantes, se trata de una obra hecha con hilos de oro, característica que le imprime al objeto cierto valor crematístico inalcanzable para muchas personas. Formalmente, la voz siempre aparece bajo la variante feligrana. Esta alternancia es frecuente en palabras en las que la /e/ /i/ átonas están en un contexto en el que hay otra vocal /i/ produciéndose normalmente un fenómeno de disimilación de /i-i-/ en /e-i-/ (Morala, 2012a: 562).

\section{FLECO [flueco]}

Sust. m. 'Adorno compuesto de una serie de hilos o cordoncillos colgantes de una tira de tela o de pasamanería' (DRAE). Del anticuado flueco, descendiente semiculto de del latín flŏccus (DECH, s.v. fleco).

Una colcha de damasco carmesí con flueco de seda (La Bañeza, 1643)

Un cobertor de tres lienzos de estameña verde con fleco (Grajal de la Ribera, 1723)

Un cobertor de estameña azul con fleco de dos lienzos (Grajal de la Ribera, 1723)

Un cobertor de estameña azul con su fleco (Laguna de Negrillos, 1734)

Es un término común que aparece en el corpus con el significado que da el DRAE. Formalmente, el ejemplo del S. XVII, presenta la variante diptongada.

\section{GALÓN}

Sust. m. 'Tejido fuerte y estrecho, a manera de cinta, que sirve para guarnecer vestidos u otras cosas' (DRAE). Del francés galon íd., derivado del francés antiguo galonner 'adornar la cabeza con cintas' (DECH, s.v. galón).

Unas enaguas de bayeta con galón (La Bañeza, 1643)

Unos cuerpos de raso encarnado con galones buenos (Grajal de la Ribera, 1723)

Un jubón de ante con galones de plata (Robledo de la Valduerna, 1726)

Cinco varas de galón (Grajal de la Ribera, 1806)

Una mantilla de bayeta negra con galón (Alija del Infantado, 1812)

Es un término de uso general que fundamentalmente aparece con prendas de vestir ya que se trata de un tipo de 'cinta de adorno' que añade a la prenda cierto valor. 


\section{GARAPIÑA}

Sust. f. 'Galón adornado en uno de sus bordes con ondas de realce' (DRAE). Término derivado de garapiñar, procedente de un latín vulgar * carpiniare, derivado de carpěre (DECH, s.v. garapiñar).

Un guardapiés de estameña azul con garapiñas (La Bañeza, 1714)

Una mantilla redonda negra con su garapiña (Miñambres, 1729)

Solo se han registrado estos dos ejemplos pertenecientes al S. XVIII. A pesar de la escasez de casos del término, la muestra es significativa si se compara con corpus como el CORDE donde solo hay un caso, fechado en el S. XVI, en el que la voz tenga este significado. Las primeras ediciones del DRAE definen la palabra como 'un género de galón negro que se usaba antiguamente en semicírculos' y a partir de la edición de 1899 lo define como 'galón adornado'. El contexto en el que aparecen los ejemplos permite concluir que se trata de un elemento de adorno que lleva la prenda en cuestión, por tanto, el término tendría el significado que da el DRAE en sus últimas ediciones.

\section{GUSANILLO}

Sust. m. ' Cierto género de labor menuda que se hace en los tejidos de lienzo y otras telas' (DRAE). Término derivado de gusano, de etimología incierta, quizá prerromano (DECH, s.v. gusano).

Una mesa de manteles de gusanillo biexos y rotos (Coomonte de la Vega, 1643)

Una tabla de manteles de gusanillo de cosa de dos baras de largo buenos (Alija del Infantado, 1646)

Otra tabla de manteles de dos lienzos de gusanillo buenos (Alija del Infantado, 1646)

Quatro servilletas de gusanillo pequeñas buenas (Alija del Infantado, 1646)

Seis servilletas de gusanillo nuebas (La Bañeza, 1647)

Dos tablas de manteles de gusanillo (La Bañeza, 1647)

Dos tavlas de manteles de gusanillo (La Bañeza, 1649)

Seis servilletas de gusanillo nuevas (La Bañeza, 1649)

Una colcha de gusanillo con encajes alrededor (La Bañeza, 1714)

Una tabla de manteles de gusanillo de tres varas de largo y dos lienzos (La Bañeza, 1714)

Más otros (manteles) de gusanillo más gordos de vara y media (La Bañeza, 1714)

Seys servilletas de gusanillo (Coomonte de la Vega, 1719)

Unas servilletas de gusanillo ussadas pequeñas (Huerga de Garaballes, 1720)

Unos manteles de gusanillo de tres varas de largo (Laguna de Negrillos, 1721)

Quatro docenas de servilletas de gusanillo buenas (Robledo de la Valduerna, 1726)

Doze paños de manos de gusanillo (Robledo de la Valduerna, 1726)

Una tabla de manteles de gusanillo (Robledo de la Valduerna, 1726)

Treinta y nuebe baras de gusanillo en pieza (Robledo de la Valduerna, 1726)

Dos sábanas y una colcha de gusanillo (Laguna de Negrillos, 1734)

Dos manteles de gusanillo (Alija del Infantado, 1737)

Unos manteles de gusanillo (Genestacio de la Vega, 1738)

Una tabla de manteles grandes y finos de gusanillo muy usados (Destriana, 1843) 
Como se aprecia en los ejemplos, es un término que aparece con mucha frecuencia en los inventarios para designar un tipo de lienzo con una determinada labor denominada gusanillo, de larga duración que se emplea fundamentalmente en ropa de casa, especialmente de mesa, manteles y servilletas pero también en colchas, sábanas y paños. El DRAE recoge el término desde 1734 hasta la edición actual con esta acepción.

\section{HILAZA [ylaza]}

Sust. f. 'Contextura o tejido' (DRAE). Término derivado de hilo, del latín fïlum (DECH, s.v. hilo).

Zinco libras de ylaza (La Bañeza, 1721)

Diez y ocho libras de ylaza casera (Robledo de la Valduerna, 1726)

Veinte y quatro libras de ylaza cosida en obillos (Palacios de la Valduerna, 1728)

Onze libras de ylaza que está a media cura (La Bañeza, 1758)

Una colcha afelpada de hilaza buena (Alija del Infantado, 1812)

Dos obillos de ylaza (Requejo de la Vega, 1735)

Una colcha de ylaza felpada (La Nora del Río, 1823)

El término se utiliza con el significado de 'hilo grueso que resulta de hilar el lino' (Miguélez, 1998:155). La voz aparece en el corpus bien de forma aislada o bien relacionada con otro objeto fabricado con este tipo de hilo. No se ha recogido ningún ejemplo del término bajo la forma filaza, forma propia del leonés con conservación de /f-/. Probablemente, el hecho de que se trate de un término del campo semántico del textil conlleva una mayor influencia del castellano, de ahí que ya aparezca bajo la forma hilaza.

\section{PASAMANOS}

Sust. m. 'Género de galón o trencilla, cordones, borlas, flecos y demás adornos de oro, plata, seda, algodón o lana, que se hace y sirve para guarnecer y adornar los vestidos y otras cosas' (DRAE). Término compuesto de pasar y mano, con el significado de 'especie de galón' tomado del francés passement (DECH, s.v. paso).

Un jubón de estameña con pasamanos (La Bañeza, 1641)

Un capote de pardo biexo con sus pasamanos (Coomonte de la Vega, 1643)

Un rebociño con tres pasamanos de oro (Coomonte de la Vega, 1643)

Unos balones con pasamanos de estameña (Coomonte de la Vega, 1645)

Unos cuerpos con pasamanos (La Antigua, 1648)

Un guardapié de paño encarnado con tres vueltas de pasamanos (Palacios de la Valduerna, 1730)

Unos cuerpos encarnados con pasamanos (Requejo de la Vega, 1735)

Un mandil con pasamanos (Requejo de la Vega, 1735) 
Es un término común que en el corpus solamente se utiliza con el significado de 'galón que sirve para adornar prendas de vestir'. En algunos casos incluso se especifica el tipo de tela de la que está hecha el galón, ya que es un dato importante para fijar el valor de la prenda. Además de esta acepción, el término tiene el significado de 'barandilla', que también aparece en el DRAE y, aplicado al carro, el significado de 'listón de madera que se coloca sobre el sardo y se apoya sobre los estadonjos' (Le Men 2009, s.v. pasamanos) no registrado en el diccionario académico. Con estas dos acepciones no se han recogido ejemplos en el corpus estudiado.

\section{PUNTAS}

Sust. f. El DRAE define el término en la $20^{\text {a }}$ acepción como 'encaje que forma ondas o puntas en una de sus orillas'. Del latín tardío pŭncta 'estocada', propiamente, participio de pŭngĕre 'punzar' (DECH, s.v. punta).

Otra camisa de honbre con puntas (Coomonte de la Vega, 1643)

Quatro tocas con puntas (Coomonte de la Vega, 1643)

Un paño de manos con puntas (Coomonte de la Vega, 1643)

Una balona de puntas buena (Alija del Infantado, 1644)

Otras dos toallas de caparrosaizilestre de cosa de bara y media de largo cada una que la una dellas tiene puntas de lo mismo todo alrededor, la otra tiene unos desylados que anbas son buenas (Alija del Infantado, 1646)

Dos paños de manos labrados de amarillo con sus puntas (La Bañeza, 1647)

Tres valonas con sus puntas grandes finas y dos pares de vueltas de lo mismo y unas orexeras leonadas y una volsilla dorada (La Bañeza, 1649)

Dos pares de calconzillos de lienzo delgado con sus puntas (La Bañeza, 1649)

Una valona con sus vueltas de los caños de Carmona con sus puntas (La Bañeza, 1649)

Una tualla con sus puntas (Alija del Infantado, 1720)

Una sávana de lienzo de tres puntas (Laguna de Negrillos, 1721)

Otra de lienzo con sus puntas de dos baras de largo (Laguna de Negrillos, 1721)

Un encubridor de tafetán encarnado con sus puntas de ylo (Laguna de Negrillos, 1721)

Otra tualla de lienzo con sus puntas (Laguna de Negrillos, 1721)

Una mesa de manteles con sus listas a las puntas (Quintanilla de Somoza, 1831)

Es un término frecuente en el corpus. Se trata de un tipo de encaje concreto que se caracteriza por el tipo de remate. El DHTT define el término como 'encaje muy angosto hecho en puntas, ondas o picos, que se suele añadir y coser a la orilla de otro encaje ancho, y sirve para adornar en el borde pañuelos, toallas y vestidos, etc. Originariamente denominado randa, y posteriormente puntilla por terminar en puntas' (DHTT, s.v. puntas). 


\section{RANDA}

Sust. f. 'Guarnición de encaje con que se adornan los vestidos, la ropa blanca y otras cosas' (DRAE). De origen incierto, probablemente del céltico randa. Al parecer pasó de de lengua de Oc, por el catalán al castellano y de ahí al portugués (DECH, s.v.randa).

Una almoada buena con su lana con randa blanca (Coomonte de la Vega, 1643)

Otro paño de ofrecer de cosa de una bara con randa blanca (Alija del Infantado, 1646)

El término randa es sinónimo de encaje, concretamente se llama randa al 'adorno de encaje para ropas y lencería de cama'. En el DHTT se señala que fue el primer nombre que se le dio al encaje cuyo origen se encuentra en el sajón rand (borde) y designaba los calados hechos a la aguja con que antiguamente se unían las piezas de una tela, cuando la randa se hizo independiente de la tela y se tenía que encajar, pasó a llamarse encaje (DHTT, s.v. randa); por ello los ejemplos del término pertenecen a inventarios del S. XVII y posteriormente el término que aparece es encaje.

\section{VARETA [bareta]}

Sust. f. 'Lista de color diferente del fondo de un tejido' (DRAE). Derivado de vara, del latín vara (DECH, s.v. vara).

Seis cortinas de bareta encarnada biejas con sus cenefas (Robledo de la Valduerna, 1726)

Dos capotillos de bareta blanca (La Bañeza, 1754)

Solo se han recogido estos dos ejemplos del término que, aunque parece nombrar un tipo de tela, se trata sin embargo de una técnica puesto que hace referencia a las tiras que aparecen sobre un tejido de diferente color que el fondo. En el corpus se documenta el término vareta, que es el que recoge el DRAE. Sin embargo, el CorLexIn siempre recoge el adjetivo vareteado o su variante bareteado que localiza en inventarios del centro y sur peninsular y un caso en un inventario de Colombia. El DHTT también recoge el término vareteado en lugar de vareta y lo define como 'lo que está tejido a listas de diversos colores diferentes al fondo del tejido' (DHTT, s.v. vareteado).

\subsubsection{Otros}

\section{ALFILETERO}

Sust. m. 'Especie de canuto pequeño de metal, madera u otra materia, que sirve para tener en él alfileres y agujas' (DRAE). Derivado de alfiler del ár. hilâl 'astilla aguda empleada para prender unas con otras las piezas de vestir' (DECH. s.v. alfiler). 
Un alfiletero de azero (Robledo de la Valduerna, 1726)

Un alfiletero de metal (Grajal de la Ribera, 1806)

Aunque los ejemplos son escasos, los dos casos no son anteriores al S. XVIII, dato que concuerda con los recogidos en el CORDE, que datan la gran mayoría de los siglos XIX y XX. El término alfiletero no aparece en el diccionario académico hasta 1780, aunque J. Corominas y J.A. Pascual fechan su primera documentación en 1620. En cualquier caso, del S. XVII no se ha recogido ni un solo ejemplo. Por otra parte, algunos autores como Le Men señalan que es frecuente en León encontrar el término bajo la forma alfilitero (Le Men, 2002, s.v. alfiletero), sin embargo, los ejemplos que aquí aparecen no presentan en ningún caso vacilación y aparecen bajo la forma normativa.

\section{ARGADILLO}

Sust. m. El DRAE da como $1^{\text {a }}$ acepción del término 'devanadera'. Procede del latín vulgar *ergatellus, diminutivo del latín ergăta, 'cabrestante' (DECH, s.v. argadillo).

Un argadillo con su pie (Coomonte de la Vega, 1645)

Un argadillo (La Antigua, 1648)

Un argadillo (Palacios de la Valduerna, 1728)

Un argadillo y una devanadera (Destriana, 1730)

Un pie de argadillo con sus alas (La Bañeza, 1758)

La voz aparece recogida solo en los SS. XVII y XVIII, no hay ejemplos del S. XIX. Este dato coincide con las muestras recogidas en el CORDE ya que con el significado de 'devanadera' aparece en los SS. XVI y XVII, mientras que los ejemplos que allí se recogen del S. XIX, emplean el término mayoritariamente con un uso metafórico: "el tejemaneje de las manos, que parecían un argadillo" (1888, José María de Pereda).

\section{ASPA [naspa, naspador]}

Sust m. y f. El DRAE en su $2^{\text {a }}$ acepción define el término como 'instrumento que sirve para aspar el hilo y que por lo regular se compone de un palo y de otros dos menos gruesos atravesados en los extremos de aquel con dirección opuesta entre sí'. Término procedente del gót. *haspa ( $D E C H$, s.v. aspa). La voz aparece a lo largo de todo el corpus estudiado.

Una naspa con un poco de ylado fino (Coomonte de la Vega, 1650)

Una aspa con sus alas (Coomonte de la Vega 1650)

Una naspa de rueda (Coomonte de la Vega, 1719)

Una naspa (Requejo de la Vega, 1735)

Un aspa (La Bañeza, 1735)

Un naspador (Quintanilla de Somoza, 1831) 
Una naspa buena (Santibáñez de la Isla, 1844)

Es una palabra de uso general en el CORDE donde siempre aparece recogida bajo la forma aspa. En los ejemplos analizados, excepto en dos casos, siempre aparece la voz naspa, hay un ejemplo en el que se recoge la forma naspador, que no he encontrado documentada en otros corpus, pero que probablemente está refiriéndose al mismo objeto que se define como una 'devanadera', concretamente Miguélez señala que "sobre dos soportes se apoya un cuerpo que gira a impulsos de un mango que se le coloca en uno de los extremos. El cuerpo lleva cruzados dos palos en forma de aspa sobre los que se apoya la madeja. Seguramente, se ha tomado la parte por el todo y se ha dado el nombre de naspa ('aspa') a todo el aparato"' (Miguélez, 1998: 165).

\section{DEVANADERA [devanador]}

Sust. f. 'Armazón de cañas o de listones de madera cruzados, que gira alrededor de un eje vertical y fijo en un pie, para que, colocadas en aquel las madejas del hilado, puedan devanarse con tranquilidad' (DRAE). Término derivado de devanar, del latín vulgar *depanare, del latín panus 'hilo de trama puesto en la devanadera' (DECH, s.v. devanar).

Un pie de devanadera (Alija del Infantado, 1644)

Una devanadera (Coomonte de la Vega, 1719)

Un devanador (Miñambres, 1731)

Un argadillo y una devanadera (Destriana, 1730)

Se han localizado estos ejemplos de los cuales uno presenta la forma devanador que el DRAE define de forma distinta. Para devanadera da la acepción de 'armazón sobre el que devana la madeja', mientras que para devanador da la de 'alma de cartón, madera, etc., sobre la que se devana el hilo', aunque parece ser más frecuente en todas las épocas la voz devanadera, como se refleja en este corpus, es probable que no solo se trate de confusión entre sufijos sino que puedan referirse a objetos distintos (Morala, 2012d: 350). No obstante, los casos recogidos en este corpus reflejan una vez más que el uso de devanadera es mayor que el de devanador que tiene un uso muy localizado ya que por ejemplo atendiendo a los casos del CorLexIn solo se recoge en Cáceres y Ciudad Real.

\section{DEVANAR}

Verb. 'Ir dando vueltas sucesivas a un hilo, alambre, cuerda, etc., alrededor de un eje, carrete, etc.' (DRAE). Del latín vulgar *depanare, del latín panus 'hilo de trama puesto en la devanadera' (DECH, s.v. devanar). 
La devanadera se utilizaba para devanar, es decir, 'formar un cadejo con el hilo, de lino o de lana, ya hilado, mediante el argadío o utilizando los brazos horizontales de otra persona' (Rivas, 1996: 92).

\section{ESPADAR}

Verb. 'Macerar y quebrantar con la espadilla el lino o el cáñamo para sacarle el tamo y poderlo hilar' (DRAE). Término derivado de espada (DECH, s.v. espada).

Una fitera de espadar (Alija del Infantado, 1647)

$\mathrm{Su}$ significado es el que aparece en el diccionario académico.

\section{ESPADILLA}

Sust. f. 'Instrumento de madera, a modo de machete, que se usa para espadar'. (DRAE). Término derivado de espada (DECH, s.v. espada).

Una fitera con su espadilla (Fresno, 1726)

Dos fiteras y una espadilla (Castrocalbón, 1814)

Una espadilla (Palacios de la Valduerna, 1831)

Son pocos los ejemplos, aunque es una voz conocida en toda la zona ya que aparece en los vocabularios dialectales (Rivas, 1996: 117; Descosido, 1993: 178). Este dato se ve corroborado por la presencia del término en el CORDE, ya que de setenta y cuatro casos que aparecen del término, solamente dos están utilizados con esta acepción. Se trata de dos ejemplos del S. XVII pertenecientes a Sebastián de Covarrubias y Gonzalo Correas. En este corpus, mucho menor, también aparecen dos casos, que tienen este significado ya que en el primero el propio contexto lo determina y en el segundo la relación de objetos con la que aparece (naspa, dogal, alforjas), es decir, objetos relacionados con la tareas agrícolas y ganaderas; lleva a concluir que puede tener también este significado.

\section{FITERA}

Sust. f. "Tabla vertical de alrededor de un metro, que por un extremo se encaja en un madero y en el otro, afilado, se coloca el puñado de lino para espadarlo' (Le Men, 2005, s.v. fitera). Tal vez relacionado con fito, del latín arcaico y vulgar fictus, participio pasivo de figĕre clavar (DECH, s.v. hito).

Una fitera de madera buena (Alija del Infantado, 1644)

Una fitera de espadar (Alija del Infantado, 1647)

Una fitera con su espadilla (Fresno, 1726)

Dos fiteras y una espadilla (Castrocalbón, 1814) 
Una fitera y un escodillon de madera (San Feliz, 1838)

Tres fiteras (Calzada, 1838)

Es una voz que no recoge el DRAE. En el corpus solo aparece el término bajo la forma fitera, no se registran casos de fitero, ni bajo la forma diptongada, variantes que sí se recogen en León. Se trata tal vez de un occidentalismo ya que solo se ha documentado en la zona occidental de la Península. Este dato explicaría que se trate del único término en el que siempre se conserva la /f-/ latina frente a lo que ocurre en otros casos en los que, aunque haya algún ejemplo aislado, suelen mantener la solución castellana.

\section{FUSA}

Sust. f. Se trata de un término derivado de fuso, no lo recoge el DRAE.

Tres fusas (Calzada, 1838)

Solo se ha recogido este ejemplo perteneciente a la zona de la Valdería. Su significado es el de 'objeto de madera alargado en el que se enrolla el hilo a medida que se va sacando la lana de la rueca. Huso'. (Rivas, 1996: 129). Se trata de un término documentado en el occidente de León, por lo que en otros corpus como el CORDE no se recogen ejemplos del término. Como en el caso anterior, no se recogen ejemplos con la variante castellana husa y aparece siempre con el mantenimiento de la /f-/ latina, rasgo propio del leonés.

\section{FUSO}

Sust. m. El DRAE recoge el término como huso, con la notación de antiguo. Define el término como 'instrumento manual, generalmente de madera, de forma redondeada, más largo que grueso, que va adelgazándose desde el medio hacia las dos puntas, y sirve para hilar torciendo la hebra y devanando en él lo hilado'. Del latín fūsus íd. (DECH, s.v. huso).

Un torno biejo con su fuso (Quintanilla de Somoza, 1831)

Un torno con su fuso (Quintanilla de Somoza, 1831)

Solo se han recogido estos dos ejemplos que pertenecen al mismo inventario. El fuso aparece como parte del torno. Este dato nos permite concluir que, de las diferentes acepciones que el término tiene en León, en estos ejemplos se utiliza la palabra con el significado de 'parte del torno que retuerce la lana haciendo el hilo' (Le Men, 2005, s.v. fuso). No se recogen tampoco ejemplos bajo otras variantes gráficas como huso. 


\section{HILO [ylo]}

Sust. m. 'Hebra larga y delgada de una materia textil, especialmente la que se usa para coser' (DRAE). Del latín fillum (DECH, s.v. hilo).

Seis pares de calcetas de $y l o$ de pana (La Bañeza, 1643)

Sendos pares de calzeta finas de ylo (La Bañeza, 1643)

Media libra de ylo gallego (La Bañeza, 1721)

Nuebe libras y media de ilo calzetero (Robledo de la Valduerna, 1726)

Unos obillicos de ylo (La Bañeza, 1754)

Un quarterón de ylo blanco (Grajal de la Ribera, 1806)

Dos livras de hilo blanco (Alija del Infantado, 1812)

Dos manteles viejos con un poco de ylo blanco (Castrocalbón, 1814)

Seis libras de hilo gallego calcetero (La Bañeza, 1829)

Tres cuarterones hilo negro de Cordova (Requejo de la Vega, 1839)

Dos onzas hilo blanco (Requejo de la Vega, 1839)

El término tiene el significado que da el DRAE y que es el actual. En el corpus, la voz aparece bien para indicar el material con el que está fabricada otra prenda, bien como un elemento aislado en el que se especifica la cantidad de hilo concreta.

\section{MADEJA [madexa]}

Sust. f. 'Hilo recogido sobre un torno o aspadera, para que luego se pueda devanar fácilmente' (DRAE). Del latín mataxa 'hilo', 'seda cruda', que en todas las lenguas romances ha tomado el mismo sentido que en castellano (DECH, s.v. madeja).

Dos madejas de estopa (La Bañeza, 1641)

Doce madexas de lino ylado y seis de estopa (Coomonte de la Vega, 1643)

Cuatro madejas de estopa de lino (Coomonte de la Vega, 1719)

Nuebe madexas, las siete de lino y dos de estopa (Grajal de la Ribera, 1723)

Quatro madejas de lino (Ribas de la Valduerna, 1726)

Una madeja de estopa cruda (Fresno, 1726)

Tres madejas de lino (Palacios de Jamuz, 1728)

Tres madexas de lino gordo (Miñambres, 1731)

Dos madejas de lana azul y blanca (Saludes de Castroponce, 1808)

Dos madejas de lino (Alija del Infantado, 1812)

Una madeja de ylaza (La Nora del Río, 1823)

Es un término común que se utiliza con el significado que da el DRAE y, como se observa en los ejemplos, lo más frecuente es encontrar madejas de lino o de estopa, por ser materiales textiles comunes en la época. Formalmente, la variante normativa alterna con la forma madexa, que como ocurre en otras palabras, se trata de una alternancia habitual de las grafías “j”, "x" para el sonido /x/.

\section{MANIZO [mañizo]}

Sust. m. 'Haz de hierba, de paja o de lino'. 'Ganado amontonado' (Le Men, 2007, s.v. mañiza). Del latín *manicium 'manojo' (DEEH, s.v. *manicium). 
Dos manizos de lino (Coomonte de la Vega, 1650)

Quatro mañizos de lino (Fresno, 1726)

Comanizos de lino (Requejo de la Vega, 1735)

Dos manizos de lino (Miñambres, 1731)

Ocho manizos de lino (Priaranza, 1732)

Seis manizos de lino (Castrocalbón, 1814)

Veinte y nuebe manizos de lino (La Nora del Río, 1820)

Dos manizos de lino (Jiménez de Jamuz, 1825)

Cincuenta y cinco mañizos de lino (Valle de la Valduerna, 1829)

Setenta y tres mañizos de lino (Palacios de la Valduerna, 1831)

Ocho manizos de lino (San Feliz, 1838)

Nobenta y dos mañizos de lino (Santibáñez de la Isla, 1844)

Se trata de una voz conocida y documentada en toda la zona noroccidental, aunque no recogida por el DRAE ni por corpus como el CORDE. En algunos vocabularios de la zona se define como 'haz, atado con bilortos, de cualquier tipo de leña para quemar o de hierba seca recogida para darle de comer a los animales durante el invierno. Si el haz es de lino, es mayor que la maña, consta de varias majaduras, a las que ya se le ha sacado la linaza y se han enriado' (Rivas, 1996: 154). 'Haz de lino una vez que ha sido desbagada'. El significado genérico con el que se utiliza el término es el de 'manojo', y en los ejemplos concretos siempre son de lino, como aparece especificado en todos ellos. Formalmente, alternan las formas manizos, mañizos, siendo esta última más frecuente en la zona más occidental del ámbito comprendido en el corpus, aunque este hecho puede combinarse con una confusión meramente gráfica de $n / \tilde{n}$, bastante común en esta época.

\section{MAZORCA}

Sust. f. 'Porción de lino o lana ya hilada y recogida en el huso' (DRAE). Término de origen incierto (DECH, s.v. mazorca).

Un poco de lino con unas mazorcas (La Bañeza, 1721)

Diez mazorcas de lino (Palacios de Jamuz, 1728)

Aunque con este nombre también se conoce a la 'espiga del maíz', es evidente que en los ejemplos recogidos, por sus referencias al lino, tiene el significado de 'lino hilado y recogido en el huso'. Además la voz maíz es de entrada tardía, a la que se le aplica el término mazorca por la forma.

NASPA (vid. aspa) 


\section{OVILLO [obillo]}

Sust. m. 'Bola o lío que se forma devanando hilo de lino, algodón, seda, lana, etc.' (DRAE). Del antiguo luviello. Este procede del latín globellum, diminutivo de globus 'bola', 'amontonamiento', 'grupo de gente' (que en vulgar se confundió con glomus 'ovillo', 'bola') (DECH, s.v. ovillo).

Dos obillos pequeños de lana blanca (Alija del Infantado, 1644)

Dos obillos de lana blanca (La Nora del Río, 1645)

Tres ovillos de lino (Vidriales, 1645)

Dos obillos de lino ylado que pesaron media libra poco más o menos (Alija del Infantado, 1647)

Dos ovillos de pavilos que pesarán una libra (Alija del Infantado, 1647)

Veinte y quatro libras de ylaza cosida en obillos (Palacios de la Valduerna, 1728)

Dos obillos de ylaza (Requejo de la Vega, 1735)

Unos obillicos de ylo (La Bañeza, 1754)

Un ovillito de ilo fino (La Bañeza, 1829)

Se trata de una voz de uso general cuyo uso en el corpus no añade datos significativos.

\section{PEINE [peyne]}

Sust. m. 'Utensilio de madera, marfil, concha u otra materia, provisto de dientes muy juntos, con el cual se desenreda y compone el pelo' (DRAE). Término derivado del latín pĕctĭne (DECH, s.v. peine).

Unos peynes (Castrocalbón, 1643)

Dos peynes de peynar estopas (Alija del Infantado, 1644)

Un peine de cubrir un ras y una rastra (Coomonte de la Vega, 1719)

Unos peines (Santiago Millas, 1735)

Sus peines de texer (Grajal de la Ribera, 1750)

Un peine de teger lino (La Bañeza, 1758)

Un peine de lino (Quintana del Marco, 1839)

Un peine de lana (Quintana del Marco, 1839)

Es un término que está utilizado con diferentes significados. En el ejemplo de Grajal de la Ribera, el significado es el de 'aparato del telar que aprieta el hilo al tejer', puesto que el objeto que aparece en el inventario inmediatamente antes son dos telares. En la mayoría del resto de casos, designa un objeto que sirve para desenredar, pero no exactamente el pelo, sino materiales textiles como el lino o la lana. En los dos casos en los que no se da más información puede estar refiriéndose a este tipo de peine o al destinado a componer el pelo. 


\section{TELAR}

Sust. m. 'Máquina para tejer' (DRAE). Término derivado de tela, del latín têla (DECH, s.v. palma).

Dos telares (Grajal de la Ribera, 1730)

Un telar (La Bañeza, 1758)

Un telar de tejer lienzo con sus tenpleros de madera con yerro a las puntas (San Feliz, 1838)

En los tres casos el término tiene el significado que recoge el DRAE como primera acepción. Los dos primeros ejemplos no especifican más, a diferencia del tercero en el que se indica el uso específico. Este hecho permitiría interpretar la palabra telares en el primer ejemplo, usada en plural, con el significado dado en León a este término a las cosas sin importancia, los trastos. Sin embargo, el hecho de aparecer en una relación de bienes en la que además le precede «un torno de hacer canillas» y le siguen los «peines del telar», permite fijar con exactitud el significado de 'máquina de tejer'.

\section{TORNO}

Sust. m. 'Máquina que por medio de una rueda, cigüeña, etc., hace que algo dé vueltas sobre sí mismo, como las que sirven para hilar, torcer seda, devanar, hacer obras de alfarería, etc.' (DRAE). Del latín tornus, y este del griego tórnos 'torno, instrumento de torneador o tornero' (DECH, s.v. torno).

Un torno de torcer ylo con su pie (Coomonte de la Vega, 1645)

Un torno de azer canillas (Grajal de la Ribera, 1730)

Dos tornos con sus aparejos (Santiago Millas, 1735)

Un torno (La Bañeza, 1758)

Un torno biejo con sus fuso (Quintanilla de Somoza, 1831)

Se trata de un término polisémico cuyo significado general es el de 'máquina que gira alrededor de un eje'. Los ejemplos que recoge el corpus nos indican, por el contexto, que se trata de una maquinaria utilizada para trabajar con el hilo en tareas artesanales, es decir, un tipo de hiladoras. El ejemplo de Santiago Millas es el que puede ofrecer más dudas, aunque en la relación de bienes, los objetos que aparecen inmediatamente antes, son prendas de vestir y un bufete. El contexto lleva, por tanto, a pensar que se trata de un torno de hilo. 


\section{URDIDOR}

Sust. m. 'Devanadera, urdidera' (DRAE). Término derivado de urdir, del latín ordiri (DECH, s.v. urdir).

Un clabetero y un urdidor (La Bañeza, 1754)

Se trata de un instrumento textil que el DRAE define como sinónimo de devanadera. Es probable y este hecho explicaría su uso minoritario ya que es el único caso recogido, pero su escasa frecuencia es general en los inventarios no solo de esta zona (Morala, 2012d: 349).

\subsection{ANIMALES}

Los animales constituian, junto a la agricultura, la base de la economía en esta zona. Servían no solo como medio para obtener productos de alimentación, sino también como herramienta de trabajo para las tareas agrícolas. Los términos que aquí aparecen se agrupan por grupos de ganado (vacuno, caballar, porcino, etc.). Al final, se recogen las voces que no nombran especies de animales, sino cualidades o características de estos.

\subsubsection{Ganado vacuno}

\section{BUEY [buei, vuey]}

Sust. m. El DRAE define el término como 'macho vacuno castrado'. Término procedente del lat. bōs, bŏvis (DECH, s.v. buey).

Un buey color negro (Coomonte de la Vega, 1645)

Un buey fosco de ocho años poco más o menos (Coomonte de la Vega, 1650)

Un buey de labranza pardo (Genestacio de la Vega, 1650)

Dos vueies el uno castaño (Laguna de Negrillos, 1721)

Un buei negro pequeño (Grajal de la Ribera, 1723)

Un buey gacho pardo (Palacios de la Valduerna, 1727)

Dos bueies negros (Palacios de Jamuz, 1728)

Un buei color rojo (Palacios de la Valduerna, 1730)

Un buei fosco (Requejo de la Vega, 1735)

Un buey de labranza (Alija del Infantado, 1737)

Un vuey castaño (Valle de la Valduerna, 1829)

Un buey de color morao de siete años (Santibáñez de la Isla, 1844)

Es frecuente que aparezca bajo la variante actual, buey, aunque se pueden apreciar bastantes casos con la forma buei, frecuente en León. Los ejemplos que se han encontrado con esta variante se registran fundamentalmente en la zona más occidental. Sin embargo, cuando la palabra está en plural, no aparece con la forma frecuente del 
leonés bueis, sino bueies. A diferencia de otros términos, la vacilación entre la oclusiva bilabial y la fricativa es escasa, tan solo aparece en dos de los ejemplos mostrados.

El término aparece referido con algún tipo de especificación, normalmente se documenta haciendo referencia al color y a la edad del animal.

\section{BECERRO [vecerro]}

Sust. m. 'Cría macho de la vaca hasta que cumple uno o dos años o poco más' (DRAE). Término de origen ibér., probablemente del hispanolat. ibex, -̌̌cis 'rebeco' (DECH, s.v. becerro).

Un vecerro afoscado de dos años y va a tres (Alija del Infantado, 1644)

Otro becerro sanguino y bragado (Alija del Infantado, 1644)

Un becerro sanguino de dos años que ba a tres (Alija del Infantado, 1647)

Un becerro (Miñambres, 1727)

Dos sillas forradas de vecerro (Quintanilla de Somoza, 1831)

Aunque se trata de un animal común en la zona, no son demasiados los ejemplos encontrados, ya que en el corpus estudiado esta palabra alterna con su sinónimo jato/a. Rivas señala que el jato es un animal de menor edad (Rivas, 1996:143). Sin embargo, aparecen ejemplos de este término con un uso idéntico al de becerro: «Un jato color rojo de cuatro años», entre otros.

\section{JATO/A [xato/a]}

Sust. m. y f. 'Becerro o ternero' (DRAE). Término de origen incierto (DECH, s.v. choto).

Un xato fosco que va a un año (Alija del Infantado, 1644)

Un xatico blanquezino de un año y ba a dos (Alija del Infantado, 1647)

Una xata color fosco de un año (Coomonte de la Vega, 1650)

Una jata de dos años (Laguna de Negrillos, 1721)

Un jato color rojo de quatro años (Laguna de Negrillos, 1722)

Un jato de un año color sanguino (La Nora del Río, 1724)

Una baca roja con un jato (Palacios de Jamuz, 1728)

Un jato negro de dos años (Palacios de la Valduerna, 1728)

Un jato de un año (Destriana, 1730)

Una vaca con un jato al pie (Genestacio de la Vega, 1734)

Una jata de un año (Pobladura del Valle, 1734)

Un xato zerril (Santiago Millas, 1735)

Un jato de dos años (Castrocalbón, 1814)

Una jata lechuza (Calzada, 1838)

Una jata de un año (Santibáñez de la Isla, 1844)

Es un término común que mantiene la diferencia de significado que da el DRAE.

Se denomina jato al ternero, son frecuentes los ejemplos en los que se dice "un jato de un año”, expresión que a veces en el corpus alterna con ternero: «Un xato fosco que va a un año/ un ternero de un año fosco (Alija del Infantado)»; o también encontramos 
ejemplos en los que se indica «una vaca con un jato al pie», lo que indica que se trata de un animal de corta edad. Además, encontramos ejemplos en los que la edad del animal es superior y, por tanto, ya no estaríamos hablando de un jato o de un becerro, sino de un animal de más edad que podríamos definir como 'macho reproductor'. Esta variedad significativa ha estado presente en los diccionarios académicos donde hasta la edición de 1925 se define como 'becerro', a partir de esta fecha se sustituye por 'ternero' y a partir de 1970 el diccionario da la acepción que se mantiene hasta hoy. Formalmente alternan las variantes jato/xato, en el S. XVII es más frecuente la voz xato y posteriormente abunda jato quedando algún ejemplo de xato, fundamentalmente en la zona más occidental del territorio comprendido en este estudio.

\section{MAGÜETO [magueto]}

Sust. m. 'Novillo, res vacuna de dos a tres años' (DRAE). Término de origen desconocido, probablemente prerromano (DECH, s.v. magüeto).

Seis bueies de azada buenos y un magueto de tres años y un xato de dos años (Bercianos, 1648)

Es el único ejemplo recogido, usado en este ejemplo como sustantivo con el significado de 'novillo' en este caso de tres años. Es una voz que se localiza en la zona noroccidental y no tiene un carácter general, de ahí quizá su escaso uso. El tramo de edad al que se suele referir el término es el que va de dos a cuatros años (Morala, 2010: 269), en este caso lo sitúa en tres años frente al jato que aparece en el mismo ejemplo con la edad de dos años.

\section{NOVILLO/A [nobillo/a]}

Sust. m. y f. 'Res vacuna de dos o tres años, en especial cuando no está domada' (DRAE).

Término derivado de nuevo, del latín nŏvus,-a,-um (DECH, s.v. nuevo).

Un nobillo negro (Genestacio de la Vega, 1721)

Un nobillo rojo (Genestacio de la Vega, 1721)

Un novillo negro de tres años (La Nora del Río, 1724)

Un novillo de tres años (Ribas de la Valduerna, 1726)

Un nobillo de dos a tres años negro (Fresno, 1726)

Un par de novillos el uno negro y el otro rojo (Viñas, 1726)

Otra novilla roja (Viñas, 1726)

Otra novilla parda (Viñas, 1726)

Un nobillo rojo de zinco a seis años (Miñambres, 1727)

Otro nobillo moreno de zinco años (Miñambres, 1727)

Una nobilla fosca (Miñambres, 1727)

Una nobilla parda de tres años (Miñambres, 1727)

Un nobillo bragado de zinco años (Palacios de la Valduerna, 1728) 
Una nobilla de dos años bragada (Palacios de la Valduerna, 1728)

Un novillo (Miñambres, 1731)

Un nobillo de dos a tres años (Coomonte de la Vega, 1734)

Otro novillo pelo castaño (Valle de la Valduerna, 1829)

Un nobillo color morado (Santibáñez de la Isla, 1844)

En algunos vocabularios dialectales se define el término como 'res vacuna mayor que el choto y menor que el buey o toro' o en el caso de novilla 'res vacuna de más de dos años y que no ha parido todavía por primera vez' y en el caso de novillo 'toro semental' (Le Men, 2007, s.v. novillo). Teniendo en cuenta los ejemplos encontrados en el corpus, es posible afirmar que el término no está utilizado con la acepción del DRAE ya que aparecen bastantes casos en los que el animal tiene más de tres años. A diferencia de otros términos, referidos al ganado vacuno, en los que sí hay un criterio de edad más ajustado, como en el caso de becerro que aparece siempre en torno a dos, tres años o el de magüeto, que vendría a ser un sinónimo de becerro menos frecuente; en el caso de novillo los ejemplos muestran una franja de edades que va desde los dos a seis años. Este dato permite suponer que el término no se utiliza para denominar una etapa determinada del desarrollo del animal, sino más bien para designar al semental, en el caso del macho o a la res que aún no ha parido en el caso de la hembra.

\section{TERNERO/A}

Sust. m. y f. 'Cría de la vaca' (DRAE). Término derivado de tierno, del latín těner, -ěra, ĕrum (DECH, s.v. tierno).

Una baca de leche con un ternero (Urdiales del Páramo, 1645)

Un ternero de un año fosco (Alija del Infantado, 1646)

Una vaca color blanquilla con un ternero al pie (La Antigua, 1647)

Una baca negra con su ternera de cuatro años (Huerga de Garaballes, 1720)

Una vaca con un ternero (Genestacio de la Vega, 1721)

Una baca parda con su ternero (Fresno, 1726)

Una baca fosca con su ternera roja (Palacios de la Valduerna, 1728)

Una vaca negra con un ternero (Coomonte de la Vega, 1738)

Es un término frecuente que se utiliza para designar al animal de corta edad, aunque con este significado también se utiliza la voz jato/a, quizá más frecuente que ternero o becerro. En todos los términos encontramos ejemplos que abarcan un período de edad de cero a cuatro años, por lo que, al menos en la mayoría de los casos, se utilizan como voces sinónimas con predominio del término jato/a, en primer lugar y de ternero/a en segundo lugar. En León, se documenta fundamentalmente en zona de montaña, pero también hay casos en el sur, la voz tenral que con un origen común, 
tendría el mismo referente (Morala, 2010: 264). Este término no se ha recogido en el corpus.

\section{VACA [baca]}

Sust. f. 'Hembra del toro' (DRAE). Del latín vacca (DECH, s.v.vaca).

Una baca negra bragada de cinco años (Alija del Infantado, 1644)

Otra baca sanguina bragada (Alija del Infantado, 1644)

Una baca color fosca (Coomonte de la Vega, 1645)

Una baca de leche con un ternero (Urdiales del Pámo, 1645)

Unos zuecos de baca a medio serbir (Alija del Infantado, 1647)

Un baca de tres años negra buena (Alija del Infantado, 1647)

Dos bacas y las dos están paridas tienen cada una su xato (Bercianos del Páramo, 1648)

Una vaca vardina preñada de hedad de seis años (Huerga de Garaballes, 1720)

Una baca negra con su ternera de cuatro años (Huerga de Garaballes, 1720)

Una baca sanguina de tres años (La Nora del Río, 1724)

Una vaca calzona de quatro años (La Nora del Río, 1724)

Una vaca negra preñada (Genestacio de la Vega, 1738)

Una vaca con un jato al pie (Genestacio de la Vega, 1738)

Una baca castaña de nuebe a diez años (Grajal de la Ribera, 1750)

Una baca de quatro para cinco años (Castrocalbón, 1814)

Otra (vaca) con su ternero (Castrocalbón, 1814)

Una baca colorada con una cría (La Nora del Río, 1820)

Una vaca pelo castaño (Valle de la Valduerna, 1829)

Una baca roja (Palacios de la Valduerna, 1831)

Una baca morada (Palacios de la Valduerna, 1831)

Una baca color morada (Santibáñez de la Isla, 1844)

Es un término común que abunda en los inventarios ya que se trata de un animal básico para la economía doméstica de la época. Las referencias más frecuentes son las que se refieren al color del pelo y a la edad del animal; o al estado, referencias a si está preñada o recién preñada, etc.

\subsubsection{Ganado equino}

\section{BURRO [burra]}

Sust. m. y f. 'Asno' (DRAE). Término derivado de borrico, regresivo de la pronunciación vulgar burrico, y este del lat. tardío bŭrricus 'caballo pequeño' (DECH, s.v, borrico).

Una burra parda viexa (Coomonte de la Vega, 1645)

Una burra blanca preñada de tres o cuatro años (Alija del Infantado, 1646)

Término de uso general cuyo significado es el que aparece en el diccionario académico. 


\section{MACHO}

Sust. m. El DRAE lo define, entre otras acepciones, como sinónimo de mulo. Del lat. mascŭlus íd., propte. Diminutivo de mas, maris, de igual significado (DECH, s.v. macho).

Un macho color pardo con sus adreços (La Bañeza, 1643)

Dos machos buenos (Bercianos del Páramo, 1648)

Un macho cría de dicha yegua (Palacios de la Valduerna, 1728)

Tres machos de Avelvia (Santiago Millas, 1735)

Quatro pieles de macho cabrío (Destriana, 1730)

Un macho de cría burreño (Toralino, 1734)

Aunque la voz macho tiene muchos significados que no tienen que ver con referencias a un animal, en estos ejemplos, siempre se usa con el significado de 'animal hermano de la mula', a excepción del ejemplo de Destriana donde aparece el término macho cabrío, para referirse al 'cabrón'. En el resto de casos se refiere al animal equino, que se utilizaba para las labores agrícolas, y en algún caso especifica si es cría de burra o de yegua. Sí se registra la voz mula en femenino, pero no en masculino ya que siempre se recoge macho. A este respecto, señala Marcos Álvarez que la mayor influencia del macho puede ser por influjo del portugués ya que antes del S. XVII había un escaso empleo de macho frente a mulo (Marcos Álvarez, 1987: 891).

\section{MULA}

Sust. f. 'Hija de asno y yegua o de caballo y burra. Es casi siempre estéril' (DRAE). Del latín mūla (DECH, s.v. mulo).

Una yegua con su cría mula (Miñambres, 1729)

Una mula moína de doze años (Laguna de Negrillos, 1734)

Son los dos únicos ejemplos recogidos, aunque se trata de un término de uso general, incluso señala Marcos Álvarez que en la zona de Badajoz se prefería la hembra al macho por su mayor docilidad (Marcos Álvarez, 1987: 890). Se desconoce cuál era la preferencia en esta zona, pero en el corpus se constata mayor presencia del macho frente a la mula en las pertenencias de los propietarios de estos inventarios.

\section{MULAR}

Adj. m. y f. 'Perteneciente o relativo al mulo o a la mula' (DRAE). Término derivado de mula.

Un vocado mular con su cavezada (La Bañeza, 1829) 


\section{POLLINO/A}

Sust.m. y f. 'Asno joven y cerril'. 'Asno' (DRAE). De püllus (DECH, s.v. pollo).

Una pollina rubia buena (La Nora del Río, 1645)

Un pollino (Vidriales, 1645)

Una pollina buena de quatro años (Laguna de Negrillos, 1721)

Una pollina color parda (Laguna de Negrillos, 1722)

Una pollina negra preñada (Grajal de la Ribera, 1723)

Una pollina negra de ocho años (Palacios de la Valduerna, 1728)

Una pollina blanca vieja (Palacios de la Valduerna, 1728)

Una pollina pequeña (Grajal de la Ribera, 1730)

Una pollina de carga con sus aparejos (Destriana, 1730)

Una pollina (Genestacio de la Vega, 1734)

Una pollina negra (Pobladura del Valle, 1734)

Un pollino (Santiago Millas, 1735)

Una pollinita pequeña color parda (Laguna de Negrillos, 1740)

Una pollina parda de siete a ocho años (Grajal de la Ribera, 1750)

Una pollina de pelo negro con sus aparejos (Valle de la Valduerna, 1829)

Un pollino con su albarda (Quintanilla de Somoza, 1831)

Una pollina negra (Santibáñez de la Isla, 1844)

Los términos pollina y burra, se podría señalar, que alternan en el corpus como sinónimos, aunque aparece con más frecuencia el término pollina. Morala señala que probablemente la elección de estos términos, junto a otros sinónimos que no se recogen en este corpus, obedezca a razones estilísticas (Morala, 2010: 276). En cualquier caso, como se observa en los ejemplos, no obedece a razones de edad del animal ni a razones geográficas, ya que la voz burra aparece en la zona próxima a Zamora o en esta provincia, pero también aparece pollina (ejemplo de Genestacio o Pobladura del Valle, entre otros).

\section{POTRO/A}

Sust. f. 'Caballo o yegua desde que nace hasta que muda los dientes de leche, que, generalmente, es a los cuatro años y medio de edad'. 'Máquina de madera que sirve para sujetar los caballos cuando se resisten a dejarse herrar o curar'. (DRAE). Palabra de origen incierto (DECH, s.v. potro).

Una potra color castaña cardona de siete u ocho meses poco más o menos (Coomonte de la Vega, 1643)

Una potra negra de dos años (Coomonte de la Vega, 1645)

Un potro castaño de dos a tres años (Fresno, 1726)

Es un término común que mantiene el significado general. Como se refleja en los ejemplos el término suele aparecer en los inventarios con las referencias al color y a la edad concreta del animal. 
Además se recoge un ejemplo del término con la acepción de 'máquina de madera que sirve para sujetar a los animales', ya que, aunque se trata de un término polisémico, el hecho de que aparezca en la relación al lado de otros objetos que pertenecen al campo semántico de la caballería, hace suponer esta acepción para el término en el siguiente ejemplo:

Un potro de madera con sus pies (Destriana, 1843)

\section{YEGUA [iegua]}

Sust. f. 'Hembra del caballo' (DRAE). Del latín ěqua, femenino de equus 'caballo' (DECH, s.v. yegua).

Una yegua negra cardona (Coomonte de la Vega, 1643)

Una yegua castaña biexa (Alija del Infantado, 1644)

Una yegua castaña oscura preñada (Coomonte de la Vega, 1650)

Una yegua blanca preñada biexa (Huerga de Garaballes, 1720)

Una yegua negra zerrada (Huerga de Garaballes, 1720)

Otra yegua negra de siete años (Huerga de Garaballes, 1720)

Una yegua blanca viexa (Huerga de Garaballes, 1720)

Una yegua cardina de quatro años (Huerga de Garaballes, 1720)

Una yegua color parda de siete a ocho años (Laguna de Negrillos, 1722)

Otra yegua color castaña tuerta de un ojo (Laguna de Negrillos, 1722)

Una yegua grande vieja (Palacios de la Valduerna, 1726)

Una yegua vieja roja (Miñambres, 1727)

Una yegua castaña preñada (Palacios de la Valduerna, 1727)

Una yegua cardiña (La Bañeza, 1743)

Una iegua color negra de diez y ocho años (Laguna de Negrillos, 1734)

Es un término común que aparece con frecuencia ya que era uno de los animales básicos en la economía doméstica. Normalmente cuando aparecen en las relaciones de inventarios se refleja la edad y el color del pelo. Si tiene alguna otra característica digna de mencionar, también se señala.

\subsubsection{Ganado porcino}

\section{CERDO/A [zerdo/a]}

Sust. m.y f. 'Mamífero artiodáctilo del grupo de los Suidos, que se cría en domesticidad para aprovechar su cuerpo en la alimentación humana y en otros usos' (DRAE). Derivado de cerda 'cada uno de los pelos duros y gruesos de ciertos animales, como el caballo y el cerdo'. Del latín vulgar črra 'vellón', 'mechón de pelos'. El término cerdo es una creación eufemística resultado de abreviar la expresión ganado de cerda, con el objeto de reemplazar a puerco, y a sus sucedáneos marrano y cochino, cuando estas se 
hicieron palabras de mal tono (DECH, s.v. cerda).

Una marrana con dos cerdicos (Huerga de Garaballes, 1720)

Una zerda de ofrecer (Coomonte de la Vega, 1724)

Tres zerdas de ceba y seis de cría (Robledo de la Valduerna, 1726)

Un zerdo de cría (Viñas, 1726)

Otra zerda de cría (Viñas, 1726)

Dos zerdas de ceba (Palacios de la Valduerna, 1728)

Tres zerdos pequeños (Coomonte de la Vega, 1734)

Un zerdo mediano (Grajal de la Ribera, 1750)

Un zerdo (Miñambres, 1731)

Dos cerdos (Castrillo de la Valduerna, 1828)

Un cerdo de lechón (Jiménez de Jamuz, 1825)

Se trata de un término común. No se registran casos que pertenezcan al S.XVII, pero se debe más bien a una casualidad ya que es un término también usado en esta época. Es frecuente que se señale el fin del animal, es decir, si era para cebar o para criar.

\section{LECHÓN/A}

Sust. m. y f. 'Cochinillo que todavía mama' (DRAE). El diccionario académico da como $2^{\mathrm{a}}$ acepción del término la siguiente 'puerco macho de cualquier tiempo'. Voz derivada de leche, del lat. lac, lactis (DECH, s.v. leche).

Tres lechones y una lechona pequeña (La Bañeza, 1641)

Un tozino de lechón salado curado (Coomonte de la Vega, 1643)

Dos tozinos de lechón nuebos salados y enteros (Coomonte de la Vega, 1643)

Un lechón blanco de cosa de diez meses poco más o menos (Coomonte de la Vega, 1643)

Una lechona buena cebada (Coomonte de la Vega, 1645)

Una lechona y un lechón medianos (Coomonte de la Vega, 1645)

Un lechón (Vidriales, 1645)

Una lechona grande buena recién parida con dos lechones mamones pequeños (Alija del Infantado, 1646)

Una lechona mediana que tendrá seis o siete meses (Alija del Infantado, 1647)

Un lechoncico pequeño (La Antigua, 1647)

Un espinazo de lechón salado (Coomonte de la Vega, 1650)

Un lechón mediano de siete u ocho meses (Genestacio de la Vega, 1650)

Una lechona del mismo tamaño (Genestacio de la Vega, 1650)

Un cerdo lechón (Jiménez de Jamuz, 1825)

Es un término muy utilizado, aunque la mayoría de los ejemplos se sitúan en la Ribera del Órbigo, al sur de León o norte de la provincia de Zamora. El significado general con el que se utiliza el término es el de 'cerdo de poco tiempo', significado que da el DRAE en su $1^{\text {a }}$ acepción. Sin embargo, el diccionario académico a partir del S. XIX señala que esta palabra también designa al animal grande pero macho. En el corpus aparece la voz designando a un animal grande pero hembra, ejemplo de Alija del 
Infantado de 1646. En general, el término lechón aparece en los documentos como voz genérica para nombrar al cerdo macho o hembra, independientemente de su edad.

\section{MARRANO/A}

Sust. m. y f. El DRAE en su $6^{\mathrm{a}}$ y $7^{\mathrm{a}}$ acepción lo define como 'cerdo'. Marrano en el sentido de 'cerdo' viene del árabe máhrán 'cosa prohibida', que alude a dicha prohibición (DECH, s.v. marrano).

Una marrana (Coomonte de la Vega, 1719)

Una marrana con dos cerdicos (Huerga de Garaballes, 1720)

Un marrano pequeño (Laguna de Negrillos, 1721)

Un marrano de cría (Grajal de la Ribera, 1723)

Una marrana parda (Fresno, 1726)

Un marranico mamón (Fresno, 1726)

Una marrana mamona (Fresno, 1726)

Dos marranas de zeva la una preñada (Miñambres, 1727)

Una marrana de zebar (Palacios de la Valduerna, 1728)

Un marrano de zeba mediano (Palacios de la Valduerna, 1728)

Una marrana de zeba (Palacios de la Valduerna, 1728)

Tres marranas de cría (Palacios de la Valduerna, 1728)

Una marrana (Coomonte de la Vega, 1734)

Una marrana buena (Laguna de Negrillos, 1734)

Dos marranos de zeba (Santiago Millas, 1735)

Una marrana grande (Alija del Infantado, 1737)

Una marrana mediana (Alija del Infantado, 1737)

Una marrana mediana (Genestacio de la Vega, 1738)

Una marrana mediana para matar (Laguna de Negrillos, 1740)

Una marrana mediana (Castrocalbón, 1814)

Una marrana mediana (Santibáñez de la Isla, 1844)

Es otro de los términos que aparecen en el corpus para designar al animal porcino, aunque se trata de una voz que tiene otras acepciones, en ningún caso se emplea en el corpus con otro significado distinto del de 'cerdo'. Es el término que más aparece y designa tanto al animal pequeño como al adulto. A pesar de ser una palabra muy frecuente, los ejemplos se sitúan todos a partir del S. XVIII, aunque es un término ya documentado anteriormente con este significado. Si se observan los ejemplos, se aprecia que es frecuente encontrar junto al término la matización "de ceba" o "de cebar", aclaración que, sin embargo, nunca aparece en lechón, sí en cerdo. Este dato permite deducir que el término marrano se utiliza fundamentalmente para referirse a los cerdos destinados al engorde. Este dato guarda relación con lo que señalan Morala y Le Men que afirman que esta acepción se corresponde con el significado original de 'carne prohibida' que una vez asentado pudo pasar a designar el cerdo en general (Morala-Le Men, 1996: 561). No obstante, la diferencia entre los términos no queda muy clara en su uso en el corpus. 


\subsubsection{Ganado caprino}

\section{CABRA [cabrío]}

Sust. y adj. f. y m. 'Mamífero rumiante doméstico, como de un metro de altura, ligero, esbelto, con pelo corto, áspero y a menudo rojizo, cuernos huecos, grandes, esquinados, nudosos y vueltos hacia atrás, un mechón de pelos largos colgante de la mandíbula inferior y cola muy corta' (DRAE). Término procedente del latín capra (DECH, s.v. cabra).

Una cabra y un castrón de un año (Coomonte de la Vega, 1643)

Noventa cabras de vientre cada una con su cabrito al pie (Genestacio de la Vega, 1650)

Quatro cabras (Alija del Infantado, 1720)

Seis cabras (Alija del Infantado, 1734)

Treinta reses lanares y cabríos (Castrillo de la Valduerna, 1828)

Dos cabras metrizes (San Feliz, 1838)

Dos cabras matrices (Calzada, 1838)

Término común usado con el significado general.

\section{CABRITO}

Sust. m. 'Cría de la cabra desde que nace hasta que deja de mamar' (DRAE). Término derivado de cabra, por tanto procedente del latín capra (DECH, s.v. cabra).

Noventa cabras de vientre cada una con su cabrito al pie (Genestacio de la Vega, 1650)

Es un término muy común, aunque solo se ha recogido este ejemplo.

\section{CASTRÓN}

Sust. m. 'Macho cabrío, morueco o puerco castrado' (DRAE). Término derivado de castrar, del latín castrare (DECH, s.v. castrar).

Una cabra y un castrón de un año (Alija del Infantado, 1644)

Treinta castrones anexos buenos (Genestacio de la Vega, 1650)

Una piel negra de castrón (Quintanilla de Somoza, 1831)

Es una voz común en toda la Península Ibérica, pero especialmente en la zona occidental. El significado con el que se utiliza es el de 'macho cabrío castrado'.

\section{CHIVO/A [chiba]}

Sust. m. y f. 'Cría de la cabra desde que no mama hasta que llega hasta la edad de procrear' (DRAE). Originariamente voz de llamada para hacer que acuda el animal, y en 
este sentido es creación expresiva común a varios idiomas (DECH, s.v. chivo).

Dos chibas (Alija del Infantado, 1734)

Un chivato de dos años (San Feliz, 1838)

Es un término de uso común, aunque solo se hayan recogido esos ejemplos. En algunas zonas de León se llama chivo al 'macho adulto' (Le Men, 2000, s.v. chivo). En este caso la información de la edad del animal nos indica que se usa con el significado del DRAE. El último ejemplo usa el término chivato que define el DRAE como 'chivo que pasa de seis meses y no llega al año', aunque sin embargo, el ejemplo señala que tiene dos años.

\subsubsection{Ganado bovino}

AÑINO (vid. tejidos)

\section{BORREGO/A}

Sust. m. El DRAE define el vocablo como 'cordero de uno o dos años' (DRAE). Término quizá derivado de borra, por la lana tierna de que está cubierto ( $D E C H$, s.v. borrego).

Quarenta carneros y borregos (Alija del Infantado, 1720)

Un borrego (Ribas de la Valduerna, 1726)

Cinco borregos (Alija del Infantado, 1812)

Cinco borregas (Alija del Infantado, 1812)

Son muy pocos los ejemplos encontrados y tres de ellos pertenecen al mismo lugar, pero no se trata de un dato significativo sino más bien de una casualidad. Algunos diccionarios propios de la zona estudiada definen el término como el 'cordero mayor de todo un rebaño' (Rivas, 1996: 50). Sin embargo, el número de cabezas al que se refieren los datos nos hace suponer que el término se utiliza con el significado que da el DRAE.

\section{CARNERO}

Sust. m. 'Mamífero rumiante, que alcanza de siete a ocho decímetros de altura hasta la cruz, con frente convexa, cuernos huecos, angulosos, arrugados transversalmente y arrollados en espiral, y lana espesa, blanca, negra o rojiza' (DRAE). Término derivado de carne, del lat. caro, carnis (DECH, s.v. carne).

Ochenta y dos carneros (La Bañeza, 1647)

Un carnero para el día de la boda (Villanueva de Valdejamuz, 1704)

Un carnero y un cordero (Alija del Infantado, 1720)

Cuarenta carneros y vorregos (Alija del Infantado, 1720) 
Es un término que, referido al animal, tiene dos acepciones 'macho ovino' y 'morueco'. En la zona de La Bañeza se utiliza con la segunda acepción, alternando con otros término como marón o borrego (Le Men, 2004, s.v. carnero). En el primer ejemplo de Alija del Infantado es posible que se trate de un morueco, es decir, 'macho semental', puesto que se relaciona un animal, o en el ejemplo de Villanueva. Sin embargo, en los otros dos ejemplos el número de animales que se relacionan hace pensar que el término carnero se use con el significado de 'macho castrado'.

\section{CORDERO/A}

Sust. m. 'Hijo de la oveja, que no pasa de un año' (DRAE). De un vocablo *cordarius, del latín vulgar, derivado del latín cordus, adjetivo que se aplicaba a las plantas y animales nacidos tardíamente, y en particular a las crías de la oveja (DECH, s.v. cordero).

Tres obejas con sus corderos (Coomonte de la Vega, 1719)

Un carnero y un cordero (Alija del Infantado, 1720)

Cincuenta y tres cabezas de ganado obejuno y una con su cordero (Laguna de Negrillos, 1722)

Treinta obejas con sus corderos (Fresno, 1726)

Seis corderos (Coomonte de la Vega, 1734)

Seis corderas (Coomonte de la Vega, 1734)

Veinte obejas con sus corderos más nueve obejas sin corderos (Requejo de la Vega, 1735)

En algunos vocabularios leoneses se añade a la idea de edad que da el DRAE el matiz de que se trata de un animal que ya pasta, por ejemplo en zonas como la Cepeda Baja (Fuente García, 2000: 183 y 199). El dato que sí se puede afirmar a través de los ejemplos es el de la edad ya que, teniendo en cuenta que en el corpus también se recoge la voz borrego/a, documentada incluso en los mismos pueblos que en el caso de cordero, la palabra borrego se utilizaría para al animal de uno a dos años y la voz cordero para el animal hasta un año. Formalmente, el término aparece siempre bajo la forma normativa, es decir no presenta ninguna variante propia de la zona occidental como podrían ser la conservación del diptongo decreciente cordeiro, o incluso el cierre de la vocal átona curdeiro.

\section{LANAR [llanar]}

Adj. 'Dicho de un ganado o de una res que tiene lana'. 'Perteneciente o relativo a la lana' (DRAE). Término derivado de lana.

Unas tixeras lanares biejas y otras de costurera (Coomonte de la Vega, 1645)

Unas tijeras lanares (Palacios de Jamuz, 1728) 
Unas tijeras lanares (Destriana, 1728)

Treinta reses lanares y cabríos (Castrillo de la Valduerna, 1828)

Unas tijeras llanares (Calzada, 1838)

El término se utiliza con los significados señalados que ofrece el diccionario académico. En el corpus aparece para indicar el tipo de ganado, como en el ejemplo de Castrillo; o para especificar el tipo de tijeras que se usaban para esquilar. La voz aparece bajo la forma castellana en la mayoría de los ejemplos y resulta significativo que en el último, ya perteneciente al S. XIX se presenta con la palatalización de la /1-/ latina, rasgo característico del leonés. Probablemente, en este momento que ya se había producido la total normalización del castellano, utilicen esta forma como propia de la zona.

\section{OVEJA [ovexa, obeja]}

Sust. f. 'Hembra del carnero' (DRAE). Del latín tardío ov̌cŭla, diminutivo de ovis 'oveja' (DECH, s.v. oveja).

Tres obejas con sus corderos (Coomonte de la Vega, 1719)

Treinta obejas con sus corderos (Fresno, 1726)

Doze ovexas y reses lanares (Palacios de la Valduerna, 1728)

Veinte obejas que son las que pueden aver quedado (Laguna de Negrillos, 1721)

Veinte obejas (Pobladura del Valle, 1734)

Veinte obejas con sus corderos más nueve obejas sin corderos (Requejo de la Vega, 1735)

Diez obejas (Alija del Infantado, 1812)

Es una voz común cuyo significado y aparición en el corpus no ofrece datos significativos. Como se refleja en los ejemplos, la matización que se suele hacer de este tipo de animales es si tienen o no corderos.

\section{OVEJUNO [obejuno]}

Adj. m. 'Perteneciente o relativo a las ovejas' (DRAE). Término derivado de oveja.

Cincuenta y tres cavezas de ganado obejuno y una con su cordero (Laguna de Negrillos, 1722)

Cuarenta y dos cabezas de ganado obejuno (Laguna de Negrillos, 1734)

El término solo se ha recogido en estos dos ejemplos. El significado y el uso con el que aparece es el mismo que en el del término oveja. En unos casos aparece el número de ovejas y en otros de cabezas de ganado ovejuno. 


\subsubsection{Aves}

\section{ANSAR}

Sust. m. 'Ganso' (DRAE). Término procedente del lat. vulgar ansare (DECH, s.v. ansar).

Dos ansares (Alija del Infantado, 1644)

Una ansare con cinco patos (Alija del Infantado, 1650)

Es el único ejemplo que se ha recogido. Su significado es el que da el diccionario académico. Otros documentos en los que se ha recogido el término reflejan dudas acerca del género del término pues unas veces aparece en masculino y otras en femenino (Morala, 2010a: 277). En los casos recogidos en el corpus no es posible apreciar si se usa en un género u otro puesto que solo aparecen dos ejemplos y en el primero el uso del numeral no aporta información al respecto.

\section{GALLINA [gallo]}

Sust. f. 'Hembra del gallo, de menor tamaño que este, cresta pequeña o rudimentaria, cola sin cobijas prolongadas y tarso sin espolones' (DRAE). Término derivado de gallo, del latín gallus (DECH, s.v. gallo).

Doce gallinas y un gallo (La Antigua, 1647)

Onze gallinas y pollas y un gallo (La Antigua, 1648)

Doce gallinas y un gallo (Coomonte de la Vega, 1650)

Seis gallinas (Coomonte de la Vega, 1719)

Zinco gallinas y un gallo (Genestacio de la Vega, 1721)

Seys gallinas y un gallo (Laguna de Negrillos, 1722)

Catoce gallinas y un gallo (Grajal de la Ribera, 1723)

Dos gallinas y un gallo (Laguna de Negrillos, 1734)

Quatro gallinas (Castrocalbón, 1814)

Una barrila con cañamina y una gallina (La Nora del Río, 1820)

Tres gallinas (Jiménez de Jamuz, 1825)

Seis gallinas y un gallo (Felechares, 1837)

Se trata de una voz común tanto la voz gallina como la referente al término gallo.

\section{PALOMO}

Sust. m. 'Macho de la paloma' (DRAE). Derivado de paloma, del latín palŭmbes 'paloma torcaz', vulgarmente palŭmba (DECH, s.v. paloma).

Tres o cuatro pares de palomos (Quintanilla de Somoza, 1831)

Es el único ejemplo recogido del término. La voz palomo se documenta en León con otros significados además del recogido por el DRAE. También se llama así al 'cordero de color blanco' (Le Men, 2009, s.v. palomo), aunque la referencia a la cantidad 
en términos de pares no aparece en el corpus para relacionar animales como el cordero, por lo que es más lógico pensar que la acepción que se emplea es la de 'macho de la paloma'. Además, el lugar que ocupa el término en la relación no aporta ninguna información puesto que aparece junto a un colchón y un escaño.

\section{PATO/A}

Sust. m. y f. 'Ave con unas determinadas características', siguiendo la definición que da el DRAE. Voz común a varios idiomas de familias diversas. De la misma onomatopeya que ha dado pata, por alusión al andar pesado de este animal (DECH, s.v. pato).

Cuatro patas y un pato anexas (Coomonte de la Vega, 1645)

Es el único ejemplo recogido en el corpus. El término pato, tiene en algunas zonas de León otras acepciones que no recoge el DRAE, así se llama pato al 'grano de la nuez, de la avellana, piña y otras frutas', a la 'mata de garbanzos', a la 'pata del cerdo curada'; entre otras acepciones. El dato que aporta el ejemplo, en el que se recoge la voz en masculino y femenino, permite suponer que la acepción con la que se usa el término es la de 'ave', animal que no es abundante entre los animales domésticos, lo que explicaría la escasez de los ejemplos.

\section{POLLA}

Sust. f. 'Gallina nueva, medianamente crecida, que no pone huevos o que hace poco tiempo que ha empezado a ponerlos' (DRAE). Derivado de pollo, del latín pŭllus (DECH, s.v. pollo).

Onze gallinas y pollas y un gallo (La Antigua, 1648)

Dos pollas medianas (Quintana del Marco, 1820)

Es un término de uso general que se emplea en el corpus con el significado que da el diccionario académico.

\subsubsection{Otros}

\section{CABEZA [caveza]}

Sust. f. El DRAE en su $12^{\mathrm{a}}$ acepción define el término como 'res'. Término procedente de capittia , forma del latín vulgar que sustituyó a caput, -ǐtis (DECH, s.v. cabeza).

Una cabeza de yerro buena (Genestacio de la Vega, 1650)

Cincuenta y tres cavezas de ganado obejuno y una con su cordero (Laguna de Negrillos, 1722) 
Dos cavezas de ganado lanar (Palacios de Jamuz, 1728)

Cuarenta y dos cabezas de ganado obejuno (Laguna de Negrillos, 1734)

Seis cabezas de ganado cabrio incluida una cría (Castrocalbón, 1814)

Ocho cabezas de ganado lanar con cinco crías (Castrocalbón, 1814)

La acepción ofrecida por el DRAE es la que aparece en todos los ejemplos a excepción del primero. En este caso, como se deduce del complemento "de yerro", el significado no es el de ganado sino 'parte anterior del dental del arado' o 'gamella del yugo'. La primera acepción es común en la zona noroeste de León, mientras que la segunda se utiliza en general en toda Castilla y León. Estos dos significados no están recogidos en el DRAE.

\section{CEBADA}

Adj. f. Participio del verbo cebar, 'Am. Dicho de una fiera: Que, por haber probado carne humana, es más temible' (DRAE). Derivado de cebar, del latín č̌bare 'alimentar', derivado de čbus 'alimento' (DECH, s.v. cebar).

Una lechona buena cebada (Coomonte de la Vega, 1645)

Es el único ejemplo recogido del término, aunque la voz cebada usada como adjetivo es muy común en toda la zona. Se emplea con una acepción distinta a la que aparece en el diccionario académico. Se dice de un animal que está cebado/a cuando está alimentado.

\section{CERRADO/A [zerrado/a]}

Adj. m. y f. 'Estricto, rígido, terminante' (DRAE). Participio del verbo cerrar, del latín tardío serare, derivado de sera 'cerrojo', 'cerradura'

Una yegua negra zerrada (Huerga de Garaballes, 1720)

Una yegua negra zerrada (Palacios de la Valduerna, 1728)

Una yegua pelo rojo y cavos negros cerrada con defecto en los pies (Destriana, 1843)

En estos ejemplos en los que aparece junto a la voz yegua, el término designa al animal que ya tiene todos los dientes (Le Men, 2004, s. v. cerrado). En otras zonas se refiere al asno viejo, por tanto se trata de un adjetivo que aplicado a animales, indica que se trata de un animal de edad adulta. Esta acepción no la recoge el DRAE, ni se recogen casos en el CORDE, aunque no es una voz que pueda considerarse occidental, pues se recogen ejemplos del término en documentos de todo el ámbito del castellano peninsular (Morala, 2012e: 426). 


\section{GACHO}

Adj. 'Dicho de un buey o de una vaca que tiene uno de los cuernos o ambos inclinados hacia abajo' (DRAE). Término derivado de agachar, de origen incierto (DECH, s.v. agachar).

Otro (buey) gacho (Palacios de la Valduerna, 1727)

Un buey gacho pardo (Palacios de la Valduerna, 1727)

Es un término que, referido a las vacas, tiene el significado que da el DRAE pero también en algunas zonas de León se utiliza con la acepción de 'vaca enferma' (Le Men, 2007, s.v. gacho). Este significado se recoge en zonas de la montaña. En otras zonas situadas al sur de la provincia, la Cepeda, la Ribera del Órbigo, etc. el significado es el de 'vaca que tiene los cuernos hacia abajo'. Por tanto, el uso del término en los ejemplos es este, teniendo además en cuenta que es frecuente inventariar tanto los objetos como los animales con todo detalle.

\section{LECHUZA}

Adj. f. 'Dicho de un muleto: que aún no tiene un año' (DRAE). Término derivado de leche.

Una jata lechuza (Calzada, 1838)

El término mantiene el significado que da el DRAE, aunque en el diccionario académico aparece como un adjetivo que se aplica al mulo. Es el único ejemplo recogido ya que es frecuente, especialmente en el caso del ganado bovino, reflejar en los inventarios la edad en años del animal. Se utiliza como término sinónimo el adjetivo mamón/a para el ganado porcino.

\section{MAMÓN/A}

Adj. 'Que todavía está mamando' (DRAE). Término derivado de mamar, del latín mamma (DECH, s.v. mama).

Una lechona grande buena recién parida con dos lechones mamones pequeños (Alija del Infantado, 1646)

Un marranico mamón (Fresno, 1726)

Una marrana mamona (Fresno, 1726)

El término siempre aparece como adjetivo que acompaña al sustantivo lechón o marrano, por tanto designa a un 'cerdo pequeño que mama'. 


\section{MOHÍNO/A [moína]}

Adj. m. y f. 'Dicho de un macho o de una mula, hijo de caballo y burra'. 'Dicho de una caballería o de una res vacuna, que tiene el pelo y sobre todo el hocico, de color muy negro' (DRAE). De origen incierto, quizá del árabe mûhim 'malsano, echado a perder' (DECH, s.v. mohíno).

Una mula moína de doze años (Laguna de Negrillos, 1734)

Una pollina color negra moína (Laguna de Negrillos, 1734)

Son los únicos ejemplos recogidos, ambos pertenecientes al mismo inventario. El DRAE recoge dos acepciones del término aplicadas a animales. Esas dos acepciones podrían estar utilizándose en los dos ejemplos mostrados. Así en el primero de ellos, y puesto que se trata de una mula, podríamos tener el significado de 'hija de caballo y burra', mientras que en el segundo el hecho de que el término mohína especifique al adjetivo negra, permite suponer con lógica que se trata de una pollina muy negra. No obstante, tampoco es claro que en el primer caso se refiera al tipo de cruce biológico y no al color, por tanto el adjetivo mohína puede estar utilizándose o bien con el mismo significado en los dos casos, o bien como un término con diferente acepción en cada uno de los ejemplos.

\section{RES}

Sust. f. 'Animal cuadrúpedo de ciertas especies domésticas, como del ganado vacuno, lanar, etc. o de los salvajes, como venados, jabalíes, etc.' (DRAE). Probablemente del latín rēs 'cosa', por una concreción del sentido semejante a la sufrida por ganado que propiamente significaba 'bienes adquiridos' (DECH, s.v. res).

Treinta reses lanares (Viñas, 1726)

Doze ovexas y reses lanares (Palacios de la Valduerna, 1728)

Treinta reses lanares y cabrios (Castrillo de la Valduerna, 1828)

El término se utiliza con el significado que aparece en el DRAE, aunque solo aplicado al ganado lanar, quizá porque en el ganado vacuno se documentan en uno o dos animales; mientras que en este caso hablamos de un conjunto de animales numeroso.

\subsection{ARMAS}

Los términos que designan armas no son muy frecuentes en los inventarios analizados en este trabajo. No obstante aparecen algunas voces de uso general que, en algunos casos, pueden estar relacionadas con la actividad de la caza. 


\section{ALABARDA}

Sust. f. 'Arma ofensiva, compuesta de un asta de madera de dos metros aproximadamente de largo, y de una moharra con cuchilla transversal, aguda por un lado y en forma de media luna por el otro' (DRAE). Término procedente del a. alem. medio helmbarte íd. compuesto de barte 'hacha' y helm 'empuñadura' (DECH, s.v. alabarda).

Una alabarda de yerro (Miñambres, 1729)

Se trata de una palabra común en la lengua de esta época, aunque solo se ha recogido este ejemplo.

\section{ARCABUZ [arcavuz, alcabuz]}

Sust. m. y f. 'Arma antigua de fuego, con cañón de hierro y caja de madera, semejante al fusil, que se disparaba prendiendo la pólvora mediante una mecha móvil colocada en la misma arma'. (DRAE). Se trata de un término procedente del fr. arquebuse íd., y este del neerl. med. hakebus (DECH, s.v. arcabuz).

Una $\operatorname{arcavuz}$ (La Antigua, 1647)

Un alcabuz con su llave (Laguna de Negrillos, 1734)

Una alcabuz vieja (Santiago Millas, 1735)

Esta palabra solo aparece en los tres casos mostrados que datan del S. XVII comienzos del S. XVIII. A partir de las ediciones del S. XIX, la Academia señala en su diccionario que se trata de un término antiguo. La escasez de ejemplos puede deberse a que se trata de un término poco común pero también a que el objeto al que se refiere no era muy común en los inventarios domésticos. En el ejemplo más antiguo encontramos la palabra bajo la variante arcavuz, con la grafía "v" para representar el sonido bilabial fricativo, que en este momento es una mera vacilación gráfica; y con confusión /r/ /l/, fenómeno característico del leonés.

\section{BALLESTA}

Sust. f. 'Arma portátil, antigua' (DRAE). Del latín ballǐsta (DECH, s.v. ballesta).

Una ballesta buena (Alija del Infantado, 1650)

Es el único ejemplo recogido del término, probablemente su significado sea el de 'arma', aunque el DRAE también recoge como $3^{\text {a }}$ acepción la de 'muelle, en forma de arco, construido con varias láminas elásticas de acero superpuestas, utilizado en la suspensión de los carruajes', acepción que también podría ser válida de acuerdo a los objetos que se relacionan en estos inventarios. 


\section{CHARPA}

Sust. f. 'Tahalí que hacia la cintura lleva unido un pedazo de cuero con ganchos para colgar armas de fuego'. Del francés écharpe 'bandolera', 'charpa' (DECH, s.v. charpa).

Un trabuco y una charpa (Palacios de la Valduerna, 1726)

Solo se ha encontrado este ejemplo del término. Probablemente se trata de un caso aislado ya que se refiere a un objeto no habitual en los inventarios. En la zona noreste de León e incluso de Castilla y León, esta voz tiene la acepción de 'chapa de hierro que forma parte de la cocina económica y que se utiliza para regular el tiro de la misma' (Le Men, 2000, s.v. charpa). En este ejemplo concreto está claro que el término se utiliza con la acepción que da el DRAE, ya que aparece inventariado junto a otro objeto del campo semántico de las armas: trabuco. Además geográficamente el corpus se localiza en zona occidental donde la voz se usaría con el significado académico ya que la acepción de 'chapa de hierro' solo se ha documentado en la zona noreste de León.

\section{CHUZO}

Sust. m. 'Palo armado con un pincho de hierro, que se usa para defenderse y ofender' (DRAE). Origen incierto, quizá derivado regresivo de chuzón, que a su vez sería alteración de zuizón derivado de suizo o zuizo (DECH, s.v. chuzo).

Un chuzo (Destriana, 1730)

Dos chuzos (Pobladura del Valle, 1733)

Un vastón con su chuzo (La Nora del Río, 1823)

El término aparece documentado en León con otros significados distintos a los recogidos en el diccionario académico. Se denomina chuzo a la 'reja del arado' (Le Men, 2004, s.v. chuzo). Esta no parece ser la acepción empleada en estos ejemplos ya que en el segundo el término aparece junto a los términos escopeta y espada, se decir, voces del campo semántico de las armas por lo que es lógico pensar que más bien se trate del palo armado. En el último ejemplo, el propio contexto en el que aparece determina su significado. En el terreno agrícola siempre se emplea en el corpus la voz reja. También se utiliza la voz chuzo para designar una 'vara de hierro con punta afilada que llevaban el criado y el Presidente' (op. cit. s.v. chuzo). En definitiva, se trata de una concreción del significado general de palo con un pincho de hierro, que es el uso genérico que se le da al término en el corpus. 
DAGA

Sust. f. 'Arma blanca, de hoja corta y con guarnición para cubrir el puño, y gavilanes para los quites, que solía tener dos cortes y a veces uno, tres o cuatro filos' (DRAE). Término de origen incierto, común a todas las lenguas romances de Occidente y a otros idiomas europeos. Quizá sea de origen céltico (DECH, s.v. daga).

Dos estoques y dos dagas (Robledo de la Valduerna, 1726)

Como en términos anteriores, solo se ha recogido este ejemplo con el significado que aparece en el diccionario académico.

\section{ESCOPETA}

Sust. f. 'Arma de fuego portátil, con uno o dos cañones de siete a ocho decímetros de largo, que suele usarse para cazar' (DRAE). Del italiano anticuado scopietta o scopietto, diminutivo de schioppo 'explosión, estallido' (DECH, s.v. escopeta).

Una escopeta de cinco palmos (La Bañeza, 1643)

Zinco escopetas (Pobladura del Valle, 1722)

Quatro escopetas largas (Robledo de la Valduerna, 1726)

Quatro escopetas (Pobladura del Valle, 1734)

Es un término común que se usa con el significado actual. Formalmente la palabra no presenta ninguna variante significativa.

\section{ESPADA}

Sust. f. 'Arma blanca, larga, recta, aguda y cortante con guarnición y empuñadura' (DRAE). Del latín spatha 'espada ancha y larga' y este del griego $\sigma \pi \alpha ́ \theta \eta$, íd. (DECH, s.v. espada).

Una espada biexa (Coomonte de la Vega, 1645)

Tres espadas, una quebrada (Pobladura del Valle, 1722)

Dos espadas anchas (Robledo de la Valduerna, 1726)

Un espadín de puño de ojalata (Robledo de la Valduerna, 1726)

Tres espadas, la una quebrada (Pobladura del Valle, 1734)

Una espada (La Nora del Río, 1823)

El término espada tiene, junto al significado que da el diccionario académico, otra acepción que no recoge el $D R A E$ y que se usa en la zona de la Maragatería, próxima a la estudiada. Se define como 'vara de la linaza' (Botas, 1993: 158). El uso generalizado que tiene la voz en el corpus analizado es el de 'arma', ya que en todos los ejemplos aparece en una relación en la que se encuentran otros objetos que designan diferentes tipos de armas (pistolas, escopetas o trabucos). No obstante, el primer ejemplo mostrado podría resultar dudoso ya que en este caso no se cumple lo afirmado para los otros 
casos, aparece junto a objetos totalmente diferentes como azadas o coberteras. La voz espadín no es un diminutivo sin más sino que designa un 'tipo de espada específico de hoja muy estrecha o triangular'.

\section{ESTOQUE}

Sust. m. 'Espada estrecha, que por lo regular suele ser más larga de lo normal, y con la cual solo se puede herir de punta' (DRAE). Del francés antiguo estoc 'punta de una espada' (DECH, s.v. estoque).

Dos estoques y dos dagas (Robledo de la Valduerna, 1726)

Solo se ha recogido este ejemplo, igual que sucede con otras voces, como el término daga que aparece en el mismo ejemplo e inventario. El significado con el que se utiliza es el que da el diccionario académico.

\section{MUNICIÓN [munizión]}

Sust. f. 'Carga que se pone en las armas de fuego'. 'Pedazos de plomo de forma esférica con que se cargan las escopetas para carga menor' (DRAE). Del latín munitio, -ōnis (DECH, s.v. munición).

Un frasquillo de munizión (Pobladura del Valle, 1722)

Es el único ejemplo recogido que se utiliza con el significado que da el DRAE. Al igual que otros términos referidos a este campo semántico, son muy pocos los ejemplos de estas voces que se recogen en los inventarios.

\section{PISTOLA}

Sust. f. 'Arma de fuego, corta y en general semiautomática, con la que se apunta y dispara con una sola mano' (DRAE). Del alemán pistole, y este del checo pistal 'arma de fuego corta' (DECH, s.v. pistola).

Dos pares de pistolas unas de arrón y otras de faltriquera (Robledo de la Valduerna, 1726)

Una pistola (La Nora del Río, 1823)

Es un término poco frecuente, aunque es común y se utiliza con el significado actual.

\section{PÓLVORA [pólbora]}

Sust. f. 'Mezcla por lo común de salitre, azufre y carbón, que a cierto grado de calor se inflama' (DRAE). Del latín pǔlvěra, plural de pulvis (DECH, s.v. polvo). 
Seis libras de pólbora (La Nora del Río, 1823)

Como en otras entradas de este apartado, es el único ejemplo en el corpus, aunque se trata de una voz de uso común.

\section{TRABUCO}

Sust. m. 'Arma de fuego más corta y de mayor calibre que la escopeta ordinaria' (DRAE). Como máquina de guerra, del catalán trabuc (DECH, s.v. trabucar).

Un trabuco y una charpa (Robledo de la Valduerna, 1726)

Es el único ejemplo encontrado cuyo significado es el que aparece en el diccionario académico.

\subsection{COLORES}

En las relaciones de bienes que se recogen en los inventarios, es común inventariar los objetos de forma detallada. En ese intento por describir exhaustivamente al animal, la prenda de vestir, etc. se encuentran los adjetivos de color. Como se puede observar en este apartado, algunos de estos términos suelen tener un uso más frecuente en animales y otros en tejidos u otros objetos, información que se detalla en cada una de las entradas.

\section{ACABELLADO [acavellado]}

Adj. m. 'De color castaño claro' (DRAE). Término derivado de cabello, del latín capüllus (DECH, s.v. cabello).

Un vestido de damasco acavellado (La Bañeza, 1649)

Es el único ejemplo encontrado. En él se hace referencia a la tela de damasco, que es un tipo de seda labrada, y en el NTLLE desde la edición de 1926 se indica en la entrada del término acabellado, la expresión seda acabellada, haciendo referencia al color de la misma. Esta sería la expresión usada en este ejemplo en el que se sustituye la voz genérica seda, por el hipónimo concreto. Señala Rello que el prefijo $a$ - unido a esta base resultando el adjetivo acabellado tiene el matiz de más claro frente a otras bases en las que puede presentar otros matices semánticos: semejanza o cualidad (Rello, 2009: 119). 


\section{AVINAGRADA [abinagrada]}

Adj. f. 'De condición acre y áspera' (DRAE). Derivado de vinagre, del latín vīnum (DECH, s.v. vino).

Una mantilla abinagrada buena (Alija del Infantado, 1650)

Otra (mantilla) avinagrada usada (Palacios de la Valduerna, 1728)

Una mantilla abinagrada (Destriana, 1730)

El término siempre aparece acompañando al sustantivo mantilla, aunque quizá se trate de una casualidad y no guarde una relación directa con este sustantivo. Siguiendo la definición del DRAE, el término puede referirse a un tipo de tela áspera, probablemente no común en las mantillas, pero también a un color semejante al color del vino. El CORDE recoge abundantes ejemplos del término, aunque muchos de ellos se aplican a rasgos de carácter y en ningún caso se recogen ejemplos que acompañen a prendas de vestir.

\section{BARDINO}

Adj. El DRAE recoge el término bajo la forma barcino, na que define como 'dicho de ciertos animales, especialmente de perros, toros y vacas: de pelo blanco y pardo, y a veces rojizo'. Término de origen desconocido (DECH, s.v. barcino).

Un jato bardino (Palacios de la Valduerna, 1727)

Es el único ejemplo encontrado. Se trata de una voz que se usa para nombrar al ganado vacuno que tiene el pelo pardo. Sin embargo, para nombrar este color se usan también otros términos como ratino/a, o simplemente pardo, más frecuentes en el corpus estudiado. En otros más extensos como el CORDE son también escasos los ejemplos, aunque la variante barcino es más común que bardino.

Con un significado próximo también se documenta el término cardino/a, término que tampoco aparece recogido en el DRAE. En este caso se aplica al ganado caballar que tiene el pelaje ceniciento (Le Men, 2004, s.v. cardino). Bardino y cardino son sinónimos aplicados a animales distintos, vacuno en un caso, caballar en otro:

Una yegua cardina de quatro años (Huerga de Garaballes, 1720)

Una yegua cardina (La Bañeza, 1743)

\section{BRAGADO/A}

Adj. 'Dicho del buey o de otros animales que tienen la bragadura de diferente color que el resto del cuerpo' (DRAE). Término derivado de braga, del latín braca 'calzón' y este del galo (DECH, s.v. braga). 
Una baca negra bragada de cinco años (Alija del Infantado, 1644)

Otra baca sanguina bragada (Alija del Infantado, 1644)

Otro becerro sanguino y bragado (Alija del Infantado, 1644)

Un nobillo bragado de zinzo años (Palacios de la Valduerna, 1728)

Una nobilla de dos años bragada (Palacios de la Valduerna, 1728)

Es un término común que se utiliza para referirse a aquellos animales bovinos que tienen una mancha blanca en la panza.

\section{CALZÓN/A}

Adj. m. y f. ' Se dice del ganado vacuno u ovino que tiene color blanco hasta media pata' (Le Men, 2004, s.v. calzón). Término derivado de calza, del latín vulgar * calcěa 'media', derivado del latín calceus 'zapato' (DECH, s.v. ballesta).

Una baca calzona de quatro años (La Nora del Río, 1724)

Es un adjetivo que no recoge el DRAE ni se documentan casos en el CORDE. Se aplica a los animales para describir el color de su pelo, concretamente la presencia de manchas. Es un término próximo al adjetivo bragado/a, aunque en este caso la mancha llega hasta media pata. Este término se localiza en otras zonas de Castilla, en Salamanca o Valladolid, aunque también se llama así en esta provincia a la 'vaca u oveja que tiene las patas negras' (Le Men, op. cit). No obstante el significado más general es el que se documenta en este caso: 'animal de otro color pero con pelaje blanco hasta media pata'.

CAPARROSA (vid. textil/tejidos)

\section{CARDINO (vid. bardino)}

\section{CARMESÍ}

Adj. 'Se dice del color de grana dado por el insecto quermes'. 'De este color' (DRAE). Del árabe hispánico qarmazî íd., derivado de qármaz 'cochinilla' (DECH, s.v. carmesî).

Una colcha de damasco carmesí con flueco de seda (La Bañeza, 1643)

Una bata de damasco carmesí forrada en tafetán doble (Robledo de la Valduerna, 1726)

A diferencia de otros adjetivos sinónimos muy frecuentes en el corpus, solo se han recogido estos dos ejemplos del término carmesí. Es un vocablo que tiene el significado de 'rojo intenso'. En los dos ejemplos del corpus aparece acompañando a prendas que llevan también el adyacente "de damasco", es decir, designa la tela de la que están hechas la colcha y la bata respectivamente. Se trata de una tela usada por 
gentes de alto poder adquisitivo, por tanto este adyacente imprime un cierto valor a la prenda. Es posible que este cierto valor se vea reforzado por la aparición de un adjetivo poco frecuente que refuerza ese carácter frente a un término más coloquial, como pueda ser encarnado o rojo. También esta combinación pueda deberse a que este color en este tipo de tela adquiera una tonalidad precisa que se corresponde con el tono carmesí.

\section{CASTAÑO}

Adj. m. y f. 'Dicho de un color: Propio de la cáscara de la castaña' (DRAE). Del latín castaněa, derivado del griego kástanon (DECH, s.v. cerrar).

Una potra color castaña cardona de siete u ocho meses poco más o menos (Coomonte de la Vega, 1643)

Una yegua castaña oscura preñada (Coomonte de la Vega, 1650)

Un buey color castaño de labranza (Coomonte de la Vega, 1719)

Un buey castaño de seis a siete años (Fresno, 1726)

Un potro castaño de dos a tres años (Fresno, 1726)

Dos vueies el uno castaño (Laguna de Negrillos, 1721)

Otra yegua color castaña tuerta de un ojo (Laguna de Negrillos, 1721)

Una baca castaña (Pobladura del Valle, 1734)

Un novillo castaño (Grajal de la Ribera, 1750)

Un vuey castaño (Valle de la Valduerna, 1829)

Otro novillo pelo castaño (Valle de la Valduerna, 1829)

Una vaca pelo castaño (Valle de la Valduerna, 1829)

Es un término muy común, referido como aparece en los ejemplos, al color del pelo de los animales. Ya definía Covarrubias el término aplicado al color como 'color en los caballos y mulas y divídese en castaño oscuro y castaño claro por tener el color de la cáscara de la castaña'.

CELESTRE [cilestre, zilestre] (vid. textil/ tejidos)

\section{COCHINILLA}

Sust. f. 'Materia colorante obtenida del insecto hemíptero, originario de México' (DRAE). Origen incierto, aunque la documentación localiza la grana en América, el vocablo no parece ser indigenismo indiano, más bien parece ser de origen romance, y quizá ya procedente de España, con la forma primitiva *conchalilla, derivado mozárabe del griego konkhýlion 'concha' (DECH, s.v. cochinilla).

Un capote de barragán forrado en cochinilla viejo (Robledo de la Valduerna, 1726)

Es el único ejemplo encontrado. No utiliza el término para denominar la sustancia colorante ni el insecto sino el color del que está forrada la prenda. Se entiende 
que está forrado de color rojo, con un tono más bien grana que lo diferencia de otros rojos nombrados con los términos encarnado o colorado, más comunes en el corpus.

\section{COLORADO/A}

Adj. 'Que por naturaleza o arte tiene color más o menos rojo' (DRAE). Término derivado de color, del latín color, ōris (DECH, s.v. color).

Un cobertor colorado (Castrocalbón, 1643)

Un cobertor colorado biexo (Coomonte de la Vega, 1643)

Una olla de barro colorado (Coomonte de la Vega, 1643)

Tres barriles colorados (Coomonte de la Vega, 1643)

Dos xarricos de barro colorados (Coomonte de la Vega, 1643)

Una ollita de barro colorado biexa (Coomonte de la Vega, 1643)

Una botija de barro colorado grande desbocada (Coomonte de la Vega, 1643)

Tres barriles de barro colorado quebrado (Alija del Infantado, 1644)

Dos barreñas de barro colorado (Alija del Infantado, 1644)

Unos cuerpos colorados de media grana (Vidriales, 1645)

Un cobertor colorado que es de blanqueta teñido bueno y doble (Alija del Infantado, 1646)

Un barreñón de barro colorado (Alija del Infantado, 1647)

Un cántaro y una barrila de barro colorado (Alija del Infantado, 1647)

Una olla de barro colorado mediana (Alija del Infantado, 1647)

Quatro taburetes los dos de ellos colorados y los dos negros (La Bañeza, 1647)

Dos almuadas de olanda labradas de seda coloradas buenas (La Bañeza, 1647)

Un repostero de listas coloradas (La Antigua, 1648)

Dos barriles de barro colorado (Coomonte de la Vega, 1650)

Una mantilla de contray buena con listas coloradas (Coomonte de la Vega, 1650)

Dos xarros de barro colorado (Genestacio de la Vega, 1650)

Un jubón azul con mangas coloradas (Palacios de Jamuz, 1728)

Unos cuerpos colorados (Palacios de Jamuz, 1728)

Unas medias coloradas (Toral, 1728)

Un cofre forrado en colorado con barretas de yerro, cerradura y llabe (Palacios de la

Valduerna, 1730)

Una vaca colorada con una cría (La Nora del Río, 1820)

\section{ENCARNADO/A}

Adj. El DRAE en su $2^{\text {a }}$ acepción señala este término como sinónimo de colorado.

Término derivado de carne, del latín caro, carnis (DECH, s.v. carne).

Otras dos almuadas grandes de olanda lavradas de ylo vlanco de cadeneta con su tafetán encarnado (La Bañeza, 1649)

Un cobertor de Palencia encarnado (Genestacio de la Vega, 1721)

Unos cuerpos encarnados (Genestacio de la Vega, 1721)

Unos cuerpos de raso encarnados con galones buenos (Grajal de la Ribera, 1723)

Unos cuerpos encarnados (Alija del Infantado, 1724)

Un zíngulo de seda encarnado (Robledo de la Valduerna, 1726)

Una colgadura de cama en jerguilla encarnada (Robledo de la Valduerna, 1726)

Seis cortinas de bareta encarnada biejas con sus cenefas (Robledo de la Valduerna, 1726)

Unos cuerpos encarnados guarnezidos (Miñambres, 1727) 
Una bara de cordelate encarnado (Palacios de Jamuz, 1728)

Unos cuerpos encarnados con galón de plata falsa (Toral, 1728)

Unos cuerpos encarnados con pasamanos (Requejo de la Vega, 1735)

Un manteo de Baeza verde bordado en blanco y encarnado (Alija del Infantado, 1737)

Un guardapié de paño encarnado con tres vueltas de pasamanos (Palacios de la Valduerna, 1730)

Un capote de camellón con su forro encarnado (Laguna de Negrillos, 1734)

Un dengue de bayeta de Portugal encarnado (La Bañeza, 1743)

Otro pañuelo encarnado con cenefa blanca (Grajal de la Ribera, 1806)

Un manteo pajizo de rodadura encarnada (Grajal de la Ribera, 1806)

Un dengue encarnado con cinta (Grajal de la Ribera, 1806)

Un capotón de ratina encarnado (Alija del Infantado, 1812)

Un dengue encarnado de bayeta (Quintana del Marco, 1820)

Dos dengues encarnados viejos (Jiménez de Jamuz, 1825)

Un pañuelo encarnado (Jiménez de Jamuz, 1825)

Una mantilla de un niño encarnada (Alija del Infantado, 1827)

Una carpeta de damasco de lana encarnada (La Bañeza, 1829)

Cuatro cortinas de esparragón de lana encarnadas viejas (La Bañeza, 1829)

Una manta encarnada (Quintanilla de Somoza, 1831)

Una servilleta con listas encarnadas y un pañuelo encarnado todo biexo (Quintanilla de Somoza, 1831)

Una mantilla verde con cinta encarnada (San Feliz, 1838)

Un justillo encarnado (Calzada, 1838)

Cuatro cortinas de morsolina encarnadas (Requejo de la Vega, 1839)

Dos cobertores encarnados (Requejo de la Vega, 1839)

Un pañuelo blanco con flores encarnadas (Requejo de la Vega, 1839)

Dos fajas encarnadas 10 palmos una de ellas manchada (Requejo de la Vega, 1839)

Un pañuelo encarnado (Santibáñez de la Isla, 1844)

\section{ROJO/A}

Adj. 'Encarnado muy vivo'. 'Dicho del pelo: de un rubio muy vivo, casi colorado' (DRAE). Del latín rŭssěus (DECH, s.v. rojo).

Un nobillo rojo (Genestacio de la Vega, 1721)

Un jato color rojo de quatro años (Laguna de Negrillos, 1722)

Un jato rojo de un año (La Nora del Río, 1724)

Un buey rojo de ocho años a nuebe (Miñambres, 1727)

Un novillo rojo de zinco a seis años (Miñambres, 1727)

Una yegua bieja roja (Miñambres, 1727)

Una baca roja con un jato (Palacios de Jamuz, 1728)

Un par de novillos el uno negro y el otro rojo (Viñas, 1728)

Otra baca roja (Viñas, 1728)

Otra novilla roja (Viñas, 1728)

Tres jatas y un jato, las dos rojas y la otra y el jato negro (Viñas, 1728)

Un buei color rojo (Palacios de la Valduerna, 1730)

Una baúl de pellejo rojo (La Bañeza, 1743)

Unos calzones rojos usados (La Nora del Río, 1823)

Un buey color rojo de doce años (Santibáñez de la Isla, 1844)

Estos tres términos son adjetivos casi sinónimos, aunque tienen ciertas

diferencias. Así, el adjetivo colorado se usa especialmente para cacharros de cocina elaborados con barro, lo que se llama barro colorado. Este adjetivo aplicado a la tierra 
tiene el significado de 'amarillento'. En los ejemplos se observa que el término aparece también acompañando a sustantivos que nombran prendas de vestir. En este caso, toma el significado de 'rojo', y es especialmente usado entre los SS. XV y XVII, de ahí que aparezca en ejemplos del S. XVII. Resulta interesante el último ejemplo de la Nora del Río, que utiliza el término para referirse al color de la vaca, frente a todos los anteriores que aparecen con objetos. El adjetivo encarnado, que tiene también el significado de 'rojo, rojizo', se aplica en el corpus a prendas de vestir y su uso predomina de forma clara en los SS. XVIII y XIX. Finalmente, el adjetivo rojo aparece en todos los ejemplos, excepto en uno, con sustantivos que nombran animales bovinos. Este término aplicado a animales tiene el significado de 'rubio, con el pelo de color semejante al de la miel' (Fuente García, 2000: 509). Por tanto, se trata de tres adjetivos casi sinónimos pero claramente diferenciados en su uso.

\section{FOSCO/A [afoscado]}

Adj. 'De color oscuro, que tira a negro' (DRAE). Del latín fŭscus 'pardo, oscuro' (DECH, s.v. hosco).

Un vecerro afoscado de dos años y ba a tres (Alija del Infantado, 1644)

Un xato fosco que va a un año (Alija del Infantado, 1644)

Una baca color fosca (Coomonte de la Vega, 1645)

Dos bueyes foscos de labranza de nuebe o diez años cada uno (Alija del Infantado, 1646)

Una baca fosca biexa (Alija del Infantado, 1646)

Un ternero de un año fosco (Alija del Infantado, 1646)

Un buey fosco de ocho años poco mas o menos (Coomonte de la Vega, 1650)

Otro buey fosco de seis años (Coomonte de la Vega, 1650)

Una baca color fosca biexa (Coomonte de la Vega, 1650)

Una xata color fosco de un año (Coomonte de la Vega, 1650)

Un buey color fosco de seis años bueno (Genestacio de la Vega, 1650)

Un par de bueies el uno de color fosco y el otro blanco (Viñas, 1726)

Una baca color fosca (Viñas, 1726)

Una nobilla fosca (Miñambres, 1727)

Otro bezerro fosco (Palacios de la Valduerna, 1727)

Una baca fosca (Palacios de la Valduerna, 1727)

Un buey fosco de siete años y otro del mismo color de ocho (Palacios de la Valduerna, 1728)

Una baca fosca con su ternera roja (Palacios de la Valduerna, 1728)

Un buei fosco (Requejo de la Vega, 1735)

Es un término muy común, que aparece siempre en el corpus acompañando a sustantivos que designan animales bovinos. El DRAE en sus ediciones define el adjetivo hosco como 'color muy oscuro, casi negro'. Por tanto, resulta interesante destacar la precisión con que inventarían los animales en este tipo de relaciones, ya que en un 
mismo inventario podemos encontrar vacas o bueyes negros, o incluso oscuros o morenos.

Un buey cabrito obscuro / otro negro (Palacios de la Valduerna, 1727)

Dos bacas morenas/ una baca negra con su jato al pie (Palacios de la Valduerna, 1728)

A pesar de que se trata de una voz muy frecuente en el corpus, no se registra ningún ejemplo en el S. XIX. Esta ausencia puede ser casual, debida a una falta de animales de este color; o tal vez se trate de una generalización del adjetivo negro/a que aparece en este siglo en bastantes ocasiones. Además, la palabra es usada en León con una acepción referida a vaca, que no aparece recogida en el $D R A E$ 'vaca que mueve las patas traseras en círculo cuando anda' (Le Men, 2005, s.v. fosco). Los ejemplos llevan, en su mayoría, a concluir que el término se utiliza con la acepción de color, no de un tipo específico de animal, ya que es frecuente que aparezca en el ejemplo la palabra color. No obstante, hay casos en los que se cita "una vaca fosca" y, por tanto, es factible que en ellos el término se pueda estar utilizando con este último significado. Formalmente, el término conserva siempre la /f-/ latina, dato que refleja que en esta voz el fenómeno está totalmente lexicalizado (Morala, 2009b: 13).

\section{FRAILENGO}

Adj. 'Perteneciente o relativo a frailes' (DRAE). Término derivado de fraile, del occitano fraire, y este del latín frater, -tris (DECH, s.v. fraile).

Una saya de pardo fraylengo y negro lo negro biexo y lo fraylengo nuevo (Alija del Infantado, 1647)

Es un término que, en este contexto, está haciendo referencia a un color, por su coordinación con el color negro y porque es frecuente que en los inventarios aparezca el color de la prenda que se inventaría. Puesto que se trata de una voz relacionada con el término fraile, es lógico pensar que se refiere al color de los hábitos de fraile, probablemente al color marrón. No obstante, es un término poco común ya que es frecuente encontrar la voz pardo/a para designar el color amarronado, aunque en los textos notariales también se documenta la variante fraylesco para referirse a un tipo de tela o de paño (Perdiguero, 2012a: 340), uso que podría estar empleándose en el ejemplo y referirse no a un color sino a un tipo de paño, aunque la coordinación con la voz negro hace pensar que se trate más bien de un color. Esta palabra es escasa también en el CORDE donde solo hay un ejemplo de frailengo y dos del término sinónimo frailego de los que solo uno tiene que ver con el color, todos ellos también 
pertenecientes al S. XVII. Bajo las formas frailero o fraylesco no se han recogido casos en este corpus.

\section{MORADO/A}

Adj. m. y f. 'De color entre carmín y azul' (DRAE). Término derivado de mora, del latín vulgar mōra (DECH, s.v. mora).

Otro (buey) pelo morado (Valle de la Valduerna, 1829)

Una baca morada (Palacios de la Valduerna, 1831)

Diez baras de cinta morada (Requejo de la Vega, 1839)

Un nobillo color morado (Santibáñez de la Isla, 1844)

Una baca color morada (Santibáñez de la Isla, 1844)

Un buey de color morao de siete años (Santibáñez de la Isla, 1844)

Es un adjetivo que aplicado al color del pelo de los animales es bastante frecuente como lo muestran los ejemplos. Evidentemente, está claro que el término no se corresponde con lo que actualmente conocemos por color morado. El NTLE recoge el término documentado en el año 1604 con el significado de 'gris marrón', este dato permite tal vez esclarecer la acepción precisa que el término tiene en estos ejemplos, probablemente designe a un tipo de animales vacunos que se caracterizan por tener un pelo de color gris, un gris que tiene un cierto color añil, azulado, etc. El hecho de que dentro de la zona estudiada, los ejemplos se localicen en la parte noroccidental, puede deberse a una casualidad o tal vez se trate de un tipo de raza más común en esta zona. Además existe algún ejemplo en el que el adjetivo acompaña a una prenda textil y cuyo significado alude al color que conocemos como morado «Un brial morado (Alija del Infantado, 1812)».

\section{MORENO/A}

Adj. m. y f. 'Dicho de un color, oscuro que tira a negro' (DRAE). Del latín maurus 'habitante del NE de África'. Con el sentido 'de color oscuro' (DECH, s.v. moro).

Otro nobillo moreno de zinco años (Miñambres, 1727)

Dos bacas morenas (Palacios de la Valduerna, 1728)

Se trata del término de color que se utiliza para referirse a aquellos animales de color muy oscuro, casi negro.

\section{NEGRO/A}

Adj. $m$ y f. 'Se dice del aspecto de un cuerpo cuya superficie no refleja ninguna radiación visible' (DRAE). Del latín nı̆ger, nügra, n̆grum (DECH, s.v. negro). 
Una olla grande negra de dos asas (Coomonte de la Vega, 1643)

Un cofre grande negro encorado (La Bañeza, 1643)

Quatro taburetes los dos dellos colorados y los dos negros (La Bañeza, 1647)

Un vaúl negro atachonado con sus erraduras y llabe (La Bañeza, 1649)

Dos sillas de vaqueta negra (Laguna de Negrillos, 1722)

Una mantica biexa y rota de xerga blanca y negra (Coomonte de la Vega, 1643)

Una mantilla de ceñir de lana negra (Coomonte de la Vega, 1643)

Un rebociño negro de bayeta negra (La Bañeza, 1643)

Una anguariña de paño negra usada (Laguna de Negrillos, 1722)

Unos calzones negros forrados (Laguna de Negrillos, 1725)

Un mandil de frisa negra (Fresno, 1726)

Unos botines de paño negro (Robledo de la Valduerna, 1726)

Un sayuelo negro (Miñambres, 1729)

Un chaleco paño negro (La Nora del Río, 1823)

Un bestido negro nuevo (Requejo de la Vega, 1839)

Un fra de paño negro (Requejo de la Vega, 1839)

Una yegua negra cardona (Coomonte de la Vega, 1643)

Una potra negra de dos años (Coomonte de la Vega, 1645)

Un buey color negro (Coomonte de la Vega, 1645)

Otro (buey) negro de siete a ocho años (Fresno, 1726)

Otro par de bueies el uno color negro y el otro aconejado (Viñas, 1726)

Una pollina negra de ocho años (Palacios de la Valduerna, 1728)

Una yegua negra zerrada (Palacios de la Valduerna, 1728)

Una pollina color negra moína (Laguna de Negrillos, 1734)

Una pollina de pelo negro con sus aparejos (Valle de la Valduerna, 1829)

Es un término que aparece frecuentemente, por lo que los ejemplos citados son una muestra de los encontrados en el corpus. Estos ejemplos están dispuestos en tres grupos, por una parte los que aparecen junto a nombres de objetos, por otra los que aparecen junto a prendas de vestir y finalmente los que aparecen para designar el color de los animales. El término negro se utiliza mucho junto a prendas de vestir ya que era un color frecuente en muchas tipos de telas y prendas donde además hay que tener en cuenta que era el color que se utilizaba también para las ceremonias como un color elegante, y para el luto. Finalmente, el uso del adjetivo para referirse al color de los animales también es frecuente. Es variada la terminología usada para designar esta realidad, de ahí que este adjetivo indique el color exacto del pelo del animal, diferenciándolo del pardo u oscuro sin más, incluso a veces aparecen otros adjetivos que matizan la intensidad del color, como el término mohíno/a. Desde el punto de vista formal, siempre aparece bajo la forma normativa negro, y nunca con palatalización de la nasal, que sí se encuentra en algunos puntos al occidente de León.

\section{PAJIZO/A [paxizo/a]}

Adj. 'De color de paja'. Término derivado de paja, del latín paléa 'cascabillo de los cereales' y de ahí 'paja desmenuzada' (DECH, s.v. paja). 
Una casa tejada y pajiza con su corral (Alija del Infantado, 1720)

Las casas que quedaron de dicho difunto tejadas y pajizas en el casco de esta villa (Laguna de Negrillos, 1721)

Una casa pajiza más un carro ya viejo (Ribas de la Valduerna, 1726)

Una pajiza usada (Laguna de Negrillos, 1726)

Una casa pajiza en el casco de esta villa que tiene dos aposentos con su corral (Altobar de la Encomienda, 1729)

Unas casas pajizas en el casco de esta villa (Palacios de la Valduerna, 1730)

Dos pajizas biexas (Grajal de la Ribera, 1730)

Seis pajizas viejas (Laguna de Negrillos, 1734)

Una casa pajiza (Requejo de la Vega, 1735)

Dos uronas pajizas (Santiago Millas, 1735)

Las casas de la morada del difunto que están en la ramal de avaxo de esta villa paxizas

(Laguna de Negrillos, 1740)

Un rodao paxizo de estameña (Grajal de la Ribera, 1806)

Un zagalexo de bayeta paxiza (Saludes de Castroponce, 1808)

Un rodao de bayeta pajiza nuevo (Alija del Infantado, 1812)

Otro de estameña pajizo usao (Alija del Infantado, 1812)

Otro manto de estameña pajizo usado (Quintana del Marco, 1820)

Una armilla de vayeta pajiza (La Nora del Río, 1823)

Un manteo pajizo biejo (Quintanilla de Somoza, 1831)

Otro manteo pajizo y otro azul (Castrocalbón, 1832)

Una mantilla pajiza rodeada con zinta azul (Calzada, 1838)

Un pañuelo con fondo pajizo (Requejo de la Vega, 1839)

Un manteo pajizo de estameña (Requejo de la Vega, 1839)

Es un término muy común que siempre aparece en el corpus como adjetivo, aunque se encuentra ampliamente documentado en León también como sustantivo para nombrar diferentes objetos o realidades. En los ejemplos encontramos dos bloques, en primer lugar el uso de pajizo/a acompañando al sustantivo casa que se emplea para indicar que es una casa cuya techumbre es de paja y que se diferencia de la casa tejada que sería de teja. En segundo lugar encontramos un bloque de ejemplos en los que el adjetivo acompaña a sustantivos relacionados con prendas textiles. En este caso la voz pajizo/a designa un color, normalmente suele ser un color próximo al amarillo, el color de la paja. A este respecto, señala Luz Rello que el sufijo -izo unido a una base sustantiva que designe un término de color tiene el matiz de semejanza, es decir, en este caso parecido a la paja en el color (Rello, 2009: 109), tono muy frecuente sobre todo en rodaos.

\section{PARDO}

Adj. 'Del color de la tierra, o de la piel del oso común, intermedio entre blanco y negro, con tinte rojo amarillento, y más oscuro que el gris' (DRAE). Del latín pardus, griego $\pi \alpha ́ \rho \delta o \varsigma$ 'leopardo' o del griego $\pi \alpha ́ \rho \delta \alpha \lambda o \varsigma$, probablemente nombre del gorrión, por el color oscuro de ambos animales; no se puede asegurar de cuál de los dos procede el 
adjetivo castellano pero ya en griego tenían ambos nombres raíz común, precisamente por el color parecido en los dos casos (DECH, s.v. pardo).

Dos baras y media de estameña parda (La Bañeza, 1641)

Un capote de pardo biexo con su pasamanos (Coomonte de la Vega, 1643)

Un macho color pardo con sus adreços (La Bañeza, 1643)

Una burra parda biexa (Coomonte de la Vega, 1645)

Una capa de pardo nueba aforrado el quello en fustán (Coomonte de la Vega, 1645)

Una mantilla de cubrir de pardo (Coomonte de la Vega, 1645)

Un capote de pardo cerrado bueno (Coomonte de la Vega, 1645)

Unos calçones de pardo y un sombrero bueno (Vidriales, 1645)

Un capote de pardo ya viejo (Vidriales, 1645)

Una gabardina de pardo biexa (Alija del Infantado, 1646)

Una saya de pardo y usada a medio serbir (Alija del Infantado, 1647)

Una saya de pardo (La Antigua, 1647)

Una mantilla de pardo (La Antigua, 1647)

Un sayazo de pardo biexo (La Antigua, 1648)

Una vasquina y un jubón de estameña parda (La Bañeza, 1649)

Otro vestido de chamelote de aguas pardo (La Bañeza, 1649)

Un capote de pardo zerrado bueno (Coomonte de la Vega, 1650)

Un sayo y un xubón de pardo usado (Coomonte de la Vega, 1650)

Un buey de labranza pardo (Genestacio de la Vega, 1650)

Una pollina color parda (Laguna de Negrillos, 1722)

Una yegua color parda de siete a ocho años (Laguna de Negrillos, 1722)

Un buey color pardo de cinco años (La Nora del Río, 1724)

Un sayuelo pardo nuevo forrado de lienzo (Fresno, 1726)

Una marrana parda (Fresno, 1726)

Una baca parda con su ternero (Fresno, 1726)

Otra novilla parda (Viñas, 1726)

Una capa de pardo y una anguarina (Viñas, 1726)

Una nobilla parda de tres años (Miñambres, 1727)

Dos baras de pardo casero (Palacios de Jamuz, 1728)

Un saiuelo de pardo usado (Palacios de Jamuz, 1728)

Dos mantillas de pardo (Palacios de Jamuz, 1728)

Un buei pardo (Palacios de la Valduerna, 1730)

Dos ropillas de pardo y unos calzones de lo mismo (Destriana, 1730)

Una pollinita pequeña color parda (Laguna de Negrillos, 1740)

Casaca, chupa y calzón de pardo de hombre (La Bañeza, 1743)

Un sayuelo de pardo usado (Santiago Millas, 1735)

Una pollina parda de siete a ocho años (Grajal de la Ribera, 1750)

Un zagalexo de paño pardo tiñido (Saludes de Castroponce, 1808)

Un poco de pardo (Castrocalbón, 1814)

Otro (manteo) nuevo de paño pardo (Jiménez de Jamuz, 1825)

Una mantilla nueba de paño pardo (Jiménez de Jamuz, 1825)

Un manto de pardo biejo ya roto (Alija del Infantado, 1827)

Un mandil de pardo y una mantilla nueba de paño (San Feliz, 1838)

Un manteo nuevo de pardo (Calzada, 1838)

Un sayuelo de pardo (Calzada, 1838)

Un mandil de pardo (Calzada, 1838)

Es un término muy común que se utiliza en el corpus con dos acepciones que conllevan una diferencia en la categoría gramatical del término. Usado como adjetivo, la voz tiene el significado de 'tipo de color'. Con esta acepción se utiliza para referirse al 
color del pelo de los animales, un 'color oscuro que está próximo al gris, con un tinte rojo'. Además el término se usa como sustantivo para designar un 'tipo de tejido fuerte de lana que se utilizaba para hacer los manteos, las sayas y las capas'. Con este significado se encuentran un gran número de ejemplos referidos a prendas de vestir y alguno menos frecuente referido a la tela a granel, sin confeccionar. No obstante, ambas acepciones guardan relación, puesto que este tejido recibió este nombre porque era un tipo de paño sin teñir y se aplicó esta denominación al color de lana marrón oscura (Cavero y Alonso, 2001: 288).

\section{RUBIO}

Adj. m. y f. 'Dicho especialmente del cabello: de color parecido al del oro. Se dice también de la persona que lo tiene' (DRAE). Del latín rŭběus 'rojizo' (DECH, s.v. rubio).

Una pollina rubia buena (La Nora del Río, 1645)

Es el único ejemplo encontrado, dato que puede explicarse porque la realidad a la que se refiere este término aparece en el corpus nombrada a través de otras voces como rojo o sanguino. El adjetivo rubio aplicado al pelo de los animales se define como de 'color rojo', entendiendo por rojo quizá el color próximo al color de la miel, por tanto tal vez se trate de términos sinónimos siendo frecuente el adjetivo rojo/a que aparece en numerosos casos, frente a rubio.

\section{SANGUINO/A}

Adj. m. y f. 'De color de sangre' (DRAE). Término derivado de sangre, del latín sanguis, ı̌nis (DECH, s.v. sangre).

Otra baca sanguina bragada (Alija del Infantado, 1644)

Otro becerro sanguino y bragado (Alija del Infantado, 1644)

Una baca color sanguina (Coomonte de la Vega, 1645)

Un becerro sanguino de dos años que ba a tres (Alija del Infantado, 1647)

Un buey sanguino (La Antigua, 1648)

Un bezerro de un año color sanguino (Genestacio de la Vega, 1650)

Un jato de un color sanguino (La Nora del Río, 1724)

Una baca sanguina de tres años (La Nora del Río, 1724)

Una baca color sanguina (Viñas, 1726)

Es un término común que se emplea para designar el color del pelo de los animales, en concreto de los bóvidos. El significado que da el DRAE es 'de color de la sangre', por tanto el término es un sinónimo de rojo que, aplicado al color del pelo, indica que se trata de un pelo rubio. Si atendemos a las diferencias con respecto al color rojo, encontramos que en este caso el adjetivo sanguino solo aparece con animales 
bovinos, dato que puede ser casual; y las localidades en las que el término aparece documentado pertenecen todas a la comarca del Bajo Órbigo, lo que podría hacer pensar que en esta zona se utiliza más un adjetivo que otro.

\subsection{PRODUCTOS PERECEDEROS}

Siendo la agricultura y la ganadería la base de la economía en esta zona, las personas solían acumular diversos productos obtenidos de sus tareas agrícolas y de las matanzas. Estos se acumulaban para el consumo doméstico o, incluso, para el desarrollo de pequeñas industrias familiares. Los términos se agrupan según sean agrícolas o procedentes de los animales.

\section{ARVEJA [arvexa]}

Sust. f. El DRAE define el término como sinónimo de algarroba. Del latín ervĭlǐa 'planta análoga a los yeros y a los garbanzos' (DECH, s.v. arveja).

Unas pocas de arbexas que será un celemín dellas poco más o menos (Coomonte de la Vega, 1643)

Es una voz que se documenta con el significado de 'guisante' en el noroeste y centro-oeste de León (Le Men, 2000, s.v. arveja). No obstante, solo se ha encontrado un ejemplo. Esta escasez de ejemplos no resulta extraña si tenemos en cuenta que en un corpus extenso como el CORDE solo se recogen cuarenta casos.

\section{BARBILLA}

Sust. f. 'Variedad de trigo que tiene la espiga y caña gruesas y largas las barbas, frente al mocho que no las tiene' (Le Men, 2002, s.v. barbilla). Término derivado de barba, del lat. barba 'pelo de la barba' (DECH, s.v. barba).

Tres cargas de barbilla (Santibáñez de la Isla, 1844)

Solo se ha recogido este ejemplo que unido al término cargas que significa 'medida de granos', permite deducir que tiene el significado expresado. Este término no aparece recogido en el DRAE.

\section{CANTUDA}

Sust. f. 'Cada una de las semillas leguminosas, de forma aplanada, que salen mezcladas con los garbanzos' (Rivas, 1996: 60).

Un zelemín de cantudas (Quintana del Marco, 1820) 
Dos heminas de cantudas (Jiménez de Jamuz, 1825)

Ocho quartales de cantudas (Santibáñez de la Isla, 1844)

El término no aparece recogido en el DRAE. Se trata de una palabra que se documenta en toda la zona de Castilla y León, especialmente en las zonas rurales. Este vocablo tiene otros sinónimos que no se han recogido en el corpus, como son almorta, muela o tito (Le Men, 2004, s.v. cantuda). No son muchos los ejemplos encontrados del término cantuda y todos ellos pertecen al S. XIX.

\section{CEBADA}

Sust. f. 'Planta anual de la familia de las gramíneas, parecida al trigo, con cañas de algo más de seis decímetros, espigas prolongadas, flexibles, un poco arqueadas, y semilla ventruda, puntiaguda por ambas extremidades y adherida al cascabillo, que termina en arista larga. Sirve de alimento a diversos animales, y tiene además otros usos' (DRAE). Derivado de cebar, del latín č̌bare 'alimentar', derivado de č̌bus 'alimento' (DECH, s.v. cebar).

Se alló un poco de cebada en la panera (Coomonte de la Vega, 1643)

Dos cargas de cebada (Alija del Infantado, 1812)

Es un término muy conocido de uso común, aunque solo se recojan estos ejemplos en el corpus.

\section{ESPLIEGO}

Sust. m. 'Semilla de esta planta que se emplea como sahumerio' (DRAE). Del antiguo y aragonés espligo, descendiente semiculto del latín tardío spīcŭlum, diminutivo de spicum 'espiga' (DECH, s.v. espliego).

Un poco de espliego (La Bañeza, 1721)

Es el único ejemplo encontrado. El término tiene un único significado que da nombre a un tipo de planta aromática, que probablemente se use con ese fin.

\section{FRÉJOL [frégol]}

Sust. m. 'Judía, planta papilionácea' 'Fruto y semilla de esta planta' (DRAE). Del latín faseŏlus, y este del griego phásēlos (DECH, s.v. frijol).

Unos pocos de frégoles secos de avas yndias (Valle de la Valduerna, 1829)

Solo se ha recogido este ejemplo, utilizado probablemente con el significado de 'semilla de la judía verde', ya que el adjetivo seco indica que se trata de la semilla y no de las vainas. 


\section{LINAZA}

Sust. f. 'Simiente de lino, en forma de granillos elipsoidales, duros, brillantes y de color gris. Molida, proporciona una harina muy usada para cataplasmas emolientes; por presión, suelta un aceite secante de gran empleo en la fabricación de pintura y barnices, y, echada en agua, da un mucilago de mucha aplicación en la industria' (DRAE). Término derivado de lino, del latín līnum íd. (DECH, s.v. lino).

Tres eminas de linaza (Castrocalbón, 1643)

Siete heminas de linaza (Genestacio de la Vega, 1721)

Una orona vieja que ará una carga de linaza (Miñambres, 1727)

Dos eminas y media de linaza (Palacios de la Valduerna, 1728)

Media carga de linaza (Alija del Infantado, 1737)

Quinientos noventa reales de catorce eminas de linaza embiada compostura de ella y abono (Alija del Infantado, 1812)

Una botija y un cribo de linaza (La Nora del Río, 1820)

Quince quartales de linaza (Santibáñez de la Isla, 1844)

Es un término común que tiene el significado que da el DRAE de 'semilla de lino', por ello siempre aparece inventariado junto a una medida de peso para especificar la cantidad exacta de semillas que se inventariaban. No obstante, en el ejemplo de La Nora del Río y, teniendo en cuenta el contexto en el que aparece el término, podríamos suponer que se trata de una botija, con un complemento sobrentendido de linaza y "un cribo de linaza", donde la botija haría referencia al contenido de la misma que en este caso podría ser la aceite obtenida de esta semilla.

\section{LONGANIZA}

Sust. f. 'Pedazo largo de tripa estrecha rellena de carne de cerdo picada y adobada' (DRAE). Del latín vulgar lǔcanicia, derivado del latín lucanica íd., así llamada porque se hacía en el sur de Italia (DECH, s.v. longaniza).

Libra y media de longaniza (Castrocalbón, 1814)

Se trata de una palabra de uso común, aunque sea el único ejemplo recogido del término. El término aparece sin palatalización de la /l-/ fenómeno que, por otra parte, no aparece de forma extensiva en el corpus.

\section{MELONERA}

Adj. 'Persona que siembra, guarda o vende melones' (DRAE). Derivado de melón, del latín tardío melo, -ōnis (DECH, s.v. melón).

Una carga melonera de binbre biexa (Coomonte de la Vega, 1643)

Una carga melonera biexa (Alija del Infantado, 1644) 
Son los únicos ejemplos recogidos en el corpus, ambos próximos en la fecha y en la zona ya que se encuentran en pueblos limítrofes, pertenecientes al mismo señorío. Alija del Infantado tuvo hasta 1960 el nombre de Alija de los Melones, de ahí que no sea extraña la presencia de este término. La voz aparece junto a la unidad de medida carga por lo que es probable que el término melonera, en estos ejemplos, haga referencia al fruto, concretamente al melón ya que además en el primer caso aparece en la relación junto a otros productos perecederos, como son miel o garbanzos; y la especificación "de mimbre" se refiera a que se encuentran en un cesto de este material, en el segundo ejemplo aparece junto a artículos diversos que no guardan relación semántica, pero es probable que el término tenga el mismo significado.

\section{MORCAJO}

Sust. m. 'Mezcla de trigo y centeno' (DRAE). Término derivado de amurca 'orujo de aceituna', tomado del latín amurca (DECH, s.v. amurca).

Diez y ocho heminas de morcajo (La Nora del Río, 1820)

Carga y media de morcajo (Jiménez de Jamuz, 1825)

En León se documenta el término con dos acepciones, se llama morcajo al 'tipo de trigo que se queda pequeño, grana mal y es de mala calidad' y a la 'sembradura de varios cereales juntos, especialmente centeno y barbilla' (Le Men, 2007, s.v. morcajo). En Estébanez de la Calzada, lugar bastante próximo a la zona estudiada en este corpus, el término morcajo se utiliza con el significado de 'mezcla de varios cereales', por lo que es probable que este sea el uso que se hace del término en estos ejemplos (Martínez Martínez, 1985: 183).

\section{ESPINAZO}

Sust. m. 'Columna vertebral' (DRAE). Término derivado de espina, del latín spīna (DECH, s.v.espina).

Un espinazo de lechón salado (Coomonte de la Vega, 1650)

Una arrova de menudos, patas, espinazos, cabezas (Palacios de la Valduerna, 1831)

El contexto en el que aparecen los ejemplos indica que el significado del término en ambos casos es el de 'parte del cerdo entre los perniles y los jamones' (Le Men, 2005, s.v. espinazo), acepción que no recoge el DRAE. 


\section{MANTECA}

Sust. f. 'Producto obtenido por el batido, amasado y posterior maduración de la crema extraída de la leche de vaca o de otros animales' (DRAE). Término de origen incierto, probablemente prerromano, quizá indoeuropeo y relacionado con el eslavo smetana (DECH, s.v. manteca).

Dos arrobas y media de manteca (La Bañeza, 1641)

Una olla de manteca vacía (Villamor de Órbigo, 1648)

Dos ollas con un poco de manteca (Genestacio de la Vega, 1721)

Beinte libras de manteca (Alija del Infantado, 1812)

Libra y media de manteca (Castrocalbón, 1814)

Es un término conocido que presenta distintas acepciones. Se denomina manteca a la 'mantequilla', a la 'nata de la leche' o a 'cada apéndice del cuello de las cabras', aunque teniendo en cuenta el contexto en el que aparecen los términos, siempre relacionados con unidades de medida, y considerando que se trata de un inventario de enseres donde es improbable que aparezcan términos como mantequilla o nata de la leche, cabe pensar que el significado del término en los ejemplos del corpus es el de 'grasa, en crudo, del cerdo y en especial la más espesa que recubre ciertas partes o vísceras de él'. Formalmente, la voz solo aparece recogida bajo la forma manteca.

\section{MENUDO}

Sust. m. 'Vientre, manos y sangre de las reses que se matan' (DRAE). Del latín mĭnūtus participio pasivo de minuere 'disminuir' (DECH, s.v. espina).

Una arrova de menudos, patas, espinazos, cabezas (Palacios de la Valduerna, 1831)

Es el único ejemplo recogido del término cuyo uso más frecuente en la zona es el diminutivo menudillos, usado también en plural que designa el 'conjunto de los desperdicios o vísceras de un animal constituidos por tripas, hígado, riñones, etc.' (Rivas, 1996: 158). El DRAE da otro significado para el diminutivo menudillo que define como 'en los cuadrúpedos, articulación entre la caña y la cuartilla'.

\section{PERNIL}

Sust. m. 'Anca y muslo del animal'. 'Por antonomasia anca y muslo del cerdo' (DRAE). Término derivado de pierna, del latín perrna 'muslo y piernas juntos en un animal' (DECH, s.v. pierna).

Dos perniles de tocino curados (Comonte de la Vega, 1643) 
Es el único ejemplo recogido, aunque se trata de un término de uso común. El significado con el que se utiliza es próximo al que da el DRAE, se denomina pernil a la 'pata de cerdo curada y formada de tocino'.

\section{TOCINO [tozino]}

Sust. m. 'Panículo adiposo, muy desarrollado, de ciertos mamíferos, especialmente del cerdo' (DRAE). Probablemente derivado del latín provincial tŭcca, al parecer de origen céltico. Tucca significaba 'jugo mantecoso' y de ahí viene el derivado más conocido tŭccētum 'carne de cerdo conservada en salmuera' (DECH, s.v. tocino).

Un tozino de lechón salado, curado y anexo entero mediano y bueno (Coomonte de la Vega, 1643)

Dos tozinos de lechón nuebos salados y enteros (Coomonte de la Vega, 1643)

Un tocino de lechón mediano (Alija del Infantado, 1644)

Dos tozinos que pesarán zien libras (Coomonte de la Vega, 1650)

Dos tozinos que pessan siete arrovas (Huerga de Garaballes, 1720)

Quatro pedazos de tozino (La Bañeza, 1721)

Dos tozinos que pesaron quatro arrobas (Miñambres, 1723)

Quatro arrobas y cinco libras de tozino (Robledo de la Valduerna, 1726)

Dos tocinos con sus menudos que pesaron dos arrobas (Palacios de Jamuz, 1728)

Dos arrobas y media de tozino (Palacios de la Valduerna, 1728)

Dos arrovas de tocino (Miñambres, 1729)

Tres retazos de tozino (Miñambres, 1731)

Doze livras de tozino (Quintana del Marco, 1820)

Quatro libras de tozino (Jiménez de Jamuz, 1825)

Tres arrobas de tozino (Castrillo de la Valduerna, 1828)

Ciento ochenta y tres libras de tozino (Palacios de la Valduerna, 1831)

Es un término común que semánticamente no ofrece ninguna particularidad ya que mantiene el significado genérico usado actualmente. Desde el punto de vista formal, es preciso señalar que todos los ejemplos del término que se recogen en el corpus mantienen la forma normativa con la alternancia común en las grafías para representar el sonido interdental.

\section{UNTO}

Sust. m. 'Crasitud o gordura interior del cuerpo del animal' (DRAE). Término derivado de untar, del latín vulgar ünctare, derivado del latín ŭngěre 'untar, ungir' (DECH, s.v. untar).

Veinte libras de unto (Destriana, 1750)

Una arrova de unto (Palacios de la Valduerna, 1831)

El término se utiliza con el significado que le da el DRAE, aunque se concreta más la acepción en el uso ya que se denomina unto a 'la grasa de la vaca' a diferencia de 
la manteca que es la 'grasa del cerdo'. Con el mismo valor que manteca se usa la palabra untaza, que comparte la misma raíz que unto, y se refiere a la 'grasa del cerdo que se pela de entre las tripas, se coloca junta en una especie de torta aplanada, se deja secar y enfriar, y se adoba con sal los días de la matanza para irla utilizando, a trocitos, con el fin de hacer sopas de ajo, el resto de días del año. También se usa con fines de conservación de cuero o para engrasar ciertas maquinarias, como las ruedas del carro' (Rivas, 1996: 232). Sin embargo, el término untaza no se recoge en ningún ejemplo en el corpus analizado.

\subsection{OBJETOS RELIGIOSOS Y DE DEVOCIÓN}

La presencia de la religión católica en la sociedad de la época, hace que en los inventarios se encuentren con cierta frecuencia objetos religiosos y de devoción. En algunos casos se trata de prendas eclesiásticas, incluso muebles para uso religioso que se encuentran entre los bienes de los sacerdotes. En otros casos se trata de objetos de devoción que, incluso, podrían formar parte de las joyas de una persona, cumpliendo una doble función: servir de protección y de adorno.

\section{ALBA}

Sust. f. 'Vestida o túnica de lienzo blanco que los sacerdotes, diáconos y subdiáconos se ponen sobre el hábito y el amito para celebrar los oficios divinos' (DRAE). Derivado de albo, del latín albus (DECH, s.v. alba).

Una alba con su amito de encajes (Robledo de la Valduerna, 1726)

Es el único ejemplo recogido en el corpus. El término alba se usa en León con otras acepciones que no recoge el DRAE como 'agua o fuente', o en la zona de Valencia de Don Juan 'vino que cría una especie de nata por encima' (Le Men, 2002, s.v. alba). En el corpus, el único ejemplo recogido, muestra por su contexto que su significado es el de 'prenda eclesiástica'.

\section{AMITO}

Sust. m. 'Lienzo fino, cuadrado y con una cruz en medio, que el preste, el diácono y el subdiácono se ponen sobre la espalda y los hombros para celebrar algunos oficios divinos' (DRAE). Tomado del latín amictus, - $-\bar{u} s$, 'envoltura, lo que cubre', 'vestido', derivado de amicire 'envolver' (DECH, s.v. amito).

Otra (pelliza) de morlés con un amito (Robledo de la Valduerna, 1726) 
Una alba con su amito de encajes (Robledo de la Valduerna, 1726)

Son los únicos casos recogidos, aparecen en el mismo inventario perteneciente a un sacerdote, dato que no es extraño puesto que se trata de una prenda eclesiástica y son pocos los inventarios de sacerdotes que se han analizado en este corpus.

\section{CÍNGULO [zíngulo]}

Sust. m. 'Cordón o cinta de seda o de lino, con una borla en cada extremo, que sirve para ceñirse el sacerdote el alba' (DRAE).

Un zíngulo de seda encarnada (Robledo de la Valduerna, 1726)

Es el único ejemplo encontrado que pertenece al inventario de bienes de un sacerdote. Aparece en el corpus, aunque tampoco con frecuencia, el término ceñidor que aunque también sirve para ceñir tiene un uso más general, mientras que el uso del cíngulo se restringe al ámbito eclesiástico.

\section{ROQUETE}

Sust. m. 'Especie de sobrepelliz cerrada y con mangas' (DRAE). Del catalán u occitano roquet 'sobrepelliz', diminutivo de roc también nombre de vestido. Este se tomó del fráncico *rok 'chaqueta' (DECH, s.v. roquete).

Un roquete de tela bastante usado (Destriana, 1843)

Otro (roquete) más usado (Destriana, 1843)

Son los únicos ejemplos recogidos ya que, como señala el $D E C H$, se trata de una sobrepelliz eclesiástica. Los dos ejemplos encontrados pertenecen al inventario de un sacerdote, cura prior de esa villa. Son pocas las relaciones de bienes estudiadas pertenecientes a sacerdotes, pero solo en este caso se han recogido ejemplos del término.

\section{SOLIDEO}

Sust. m. 'Casquete de seda u otra tela ligera, que usan los eclesiásticos para cubrirse la coronilla' (DRAE). Del latín soli Deo 'a Dios solo' porque se lo quitan solamente ante el sagrario (DECH, s.v. solo).

Un solideo (Robledo de la Valduerna, 1726)

Es el único ejemplo encontrado, probablemente debido a una casualidad puesto que se trata de un término común dentro del campo semántico de las prendas 
eclesiásticas y el de Robledo no es el único inventario perteneciente a sacerdotes que se ha analizado en este corpus.

\section{SOTANA}

Sust. f. 'Vestidura talar, abrochada a veces de arriba abajo, que usan los eclesiásticos y los legos que sirven en las funciones de iglesia' (DRAE). Término derivado de so 'debajo de ', del latín sŭb (DECH, s.v. so).

Una media sotanica biexa (Coomonte de la Vega, 1643)

Una sotanilla negra buena (Coomonte de la Vega, 1643)

Una sotana de lo mimo (tafetán) (Robledo de la Valduerna, 1726)

Una sotana con cenidor (Felechares, 1837)

Una sotana tela de paño usada forrada en alapín (Destriana, 1843)

Los ejemplos encontrados pertenecen todos a relaciones de bienes propiedad de sacerdotes, por lo que no es extraño que tampoco abunden los ejemplos, aunque sea una palabra de uso común que tiene el significado actual que aparece en el diccionario académico.

\section{ESCLAVINA}

Sust. f. 'Vestidura de cuero o tela, que se ponen al cuello y sobre los hombros quienes van en romería' (DRAE). Término derivado de esclavo, tomado del griego bizantino sklávos 'esclavo' (DECH, s.v. esclavo).

Una esclavina de tafetán negro (Laguna de Negrillos, 1721)

Solo se ha encontrado este ejemplo a lo largo del corpus. Se trata de una vestimenta que está ligada al ámbito eclesiástico o de peregrinación, dato que explicaría que no sea una prenda que aparezca con frecuencia en los inventarios estudiados.

\section{BREVIARIO [brebiario, vrebiario]}

Sust. m. 'Libro que contiene el rezo eclesiástico de todo el año' (DRAE). Derivado de breve tomado del lat. brěvis (DECH, s.v. breve).

Un brebiario pequeño de todo el año (Robledo de la Valduerna, 1726)

Un juego de vrebiarios (La Nora del Río, 1823)

Un brebiario usado (Felechares, 1837)

Un breviario completo en vuen uso (Destriana, 1843)

En el primer ejemplo y en el último, probablemente la acepción de la palabra es la que da el DRAE en primer lugar y que aparece reflejada al principio, ya que los bienes detallados en estos inventarios pertenecen a sacerdotes. El ejemplo de Felechares forma parte de un inventario perteneciente al Ayuntamiento de dicho lugar. Este dato 
hace suponer que puede tener el mismo significado que en el caso anterior, pero también pudiera tomar la $4^{\text {a }}$ acepción que da el $D R A E$ en la que especifica que se trata de un significado antiguo 'libro de memoria o apuntamiento'. No obstante, ya desde la segunda edición del DRAE se hace la matización "de antiguo", dato que puede hacer dudar de que se esté utilizando con este significado. En cuanto al tercer ejemplo, no hay datos que nos lleven a ninguna conclusión a este respecto, puesto que se desconoce al propietario del bien. Formalmente, el término se presenta de dos maneras. En los dos primeros ejemplos aparece bajo la forma brebiario, que aparece también recogida en diez casos del CORDE, todos ellos ejemplos pertenecientes a relaciones de bienes. La forma del tercer ejemplo, es muy poco frecuente.

\section{EVANGELIO [ebangelio]}

Sust. m. El DRAE en su $6^{\mathrm{a}}$ acepción define el término como 'libro forrado comúnmente en tela de seda, en que se contiene el principio del Evangelio de San Juan y otros tres capítulos de los otros tres evangelistas, el cual se solía poner entre algunas reliquias y dijes a los niños, colgado en la cintura'. Del latín evangelium, griego euangélion 'el buen anuncio, la buena nueva' (DECH, s.v. ángel).

Un rocadero bordado, una bolsa y ebangelios (Grajal de la Ribera, 1806)

Unos evangelios (Saludes de Castroponce, 1808)

Los evangelios, normalmente usado el término en plural, aparecen en los inventarios como objetos de devoción ya que se usaban como un tipo de escapularios. Solían ir forrados de seda, incluso con algún bordado, y se llevaban como protectores.

\section{REGLA (vid. herramientas profesionales)}

\section{ESCAPULARIO}

Sust. m. 'Objeto devoto formado por dos pedazos pequeños de tela unidos con dos cintas largas para echarlo al cuello' (DRAE). Término tomado del latín scapularia, neutro plural del adjetivo scapularis 'que cuelga sobre los hombros' (DECH, s.v.escapulario).

Tres pares de escapularios (Grajal de Ribera, 1806)

Siete pares de escapularios bordados en seda y plata (Grajal de Ribera, 1806)

Cinco lazos de cinto, cinco gondones de seda, dos escapularios, una regla de S. Benito y otros dijes (Jiménez de Jamuz, 1825)

Un zesto de ofrecer y un escapulario (Felechares, 1838)

Unas reglas de S. Benito con su zerna y dos escapularios (Calzada, 1838) 
Es un término común. No presenta ninguna particularidad ni semántica ni formal. No son muchos los ejemplos y todos son del S. XIX. Este dato no es significativo y se debe más bien a una casualidad.

MISAL

Sust. m. 'Adj. Se dice del libro en que se contiene el orden y modo de celebrar la misa' (DRAE). Derivado de misa, tomado del latín m̌ssa (DECH, s.v. misa).

Un misal nuevo con sus broches de metal sin perjuicio que corresponda o no a la Yglesia (Destriana, 1843)

Es el único ejemplo recogido en un inventario perteneciente al cura prior de esta villa. Aunque el diccionario académico señala el término como adjetivo libro misal, el uso gramatical que se hace en el corpus es el de sustantivo.

\section{SEMANILLA}

Sust. f. 'Libro que contiene el rezo y los oficios de Semana Santa' (DRAE). Término derivado de semana, del latín septǐmāna (DECH, s.v. siete).

Una semanilla con broches de metal (Destriana, 1843)

Es el único ejemplo recogido que aparece en el inventario de un sacerdote, el significado es el que actualmente tiene el término y que aparece recogido en el DRAE.

PILA (vid. otros)

\section{ANDAS}

Sust. f. 'Tablero que, sostenido por dos varas paralelas y horizontales, sirve para conducir efigies, personas o cosas' (DRAE). Término procedente del lat. amŭtes, pl. de ames (DECH, s.v. andas).

Unas andas de santo con sus varas (Pobladura del Valle, 1733)

Solo se ha recogido este ejemplo. Se trata de una palabra común pero el objeto que denomina no suele aparecer en relaciones de enseres de personas particulares. Este dato explicaría la escasez de ejemplos, ya que el único recogido pertenece al inventario del concejo de la villa. 
DOSEL

Sust. m. 'Mueble que a cierta altura cubre o resguarda un altar, sitial, lecho, etc., adelantándose a un pabellón horizontal y cayendo por detrás a modo de colgadura'. 'Antepuerta o tapiz' (DRAE). Derivado de dorso, del latín dŏrsum (DECH, s.v. dorso).

Un dosel de damasco encarnado (Robledo de la Valduerna, 1726)

Es el único ejemplo recogido en el corpus, al tratarse del inventario de un sacerdote, es muy probable que se refiera a una especie de altar tal y como se refleja en el diccionario de Aut. 'Adorno honorífico y majestuoso (...), se hace de terciopelo, damasco u otra tela, guarnecido de galones o flecos, y a veces bordado de oro o seda. Sirve para poner las imágenes en los altares, y también lo usan los reyes y los prelados'.

\section{ESTAMPA}

Sust. f. 'Reproducción de un dibujo, pintura, fotografía, etc., trasladada al papel o a otra materia' (DRAE). De origen germánico, probablemente del francés estamper, antiguamente 'machacar', 'aplastar', y este del fráncico *stampôn.

Dos estanpicas, la una de papel y la otra de caxa (Alija del Infantado, 1644)

Quince estampillas de papel de diferentes pinturas (Laguna de Negrillos, 1734)

Diferentes estanpas de papel (La Bañeza, 1754)

Una estampa con la figura de un obispo (Quintanilla de Somoza, 1831)

Una estampa de Nuestra Señora del Prado (Quintanilla de Somoza, 1831)

Seis estampas en papel (Felechares, 1837)

El término toma el significado común y, como se puede apreciar en los ejemplos, la mayoría de las estampas que se recogen en los inventarios son de papel, fundamentalmente con motivos religiosos.

\section{CRUCIFIJO [crucifixo]}

Sust. m. 'Efigie o imagen de Cristo crucificado' (DRAE). Término tomado del latín crucifigěre (DECH, s.v. cruz).

La echura de un crucifijo de marfil con la cruz y peana de ébano (Palacios de la Valduerna, 1726)

Dos crucifixos pequeños (Pobladura del Valle, 1734)

Es un término común, aunque solo se han encontrado dos ejemplos, que tienen el significado que da el DRAE. Al igual que las cruces, eran símbolos de cristiandad que se utilizaban como talismán y expresión del sentimiento religioso, por ello eran frecuentes en las collaradas en diferentes advocaciones y materiales. 


\section{RELICARIO}

Sust. m. 'Caja o estuche comúnmente precioso para custodiar reliquias' (DRAE). Del latín reliquiae, -arum 'restos', 'residuos' (DECH, s.v. reliquia).

Un relicario guarnezido (La Bañeza, 1641)

Un relicario con el engaste de plata (La Bañeza, 1721)

Una cruz y dos relicarios de plata, un par de botones de lo mismo (Robledo de la Valduerna, 1726)

El culto a las reliquias se remonta a los orígenes de la Iglesia. Estas no eran fáciles de conseguir, lo que explicaría la escasez de ejemplos en el corpus. Estas reliquias solían guardarse en relicarios que eran una especie de pequeñas cajas con formas distintas que podían ser de plata, como la aquí indicada, de plata sobredorada, etc, solían estar protegidas por un vidrio en ambas caras. La reliquia solía estar apoyada en papel acartonado. En estos ejemplos la información que se da es escasa ya que desconocemos cómo era la reliquia, el fondo, etc. En definitiva eran un tipo de joya ya que formaban parte de las collaradas.

\section{RELIQUIA}

Sust. f. 'Parte del cuerpo de un santo' (DRAE). Del latín reliquiae, -arum 'restos', 'residuos' (DECH, s.v. reliquia).

Una mesa con su cajón, cerradura y llave y en ella una bolsa con diferentes reliquias (Laguna de Negrillos, 1721)

Una reliquia con su zerco de plata (Miñambres, 1727)

Una reliquia de plata mediana con las echuras de S. Carletín y S. Antolín (Grajal de la Ribera, 1730)

Una reliquia con cerco de plata (Saludes de Castroponce, 1808)

A excepción del primer ejemplo, en los otros tres podemos decir que se trata de una joya, ya que como señalé en el caso del término relicario, la reliquia solía estar protegida por un cristal rodeado de plata, normalmente. Eran especie de medallones que formaban parte de las collaradas. El primer ejemplo no se correspondería con este tipo de objeto, aunque la información que nos da tampoco nos permite saber de qué reliquias se trataba ni cómo eran.

\section{ROSARIO}

Sust. m. 'Sarta de cuentas, separadas de diez en diez por otras de distinto tamaño, unida por sus dos extremos a una cruz, que suele adornarse con medallas u otros objetos de devoción y sirve para hacer ordenadamente el rezo del mismo nombre o una de sus partes' (DRAE). Término derivado de rosa, del latín rŏsa (DECH, s.v. rosa). 
Un rosario de azabache (La Bañeza, 1641)

Sendos rosarios el uno de coral fino (La Bañeza, 1643)

Un rosario de azabache con una cruzezita de plata (La Bañeza, 1721)

Tres rosarios de Jerusalén (Grajal de la Ribera, 1806)

Un rosario de Jerusalén (La Bañeza, 1829)

Dos pendientes con diamantes, dos anillos y un rosario de plata sobredorada para el cuello (Destriana, 1870)

Los rosarios son objetos de devoción que se conocen desde el S. XIII aunque no sean muchas las muestras encontradas en el corpus. Como se observa en los ejemplos, en ellos se detalla el material del que están fabricados ya que su valor depende de este dato. Dentro de los materiales de valor era frecuente encontrarlos de azabache o de coral. Con respecto a los de azabache, hay un documento en el que Antonio de Lalaing, cuando formó parte de la corte de Felipe el Hermoso, señala que estos rosarios que compran los peregrinos en Santiago se hacían en León donde estaban las minas de azabache (Cavero y Alonso, 2002: 245). Por tanto, es de suponer que eran frecuentes este tipo de rosarios de valor, aunque aquí solo se recoja un ejemplo. Otro tipo de rosarios frecuentes, que también se documentan en el corpus, son los de Jerusalén, llamados así porque llevaban la cruz llamada de Jerusalén. El último ejemplo especifica el uso y señala que es para el cuello. Este dato indica que eran rosarios que se utilizaban de adorno y se incorporaban a las collaradas, son frecuentes sobre todo en el S. XVIII.

\subsection{MATERIALES}

Igual que ocurre con los términos de color, en un intento por describir detalladamente los objetos que aparecen en las relaciones de bienes, es frecuente que se especifique el material del que están elaborados. Por este motivo, he agrupado estos términos bajo la denominación de materiales. Asimismo en este apartado los términos se agrupan por el parecido que existe en el tipo de material (metal, madera, mimbre, etc.).

\subsubsection{Metales}

\section{AZÓFAR [açófar]}

Sust. m. 'Latón' (DRAE). Del árabe sufr (derivado de 'ásfar 'amarillo') (DECH, s.v. azófar).

Dos candeleros de azófar buenos (Coomonte de la Vega, 1645)

Un candelero de azófar pequeño (Coomonte de la Vega, 1650)

Un perol de açófar mediano (La Bañeza, 1647)

Un caço de açófar grande bueno (La Bañeza, 1647)

Un cazo de azófar mediano bueno (Huerga de Garaballes, 1720)

Un cazo de azófar pequeño (Huerga de Garaballes, 1720) 
Un cazo bueno de azófar (Genestacio de la Vega, 1721)

Un calentador de azófar con el mango de yerro (La Bañeza, 1721)

Cuatro cazos de azófar dos medianos y dos pequeños (Laguna de Negrillos, 1722)

Tres cazos viejos y uno nuevo de azófar (Robledo de la Valduerna, 1726)

Un perol y una caldereta de azófar (Robledo de la Valduerna, 1726)

Un cazo de azófar (Destriana, 1730)

Una caldera de azófar (Laguna de Negrillos, 1734)

Otro (cazo) de azófar mediano (Requejo de la Vega, 1735)

Dos cazos de azófar medianos (Laguna de Negrillos, 1740)

Un calderico de azófar (La Nora del Río, 1823)

Una espumadera de azófar (Castrillo de la Valduerna, 1828)

Un cazo de azófar (Castrillo de la Valduerna, 1828)

Un caldero chico de azófar (Quintana del Marco, 1839)

Un cazo de azófar (Destriana, 1843)

Un caldero de azófar usado (Destriana, 1843)

Una chocolatera de azófar regular con su molinillo y tapa (Destriana, 1843)

Es el término que se usaba para designar el latón. Es muy frecuente en las relaciones de bienes ya que, como se observa en los ejemplos, era un material que se utilizaba mucho en los utensilios de cocina. Todos los ejemplos que se recogen aparecen en este contexto.

\section{COBRE}

Sust. m. 'Elemento químico de núm. atóm. 29. Metal abundante en la corteza terrestre, se encuentra nativo o, más corrientemente, en forma de sulfuro. De color rojo pardo, brillante, maleable y excelente conductor del calor y la electricidad. Forma aleaciones como el latón o el bronce, y se usa en la industria eléctrica, así como para fabricar alambre, monedas y utensilios diversos' (DRAE). Del latín cŭprum, procedente del griego Kýpros, nombre propio de la isla de Chipre, donde se obtenía en abundancia este metal (DECH, s.v. cobre).

Dos pesas de valanças de cobre (La Bañeza, 1641)

Un caldero de cobre usado (La Bañeza, 1641)

Una caldera grande biexa de cobre (Coomonte de la Vega, 1643)

Una caldera de cobre mediana (Coomonte de la Vega, 1645)

Un peso de balanzas de cobre (La Bañeza, 1710)

Un gubilete de cobre (La Bañeza, 1721)

Una caldera grande de cobre (La Bañeza, 1721)

Una chocolatera de cobre con su molinillo sin tapa (La Bañeza, 1721)

Un caldero de cobre de sacar agua biejo (Laguna de Negrillos, 1722)

Un braserico de cobre (Grajal de la Ribera, 1723)

Un brasero de cobre con caja de nogal (Robledo de la Valduerna, 1726)

Una caldera de cobre que ará tres cántaros (Palacios de la Valduerna, 1728)

Un peso de balanzas de cobre y una pesa (Palacios de la Valduerna, 1730)

Un brasero de cobre (Pobladura del Valle, 1734)

Una gubiletera de cobre con unas tijeras de espabilar (Laguna de Negrillos, 1734)

Una caldera de cobre (Requejo de la Vega, 1735)

Una chocolatera de cobre (Grajal de la Ribera, 1806) 
Una chocolatera de cobre (Alija del Infantado, 1823)

Una tartera de cobre mediana (Quintanilla de Somoza, 1831)

Una chocolatera grande de cobre (Requejo de la Vega, 1839)

Dos tarteras de cobre medianas (Requejo de la Vega, 1839)

Es un nombre muy común que aparece a menudo en los inventarios puesto que es un metal con el que se fabricaban bastantes objetos, especialmente recipientes.

\section{HIERRO [yerro, ierro, yierro, fierro]}

Sust. m. 'Metal más empleado en la industria; aleado con el carbono forma aceros y fundiciones' (DRAE). Del latín fĕrrum (DECH, s.v. hierro).

Una cadena de yerro de prender una cabalgadura (Coomonte de la Vega, 1643)

Una pesa de yerro de una libra (Coomonte de la Vega, 1643)

Una garlopa con su yerro de acepillar (Coomonte de la Vega, 1643)

Dos ferraduras de yerro biexas (Coomonte de la Vega, 1643)

Un yerro de un frasco (Coomonte de la Vega, 1643)

Dos assadores de ierro (Urdiales del Páramo, 1645)

Dos garabitos de ierro (Urdiales del Páramo, 1645)

Un gato de ierro de enarcar (Urdiales del Páramo, 1645)

Una mela de yerro (Alija del Infantado, 1650)

Una plomada de yerro (Coomonte de la Vega, 1719)

Dos tiraderos con sus yerros (Genestacio de la Vega, 1721)

Un candil de hierro (La Nora del Río, 1724)

Unos morrillos pequeños de yerro (Robledo de la Valduerna, 1726)

Setenta y zinco libras de ierro biejo (Robledo de la Valduerna, 1726)

Una garduñera de ierro bieja (Miñambres, 1727)

Un arca de yerro (Miñambres, 1727)

Un peso de ierro (Palacios de Jamuz, 1728)

Un pote de yerro (Miñambres, 1728)

Una alabarda de yerro (Miñambres, 1728)

Una reja y una clavija de yerro (Destriana, 1730)

Una trona bieja y un caldero de yerro (Priaranza, 1732)

Unos garfios de ierro (Laguna de Negrillos, 1734)

Unas trévedes de yerro buenas (Laguna de Negrillos, 1740)

Unas trébedes pequeñas de fierro (La Bañeza, 1758)

Dos coverteras de yerro (Alija del Infantado, 1812)

Un poco de yerro y una aldaba (Castrocalbón, 1814)

Un candil de hierro (Castrillo de la Valduerna, 1828)

Un azadín de hierro (Valle de la Valduerna, 1829)

Unas espaviladeras de yerro (La Bañeza, 1829)

Una arroba de yierro biejo (Quintanilla de Somoza, 1831)

Una pala de yierro (Quintanilla de Somoza, 1831)

Una forcada de yierro en dos (Quintanilla de Somoza, 1831)

Una forca de yierro para la yerba (Quintanilla de Somoza, 1831)

Un tajo de yerro (Felechares, 1836)

Seis cubiertos de hierro (Requejo de la Vega, 1839)

Todo el yerro menudo tasado con una cerradura, dos cachos de gadaña y otros chismes (Santibáñez de la Isla, 1844)

Son numerosos los ejemplos que aparecen del término, por ello los que se muestran son una selección. En todos los casos, excepto en uno, la voz hierro nombra el 
metal del que están hechos los objetos que se relacionan, ya sean palas, cubiertos, candiles, pesas, etc. Hay además algunos ejemplos en los que, nombrando también el metal, se refiere a piezas de este material sin conformar. Sin embargo, en repertorios leoneses se documenta el término hierro con otras acepciones más concretas. Así se denomina hierro a 'hierro que sirve para marcar el ganado', 'conjunto de cencerras de un rebaño y el sonido peculiar que producen', pl. 'conjunto del martillo y del yunque para sacar o renovar el corte a la guadaña' (Le Men, 2005, s.v. fierro). En el corpus estudiado solo se ha recogido un ejemplo en el que el significado es el de 'hierro para marcar el ganado', pero el término con el que se nombra el objeto no es hierro, este sería el material, sino que es la voz mela. No obstante, la mela suele utilizarse con las ovejas ya que se las marca con pintura, mientras que el hierro que sirve para melar es un hierro que se calienta y que marca a los animales sobre su piel, a equinos y ovinos. Formalmente, es significativo señalar que a pesar de que el corpus forma parte de una zona occidental en la que sería esperable encontrar la conservación de /f-/, solo aparece en un ejemplo aislado, a diferencia de otras palabras que incluso sí la mantienen y que aparecen en estos ejemplos, como es el caso de la forcada de Quintanilla de Somoza.

\section{HOJALATA [ojalata]}

Sust. f. 'Lámina de hierro o acero, estañada por las dos caras' (DRAE). Término compuesto, antes hoja de lata. Hoja del latín fŏlĭa, plural de fŏlı̆um (DECH, s.v. hoja).

Un espadín de puño de ojalata (Robledo de la Valduerna, 1726)

Otro (candil) de ojalata (Castrillo de la Valduerna, 1828)

Una linterna de ojalata (La Nora del Río, 1823)

Una fiambrera de ojalata (La Nora del Río, 1823)

Es un término común que es utilizado con el significado que da el diccionario académico.

\section{LATÓN}

Sust. m. 'Aleación de cobre y cinc, de color amarillo pálido y susceptible de gran brillo y pulimento' (DRAE). Del árabe lātûn, que parece ser voz procedente del Asia central, en cuyas lenguas turco-tártaras altun y sus variantes designan el oro y, en algunas partes, el cobre (DECH, s.v. latón).

Un belón de latón con su pie (La Bañeza, 1721)

Una lámpara pequeña de latón con su baso (La Bañeza, 1721)

Solo se han recogido estos ejemplos del término ya que al ser sinónimo de 
azófar, esta es la voz que aparece generalizada en el corpus, quizá el empleo de este término en este inventario tenga relación con que aparece con objetos que no son utensilios de cocina, sino artículos que tienen además de su función una finalidad decorativa. En el NTLLE también se registra la voz alatón, aunque se indica ya en la edición de 1726 que es voz de poco uso. Bajo esta forma no se recoge ningún ejemplo en el corpus.

\section{ORO}

Sust. m. 'Metal, se usa como metal precioso en joyería y en la fabricación de monedas y, aleado con platino o paladio, en odontología' (DRAE). Del latín aurum (DECH, s.v. oro).

Dos anillos de oro con sus piedras una blanca y otra verde (La Bañeza, 1641)

Un jubón de tela de oro (La Bañeza, 1643)

Un rebociño con tres pasamanos de oro (La Bañeza, 1643)

Una pieza de cristal con sus estremos de oro y dos láminas de Nuestro Salvador y María (La Bañeza, 1649)

Dos sortijas de oro la una de cuatro piedras y la otra de una flor de lis (La Bañeza, 1649)

Un cruz de cristal con sus remaches de oro (La Bañeza, 1649)

Un anillo y una sortija de oro con piedras falsas (Robledo de la Valduerna, 1726)

Al tratarse de un término que designa un metal valioso, los ejemplos se reducen a un número reducido de inventarios, la mayor parte de ellos, como ocurre con otros objetos de valor, pertenecientes a inventarios localizados en La Bañeza, y los dos últimos pertenecientes a un inventario de gran valor, propiedad de un sacerdote. En la mayor parte de los casos, el término aparece especificando el material de diferentes joyas y en algunos casos indicando o bien la tela o bien el hilo de alguna prenda de gran valor.

\section{PELTRE}

Sust. m. 'Aleación de cinc, plomo y estaño' (DRAE). Voz común a todos los romances de Occidente y a algunas lenguas germánicas, de origen desconocido, la forma castellana parece tomada del occitano o catalán (DECH, s.v. peltre).

Una serbilla de peltre buena (Coomonte de la Vega, 1643)

Dos platos de peltre el uno grande y el otro pequeño (Alija del Infantado, 1644)

Un plato quebrado de peltre (La Bañeza, 1721)

Una servilla de peltre vieja (La Bañeza, 1829)

Una servilla de peltre (Castrocalbón, 1832)

Una palancana de peltre rota (Destriana, 1843) 
El término se usa con el significado que aparece en el diccionario académico, se encuentra ampliamente documentado en los inventarios puesto que el peltre es un tipo de aleación que se usó en los utensilios de cocina.

\section{PLATA}

Sust. f. 'Metal escaso en la corteza terrestre, se encuentra nativo, en granos o vetas, y en algunos minerales. De color blanco, brillante, con sonoridad peculiar, muy dúctil y maleable y muy buen conductor del calor y la electricidad. Se usa como catalizador, en la fabricación de utensilios y monedas, en joyería y en odontología y muchas de sus sales tienen empleo en fotografía por ser sensibles a la luz' (DRAE). Del femenino del adjetivo latino * plattus, que en bajo latín aparece sustantivado con el sentido de 'lámina, por lo general metálica', y en la Península Ibérica se especializó todavía más designando el metal llamado en latín argentum (DECH, s.v. plata).

Una gargantilla de azabache con siete piezezillas de plata (La Bañeza, 1641)

Tres cornalinas guarnecidas de plata (La Bañeza, 1641)

Una cruz de Santo Toribio guarnezida en plata (La Bañeza, 1641)

Tres cuchares de plata buenas (Coomonte de la Vega, 1643)

Un jarro y un salero y un salpimentero y un azucarero todo de plata (La Bañeza, 1643)

Un par de chapines con hevillas de plata (La Bañeza, 1643)

Cinco vueltas de corales con cinco alconciles y dos sortijas de plata (Coomonte de la Vega, 1645)

Una cruceta de plata con una figura de un Santo Cristo (Coomonte de la Vega, 1645)

Un cristo de plata pequeño (Coomonte de la Vega, 1645)

Un xoel de plata (La Antigua, 1647)

Unas almendrillas de plata pequeñas (La Antigua, 1647)

Una xoya de plata (La Antigua, 1648)

Unas alvillas de plata lissa, una lamparita de beber, una pililla de agua vendita (La Bañeza, 1649)

Una cama con balaustres de plata (Laguna de Negrillos, 1721)

Dos votones de plata (Coomonte de la Vega, 1722)

Un jubón de ante con galones de plata (Robledo de la Valduerna, 1726)

Beinte y dos libras de plata labrada (Robledo de la Valduerna, 1726)

Dos juncos uno con puño de plata (Robledo de la Valduerna, 1726)

Seis alconziles y una cruz de plata (Miñambres, 1727)

Un anillo grande y dos más chicos todo de plata (Miñambres, 1727)

Una buelta de corales con tres alconziles de plata (Palacios de Jamuz, 1728)

Unas almendrillas de cristal guarnecidas en plata (Palacios de la Valduerna, 1730)

Un joel de plata con la echura del Ángel y la Soledad (Palacios de la Valduerna, 1730)

Una reliquia de plata mediana con las echuras de S. Carletín y S. Antolín (Palacios de la Valduerna, 1730)

Una taza y dos vasos de plata (Coomonte de la Vega, 1734)

Siete pares de escapularios bordados en seda y en plata (Grajal de la Ribera, 1806)

Tres medallas de plata y una piedra con el asa de plata y una cruz encartonada de plata (Grajal de la Ribera, 1806)

Una reliquia con cerco de plata (Saludes de Castroponce, 1808)

Seis cuchillos con mangos de plata (La Nora del Río, 1823) 
Seis cubiertos de plata usados que pesan treinta y una onzas a razón de quince cada una (La Bañeza, 1829)

Un espejo antiguo con labores de cascarilla de plata (Requejo de la Vega, 1839)

Es un término muy común. Como se aprecia en los ejemplos, en algunos casos la voz aparece junto a objetos como pueden ser vasos, cubiertos, etc. pero lo más frecuente es encontrar la voz junto a joyas, ya que normalmente estas eran de plata. Aunque el término se ha documentado en la zona centro occidental de León bajo la variante prata, no se ha recogido ningún ejemplo con esta forma en el corpus.

\section{SOBREDORADO/A [sovredorado/a]}

Adj. m. y f. Término derivado de sobredorar 'dorar los metales, y especialmente la plata' (DRAE). Palabra compuesta de sobre, del latín sŭper (DECH, s.v. sobre) y dorar del latín deaurare (DECH, s.v. oro).

Una caxa de madera sobredorada con una echura de un Santo Cristo de bulto (La Bañeza, 1647)

Un espexo grande con su caxa y figuras sobredorados (La Bañeza, 1649)

Unas arracadas de plata sobredoradas (Destriana, 1730)

Un aderezo de plata sobredorado (Grajal de la Ribera, 1806)

Un adrezo de cruz y pendientes sovredorado (Alija del Infantado, 1812)

El metal más común del que estaban hechas las joyas era la plata, no en vano, había artesanos que trabajaban la plata tanto en La Bañeza como en Astorga. Este metal podía estar sin dorar, se llamaba plata blanca o dorada que era la denominada sobredorada.

\subsubsection{Piel}

\section{BADANA [vadana]}

Sust. f. 'Piel curtida y fina de carnero u oveja' (DRAE). Del árabe bitâna 'forro', vulgarmente batâna, que en España y otras partes tomó el significado de 'badana' porque con ella se forraban otros cueros (DECH, s.v. badana).

Un cofre forrado por fuera en vadana (Alija del Infantado, 1734)

La escasez de ejemplos resulta, en este caso, más bien casual puesto que se trata de un término muy usado y frecuente en los corpus. 


\section{CUERO [quero]}

Sust. m. 'Pellejo después de curtido y preparado para los diferentes usos a que se aplica en la industria'. 'Odre' (DRAE). Del latín cŏrĭum 'piel del hombre o de los animales' (DECH, s.v. cuero).

Unas bolsas de cuero de cacador con un martillico y un poco de plomo (Coomonte de la Vega, 1643)

Un quero bueno que haçe dos cántaras de vino (Coomonte de la Vega, 1645)

Un cuerón nuevo de tener vino que ara dos cántaras (Coomonte de la Vega, 1650)

Quatro cueros biexos de tener bino (Bercianos, 1648)

Un cofre forrado en cuero de cavallo con zerradura (Miñambres, 1727)

El término se usa con los dos significados que da el DRAE, el de 'pellejo curtido empleado para diferentes usos', ya sea una bolsa de cazador o como forro de un cofre; y con el de 'odre para guardar el vino' en los ejemplos de Coomonte de la Vega de 1650 y en el de Bercianos. En el de 1650, el término aparece con un sufijo cuyo valor es el de aumentativo, indica un odre grande con capacidad de 641.

\section{ENCORADO}

Adj. m. Participio de encorar 'cubrir con cuero algo' (DRAE). Término derivado de cuero, del latín cŏrĭum (DECH, s.v. paloma).

Un cofre encorado bueno (La Bañeza, 1643)

Un cofre grande negro encorado (La Bañeza, 1643)

Un cofre encorado grande bueno con su cerradura y llabe (La Bañeza, 1647)

Son los únicos ejemplos del corpus. En todos ellos aparece junto al término cofre para señalar que está cubierto de cuero.

\section{GUADAMECIL [guadamaçil]}

Sust. m. 'Cuero adobado y adornado con dibujos de pintura o relieve' (DRAE). Del árabe ŷild gadèmesî 'cuero de Gadámes' ciudad de Tripolitamia donde se preparaba este famoso artículo (DECH, s.v. guadamecí).

Un vufete de nogal vueno de dos tavlas con su erraxe y cantoneras y su tapete de guadamaçil usado (La Bañeza, 1649)

Es el único ejemplo encontrado. Esta ausencia es explicable ya que se trata de un término que, como en otros casos, designa un material muy específico y de cierta calidad que no es frecuente en los inventarios de enseres dométicos. La variante con /a/ guadamacil se debe a un fenómeno de asimilación que no es significativa y se encuentra en documentos de todas las procedencias. 


\section{PELLEJO [pellexo, pelexo, pillejo]}

Sust. m. 'Piel del animal, especialmente cuando está separada del cuerpo'. 'Odre' (DRAE).

Término derivado de piel, del latín pĕllis (DECH, s.v. piel).

Un pellexo de tener vino que ará dos cántaras (Coomonte de la Vega, 1643)

Dos cobertores de pellexo de perro (Alija del Infantado, 1644)

Seis pelexos de obexas y carneros (Coomonte de la Vega, 1645)

Una bolsa de pellexo grande (Alija del Infantado, 1647)

Un pellexo de tener bino que ará tres cántaras buenas (Coomonte de la Vega, 1650)

Diez pellejos de azer bino (Robledo de la Valduerna, 1726)

Dos pellejos viejos de azer bino (Palacios de Jamuz, 1728)

Un cofre forrado en pellejo de cavallo con zerradura y llave (La Bañeza, 1714)

Un baúl de pellejo rojo (La Bañeza, 1743)

Un baúl forrado en pellejo (La Bañeza, 1743)

Tres pellejos viejos de hacer bino (La Bañeza, 1754)

Un pellejo de tener vino (Castrocalbón, 1814)

Quatro pellejos de tener vino (La Nora del Río, 1823)

Dos pellejos de hacer vino (Quintanilla de Somoza, 1831)

Dos baúles grandes forrados de pellejo (Castrocalbón, 1832)

Dos pellejos para vino (Felechares, 1837)

Un pillejo de tener vino (Calzada, 1838)

Un pellejo de hacer vino (Destriana, 1843)

Dos pellejos de tener vino el uno roto y el otro en vuen uso (Destriana, 1843)

Es un término común que aparece en el corpus con dos acepciones, ambas recogidas en el diccionario académico. Por una parte, se denomina pellejo a la 'piel de los animales cuando ya está separada del cuerpo', esta piel se utiliza para forrar baúles y otros objetos y también se usa el término con el significado de 'odre', en este caso siempre aparece acompañado de las expresiones de "hacer vino" o "tener vino". Formalmente, el término suele aparecer bajo la forma común pellejo, aunque hay algún caso en el que se produce un cierre de la vocal /e/ en /i/.

PIEL

Sust. f. 'Cuero curtido' (DRAE). Del latín pĕllis (DECH, s.v. piel).

Una basquiña de piel de rata aforrada (La Bañeza, 1641)

Una piel de yegua (Miñambres, 1729)

Quatro pieles de macho cabrío (Destriana, 1730)

Una cubierta de silla de pieles (Alija del Infantado, 1812)

Dos pieles de cabra (Quintanilla de Somoza, 1831)

Una piel negra de castrón (Quintanilla de Somoza, 1831)

Dos pieles de perro (Quintanilla de Somoza, 1831)

Es un término de uso común. Su significado es el de 'pellejo de animal'. Aunque en León y en otras zonas del occidente peninsular se documenta la forma pel, en el corpus solo se recoge el término con la variente diptongada. 


\section{RAPOSO}

Sust. m. El DRAE señala el término como sinónimo de zorro. Variante del antiguo y dialectal rabosa, probablemente derivado de rabo, por lo gordo y característico de esta parte del cuerpo en este animal (DECH, s.v. raposa).

Unos esquilones con collares de raposo (Coomonte de la Vega, 1645)

Es un término común que se utiliza con el significado de 'zorro'. En el contexto en el que aparece el único ejemplo recogido del término, hay que interpretar que se trata de unos esquilones cuyos collares para colgarlos del cuello del animal están hechos de piel de zorro.

\section{VAQUETA [baqueta]}

Sust. f. 'Cuero de ternera curtido y adobado' (DRAE). Término derivado de vaca, del latín vacca (DECH, s.v. vaca).

Una sombrerera de baqueta buena (Coomonte de la Vega, 1643)

Unos capatos de baqueta buenos (Coomonte de la Vega, 1643)

Seis taburetes de baqueta (La Bañeza, 1721)

Dos sillas de vaqueta (La Bañeza, 1721)

Dos sillas de vaqueta negra (Laguna de Negrillos, 1722)

Quatro sillas de vaqueta viejas (Laguna de Negrillos, 1734)

Unos zapatos de baqueta (Alija del Infantado, 1737)

Una silla de baqueta (Grajal de la Ribera, 1750)

Es un término común que mantiene el significado que da el diccionario académico y puesto que se trata de un tipo de cuero, en el corpus aparece sobre todo, al igual que los ejemplos que ofrece el CORDE, aplicado a sillas y a calzado.

\subsubsection{Madera}

\section{HUMERO [omero, umero]}

Sust. m. 'Omero, aliso, árbol que bordea las orillas de los arroyos y da una madera de color amarillento, dura, muy buena para estacadas y otras obras en el agua' (Le Men, 2007, s.v. humero). De un *aminarius de origen desconocido o de *ulminarius o *ulmanarius de ulmus, 'olmo', o acaso un cruce de olmus con alnus (DECH, s.v. álamo).

Un baral de omero mediano (Coomonte de la Vega, 1643)

Dos docenas de latas de umero (Coomonte de la Vega, 1645)

Una arca de umero (Priaranza, 1732)

Un banco de humero (Destriana, 1825)

Es un término bastante común que no es recogido por el DRAE, aparece para nombrar la madera de la que están hechos distintos objetos. Se trata de la palabra 
utilizada en esta área para denominar el aliso, término que, por otra parte, no se recoge en el corpus. La voz presenta distintas variantes, todas ellas documentadas en distintas zonas de León e incluso en zonas próximas a la estudiada, como Benavente. El DRAE recoge el término bajo la forma omero.

\section{MADERA}

Sust. f. 'Pieza de madera labrada que sirve para cualquier obra de carpintería' (DRAE).

Del latín matěria 'madera de árbol', 'madera de construcción', 'materiales', 'materia' (DECH, s.v. madera).

Un arca de madera con su llave (Castrocalbón, 1643)

Una panera de madera (Castrocalbón, 1643)

La madera de una cama nueba de nogal al parezer (Coomonte de la Vega, 1643)

Una mesica de madera de álamo buena (Coomonte de la Vega, 1643)

Un albardonzico con sus aziones y estribos de madera buenos (Coomonte de la Vega, 1643)

La madera de otro cepillo (Coomonte de la Vega, 1643)

Siete cucharitas de madera curiosas y buenas (Coomonte de la Vega, 1643)

Un bufete con los pies de madera y un caxón debajo del sin llave (Coomonte de la Vega, 1643)

Un escaño de madera ya usado (Coomonte de la Vega, 1643)

Dos tajadores de madera (Alija del Infantado, 1644)

Doçe pieças de madera de negrillo (La Antigua, 1647)

Un yugo de yeguas de madera (Coomonte de la Vega, 1650)

La madera de una cama (La Bañeza, 1712)

Una ruedas desquartadas con una porción de madera (Viñas, 1726)

Dos tornaderas de madera (Palacios de la Valduerna, 1728)

La madera suelta de una casa con sus maderitos (Palacios de la Valduerna, 1730)

Un pilón de madera (Laguna de Negrillos, 1750)

La madera de una cama de aya con sus balaustres (Grajal de la Ribera, 1750)

Dos fuentes de madera (La Bañeza, 1754)

Un plato de madera y quatro cubiertos de boga (Grajal de la Ribera, 1806)

Dos taburetes de madera (Alija del Infantado, 1812)

Dos catres de madera vlanca (La Nora del Río, 1823)

Tres platos de madera (Castrillo de la Valduerna, 1828)

Un catre de testera dorada madera de pino (La Bañeza, 1829)

Dos pesebres de madera (Felechares, 1837)

Un telar de tejer lienzo con sus tenpleros de madera con yerro a las puntas (San Feliz, 1838)

Un estante de madera (Requejo de la Vega, 1839)

Nuebe cajones de madera ordinarios (Requejo de la Vega, 1839)

Un rastrillo de telas de madera (Requejo de la Vega, 1839)

Una pitera de madera (Requejo de la Vega, 1839)

Un pilón de madera (Santibáñez de la Isla, 1844)

El término es muy frecuente en los inventarios puesto que son muchos los objetos fabricados con madera. Prácticamente en todos los ejemplos, la palabra aparece precedida de la preposición de, complementando así al sustantivo que nombra el objeto que se relaciona: taburetes, platos, escaño, etc. En algunos casos, cuando se nombra 
algún mueble o parte de mueble se especifica el tipo de madera ya que el valor del mueble depende también de este aspecto, como es el caso del ejemplo de La Bañeza de 1829, o el de Coomonte de la Vega de 1643, entre otros.

\section{MADERO}

Sust. m. 'Pieza larga de madera escuadrada o rolliza' (DRAE). Término derivado de madera.

Un plato de madero y dos escudillas de lo mismo (Coomonte de la Vega, 1643)

Dos maxaderas de madero (Coomonte de la Vega, 1643)

Un banco de quatro pies de un madero de peral (Coomonte de la Vega, 1643)

Una escudilla de madero (Coomonte de la Vega, 1719)

Quatro maderos de álamo (La Nora del Río, 1724)

Un madero de negrillo y unos palos (Fresno, 1726)

Maderos de roble y tres de pino (Palacios de Jamuz, 1728)

La madera suelta de una casa con sus maderitos (Palacios de la Valduerna, 1730)

Un escaño de madero (Miñambres, 1731)

Una errada de madero (Requejo de la Vega, 1735)

Tres maderos pequeños (Laguna de Negrillos, 1750)

Quatro maderos de encina y roble (Castrocalbón, 1814)

Es una palabra frecuente, aunque su uso es menor que el de madera. Como ocurre en el término anterior, la voz aparece precedida de la preposición de, para especificar el material del objeto que se relaciona. En estos casos el significado del término es el de 'tronco de árbol', por tanto una madera más basta que en el caso de los objetos de madera, cuyo material está trabajado. Hay algunos ejemplos en los que el propio término nombra al objeto que se relaciona, en este caso el significado puede ser el de 'tronco de árbol' pero también el de 'tronco de árbol o un pedazo de él que aún se coloca junto a la puerta, y en el que se sienta la gente en las noches de verano a hacer tertulia' (Le Men, 2007, s.v. madero).

\section{MIMBRE [binbre, vimbre, minbre]}

Sust. m. 'Cada una de las varitas correosas y flexibles que produce la mimbrera' (DRAE).

Del antiguo vimbre y este del latín vimmen, -rnis (DECH, s.v. bimbre).

Una carga melonera de binbre biexa (Coomonte de la Vega, 1643)

Una cestica frutera de binbre con cosa de medio celemín de garbanzos (Coomonte de la Vega, 1643)

Un zesto de binbre blanco con una asa (Coomonte de la Vega, 1643)

Un cestico de binbre pequeño (Alija del Infantado, 1644)

Una cestica de ofreçer de binbre blanca (Coomonte de la Vega, 1645)

Dos talegas buenas de binbre (Coomonte de la Vega, 1645)

Una talega pequeña de binbre (Alija del Infantado, 1647)

Dos talegas de binbre pequeñas biexas (Alija del Infantado, 1647)

Una cesta de binbre biexa (La Antigua, 1648) 
Dos çestas de binbre biexas (La Antigua, 1648)

Dos zestos de binbre (La Bañeza, 1721)

Un zesto de minvre (Laguna de Negrillos, 1726)

Otra (cesta) de vimbres (Palacios de la Valduerna, 1728)

Dos zestillas de binbres (Destriana, 1728)

Una talega de mimbre (Castrillo de la Valduerna, 1828)

Una talega de mimbre (Castrillo de la Valduerna, 1828)

Un par de costanas de vimbre (Valle de la Valduerna, 1829)

Una cesta tabliza y otra de minbres (Quintanilla de Somoza, 1831)

Una tabla de chopo y un cesto de binbre (Calzada, 1838)

Dos talegas de mimbre negra (Quintana del Marco, 1839)

Una cestilla de mimbres (Destriana, 1843)

Es un término común que se utiliza en toda la zona con el significado que da el $D R A E$, cada una de esas varas de la mimbrera se utilizaban después para tejer cestos, cestas (con diferentes usos), talegas o talegones. Lo más significativo de este término son sus variantes formales. El $D E C H$ señala que el cambio de vimbre en mimbre se debe a una dilación de la nasalidad, pero contribuiría a él la etimología popular que relacionaba el vocablo con membrillo ( $D E C H$, s.v. mimbre). Las diferentes formas alternan en todo el período estudiado, aunque en el S. XIX predomina la variante actual.

\section{NEGRILLO}

Sust. m. 'Olmo' (DRAE). Término derivado de negro, del latín nı̆ger, nŭgra, nı̆grum (DECH, s.v. negro).

Un poste de negrillo bueno (Coomonte de la Vega, 1645)

Un poste de negrillo de dos baras de largo (Coomonte de la Vega, 1645)

Doçe pieças de negrillo (La Antigua, 1647)

Dos roldos de negrillo buenos (Villamediana, 1723)

Una orca de negrillo (Laguna de Negrillos, 1725)

Un madero de negrillo y unos palos (Fresno, 1726)

Dos tablas de negrillo (Palacios de la Valduerna, 1728)

Dos pies de negrillo (Miñambres, 1731)

Dos roldos de negrillo uno gordo y otro delgado (Requejo de la Vega, 1735)

Una mesa chica de negrillo (Santiago Millas, 1735)

Un palo de negrillo (Calzada, 1838)

Unos pies de negrillo (Santibáñez de la Isla, 1844)

Es un término común en toda la provincia, concretamente en algunos vocabularios de la zona se define el negrillo como una 'especie de olmo con las hojas verdes, tanto por el haz como por el envés, cuyo nombre científico es populus nigra contra el denominado populus alba cuyas hojas son de color blanco en el envés. Ambos se crían al lado de los ríos' (Rivas, 1996: 166). Algunos autores señalan que incluso en una zona muy próxima a la estudiada, concretamente en Benavente, la palabra olmo 
apenas se conoce (Barrio, 2000: 184). De acuerdo con este dato, en el corpus no se recogen ejemplos de olmo, solo de negrillo para referirse a la madera de dicho árbol.

\section{NOGAL}

Sust. m.'Tipo de árbol' siguiendo la definción que da el diccionario académico. 'Madera de este árbol' (DRAE). Término derivado de nuez, del latín nux, nŭcis (DECH, s.v. nuez).

Un banquito de nogal (La Bañeza, 1641)

Un aparador viejo de nogal (La Bañeza, 1643)

Un escritorio guarnecido de marfil mediano con otro escritorio de nogal (La Bañeza, 1643)

Un bufete de nogal pequeño y bueno (Alija del Infantado, 1644)

Un arca grande de nogal con su llabe, cerradura y cantoneras (Coomonte de la Vega, 1650)

Una cama de nogal sin cordeles (Coomonte de la Vega, 1650)

Una mesilla de nogal (La Bañeza, 1714)

Un escañil de nogal bueno (Laguna de Negrillos, 1722)

Un roldo de nogal bueno (Villamediana, 1723)

Un banco de nogal de quatro pies (Fresno, 1726)

Un brasero de cobre con caja de nogal (Robledo de la Valduerna, 1726)

Un arquetón de nogal viejo (Miñambres, 1729)

Una mesa de nogal pequeña (Laguna de Negrillos, 1734)

Un ropero de nogal (La Nora del Río, 1823)

Un catre de nogal (La Nora del Río, 1823)

Una mesa con tres cajones de madera de nogal (Quintanilla de Somoza, 1831)

Dos cuadros de nogal con imágenes (Requejo de la Vega, 1839)

Los ejemplos encontrados del término son numerosos, por tanto los citados son una selección. Aparece siempre con muebles hechos con este tipo de madera, especialmente arcas, escritorios, bufetes y en menor medida camas, mesas, bancos, etc. Formalmente el término se ha documentado en diversas zonas, entre ellas la comprendida en este corpus bajo las variantes anogal o con cierre de la vocal nugal. Sin embargo, a pesar de los numerosos ejemplos, en los inventarios analizados el término siempre aparece bajo la forma nogal.

\section{OMERO (vid. humero)}

\section{PALERO}

Sust. m. y f. El DRAE señala que en León y Tierra de Campos 'saúce, salguero'. En León 'chopo, álamo'. Derivado de palo, 'rama de un árbol', que se ha especializado en distintos árboles para cada zona, que a su vez parte del latín palum 'poste', más el sufijo -era con valor abundancial (Morala, 1990: 309).

Una pesebrera de palero (Alija del Infantado, 1644) 
Un banco de palero biexo (Coomonte de la Vega, 1645)

Un banco de palero (Coomonte de la Vega, 1645)

Una pesebrera de palero buena (Coomonte de la Vega, 1650)

Un banco de palera largo (Palacios de la Valduerna, 1728)

Tres cabijales de palera (Valle de la Valduerna, 1829)

Dos pies de palera (Valle de la Valduerna, 1829)

Otro pesebre de palera con su prisión (Palacios de la Valduerna, 1831)

El término se usa en masculino o en femenino, aunque el DRAE solo lo recoge en masculino con este significado a partir de la edición de 1970, ya que en femenino le da la acepción de 'nopal' en Murcia, significado que no guarda relación con el aquí empleado. La voz aparece en todos los ejemplos precedida de la preposición de para especificar el tipo de madera del que está hecho el objeto, ya sea el banco, la pesebrera, etc. La palabra palera designa un 'tipo de sauce al que, a una altura de unos dos metros del suelo, se le corta su rama principal para que forme una especie de cabeza de la que después nace abundate ramaje. Son árboles muy longevos y su figura es característica de las zonas húmedas y de las márgenes de presas y regueros, así como de los setos que cierran las huertas' (op. cit: 309). Concretando, en La Bañeza, palera se define en algunos vocabularios de la zona por ejemplo, de la Valdería, como 'árbol semejante al sauce, aunque de hojas más verdes y alargadas, que produce como rama la mimbre para tejer cestos, talegas y talegones' (Rivas, 1996: 172), en Santibáñez de la Isla se define palera como 'árbol de ramas y hojas parecidas a las del sauce pero más erectas' (Miguélez, 1998: 167). Por tanto en los ejemplos la voz hace alusión a la madera de este tipo de árbol próximo al sauce. El uso del masculino y femenino aparece muy bien acotado en el corpus, ya que en la zona de la Valduerna siempre se recoge en femenino, mientras que en los ejemplos de la zona sur de León y norte de la actual provincia de Zamora siempre aparece en masculino. A pesar de que el femenino, en general, es el más empleado, probablemente se deba a cuestiones de uso, aunque este hecho no suponga que en las zonas que se utiliza el masculino no se utilice el femenino, ya que por ejemplo en Benavente, que está muy próximo, se documenta la voz palera (Barrio, 2000: 185).

\section{ROBLE}

Sust. m. 'Madera del árbol del roble' (DRAE). Del latín rōbur, rōbōris (DECH, s.v. roble).

Una messa grande de una tavla de roble (La Antigua, 1647)

Un escaño de roble sin clavos usado (Laguna de Negrillos, 1722)

Una puerta de roble (Laguna de Negrillos, 1725)

Un escañil de roble bueno (Toral, 1728)

Una cama viexa de roble (Pobladura del Valle, 1734) 
Un escañil de roble (Pobladura del Valle, 1734)

Un vanco de roble (Pobladura del Valle, 1734)

Un vanco de roble (La Nora del Río, 1823)

Seys rejeras de roble (Valle de la Valduerna, 1829)

Un cargadero de roble (Destriana, 1843)

Es un término que aparece como adyacente para designar el tipo de madera del que están hechos diversos objetos: bancos, camas, escaños, etc. En los inventarios es un dato significativo porque en función del tipo de madera, se fija el valor del objeto.

\subsubsection{Cáñamo}

\section{BROCATEL}

Sust. m. 'Tejido de cáñamo y seda, a modo de damasco, que se emplea en muebles y colgaduras' (DRAE). Término derivado de brocado, probablemente del it. broccato (DECH, s.v. brocado).

Una sobremesa de terçiopelo de colores con las caydas de brocatel ya forrada en olandilla (La Bañeza, 1643)

Es el único ejemplo encontrado y se usa con la acepción que da el diccionario académico, ya que anteriormente al S. XVI no era una tela, sino que el término designaba una especie de brocado de oro o plata. Existen dos tipos de brocatel, aunque en el ejemplo encontrado no se dan más detalles. Uno consta de urdimbre y una o más tramas de seda, y una de hilo de lino; la trama de hilo de lino no figuraba en la cara del tejido, solamente en el revés, sirviendo para dar mayor fuerza y realce a los efectos del dibujo, siendo estos muy variados: medallones, listas, grandes ramos, etc., el otro era un tipo de damasco grueso, urdimbre de seda y trama de algodón, con grandes dibujos brillantes sobre un fondo mate (DHTT, s.v. brocatel). En cualquier caso ambos se usaban en tapicería, como adorno, que es el uso que tiene en este caso.

\section{CÁÑAMO}

Sust. m. 'Filamento textil de esta planta' (DRAE). Del latín vulgar cannăbum, latín cannăbis (DECH, s.v. cáñamo).

Un cordel de cáñamo de lino para camas de veynte (Coomonte de la Vega, 1643)

Unas sogas de cáñamo de meter paxa con sus tiraderos y usadas (Alija del Infantado, 1650)

Una quilma de cáñamo (Coomonte de la Vega, 1719)

Quatro libras de cáñamo (La Bañeza, 1721)

Un dogal de cáñamo (Palacios de la Valduerna, 1728) 
Es un término más frecuente que su variante cañamina, no solo en este corpus concreto, sino que también en los corpus académicos. El filamento textil de esta planta se solía utilizar en cordelería, como se muestra en los ejemplos en los que el término designa el material empleado para distintos tipos de cuerdas o para fabricar estopas bastas, como la quilma. También se puede usar como fibra más fina para la elaboración de otros tipos de telas, pero con este uso no se recogen muestras en el corpus.

\section{CAÑAMINA}

Sust. f. 'Cáñamo hembra, más fino que el corriente' (Le Men, 2004, s.v. cañamina). Del latín vulgar cannăbum, latín cannăbis (DECH, s.v. cáñamo).

Una barrila con cañamina y una gallina (La Nora del Río, 1820)

Es el único ejemplo recogido del término. Esta escasez de ejemplos no es extraña si se tiene en cuenta que el término se documenta fundamentalmente en la zona noreste de la provincia de León (op. cit. s.v. cañamina), por lo que tal vez es un ejemplo casual. En el corpus académico no aparece ningún caso y en el DRAE no figura.

CUELMO (vid. aperos y labores agrícolas/recipientes).

\section{ESPARTO}

Sust. m. 'Hojas de esta planta, empleadas en la industria para hacer sogas, esteras, tripe, pasta para fabricar papel, etc.' (DRAE). Del latín spartum y este del griego spártos (DECH, s.v.esparto).

Dos serones de esparto (La Bañeza, 1721)

Es un término común, aunque solo se haya recogido este ejemplo, en el que el término se usa con el significado que recoge el diccionario académico.

PAJIZO/A [paxizo/a] (vid. colores)

\subsubsection{Otros}

\section{ALMAGRE}

Sust. m. 'Óxido rojo de hierro, más o menos arcilloso, abundante en la naturaleza, y que suele emplearse en la pintura' (DRAE). Del árabe mágra (DECH, s.v. almagre).

Una @ de almagre (La Bañeza, 1712) 
Es el único ejemplo recogido. El término se utiliza con el significado actual.

CERA

Sust. f. 'Sustancia sólida, blanda, amarillenta y fundible que segregan las abejas para formar las celdillas de los panales y que se emplea principalmente para hacer velas. También la fabrican algunos insectos' (DRAE). Del latín cēra (DECH, s.v. cera).

Doçe libras de cera (Coomonte de la Vega, 1645)

Trece libras y media de cera en velas (La Nora del Río, 1823)

Cera vlanca (La Bañeza, 1829)

Cera amarilla (La Bañeza, 1829)

Cera entallada (La Bañeza, 1829)

Cera vlanca en rama (La Bañeza, 1829)

Cera amarilla en rama (La Bañeza, 1829)

Es un término común que se usa con el significado que da el DRAE.

PEZ

Sust. f. 'Sustancia resinosa, sólida, lustrosa, quebradiza y de color pardo amarillento, que se obtiene echando en agua fría el residuo que deja la trementina al acabar de sacarle el aguarrás' (DRAE). Del latín pusscis (DECH, s.v. pez).

Más un barreñón pegado con pez de barro colorado (Coomonte de la Vega, 1645)

Una @ de pez (La Bañeza, 1712)

Es el único ejemplo encontrado en el corpus, aunque se trata de un término polisémico, la acepción con la que se utiliza el término en este ejemplo es la indicada como acepción del DRAE ya que en la misma relación, inmediatamente después, se indica la misma cantidad de otro elemento del mismo campo semántico, el almagre. Formalmente, es preciso señalar cómo aparece el signo @, actualmente tan asociado al mundo informático, como abreviatura perfectamente conocida del término arroba.

\section{CRISTAL}

Sust. m. 'Vidrio, especialmente el de alta calidad' (DRAE). Del latín crystallus, tomado del griego krýstallos (DECH, s.v. cristal).

Una pieza de cristal con sus estremos de oro (La Bañeza, 1649)

Una cruz de cristal con sus remaches de oro (La Bañeza, 1649)

Unas almendrillas de cristal guarnecidas en plata (Grajal de la Ribera, 1730)

Un frasco de cristal pintado (La Bañeza, 1743)

Un lignum cruzis guarnecido en plata con vidrieras de cristal (La Bañeza, 1743)

La voz cristal tiene diferencias con respecto a su sinónimo vidrio. Se llama cristal al mejor vidrio que define el Diccionario de Autoridades como 'los muy tersos y 
transparentes'. Este matiz se aprecia en los ejemplos recogidos en el corpus en los que existen diferencias contextuales ya que, a pesar de que el número de ejemplos de cristal es inferior, los objetos con los que aparece esta voz no pertenecen a objetos cotidianos sino que se trata fundamentalmente de joyas o enseres de valor, como el caso del frasco pintado.

\section{VIDRIO [bidrio]}

Sust. m. 'Pieza o vaso de vidrio'. 'Ant. vasos de cristal' (DRAE). Del latín vĭtrěum 'objeto de vidrio', derivado de vitrum 'vidrio' (DECH, s.v. vidrio).

Un baso de bidrio (Coomonte de la Vega, 1643)

Dos basos de bidrio (Coomonte de la Vega, 1645)

Una redoma de bidrio (Coomonte de la Vega, 1650)

Un bestido de mujer, ropa, jubón y basquiña de tafetán doble negro guarneçido de esparragón con botones de bidrio (La Bañeza, 1643)

Un orinal de bidrio (La Bañeza, 1721)

Dos vasos de vidrio y dos de cristal (Castrocalbón, 1832)

Dos pomos uno de vidrio y otro de Talavera (Castrocalbón, 1832)

Un orinal de bidrio blanco (Requejo de la Vega, 1839)

Una canasta de bidrio pequeña (Requejo de la Vega, 1839)

Una botella de bidrio (Destriana, 1843)

El término vidrio se empleaba con el mismo uso que hoy le damos al cristal y aparece en aquellos objetos comunes en la vida ordinaria como son vasos, botellas, etc.

\section{BARRO [varro]}

Sust. m. 'Material arcilloso moldeable que se endurece por la cocción, utilizado en alfarería y cerámica' (DRAE). Voz prerromana (DECH, s.v. barro).

Zien carvoneras de barro (La Bañeza, 1641)

Una olla de barro colorado (Coomonte de la Vega, 1643)

Otras dos botixas de barro colorado (Coomonte de la Vega, 1643)

Dos ollicas de barro blanco pequeñas (Coomonte de la Vega, 1643)

Dos xarricos de barro colorado (Coomonte de la Vega, 1643)

Un barreñón de barro (Coomonte de la Vega, 1643)

Una botixa de barro colorado grande desbocada (Coomonte de la Vega, 1643)

Tres barriles de barro colorados quebrados (Alija del Infantado, 1644)

Una xarra y un xarrico de barro colorado (Alija del Infantado, 1644)

Dos barreñas de barro colorado (Alija del Infantado, 1644)

Una barrila biexa y otra buena y un cántaro todo de barro (Alija del Infantado, 1644)

Un barril de barro colorado (Coomonte de la Vega, 1645)

Dos xarricos de barro colorado (Coomonte de la Vega, 1645)

Dos xarros de barro colorado nuebos (Alija del Infantado, 1646)

Una olla de barro zamorano quebrada con dos cuartillos de sal poco más o menos (Alija del Infantado, 1647)

Un barreñón de barro colorado (Alija del Infantado, 1647)

Un cántaro y una barrila de barro colorado (Alija del Infantado, 1647)

Una olla de barro colorado mediana (Alija del Infantado, 1647) 
Una olla grande de barro blanco digo zamorana (Coomonte de la Vega, 1650)

Dos barriles de barro colorado (Coomonte de la Vega, 1650)

Una barrila de tener bino de barro colorado (Coomonte de la Vega, 1650)

Un xarro de barro colorado biexo (Coomonte de la Vega, 1650)

Una botixa de tener aceyte de barro (Coomonte de la Vega, 1650)

Tres ollas de barro blanco (Coomonte de la Vega, 1650)

Seis barreñas de barro colorado (Coomonte de la Vega, 1650)

Un xarro grande de barro (Coomonte de la Vega, 1650)

Cántaros de varro (Huerga de Garaballes, 1720)

Un jarro de varro (Quintana del Marco, 1820)

Una vasija de varro melao (Quintana del Marco, 1820)

Una jarra de barro melao (Quintana del Marco, 1839)

Un cántaro de barro (Quintana del Marco, 1839)

Dos barriles de barro (Destriana, 1843)

Tres tarteras de varro vidriadas regulares (Destriana, 1843)

Todas las ollas de piriyuela y barro, cántaros, cazuelas, barreñones (Santibáñez de la Isla, 1844)

Son numerosos los ejemplos encontrados del término que se utiliza de forma general con el significado que da el DRAE. Sin embargo, prácticamente todos pertenecen al S. XVII y a la zona norte de la provincia de Zamora, sur de la provincia de León. Este dato explica que el tipo de barro, denominado en muchos ejemplos barro colorado, es el que se hacía por la zona de Zamora, concretamente el típico de la localidad de Pereruela que en épocas posteriores se fue extendiendo encontrándose más ejemplos del término pereruela que del término barro colorado. En algún caso el propio ejemplo da cuenta de este dato: «Una olla grande de barro blanco digo zamorana (Coomonte de la Vega, 1650) », en el que se cita un tipo de barro para después rectificar y señalar que es zamorana, por tanto seguramente de barro colorado. En los últimos ejemplos, pertenecientes ya a los SS. XVIII y XIX, desaparece el adjetivo colorado, que probablemente es sustituido por la voz pereruela, que nombra una cerámica diferente a la denominada simplemente barro, como lo demuestra el último ejemplo en el que se coordinan ambos términos, lo que indica que en este caso se refiere a cerámicas distintas.

\section{MELADO/A}

Adj. 'Baño brillante que tienen las piezas de barro como si se les hubiese pasado un baño de miel' (Le Men, 2007, s.v. melada). Término derivado de miel.

Una botixa melada que ará dos libras de aceyte (Coomonte de la Vega, 1645)

Una vasija de barro melao (Quintana del Marco, 1820)

Dos jarras meladas (Castrillo de la Valduerna, 1828)

Dos ollas grandes meladas (Quintanilla de Somoza, 1831)

Una jarra melada, una fuente de barro, una taza blanca, dos barrilas y unas cazuelas (Calzada, 1838) 
Una jarra de barro melao (Quintana del Marco, 1839)

Se trata de un adjetivo muy común ya que designa una característica de las piezas de barro frecuentes en la zona. La variante melao que aparece en dos ejemplos, no es más que la forma coloquial que supone la pérdida de la /-d- / en los finales en $a d o$, aunque es significativo el contexto en el que aparece puesto que esa pérdida se da en el adjetivo masculino y no es frecuente en otros finales en -ado recogidos en el corpus. Probablemente, la explicación está en que se trata de ejemplos situados en fechas tardías.

\section{LLÁBANA [labanca/o]}

Sust. f. 'Laja tersa y resbaladiza' (DRAE). Del port. lague o laja. En portugués viene del hispano-latino lagěna id., de origen incierto, probablemente del céltico, donde designa una lámina u hoja de metal, de ahí pasó a designar en romance una piedra lisa, plana y de poco grueso o una piedra pizarrosa (DECH, s.v. laja).

Dos labancas y un labanco (Coomonte de la Vega, 1645)

Es el único ejemplo del término. El diccionario académico da esa acepción para la voz llábana que localiza en Asturias, aunque se documenta en todo el norte de la provincia de León con el significado de 'piedra grande, plana, lisa, usada como pavimento en las casas' o también con el significado de 'tocinos del cerdo' (Le Men, 2007, s.v. llábana). El ejemplo que se recoge en el corpus resulta significativo ya que se encuentra en el norte de la provincia de Zamora, es decir, bastante distante de donde se ha documentado el término y aparece bajo la forma labanca y labanco que también se localiza en Asturias pero con una acepción algo diferente, se llama llabanca o llabancu en Somiedo a 'una piedra grande y plana mayor que la llábana' (García Valdés, 1979: 220), tal vez este sea el significado usado en el ejemplo, pero con una castellanización del término desde el punto de vista formal al no presentar la palatalización de la /1-/. No obstante, la escasez de ejemplos demuestra que se trata de un término inusual en esta zona.

\section{PIEDRA}

Sust. f. 'Sustancia mineral, más o menos dura y compacta, que no es terrosa ni de aspecto metálico' (DRAE). Del latín pĕtra 'roca', y este del griego pétra (DECH, s.v. piedra).

Dos anillos de oro con sus piedras una blanca y otra verde (La Bañeza, 1641) 
Una pila de piedra de grano grande (Coomonte de la Vega, 1645)

Una pila de piedra (La Antigua, 1648)

Dos sortijas de oro la una de cuatro piedras y la otra de un flor de lis (La Bañeza, 1649)

Una pila de piedra pequeña (Laguna de Negrillos, 1722)

Un anillo y una sortija de oro con piedras falsas (Palacios de la Valduerna, 1726)

Una pila mediana de piedra (Miñambres, 1727)

Una pila de piedra (Palacios de Jamuz, 1728)

Una pila de piedra buena (Palacios de la Valduerna, 1728)

Una trona de piedra de grano con su argolla (Miñambres, 1729)

Una pila de piedra (Palacios de la Valduerna, 1730)

Dos pilas de piedra pequeñas (Laguna de Negrillos, 1740)

Tres medallas de plata y una piedra con el asa de plata y una cruz encartonada de plata (Grajal de la Ribera, 1806)

Nueve fícaras de piedra (La Nora del Río, 1823)

Una pila de piedra con su tapa (Felechares, 1837)

Dos jarras blancas de piedra (Requejo de la Vega, 1839)

Es un término común del que podemos señalar tres usos o acepciones distintas en el corpus. Hay un abundante número de ejemplos que con el término piedra designan el material del que está hecha la pila, en la mayoría de casos, material que se corresponde con esa sustancia mineral dura de color más o menos grisáceo, es decir pedernal. En dos ejemplos fechados en el S. XIX, el término aparece junto a las voces fícara y jarra. Parece evidente que en estos casos el término no tiene el valor de pedernal, sino que se trataría de otro tipo de piedra, probablemente se trate de lo que se denomina la piedra ollar que define el DRAE como una 'variedad de serpentina compuesta principalmente de talco y clorita, de la cual se tallan vasijas en algunos países'. Además con este uso son pocos los ejemplos y todos bastante posteriores, dato que no es extraño tratándose de este valor. Finalmente, hay algunos ejemplos en los que el término tiene el valor de piedra preciosa empleada para joyas.

\section{ZAPA}

Sust. f. 'Piel labrada de modo que la flor forme grano como el de la lija' (DRAE). Es probable que de la variante zapo, nombre del batracio, derive zapa 'lija' por lo granulado de la piel del sapo, de ahí pasó a designar la piel de lija (DECH, s.v. sapo).

Un estuche de zapa guarnecido de plata (Robledo de la Valduerna, 1726)

Una muestra de relox descompuesta con caja de plata con fábrica de Francia con sobrecaja de zapa (Robledo de la Valduerna, 1726)

Son los únicos ejemplos recogidos y ambos pertenecen al mismo inventario, el NTLLE registra el término en 1739 y señala que "se llama igualmente zapa un género de labor que los plateros y otros artífices abren en las cajas y otras obras, imitando los granitos que tiene la lija”. Teniendo en cuenta que en ambos ejemplos la voz aparece 
junto a objetos de plata, es probable que el uso del término en estos casos sea el que aparece en el NTLLE, aunque también se utiliza y en el CORDE se recogen varios ejemplos con la acepción del DRAE de tipo de piel, uso que también sería aplicable a los ejemplos de este corpus.

\subsection{TÉRMINOS CON PROCEDENCIA GEOGRÁFICA}

Como se ha comentado en otros apartados, el interés por detallar de la manera más exacta posible los objetos inventariados ha llevado a que en las relaciones aparezcan términos de procedencia geográfica que en algunos casos aparecen siempre asociados a determinados objetos formando casi con ellos una unidad léxica.

\section{ALEMANISCO}

Sust. m. Se decía de cierto género de mantelería labrada a estilo de Alemania, donde tuvo origen (DRAE).

Una mesa de manteles de alemanisco (La Bañeza, 1641)

Unos manteles alemaniscos viexos (Urdiales del Páramo, 1645)

Unos manteles de alemanisco de tres varas (Huerga de Garaballes, 1720)

Unos manteles de alemanisco (Genestacio de la Vega, 1721)

Una colcha blanca usada con sus colgaduras de alemanisco (Laguna de Negrillos, 1722)

Unos manteles viejos de alemanisco (La Nora del Río, 1724)

Beinte y dos servilletas de alemanisco (Robledo de la Valduerna, 1726)

Dos tablas de alemanisco (Robledo de la Valduerna, 1726)

Diez baras de alemanisco (Robledo de la Valduerna, 1726)

Una serbilleta de alemanisco (Miñambres, 1727)

Unos manteles de alemanisco (Palacios de la Valduerna, 1727)

Unos manteles de alemanisco (Pobladura del Valle, 1733)

Unos manteles de alemanisco de diez varas de largo (Genestacio de la Vega, 1738)

Unos manteles de alemanisco (Castrillo de la Valduerna, 1838)

Es un término muy frecuente en los inventarios ya que, como en el caso de la voz gusanillo, designa un tipo de bordado que tenían especialmente ciertos tejidos empleados fundamentalmente para manteles y servilletas. El DRAE da al término la categoría de adjetivo y como tal lo define en la primera acepción. En el corpus estudiado casi todos los ejemplos tienen un uso sustantivo, nominalizando así el tipo de tejido. Todos los ejemplos recogidos aparecen bajo la variante castellana, aunque en el CORDE se registra la variante alimanisco, que se explica por la variación de las vocales átonas que había en castellano (Morala, 2010: 388). 


\section{ANJEO [angeo]}

Sust. m. 'Especie de lienzo basto'. De Angeu, nombre provenzal del Ducado de Anjou $(D R A E)$.

Vara y media en un pedazo de angeo (Requejo de la Vega, 1839)

Es el único ejemplo encontrado. El término alude a un tipo de tela procedente del ducado de Anjou en el occidente de Francia. Es un término conocido en León, que se documenta con relativa frecuencia en los inventarios, especialmente de los SS. XVI y XVII (Morala, 2010: 389), al igual que en el CORDE, donde la mayor parte de los casos pertenecen a esos siglos. Es frecuente que aparezcan como tela de colchones y sábanas, aunque en el corpus analizado aparece como tela en pieza y solo en un ejemplo del s. XIX.

\section{ASTUDILLO [estudillo]}

Sust. 'Nombre de una localidad de la provincia de Palencia'.

Una mantilla de astudillo (Castrocalbón, 1814)

Un manteo nuevo de astudillo (Jiménez de Jamuz, 1825)

Una mantilla de astudillo (Destriana, 1825)

Un manteo nuevo con astudillos (Alija del Infantado, 1827)

Unos votines de astudillo (La Nora del Río, 1823)

Unos calzones de estudillo aforrados (Castrillo de la Valduerna, 1828)

Un chupa de estudillo con botones de ballena (Castrillo de la Valduerna, 1828)

Una enguarina de paño astudillo (Quintana del Marco, 1839)

Una mantilla de astudillo usada (Quintana del Marco, 1839)

Una capa de estudillo con sus bueltas (Destriana, 1843)

Un manteo de estudillo (Destriana, 1843)

En esta localidad palentina se tejían unos paños que fueron muy utilizados en las tierras leonesas, por ello el término aparece prácticamente lexicalizado de manera que se presenta como un adyacente que parece designar más un tipo de paño con unas características concretas, que la procedencia del mismo. Probablemente, el mayor uso de este tejido se hizo a finales del S. XVIII y XIX ya que en los inventarios el término aparece en torno a estas fechas. Formalmente, se recogen varios ejemplos bajo la variante estudillo, vacilación de vocales que es frecuente sobre todo cuando la /a/ se encuentra trabada por /s/, como es en este caso (Morala, 2009: 559).

\section{ÁVILA}

Sust. f. De Ávila, ciudad de Castilla y León.

Una capa de paño de Ávila (La Bañeza, 1743) 
En Ávila en el S. XVIII surge una industria textil: la Real Fábrica de algodón de donde probablemente proceda el paño que aparece en este ejemplo, que es el único recogido en el corpus.

\section{BAEZA}

Sust. De Baeza, localidad perteneciente a la provincia de Jaén.

Un manteo de Baeza verde bordado de blanco y encarnado (La Bañeza, 1721)

Un zagalejo de Baeza blanco (La Bañeza, 1721)

Durante el S. XVIII y anteriores, en diferentes puntos de la provincia de Jaén, entre ellos Baeza, había una importante industria textil de la lana. En los ejemplos recogidos en el corpus, pertenecientes al mismo inventario, el término aparece designando el tejido de lana procedente de Baeza con el que se habían confeccionado las dos prendas femeninas mencionadas. Es probable que la escasez de ejemplos sea debida a que este tipo de prendas abundaban en estameña y en astudillo, que por cercanía geográfica probablemente fuera un tejido más frecuente en la zona estudiada.

\section{CALABRIA}

Sust. f. 'Nombre de una región del Sur de Italia'

Una petrinilla de damasco con su pasamanos de Calabria (La Bañeza, 1641)

El término hace referencia a la procedencia del tejido, de la región de Calabria con la que España tenía relaciones comerciales, aunque en unas ordenanzas de 15401553 se prohibe expresamente la importación de seda de Nápoles y Calabria (Morala, 2010: 391). Este ejemplo pertenece al siglo posterior, aunque el hecho de que solamente aparezca un ejemplo puede deberse a la escasez de relaciones comerciales todavía en este momento y al coste del tejido procedente de allí.

\section{CAMBRAY [canbrai]}

Sust. m. 'Especie de lienzo blanco y sutil' (DRAE). Del nombre de Cambray, ciudad del norte de Francia, donde se fabricaba (DECH, s.v. cambray).

Dos pañuelos de Canbrai (Robledo de la Valduerna, 1726)

Una pelliza de Canbrai usada (Robledo de la Valduerna, 1726)

Es un término ampliamente documentado en los inventarios, aunque en este corpus solo se recoge en dos ejemplos que pertenecen al mismo inventario. El término nombra el lienzo que se fabricaba en esta ciudad. Formalmente, en ambos casos aparece con la terminación - ai frente a -ay, como ocurre en buey y buei, ambas documentadas 
también en el corpus; y en los dos ejemplos del término cambray, aparece /n/ en lugar de $/ \mathrm{m} /$, hecho frecuente ya que ambos términos se neutralizan en esta posición (Morala, 2011: 392).

\section{CHINA}

Sust. f. El DRAE define el término en la $4^{\text {a }}$ acepción como 'porcelana, loza fina'.

Dos saleros uno de cristal y otro de china (Requejo de la Vega, 1839)

Un platillo de china (Requejo de la Vega, 1839)

Dos saleros de china floreados (Destriana, 1843)

El significado que el término china tiene en estos ejemplos correponde con el que aparece en el DRAE. En los tres casos se refiere tanto a un salero o a un platillo hecho de porcelana, que frecuentemente se importaba de allí, a pesar de que en muchos casos en la documentación se identifican los términos china e india para referirse al Oriente (Morala, 2011: 400).

COLONIA (vid. complementos de cabeza y tocado/otros)

\section{CONTRAY [contrae]}

Sust. 'Especie de paño fino'. De Kortrijk, pronunciado kortraik, nombre de Courtrai en Flandes (DRAE).

Un sayuelo de contray (Coomonte de la Vega, 1645)

Otro sayuelo de contray con ribetes de terciopelo (Coomonte de la Vega, 1645)

Una mantilla de contray usada (Coomonte de la Vega, 1645)

Otra mantilla de contray (Urdiales del Páramo, 1645)

Una mantilla de contray biexa (Alija del Infantado, 1647)

Una mantilla de contray buena con listas coloradas (Coomonte de la Vega, 1650)

Una mantilla de contray buena (Genestacio de la Vega, 1650)

Una facha de contray (Huerga de Garaballes, 1720)

Quinze reales de una facha de contray porque está empeñada (Huerga de Garaballes, 1720)

Una mantilla de contray buena (Toral, 1728)

Un saiuelo de contray bueno (Palacios de la Valduerna, 1728)

Una mantilla de contray buena (Palacios de la Valduerna, 1728)

Una mantilla de cubrir de Contray (Miñambres, 1729)

Un saiuelo de contrae (Santiago Millas, 1735)

Una facha de contrae (Santiago Millas, 1735)

Un manto de contrae (Santiago Millas, 1735)

Un saiuelo de contrae (La Isla, 1735)

Es un término que aparece frecuentemente en el corpus, especialmente en los SS. XVII Y XVIII. Sin embargo, en el S. XIX no se recogen ejemplos. Esta falta de casos también se muestra en el CORDE que solo recoge dos casos del S. XIX. Se trataba de un 
paño muy fino que parece ser que usaba en época antigua, fabricado en Flandes, lugar donde se fabricaban ricas telas que eran demandadas por las élites europeas, hecho que hizo que tuvieran lugar muchos comerciantes y manufacturero que contribuyeron al desarrollo de la economía (Gómez Pablos, 2014: 224). La mayor parte de los ejemplos recogidos del término aparecen junto a mantillas y sayuelos.

\section{CÓRDOBA}

Sust. f. De Córdoba, ciudad de Andalucía

Tres cuarterones de hilo negro de Córdova (Requejo de la Vega, 1839)

Dentro de la diversidad de material textil que aparece en los inventarios, se recoge este ejemplo en el que se documenta una cantidad de hilo, en este caso como señala el ejemplo procedente de la ciudad de Córdoba.

\section{DAMASCO [damasquillo]}

Sust. m. 'Tela fuerte de seda o lana y con dibujos formados con el tejido' (DRAE). Del nombre de la ciudad de Damasco, gran centro de intercambio comercial entre el Occidente y el Oriente, región desde donde se importaron estos productos (DECH, s.v. damasco).

Una petrinilla de damasco con su pasamanos de calabria (La Bañeza, 1641)

Un capillo de damasco azul (La Bañeza, 1641)

Unas mangas de damasco negro (La Bañeza, 1643)

Un fardellino de damasco azul (La Bañeza, 1643)

Una colcha de damasco carmesí con flueco de seda (La Bañeza, 1643)

Unas enaguas de damasco de lana (La Bañeza, 1643)

Un xubón de damasquillo de lana de colores con mangas negras biexas (Coomonte de la Vega, 1643)

Un vestido de damasco acavellado (La Bañeza, 1649)

Un justillo de damasco (La Bañeza, 1721)

Una sobremesa de damasco vieja (Robledo de la Valduerna, 1726)

Dos alzaquellos uno de damasco y otro de tafetán (Robledo de la Valduerna, 1726)

Una bata de damasco carmesí forrada en tafetán doble (Robledo de la Valduerna, 1726)

Una carpeta de damasco de lana encarnada (La Bañeza, 1829)

El término designa un 'tipo de tela de alta calidad con una sola urdimbre y una sola trama, formadas por hilos del mismo grosor, color y calidad, y con dibujo entretejido' (DHTT, s.v. damasco), por tanto se trata de una tela de cierto coste por su calidad que se encuentra en prendas variadas como se aprecia en los ejemplos, tanto de vestir como en ropa del hogar. El dato de que se trate de un buen tejido justifica que los ejemplos recogidos pertenecen, prácticamente a dos inventarios. Hay un caso en el que 
aparece el término damasquillo, 'tejido parecido al damasco pero no tan noble y de menor consistencia' (DHTT, s.v. damasquillo). También es frecuente encontrar en los inventarios el adjetivo derivado adamascado, aunque en este corpus no se recoge este término.

\section{FRECHILLA [grechilla, brechilla]}

Sust. 'Nombre de una localidad de la provincia de Palencia'.

Una capa de frechilla buena (Alija del Infantado, 1644)

Un sayo de frechilla (Alija del Infantado, 1644)

Un capotillo de frechilla a medio traer (Alija del Infantado, 1644)

Una capa de grechilla nueva (Coomonte de la Vega, 1719)

Una capa de brechilla nueba (Ribas de la Valduerna, 1726)

Una capa de frisa, otra de grechilla (Palacios de la Valduerna, 1727)

Unos cuerpos nuebos de grechilla (Toral, 1728)

Otro (saiuelo) de frechilla nuevo (Palacios de la Valduerna, 1728)

Una capa de brechilla biexa (Grajal de la Ribera, 1730)

Una capa de frechilla vieja (Requejo de la Vega, 1735)

Una capa de frechilla nueba (Santiago Millas, 1735)

Un sayuelo de brechilla (Grajal de la Ribera, 1750)

En esta localidad palentina se tejían unos paños que fueron muy utilizados en las tierras leonesas llegando a ser más valorados que los de Astudillo. El término aparece prácticamente lexicalizado de manera que se presenta como un adyacente que parece designar más un tipo de paño con unas características concretas, que la procedencia del mismo. Se trataba de un paño muy conocido ya que precisamente los comerciantes bañezanos compraban en el mismo lugar donde se tejía (Cavero y Alonso, 2002: 285). A lo largo de todo el corpus el término se presenta bajo diferentes formas en las que se presenta confusión de las oclusivas /b/ y /g/ en posición inicial y de la /f/ también en esta posición.

\section{GALLEGO}

Adj. m. Relativo a Galicia.

Treinta baras de lienzo gallego ancho (Robledo de la Valduerna, 1726)

Seis libras de hilo gallego calcetero (La Bañeza, 1829)

En la Galicia del S. XVIII destacó el cultivo del lino. En la primera mitad del siglo hay una importante producción de lienzos ordinarios que disminuyeron posteriormente con la introducción del lino báltico. Estos ejemplos son los únicos recogidos del término, que indican la procedencia tanto del lienzo como del hilo, seguramente de lino, empleado para la labor específica de hacer calceta. 


\section{HOLANDA}

Sust. f. 'Lienzo muy fino de que se hacen camisas, sábanas y otras cosas' (DRAE). Del nombre de Holanda, de donde se traía (DECH, s.v. holanda).

Dos almuadas de olanda labradas de seda coloradas buenas (La Bañeza, 1647)

Una colcha de olanda (La Bañeza, 1647)

Otras dos almuadas grandes de olanda lavradas de ylo vlanco de cadeneta con su tafetán encarnado (La Bañeza, 1649)

A pesar de que es un término muy frecuente en los inventarios para nombrar el tejido de sábanas, colchas, camisas, etc., en el corpus solo se han recogido estos ejemplos. Junto a la voz holanda, también es frecuente encontrar en los inventarios el diminutivo holandilla del que no se registra ningún ejemplo.

\section{INDIA [yndia]}

Sust. f. 'Relativo a la India'.

Unos pocos de frégoles secos de avas yndias

Es el único ejemplo recogido del término, aparece como adjetivo del sustantivo habas. Hay que tener en cuenta que el término India, cuando aparece en la documentación, no siempre tiene que ver con la India, sino que a veces se relaciona con las Indias (Morala, 2011: 400), como puede ocurrir en este ejemplo, puesto que los objetos en los que aparece este término refiriéndose al Oriente, suelen ser objetos de porcelana, telas de seda; en general artículos exóticos.

\section{INGLÉS [ynglés]}

Adj. m. y f. 'Perteneciente o relativo a Inglaterra' (DRAE).

Dos pares de medias finas de Ynglaterra (La Bañeza, 1643)

Una basquiña de estameña inglesa (Alija del Infantado, 1812)

Una romana inglesa (Alija del Infantado, 1812)

Zinco varrenos yngleses (La Nora del Río, 1823)

Una almohada de lienzo inglés por estrenar con su guarnición (Jiménez de Jamuz, 1825)

Un cobertor inglés vien maltratado (La Bañeza, 1829)

Una toca de lienzo ynglés (San Feliz, 1838)

El término se usa para designar aquellas telas $u$ otros objetos que son de procedencia inglesa y que, por tanto, se diferencian de las originarias del país. En la mayor parte de casos se utiliza el adjetivo, salvo en el primer ejemplo que se emplea el sintagma "de Inglaterra". 


\section{LIMISTE}

Sust. m. 'Cierta clase de paño, fino y de mucho precio, que se fabricaba en Segovia'. Del mismo origen que el francés limistre 'especie de paño de lana', del inglés anticuado lemster íd., propte. nombre de la ciudad de Inglaterra donde se fabricaban estos paños (DECH, s.v. limiste).

Una casaca chupa y calzón de paño limiste negro (Robledo de la Valduerna, 1726)

Es el único ejemplo encontrado en el corpus del término limiste. Esta voz aparece ya desde Autoridades para referirse a un tipo de paño fino que se fabricaba en Segovia. Sin embargo tanto en el NTLLE como en el CORDE se usa únicamente con el significado de 'tela fina de gran valor' y no se hace referencia al lugar donde se fabrica. Morala señala que probablemente se trate de un tecnicismo del gremio de tejedores y por ello sea en inventarios de estos artesanos en los que la voz aparezca con frecuencia (Morala, 2012b: 303-304).En este caso se trata del inventario de un sacerdote y el ejemplo aislado que aquí se recoge pueda deberse a que se trate de un término familiar para el escribano o el tasador.

\section{MADRID}

Sust. f. De Madrid, capital de España.

Tres y media docena cordones de Madrid (Requejo de la Vega, 1839)

En el mismo inventario que el ejemplo anterior, aparecen otros objetos en los que se señala su procedencia, aunque sea el único caso recogido en el corpus.

\section{MANCHESTER}

Sust. Ciudad de Manchester

Un justillo de manchester (Sanibáñez de la Isla, 1844)

En la época de la Revolución Industrial, la ciudad de Manchester fue un gran centro de transformación del algodón, hasta el punto de que se convirtió en uno de los mayores mercados de productos de algodón llegando a llamarse Cottonopolis. El término se empleaba para denominar un tejido de terciopelo con listas de algodón que se fabricó por primera vez en Manchester (DHTT, s.v. Manchester). Es el único ejemplo recogido, este hecho se debe a que el algodón de Manchester se extendió fundamentalmente a partir del S. XIX, por lo que anteriormente es difícil encontrar el término; y porque se utilizaban otros tejidos como el monfor, la estameña, o incluso la cotonía. 


\section{MONFORT [monfor]}

Sust. De la ciudad de Monfort (Francia).

Un justillo de monfor escarlatinado (Saludes de Castroponce, 1808)

Un juvón de monfor berde usado (Alija del Infantado, 1812)

Un chaleco de monfor azul (Castrocalbón, 1814)

Una quarta de monfor (Quintana del Marco, 1820)

Un justillo de monfor (Jiménez de Jamuz, 1825)

Dos justillos de monfor verde y otro azul (Castrocalbón, 1832)

Un justillo de monfor azul (Calzada, 1838)

Es significativo el uso del término en este estudio lexicográfico ya que en contraste con otros corpus como el CORDE, en el que no se recoge ningún ejemplo, son muchos los casos encontrados. El término monfort, que tampoco recoge el diccionario académico, alude a un tipo de paño que podía ser labrado o liso y que procedía de la ciudad francesa que lleva su nombre (DHTT, s.v. monfort). Al parecer, según señala Terreros (Terreros, 1987: 610) era un tejido de mucha duración que se fabricaba en muchos colores. Como se observa en los ejemplos, todos ellos pertenecientes al S. XIX, se trata de un tipo de paño que fundamentalmente se empleó en prendas de busto, especialmente en este caso en justillos, pero también en jubones, chaquetillas, etc.

\section{MORLÉS}

Sust. m. 'Tela de lino, no muy fina, fabricada en Morlés, ciudad de la región de Bretaña, en Francia' (DRAE). Del nombre de Morlaix, ciudad de Bretaña donde se fabricaba (DECH, s.v. morlés).

Otra (pelliza) de morlés con un amito (Robledo de la Valduerna, 1726)

Seis camisas de morlés (Robledo de la Valduerna, 1726)

Dos pares de calzoncillos de morlés (Robledo de la Valduerna, 1726)

Son los únicos casos recogidos, todos pertenece al mismo inventario. Probablemente se trata de un tipo de tejido que no era frecuente ya que el CORDE registra solo tres casos.

\section{MOSCOVIA [moscobia]}

Sust. f. 'Perteneciente o relativo al antiguo principado de la ciudad de Moscú' (DRAE).

Una maleta de moscobia (La Nora del Río, 1823)

Es el único ejemplo recogido. Es un término que aparece siempre documentado en los inventarios en relación a las baquetas, varillas, etc. En algunos documentos se puede encontrar como baqueta de moscovia, pero en el único ejemplo encontrado, se 
omite la voz baqueta quedando sobreentendida ya que el término de moscovia hacía referencia a este material.

\section{PALENCIA [Palenzia]}

Dos cobertores vlancos de Palenzia (La Bañeza, 1641)

Tres cobertores nuebos de Palencia (La Bañeza, 1641)

Un cobertor blanco de Palencia (La Bañeza, 1721)

Un cobertor de Palencia blanco (Laguna de Negrillos, 1721)

Un cobertor de Palencia encarnado (Genestacio de la Vega, 1721)

Un cobertor de Palencia (Alija del Infantado, 1734)

Una manta de Palenzia (Alija del Infantado, 1734)

Un cobertor de Palenzia encarnado (Alija del Infantado, 1812)

Dos cobertores de Palencia muy deteriorados (Felechares, 1837)

En Palencia durante los SS. XVI y XVII hubo una importante industria lanera que sobresalió por encima de otras actividades industriales, por lo que eran famosas las mantas y los cobertores confeccionados allí. Es muy común encontrar estas referencias en el corpus, especialmente el cobertor de Palencia, más que la manta, de la que solo se recoge un ejemplo. No obstante, la voz cobertor en estos ejemplos aparece con la segunda acepción del DRAE de 'manta o cobertura de abrigo para la cama'.

\section{PERERUELA [periguela, piriguela, piriyuela]}

Sust. f. 'Pueblo de la provincia de Zamora, perteneciente a la comarca de Sayago'. Material o clase de cerámica o barro arenoso cocido del que están hechas cazuelas y ollas, son originarias de Pereruela, pueblo zamorano' (Rivas, 1996: 179)

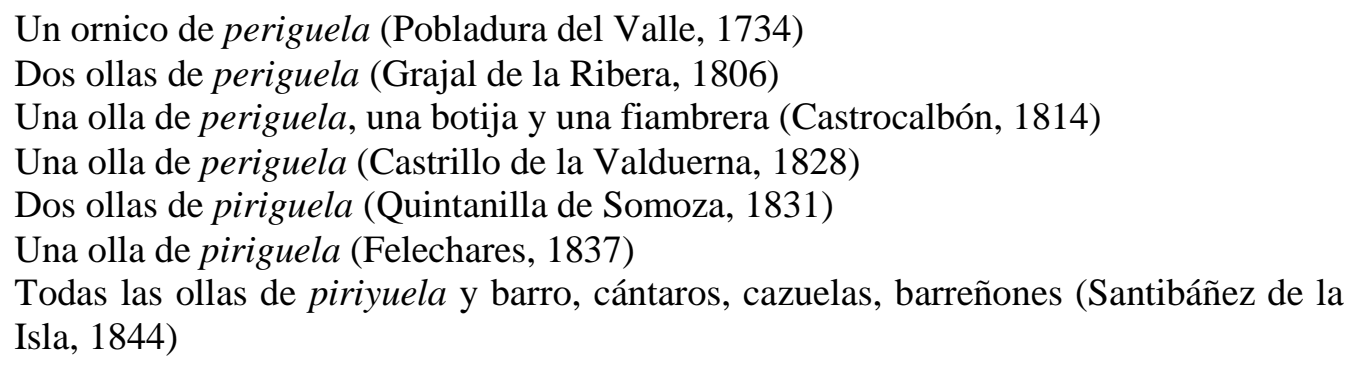

Se trata de un término que especifica un tipo de ollas de alfarería que se fabrican en el pueblo de Pereruela, del que han tomado el nombre. Así el término se utiliza para designar un tipo de 'material o clase de cerámica o barro arenoso cocido del que están hechas cazuelas y ollas, son originarias de Pereruela, pueblo zamorano' (Rivas, 1996: 179). Formalmente, la voz presenta dos variantes que se caracterizan por el cierre de la vocal palatal /e/ en /i/ periguela e incluso por un doble cierre de la /e/ 
piriguela, vacilación que es frecuente en los textos encontrados en estos siglos y que responden a diferentes adaptaciones populares del término.

\section{PORTUGAL (portugués/a)}

Sust. Relativo a Portugal.

Un dengue de vayeta de Portugal encarnado (La Bañeza, 1743)

Una colcha de colores portuguesa (Alija del Infantado, 1812)

Las referencias a Portugal que aparecen en el corpus son escasas, dato que no es extraño ya que parece ser general en los inventarios, todas además están relacionadas con el campo textil, como en estos ejemplos.

\section{PRÁDANOS}

Sust. Del pueblo de Prádanos de Ojeda, situado al Norte de Palencia.

Un sayuelo de paño de Prádanos labrado con seda (Jiménez de Jamuz, 1825)

El término prádanos alude al pueblo de Prádanos de Ojeda situado en la provincia de Palencia. Esta localidad era destacada en la zona, especialmente hacia finales del S. XVIII, porque contaba con una importante fábrica de paños milenos y burdos, actividad a la que se dedicaba una gran parte de la población. La producción textil que se obtenía de esta fábrica se comercializaba sobre todo en Galicia, Asturias y toda Castilla, a un precio moderado ya que el producto era de mediana calidad. Este dato hace suponer que, probablemente aunque solo se haya recogido un ejemplo, este paño fabricado allí fuera muy conocido y usado en la zona estudiada.

\section{RUAN}

Sust. m. 'Tela de algodón estampada en colores que se fabrica en Ruan, ciudad de Francia' (DRAE).

Un paño de manos de ruan labrado (Coomonte de la Vega, 1643)

Un paño de ruan bueno labrado de caparrosa y seda (Coomonte de la Vega, 1645)

El término ruan designa también un 'tipo de lienzo fino, llamado así por haberse tejido y fabricado en la ciudad de Ruan' (Aut.). Se trata de un tejido bastante conocido con el que se hacían distintas prendas: paños, tocas, etc. En el corpus solo se han recogido estos ejemplos, aunque es un término que aparece con frecuencia en los inventarios. Es también frecuente que aparezca con una cuidada confección (con encajes, puntas o labrado como en estos ejemplos) (Morala, 2011: 407). 


\section{SEGOVIA}

Sust. Relativo a Segovia.

Una casaca de paño de Segovia negro (Laguna de Negrillos, 1725)

Unos calzones de paño de Segovia viejos (Robledo de la Valduerna, 1726)

Otra (casaca) de paño de Segovia usada (Robledo de la Valduerna, 1726)

Un mantillín de paño de Segovia con blonda (Grajal de la Ribera, 1806)

Una mantilla negra de Segovia buena con cinta ancha de terciopelo (Jiménez de Jamuz, 1825)

Un manteo usado paño de Segovia (Quintanilla de Somoza, 1831)

Segovia es una ciudad que tuvo gran tradición textil, por ello es frecuente encontrar en los inventarios la expresión paño de Segovia, que como en este corpus, aparece con distintos tipos de prendas: mantillas, casacas, manteos, etc. Cuando se hace referencia al color, en este tipo de paños de Segovia, este suele ser negro (Morala, 2011: 408), como se refleja en el ejemplo de Laguna de Negrillos.

\section{SEVILLA}

Sust. Relativo a Sevilla

Un manto de Sevilla usado (La Bañeza, 1649)

Resulta significativa la escasez de referencias a Sevilla en materia textil que aparecen en este corpus ya que son quizá más frecuentes que las de Segovia y, sin embargo, la presencia en este corpus se reduce a este ejemplo que significativamente pertenece a un inventario de La Bañeza, capital del Partido Judicial. Quizá en la zona estudiada se prefería el paño de Segovia por proximidad o tal vez se deba a una casualidad porque la presencia de textiles de Sevilla en los inventarios es frecuente.

\section{TALAVERA [Talabera]}

Una xarra de Talabera fina buena (Coomonte de la Vega, 1643)

Un barquillo de Talabera fina (Coomonte de la Vega, 1643)

Un salero de Talabera fina (Coomonte de la Vega, 1643)

Una xarra de Talabera (Alija del Infantado, 1644)

Dos platos blancos de Talabera (Alija del Infantado, 1644)

Otros tres platos pintados de Talabera (Alija del Infantado, 1644)

Dos taçicas de Talabera pintadas (Alija del Infantado, 1644)

Un plato de Talabera basta (Alija del Infantado, 1644)

Una escodilla de Talabera fina (Alija del Infantado, 1644)

Seis platos de Talabera fina pintados los cinco buenos y el otro desborcillado (Coomonte de la Vega, 1645)

Una tazica de beber de Talabera (Coomonte de la Vega, 1645)

Una xarra de Talabera fina con el pie quebrado y un barril de barro colorado (Coomonte de la Vega, 1645)

Dos xarras de Talabera pintadas (Alija del Infantado, 1646) 
Docena y media de platos de Talavera finos y escudillas, una fuente grande y otra pequeña (La Bañeza, 1649)

Un salero de Talabera fino (Coomonte de la Vega, 1650)

Un salero de Talavera (La Bañeza, 1721)

Un salero de Talavera con tres caxas (Laguna de Negrillos, 1722)

Dos platos de Talavera (Alija del Infantado, 1724)

Ocho platos y ocho medias fuentes de Talabera (Grajal de la Ribera, 1750)

Una artesa de Talavera (La Bañeza, 1754)

Dos escudillas de Talavera (La Bañeza, 1754)

Un salero de Talavera y dos vinagreras de lo mismo (Grajal de la Ribera, 1806)

Seis platos de Talavera y una fuente fina (Grajal de la Ribera, 1806)

Dos platos de Talavera finos (Alija del Infantado, 1812)

Una jarra de Talavera y otra de León (Alija del Infantado, 1812)

Un zesto vlanco chico, un jarro de varro un plato de Talavera dos escudillas y dos cucharas de madera (Quintana del Marco, 1820)

Tres fuentes de Talabera (Castrillo de la Valduerna, 1828)

Varias piezas de Talabera (Quintanilla de Somoza, 1831)

Dos pomos uno de vidrio y otro de Talavera (Felechares, 1836)

Ocho jilgueras de Talabera (Requejo de la Vega, 1839)

Un barril de Talabera (Requejo de la Vega, 1839)

Dos fuentes de Talabera (Requejo de la Vega, 1839)

Un plato de Talabera (Destriana, 1843)

Una fuente de Talabera planchada (Destriana, 1843)

Dos fuentes de Talavera (Destriana, 1870)

Como se observa en el corpus, las referencias a la cerámica de Talavera son numerosas. Es frecuente que junto al sintagma "de Talavera" aparezcan adjetivos que dan muestra de sus características y su valor, adjetivos como fina o pintada.

\section{TARAZONA}

Sust. f. De Tarazona, ciudad de Aragón.

Una mantilla grande de Tarazona (Castrocalbón, 1832)

Tarazona fue un importante centro textil lanar hasta bien avanzado el S. XIX. Se fabricaban fundamentalmente paños toscos de lana de los que se hacía la ropa de los campesinos. Probablemente, esta mantilla que aparece en este inventario fuera de ese paño ordinario, originario de esta localidad y diferente al que aparece en otras mantillas de paño fino.

\section{TOLEDO (toledano)}

Una colcha de tierra de Toledo de diferentes colores (Laguna de Negrillos, 1721)

Diez y ocho cordones toledanos (Requejo de la Vega, 1839)

Las referencias a Toledo en este caso son escasas, solo se recogen estos ejemplos, ambos pertenecientes al campo semántico del textil. 


\section{ZAMORANO/A [çamorano/a]}

Adj. m. y f. 'Perteneciente o relativo a Zamora' (DRAE).

Un cabeçalito çamorano con pluma ya biexo (Coomonte de la Vega, 1643)

Un mandil camorano con listas, un cuerpo de camisa con sus mangas labradas de blanco (Coomonte de la Vega, 1645)

Una olla camorana (Coomonte de la Vega, 1645)

Una olla de barro zamorano quebrada con dos cuartillos de sal poco más o menos (Alija del Infantado, 1647)

Tres ollicas pequeñas zamoranas (Alija del Infantado, 1647)

Una olla grande de barro blanco digo zamorana (Coomonte de la Vega, 1650)

Una olla zamorana (Coomonte de la Vega, 1719)

Un puchero zamorano (Coomonte de la Vega, 1724)

Una tinaja zamorana (La Nora del Río, 1823)

El término zamorano/a como adjetivo que significa relativo a Zamora, lo encontramos en los archivos referidos a dos grupos de objetos, por una parte textiles, como se refleja en los dos primeros objetos, y por otra referido a utensilios de cocina (ollas, tinajas, pucheros) hechos de barro colorado, en este caso. Resulta significativa la distribución tanto geográfica como temporal de los ejemplos que aparece en el corpus referida a este último grupo de objetos. En los ejemplos en los que aparece el adjetivo zamorano/a observamos que todos los ejemplos son del s. XVII mayoritariamente y del s. XVIII, geográficamente todos se documentan en inventarios de Coomonte de la Vega, localidad perteneciente a la provincia de Zamora y uno de Alija del Infantado, pueblo del sur de la provincia de León, próximo al límite con Zamora. Este adjetivo probablemente alude a la cerámica zamorana, propia de la localidad de Pereruela. Si observamos la presencia del término pereruela y sus variantes en el corpus, se constata que aparece en los inventarios del s. XIX y ya se localiza por distintos puntos del P. J. de la Bañeza. Este dato explicaría que esta cerámica o actividad alfarera se fue extendiendo y dándose a conocer fundamentalmente a partir del s. XIX.

\subsection{BIENES INMUEBLES}

En las relaciones de bienes también aparecen inventariadas propiedades tales como viviendas o terrenos plantados de algún producto específico o sin plantar. Todos estos términos se recogen en este apartado bajo el nombre de bienes inmuebles. Al final se introduce un subapartado denominado arquitectura de la casa en el que se recogen las voces que guardan relación con la construcción de la misma. 


\section{BARBECHO}

Sust. m. 'Tierra labrantía que no se siembra durante uno o más años' (DRAE). Del latín vervactum (DECH, s.v. barbecho).

Nuebe cargas de barbechos (Genestacio de la Vega, 1721)

Es el único ejemplo recogido, el término aparece utilizado con el significado que aparece en el diccionario académico.

\section{CENTENAL}

Sust. m. 'Sitio sembrado de centeno' (DRAE). De centeno, del latín hispánico centēnum y este del clásico centēnī (DECH, s.v. centeno).

Una tierra centenal que llaman Los humillares (Altobar de la Encomienda, 1729)

Una tierra centenal (Grajal de la Ribera, 1730)

Este término aparece en los dos ejemplos usado como adjetivo y acompañando al sustantivo tierra. Sin embargo, se documenta con la acepción de 'terreno sembrado de centeno', pero también de 'terreno cascajero, muy seco, y de peor calidad que el que, por oposición, se conoce como trigal' (Le Men, 2004, s.v. centenal).

\section{COLMENAR}

Sust. m. 'Lugar donde están las colmenas' (DRAE). Término derivado de colmena, voz típica del castellano y el portugués, de origen incierto, probablemente prerromano; quizá de un céltico *colmena, derivado de kŏlmos 'paja' (DECH, s.v. colmena).

Un colmenar (Robledo de la Valduerna, 1726)

Es el único ejemplo recogido. $\mathrm{Su}$ uso es el que aparece en el diccionario académico

\section{CORRAL [corralón]}

Sust. m. 'Sitio cerrado y descubierto, en las casas o en el campo, que sirve habitualmente para guardar animales' (DRAE). Posiblemente del lat. *currale, 'lugar donde se encierran los vehículos', derivado a su vez, del lat. currus, 'carro' (DECH, s.v. corral).

Una casa tejada y pajiza con su corral (Alija del Infantado, 1720)

Un colchón que era de la cama de dicho difunto que está en el corral al sol por causa de estar suzio y de la mala calidad (Laguna de Negrillos, 1722)

Unos corrales que están en frente de la casa a donde murió el difunto (Laguna de Negrillos, 1722)

Una casa en el casco de esta villa, paxiza, con quatro cuartos y un portal, corral y pozo (Altobar de la Encomienda, 1729) 
Una casa en el casco de esta villa, paxiza, que tiene dos aposentos con su corral (Altobar de la Encomienda, 1729)

Unas casas pajizas en el casco de esta villa que tienen cuerpo de casa y aposento doblado, cozina, corral, trascorral, guerto, puertas de calle (Grajal de la Ribera, 1730)

Un corralón en el casco de este lugar (Requejo de la Vega, 1735)

La casa se compone de cuerpo de casa, cozina, cuarto de guarda, pajar, establo, corral, trascorral y portal (Grajal de la Ribera, 1750)

Primeramente la casa donde vivió y murió la citada Francisca Luengo que se compone de una cocina, su cuerpo de casa, un cuarto y su pedazo de corral toda ella de piedra (Destriana, 1825)

Son bastantes los ejemplos encontrados, es frecuente encontrar el término como primer elemento de la relación junto a la casa que es lo primero que se detalla. En este corpus, el término corral suele designar un espacio contiguo a la vivienda que se utiliza para tener en él las gallinas, los aperos de labranza, el carro, etc. o casi como almacén, como se refleja en el segundo ejemplo. Era una parte fundamental de la casa aunque, como muestra el ejemplo de Laguna de Negrillos, también podían estar próximos a esta pero no formando parte de ella; como parte integrante del casco urbano aparece el ejemplo de Requejo de la Vega en el que solo se hace referencia al corral, pero no a la casa.

\section{MULADAR [muradal]}

Sust. m. 'Lugar o sitio donde se echa el estiércol o la basura de las casas' (DRAE). Término derivado de muro, del latín mūrus (DECH, s.v. muro).

Un muradal de estiércol que tendrá dos carros (Coomonte de la Vega, 1644)

El propio ejemplo ya especifica el significado del término que coincide con el que aparece en el DRAE, aunque también se conocen otras acepciones como 'pared, generalmente caída o con piedras por el suelo', 'acantilado, barranco cortado a plomo, como un muro', 'mata baja y espesa, con zarzas, arbustos, donde se entra con dificultad' (Le Men, 2007, s.v. muradal), significados que no recoge el DRAE.

\section{TENADA [tenado]}

Sust. f. El DRAE da como sinónimos los términos cobertizo y la voz henil y especifica que es voz de Asturias y León. Término derivado del latín tena o tiña y este tomado por vía semiculta del latín tĭgna 'vigas', 'materiales de construcción' (DECH, s.v. tinada).

La leña y madera de los tenados (Castrocalbón, 1814)

La tenada de leña (Palacios de la Valduerna, 1831)

La madera vieja del corral fuera de la tenada (Palacios de la Valduerna, 1831)

La tenada de la leña (Palacios de la Valduerna, 1831) 
En algunos vocabularios dialectales se define como 'lugar de la casa situado en el corral, cubierto con leña o céspedes, en el que se almacena la leña para que no se moje si llueve o nieva' (Rivas, 1996: 223). Este es el significado que se utiliza en el primer ejemplo que por otra parte aparece en masculino, aunque esta diferencia de género no afecta para el significado. Sin embargo, en el segundo y cuarto ejemplo la acepción que parece deducirse del contexto es la de 'montón de leña', acepción que Corominas y Pascual ya recogen en un documento de Sahagún del S. XIII, aunque posteriormente también se recoge esta acepción en otras zonas de Zamora, concretamente en Sanabria, bajo la forma teinada (Kruger, 1991: 113). El tercer ejemplo está menos claro, aunque es probable que también se utilice con la misma acepción. Por tanto se trata de un término que se usa con los dos significados sin diferencias cronológicas ni geográficas como se aprecia en los ejemplos que pertenecen al mismo inventario. El DRAE incorpora en la edición de 1925 su uso en León, en el CORDE solo se recogen cuatro casos, tres de ellos pertenecientes al S. XIX y uno a la última década del S. XVIII.

\section{CUERPO}

Sust. m. 'Parte del vestido, que cubre desde el cuello o los hombros hasta la cintura'

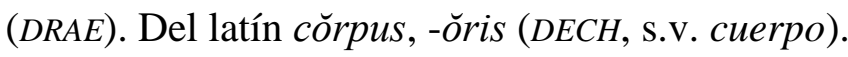

Un cuerpo de camisa con sus mangas labradas de blanco (Coomonte de la Vega, 1645)

Unas casas pajizas en el casco de esta villa que tienen cuerpo de casa y aposento doblado, cozina, corral, trascorral, guerto, puertas de calle (Palacios de la Valduerna, 1730)

Las casas de la morada del difunto con su cuerpo de casa, cozina, guerto, corral y demás servidumbres (Laguna de Negrillos, 1730)

La casa donde vivió y murió la citada Francisca Luengo que se compone de una cocina, su cuerpo de casa, un cuarto y su pedazo de corral toda ella de piedra (Destriana, 1730)

La casa se compone de cuerpo de casa, cozina, cuarto de guarda, pajar, establo, corral, trascorral y portal (Grajal de la Ribera, 1750)

Cuerpo de bienes (Requejo de la Vega, 1839

La voz cuerpo utilizada en singular aparece en el corpus con distintas acepciones. En el primer ejemplo de Coomonte de la Vega, 1645 tiene la acepción que da el DRAE. Además, es frecuente, como se refleja en los ejemplos, encontrar en los inventarios la expresión cuerpo de casa. El DRAE define este sintagma como 'conjunto de faenas domésticas que están a cargo de una sirvienta, con exclusión de las que corresponden a la cocinera'. Evidentemente, en un inventario se relacionan objetos, no 
faenas, pero probablemente la expresión cuerpo de casa hace referencia a aquellos espacios que se corresponden con la parte principal de la casa, y por tanto, podría guardar relación con las faenas de las que habla el DRAE. Además, hay que tener en cuenta que las cocinas no solían estar dentro de la vivienda, sino que se trataba de un espacio independiente que estaba normalmente en los patios. Finalmente, el término aparece con frecuencia antes de una relación de enseres bajo el sintagma "cuerpo de bienes", es decir 'conjunto de las cosas que allí se relacionan'.

\section{APOSENTO}

Sust. m. El DRAE define el término en su $3^{\mathrm{a}}$ acepción como 'habitación, espacio entre tabiques de una vivienda'. Término derivado de posar, del latín tardío pausare (DECH, s.v. posar).

Una casa en el casco de esta villa paxiza que tiene dos aposentos con su corral (Altobar de la Encomienda, 1729)

Unas casas pajizas en el casco de esta villa que tienen cuerpo de casa y aposento doblado, cozina, corral, trascorral, guerto, puertas de calle (Grajal de la Ribera, 1730)

El término se emplea con el significado de 'habitación'. Son pocos los ejemplos encontrados debido a que aparecen cuando se refieren las casas y no siempre se señala el número de aposentos que contienen.

\section{CUEVA [cueba]}

Sust. f. 'Cavidad subterránea más o menos extensa, ya natural, ya construida artificialmente' (DRAE). Del latín vulgar *cŭva 'hueca', femenino del adjetivo co(v)us, variante arcaica del latín cavus 'hueco' (DECH, s.v. cueva).

La cueva que está en término de Cazanuecos (La Antigua, 1647)

Una cueba en el casco de esta villa con tres bentanos, su lagar y aparejos (Palacios de la Valduerna, 1730)

Es un término conocido, aunque solo se hayan recogido dos ejemplos. El significado con el que se utiliza el término es el de 'bodega'.

\section{PAJAR}

Sust. m. 'Sitio donde se guarda la paja' (DRAE). Del latín palěa 'cascabillo de los cereales' y de ahí 'paja desmenuzada' (DECH, s.v. paja).

Un pajar que está pegado a la casa (Robledo de la Valduerna, 1726)

La casa se compone de cuerpo de casa, cozina, cuarto de guarda, pajar, establo, corral, trascorral y portal (Grajal de la Ribera, 1750) 
Es un término común que se usa con el significado que aparece en el DRAE. Formalmente la voz aparece con la solución castellana, frente a otras variantes que se encuentran en León como pachar, pallar, payar.

\section{QUIÑóN}

Sust. m. 'Parte que alguien tiene con otros en una cosa productiva, especialmente una tierra que se reparte para sembrar'. 'Porción de tierra de cultivo de dimensión variable' (DRAE). Del latín quinio, -onis 'grupo de cinco' (DECH, s.v. cinco).

Un quiñón de quatro de corral (Miñambres, 1729)

Otro quiñón de casa en donde vibió que es el cuarto de la calle que se compone de alto y vajo que está tablado cubierto de teja (Palacios de la Valduerna, 1831)

Un quiñón de casa (Felechares, 1836)

Se trata de un término muy común en la zona, aunque solo se hayan recogido estos ejemplos. Es además es una voz muy común en diferentes puntos de la provincia, aunque presenta diferentes matices de significado que también se reflejan en el P.J. de la Bañeza. Los ejemplos recogidos pertenecen a las comarcas de la Valduerna y la Valdería y probablemente el significado con el que se utiliza el término es el de 'cada una de las partes en las que se divide una herencia' por la información que aportan los adyacentes que acompañan al término. No obstante, en el P.J. de la Bañeza la voz quiñón también se emplea con otros usos, en la Valdería también se conoce con este término al 'terreno del monte, normalmente de encinas y robles, propiedad de varias personas de la misma familia que aún está sin partir desde dos o tres generaciones atrás' (Rivas, 1996: 193). En la zona del Bajo Órbigo es un término común que se usa con la acepción de 'finca de propiedad comunal que se reparte entre los vecinos de un pueblo' (transmisión oral), datos que muestran las diferencias de significado en zonas muy próximas.

\section{TRASCORRAL}

Sust. m. 'Sitio cerrado y descubierto que suele haber en algunas casas después del corral' (DRAE). Palabra compuesta de tras, del latín trans 'más allá de' y corral posiblemente del lat. *currale, 'lugar donde se encierran los vehículos', derivado a su vez, del lat. currus, 'carro' (DECH, s.v. tras y corral).

Unas casas pajizas en el casco de esta villa que tienen cuerpo de casa y aposento doblado, cozina, corral, trascorral, guerto, puertas de calle (Palacios de la Valduerna, 1730) 
La casa se compone de cuerpo de casa, cozina, cuarto de guarda, pajar, establo, corral, trascorral y portal (Grajal de la Ribera, 1750)

El término aparece en estos dos ejemplos, mantiene el significado que registra el diccionario académico. Probablemente era un espacio que se utilizaba para guardar aperos u otros objetos.

TRIGAL

Sust. m. 'Campo sembrado de trigo' (DRAE). Término derivado de trigo, del latín trītǐcum (DECH, s.v. trigo).

Una tierra trigal (Genestacio de la Vega, 1721)

Una tierra trigal (Altobar de la Encomienda, 1729)

Una tierra trigal (Grajal de la Ribera, 1730)

Zinco cargas de sementera en tierras trigales (Pobladura del Valle, 1738)

Este término en el corpus siempre aparece usado como adjetivo y acompañando al sustantivo tierra, designando así el producto que se siembra en estas propiedades agrícolas que aparecen en los inventarios.

VIÑA

Sust. f. 'Terreno plantado de muchas vides' (DRAE). Del latín vīnĕa (DECH, s.v. vino).

Una viña en termino de esta villa aze cinco cuarterones (Grajal de la Ribera, 1730)

Una viña que ará cuatro cuartas y media (Grajal de la Ribera, 1730)

Una viña zercada de tapia (Laguna de Negrillos, 1742)

Es un término común que se utiliza con el significado actual.

\subsubsection{Arquitectura de la casa}

\section{CARPONTES}

Sust. m. 'Pares, maderos que dan la inclinación al tejado' (Le Men, 2004, s.v. carpontes).

Seis carpontes de álamo biexos (Alija del Infantado, 1650)

Cinco carpontes biejos (Alija del Infantado, 1650)

Se trata de una voz que no recoge el DRAE ni se registra ningún ejemplo en el CORDE, solo se ha encontrado documentada en el centro-occidente de León y en Santander. Por tanto, en la zona que comprende este corpus es una voz que se registra, aunque solo se recogen estos dos ejemplos pertenecientes al mismo inventario.

FRONTAL 
Sust. m. 'Perteneciente o relativo al frente, parte delantera de alguna cosa' (DRAE). Término derivado de frente, del latín frŏns, -tis (DECH, s.v. frente).

Un frontal de tapiar (Alija del Infantado, 1644)

Unos terziales con sus aparejos, un frontal, una regla, tres tablas, una biga de álamo (Coomonte de la Vega, 1719)

El significado que adquiere el término es el de 'especie de tablero que se utilizaba para hacer las tapias'.

\section{LUMBRAL}

Sust. m. 'Escalón de la puerta de entrada de una casa' (DRAE). Procedente de latín lìmǐnāris, derivado de limen 'umbral'. De liminare salió regularmente limbrar, alterado en lumbral, en parte por influjo del cast. ant. lumbre 'luz'; la l inicial desapareció por confusión con el artículo (DECH, s.v. umbral).

Un lumbral de labranza (Destriana, 1728)

Un roldo de roble que tiene un lumbral (Destriana, 1728)

Son los únicos ejemplos recogidos en el corpus y los dos pertenecen al mismo inventario. El NTLLE da en las sucesivas ediciones la acepción siguiente: 'entre los arquitectos se llama por semejanza el palo grueso o viga que atraviesan en el hueco de la pared por la parte de arriba para asegurar la puerta o la ventana'. Teniendo en cuenta esta acepción, probablemente el término lumbral en este corpus designe un tipo de madera gruesa usada bien para umbralar o para otros usos.

\section{HORMA [forma, orma]}

Sust. f. 'Molde con que se fabrica o forma algo. Se llama así principalmente al que usan los zapateros para hacer zapatos, y los sombrereros para formar la copa de los sombreros. Las hay también de piezas articuladas, que sirven para evitar que se deforme el calzado' (DRAE). Del latín fōrma 'forma, figura, imagen, configuración' (DECH, s.v. forma).

Tres ormas de azer adobes (La Bañeza, 1641)

Más una forma de hacer adobes grande (Alija del Infantado, 1644)

Una horma grande de hacer adobes (Alija del Infantado, 1644)

Una orma de hacer adobes grande (Alija del Infantado, 1647)

El significado es el de 'molde', en este caso para hacer los adobes, donde se colocaba la pasta que quedaba en forma de cuadro y que después se ponía a secar. Formalmente en los ejemplos predominan la variante horma con o sin la grafía "h"; sin 
embargo, hay un ejemplo que presenta conservación de la /f-/ latina y que por tanto es señal de dialectalismo.

\section{TERRÓN}

Sust. m. 'Masa pequeña y suelta de tierra compacta' (DRAE). Término derivado de tierra, del latín těrra (DECH, s.v. tierra).

Un mazo de terrones y una tornadera (Palacios de la Valduerna, 1831)

Es el único ejemplo recogido, hace referencia probablemente a los bloques de tierra y el molde con que se hacían que luego se utilizaban en la construcción de casas, etc.

\section{VIGA [biga]}

Sust. f. 'Madero largo y grueso que sirve, por lo regular, para formar los techos en los edificios y sostener y asegurar las fábricas' (DRAE). De origen incierto, quizá del latín biga (DECH, s.v. viga).

Unos terziales con sus aparejos, un frontal, una regla, tres tablas, una biga de álamo (Coomonte de la Vega, 1719)

Un roldo con una biga de álamo (Villamediana, 1723)

Una viga de chopo (Castrocalbón, 1814)

Es un término común que tiene al menos dos acepciones, se llama viga a 'cada uno de los maderos gruesos colocados horizontalmente en la base de la techumbre, sobre los que se apoyan, formando triángulo, los cabrios', 'madero largo que sirve de prensa en las bodegas' (Le Men, 2012, s.v. viga). Con cualquiera de los significados puede estar utilizado el término, aunque probablemente se utilice con la primera acepción, puesto que ambos casos no hay referencias en las relaciones a las bodegas ni a objetos que guarden relación con ellas.

\section{VIGADA [bigada]}

Sust. f. 'Distancia entre dos vigas sucesivas'. (Le Men, 2012, s.v. vigada).

Un pajar de dos bigadas (Palacios de Jamuz, 1728)

Es un término que no aparece recogido en el DRAE ni recoge ningún caso el CORDE. Se documenta en la zona centro-occidental de León y en zonas del norte peninsular. Fuente García señala que es voz documentada en protocolos del S. XIX (Fuente García 2000: 584), aunque el único ejemplo recogido en este corpus pertenece a un inventario del S. XVIII. El término, en este ejemplo, está empleado como unidad de 
medida indicando así la extensión del pajar, uso que se encuentra frecuentemente en la montaña de León como medida de casas.

\subsection{OTROS}

El caudal léxico que aportan los inventarios es tan grande que hay términos que no encajan en ninguno de los apartados descritos anteriormente. Por ello en último lugar he establecido un grupo de voces bajo la denominación de otros que a su vez, en la medida que sea posible, se han agrupado siguiendo un criterio de proximidad semántica (adjetivos que califican el estado de los objetos, utensilios de pesca, términos administrativos, entre otros). No obstante, hay palabras que no se agrupan ya que no tienen una semejanza clara con otras.

\section{APAREJO}

Sust. m. El DRAE define el término en su $4^{\mathrm{a}}$ acepción como 'conjunto de objetos necesarios para hacer ciertas cosas'. Término derivado de par, del lat. par, -is 'igual', 'semejante' (DECH, s.v. par).

Unos terziales con sus aparejos (Coomonte de la Vega, 1719)

Un yugo con sus aparejos (Alija del Infantado, 1720)

Tres yugos con sus aparejos (Viñas, 1726)

Dos carros con sus aparejos (Miñambres, 1727)

Un jugo con sus aparejos (Palacios de la Valduerna, 1727)

Dos yugos con sus aparejos usados (Palacios de la Valduerna, 1728)

Un carro nuevo con sus aparejos (Palacios de la Valduerna, 1728)

Una cueva en el casco de esta villa con tres bentanos, su lagar y aparejos (Palacios de la Valduerna, 1730)

Una pollina de carga con sus aparejos (Destriana, 1730)

Una bodega con su lagar y aparejos (Laguna de Negrillos, 1734)

Un carro con sus aparejos (Santiago Millas, 1735)

Dos tornos con sus aparejos (Santiago Millas, 1735)

Una pollina de pelo negro con sus aparejos (Valle de la Valduerna, 1829)

Es un término muy común que siempre se utiliza en plural. Se usa con el significado que da el DRAE como queda reflejado en los ejemplos donde la voz se combina con objetos de diverso tipo: yugo, carro, bodega, etc. Es por tanto, un término genérico que engloba un conjunto de cosas, aunque aplicado a las caballerías se define como 'el arreo compuesto de todo lo necesario para cargar las caballerías' (DRAE).

\section{ANGOSTO/A}

Adj. m. y f. 'Estrecho o reducido' (DRAE). Del latín angŭstus (DECH, s.v. angosto).

Otros manteles angostos de lo mismo (Coomonte de la Vega, 1645) 
Otro encaje más angosto (La Bañeza, 1721)

Un mandil angosto (Viñas, 1726)

Quatro tablas más angostas (Castrillo de la Valduerna, 1828)

Una mesa larga y angosta (Quintana del Marco, 1839)

Es un término que se utiliza con frecuencia para calificar un objeto, una prenda, etc. que es estrecha. La voz estrecha, muy común actualmente en el habla ordinaria, no aparece, sin embargo, en el corpus con este significado sino que siempre encontramos angosto/a.

\section{AJADO}

Adj. m. y f. De ajar 'Desgastar, deteriorar o deslucir algo por el tiempo o el uso' (DRAE). Del antiguo ahajar, voz emparentada con el gascón halhà y languedociano falhà, de origen incierto, probablemente derivado del latín vulgar *fallia 'defecto', 'grieta', derivado de fallěre 'faltar, fallar' (DECH, s.v. ajar).

Cuatro pañuelos muy ajados (Requejo de la Vega, 1839)

Dos pañuelos ajados también y un pechador blanco (Requejo de la Vega, 1839)

Es un adjetivo común que se emplea con este significado. En el corpus solo se han encontrado estos dos ejemplos que pertenecen al mismo inventario. Es quizá más frecuente encontrar el adjetivo usado/a.

\section{CASERO}

Adj. m. y f. 'Que se hace o cría en casa o pertenece a ella' (DRAE). Término derivado de casa, del latín casa 'choza, cabaña' (DECH, s.v. casa).

Una capa de pardo casero nueva (La Antigua, 1646)

Nuebe baras de lienço casero en dos pieças (La Bañeza, 1647)

Dieziocho baras de lienzo casero ordinario (Robledo de la Valduerna, 1726)

Veinte y una libras de ylo casero (Robledo de la Valduerna, 1726)

Catorze sábanas de lienzo casero buenas (Robledo de la Valduerna, 1726)

Dos baras de pardo casero (Palacios de Jamuz, 1728)

Dos camisas de lienzo casero algo usados (Quintana del Marco, 1820)

Seis varas de lienzo casero regular de marca estrecha (La Bañeza, 1829)

Dos colchones terliz casero (La Bañeza, 1829)

Es un término que aparece en el corpus para indicar que la tela en cuestión es de producción propia, y por tanto, tiene poca elaboración. Con este mismo sentido se emplean en los inventarios expresiones como de la tierra, de acá (Morala, 2011: 386), que solo aparecen en un caso: «dos mantas fábrica de esta tierra». 


\section{DESBARATADO}

Adj. m. 'Adj. coloq. De mala vida, conducta o gobierno' (DRAE). De desbaratar, derivado de barato, de origen incierto (quizá prerromano y emparentado con el céltico *mratos 'engaño, traición') (DECH, s.v. barato).

Un escañil desbaratado (Laguna de Negrillos, 1725)

Es el único ejemplo del término, por lo que resulta difícil precisar el uso concreto que tiene este adjetivo. En la relación en la que aparece también se registra la voz quebrado, por lo que, en principio, habría que descartar que desbaratado equivalga a roto o quebrado. Probablemente y, teniendo en cuenta el significado original que da el diccionario académico, es posible que designe un escañil que está usado o incluso al que le faltan elementos, respaldo, etc. que originariamente tenía, tal vez que está en un estado que impide el uso del objeto en cuestión.

\section{DESBORCILLADO/A}

Adj. m. y f. Participio del verb. desborcillar 'quitar el borde a alguna vasija o loza' (Le Men, 2005, s.v. desborcillar). Derivado de bocelo, del latín bŭccělla, 'boquilla', con influjo de borde para las variantes con /r/ (DEEH, s.v. büccĕlla; DECH, s.v. bocel).

Seis platos de Talabera fina pintados los cinco buenos y el otro desborcillado (Coomonte de la Vega, 1645)

Es un término que no recoge el DRAE, pero que se documenta en León, Zamora, Salamanca, Galicia. En el corpus es el único ejemplo y, como muestra el propio contexto, el significado es el indicado, es decir se trata de un plato que no tiene borde.

\section{MOCHO/A}

Adj. m. y f. 'Dicho especialmente de un animal cornudo, de un árbol o de una torre: que carece de punta o de la debida terminación' (DRAE). Origen incierto. En vista de las variantes que se hallan en otras lenguas romance y en otras varias, parece ser palabra de creación expresiva (DECH, s.v. mocho).

Un zadoncico mocho desmangado (Alija del Infantado, 1644)

Una azada mocha buena (Coomonte de la Vega, 1650)

Se trata de un adjetivo que aplicado, como en los ejemplos, a unos instrumentos de labranza significa que no tienen punta. Este adjetivo también se utiliza en la zona para referirse al ganado que no tiene cuernos, como especifica el DRAE, pero también para referirse a un tipo de trigo, trigo mocho, que se diferencia del trigo de 
barbilla que tiene el grano grueso y los filamentos largos. Solo se ha recogido el término en estos casos, no se han recogido ejemplos referidos al ganado, y con menos probabilidad al trigo, que es más difícil de recoger en un inventario.

\section{ORDINARIO/A [hordinario]}

Adj. m. y f. 'Bajo, basto, vulgar y de poca estimación' (DRAE). Término derivado de ordenar, del latín ordinare (DECH, s.v. orden).

Dos mantas buenas que andan a la cama ordinaria (Alija del Infantado, 1646)

Un cuadro de Santiago, pintura hordinaria (Laguna de Negrillos, 1725)

Otro (cuadro) de Nuestra Señora de Belén pintura ordinaria (Robledo de la Valduerna, 1726)

Dieziocho baras de lienzo casero ordinario (Robledo de la Valduerna, 1726)

Dos capas usadas de lana vieja y una casaca, chupa y calzón de paño ordinario (Laguna de Negrillos, 1734)

Otras diez y nuebe baras de lienzo más ordinario (Alija del Infantado, 1812)

Un baúl ordinario de cuatro varas (La Bañeza, 1829)

Tres pares de enaguas de muger de lienzo ordinario (La Bañeza, 1829)

Un somvrero apuntado muy ordinario y usado (La Bañeza, 1829)

Ocho varas de amantelado ordinario (La Bañeza, 1829)

Un vanco con su mesa ordinario (La Bañeza, 1829)

Una mesa ordinaria con su carpeta (Requejo de la Vega, 1839)

Un pañuelo hárave ordinario (Requejo de la Vega, 1839)

Nueve tigeras ordinarias (Requejo de la Vega, 1839)

Nuebe cajones de madera ordinarios (Requejo de la Vega, 1839)

Es un adjetivo que aparece con frecuencia. En los ejemplos se utiliza el término con las acepciones de 'habitual', por ejemplo en el primer caso; y de 'vulgar', entendido en la mayor parte de los casos como 'común', aunque en algunos ejemplos podría tener la connotación de basto, quizá sea el caso del ejemplo de La Bañeza en el que se indica un «somvrero apuntado muy ordinario y usado».

\section{QUEBRADO/A}

Adj. m. y f. 'Quebrantado, debilitado' (DRAE). De quebrar 'romper'. Del latín crěpare (DECH, s.v. quebrar).

Tres barriles de barro colorado quebrados (Alija del Infantado, 1644)

Una xarra de Talabera fina con el pie quebrado y un barril de barro colorado (Coomonte de la Vega, 1645)

Un rastrillo quebrada la tabla (La Bañeza, 1712)

Un plato quebrado de peltre (La Bañeza, 1721)

Un rastrillo quebrada la tabla (La Bañeza, 1721)

Dos taburetes el uno quebrado y el otro sano (Laguna de Negrillos, 1722)

Un taburete quebrado (Laguna de Negrillos, 1725)

Un enbudo quebrado (Grajal de la Ribera, 1730)

Un escañil biejo quebrado (Destriana, 1730)

Tres espadas la una quebrada (Pobladura del Valle, 1733) 
Unas parrillas y dos pares de trévedes las unas quebradas (Laguna de Negrillos, 1734)

Unas escaleras quebradas (Laguna de Negrillos, 1740)

Un escañil pequeño quebrado en una esquina (Laguna de Negrillos, 1740)

Es un adjetivo que aparece con frecuencia en el corpus a lo largo de los SS. XVII y XVIII. Su uso parece ser el de un sinónimo de roto, pero como se muestra en los ejemplos, solo aparece con objetos. No se encuentran ejemplos del término en el S. XIX, mientras que sí se encuentran de roto, que tal vez se generaliza a partir de esta época.

\section{REGULAR}

Adj. 'Uniforme, sin cambios grandes o bruscos'. 'Ajustado, medido, arreglado en las acciones y modos de vivir' (DRAE). Del latín regulāris (DECH, s.v. regla).

Cuatro rodapisas vlancas regulares (La Bañeza, 1829)

Seis varas de lienzo casero regular de marca estrecha (La Bañeza, 1829)

Un velón nuevo de metal regular (La Bañeza, 1829)

Cuatro cazos regulares usados (La Bañeza, 1829)

Ocho platos regulares (Requejo de la Vega, 1839)

Es un adjetivo que aparece con relativa frecuencia para definir aquello que es común, es decir que no sobresale por su calidad, ya sean, como se observa en los ejemplos, telas u otros objetos.

\section{ROTO/A}

Adj. m. y f. 'Andrajoso y que lleva rotos los vestidos' (DRAE). De romper, del latín rümpěre (DECH, s.v. romper).

Un cabezal biexo de lana blanca y negra roto (Coomonte de la Vega, 1643)

Un costal biexo roto y aumado (Coomonte de la Vega, 1643)

Otro cabezalito muy biexo y roto sin pluma (Coomonte de la Vega, 1643)

Una mantica biexa y rota de xerga blanca y negra (Coomonte de la Vega, 1643)

Unos balones de paño buenos ya rotos de las entrepiernas (Coomonte de la Vega, 1643)

Unas alforzas biexas y rotas (Alija del Infantado, 1644)

Dos cazetas de yerro una buena y otra rota (Alija del Infantado, 1647)

Una massera rota (La Antigua, 1647)

Una cazeta rota (Alija del Infantado, 1650)

Un arca chiquitta y rota con zerradura y llave (Viñas, 1726)

Un manto de pardo biejo ya roto (Alija del Infantado, 1827)

Un par de pantalones de paño azul todos rotos (La Bañeza, 1829)

Un espejo roto y de mal uso (La Bañeza, 1829)

Una caldera rota de hacer un cántaro de agua (Quintanilla de Somoza, 1831)

Un jergón todo roto (Palacios de la Valaduerna, 1831)

Un cesto de sembrar roto (Palacios de la Valaduerna, 1831)

Una colcha rota (Palacios de la Valaduerna, 1831)

Dos paraguas rotos (Felechares, 1837)

Una sábana rota (Santibáñez de la Isla, 1844) 
Si se compara el término junto a su sinónimo quebrado, se observa que durante los SS. XVII y XVIII, el adjetivo roto/a aparece fundamentalmente junto a prendas de textil, siguiendo el significado primero que da el diccionario académico; y solo aparecen algunos casos junto a otros objetos. Sin embargo, en el S. XIX, sigue apareciendo junto a textiles, pero se generalizan los ejemplos en los que el adjetivo roto/a aparece junto a otros objetos.

\section{ANZUELO}

Sust. m. 'Arponcillo o garfio, pequeño por lo común, de hierro u otro metal, que, pendiente de un sedal o alambre y, puesto en él algún cebo, sirve para pescar' (DRAE). De una forma romance primitiva *hamiciolus, diminutiva del latín hamus (DECH, s.v. anzuelo).

Ciento y medio de anzuelos (Requejo de la Vega, 1839)

El término solo se recoge en un corpus, en este caso pertenece a los bienes hallados en una tienda y se usa con el significado general de 'instrumento para pescar'.

\section{RED}

Sust. f. 'Aparejo hecho con hilos, cuerdas o alambres trabados en forma de mallas, y convenientemente dispuesto para pescar, cazar, cercar, sujetar, etc.' (DRAE). Del latín rēte (DECH, s.v. red).

Una manta de red de pescar sardas (Alija del Infantado, 1646)

Una red de ylo que llaman rabadilla (Alija del Infantado, 1647)

Son los ejemplos recogidos en el corpus que se emplean con el significado general.

\section{REFOLLETA}

Sust. f. 'Arte de pesca de red, en forma cónica y atada a un palo largo con una especie de litrón pequeño que iban arrastrando por el fondo de la presa para coger pesca menuda' (Le Men, 2012, s.v. refolleta).

Una refolleta bieja (Villazala, 1723)

Una refolleta de pescar (Palacios de la Valduerna, 1728)

Es un término que no aparece recogido en el DRAE y del que solo se han recogido estos ejemplos. El significado del término es el de 'red que se utiliza para pescar'. Es un término que se recoge en algunas zonas de la provincia de León y de 
Palencia, se ha registrado con este significado, entre otros, en un pueblo de la provincia de Palencia llamado Camporredondo (Martínez Mancebo, 1995: 361).

\section{SEDAL}

Sust. m. 'Trozo corto de hilo fino y muy resistente que se ata por un extremo al anzuelo y por el otro a la cuerda que pende de la caña de pescar' (DRAE). Término derivado de seda, de origen incierto. Quizá del latín saeta 'cerda de puerco, de caballo, etc.', 'sedal de pescar', que en la Edad Media debió de aplicarse al hilo de seda, porque entonces este género se importaba en hilo; de ahí pasaría al tejido de seda (DECH, s.v. seda).

Tres cuerdas de pescar y dos sedales (Alija del Infantado, 1724)

Es el único ejemplo recogido, aunque se trata de una palabra conocida cuyo significado es el que aparece en el DRAE.

\section{BOLSA}

Sust. f. 'Especie de talega o saco de tela u otro material, que sirve para llevar o guardar algo' (DRAE). Del latín bŭrsa, y este del griego býrsa 'cuero', 'odre' (DECH, s.v. bolsa).

Unas bolsas de cuero de caçador con un martillico y un poco de plomo (Coomonte de la Vega, 1643)

Una bolsa de pellexo grande (Alija del Infantado, 1647)

Una mesa con su cajón, cerradura y llave buena y en ella una bolsa con diferentes reliquias (Laguna de Negrillos, 1721)

Un rocadero bordado una bolsa y ebangelios (Grajal de la Ribera, 1806)

Una bolsa con antiojos y cartera (La Nora del Río, 1820)

Es un término de uso común que mantiene en los ejemplos la acepción que da el DRAE. Servían para guardar cosas de diferente tipo y en algunos casos se hace referencia al material del que estaba confeccionada. Quizá es más común en el corpus la voz talega que, probablemente se diferencia de la voz común bolsa en el uso e incluso en el tamaño.

\section{CAJA [caxa]}

Sust. f. 'Recipiente que, cubierto con una tapa suelta o unida a la parte principal, sirve para guardar o transportar en él algo' 'caja, por lo común de hierrro o acero, para guardar con seguridad dinero, alhajas y otros objetos de valor' (DRAE). Del latín capsa (DECH, s.v. caja).

Cinco cajas de chocolate (La Bañeza, 1643)

Un brasero con su caja (La Bañeza, 1643)

Una caja de siete cuchillos de Palermo (La Bañeza, 1643) 
Dos estanpicas la una de papel y la otra de caja (Alija del Infantado, 1644)

Una caxa de cobre con trece reales (Coomonte de la Vega, 1645)

Un espexo grande con su caxa (La Bañeza, 1649)

Una caxa de madera sobredorado con una echura de un Santo Cristo de bulto (La

Bañeza, 1647)

Un salero de Talavera con tres caxas (Laguna de Negrillos, 1722)

Una caja de tener conserva (Laguna de Negrillos, 1725)

Una caja de cuchillos con zinco y un tenedor (Robledo de la Valduerna, 1726)

Una muestra de relox descompuesta con caja de plata (Robledo de la Valduerna, 1726)

Otra caja de concha (Robledo de la Valduerna, 1726)

Una caja de plata (La Nora del Río, 1823)

Un relox alemán con su caja (La Nora del Río, 1823)

Una caja de serbizio (La Nora del Río, 1823)

Un relox con caja (Felechares, 1837)

Una caja bien usada de paño negro (Felechares, 1837)

Una caja para tabaco (Destriana, 1843)

Es una voz de uso general. En León y concretamente en la zona de la Valdería este término tiene acepciones del ámbito agrícola no incluidas en el diccionario académico como la de 'manada de lino que se puede apuñar para rastrillarlo' (Le Men, 2004, s.v. caja). Con este significado no se ha recogido ningún ejemplo. El término siempre se utiliza con las dos primeras acepciones que da el DRAE, así podemos encontrar recipientes para guardar diversos objetos: cuchillos, conserva, chocolate, etc. o para guardar objetos de valor, como relojes o dinero. Aparecen ejemplos donde no se especifica lo que se guarda en ellas sino el material del que están fabricadas, por lo que el objeto en sí tiene su propio valor, pueden ser de plata o concha. Formalmente, la voz presenta dos variantes (caja, caxa), especialmente en el S. XVII que responden a una mera vacilación gráfica.

\section{ESTUCHE [stuche]}

Sust. m. 'Caja o envoltura para guardar ordenadamente un objeto o varios, como joyas, instrumentos de cirugía, etc.' (DRAE). Del occitano antiguo estug, derivado del verbo estujar 'guardar cuidadosamente, ocultar', procedente del latín vulgar *studiare 'guardar, cuidar', derivado de stŭdŭum 'celo, aplicación, ardor, esfuerzo' (DECH, s.v. estuche).

Un estuche de tapa guarnecido de plata (Robledo de la Valduerna, 1726)

Un stuche viejo de concha perdidas las piezas (Robledo de la Valduerna, 1726)

Solo se han recogido estos dos ejemplos en los inventarios estudiados, que pertenecen a la misma relación de enseres. Se trata de un término poco usado ya que denomina un objeto de cierto valor, puesto que denomina una especie de caja en la que se guardan objetos valiosos que no son muy frecuentes en estos inventarios. 


\section{CACHIVACHE [cachivaque]}

Sust. m. Despect. 'Vasija, utensilio, trebejo' (DRAE). Término derivado de cacho, eco de cachi-bachi con cambio de la $1^{\mathrm{a}}$ consonante para indicar la variedad caprichosa de los muchos cachivaques (DECH, s.v. cacho).

Unas cintas y otros cachivaques (Saludes de Castroponce, 1808)

El propio significado del término explica que no aparezca con frecuencia en los inventarios ya que designa cosas inútiles, de poco valor. Hay otros términos que se utilizan con el mismo significado pero de los que no hay muestras en los inventarios analizados. Estos términos son achiperres y cachirulos.

\section{CHISME}

Sust. m. 'Coloq. Baratija o trasto pequeño' (DRAE). Término de origen incierto, parece ser aplicación figurada del antiguo chisme 'chinche', procedente del latín cīmex, -řcis, en el sentido de 'niñería, cosa despreciable' (DECH, s.v. chisme).

Todo el yerro menudo tasado con una cerradura dos cachos de gadaña y otros chismes (Santibáñez de la Isla, 1844)

Es el único ejemplo recogido del término aunque sea una voz bastante común. Con un significado sinónimo se han documentado otros términos en el corpus como cachivaches.

\section{CHUCHERÍA}

Sust. f. 'Cosa de poca importancia, pero pulida y delicada' (DRAE). Comparte la raíz chuch- raíz de significados varios, de creación expresiva y en parte onomatopéyica 'cosa de poca importancia pero pulida y delicada' (DECH, s.v. chuch-).

Diferentes chucherías de plata (La Bañeza, 1743)

Solo aparece recogido este ejemplo. Se utiliza con el significado que da el $D R A E$ de 'pequeñas cosas de plata', acepción que ya recoge el diccionario académico en la edición de 1729 e incluso se documenta por primera vez en el S. XVII según recoge el Nuevo Tesoro Lexicográfico, aunque por ejemplo en el CORDE no hay ejemplos de época tan temprana con esta acepción.

\section{TIESTO}

Sust. f. 'Pedazo de cualquier vasija de barro' (DRAE). Del latín těstu 'tapadera de barro' y 'vasija de barro' (DECH, s.v. tiesto). 
Diferentes tiestos y otras cosas de madera de poco uso (Destriana, 1843)

El término tiesto en el ejemplo tiene probablemente un valor genérico. Si atendemos al significado que da el diccionario académico, podemos interpretar que la voz tiesto hace referencia a diversos objetos de barro, quizá de poco uso o valor, que se engloban en este término general. Probablemente, en el contexto en el que aparece podría usarse como sinónimo de trastos, entendido cosas en general de poca importancia.

\section{TRASTO}

Sust. m. 'Despect. Cosa inútil, estropeada, vieja o que estorba mucho'. 'Pl. Armas, utensilios o herramientas de algún arte o ejercicio' (DRAE). Del latín transtrum 'banco de remero' (DECH, s.v. trasto).

Diferentes trastos y otras cosas de madera de poca consideración y valor (Destriana, 1843)

Dos cazuelas, cántaros y otros trastos de cocina de poca consideración (Destriana, 1843)

Unos trastos viejos de poca consideración (Destriana, 1843)

Es un término común que se utiliza con el significado general de cosas de poco valor, aunque tanto en el diccionario académico como en vocabularios dialectales, se contempla el rasgo semántico de cosa estropeada, rasgo que no necesariamente se utiliza en estos ejemplos. Existen en el corpus otras voces que aparecen en sus usos como términos sinónimos y cuya aparición también es escasa en el corpus, aunque también son términos de uso general: chismes o cachivaques. La escasa presencia de este tipo de voces en las relaciones de bienes es lógica ya que es necesario precisar y tasar cada objeto concreto y solo hay unos pocos que se engloben en el conjunto de cosas de poco valor.

\section{CANCILLA}

Sust. f. 'Puerta hecha a manera de verja, que cierra los huertos, corrales o jardines' (DRAE). Del latín cancěllus 'verja o barandilla enrejada', por vía culta o por conducto de otro romance (DECH, s.v. cancel).

Dos cancillas (Calzada, 1838)

Solo se ha recogido este ejemplo tanto en la variante masculina y femenina, como en variantes más típicamente leonesas como las diptongadas canciella. El significado del término es el de 'portilla hecha de tablas'. Algunos diccionarios dialectales señalan que podía tener dos funciones, la de cerrar la entrada de las huertas, 
o uniendo varias de estas cancillas, formar un redil para allanar la tierra tirado por una pareja de vacas (Le Men, 2004, s.v. cancilla/cancillo). La escasez de ejemplos junto a la escasa información del único ejemplo recogido nos impide llegar a conclusiones sobre el uso.

\section{CANDADO}

Sust. m. 'Cerradura suelta contenida en una caja metal, que por medio de armellas asegura puertas, ventanas, tapas de cofres, maletas, etc.' (DRAE). Del latín catenatum (DECH, s.v. candado).

Un candado bueno grande sin llabe ni manilla (Alija del Infantado, 1644)

Un candadico pequeño de maleta (Alija del Infantado, 1644)

Un candado con su llabe pequeño y biexo (Coomonte de la Vega, 1650)

Son pocos los ejemplos encontrados y todos ellos pertenecientes a la misma época, siglo XVII y muy próximos geográficamente, puesto que pertenecen a pueblos limítrofes. Este dato no es significativo ya que es una palabra muy común. El significado es el que da el diccionario académico que coincide con el actual.

\section{EJECUTORIA}

Sust. f. El DRAE remite a la expresión carta ejecutoria que define como 'título de nobleza o hidalguía'. De exsecūtor, derivado de sěqui (DECH, s.v. seguir).

Una ejecutoria sin prinzipio ni fin (Pobladura del Valle, 1722)

Otra ejecutoria con pergamino y sin prinzipio (Pobladura del Valle, 1722)

Es un término poco común puesto que en inventarios de este tipo no abundan los títulos nobiliarios. De hecho, los dos ejemplos pertenecen a una relación de bienes del concejo de Pobladura del Valle.

\section{FORO}

Sust. m. 'Contrato consensual por el cual alguien cede a otra persona, ordinariamente, por tres generaciones el dominio útil de algo mediante cierto canon o pensión'. 'Canon o pensión que se paga en virtud de este contrato' (DRAE). Del latín fŏrum (DECH, s.v. fuero).

Un foro de tierras y casas todo en término de este lugar (Robledo de la Valduerna, 1726)

Un foro que se compuso de tres cargas de tierras que se allaron en los términos de este lugar en cuio foro entran las casas de este ynbentario que se paga a las monxas de Villoria cada año de venta y foro (Palacios de la Valduerna, 1728) 
Es un término que se documenta en León con el significado de 'impuesto vitalicio', acepción que no aparece recogida en el DRAE (Le Men, 2005, s.v. fuero). Probablemente, este sea el significado que tiene la palabra en los ejemplos recogidos. No se ha recogido el término bajo la variante diptongada.

\section{LEGAJO}

Sust. m. 'Atado de papeles o conjunto de los que están reunidos por tratar de una misma materia' (DRAE). De la antigua variante legar 'ligar' (DECH, s.v. ligar).

Un legajo de cuentas de concejo (Pobladura del Valle, 1722)

Dos legajillos de cartas de pago (Pobladura del Valle, 1722)

Solo se han encontrado estos dos ejemplos del término. Esta escasez no es extraña puesto que la voz legajo se utiliza fundamentalmente para referirse a papeles que tratan temas de cuentas, etc. y no es algo frecuente en los testamentos, cartas de dote, etc.

\section{LIBRO}

Sust. m. 'Conjunto de muchas hojas de papel u otro material semejante que, encuadernadas, forman un volumen'. 'Obra científica, literaria o de cualquier otra índole con extensión suficiente para formar volumen, que puede aparecer impresa o en otros soporte'. (DRAE). Del latín liber, -bri (DECH, s.v. libro).

Un libro de caza (La Antigua, 1648)

Un libro de octavo devoción de las ánimas de purgatorio (La Bañeza, 1721)

Un libro de octavo en latín (La Bañeza, 1721)

Dos libros de la nueva recopilación, uno sin prinzipio y ambos con pergamino (Pobladura del Valle, 1722)

Dos libros de la nueva recopilazión, el uno sin prinzipio (Alija del Infantado, 1734)

Un libro de filosofía de la conzienzia (La Bañeza, 1754)

Un libro de Sacristán (Destriana, 1843)

Tres libros grandes (Destriana, 1843)

Dos libros (San Feliz, 1838)

Un libro que se intitula Despertador Christiano (Calzada, 1838)

Los libros son un objeto cuya presencia suele ser bastante escasa en los inventarios. Normalmente, se indicaba en la relación el tema del que trataban, aunque en este caso hay ejemplos en los que simplemente se indica el número de libros. Además de inventariarlos citando la palabra libro, era frecuente, en la línea de lo explicado anteriormente, citar el título o el autor, es el caso de los ejemplos siguientes de un inventario fechado en 1726 en Robledo de la Valduerna, perteneciente a un sacerdote, persona que por su cultura era más proclive a tener libros entre sus bienes: 
siete tomos de a folio y Historia de los anales de Aragón con su ýndice otro tomo de las guerras cívicas de Francia

otro tomo de Espejo de las cristalinas aguas

Istoria de Mariana en un tomo

Istoria de Méjico

Agricultura de Herrera

Bocavulario eclesiástico

Corella Practica de confesores, tres tomos, uno de folio y los dos de quarto

Opúsculos de oro virtudes morales y cristianas de Calderón

Cartilla moral

Fuero de la conzienzia

Corona gótica

Obras de Góngora

Parnaso de Quebedo un tomo en pasta

Ignozenzia mendicada un tomo

Dos tomecillos Nobleza española y genealogía de la casa Leiba

Canto llano

Los quinze cantos de la Numantina

Autos de Calderón

D. Alejo de Piamontes

Garcilaso de La Vega

Manual de confesores de Villalobos

Conjuros de Remijio

Antorcha moral

Santo Tomás

Salazar dos tomos

Ordenantes

Bustamante de V/Rúbricas

Entremeses

Floresta española

El diablo cojuelo

Doctrina cristiana

Secreto de Naturaleza

Especulum Granatti forum

Barias cuestiones morales dos tomos

Dos conzilios

Dos divinos

Dos semanas santas

En esta relación no se cita el término libro, sino el autor, el título o el tomo del que trata la obra. La mayoría son obras religiosas y literarias, aunque también hay de historia.

\section{ORDENANZAS}

Sust. f. 'Conjunto de preceptos referentes a una materia' (DRAE). Término derivado de ordenar, del latín ordinare (DECH, s.v. orden).

Las ordenanzas de esta villa (Pobladura del Valle, 1722)

Este ejemplo se encuentra en un inventario en el que se detallan los bienes del concejo. La mayoría de los inventarios son de personas particulares, lo que explica que 
no haya ejemplos del término a excepción de este. El significado es el que ofrece el $D R A E$, 'el conjunto de preceptos que rigen el concejo'.

\section{ESCALERA}

Sust. f. 'Serie de escalones que sirven para subir a los pisos de un edificio o a un plano más elevado, o para bajar de ellos' (DRAE). Del latín scala 'escalón', 'escala', 'escalera' (DECH, s.v. escala).

Unas escaleras de trece pasales (Coomonte de la Vega, 1645)

Unas escaleras viejas de seis pasales (Vidriales, 1645)

Unas escalericas biexas de ocho pasales (Alija del Infantado, 1646)

Unas escaleras de diez pasos (Laguna de Negrillos, 1725)

Unas escaleras de quatro pasos (Laguna de Negrillos, 1726)

Unas escaleras buenas (Palacios de la Valduerna, 1728)

Unas escaleras de doze pasales (Pobladura del Valle, 1734)

Unas escaleras de mano (Requejo de la Vega, 1735)

Unas escaleras quebradas (Laguna de Negrillos, 1740)

Unas escaleras (Laguna de Negrillos, 1742)

Unas escaleras de mano (Destriana, 1843)

Es un término común que se usa con el significado actual. Como se ve reflejado en los ejemplos es frecuente que se inventaríe haciendo referencia al número de escalones que tenía.

\section{PASAL}

Sust. m. 'Escalón, peldaño de la escalera' (Le Men, 2009, s.v. pasal).

Una escalera de trece pasales (Coomonte de la Vega, 1645)

Unas escalericas de biexas de ocho pasales (Alija del Infantado, 1646)

Unas escaleras de diez pasales (Villamor de Órbigo, 1648)

Unas escaleras de doze pasales (Pobladura del Valle, 1734)

Se trata de un término que tiene el significado genérico de 'peldaño'. En el corpus siempre aparece junto a la voz escalera, entendida como escalera de mano, por tanto el término pasal se refiere a los travesaños de este tipo de escaleras. Es una voz que se documenta en la zona noroccidental de la Península, no solo en León y Zamora, sino también en Galicia y Asturias, aunque no está recogida en el DRAE.

\section{ESCARPIA}

Sust. f. 'Clavo con cabeza acodillada, que sirve para sujetar bien lo que se cuelga' (DRAE). De origen incierto, quizá tomado del catalán donde escarpia. íd., se halla junto al dial. escarpi o escarpe, 'escoplo', procedente del latín scalprum (DECH, s.v. escarpia).

Una clavera con dos órdenes de escarpias (La Bañeza, 1721) 
Una espetera con sus escarpias (Fresno, 1726)

Una espetera con sus escarpias (Toral, 1728)

Una clabexa con sus escarpias (Palacios de la Valduerna, 1728)

Una romana chica de escarpias (Castrillo de la Valduerna, 1828)

Una espitera con sus escarpias (Quintanilla de Somoza, 1831)

En la mayoría de los ejemplos el término aparece como un elemento de otro objeto, ya sea una espetera o una clabexa o de una romana. En cualquier caso el significado general es el de 'gancho que sirve para colgar algo'.

\section{GAJO [gallo]}

Sust. m. 'Cada uno de los vástagos o puntas de las horcas u otros instrumentos de labranza' (DRAE). Del adjetivo latino vulgar *gallěus (DECH, s.v. gajo).

Dos asadores de gaxos (Coomonte de la Vega, 1645)

Onçe asadores de yerro medianos uno con gaxos y los demás sin ellos (Alija del Infantado, 1646)

Dos asadores pequeños sin gaxos de yerro (Alija del Infantado, 1647)

Seis asadores de gaxos y los demás llanos (La Antigua, 1648)

Un asador de yerro grande sin gaxos (Coomonte de la Vega, 1650)

Ocho asadores de yerro llanos sin gaxos (Genestacio de la Vega, 1650)

Otros dos asadores de gaxos grandes (Genestacio de la Vega, 1650)

Dos argollas de yerro, dos gaxos, dos visagras y un candado (Castrocalbón, 1814)

Dos gallos de yerro para sostener pucheros (Destriana, 1843)

Unas trévedes de gallo pequeñas (Destriana, 1843)

El término casi siempre aparece documentado en el corpus acompañando a la palabra asador, excepto en los tres últimos ejemplos. El significado es el que aparece en el diccionario académico que, aplicado a este contexto, se refiere a cada uno de los pinchos en los que se asa. En los ejemplos en los que no acompaña a la palabra asador, su significado es el genérico de 'punta'. Formalmente, destacan los ejemplos de Destriana en los que aparece la variante gallo que se localiza en el Bierzo o en una zona próxima a la que pertenecen los ejemplos como La Cepeda (Le Men, 2007, s.v. gajo).

\section{GARFIO}

Sust. m. 'Instrumento de hierro curvo y puntiagudo, que sirve para aferrar algún objeto' (DRAE). Garfio 'gancho fuerte', procedente del latín graphium, influido a su vez en su forma y significado por garfa (DECH, s.v. garra).

Un peso de garfios (Coomonte de la Vega, 1645)

Un asador de tres garfios (Genestacio de la Vega, 1721)

Un asador de tres garfios (Fresno, 1726)

Un peso de garfios (Palacios de la Valduerna, 1727)

Una harada de garfios buena (Destriana, 1728)

Un peso de garfios (Grajal de la Ribera, 1730)

Una clabera con ocho garfios (Grajal de la Ribera, 1730) 
Unos garfios de ierro (Laguna de Negrillos, 1734)

Dos asadores de garfios (Grajal de la Ribera, 1750)

Un peso pequeño de garfios con una pesa de una libra en tres (Grajal de la Ribera, 1750)

Un peso pequeño de garfios (Alija del Infantado, 1812)

Un peso de garfios (Castrocalbón, 1814)

Un asador de tres garfios (Castrillo de la Valduerna, 1828)

El término se documenta en el corpus con el significado de 'gancho'. Es preciso señalar el uso contextual que se hace del término, en principio en estos inventarios analizados se emplean como sinónimos los términos gancho y gajo, aunque se produce una especialización de ambas voces. Así gajo solo aparece con el término asador en inventarios del S. XVII, mientras que con la palabra asador, el término garfio aparece en los siglos posteriores. Además, este último término se utiliza con el significado de 'gancho', aplicado a otros objetos distintos del asador.

\section{JERINGA}

Sust. f. 'Instrumento compuesto de un tubo que termina por su parte anterior en un cañoncito delgado, y dentro del cual juega un émbolo por medio del que asciende primero, y se arroja o inyecta después, un líquido cualquiera'. 'Instrumento de igual clase dispuesto para impeler o introducir materias no líquidas, pero blandas, como la masa con que se hacen los embutidos' (DRAE). Tomado del latín syringa 'jeringa, lavativa', que a su vez procedía del gr. sŷrinx, sýringos, 'caña', 'flauta', 'tubo' (DECH, s.v. jeringa).

Una jeringa (Miñambres, 1727)

Es el único ejemplo recogido. Además de las dos acepciones señaladas por el $D R A E$, en León el término se utiliza con el significado de 'especie de tubo de madera que utilizan los mozos en carnaval para arrojar agua a las mozas' y 'planta cuyos tallos sirven para hacer flautas' (Le Men, 2007, s.v. jeringa). De todas las acepciones señaladas es lógico pensar que, en este caso, la utilizada en el corpus es la primera acepción del DRAE. Aunque el ejemplo no ofrece datos que aporten ninguna información al respecto, el término aparece en la relación junto a objetos como arcas o prendas de vestir, de ahí que la primera acepción sea la más apropiada.

\section{LAVATIVA [labatiba]}

Sust.f. 'Enema' (DRAE). Término derivado de lavar, del latín lavare (DECH, s.v. lavar).

Una labatiba con puerta (La Nora del Río, 1823) 
Es el único ejemplo encontrado cuyo significado, probablemente, es el de 'jeringa y recipiente usados para el enema'. La matización “con puerta”, probablemente se refiera al tipo de jeringa, y es la información que nos permite descartar que el término tenga el significado de 'gabardina larga' que se ha documentado en algunas zonas de León (Le Men, 2007, s.v. lavativa).

\section{СACHO}

Sust. m. 'Pedazo o trozo de algo' (DRAE). Probablemente del latín vulgar *caccŭlus, procedente del latín caccăbus (DECH, s.v. cacho).

Un martillo y un cacho de planchón (Castrocalbón, 1814)

Un cacho de masera (Castrocalbón, 1814)

Una trasga de yerro quebrada con su cacho de sobeyuelo y un dogal (Castrocalbón, 1814)

Mas cachos de Talavera (Quintanilla de Somoza, 1831)

Todo el yerro menudo tasado con una cerradura dos cachos de gadaña y otros chismes (Santibáñez de la Isla, 1844)

Todos los ejemplos pertenecen al S. XIX, aunque es una palabra que ya recoge el CORDE en siglos anteriores aunque el mayor número de ejemplos pertenece también a los SS. XIX y XX. En los ejemplos recogidos la voz cacho se emplea con dos acepciones, la más generalizada es la que da el DRAE de 'trozo de algo', pero en el ejemplo de Quintanilla de Somoza, puesto que se está refiriendo a la cerámica típica de Talavera, es probable que la acepción utilizada sea la de 'cacharro, vasija de barro de proporciones pequeñas'. Además en la zona de la Valdería, el término también se usa con los significados de 'rectángulo de madera que sirve para rallar la ceniza del horno antes de meter el pan a cocer y para arrastrar las brasas hacia los extremos cuando se arroja, antes de meter el pan', o 'nombre dado a una especie de amuleto comunitario de todo el pueblo de Calzada de la Valdería que tiene por finalidad la de ahuyentar la tormenta y, sobre todo, el peligro de rayos o granizo que puedan perjudicar los frutos'. En realidad sirve para saber a quién, de entre todo el vecindario, le corresponde tocar la campana el día que haya tormenta. Además, empleado en plural, también se utiliza en esta zona con la acepción de 'trozos grandes de patatas cocidas con agua y sazonadas con pimentón' (Rivas, 1996: 55). Con ninguna de estas acepciones se usa el término en el corpus.

\section{PEDAZO [pedaço]}

Sust. m. 'Parte o porción de algo separada del todo' (DRAE). Del latín pittacium 'trozo de cuero', y este del griego pittákion (DECH, s.v. pedazo). 
Un pedaço de yerro en barras (Coomonte de la Vega, 1645)

Quatro pedazos de tocino (La Bañeza, 1721)

Dos pedazos de manta (Coomonte de la Vega, 1724)

Una masera de un pedazo (Destriana, 1730)

Un escritorio echo pedazos muy antiguo (La Bañeza, 1829)

Un pedazo de tabla (Palacios de la Valduerna, 1831)

Un pedazo de tabla para una mesa con un palo atrabesado (Palacios de la Valduerna, 1831)

Vara y media en un pedazo de angeo (Requejo de la Vega, 1839)

Dos pedazos de pana de colores (Requejo de la Vega, 1839)

Dos pedazos de estameña fina (Requejo de la Vega, 1839)

Dos pedazos de crespón (Requejo de la Vega, 1839)

Tres piezas y media de yladillos en barios pedazos (Requejo de la Vega, 1839)

Dos pedazos de encages con diez y seis baras (Requejo de la Vega, 1839)

Es un término común que se utiliza con el significado actual de 'trozo', aplicado a diferentes objetos. El término se recoge siempre bajo la variante normativa, aunque en algunas zonas de León se documenta con cierre de las vocales /e/ en /i/ y /o/ en /u/.

\section{PIEZA [pieça]}

Sust. f. 'Pedazo o parte de una cosa'. 'Alhaja, herramienta, utensilio o muebles trabajados con arte'. 'Porción de tejido que se fabrica de una vez' (DRAE). Del céltico pěttīa 'pedazo' (DECH, s.v. pieza).

Siete piezas de zintas de plata y sseda (La Bañeza, 1643)

Dos piezas de cordonzillos de lana blancos y negros de Valladolid (La Bañeza, 1643)

Nuebe baras de lienço caseros en dos pieças (La Bañeza, 1647)

Doçe pieças de madera de negrillo (La Antigua, 1647)

Una pieza de cristal con sus estremos de oro (La Bañeza, 1649)

Treinta y nuebe baras de gusanillo en pieza (Palacios de la Valduerna, 1726)

Unas piezas de Talabera (Quintanilla de Somoza, 1831)

Dos y media piezas de cinta de raso (Requejo de la Vega, 1839)

Una pieza escasa de cinta de gasa (Requejo de la Vega, 1839)

Tres piezas y media de yladillos en barios pedazos (Requejo de la Vega, 1839)

Diez y ocho piezas de cinta de cuello (Requejo de la Vega, 1839)

Una gargantilla con quatro piezas y su cruz (Destriana, 1843)

Es un término común que tiene un significado general: 'porción', aunque este significado se concreta en acepciones más precisas. En la mayor parte de los ejemplos la voz aparece con términos relacionados con el textil, por lo que su acepción concreta es la de 'porción de tejido que se fabrica de una vez', en otros casos como en el ejemplo de Quintanilla de Somoza el término pieza se refiere a una parte de algo, en ese caso una parte de objetos de cerámica o de madera en el caso del ejemplo de La Antigua y finalmente en el ejemplo de La Bañeza de 1649, el término se está refieriendo a un objeto de cristal trabajado con arte. En cualquier caso, en todos los usos se trata de una porción de algo. 


\section{RETAZO}

Sust. m. 'Pedazo de cualquier cosa' (DRAE). Palabra derivada de *tractiare 'descuartizar, despedazar', derivado del latín trahěre 'arrastrar' (DECH, s.v. atarazar).

Un retazo de casa en Castrillo que es la cozina y un retazo de casa fuera (Miñambres, 1729)

Tres retazos de tozino (Requejo de la Vega, 1735)

Un retazo de algodón (Grajal de la Ribera, 1806)

Un retazo de lienzo y otro de bayeta (Grajal de la Ribera, 1806)

Dos retazos de estameña azul (Castrocalbón, 1814)

Un retazo de cinta (Requejo de la Vega, 1839)

En retazos de listones y chambergas (Requejo de la Vega, 1839)

Es un término que tiene el significado que da el DRAE. Se utiliza con relativa frecuencia en el corpus, aunque en la actualidad se usan más otros sinónimos para esta acepción.

\section{ORINAL}

Sust. m. 'Recipiente de vidrio, loza, barro u otros materiales para recoger los excrementos humanos' (DRAE). Término derivado de orina, del latín ūrīna (DECH, s.v. orina).

Un orinal de bidrio blanco (Requejo de la Vega, 1839)

Un orinal de Talavera vlanco (Destriana, 1843)

Son los únicos ejemplos encontrados, aunque se trata de un término de uso común.

\section{PALANGANA [palancana]}

Sust. f. 'Jofaina' (DRAE). Voz común a las tres lenguas romances hispánicas, de origen incierto, quizá de un lat. hispánico *palangana, nombre de las artesillas o bateas empleadas por los buscadores de oro, derivado del ibérico palaga 'pepita de oro'. Etimología dudosa por la fecha tardía en que aparece el vocablo castellano ( $D E C H$, s.v. palangana).

Una palancana vieja (La Nora del Río, 1823)

Una palancana (Quintanilla de Somoza, 1831)

Una palancana bieja (Requejo de la Vega, 1839)

Una palancana de peltre rota (Destriana, 1843)

Es una palabra común que se recoge con la variante palancana, frecuente en todas las zonas. Su significado se mantiene actualmente. 


\section{FACERÓN [fazerón]}

Sust. m. 'Tronco grueso de un árbol que, apoyado en el suelo, sirve para cortar sobre él la leña' (Le Men, 2005, s.v. facirón).

Dos fazerones (Miñambres, 1729)

Dos fazerones (Miñambres, 1731)

Un facerón de negrillo (Valle de la Valduerna, 1829)

Un facerón de tabla, una espetera y un poco de teja (La Isla, 1829)

Una cesta y un facerón (San Feliz, 1838)

Es un término que no aparece registrado en el DRAE. En León se documenta en la zona de la Maragatería y la Cepeda. En el corpus estudiado no se recoge el término bajo la forma facirón.

\section{LEÑA}

Sust. f. 'Parte de los árboles y matas que, cortada y hecha trozos, se emplea como combustible' (DRAE). Del latín lı̆gna, plural de l̆gnum 'madero', 'madera' (DECH, s.v. leña).

Dos carros de leña (Miñambres, 1731)

Leña que ai en casa y fuera de ella (Santiago Millas, 1735)

Es un término de uso común que se utiliza con el significado que da el DRAE y que actualmente se mantiene.

\section{LATA}

Sust. f. 'Envase hecho de ojalata'. 'Tabla delgada sobre la cual se aseguran las tejas'. 'Madero, por lo común en rollo y sin pulir, de menor tamaño que el cuartón'. 'Tabla delgada sobre la cual se aseguran las tejas' (DRAE). Del bajo latín antiguo latta, común con el céltico y el germánico (debió de tomarse del primero) (DECH, s.v. lata).

Dos docenas de latas de umero (Coomonte de la Vega, 1645)

Quatro docenas de latas chicas y grandes (Miñambres, 1727)

Dos dozenas de latas chicas y grandes (Miñambres, 1729)

En la provincia de León, la voz lata tiene además otras acepciones. En algunas zonas comprendidas en el P.J. de la Bañeza, como la zona de la Valdería, este término tiene varios significados se denomina lata a 'cada una de las vigas descortezadas que sujetan el tejado por debajo y que van entrecruzadas', 'palo largo y ancho, descortezado y cilíndrico, que se usa para tirar algunos frutos secos de los árboles, o de las ramas de los mismos demasiado altas a las que no se llega con la mano y desde el suelo, como nogales o castaños', 'palo también descortezado, que se coloca de forma horizontal, atado por cada uno de sus extremos a un clavo del techo, para colgar en él los chorizos' 
(Rivas, 1996: 147). En Santibáñez de la Isla se llama lata a 'rama grande y relativamente gruesa de palera o chopo. Una vez cortada, se emplea para machacar las alubias o como forganero o mango de herramientas' (Miguélez, 1998: 161). Atendiendo a los escasos ejemplos encontrados del término, no es posible precisar con qué acepción se utiliza la palabra en cada caso. No obstante, en el ejemplo de Coomonte de la Vega, el complemento "de umero" indica que se trata de un tipo de palo, más bien de una vara. Teniendo además en cuenta que se localiza muy próximo a Benavente donde se llama lata a 'vara larga y delgada que se emplea para derribar frutos y apalear las habas; también se utiliza para colgar los chorizos y ponerlos al humo' (Barrio, 2000: 181), es posible pensar que en este caso el término se utilice con este significado. En el caso de los ejemplos de Miñambres no hay información suficiente para llegar a una conclusión, por lo que podría utilizarse con cualquiera de las acepciones.

\section{FRASCO}

Sust. m. 'Vaso de cuello recogido, hecho de vidrio u otra materia, que sirve para contener líquidos, sustancias en polvo, comprimidos, etc.' (DRAE). Probablemente del gótico *flaskô 'funda de mimbres para una botella', 'botella' (DECH, s.v. frasco).

Un yerro de un frasco (Coomonte de la Vega, 1643)

Un frasquillo de munición (Pobladura del Valle, 1722)

Un frasco de cristal pintado (La Bañeza, 1743)

Un frasco de cristal (Requejo de la Vega, 1839)

Un frasco de vidrio grande (Destriana, 1843)

El término se utiliza con el significado de 'objeto que sirve para contener líquido u otras cosas' y con la acepción, también señalada en el DRAE de 'vaso en el que se llevaba la pólvora para cargar la escopeta, este sería el significado que tiene el término en el ejemplo de Pobladura del Valle'.

\section{POMO}

Sust. m. 'Frasco o vaso pequeño de vidrio, cristal, porcelana o metal, que sirve para contener y conservar los licores y confecciones olorosas' (DRAE). Tomado del latín pōmum 'fruto comestible del árbol', de donde las demás acepciones, por comparación (DECH, s.v. pomo).

Dos pomos uno de vidrio y otro de Talavera (Felechares, 1836)

Los materiales con el que están hechos estos pomos, según se especifica en el ejemplo determinan que el término se refiere en el corpus al 'frasco' que señala el 
diccionario académico. Se desconoce el empleo que tenían ya que podían guardar bebidas, pero también perfumes u otros afeites.

\section{CADENA}

Sust. f. 'Serie de muchos eslabones enlazados entre sí. Se hacen de hierro, plata y otros metales o materias' (DRAE). Término procedente del latín catēna (DECH, s.v. cadena).

Una cadena de yerro de prender una cabalgadura (Coomonte de la Vega, 1643)

Una cadena de una burra biexa (Alija del Infantado, 1644)

Dos zinchas y una cadena (La Bañeza, 1641)

Una cadena pequeña con diez y seis eslavones sin argolla (Pobladura del Valle, 1722)

Una cadena grande con cincuenta y cuatro eslavones y sin argolla (Pobladura del Valle, 1722)

Una cadena grande con zinquenta i siete eslabones (Pobladura del Valle, 1734)

Una cadena de perlas con un sacramento de oro (Requejo de la Vega, 1839)

El término, normalmente utilizado en plural, tiene otras acepciones que están documentadas en zonas leonesas, como la de 'maderas o tablas que ensambladas por sus extremos en las pértigas sostienen las tablas que forman el suelo del carro' (Le Men, 2000, s.v. cadena). Sin embargo, en los ejemplos extraídos del corpus estudiado, cabe pensar que el significado con el que se utiliza es el dado por la Academia, ya que no hay referencias al carro y además el término está utilizado en singular. No obstante, ese significado genérico tiene una restricción en el uso, según muestran los ejemplos. Así en los tres primeros casos el término cadena es sinónimo de estrinque, en los tres siguientes tendría un significado más general, aunque resulta significativo que en todos ellos señala el número de eslavones, dato que nos permite concluir que en ese detalle está el valor del objeto. Finalmente, el último ejemplo hace referencia a un objeto de orfebrería, es decir a una gargantilla o collar de perlas engarzadas formando una cadena.

\section{CALESA}

Sust. f. 'Carruaje de cuatro, y más comúnmente de dos ruedas, con la caja abierta por delante, dos o cuatro asientos y capota de vaqueta' (DRAE). Término tomado del francés calèche, que por conducto del alemán kalesche, viene de una lengua eslava, probablemente del checo (DECH, s.v. calesa). Solo se ha recogido un ejemplo.

Una calesa vieja con dos almohadones (Robledo de la Valduerna, 1726)

Es un término muy poco común ya que designa un objeto que la mayor parte de las personas no poseían. Los ejemplos que incluye el CORDE son fundamentalmente de los siglos XIX, XX y algunos del siglo XVIII. 


\section{CHAVETA [chapeta]}

Sust. f. 'Clavija o pasador que se pone en el agujero de una barra e impide que se salgan las piezas que la barra sujeta' (DRAE). Del italiano dialectal ciavetta, diminutivo del italiano chiave, del mismo origen y sentido que llave (DECH, s.v. chaveta).

Una trasga de yerro que está abierta y una chapeta y otro poco de yerro (Palacios de la Valduerna, 1831)

El significado general del término coincide con la acepción del DRAE. Si concretamos el uso que se le da a la palabra en León y más concretamente en las zonas comprendidas por este Partido Judicial, encontramos que se denomina así a un tipo de cerradura o manilla de la puerta, concretamente en algún repertorio léxico se define como 'especie de cerradura o agarradero, con forma de azada pequeña, que pasa de un lado a otro de las puertas y que se ase con la mano con el fin de abrirlas o cerrarlas fácil y directamente a la vez que se arrastra la puerta y sin necesidad de llave o pestillo' (Rivas, 1996: 68). Formalmente, es frecuente encontrar el término como aparece en el corpus, bajo la variante chapeta, variante que no es común en repertorios como el CORDE que solo recoge seis casos, dos con este significado.

\section{BALDUQUE [belduque]}

Sust. m. 'Cinta estrecha, por lo común encarnada, usada en las oficinas para atar legajos' (DRAE). Nombre que los españoles daban a la ciudad holandesa de Bois-le-Duc, donde se fabricaban las cintas y los cuchillos (DECH, s.v. balduque).

Cinco dozenas de belduques (La Bañeza, 1643)

Dos dozenas de belduques finos anchos de la calidad de los de arriba (La Bañeza, 1643)

El DRAE registra la voz balduque con el significado que aparece en el corpus ya que bajo la forma belduque registra la acepción de 'cuchillo'. En el corpus solo se recogen estos dos ejemplos pertenecientes al mismo inventario y siempre con la forma en /e/. Con esta variante también se recogen ejemplos en el CORDE, menos que bajo la variante normativa, pero coincidentes con los ejemplos aquí mostrados en que también pertenecen a inventarios del S.XVII. Asimismo en el CorLexIn se registra un caso de belduque en un inventario próximo, concretamente de la provincia de Valladolid, y ninguno bajo la variante balduque. Quizá se trate de una vacilación de las átonas, que como se refleja en la información dada, no es exclusiva del área leonesa. 


\section{CORDÓN [gordón]}

Sust. m. 'Cuerda, por lo común redonda, de seda, lino, lana u otra materia filiforme' (DRAE). Término derivado de cuerda, del latín chŏrda (DECH, s.v. cuerda).

Dos piezas de cordonzillos de lana blancos y negros de Valladolid (La Bañeza, 1643)

Cinco lazos de cinto, cinco gordones de seda, dos escapularios, una regla de S. Benito y otros dijes (Jiménez de Jamuz, 1825)

Un cordón dorado para un crucifijo (La Bañeza, 1829)

Diez y ocho cordones toledanos (Requejo de la Vega, 1839)

Tres y media docena cordones de Madrid (Requejo de la Vega, 1839)

El término cordón es común y se emplea con el significado académico. La forma más común recogida en el corpus es la variante normativa cordón, aunque la variante con sonorización de la /k-/ que aparece en el ejemplo de Jiménez de Jamuz, se documenta en León y en Asturias (Le Men, 2004, s.v. gordón).

\section{EMBARRAR}

Verb. 'Untar y cubrir con barro' (DRAE). Término derivado de barro, antigua voz prerromana (DECH, s.v. barato).

Una sierra y un machado y una paleta de enbarrar y un martillo (La Bañeza, 1641)

Dos paletas de enbarrar (Coomonte de la Vega, 1719)

El término aparece documentado en los repertorios dialectales con diferentes acepciones, aunque en la zona que comprende este corpus, estas quedan reducidas a una, incluso a dos. Para la zona de La Bañeza, Rivas señala como significado de embarrar 'pintar las paredes de la cocina de humo antes de la matanza' (Rivas, 1996: 95). Próximo a esta acepción, pero más general, se documenta el significado de 'dar a las paredes una mano de barro mezclado con paja', a fin de protegerlas (Fuente García, 2000: 242). Estos usos los recoge el diccionario académico en la $4^{\text {a }}$ acepción del término especificando que se dan en Ávila, Extremadura, Salamanca y Zamora. Además, tanto en León como al este de Zamora también se usa el verbo embarrar para nombrar la acción de 'precintar una cuba' (Le Men, 2005, s.v. embarrar). Atendiendo a los ejemplos recogidos en el corpus, no hay duda de que el significado general es el de 'dar a las paredes una mano de barro o de humo', acepciones que además parecen claras puesto que el verbo aparece con el objeto que se usa para esta acción la paleta. Sin embargo, en el primer ejemplo, es posible que embarrar equivalga a 'dar de barro' ya que en la relación aparece próximo a «tres ormas de azer adobes» y junto a otras herramientas que pueden ser afines a este uso; en el segundo ejemplo no es posible precisar, ya que en la relación junto a este término aparecen muchos objetos diversos 
entre sí. No obstante, del término se recogen ejemplos de sus diferentes acepciones en el CORDE.

\section{FELPO}

Sust. m. El DRAE señala este término como un sinónimo de felpudo. Voz común con el portugués, catalán e italano felpa, íd., oc. feupo, fr. ant. y dial. feupe 'harapo', de origen incierto; en castellano es probable que sea de procedencia galorrománica ( $D E C H$, s.v. felpa).

Seis felpos viejos (La Bañeza, 1829)

Dos felpos biejos (Quintanilla de Somoza, 1831)

Cinco felpos usados (Requejo de la Vega, 1839)

Un felpo viejo (Requejo de la Vega, 1839)

Cinco felpos en buen uso (Destriana, 1843)

Todos los ejemplos pertenecen al S. XIX, y en el DRAE la voz se recoge a partir de la edición de 1925. El término tiene el significado de 'felpudo'. Solo se recogen ejemplos con esta variante. No se registran casos ni de celpo, variante vulgar que sí se utiliza en León, ni de felpudo. No obstante, a pesar de no ser muchos los ejemplos, contrastan con el único ejemplo del CORDE perteneciente al S. XVIII y de autor anónimo.

\section{GARDUÑERA}

Sust. f. 'Trampa metálica para atrapar garduñas y otros animales' (Le Men, 2007, s.v. garduñera). Término derivado de garduña, derivado de la misma raíz prerromana que ardilla (DECH, s.v. ardilla).

Una garduñera buena (Robledo de la Valduerna, 1726)

Una garduñera de ierro vieja (Miñambres, 1727)

Es un término que se documenta en León y Asturias, no aparece recogido en el DRAE. En el corpus estudiado solo se han recogido estos dos casos pertenecientes a la zona de la Valduerna. La voz aparece en ambos casos bajo la variante garduñera, aunque en algunas zonas también se recoge como garduñeira o garduneza (Le Men, 2007, s.v. garduñera).

\section{HECHURA [echura]}

El DRAE en su $8^{\text {a }}$ acepción define el término como 'imagen o figura de bulto hecha de madera, barro, pasta u otra materia'. Término derivado de hecho, participio del verbo hacer, del latín făcĕre (DECH, s.v. hacer). 
Una ymagen de Nuestra Señora cuya echura se taso en mil maravedíes (La Bañeza, 1643)

Doze platos de echura de plata de estaño (La Bañeza, 1643)

Una hechura de un Santo Christo (Alija del Infantado, 1644)

Unna echura de un Santo Christo (Alija del Infantado, 1646)

Una caxa de madera sobredorada con una echura de un Santo Cristo de bulto (La Bañeza, 1647)

La echura de Nuestra Señora de la Conzepzión (La Bañeza, 1721)

Una echura de un Santo Cristo con su cruz de bronze (La Bañeza, 1721)

La echura de un crucifijo de marfil con la cruz y peana de ébano (Robledo de la Valduerna, 1726)

Dos escaparates pequeños forrados enteros con diferentes echuras (Robledo de la Valduerna, 1726)

Un joel de plata con la echura del Ángel y la Soledad (Grajal de la Ribera, 1730)

Una reliquia de plata con las echuras de S. Carlatín y S. Antolín (Grajal de la Ribera, 1730)

Unos manteles de echura de tripa de baca (Santiago Millas, 1735)

Un joiel de plata con la echura de un Santo Cristo y de Ntra. Señora de la Concepción (Genestacio de la Vega, 1738)

Es un término muy común en el corpus que se utiliza con dos acepciones. En aquellos ejemplos en los que el término acompaña a objetos que no tienen que ver con imágenes religiosas, el término se usa como sustantivo del verbo hacer. Es decir equivaldría a indicar el material del que está hecho el objeto, de estaño en el caso de los platos, o de tripa de vaca en el caso de los manteles. En el resto de casos tiene el significado de 'imagen'. Ambas acepciones son recogidas en el DRAE. Formalmente, no se recoge ningún caso de mantenimiento del la /f-/ latina, que sí es común en León como rasgo del leonés y sí se recogen algunos casos en el corpus en otros términos como fosco/a, tampoco aparece la forma feitura, muy común en toda la zona occidental.

\section{HERRADO/A [errado/a]}

Adj. m. y f. Participio de herrar 'guarnecer de hierro un artefacto' (DRAE). Término derivado de hierro.

Una caldera herrada (La Antigua, 1647)

Una emina errada (La Antigua, 1647)

Un emina errada (Robledo de la Valduerna, 1726)

Una emina de álamo errada (La Nora del Río, 1724)

Una carreta buena errada (Laguna de Negrillos, 1734)

Un carro herrado bueno con sus aperios (Valle de la Valduerna, 1829)

Un cuartal con su regla errado (Santibáñez de la Isla, 1844)

Se trata de un adjetivo que acompaña a objetos de diverso tipo: carros, carretas, heminas; para indicar que tienen un borde o la rueda del carro etc. de hierro. 


\section{HERRADURA [ferradura]}

Sust. f. 'Hierro aproximadamente semicircular que se clava a las caballerías en los cascos o a algunos vacunos en las pezuñas para que no se los maltraten con el piso' (DRAE). Término derivado de hierro, del latín fĕrrum (DECH, s.v. hierro).

Dos ferraduras de yerro biexas (Coomonte de la Vega, 1643)

Es el único ejemplo encontrado, aunque se trata de un término de uso general. En León, además del significado de 'hierro que se pone a los animales', el término cuando se usa en plural también tiene la acepción de 'piececitas de hierro que se colocan en la suela de los zapatos' (Le Men, 2005, s.v. ferradura). Con la información que da el ejemplo, no se puede saber con qué acepción concreta se utiliza el término, pero es probable que se refiera a la herradura de los animales. Formalmente, aparece con la conservación de la /f-/ inicial latina, frecuente en la zona occidental.

\section{HERRAJE [erraxe]}

Sust. m. 'Conjunto de piezas de hierro o acero con que se guarnece un artefacto, como una puerta, un cofre, etc.' (DRAE). Término derivado de hierro, del latín fẽrrum (DECH, s.v.hierro).

Un vufete de nogal vueno de dos tavlas con su erraxe y cantoneras y su tapete de guadamaçil usado (La Bañeza, 1649)

Un erraxe de carro (Huerga de Garaballes, 1720)

Un arca de castaño larga con todo erraxe en zing y en ella se alló una montera de Somonte buena (Grajal de la Ribera, 1723)

Un scriptorio fábrica de Salamanca con herraje y nabetas doradas (Robledo de la Valduerna, 1726)

Un cofre pequeño con su herraje con zerradura y llave y en el un capote de camellón con su forro encarnado, unos calzones de paño, casaca y chupa del mismo paño (Laguna de Negrillos, 1734)

El término se usa con el significado que da el diccionario académico. Como elemento que sirve para guarnecer, aparece en cierto tipo de muebles como son bufetes, escritorios o cofres. Es común en los inventarios que cuando se relacionan objetos como los mencionados, se especifique todo aquello que el objeto lleva, como en este caso el herraje.

\section{HORNO [orno]}

Sust. m. 'Fábrica para caldear, en general abovedada y provista de respiradero o chimenea y de una o varias bocas por donde se introduce lo que se trata de someter a la acción del fuego' (DRAE). Del latín fürnus (DECH, s.v. horno). 
Una pala de orno a medio serbir (Coomonte de la Vega, 1645)

Una pala de horno (La Antigua, 1647)

Una pala de orno nueba y otra biexa (Coomonte de la Vega, 1650)

Una pala de orno y un azadón (Laguna de Negrillos, 1721)

Dos palas de orno (Grajal de la Ribera, 1723)

Una pala de orno (Palacios de Jamuz, 1728)

Una pala de orno (Grajal de la Ribera, 1750)

Dos palas de horno (Quintanilla de Somoza, 1831)

Una masera con barandas, piñeras, palo de orno (Santibáñez de la Isla, 1844)

El término aparece siempre en el corpus asociado a uno de los elementos del horno, la pala, como un fenómeno de desambiguación, para diferenciarla de la pala de labranza. Se trata de un término común que era utilizado para fabricar el pan. En León es posible encontrar el término bajo la forma forno, muy frecuente incluso en la toponimia. En el corpus no aparece ningún ejemplo con esa variante.

\section{HORQUETA [orqueta]}

Sust. f. El DRAE señala el término, entre otras acepciones, como sinónimo de horca. Término derivado de horca, del latín fürca (DECH, s.v. horca).

Orquetas (Fresno, 1726)

Unas orquetas de tenaza (Miñambres, 1727)

Solo se han recogido estos dos ejemplos de la zona de La Valduerna, aunque es un término conocido por todo el territorio comprendido en el corpus. En León este término tiene varias acepciones, se llama horqueta a un 'palo grueso cuya parte principal está formada por la unión de dos ramas y se utiliza para sostener en alto el carro o para aumentar su capacidad', 'tentemozo', 'asador que primero fue de madera y después metálico, que consiste en una hoja de hierro terminada en horquilla simétrica', 'hincón con un gajo sobre el que se apoya el roble ya mondado que se usa para el cierre de las fincas' (Le Men, 2007, s.v. forqueta). No se tienen muchos datos de los ejemplos encontrados, pero probablemente y, teniendo en cuenta que es la acepción más común se trate de un 'palo de madera con dos gajos que sirve para sostener peso'. Formalmente, el término se ha recogido bajo la forma normativa, no hay ejemplos de forqueta, forma frecuente en León.

\section{JAULA}

Sust. f. 'Armazón, cerrado o no según los casos, hecho con barras o listones y destinado a encerrar animales' (DRAE). Del francés antiguo jaole íd., hoy geôle, procedente del latín caveola, diminutivo de cavea (DECH, s.v. jaula).

Una jaula de mimbre grande (Destriana, 1843) 
Es el único ejemplo recogido del término. Es una voz común. Para este tipo de armazones se usaban tablas, alambres pero también mimbres, como muestra el ejemplo, y normalmente se guardaban aves.

\section{LAVADERO [labadero]}

Sust. m. 'Lugar utilizado habitualmente para lavar'. 'Pila para lavar la ropa' (DRAE). Término derivado de lavar, del latín lavare (DECH, s.v.lavar).

Un labadero (La Nora del Río, 1823)

Es el único ejemplo encontrado cuyo significado es el de 'tabla que sirve para lavar la ropa restregándola', acepción que no recoge el DRAE. Con este significado, se documenta en León, pero en algunas zonas de La Bañeza en concreto en la Valdería, se usa el término en masculino para designar al 'lugar comunitario donde todas las mujeres del pueblo iban a lavar la ropa' mientras que en femenino se usa para nombrar la 'piedra plana o tabla de madera que usaban las mujeres para golpear y restregar en ella la ropa sucia mezclada con jabón a la hora de lavarla' (Rivas, 1996: 147). Sin embargo, en zonas próximas como en Zamora el término lavadero se usa con el significado de 'tabla de lavar' (Krüger, 1923: 125). Este dato puede explicar que en el ejemplo extraído del corpus se emplee la voz en masculino con este significado, ya que la localidad a la que pertenece el ejemplo es fronteriza con la provincia de Zamora. En otras zonas comprendidas en el P.J. de la Bañeza se documenta la voz banca que puede tener esta acepción, de cuyos ejemplos se recogen muestras en este corpus. El otro objeto que tiene el mismo uso y se documenta en el corpus es pila, aunque presenta matices diferentes puesto que es un objeto de piedra que está fijo frente al lavadero o la banca que son objetos de madera que se transportaban hasta el lugar en el que se lavaba.

\section{PILA}

Sust. f. 'Pieza grande piedra o de otra materia, cóncava y profunda, donde cae o se echa el agua para varios usos' (DRAE). Del latín pilā 'mortero', 'tina de batán' (DECH, s.v. pila).

Un pila de piedra de grano grande (Coomonte de la Vega, 1645)

Una pila buena mediana de comer los lechones (Alija del Infantado, 1646)

Una pila de madera (Alija del Infantado, 1647)

Una pila de piedra (La Antigua, 1648)

Una pila de piedra (La Bañeza, 1721)

Una pila de bronze para agua bendita (La Bañeza, 1721)

Una pila de piedra pequeña (Laguna de Negrillos, 1722)

Una pila de piedra (Grajal de la Ribera, 1723)

Una pila de piedra (Fresno, 1726) 
Una pila mediana de piedra (Miñambres, 1727)

Una pila de piedra (Palacios de Jamuz, 1728)

Una pila de piedra buena (Palacios de la Valduerna, 1728)

Una pila de piedra (Palacios de la Valduerna, 1730)

Dos pilas de piedra pequeñas (Laguna de Negrillos, 1740)

Una pila de piedra con su tapa (Felechares, 1837)

Una pila de piedra vuena (Destriana, 1843)

Este término se usa en el corpus con, al menos, dos acepciones, aunque probablemente podríamos señalar tres. En primer lugar, se denomina pila al 'recipiente de piedra ahuecada o de cemento en el que se les echa de comer a los cerdos' (Rivas, 1996: 182). Aunque en esta definición se señala que es un objeto de piedra, sin embargo, también se define en León como 'dornajo, especie de artesa donde se le echa la comida al cerdo' (Le Men, 2009, s.v. pila), por tanto con este significado se utiliza el término en los ejemplos de Alija del Infantado de 1646, donde claramente se especifica la función; y en el de Alija de 1647. Además hay bastantes ejemplos en los que solo se especifica que se trata de una pila de piedra. En estos casos el término puede tener el significado señalado, pero también el de 'fregadero' o 'lugar que se utiliza para lavar la ropa'. Los contextos en los que aparecen estos ejemplos no nos permiten señalar con exactitud la acepción del término en cada caso, ya que se encuentran en un listado junto a objetos de labranza, objetos del hogar, etc. Finalmente, en un único ejemplo, el término se utiliza con el significado de 'pila bautismal'.

\section{PLANCHA}

Sust. f. 'Utensilio de hierro, ordinariamente triangular y muy liso y acerado por su cara inferior, que en la superior tiene un asa por donde se coge para planchar' (DRAE). Del francés planche y este del latín palanca, vulgarmente *palanca (DECH, s.v. palanca).

Dos planchas (La Nora del Río, 1823)

Dos planchas (La Bañeza, 1754)

Son los únicos ejemplos recogidos. La presencia del numeral delante del término probablemente se deba a que, en el caso de las planchas de hierro, se utilizaban de dos en dos para reponer una por otra cuando la que se estaba utilizando dejaba de calentar.

\section{PLANCHADA}

Adj. f. 'Acción y efecto de planchar' (DRAE). De plancha.

Una fuente de Talabera planchada (Destriana, 1843) 
Se trata de un adjetivo derivado de plancha, término que originariamente significa 'superficie, lámina llana', por tanto aplicado al sustantivo fuente, probablemente se esté refiriendo a que se trata de una fuente llana.

\section{MALETA}

Sust. f. 'Especie de caja o cofre pequeño de cuero, lona u otras materias, que sirve para guardar en viajes o traslados ropa u otras cosas y se puede llevar a mano' (DRAE). Del francés antiguo malete íd., diminutivo de malle 'baúl', que a su vez se tomó del fráncico *malha 'saco de viaje' (DECH, s.v. maleta).

Una maleta de baqueta con sus corras ya vieja (Destriana, 1843)

Una maleta de moscobia (Alija del Infantado, 1837)

Una maletilla (Felechares, 1837)

Aunque los ejemplo son escasos, se trata de un término común que se utiliza con el significado actual.

\section{MASCARILLA}

Sust. f. 'Máscara que solo cubre el rostro desde la frente hasta el labio superior' (DRAE). Término derivado de máscara, probablemente del árabe máshara (DECH, s.v. máscara).

Una mascarilla de alambre buena (Coomonte de la Vega, 1645)

Es el único ejemplo recogido. Es probable que el uso general que se hace del término en el corpus responda al significado común de la palabra, aunque la escasez de información y la falta de ejemplos impiden conocer con exactitud qué objeto concreto nombra el término y cuál es su función, probablemente se trata de un tipo de máscara que se usa para proteger el rostro cuando se saca la miel de las colmenas.

\section{PALANCA}

Sust. f. 'Barra inflexible, recta, angular o curva, que se apoya y puede girar sobre un punto, y sirve para transmitir una fuerza' (DRAE). Del latín palanca, vulgarmente *palanca y este del griego phálanx,-angos (DECH, s.v. palanca).

Una palanca de yerro (La Nora del Río, 1820)

Una palanquilla (La Nora del Río, 1823)

El término palanca se documenta en León con otros significados que no recoge el DRAE, se llama palanca al 'listón de madera que sirve para cerrar las puertas o las ventanas' también al 'palo que se coloca en el armazón del carro para sujetar por debajo y evitar que se derrame la carga' y al 'brazo que atravies el huso por encima del canto' 
(Le Men, 2009, s.v. palanca). La especificación "de hierro", en el ejemplo recogido, permite suponer que se usa con un significado próximo al que aparece en el DRAE, en el caso de palanquilla no se hace ninguna especificación, por lo que puede tratarse del mismo significado empleado en el otro ejemplo, pero en este caso con el término en diminutivo.

\section{PALANQUiLla (vid.palanca)}

\section{PANDERO}

Sust. m. 'Instrumento rústico formado por uno o dos aros superpuestos, de un centímetro o menos de ancho, provistos de sonajas o cascabeles y cuyo vano está cubierto por uno de sus cantos o por los dos con piel muy lisa y estirada. Se toca haciendo resbalar uno o más dedos por ella o golpeándola con ellos o con toda la mano' (DRAE). Probablemente del latín tardío pandorium, variante de pandūra, tomados del griego pandúrion, pandûra 'especie de laúd de tres cuerdas', que también se aplicó a otros instrumentos (DECH, s.v. pandero).

Un pandero de tañer (Coomonte de la Vega, 1645)

Un pandero de tañer (Coomonte de la Vega, 1645)

Son los únicos ejemplos recogidos, que a pesar de estar documentados de la misma forma y pertenecer al mismo pueblo y año, son de inventarios diferentes. La especificación “de tañer” aclara el significado que tiene el término y que coincide con el que da el DRAE de 'instrumento de percusión', ya que en el CORDE y en inventarios de Castilla de la misma época, S. XVII, se recoge este término con la acepción de 'recipiente semejante a la criba pero sin agujeros' (Perdiguero, 2012b: 1556).

PIE

Sust. m. 'Base o parte en que se apoya algo' (DRAE). Del latín pēs, pĕdis (DECH, s.v. pie).

Un banco largo tosco de quatro pies (Coomonte de la Vega, 1643)

Un pie de açófar del candil que ba dicho (Coomonte de la Vega, 1643)

Un bufete con los pies de madera y un caxón debajo del sin llave (Coomonte de la Vega, 1643)

Otra mesa mediana de cuatro pies (Coomonte de la Vega, 1643)

Un pie de devanadera (Alija del Infantado, 1644)

Una xarra de Talabera fina con el pie quebrado y un barril de barrio colorado (Coomonte de la Vega, 1645)

Un argadillo con su pie (Coomonte de la Vega, 1645)

Un banquito pequeño de quatro pies (Coomonte de la Vega, 1645)

Un torno de torcer ylo con su pie (Coomonte de la Vega, 1645) 
Una masera buena con sus pies altos (Alija del Infantado, 1646)

Unos pies de debanadera (Alija del Infantado, 1646)

Un arca de pies alta buena de álamo (Coomonte de la Vega, 1650)

Una mesa redonda de pie de nogal y una tabla con sus cuatro clavos (Laguna de Negrillos, 1722)

Un escañil de tres pies de largo con diez y ocho clabos (Grajal de la Ribera, 1723)

Una papelera con su zerradura y pie de pino (Robledo de la Valduerna, 1726)

Un arquetón con sus pies (Miñambres, 1729)

Un bufete de una tabla grande de nogal hendido por el medio con sus pies y traveseros de yerro (Palacios de la Valduerna, 1730)

Dos pies de negrillo (Miñambres, 1731)

Un pie de argadillo con sus alas (La Bañeza, 1758)

Tres pies de chopo (Castrocalbón, 1814)

Una sarten de tres pies (Quintanilla de Somoza, 1831)

Unos pies formados para sostener los dos vaúles (Destriana, 1843)

Un pote de yerro con tres pies (Destriana, 1843)

Unas trévedes pequeñas triangulares de tres pies (Destriana, 1843)

Es un término común que se emplea en prácticamente todos los ejemplos con el significado de 'soporte' que en la mayor parte de los ejemplos suele ser de un mueble. En algún caso incluso se especifica si es significativo el material o el tipo de madera del pie, puesto que es un dato importante para valorar el mueble. En el ejemplo de Grajal de la Ribera de 1723, el término adquiere el significado de 'unidad de medida'.

\section{POSTE}

Sust. m. 'Madero, piedra o columna colocada verticalmente para servir de apoyo o señal' (DRAE). Tomado del latín pŏstis (DECH, s.v. poste).

Un poste de negrillo bueno (Coomonte de la Vega, 1645)

Un poste de negrillo de dos baras de largo (Coomonte de la Vega, 1645)

Son los únicos ejemplos recogidos. Se trata de un término común cuyo significado es el que da el diccionario académico.

\section{REAL}

Sust. m. 'Moneda equivalente a 25 céntimos de peseta' (DRAE). Tomado del bajo latín realis, derivado de res 'cosa', en plural 'las cosas, la realidad, la naturaleza' (DECH, s.v. real).

Veynte reales en dinero (Coomonte de la Vega, 1719)

Zinquenta reales del gasto de la voda (Coomonte de la Vega, 1719)

Dos mil reales para la compra de un par de bueyes (Alija del Infantado, 1812)

Doscienttos reales para la compra de tiestos y otras cosas (Alija del Infantado, 1812)

El término designa el nombre de la moneda de curso legal en España en esta época. En todos los objetos que se relacionaban en el inventario se escribía su valor en reales, pero en estos casos lo que se relaciona es precisamente una cantidad de dinero 
para un fin determinado. El real en un principio se hacía en plata, pero después pasó a ser de vellón, mezcla de plata y cobre.

\section{RODEZNO}

Sust. m. 'Rueda hidráulica con paletas curvas y eje vertical'. 'Rueda dentada que engrana con la que está unida a la muela de la tahona' (DRAE). Del latín vulgar *roť̌č̆nus (DECH, s.v. rueda).

Un rodezno de molino pequeño (Coomonte de la Vega, 1645)

Semánticamente, el término no presenta ninguna singularidad ya que mantiene su significado de 'rueda hidráulica de molino'. Resulta significativo el hecho de que aparezca bajo la forma normativa, dato poco usual ya que en toda la provincia y zonas occidentales la palabra presenta muchas variantes formales que son más comunes, así en el P.J. de la Bañeza es muy común encontrar la forma rodesno.

\section{ROLDO}

Sust. m. El DRAE da para la voz rollo la acepción de 'madero redondo, descortezado, pero sin labrar'.

Un roldo de nogal bueno (Villazala, 1723)

Dos roldos de negrillo buenos (Villazala, 1723)

Un roldo con una viga de álamo que esta en Villoria (Villazala, 1723)

Un roldo de roble que tiene un lumbral (Destriana, 1728)

Dos roldos de negrillo uno gordo y otro delgado (Requejo de la Vega, 1735)

Un roldo y tres palos de chopo (Castrocalbón, 1814)

Se trata de un término común, aunque solo se hayan recogido cuatro ejemplos y tres de ellos pertenezcan al mismo inventario. El término tiene el significado de 'tronco grueso y bajo de un árbol, del que se sacan tablas o sirve de apoyo para cortar leña' (Rivas, 1996: 208). El CORDE no recoge ejemplos del término, aunque está documentado no solo en León sino también en Santander, Cuenca, Asturias, especialmente utilizado en femenino (Le Men, 2012, s.v. rollo). En otras zonas de León puede aparecer bajo las formas rueldo, roeldo o rollo, variantes que no se recogen en el corpus.

\section{RUEDA}

Sust. f. 'Pieza mecánica en forma de disco que gira alrededor de un eje' (DRAE). Del latín rŏta (DECH, s.v. rueda).

Un aciguñal de una rueda de errero (Coomonte de la Vega, 1645) 
Un carro bueno con sus ruedas y armaduras y berbixones (Alija del Infantado, 1646)

Un carro con sus ruedas (La Antigua, 1647)

Una naspa de rueda (Coomonte de la Vega, 1719)

Un carro con sus ruedas (Genestacio de la Vega, 1721)

Un carro con sus ruedas, berbixones, angarillas, sogas (Grajal de la Ribera, 1723)

Una rueda de carro (La Nora del Río, 1724)

Unas ruedas viejas (Fresno, 1726)

Dos morrillos de rueda (Fresno, 1726)

Unas ruedas desquartadas con una porción de madera vieja (Viñas, 1726)

Una rueda viexa con dos gatos (Miñambres, 1727)

Unas ruedas viejas (Palacios de la Valduerna, 1728)

Un carro con sus ruedas, berbijones y angarillas (Palacios de la Valduerna, 1730)

Una rueda de carro y unos ejes biejos (Requejo de la Vega, 1735)

Una rueda con su eje (Requejo de la Vega, 1735)

Unas ruedas viejas (Laguna de Negrillos, 1742)

Es un término muy común cuyo significado más empleado en el corpus es el de 'rueda de carro'. No obstante hay algún ejemplo en el que la palabra rueda aparece para designar un objeto que se compone de algún elemento con esta forma, como es el caso de naspa de rueda. En la zona del P.J. de la Bañeza, concretamente en el entorno de Jiménez de Jamuz, también se llama rueda al 'torno de alfarero' (Casado, 1979: 118), pero con este significado no se ha recogido ningún ejemplo. Tampoco con otras acepciones empleadas en León como 'piedra de molino' o 'instrumento agrícola de madera que se usa para allanar la tierra después de haber pasado el rastro' (Le Men, 200, s.v. rueda).

\section{SOGA}

Sust. f. 'Cuerda gruesa de esparto' (DRAE). Del latín tardío $s \bar{c} c a$, este es de origen incierto, quizá tomado de una lengua prerromana del norte de Europa (DECH, s.v. soga).

Unas sogas de meter paxa (La Antigua, 1647)

Unas sogas de meter paxa biexas (Coomonte de la Vega, 1650)

Unas sogas de cáñamo de meter paxa con sus tiraderos y usadas (Alija del Infantado, 1650)

Quatro sogas trenzadas (La Bañeza, 1721)

Unas sogas de meter paja con sus palos (Laguna de Negrillos, 1721)

Unas sogas de meter paja (Genestacio de la Vega, 1721)

Un carro con sus ruedas, berbixones, angarillas, sogas (Grajal de la Ribera, 1723)

Una soga de meter paja (Palacios de la Valduerna, 1730)

Unas sogas (Destriana, 1843)

Es un término de uso general, aparece frecuentemente en el corpus con la acepción de 'red de sogas' y junto al término suele referirse la función que tenían las sogas, normalmente se empleaban para meter paja. 
TABLA

Sust. f. 'Pieza de madera plana, de poco grueso y cuyas dos caras son paralelas entre sí' (DRAE). Del latín tabŭla (DECH, s.v. tabla).

Una tabla de messa vieja (Vidriales, 1645)

Un arca de nogal vieja con unas tablas sueltas sin cerradura ni llave (Laguna de Negrillos, 1722)

Una mesa redonda de pie de nogal y una tabla con sus cuatro clavos (Laguna de Negrillos, 1722)

Un escañil de una tabla con sus traveseros de yerro (Laguna de Negrillos, 1722)

Una mesica pequeña de dos tablas (Grajal de la Ribera, 1723)

Una cama de tablas (Fresno, 1726)

Una mesa de nogal de dos tablas (Robledo de la Valduerna, 1726)

Una mesa larga de dos tablas (Toral, 1728)

Una mesa larga de una tabla de álamo (Palacios de la Valduerna, 1728)

Una cama de tablas viejas (Miñambres, 1729)

Dos docenas de tablas de chopo (Miñambres, 1729)

Un bufete de una tabla grande de nogal hendido por el medio con sus pies y traveseros de yerro (Grajal de la Ribera, 1730)

Una banca de una tabla (Grajal de la Ribera, 1730)

Una cama de tablas usada (Destriana, 1730)

Una messa corta de una tabla (Destriana, 1730)

Una mesa de dos tablas (Miñambres, 1731)

Un bufete con su cajón de una tabla de castaño (Santiago Millas, 1735)

Dos docenas de tablas de chopo (Castrocalbón, 1814)

Diez y seis tablas (Castrocalbón, 1814)

Una tabla de mesa (Destriana, 1825)

Un escaño de dos tablas con dos estrellas (Palacios de la Valduerna, 1831)

Un pedazo de tabla para una mesa con un palo atrabesado (Palacios de la Valduerna, 1831)

Una tarima de una cama con tablas (Palacios de la Valduerna, 1831)

Un escañil de dos tablas (Palacios de la Valduerna, 1831)

Diez y ocho tablas (Palacios de la Valduerna, 1831)

Una tabla de chopo y un cesto de binbre (Calzada, 1838)

Una tabla de manteles de gusanillo de dos piernas de siete cuartas de largo (Coomonte de la Vega, 1643)

Otra tabla de manteles de dos lienzos de gusanillo buenos (Alija del Infantado, 1646)

Dos tablas de manteles de gusanillo (La Bañeza, 1647)

Una tabla de manteles de gusanillo (Robledo de la Valduerna, 1726)

Dos tablas de alemanisco (Robledo de la Valduerna, 1726)

Dos tablas de manteles usados y un zernadero de estopa (Laguna de Negrillos, 1734)

Una tabla de manteles vuena (Alija del Infantado, 1812)

Una tabla de manteles grandes y finos de gusanillo muy usados (Destriana, 1843)

Trece tablas de álamo medianas (Coomonte de la Vega, 1643)

Seis tablas de álamo (La Nora del Río, 1645)

Una tabla de castaño grande buena (Alija del Infantado, 1647)

Trece tablas de un poçal (Villamor de Órbigo, 1648)

Quatro tablas viejas (Villamor de Órbigo, 1648)

Unos terziales con sus aparejos, un frontal, una regla, tres tablas, una biga de álamo

(Coomonte de la Vega, 1719)

Seys tablas delgadas (Genestacio de la Vega, 1721)

Quatro tablas que están enzima de los tirantes del lagar (Laguna de Negrillos, 1722)

Una tabla de álamo (Palacios de la Valduerna, 1727)

Una tabla de roble (Palacios de Jamuz, 1728) 
Una tabla (Palacios de Jamuz, 1728)

Una tabla de chopo buena (Palacios de la Valduerna, 1728)

Dos tablas de negrillo (Palacios de la Valduerna, 1728)

Seis tablas anchas (Castrillo de la Valduerna, 1828)

Quatro tablas más angostas (Castrillo de la Valduerna, 1828)

Una tarima con tablas de chopo (Quintanilla de Somoza, 1831)

Cuatro tablas y una reja (Quintanilla de Somoza, 1831)

Un pedazo de tabla (Palacios de la Valduerna, 1831)

Un basalico chico y una tabla (Palacios de la Valduerna, 1831)

Una tabla buena con un banco (Miñambres, 1729)

Una tabla de chopo (Miñambres, 1731)

Dos tablas viexas (Miñambres, 1731)

Un varal de tablas (La Nora del Río, 1823)

Una porzión de tablas viejas (La Nora del Río, 1823)

Son numerosos los ejemplos recogidos del término puesto que estamos ante una voz muy común con un uso polisémico. Los ejemplos aparecen agrupados en tres bloques. Por una parte aquellos en los que el término aparece con algún tipo de mueble, ya sea una mesa, un bufete, etc. en los que la palabra adquiere el significado de 'pieza de madera plana'; con este sentido se utilizaría en los ejemplos en los que se cita una cama de tablas, para diferenciarla de una cama de encordeladura. En el segundo bloque, el sustantivo tabla aparece junto al término mantel, en este caso sirve para denominar lo que hoy conocemos como 'mantel', frente al término aislado de mantel que se utilizaría con el significado de 'paño' (vid. mantel). Finalmente, aparecen bastantes ejemplos en los que el término tabla aparece aislado o con un sintagma que especifica el tipo de madera del que está hecha la tabla. Probablemente en este último caso, el término también adquiera el significado de 'pieza de madera plana', incluso podría utilizarse como sinónimo de mesa, en los ejemplos en los que no se especifica nada podría tratarse también del mismo uso ya que el propio contexto lo determina, por ejemplo en «Quatro tablas que estan enzima de los tirantes del lagar (Laguna de Negrillos, 1722)» o incluso tener otra acepción. En una zona bastante próxima a la estudiada se llama tabla a una 'especie de cajón que sirve para lavar sobre él la ropa en el río' y a un 'tipo de arrodador para allanar el terreno' (Fuente García, 2000: 537). No está claro que estas acepciones se utilicen en alguno de los ejemplos ya que la falta de datos impide concretar más, no obstante sí se utiliza para denominar al cajón de lavar el término banca que aparece junto a la voz tabla en «una banca de una tabla (Grajal de la Ribera, 1730)». 


\section{BATIENTE}

Sust. m. 'Cada una de las hojas de una puerta o ventana' (DRAE). Término derivado de batir, del latín battuěre (DECH, s.v. batir).

Un batiente y dos tablas (Castrocalbón, 1814)

Es el único ejemplo encontrado aunque se trata de un término de uso común que se utiliza con el significado de 'jamba de la puerta'.

\section{TABLADO/A}

Adj. m. y f. 'Hecho de tablas unidas'. Término derivado de tabla.

Una zestica tablada (Coomonte de la Vega, 1643)

Un canestillo grande tablado bueno (Alija del Infantado, 1646)

Un canastillo tablado biexo (Alija del Infantado, 1647)

Un cesto tablado bueno grande (Alija del Infantado, 1647)

Un canestillo tablado (La Antigua, 1648)

Un zesto tablado grande nuevo (Genestacio de la Vega, 1650)

Otro quiñón de casa donde vibió que es el cuarto de la calle que se compone de alto y vajo que está tablado cubierto de teja (Palacios de la Valduerna, 1831)

Es un término que aparece frecuentemente con el sustantivo cesto y canastillo, para diferenciar el cesto hecho de mimbre de este que es aquel hecho de tablas.

\section{TABLIZO/A}

Adj. m. y f. 'Hecho de tablas unidas' Término derivado de tabla.

Una zesta tabliza (La Bañeza, 1721)

Un zesto tablizo (Toral, 1728)

Una zesta tabliza (Palacios de la Valduerna, 1728)

Una zesta tabliza de sembrar (Miñambres, 1729)

Dos zestas tablizas (Destriana, 1730)

Una zesta tabliza (Genestacio de la Vega, 1738)

Un cesto tablizo y un banco (Castrocalbón, 1814)

Tres cestas tablizas (La Nora del Río, 1823)

Una banastra grande tabliza (Castrillo de la Valduerna, 1828)

Una cesta tabliza y otra de mimbres (Quintanilla de Somoza, 1831)

Un cesto tablizo sin asa con un poco de yerro (Palacios de la Valduerna, 1831)

Un cesto tablizo (Palacios de la Valduerna, 1831)

Se aprecian dos diferencias en el uso de uno y otro adjetivo. El término tablizo/a aparece en el S. XVIII y XIX, los ejemplos de tablado/a son la mayoría del S. XVII y además la voz tablado/a aparece fundamentalmente, aunque hay un ejemplo de la Valduerna, en la actual zona del Bajo Órbigo y en lo que actualmente pertenece al norte de la provincia de Zamora; mientras que solamente hay un ejemplo del término 
tablizo/a en La Nora del Río. Partiendo de los datos del corpus, probablemente, aunque sean términos sinónimos el uso de ambos no es igual en una u otra zona.

\section{TACHUELA}

Sust. f. 'Clavo corto y de cabeza grande' (DRAE). Del occitano antiguo tacha (DECH, s.v. tachón).

Un millar de tachuelas (La Bañeza, 1712)

Es el único ejemplo recogido, aunque se trata de una voz conocida que se utiliza con el significado que da el diccionario académico. Tampoco se recoge el término bajo otras variantes que sí se documentan en León como trachuela, trachola y trichuela (Le Men, 2009, s.v. tachuela).

\section{TIJERA [tixera]}

Sust. f. 'Instrumento compuesto de dos hojas de acero, a manera de cuchillas de un solo filo, y por lo común con un ojo para meter los dedos al remate de cada mango, las cuales pueden girar alrededor de un eje que las traba, para cortar, al cerrarlas, lo que se pone entre ellas' (DRAE). Del latín tonsōrias, probablemente forfices tonsorias 'tijeras de esquilar', derivado de tondēre 'esquilar' (DECH, s.v. tijeras).

Unas tixeras lanales biexas y otras tixeras pequeñas de costurera (Coomonte de la Vega, 1645)

Dos pares de tixeras de trisquilar el ganado (Bercianos del Páramos, 1648)

Unas tijeras lanares (Palacios de Jamuz, 1728)

Unas tijeras lanares (Destriana, 1728)

Una gubiletera de cobre con unas tijeras de espabilar todo (Laguna de Negrillos, 1734)

Unas tixeras con su vaina (Saludes de Castroponce, 1808)

Unas tixeras llanares (Calzada, 1838)

Una tijera con augero (Requejo de la Vega, 1839)

En todos los ejemplos, el término se usa con el significado general del término. La diferencia está en los usos del objeto. En algunos casos, aquellos en los que aparece con el adjetivo lanares, se trata de las tijeras que se usaban para esquilar a las ovejas, en otros el término aparece con el uso de tijeras de costura, es el caso del primer ejemplo o del último ya que aparecen en la relación junto a artículos textiles como cortinas o felpos. También hay un ejemplo que remite a otro uso de este objeto mencionando las tijeras que se usaban para avivar la llama de las velas. En muchas zonas de León, el término tijeras se usa con el significado de 'insecto', acepción que no sería lógica en una relación de enseres; y con el significado de 'maderas que se colocan en la techumbre 
sobre las que se apoya el techo' (Le Men, 2011, s.v. tijeras), que tampoco aparece en el corpus. Formalmente, alterna la variante castellana tijeras con la forma tixeras, común en toda la zona.

VARA (vid. unidades de medida)

\section{VARAL [baral]}

Sust. m. 'Vara muy larga y gruesa'. 'Cada una de las varas del carro. U. m. en pl.' (DRAE). Término derivado de vara, del latín vara ( $D E C H$, s.v. vara).

Un baral de omero mediano (Coomonte de la Vega, 1643)

Un varal de tablas (La Nora del Río, 1823)

Un varal viejo (Felechares, 1837)

De nuevo estamos ante un término polisémico, aunque en los ejemplos encontrados el significado de esta palabra coincide con la primera acepción del DRAE. En muchas zonas esta vara se solía emplear para colgar alimentos: los chorizos de la matanza, las cebollas, etc. Probablemente este fuera el uso que también se les daba a las inventariadas en el corpus.

\section{VELLón [bellón]}

Sust. m. 'Conjunto de la lana de un carnero u oveja que se esquila' (DRAE). Del latín villus (DECH, s.v. vello).

Un medio bellón de lana blanca (Coomonte de la Vega, 1643)

Un bellón de lana (Grajal de la Ribera)

Se trata de una palabra homónima. Con este significado que aparece en el diccionario académico solo se han recogido estos términos.

Además encontramos en el corpus otro ejemplo en que el término adquiere el significado de 'moneda', que define el DRAE como 'moneda de cobre que se usó en lugar de la fabricada con liga de plata'. En este caso el término procede del francés billon, derivado de bille (DECH, s.v. vellón).

Todos los quales vienes suman la cantidad de quinientos mil trescientos y tres reales de vellón (Alija del Infantado, 1812).

Fue moneda de curso legal en España que previamente se hacía de plata y posteriormente pasó a ser de vellón. Se dividía en 34 maravedís. (Castañeda Ordóñez, 2003: 192). 


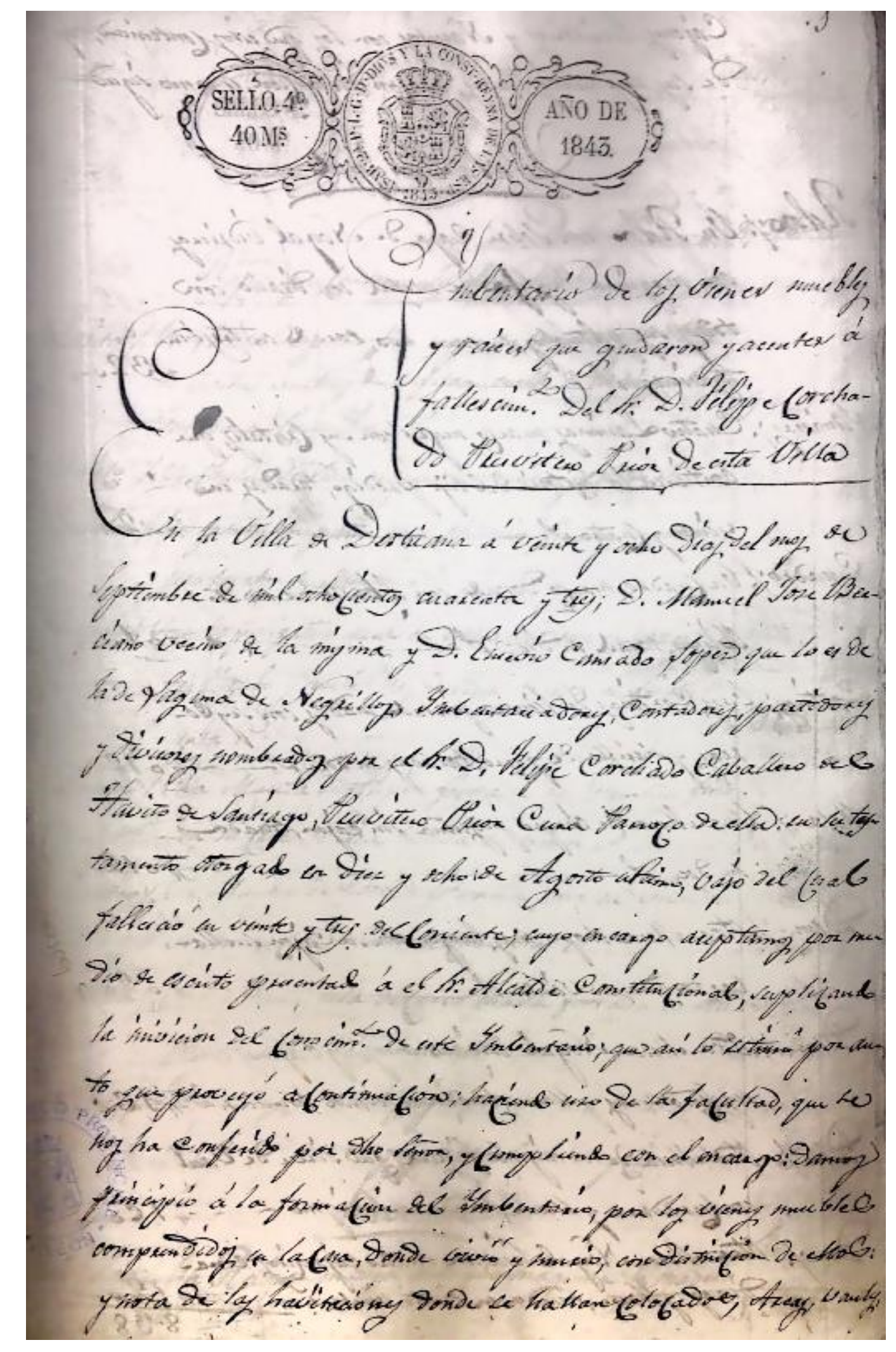

${ }^{2}$ Primeros folios de un inventario con sello, año y título. 


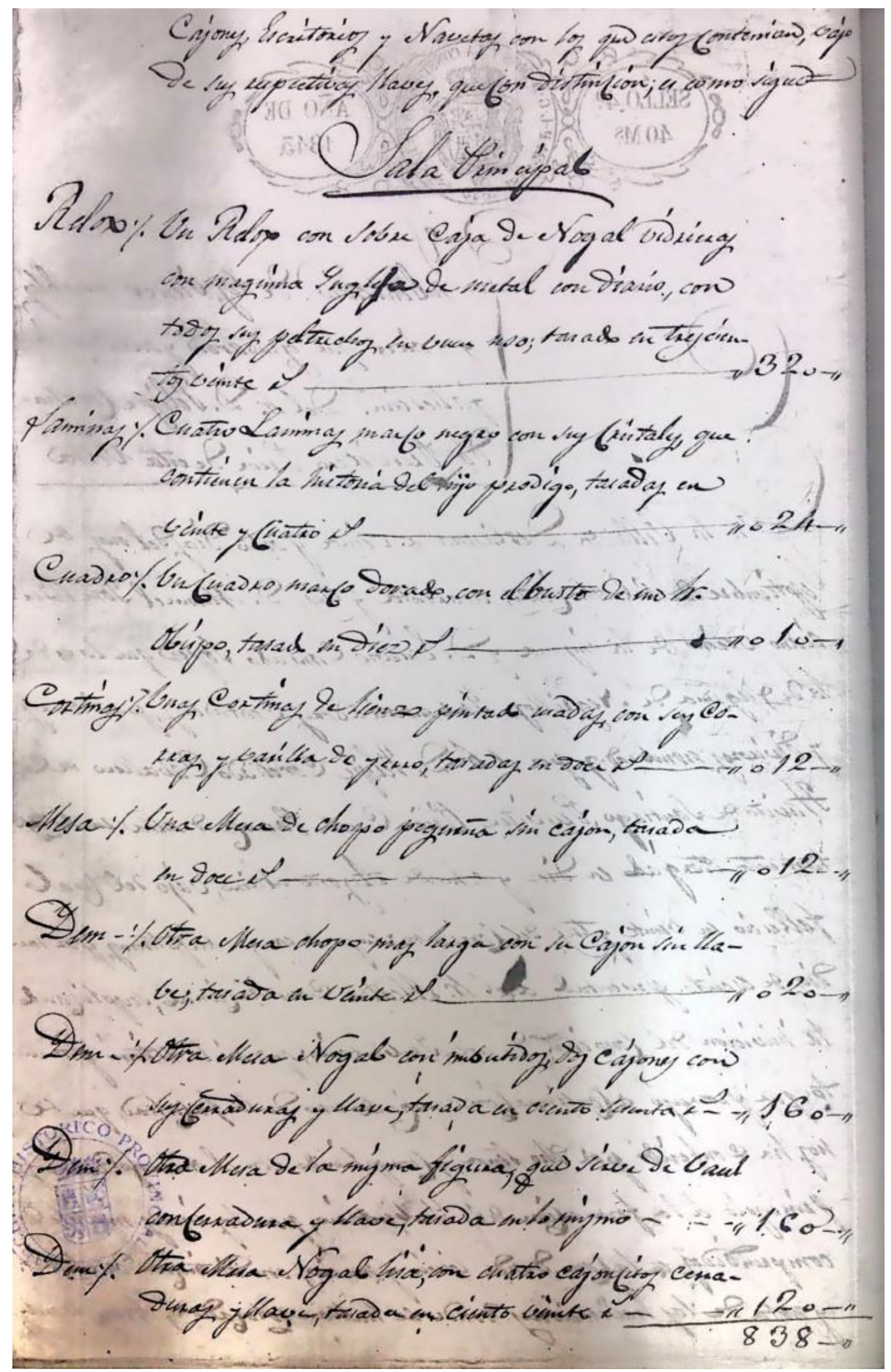




\section{CONCLUSIONES LINGÜÍSTICAS}

\section{Justificación}

Para enmarcar las conclusiones lingüísticas voy a partir de los rasgos generales que caracterizan el leonés con el fin de hacer una descripción de cuál es la lengua que en este contexto (zona comprendida por el Partido Judicial de La Bañeza) y en este período de tiempo se usa en los inventarios analizados y poder así llegar a concluir si podemos hablar de leonés o de castellano con rasgos leoneses. Seguiré el mismo planteamiento que en la introducción comentando los rasgos fonéticos significativos que aparecen en el corpus, con una diferenciación entre el vocalismo y el consonantismo y los rasgos morfológicos. Finalmente haré un breve comentario sobre los rasgos gráficos que sean reseñables y, puesto que el objeto de la tesis es el estudio del léxico, intentaré hacer un análisis que sirva de conclusión sobre cuál es el léxico que aparece, centrándome fundamentalmente en la procedencia de los términos.

En la documentación manejada en este estudio son pocos los leonesismos encontrados ya que se trata de textos escritos y por tanto en los que se usa la lengua propia de un registro formal. No hay que olvidar que, además, estos documentos eran escritos por personas habituadas al oficio de escribir que, aunque no pertenecieran a un nivel socio cultural elevado, sí tenían al menos conciencia de lo que era la lengua escrita y por tanto del uso normativo de la misma. Estos datos no invalidan que, sin embargo, los rasgos leoneses sí estuvieran presentes en la lengua hablada de la zona (e incluso alguno en la lengua escrita) ya que en épocas posteriores, concretamente en el S. XX y en la actualidad, esos rasgos siguen existiendo y han sido incluso recogidos y estudiados por los dialectólogos.

\subsection{Aspectos fonéticos. Consonantismo}

\subsubsection{Conservación de /f-/}

Analizando los casos de conservación de /f-/ recogidos en este corpus, se puede afirmar que se mantiene una inestabilidad en cuanto al fenómeno que no coincide ni con aspectos cronológicos ni tampoco geográficos. Aparecen voces en las que siempre se da el fenómeno de conservación de /f-/ como fosco o fusa, también ferreruelo ${ }^{3}$ que no resulta significativo puesto que en castellano es la forma común; otras sin embargo

\footnotetext{
${ }^{3}$ El CorLexIn recoge un amplio número de casos de ferreruelo distribuidos por documentos de toda la Península frente a un número reducido de casos de herreruelo.
} 
nunca conservan la /f-/ como horno, hilo, herraje u horca en la que de los seis casos recogidos de la voz horca, solo uno mantiene la /f-/. Este caso de conservación en la palabra horca aparece en un inventario de Quintanilla de Somoza fechado en 1831 y mantiene esta correspondencia con el único ejemplo de forcada, que no horcada, que aparece en el mismo inventario. Sin embargo, este equilibrio se rompe en voces como horno donde en el mismo inventario de Quintanilla de Somoza, encontramos horno en lugar de forno. Igualmente sucede con la palabra horma que solo recoge un caso de conservación en un inventario de Alija del Infantado fechado en 1644 en el que también se recoge la variante horma, sin conservación de /f-/. Más significativo es el caso de fierro en un inventario de La Bañeza de 1758 en el que encontramos «unas trébedes pequeñas de fierro», término que aparece ampliamente documentado en el corpus y nunca con conservación de /f-/ salvo en este caso. Por tanto se puede afirmar que la lengua que se aprecia en este aspecto fonético refleja una vacilación que en algunos casos puede estar indicando la norma escrita que usa el escribano frente a su lengua oral (horma/forma en Alija del Infantado, 1644) y en otros refleja cómo las palabras más comunes presentan una mayor influencia del castellano que impide la conservación, es el caso de horno o hilo. A este respecto, aún en el S. XX, algunos estudiosos recogen todavía formas dialectales. Así Borrego Nieto señala que en las zonas establecidas por él como zonas 2 y 3 del leonés (Borrego Nieto, 1996: 147-152), que comprenden la zona de La Bañeza y de la Ribera del Órbigo respectivamente, aún hoy se conserva este rasgo. La zona 2 que se caracteriza por una pérdida notable de rasgos, todavía conserva la /f-/ en mayor o menor medida, y en la zona 3 que estaría limitada por la isoglosa de la /f-/ inicial, aún hoy se puede rastrear; aunque se trata de un fenómeno caduco y estigmatizado (Borrego Nieto, 2007: 141, 151); lo que indica que los casos de pérdida de /f-/ inicial del corpus estudiado reflejan que el escribano toma como referencia la lengua escrita en la que la pérdida de /f-/ sería la norma.

\subsubsection{Palatalización de /l-/}

Menéndez Pidal señala como rasgo característico del consonantismo del leonés la palatalización de la /l-/ (Menéndez Pidal, 1906: 158-159 [2006]). Con posterioridad, Borrego Nieto afirma que es un rasgo cuya isoglosa va unida a la de la conservación de la /f-/ excepto en la parte oriental (Borrego Nieto, 1996:151). Por su parte, Morala señala que se trata de un rasgo que caracteriza al leonés frente a otros romances y que históricamente abarca todo el territorio de habla leonesa (Morala y Gancedo, 2009: 84). 
Sin embargo, la presencia de este fenómeno en el corpus es mucho menor que la del rasgo anterior, puesto que se reduce únicamente a un ejemplo, la voz llanares ya que la palatalización no se produce ni siquiera en el sustantivo lana del que deriva el adjetivo llanares. Este único ejemplo es casualmente el más tardío de todos los casos recogidos del término, pertenece al S. XIX, quizá porque se ha interpretado en una lengua castellanizada que no las rechaza. Además de las voces lana o lanares, encontramos otras palabras sin palatalizar como lata, lagar, lámina; por lo que coincidiendo con Morala y Gancedo (Morala y Gancedo, 2009: 84), este fenómeno se presenta con mucha diferencia en el grado de pervivencia y en este caso nos encontramos en una zona en la que en este período de tiempo prácticamente no se produce, al menos en la lengua escrita.

\subsubsection{Mantenimiento de /-mb-/}

Morala afirma que se trata de un fenómeno que no aparece en muchas palabras, pero que es significativo porque va a diferenciar al leonés del castellano, coincidiendo con el gallego (Morala y Gancedo, 2009: 87). La presencia de este rasgo en el corpus estudiado es irregular ya que se mantiene de manera constante en palabras como camba 'pieza curva' y en sus derivados, por ejemplo el verbo cambar. Sin embargo, en otras palabras donde sería esperable la presencia de este fenómeno, puesto que se trata de términos representativos en el mantenimiento de este rasgo, no aparece; es el caso de la voz palomo. El único ejemplo recogido de palomo pertenece al S. XIX, mientras que los ejemplos de camba y derivado pertenecen al S. XVII y primera mitad del S. XVIII. Este hecho puede deberse a que la voz castellanizada paloma es mucho más conocida, lo que hace que el término aparezca regularizado bajo esa forma, mientras que para la voz camba y derivados no se conoce otra forma y es la que se refleja en el corpus, sin que eso implique considerar este fenómeno como un rasgo característico del leonés en esta época y zona. Borrego Nieto señala que los ejemplos de /-mb-/ en la zona denominada 3 y que comprende la Ribera del Órbigo, se repiten monótonamente y muchos están ligados al verbo lamber (Borrego Nieto, 1996:151), que no aparece en este repertorio léxico. Este dato podría explicar que tal vez, lo que refleja el corpus es que con el paso del tiempo en esta zona se iba perdiendo y, por ello, una palabra en la que se esperaría la presencia del rasgo ya no aparece por ser de una época más tardía. 


\subsubsection{Confusión de las consonantes líquidas $/ \mathrm{l} / \mathrm{r} /$}

Otro rasgo que se presenta como característico del leonés frente al castellano es la confusión entre /1/ y /r/ (Menéndez Pidal, 1906: 167-168 [2006]). En cuanto al corpus estudiado, encontramos algunos ejemplos de cambio /1/ y /r/, aunque conviene hacer alguna matización. Se producen casos de confusión cuando la /l/ se encuentra en situación implosiva, aunque no es muy generalizada. Así encontramos dos ejemplos de armilla frente a almilla en un inventario de Laguna de Negrillos de 1734 y de Alija del Infantado de 1823, un ejemplo de arconciles frente a alconciles en otro inventario de Alija del Infantado de 1720. Esta coincidencia en la zona no nos permite llegar a conclusiones sobre la presencia de este rasgo en el corpus ya que también encontramos la forma castellana alconciles en inventarios de Genestacio de la Vega y de Saludes de Castroponce, es decir dentro de la misma comarca de Bajo Órbigo a la que pertenece Alija del Infantado. Esta misma confusión la encontramos en otras palabras como alcabuz en dos inventarios de Laguna de Negrillos y Santiago Millas, ambos del S. XVIII y el cambio contrario en un ejemplo de almario en un inventario de Castrocalbón de 1643, lo que indica que el cambio no es sistemático sino que existe gran variabilidad.

La voz vasal siempre aparece en el corpus bajo la forma vasar. En este caso sí se produce con regularidad el cambio del sufijo - al por - ar, aunque en ningún caso aparecen ejemplos de este rasgo asociados a la formación de nombres femeninos de árboles, encontrando siempre la voz nogal y en ningún caso la forma ñozar, que parece ser más común en Asturias (Zamora Vicente, 1974: 164). Algunos autores han señalado que es común encontrar confusión /l/ /r/ en grupos consonánticos. En el corpus estudiado no se documenta ningún caso de confusión ya que aparecen siempre en los inventarios las voces pluma y plato, aunque Zamora Vicente señala que hoy es usual encontrar el cambio de /l/ en segundo lugar de un grupo, en /r/ en la Bañeza entre otras zonas (op. cit.137).

Finalmente, encontramos otros casos en los que, junto a la confusión /1/ /r/ se produce un fenómeno de metátesis. Se trata de la voz peselbera que alterna con la variante normativa.

En conclusión, se trata de un fenómeno frecuente, aunque a excepción de vasar, se produce solo en algún ejemplo de los recogidos para cada término por lo que de nuevo no podemos hablar de sistematicidad en el rasgo. Por otra parte, aunque se trata de un rasgo frecuente en la zona del dominio leonés, también lo encontramos en castellano, incluso en la zona oriental, por ejemplo el CorLexIn presenta ejemplos de 
armilla en lugar de almilla en inventarios de Orihuela (Alicante) o Almería, de alcabuz en lugar de arcabuz en documentos de Murcia, Almería o Toledo; o en relación al cambio -al /-ar encontramos la forma vasar también en documentos de Escalona (Toledo).

\subsection{5. $/ \mathbf{k}^{\prime} \mathrm{l} / \mathrm{y} / \mathrm{lj} /$}

La combinación /lj/ y / $\mathrm{k}^{\prime} \mathrm{l} /$ seguida de vocal dio como resultado en la mayoría de los romances una solución palatal. Por lo que respecta al corpus estudiado, encontramos esta solución pero no de forma generalizada y reducida a algunas palabras. En cuanto al grupo /k'l/ aparece la solución leonesa en abuyeta para agujeta 'correa, cinta', en el único ejemplo recogido perteneciente a un inventario de Quintanilla de Somoza de 1831. El resto de palabras que aparecen en el corpus procedentes del grupo /k'l/ siempre presentan la solución castellana /x/: orejera, botija, navaja, espejo o cerrojo o la voz sajo o xaxo con cambio de la /s-/, palatalización de la consonante y posterior velarización, procedentes de sarculum, cuya solución en leonés serían las formas sayo, sallo, aunque también encontramos sajo y sacho. También presenta la solución castellana la palabra cabija procedente de clavicŭla, pero aparece un caso de cabía que se puede explicar porque es frecuente que la /y/ desaparezca cuando va precedida de vocales palatales, como en este caso (op. cit. 165), (Morala y Gancedo, 2009: 86). Ejemplos de /lj/ encontramos en voces como tiriyuela que registra la solución leonesa alternando con la castellana en la palabra tirijuela-tiriyuela, y en el resto de palabras siempre aparece la solución castellana: majadera y su derivado majar o en el término aneja.

\subsubsection{El fonema palatal $/ \check{\mathbf{s}} /$}

Este sonido el castellano lo mantuvo hasta los SS. XVI-XVII para dar posteriormente el resultado actual y convertirlo en /x/. En leonés no se produjo esta evolución conservando así el sonido dorsopalatal sordo. Este rasgo lo encontramos en el corpus en el vocablo xato palabra leonesa desde el punto de vista léxico, que alterna en el corpus con la solución castellana jato. En otras palabras quizá más generales, se ha producido una total castellanización y presentan siempre el resultado /x/: madeja, jeringuilla o eje. La aparición de este rasgo en el corpus resulta significativa, ya que mantiene más o menos el mismo nivel de frecuencia que el resto siendo como señala Morala un fonema que tiene una fuerte tendencia a la conversión de " $\mathrm{x}$ ” en “ $\mathrm{j}$ ”, incluso en las zonas 
lingüísticamente más conservadoras (Morala y Gancedo, 2009: 93), siendo fundamentalmente un problema de grafías ya que no es posible identificar el sonido en cada caso a partir de las grafías utilizadas.

\subsection{Aspectos fonéticos. Vocalismo}

\subsubsection{Vacilación en el timbre de las vocales átonas}

Morala, entre otros autores, señala que a partir de la primera mitad del S. XVII se empieza a reducir el fenómeno de la vacilación vocálica, al menos en la lengua escrita (Morala Rodríguez, 2012a: 555). En el corpus encontramos casos de vacilación probablemente debido a que seguían presentes en la lengua oral y se producían interferencias en la lengua escrita. Los casos de confusión /o u/ se reducen prácticamente a un contexto, cuando la vocal tónica es una /i/ que es la que provoca la inestabilidad de las vocales velares que en algunos casos es cierre de /o/ a /u/ y en otros, el fenómeno contrario (Morala, 2012a: 557). Así encontramos la alternancia en mollidamullida; un caso de calzuncillo en un inventario de Santibáñez de la Isla de 1844, morsolina en lugar de muselina o escodilla que aparece en los inventarios del S. XVII; y algún caso aislado en otros contextos, es el caso de tunel en un inventario de Destriana de 1843. Quizá sí se evidencia en los textos de este breve corpus una reducción puesto que en otros contextos en los que se han encontrado casos de inestabilidad no se producen. Por ejemplo, cuando la tónica es la /u/, cuando hay una yod en la sílaba tónica o cuando el acento está alejado de la vocal inicial que es la que sufre el cierre, nunca encontramos cubertor, siempre cobertor.

Aparece también vacilación de las vocales /a e/ fundamentalmente en los siguientes contextos: cuando va seguida de una /i/ tónica, como ocurre en las vocales velares, encontramos tresquilar en dos inventarios del Páramo del S. XVII, restrillo y restrillar en varios inventarios del Bajo Órbigo; vacilación producida por un fenómeno de disimilación en la voz arrecada, variante muy frecuente no solo en este corpus donde aparece en todos los ejemplos arrecada y ninguno de arracada; o debido a un fenómeno de asimilación en guadamacil no significativo ya que se encuentra en documentos de todas las procedencias (Morala, 2012a: 559). Como ocurre con la serie velar, existen otros ejemplos en los que en ningún caso se produce la asimilación: alemanisco o azabache.

Otro de los pares en los que encontramos inestabilidad vocálica es el cierre de /e/ en /i/, aunque, como en los casos anteriores, no presenta ningún tipo de regularidad 
ni en los contextos fónicos en los que se produce ni siquiera dentro de las mismas voces. Se recoge un caso de pillejo en un inventario de Calzada de 1838, de torniado en un inventario de Laguna de Negrillos de 1734 o dispensa en Destriana, encontramos casos de disimilación de /i-i-/ en /e-i-/ en feligrana. Sin embargo, en otras palabras se mantiene la regularidad, siempre aparece en el corpus la forma piñera o espitera, forma regular en el sur, frente a peñera o espetera, formas regulares en el norte.

Por tanto, se produce una alternancia de la que no se puede extraer ninguna conclusión ni desde el punto de vista cronológico ni contextual, tal vez se deba a que exista una vacilación en el timbre de las átonas especialmente en la lengua oral y el escribano refleje por escrito lo que oye a los inventariadores.

\subsubsection{Hiatos}

En el corpus encontramos casos de conversión de hiatos en diptongos, que no necesariamente son todos propios del leonés, sino que responden a una tendencia generalizada en toda la historia del romance (Morala y Egido, 2010: 423). En el caso del hiato /eo/ encontramos casos en los que se produce una conversión del hiato en diptongo /eo/>/io/ ante contextos en los que la /e/ es átona, es el caso de antiojo que aparece bajo esta forma en los ejemplos del corpus fechados todos ellos en el S. XIX. Situación similar se produce con el hiato /ea/ que aparece en la voz beatilla y que, en el único ejemplo recogido, perteneciente a un inventario de Palacios de la Valduerna del año 1728, el hiato se convierte en diptongo con el cierre de la /e/ en /i/, biatilla. Sin embargo, esta secuencia se mantiene casi de forma constante en el nombre de la moneda: reales, aunque en esta zona, al menos en el Bajo Órbigo, hoy todavía se escucha en la lengua oral el cierre de /e/ en /i/. En cuanto a la secuencia /oa/ encontramos casos de cierre de /o/ $/ \mathrm{u} /$ dando lugar al diptongo /ua/ en voces como toalla y almohada que alternan con las variantes almuhada y tualla.

Además encontramos otras voces en las que se produce formación de hiatos, a través de la pérdida de la -d- intervocálica en palabras como rodao o en un ejemplo del adjetivo espolinado, espolinao recogido en un inventario de La Isla de 1829, sin embargo encontramos otros adjetivos terminados en -ado en los que en ningún caso se pierde la -d-: desborcillado, ajado o desbaratado.

Otro caso de formación de hiato lo encontramos en la palabra poyino en la que al quedar la consonante en contacto con una vocal palatal, se acaba perdiendo dando la 
solución poíno, frecuente en León (Morala y Egido, 2010: 429) y única que aparece en el corpus para la palabra poyino con presencia de la grafia " $y$ " en lugar de "i".

\subsubsection{Diptongos}

Uno de los rasgos que caracterizó al leonés y al castellano frente a otros romances fue la diptongación de las vocales breves tónicas /ĕ/ y / $/$ /. Posteriormente el leonés y el castellano concluyeron en soluciones diferentes, el castellano en algunos casos redujo el diptongo, mientras que el leonés lo mantuvo (Morala y Gancedo, 2010: 76). Este rasgo no se aprecia ya en los documentos del corpus puesto que encontramos voces como cancilla, mantilla o escudilla en todos los ejemplos de los tres períodos de tiempo analizados. Cabe destacar, sin embargo, la presencia de franiela en un inventario del pueblo de Saludes de Castroponce, fechado en 1808. La explicación en este caso es que se trata de un fenómeno de ultracorrección, puesto que estamos ante una palabra que procede del francés y esta a su vez del inglés. En el caso de la /ŏ/ breve tónica se aprecia algún ejemplo, aunque aislado en voces como fleco en la que encontramos la variante diptongada flueco en un inventario de La Bañeza de 1643, solución también frecuente en castellano, encontramos en el CorLexIn ejemplos de flueco en inventarios de Toledo, Ciudad Real, Madrid, incluso México entre otros lugares.

Borrego Nieto señala que en la zona que él define como zona 2, que comprendería parte de la comprendida en este corpus, han desaparecido prácticamente tanto los diptongos decrecientes como la diptongación ante yod (Borrego Nieto, 1996: 147).

La misma tendencia de castellanización de los fenómenos lingüísticos se produce en la no conservación de los diptongos decrecientes. En leonés existe una diferencia a este respecto entre el llamado leonés occidental que, coincidiendo con el gallego, conserva los diptongos /ei/ y /ou/ y el leonés oriental que los reduce a /e/ y /o/. Las tierras que se encuentran en el occidente de la Ribera del Órbigo formarían parte del leonés occidental (Morala y Gancedo, 2010: 78). Sin embargo, en el corpus encontramos reducción de diptongos, se documenta por ejemplo la voz trosa en los dos ejemplos recogidos del término o reducción del diptongo /ei/ en voces que sí se han documentado en León con la conservación del diptongo decreciente: talladera, piñera, garduñera o cordero, entre otras.

Otro rasgo que se documenta en el corpus es la reducción del diptongo /ua/ en la voz guadaña dando lugar a gadaña, en la mayor parte de los ejemplos recogidos. Esta 
solución es frecuente en el noroeste peninsular (Morala y Egido, 2010: 433). El diptongo /ua/ en cambio se mantiene en otras voces como guadamacil o fragua, aunque también es común encontrar en el noroccidente de León la voz fraugua (Le Men, 2007, s.v. fraugua).

Otro rasgo importante que se recoge en la lengua del corpus y que se encuentra en todos los romances hispánicos, pero especialmente en leonés (Morala y Gancedo, 2009: 83) es la epéntesis de la /i/ en voces como aperios que se documenta en los tres ejemplos recogidos de la palabra pertenecientes a un inventario de Valle de la Valduerna de 1829.

En otros casos, encontramos situaciones que favorecen la creación de un diptongo como es el caso de la pérdida de la /-b-/ intervocálica en palabras como taburete que da lugar a taurete y que resulta ocasional en León (Morala y Egido, 2010: 433); en el corpus solo se recogen dos ejemplos pertenecientes a un inventario de Laguna de Negrillos de 1734, mientras en el CorLexIn se recogen ejemplos de La Rioja o de diferentes puntos de Castilla- La Mancha.

De nuevo, como ocurría con el apartado del consonantismo, encontramos casos aislados de lo que podríamos considerar rasgos occidentales, lo que pone de manifiesto que estamos ante una lengua que tiende hacia la norma castellana y que, aunque estos rasgos pervivan en la lengua oral, el escribano trata de reflejar la norma escrita produciéndose solo algún caso aislado de interferencia.

\subsubsection{Vocalismo inicial y final}

Con respecto al vocalismo inicial, en el corpus encontramos ejemplos de aféresis en los que un sustantivo que empieza por /a-/ pierde la vocal confundiéndose con la del artículo en palabras como azuela que alterna en los ejemplos encontrados con zuela. También aparecen casos en los que la /a-/ como vocal inicial aparezca en algunos verbos, esta es debida a la interferencia con su uso como prefijo, encontramos el verbo aforrar en algunos ejemplos: «Una basquiña de piel de rata aforrada (La Bañeza, 1641)», «Unos calzones de estudillo aforrados (Castrillo de la Valduerna, 1828)», entre otros.

En cuanto al vocalismo final, encontramos casos en los que se produce un mantenimiento de la vocal frente a la variante normativa, que puede considerarse como un arcaísmo, este rasgo lo encontramos en la voz ansar, que aparece en los dos ejemplos recogidos bajo la forma ansare, ambos pertenecientes a Alija del Infantado y 
fechados en el S. XVII. No se han recogido ejemplos de épocas posteriores por lo que no sabemos si se seguiría manteniendo el arcaísmo. Otras voces que también presentan variabilidad respecto a la vocal final son tenazas, que aparece mayormente bajo la forma normativa pero presenta dos ejemplos bajo la forma etimológica tenaces bastante distanciados en el tiempo, uno perteneciente a un inventario de la Bañeza de 1643 y el otro a un inventario de Quintanilla de Somoza del año 1831. Finalmente, es necesario mencionar en el vocalismo final, que no se recogen casos esperables en la zona occidental como la influencia que el morfema de número puede ejercer en algunas palabras, como el caso de buey, donde la "y" se considera como vocal /i/, por tanto, es frecuente encontrar las variantes bueys o bueis que también se documentan en castellano, por lo que no se debe considerar como una marca dialectal sino más bien de registro. En el corpus alternan las variantes gráficas "y" "i”" pero el plural siempre se construye bajo la forma bueies.

\subsection{Aspectos morfológicos}

En el apartado de la morfología y, dado que el corpus sobre el que se trabaja está formado por repertorios léxicos, el único aspecto gramatical en el que me puedo centrar es el de la morfología derivacional. A este respecto señalan Almeida Cabrejas y Díaz Moreno que la abundancia de los diminutivos es característica de los inventarios de bienes, así como la combinación de diminutivo más adjetivo indicador de tamaño pequeño (Almeida y Díaz, 2012: 57).

Siguiendo la línea de comparación con los rasgos leoneses tal y como se hizo con los aspectos fonéticos, uno de los sufijos más extendidos y que representa una clara marca del leonés es el diminutivo -in, -ino. Atendiendo a la delimitación geográfica que realiza Borrego Nieto para el leonés (Borrego Nieto, 1996: 141-154), este autor señala que en la zona de la Cepeda el sufijo -ico se va introduciendo con fuerza en el campo de -in hasta desplazarlo, especialmente en Zamora. En la zona de la Ribera del Órbigo señala la supremacía de -in como diminutivo que, sin embargo, en Sayago alterna con ico (op. cit.149, 151). Observando los usos de ambos diminutivos en el corpus, llama la atención la casi ausencia de -in, -ino, pues solo queda reducido a azadín en un inventario de Valle de la Valduerna de 1829 y a fardelino en un inventario de La Bañeza de 1643. Por tanto se puede afirmar que su uso es minoritario mientras que el uso del sufijo -ico está muy extendido especialmente en los inventarios pertenecientes al Bajo Órbigo (Alija del Infantado y Coomonte de la Vega). Encontramos ejemplos de los 
tres siglos estudiados como jarrico, escañilico, calderico, cubetico, fardelico, uronica, entre otros. El uso de este sufijo en ocasiones se emplea como diminutivo siendo frecuente que además de añadir el sufijo a la palabra esta vaya acompañada del adjetivo pequeño/a, pero también es cierto que en muchos casos, aunque informe del tamaño, el escribano recoge lo que le dicta la persona que va enumerando los objetos y probablemente usa estos diminutivos con un sentido afectivo.

Junto al diminutivo -ico aparecen en un uso mucho menos extendido otros como el sufijo -illo/-illa o -ito/-ita. En el primer caso encontramos botoncillo, manguillo, petrinilla, sotanilla o estampilla; que no resultan significativos puesto que están lexicalizados. Pero quizá sea necesario hacer una puntualización en bufetillo puesto que no se usa como un derivado sino que se trata de un término lexicalizado que presenta en esta época una entrada aparte en el diccionario académico. Otro ejemplo significativo es el de tazilla que alterna con tazica, ambos términos pertenecen a inventarios de la misma localidad de Alija del Infantado, pero si atendemos a los ejemplos, el referente es distinto para cada palabra ya que cuando se usa tazica, se está refiriendo al objeto, mientras que el ejemplo de tazilla: «Seis tazillas de dulce», no se refiere tanto al objeto sino al contenido y este se emplea con la acepción de medida.

El otro diminutivo es -ito/-ita que aparece en muy pocos casos: arquita, cofrecito, cajonito, espejito, martillito, cestito, ovillito o cucharita. El uso del diminutivo en esta última palabra no solo indica tamaño sino que es probable que añada un matiz de singularidad ya que además aparece acompañada de los adjetivos curiosas y buenas.

En conclusión, de nuevo encontramos rasgos que pueden pertenecer al leonés, pero aquellos que serían esperables como marcas representativas apenas aparecen. Por tanto podemos afirmar que en la morfología también nos encontramos no con un leonés castellanizado sino con un castellano que presenta algunos rasgos del leonés.

Finalmente, también se podrían considerar como rasgos morfológicos del corpus, algunas diferencias de sufijos en palabras como tajador-tajadero o devanaderadevanador, que ya aparecen comentados en el cuerpo de la tesis, así como la pérdida de la - $d$ - en escasos finales en -ado, por ejemplo espolinao. 


\subsection{Aspectos gráficos}

En el apartado de aspectos gráficos, en el corpus aparecen algunas vacilaciones tanto a nivel vocálico como consonántico, especialmente en los inventarios del S. XVII época en la que todavía la lengua presentaba un alto grado de inestabilidad.

En el terreno de las vocales la mayor vacilación la encontramos en las equivalencias entre "u" $\mathrm{y}$ "v" de forma que en posición inicial ( $v n, v n a)$ siempre encontramos " $\mathrm{v}$ " tanto para el fonema vocálico, como para el consonántico. Lo mismo ocurrió con la "i" e "y" iniciales que alternan con valor vocálico en el caso de ynbentario, ylo, veynte, entre otros. Otro caso es cuando la "i" va precedida de "h", situación en la que se produce una interferencia fonética consonantizando el primer elemento del diptongo dando yerba o yerro como soluciones más frecuentes, alternando en este último caso con hierro, solución que la Academia retomó posteriormente adoptando la grafía "h" procedente de la aspiración de la /f-/. Esta situación sigue apareciendo en los inventarios del S. XVIII, alternan un y vn, aunque quizá ya aparecen más casos en los que la grafía "u" representa la vocal y en el caso de la serie palatal apenas se recoge la forma veinte pero seguimos encontrando yerro, ymagen o ylo.

En el terreno de las consonantes se ha de tener en cuenta que a lo largo de la segunda mitad del S. XVII se produjo un cambio en el consonantismo que determinó el paso del sistema fonológico medieval al moderno (Lapesa, 1991: 370). En este contexto, aparecen en el corpus vacilaciones gráficas entre /b/ y /v/: berde, nuebo, biejo, entre otros ejemplos. El ensordecimiento de los fonemas /z /, grafía “z"; /ż/, grafía "s" y /ž/, grafías "g” y “j”" con sus correspondientes sordos /ŝs/ grafías “c, ç"; /s / , grafía "ss" y /š/ grafía " $x$ ", dio lugar a numerosas interferencias entres estas grafías, algunos ejemplos de ello son: jarra-xarra; zagalejo-zagalexo; taçica-tazica; En el S. XVIII la Academia emprendió una reforma que entre otros cambios supuso la solución de "u" para la vocal /u/ y "v" para representar la consonante, fijó el uso de "i" o de "y" para la semivocal, suprimió la cedilla y distribuyó el uso de "c" y "z" reservando la "c" para preceder a /e/, /i/ y "z" para anteponerse a /u/, /o/, /a/, o el uso de "c" y no "q" en palabras como cuatro; la " $\mathrm{x}$ " deja de ser grafía de /x/ siendo sustituida por “j”, así desaparece la distinción entre sibilantes sordas y sonoras. No obstante en los inventarios del S. XVIII todavía se refleja una gran inestabilidad aunque algunos fenómenos no se presentan de forma tan generalizada, por ejemplo la cedilla tiende a desaparecer y ya no encontramos calçoncillo, sino calzoncillo, como muestra de ello. En cambio la lengua que reflejan 
los inventarios del S. XIX presenta ya una estabilidad próxima a la de la lengua moderna ya que las normas de la Academia van influyendo y haciendo que predomine la estabilidad frente a la variabilidad. Finalmente hay que señalar que en relación con los aspectos gráficos también es frecuente encontrar la presencia de dobles grafías como es el caso de la "rr" en situación inicial para marcar la /r/ fuerte o la f- en palabras como fuelle o fuente que no presentan ninguna particularidad significativa.

\subsection{Aspectos léxicos}

A diferencia de lo que ocurre con los aspectos fonético-fonológicos y morfológicos, el léxico es un ámbito muy abierto por lo que resulta difícil llegar a establecer conclusiones. La mayor parte de las voces que aparecen en estas relaciones de bienes son lógicamente descendientes del latín, puesto que la lengua en la que están escritos estos textos es en castellano cuyo léxico es fundamentalmente heredero del latín. Sin embargo y, pese a la dificultad reseñada, se pueden llegar a destacar a modo de conclusión algunos aspectos léxicos: presencia de voces procedentes de otras lenguas (arabismos, galicismos, americanismos, etc.), voces dialectales o al menos norteñas y formación de palabras con repercusión en el significado.

La influencia del árabe en nuestra lengua es innegable. Señala Ralph Penny que esto es debido fundamentalmente a dos factores, la necesidad de dar nombre a las nuevas realidades llegadas de Al-Andalus y el gran prestigio del que gozaba el árabe a principios de la Edad Media ya que era el vehículo de comunicación de una cultura avanzada frente a la cristiana (Penny, 1993: 240). Esta presencia la encontramos en los documentos del corpus en voces comunes a todo el castellano que por tanto no resultan significativas, voces que pertenecen a diferentes campos semánticos. Del campo de las agricultura y ganadería encontramos palabras que penetraron en la época de la Reconquista al adoptar las prácticas árabes en esta materia, por ejemplo alforja; también encontramos voces relacionadas con los nombres de pesos y medidas que aparecen frecuentemente en el corpus: arroba o fanega. Otro grupo de palabras que penetró en el castellano procedente del árabe fue el relacionado con los útiles de la casa, grupo que por sus características abunda en las relaciones de bienes de particulares, palabras como alacena, almohada, jarra, aceitera o taza entre otras. Junto a estos arabismos comunes hemos de señalar la presencia de arabismos destacados. Hay algunas voces que a pesar de que algunos corpus lexicográficos las sitúan hasta el S. XVII o incluso en algún caso la Academia las señala como antiguas, sin embargo en este corpus se documentan, 
aunque es verdad que no son muchos los casos recogidos de cada término y reflejan que, al menos, se mantienen en el centro occidental peninsular, es el caso de voces como almofía, albornía o altamía, que también recoge el CorLexIn ya que aparecen en inventarios de otras zonas del centro peninsular, hecho que demuestra por tanto su vigencia.

Otro grupo de voces procedentes de otras lenguas que tiene una presencia destacada en el corpus son los galicismos. Muchos de estos préstamos penetraron en nuestra lengua a partir del S.XI debido a la participación de los franceses en las campañas militares de la Península, así como a la influencia de los monjes de Cluni y Císter en la reforma monástica y en la peregrinación a Santiago. En el corpus encontramos voces comunes pero pertenecientes fundamentalmente a dos campos semánticos: el de las armas y el del textil. En el momento de la Reconquista y debido a la participación francesa en este hecho histórico, penetran en nuestra lengua términos militares. En el corpus algunas de las voces recogidas en el apartado de armas son de origen francés: charpa o estoque. Sin embargo, el grupo de préstamos franceses más numeroso y más significativo cronológicamente es el perteneciente al campo del textil. El S. XVIII es el período más intenso de entrada de voces procedentes del país galo, momento en el que penetran términos del ámbito militar pero fundamentalmente relacionados con el vestido y la moda. En el corpus se documentan términos poco frecuentes de los que se recogen un escaso número de ejemplos debido a que nombran prendas o tejidos de valor y que por tanto pertenecen a particulares de buen nivel socio económico, palabras como frac, levita, pantalón, chaqueta o nombres de tejidos como piqué o moer. Estos términos aparecen siempre en inventarios del S. XIX, no anteriores, y son un reflejo de la introducción de nuevas prendas y, por tanto, de un nuevo concepto del vestido.

Una presencia más escasa es la que tienen los germanismos y los americanismos. Los germanismos llegaron al español por diferentes vías. Algunas de las voces recogidas entraron en los primeros momentos, es decir, antes de la fragmentación política del Imperio Romano, por lo que penetraron a través del latín, es el caso de la voz guadaña. Otros penetraron en momentos posteriores a través del francés que con anterioridad había tomado voces germánicas, especialmente del fráncico; en este grupo se encuentran términos documentados en este corpus como guante o estribo.

Las voces amerindias están escasamente representadas en el corpus a pesar de que el castellano tiene un número importante de palabras procedentes de las lenguas 
amerindias, especialmente de las variedades del Caribe, del náhuatl y del quechua. En el corpus encontramos términos universales como chocolatera, derivado de chocolate o jícara del náhuatl; o la voz enaguas del arahuaco.

Finalmente hay que señalar, dentro de los préstamos léxicos, la presencia escasa en el corpus de voces de otras lenguas. Del portugués términos como basquiña, o del italiano especialmente del mundo del adorno o el vestido: facha, filigrana, muselina o brocado.

A lo largo del corpus se recogen voces que no aparecen en el diccionario académico o que recogiéndolas, no registra aquellas acepciones cuyo uso se localiza en León o en la zona noroccidental de la Península. También vamos a encontrar voces, en este caso menos significativas, que presentan otras acepciones distintas a las del diccionario académico, pero que en el corpus son utilizadas solo con el significado recogido en el DRAE. León es una provincia que presenta una gran diversidad que hace que existan diferencias entre el norte y el sur, el este y el oeste, de manera que acepciones más restringidas quizá vayan a encontrarse en zonas más dialectales, mientras que en el sur y por influencia de Castilla, algunas no se documenten tanto. Dentro de los occidentalismos representativos más destacados cabe resaltar la voz abregancias bajo diferentes variantes formales; se trata de una voz que solo se documenta en León y en Asturias, mientras que en el resto de España el referente presenta otro término, como es el caso de cadena en Zamora. Significativa es la voz mullidas de uso dialectal, que se documenta en el corpus y que también aparece en Asturias, Zamora y Orense; es decir, en toda el área occidental, mientras que en el centro-este peninsular se usa la voz melena que también se recoge en el corpus, pero con menos frecuencia, aunque la diferencia de casos no es grande y tampoco existen diferencias en cuanto a los lugares en los que se localizan ejemplos de una y otra voz. Otro término representativo es costanas. El DRAE lo localiza en León, Palencia y Zamora, mientras que el CORDE recoge cinco ejemplos con otro significado, en el CorLexIn solo se documenta en la provincia de León. Estamos, por tanto, ante una voz dialectal que se localiza en el corpus en varios ejemplos. En otras zonas de la Península se usa para el mismo referente el término adral, voz que no se recoge en este corpus. Las voces meúl y palero son también significativas, el término meúl es una voz frecuente en todo el noroeste peninsular y aparece ampliamente documentada en el corpus. La voz palero, que se usa con el significado de 'sauce', es registrada por la Academia por primera vez en la edición de 1970 localizándola en León y Tierra de 
Campos con el sentido de 'sauce' y 'chopo', mientras que al término en femenino le da la acepción de 'nopal' que no tiene nada que ver con el uso que tiene en León. Ambos se documentan en este corpus, la voz en femenino se recoge únicamente en inventarios de La Valduerna. Como en el caso anterior, el CorLexIn muestra que se trata de voces norteñas ya que el término palero solo aparece documentado en León y meúl en León y Palencia. Podemos considerar también voz dialectal el término encaño del que solo se documenta un ejemplo en este corpus, concretamente de Alija del Infantado y es voz conocida en la zona de Benavente muy próxima a la estudiada. Le Men recoge la palabra encaño con este significado en Asturias, Zamora y Salamanca (Le Men, 2005, s.v. encaño), por lo que podríamos estar hablando de un leonesismo. Finalmente, como ejemplo de dialectalismo, cabe destacar la voz jato muy común en toda el área leonesa, Cantabria, norte de Palencia y zona occidental. La Academia la recoge en su diccionario con el significado de 'becerro' pero no marca su carácter dialectal y, como señala Le Men, se trata de una voz que se documenta preferentemente en el área occidental donde goza de gran vitalidad (Le Men, 2007, s.v. jato).

Finalmente, conviene hacer mención a algunos procedimientos de derivación léxica puesto que constituyen un modo de formación de palabras en nuestro léxico y en los casos comentados tienen repercusiones en el significado de algunos vocablos. En este sentido resultan significativos los sufijos -dor, -dero. Ejemplo de ello es la voz rodador, que no documenta el CORDE ni otros corpus léxicos y es recogida por el DRAE con un significado genérico, sin embargo en esta zona se le da un uso concreto a la acepción general de 'llaneador', por tanto podríamos tal vez considerarlo como término dialectal. Dentro de las voces acabadas en -dor podemos destacar como significativa, la voz escarpidor como ejemplo de palabra que tiene varias acepciones, alguna de ellas no recogida en el diccionario académico como es la de 'cardador de la lana' (Le Men, 2005, s.v. escarpidor), este significado que es común en la montaña leonesa no se recoge en el corpus, que recoge el término con el significado que aparece en el diccionario académico. En cuanto al sufijo femenino - era, son varios los nombres de objetos que lo llevan y que se recogen en los inventarios de bienes: aceitera, chocolatera o más significativo masera que siempre se utiliza con la acepción de 'recipiente para amasar' a pesar de que en castellano también nombra 'el paño con el que se cubre la masa'. A este respecto señala $\mathrm{H}$. Perdiguero que quizá se trata de un sufijo que se halla especializado en determinados contenidos semánticos, como el de designar recipientes (Perdiguero 
Villarreal, 2012c: 385). Finalmente, también encontramos términos en los que el sufijo dor, -dera conlleva un cambio de significado; es el caso de tajador-tajadera.

Por último hay que señalar que en el corpus se han encontrado términos que no recoge el diccionario académico ni he localizado en otros corpus, a los que he dado una interpretación semántica de acuerdo con el contexto lingüístico en el que aparecen, es el caso de voces como salostrero, carvoneras o pechador.

Estos son algunos de los términos que reflejan los aspectos léxicos más destacados. Sí es necesario señalar que, como puede observarse a lo largo de este trabajo, el uso de voces o acepciones específicamente noroccidentales se da fundamentalmente en términos pertenecientes a los campos semánticos relacionados con las labores agrícolas mientras que en otros campos léxicos como la ropa o los tejidos son muy escasos o inexistentes. 


\section{BIBLIOGRAFÍA}

\section{REFERENCIAS BIBLIOGRÁFICAS}

Almeda Molina, Elena (2013): "La tradición en el léxico de la indumentaria: análisis comparativo del Tesoro de Covarrubias y el Diccionario de Autoridades" en Revista de $\begin{array}{lllll}\text { Estudios } & \text { Filológicos, } & \mathrm{n}^{\mathrm{o}} & 25, & \text { julio }\end{array}$ http://www.um.es/tonodigital/znum25/secciones/estudios-04-lexico_indumentaria.htm [visto en julio de 2013].

Almeida Cabrejas, Belén y Rocío Díaz Moreno (2012): "Estudio lingüístico de inventarios de conventos de Guadalajara" en Revista de Historia de la Lengua Española 7, 39-70.

Alonso Estravís, Isaac (1986): Dicionário da língua galega 3 vols, Alhena, Madrid.

Alonso GaRrote, Santiago (1947): El dialecto vulgar leonés hablando de Maragatería y Tierra de Astorga, Consejo Superior de Investigaciones Científicas, Instituto de Antonio de Lebrija, Biblioteca de dialectología y tradiciones populares, Madrid.

Alonso, Joaquín (2009): Aperos de labranza, Edilesa, León.

Alvar EZQuerra, Manuel (1983): Lexicografía, H. López Morales (coord.), Introducción a la lingüística actual, Madrid, Editorial Playor, 115-132.

Álvarez BARdón, Cayetano (1987): Cuentos en dialecto leonés, Lancia, León.

Álvarez CabezA, Amando y F. Javier García MARTínez (1994): Vocabulario de la Cepeda, León.

Álvarez TeJedor, Antonio (1989): Estudio lingüístico del léxico rural de la zona este de la provincia de Zamora, Universidad de Salamanca, Salamanca.

Álvarez domíngueZ, Juan Miguel y Juan José sÁNCHEZ BADIOLA (2002): "La Bañeza de villa a ciudad 1895-1995" El siglo de León todos los pueblos y sus gentes II, edita Diario de León.

ANDRÉS DÍAZ, Ramón de (2013): Gramática comparada de las lenguas ibéricas, Ed. Trea, Gijón (Asturias).

BARRIO PRADA, Manuel (1999): El habla de la zona de Benavente, Brigecio 9, 157-177.

BARRIO PRADA, Manuel (2000): El habla de la zona de Benavente, Brigecio 10, 173200.

BASTARDín CANDÓn, Teresa (2012): "Léxico de los Siglos de Oro en documentos notariales: las particiones de bienes del Archivo Histórico Provincial de Cádiz" en Revista Quadernos del Instituto de Historia de la Lengua, $n^{\circ} 7$, Cilengua, San Millán de la Cogolla 31-59.

BOROBIO CRESPO, Enrique: "La indumentaria tradicional en los inventarios de bienes" Revista de Soria. http://www.dipsoria.es [visto en noviembre de 2012].

BorRego Nieto, Julio (1996): “Leonés”, Manual de dialectología hispánica, el español de España, Ariel Lingüística, Barcelona, 139-158. 
BORREGO NIETO, Julio (2007): "El dialecto leonés y sus reescrituras virtuales", Ramón Menéndez Pidal y el dialecto leonés (1906-2006), Instituto de la Lengua. Colección Beltenebros, Junta de Castilla y León, 131-153.

CALDERón, Miguel (2012): "Particularidades léxicas de las cartas de dote de los moriscos granadinos (1509-1513) en Revista Quadernos del Instituto de Historia de la Lengua, $n^{\circ} 7$, Cilengua, San Millán de la Cogolla 61-87.

CAMPos Souto, Mar (2012): "Voces gallegas (o no) en protocolos notariales del siglo XVIII" en Revista Quadernos del Instituto de Historia de la Lengua, $n^{\circ} 7$, Cilengua, San Millán de la Cogolla 89-123.

CArdiel Uceda, Pedro: Somontano sur del Moncayo, El Eco del Isuela, $n^{o}$ 16, p. 15. http://www.calcenada.com [visto en noviembre de 2012]

CARriazo RuIZ, José Ramón (2009): "El ajuar riojano del Siglo de Oro: Propuesta de organización onomasiológica para el vocabulario de los inventarios de bienes redactados entre 1606 y 1616 en el Monasterio de San Millán de Yuso (La Rioja)" en Actas del VIII Congreso Internacional de Historia de la Lengua Española. Santiago de Compostela, Tomo II, 2012, 1271-1280.

CASAdo LobATO, (1979): “Artesanía popular leonesa: la alfarería de Jiménez de Jamuz" Tierras de León 36-37, 1979, 111-121.

CASAdo LobAto, $\mathrm{M}^{\mathrm{a}}$ Concepción (1993): La indumentaria tradicional en las comarcas leonesas, Diputación de León, León.

Casado Lobato, $\mathrm{M}^{\mathrm{a}}$ Concepción (2002): El habla de la Cabrera Alta, Academia de la Llingua asturiana, Uviéu.

CASTAÑEDA ORDÓÑEZ, Ma José (2003): Inventarios de enseres domésticos (1750-1850). Estudio pragmalingüístico, Servicio de publicaciones de la Universidad de Córdoba, Córdoba.

CAVero, Olga y Joaquín Alonso (2002): Indumentaria y joyería tradicional de La Bañeza y su comarca. Instituto Leonés de Cultura, Diputación Provincial de León, León.

CORDE $=$ REAl ACADEMIA EsPañola: Banco de datos [en línea]. Corpus diacrónico del español http://www.rae.es. [visto en julio de 2014, última fecha]

Corominas, Joan y José Antonio PASCUAL (1980-1991): Diccionario Crítico Etimológico Castellano e Hispánico, 6 vols. $(=D E C H)$, Ed. Gredos, Madrid

Covarrubias Horozco, Sebastián de (2006): Tesoro de la Lengua Castellana o Español, Ed. Integral e ilustrada de Ignacio Arellano y Rafael Zafra, Universidad de Navarra. Biblioteca Áurea Hispánica.

DÁvila Corona, Rosa Maa Montserrat Durán Pujol y Máximo García Fernández (2004): Diccionario histórico de telas y tejidos. Castellano-catalán, (=DHTT), Junta de Castilla y León, Consejería de cultura y Turismo.

Descosido Fuertes, Maximino (1985): "La Valdería entre el mito y la historia" Tierras de León, 58, 73-96, León.

DESCOSIDO FUERTES, Maximino (1993): "Vocabulario usual en Valdería" Tierras de León, 91- 92, 165-190, León. 
ANDRÉS DÍAZ, Ramón de (2013): Gramática comparada de las lenguas ibéricas, Ed. Trea, Gijón (Asturias).

DíEz SuÁREZ, Ma Soledad (1994): Léxico leonés, Universidad de León, Secretariado de publicaciones, León.

Documentos selectos para el estudio de los orígenes del Romance en el Reino de León. Siglos X-XII, Edición Facsímil. León 2003.

DíCTER, Diccionario de la Ciencia y de la Técnica del Renacimiento http://dícter.eusal.es.[visto en noviembre de 2013]

DRAE, vid. Real Academia Española.

Academia de la Llingua Asturiana (2000): Diccionario de la Llingua Asturiana (DALLA). Uviéu.

EgIDO FERnÁndeZ, Ma Cristina (2008): “Aspectos léxicos en documentación colonial del oriente boliviano (S. XVII-S.XVIII)", Actas del XV Congreso Internacional de la ALFAL. (Publicación en CD), Montevideo, ALFAL.

EGIDO FERnÁNDEZ, Ma Cristina (2010): "Léxico de indumentaria femenina y joyas en relaciones de bienes de la Maragatería, Cepeda y Astorga, León (S. XVII)", en Ana M ${ }^{a}$ Cano (ed.) Homenaxe al profesor Xosé Lluis García Arias, Lletres Asturianes, anexu 1, tomo I, Academia de la Llingua Asturiana. Uviéu, 95-116.

EgIDO FERnÁNDEZ, M ${ }^{\mathrm{a}}$ Cristina (2012a) "Léxico de la esclavitud en documentación americana: relaciones de bienes (S. XVII-S.XVIII)", Revista Internacional de Lingüística Iberoamericana (RILI), X, 2 (20), 29-49.

EGIDO FERNÁNDEZ, Ma Cristina (2012b) "Léxico y esclavitud en la América colonial" en Revista Quadernos del Instituto de Historia de la Lengua, $n^{\circ} 7$, Cilengua, San Millán de la Cogolla 181-200.

EgIDo Fernández, Ma Cristina (2012c): "Léxico en documentación colonial del Alto Perú (s. XVII-S.XVIII)", en Emilio Montero Cartelle (ed.), Actas del VIII Congreso Internacional de Historia de la Lengua, Santiago de Compostela, Meubook, 1299-1311.

EgIDo FernándeZ, $\mathrm{M}^{\mathrm{a}}$ Cristina "Léxico de la indumentaria en relaciones de bienes leonesas del siglo XVII" [en prensa].

FERNÁNDEZ CATÓN, José María (1999): Index Verborum de la documentación medieval leonesa, tomos I y II, Monasterio de Sahagún (857-1300), Colección Fuentes y Estudios de Historia Leonesa, Centro de Estudios e Investigación "San Isidoro”, León.

FERNÁNDEZ CATÓN, José María (2002): Index Verborum de la documentación medieval leonesa, tomos III y IV, Archivo de la Catedral de León (775-1300), Colección Fuentes y Estudios de Historia Leonesa, Centro de Estudios e Investigación "San Isidoro", León.

FERNÁNDEZ GONZÁLEZ, José Ramón (1981): El habla de Ancares. Oviedo.

FERNÁNDEZ MARCOS, Vicenta (1984): "Variantes lingüísticas para designar a la telera en la provincia de León" Revista de Folklore, 3, 66-69.

FERNÁNDEZ NúÑEZ, Manuel F. (1988): Apuntes para la historia del Partido Judicial de La Bañeza, Excmo Ayuntamiento de La Bañeza, Distresa, $2^{a}$ edición.

Fuente GARCíA, Ana Ma de la (2000): El habla de la Cepeda. I Léxico, Ed. Universidad de León, León. 
GARCía DE DIEgO, Vicente (1954): Diccionario Etimológico Español e Histórico (=DEEH), Espasa-Calpe, Madrid, 1985.

García VALDÉs, Celsa Carmen (1979): El habla de Santianes de Pravia, Mieres.

Gómez Ferrero, María Cristina (2012): "El uso de adjetivos para caracterizar al ganado en la documentación leonesa" en Revista Quadernos del Instituto de Historia de la Lengua $n^{\circ}$ 7, Cilengua, San Millán de la Cogolla 223-238.

GÓMEz PABlos, Beatriz (2014): "Voces y frases relacionadas con Flandes en el Diccionario de Autoridades" en Revista de Filología n², Universidad de La Laguna 209-227.

GonZÁlez Ferrero, Juan Carlos (1990): Palabras y expresiones en el habla de Toro (Zamora), Zamora.

Guerrero, Ana y Américo LóPEZ (2009): "Traje maragato". Modelo del mes, Departamento de difusión del museo del traje, enero. http://museodeltraje.mcu.es [visto en abril de 2012].

JUNQUERA, Carlos (2009): Oficios y trabajos, Edilesa, León.

KRÜGER, Fritz (1991): La cultura popular en Sanabria, Instituto de Estudios Zamoranos "Florián de Ocampo", Diputación de Zamora, Zamora.

LAGÜENS, Vicente (2012): "Notas léxicas sobre documentos municipales aragoneses" en Revista Quadernos del Instituto de Historia de la Lengua, $n^{\circ} 7$, Cilengua, San Millán de la Cogolla 257-295.

LAMANO Y BENEITE, José de (1915): El dialecto vulgar salmantino, Tipografía popular, Salamanca.

LAPESA, Rafael (1991): Historia de la Lengua Española, Editorial Gredos, Madrid.

LE Men Loyer, Janick (2002-2009): Léxico del Leonés actual, tomos I-IV, Centro de Estudios e Investigación "San Isidoro", León.

LE MEN LOYeR, Janick (2003): Repertorio del léxico leonés, Universidad de León, León.

MADRID RUBIO, Victorino (1985), El habla maragata (Contribución a su estudio), Valladolid.

Marcos Álvarez, Fernando (1987): "La capa de los animales de carga y tiro en Badajoz durante el S. XVII. Notas léxicas" en M. Ariza, A. Salvador y A. Viudas (eds.) en Actas del I Congreso Internacional de Historia de la Lengua, Cáceres, 889-897.

MARTínez MANCEBO, J. Carlos (1995): El habla de Camporredondo, http://www.dialnet.unirioja.es [visto en junio de 2012].

MARTÍNEZ MARTÍNEZ, Martín (1985): Vocabulario, costumbres y paisajes agrarios en la Ribera del Órbigo (Estébanez de la Calzada). León.

Martínez MelÉnDeZ, Ma del Carmen. (1995): Estudio de los nombres de los oficios artesanales en castellano medieval. Universidad de Granada. Publicaciones de la cátedra de historia de la lengua española.

MARTínez MelÉndeZ, Ma del Carmen. (1989): Los nombres de tejidos en castellano medieval. Universidad de Granada. Publicaciones de la cátedra de historia de la lengua española. 
MENÉNDEZ PIDAL, Ramón (1906/2006): El dialecto leonés, Ed. El Búho Viajero, León.

MenÉndez PidAl, Ramón (1987): Manual de Gramática Histórica Española. Ed. Espasa- Calpe. S.A.16 edición, Madrid.

Miguélez Rodríguez, Eugenio (1993): Diccionario de las hablas leonesas (León, Zamora y Salamanca), Ed. Monte Casino, Zamora.

MiguÉlez Rodríguez, Eugenio (1998): El habla leonesa de Santibáñez de la Isla, Ed. Monte Casino, Zamora.

MiguÉlez RodrígueZ, Eugenio (2000): El dialecto leonés y el nombre de las cosas, Ediciones leonesas, León.

Morala RodríGUEZ, José R. (1986): “Toponimia y diacronía. Los sufijos diminutivos en León", Lletres Asturianes, 19, 65-82.

Morala RodríGuez, José R. (1990): Toponimia de la comarca de Los Oteros (León), 2 vols., León.

Morala Rodríguez, José R. (editor). Ramón Menéndez Pidal y el Dialecto Leonés (1906-2006). Instituto de la Lengua. Colección Beltenebros.

Morala RodrígueZ, José R. (2006): "Leonés y castellano en Zamora. De la Edad Media a nuestros días", Zamora: Anuario 2006 del IEZ “Florián de Ocampo”, 347-365.

Morala Rodríguez, José R. y Emilio Gancedo Fernández (2009a): El habla de León. Biblioteca leonesa de tradiciones, Edilesa, León.

Morala Rodríguez, José R. (2009b): "El proceso de castellanización al sur de la Cordillera Cantábrica en el siglo XVII", Lletres Asturianes, 101, 7-22.

MorAla RodríGUEZ, José R. (2010a): "Notas de lexicografía histórica leonesa: léxico de la ganadería" en Ana M Cano (ed.). Homenaxe al profesor Xosé Lluis García Arias, Lletres Asturianes, anexu 1, tomo I, Academia de la Llingua Asturiana. Uviéu, 257-277.

Morala Rodríguez, José R. y Ma Cristina EgIDO Fernández (2010): "Variantes formales en hiatos y diptongos en textos medievales del s.XVII" en R.M Castañar y V. Lagüens García (eds.). De moneda nunca usada. Estudios dedicados a J.Ma Enguita Utrilla. Institución Fernando el Católico, Zaragoza, 447-459.

MorAla RodríGUEZ, José R. (2010b): "Inventarios de bienes y lexicografía histórica", en A. M Medina Guerra y M.C. Ayala Castro (ed. y coord.). Los diccionarios a través de la historia. Universidad de Málaga, Málaga, 433-454.

Morala Rodríguez, José R. (2011): Léxico con denominaciones de origen en inventarios del Siglo de Oro", en Rosa Rabadán, Trinidad Guzmán y Marisa Fernández (eds.), Lengua, traducción, recepción. En honor de Julio César Santoyo //Language, Translation, Reception. To Honor Julio César Santoyo, vol. I, Universidad de León, León 385-417.

MORAla RodríGUEZ, José R. (2012a): “Alternancias en el vocalismo átono en textos notariales del S. XVII" en E. Montero Cartelle (ed.) Actas del VIII Congreso Internacional de Historia de la Lengua Española, Santiago de Compostela, tomo I 555564.

MORAla RodríGUEZ, José R. (2012b): "Relaciones de bienes y geografía lingüística del siglo XVII" en Revista Quadernos del Instituto de Historia de la Lengua $n^{\circ} 7$, Cilengua, San Millán de la Cogolla 301-332. 
MORAla RodRÍGUEZ, José R. (2012c): “Arabismos en textos del siglo XVII escasamente documentados" en Revista de investigación lingüística $n^{\circ}$ 5, Universidad de Murcia, Murcia 81-106.

Morala RodríGuez, José R. (2012d): "Datos sobre interferencias entre los sufijos dor y -dero en un corpus del Siglo de Oro" en Mar Campos Souto, Ramón Mariño, José Ignacio Pérez Pascual, Antonio Rifón (Eds.), "Assí como es de suso dicho": Estudios de morfología y léxico en homenaje a Jesús Pena, Cilengua, San Millán de la Cogolla, 237254.

Morala Rodríguez, José R. (2012e): El proyecto CorLexIn en Dolores Corbella, Josefa Dorta, Alejandro Fajardo Aguirre, Laura Izquierdo, Javier Medina López y Antonia Nelsi Torres (eds.), Lexicografía hispánica del siglo XXI: nuevos proyectos y perspectivas. Homenaje al profesor Cristóbal Corrales Zumbado, Arco /Libros, Madrid, 421-439.

Morala Rodríguez, José R. (dir.) Corpus Léxico de Inventarios (CorLexIn), [visto 2014] <http: //web. frl.es/ CORLEXIN.html>. [Junio de 2014].

MoRAla Rodríguez, José R. (2014): "El CorLexIn un corpus para el estudio del léxico histórico y dialectal del siglo de oro" Scrimptum digital, 3, 5-28.

Morala RodríGuez, José R. "La expresión de la calidad en el léxico de los inventarios del Siglo de Oro" [en prensa].

MORAlA RoDríguEZ, José R. "Léxico ganadero formado sobre denominaciones relativas al tiempo" [en prensa].

NIETO JIMÉNEZ, Lidio y Manuel Alvar EzQUERRA (2007): Nuevo Tesoro Lexicográfico del Español (S. XIV-1726), Arco Libros, Madrid.

NTLLE, vid. Real Academia Española.

NTLE, vid. NIETO JIMÉNEZ y ALVAR EZQUERRA.

Nuevo Cuervo, Luis Carlos (1996): “Algunas consideraciones etnolingüísticas sobre el léxico del Órbigo" Brigecio, 6.

Nuevo Cuervo, Luis Carlos (1997): "El vocabulario del Órbigo desde un punto de vista geográfico" Brigecio, 7.

Pascual Rodríguez, José A. (2009): The Preparatory Stage of the NDHE: "Divide and Rule" en Silvia Bruti, Roberta Cella and Marina Foschi Albert (Eds.) Perspectives on Lexicography in Italy and Europe, Cambridge Scholars, 3-28.

PENNY, Ralph (1993): Gramática histórica del español, (Traducción de J.I. Pérez Pascual y M.E. Pérez Pascual. Título original: A history of the Spanish language), Barcelona, Ariel Lingüística.

Perdiguero ViLlarreal, Hermógenes (2012a): "Variación léxica en protocolos notariales de Castilla en el siglo XVII" en Revista Quadernos del Instituto de Historia de la Lengua n ${ }^{\circ}$, Cilengua, San Millán de la Cogolla 333-345.

Perdiguero Villarreal, Hermógenes (2012b): "Léxico de aperos y enseres en protocolos notariales de Burgos en el S. XVII" en Emilio Montero Cartelle (ed.), Actas del VIII Congreso Internacional de Historia de la Lengua, Santiago de Compostela, Meubook 1151-1562. 
Perdiguero VillarReal, Hermógenes (2012c): "Palabras en -ero/-era en protocolos notariales de Castilla”, en Mar Campos Souto, Ramón Mariño, José Ignacio Pérez Pascual, Antonio Rifón (Eds.), «Assí como es de suso dicho»: Estudios de morfología y léxico en homenaje a Jesús Pena, Cilengua, San Millán de la Cogolla, 381-192.

Perdiguero VillarReal, Hermógenes "Léxico de bienes domésticos en documentos notariales del siglo XVII: sustantivos con sufijos diminutivos y variación diatópica" [en prensa].

Perdiguero Villarreal, Hermógenes "Bienes en la recámara: léxico de guarniciones y otros útiles en un inventario burgalés de 1639" [en prensa].

PÉREZ Gómez, José (1961): "Voces de la provincia de León" en Revista de Dialectología y Tradiciones Populares XVII, CSIC, Madrid, 525-548.

QUIRÓS GARCÍA, Mariano (2012): "El léxico de la ropa blanca en inventarios bilbaínos del Siglo de Oro" en Revista Quadernos del Instituto de Historia de la Lengua $n^{\circ} 7$, Cilengua, San Millán de la Cogolla 361-392.

RELLO, Luz. (2009): “Términos de color en español: semántica, morfología y análisis lexicográfico. Definiciones y matices semánticos de sus afijos" en Diálogo de la Lengua I, 89-164.

PuChe Lorenzo, Miguel A. (2002): El español del siglo XVI en textos notariales, Universidad de Murcia. Murcia.

Puche Lorenzo, Miguel A. (2012): "Léxico de la vida cotidiana en la Murcia áurea" en Revista Quadernos del Instituto de Historia de la Lengua, $n^{\circ} 7$, Cilengua, San Millán de la Cogolla 343-359.

Quirós García, Mariano (2011): "Léxico e inventarios de bienes en el Bilbao del Siglo de Oro" en Oihenart, 26, 423-453,

http://www.euskomedia.org/PDFAntl/literatura/26/26423453.pdf.

[visto en febrero de 2014]

Real Academia Española (1979): Diccionario de Autoridades (aUT) 3 vols., edición facsímil, $4^{\mathrm{a}}$ reimpresión, Madrid Gredos.

Real ACADEmia EsPañola: Diccionario de la Real Academia Española (DRAE). http://www.rae.es. [visto en julio de 2014, última fecha].

Real Academia Española: Banco de datos en línea. Corpus Diacrónico del español (CORDE) http://www.rae.es. [visto en julio de 2014, última fecha].

REAl ACADEMIa ESPAÑOla: Nuevo Tesoro Lexicográfico (NTLE) http://www.rae.es. [visto en julio de 2014, última fecha].

REAL ACADEMIA ESPAÑOLA: Fichero general: versión en línea. http://web.frl.es. [visto en julio de 2014, última fecha].

RIVAS TURRADO, Isidoro (2006): Voces del Eria (usos del leonés en la Valdería), Edición particular, Barcelona.

RIVERO PÉREZ Manuel (2006): "Las collaradas maragatas: iconos culturales de gran valor”, en Revista de folklore. T. XXVI a: 39-44, http://www. funjdiaz.net/folklore [visto el 19/ 07/ 2012]. 
RodríGuez BAyo, Jonatán (2007): Vocabulariu de La Baya. Academia de la Llingua Asturiana, Uviéu.

Rubio PÉREZ, Laureano M. (1987): La Bañeza y su tierra, 1650-1850. Un modelo de sociedad rural leonesa, Universidad de León, Biblioteca de Castilla y León, León.

SÁnCHEZ GonZÁlez DE HerRero, Ma Nieves (2012) "La documentación de Miranda de Ebro (siglos XIII-XIV) en Revista Quadernos del Instituto de Historia de la Lengua, $n^{\circ} 7$, Cilengua, San Millán de la Cogolla 425-453.

SAn Millán LóPeZ, Ricardo (1991): Prádanos de Ojeda, http://www.dialnet.unirioja.es [visto el 01/11/2012].

TORRES MONTES, Francisco (2000): "Estudios de los nombres de las medidas superficiales agrarias tradicionales en la provincia de Málaga" en $\mathrm{M}^{\mathrm{a}}$ Teresa Echenique, Juan Sánchez (eds.) Actas del V Congreso Internacional de Historia de la Lengua, Valencia, 2397-2410.

TERREROS Y PANDO, Esteban de (1987): Diccionario castellano con las voces de ciencias y artes. Ed. Facsímil, Arco Libros.

URDiALES, José Millán (1966). El habla de Villacidayo.

VALlADARES, Secundino (2009): Artesanos y artesanías, Edilesa, León.

VARELA MERINO, Elena (2000): "Galicismos de los S. XVI y XVII en el campo léxico de la indumentaria” en $\mathrm{M}^{\mathrm{a}}$ Teresa Echenique, Juan Sánchez (eds.) Actas del V Congreso Internacional de Historia de la Lengua, Valencia, 2411-2419.

Zamora Vicente, Alonso (1974): Dialectología española, Gredos, Madrid. 


\section{FUENTES DOCUMENTALES}

Todos los documentos pertenecen al Archivo Histórico Provincial de León. La relación de los mismos que se detalla a continuación está agrupada por siglos. Dentro de cada siglo, se organizan los documentos de acuerdo al lugar en el que se encuentra la notaría a la que pertenece el notario correspondiente. En cada protocolo se señala el nombre del notario, el lugar al que pertenece el propietario del inventario, testamento, etc., el año, la caja, la signatura y el número del folio en el que se encuentra. En algunos no es posible ya que debido al deterioro del documento no se aprecia este dato. Finalmente se señala en la mayoría de los casos el tipo de documento sobre el que se ha trabajado (inventario, carta de dote, etc.).

\section{S. XVII}

\section{Alija del Infantado}

P.N. Martín García. Coomonte de la Vega, año 1643. Caja 7033, sig. 395, fol. 29-32 (inventario de bienes).

P.N. Martín García. Alija del Infantado, año 1644. Caja 7034, sig. 396, fol. 199-202 (inventario de bienes).

P.N. Martín García. Coomonte de la Vega, año 1645. Caja 7034, sig. 397, fol. 306-307 (inventario de bienes).

P.N. Martín García. Alija del Infantado, año 1647. Caja 7035, sig. 399, fol. 36-37 (inventario de bienes)

P.N. Luis Gómez Ponce. Bercianos del Páramo, año 1648. Caja 7092, sig. 527 (inventario de bienes).

P.N. Martín García. Coomonte de la Vega, año 1650. Caja 7036, sig. 402, fol. 23-25 (inventario de bienes)

\section{Castrocalbón}

P.N. Francisco Fernández. Castrocalbón, año 1643. Caja 6955, sig. 257, fol. 17-18.

\section{La Bañeza}

P.N. Pedro Martínez. La Bañeza, año 1641. Caja 7047, sig. 422, fol. 182-186 (tasación de bienes)

P.N. Diego Castillo de la Concha. La Bañeza, año 1643. Caja 7036, sig. 385, fol. 145150 (inventario de bienes)

P.N. Pedro Martínez. La Bañeza, año 1647. Caja 7050, sig. 428, fol. 319-321 (carta de pago).

P.N. Pedro Martínez, La Bañeza, año 1649. Caja 7051, sig. 429, fol. 190-192 (carta de pago de dote). 


\section{Valdejamuz}

P.N. Matías de la Plaza, Jiménez de Valdejamuz, año 1654. Caja 7168, sig. 682, fol. 180182.

\section{Laguna de Negrillos}

P.N. Miguel de Valladares, Urdiales del Páramo, año 1645. Caja 7077, sig. 497, fol. (no se aprecia por el mal estado de conservación) (inventario de bienes).

P.N. Miguel de Valladares, La Antigua, año 1646. Caja 7077, sig. 497, fol. (no se aprecia por el mal estado de conservación) (paga de la dote).

P.N. Miguel de Valladares, Laguna de Negrillos, año 1646. Caja 7077, sig. 498, fol. (no se aprecia por el mal estado de conservación) (inventario de bienes).

\section{S. XVIII}

\section{Alija del Infantado}

P.N. José Francisco Álvarez. Coomonte de la Vega, año 1719. Caja 7382, sig. 1360 (bienes dotales).

P.N. José Francisco Álvarez. Genestacio de la Vega, año 1721. Caja 7382, sig. 1361 (inventario de bienes).

P.N. José Francisco Álvarez. Coomonte de la Vega, año 1722. fol. 71 (inventario de bienes de un forastero).

P.N. José Francisco Álvarez. La Nora del Río, año 1723. Caja 7382, sig. 1363, fol. 85-87 (inventario de bienes).

P.N. José Francisco Álvarez. La Nora del Río, año 1724. Caja 7382, sig. 1364, fol. 17-21 (bienes dotales).

P.N. José Francisco Álvarez. Alija del Infantado, año 1724. Caja 7382, 1364, fol. 170 (inventario de bienes)

P.N. José Francisco Álvarez. Coomonte de la Vega, año 1724. Caja 7382, sig.1364, fol. 186 (inventario de bienes)

P.N. José Francisco Álvarez. Pobladura del Valle, año 1733. Caja 7384, sig. 1371, fol. 132 (inventario de bienes del concejo)

P.N. José Francisco Álvarez. Genestacio de la Vega, año 1735. Caja 7386, sig. 1376, fol. 193-196 (inventario de bienes).

\section{La Bañeza}

P.N. Francisco Velasco. La Bañeza, año 1712. Caja 7353, sig. 1721, fol. 201-202 (obligación).

P.N. Juan de Acuña. La Bañeza, año 1714. Caja 7373, sig. 1328, fol. 40-41 (inventario de bienes).

P.N. Francisco Velasco. La Bañeza, año 1721. Caja 7353, sig. 1251, fol. 211-217 (inventario de bienes). 
P.N. Santos de Seijas. La Bañeza, año 1754. Caja 7411, sig. 1444, fol. 556-559 (inventario de bienes).

P.N. Santos de Seijas. La Bañeza, año 1758. Caja 7413, sig. 1448, fol. 187-192 (inventario de bienes).

\section{Valdejamuz}

P.N. Antonio Quintela.Villanueva de Valdejamuz, año 1704. Caja 7306, sig. 1112, fol. 338-339 (dote).

\section{Villazala}

P.N. Antonio Pardiñas de Losada. Huerga de Garaballes, año 1723. Caja 7359, sign. 1271 , fol. No numerada (inventario de bienes).

\section{Ribera}

P.N. Jerónimo Rodríguez de Losada. Grajal de la Ribera, año 1723. Caja 7363, sign. 1281, fol. No numerada (escritura)

\section{Laguna de Negrillos}

P.N. Jerónimo Espada. Laguna de Negrillos, año 1722. Caja 7367, sig. 1299, fol. 79-82 (inventario de bienes)

P.N. Jerónimo Espada. Laguna de Negrillos, año 1725. Caja 7367, sig. 1301, fol. 12-13 (inventario de bienes).

P.N. Jerónimo Espada. Laguna de Negrillos, año 1725. Caja 7368, sig. 1302, fol. 96 (inventario de bienes).

P.N. Jerónimo Espada. Laguna de Negrillos, año 1734. Caja 7368, sig. 1311, fol. 132134 (inventario de bienes).

\section{Palacios de la Valduerna}

P.N. García del Otero Fuente Mar, Ribas de la Valduerna, año 1726. Caja 7426, sig. 1471, fol. 24-25 (inventario de bienes).

P.N. García del Otero Fuente Mar, Fresno de la Valduerna, año 1726. Caja 7426, sig. 1471, fol. 46-47 (inventario de bienes).

P.N. García del Otero Fuente Mar, Robledo de la Valduerna, año 1726. Caja 7426, sig. 1471, fol. 61-68 (inventario de bienes).

P.N. García del Otero Fuente Mar, Tejados, año 1726. Caja 7426, sig. 1471, fol. 31-32 (inventario de bienes).

P.N. García del Otero Fuente Mar, Requejo, año 1726. Caja 7426, sig. 1471, fol. 149153 (inventario de bienes).

P.N. Domingo Jimeno Núñez, Palacios de la Valduerna, año 1727. Caja 7426, sig. 1471, fol. 150-152 (inventario de bienes). 
P.N. Domingo Jimeno Núñez, Palacios Jamuz, año 1728. Caja 7426, sig. 1472, fol. 11 12 (inventario de bienes).

P.N. Domingo Jimeno Núñez, Toral, año 1728. Caja 7426, sig. 1472, fol. 121 (inventario de bienes).

P.N. Domingo Jimeno Núñez, Palacios de la Valduerna, año 1728. Caja 7426, sig. 1472, fol. 136-137 (inventario de bienes).

P.N. Domingo Jimeno Núñez, Palacios de la Valduerna, año 1728. Caja 7426, sig. 1472, fol. 152 (inventario de bienes).

P.N. Domingo Jimeno Núñez, Palacios de la Valduerna, año 1728. Caja 7426, sig. 1472, fol. 165 (inventario de bienes).

P.N. García del Otero Fuente Mar, la Isla, año 1728. Caja 7426, sig. 1472, fol. 171- 172 (inventario de bienes).

P.N. García del Otero Fuente Mar, la Isla, año 1728. Caja 7426, sig. 1472, fol. 177- 179 (inventario de bienes).

P.N. García del Otero Fuente Mar, Biforcos, año 1729. Caja 7426, sig. 1472, fol. 157 (inventario de bienes).

P.N. García del Otero Fuente Mar, Requejo, año 1730. Caja 7427, sig. 1473, fol. 78-79 (inventario de bienes).

P.N. García del Otero Fuente Mar, Miñambres, año 1731. Caja 7427, sig. 1473, fol. 8890 (inventario de bienes).

P.N. García del Otero Fuente Mar, Requejo, año 1735. Caja 7427, sig. 1474, fol. 83- 85 (inventario de bienes).

P.N. García del Otero Fuente Mar, Santiago Millas, año 1735. Caja 7427, sig. 1474, fol. 136-137 (inventario de bienes).

P.N. García del Otero Fuente Mar, La Isla, año 1735. Caja 7427, sig. 1474, fol. 141-143 (inventario de bienes).

\section{Destriana}

P.N. Pedro Blanco de Quintanilla, Destriana, año 1730. Caja 7443, sig. 1542, fol. No se aprecia, mal estado (inventario de bienes).

P.N. Pedro Blanco de Quintanilla, Destriana, año 1731. Caja 7443, sig. 1543, fol. 11-12 (inventario de bienes).

\section{Castrocalbón}

P.N. Manuel González Barros. Castrocalbón, año 1701. Caja 7329, sig. 1190, fol. 65-68.

P.N. Manuel González Barros. Castrocalbón, año 1701. Caja 7329, sig. 1190, fol. 105109. 
S. XIX

\section{Palacios de la Valduerna}

P.N. Bernardo López, Castrillo de la Valduerna, año 1828. Caja 7718, sig. 2640, fol. 111-122 (inventario de bienes).

P.N. Bernardo López, Valle de la Valduerna, año 1829. Caja 7718, sig. 2640, fol. 1-5 (inventario de bienes).

P.N. Bernardo López, Palacios de la Valduerna, año 1831. Caja 7718, sig. 2642, fol. 6771 (inventario de bienes).

P.N. Bernardo López, Ribas de la Valduerna, año 1831. Caja 7718, sig. 2642, fol. 3-5 (inventario de bienes).

P.N. Joaquín Pérez Juana, Santibáñez de la Isla, año 1844. Caja 7750, sig. 2781, fol. 28 29 (inventario de bienes).

\section{Alija del Infantado}

P.N. Vicente Panchón, Alija del Infantado, año 1812. Caja 7669, sig. 2443. No se aprecia el número de folio (cuenta y tasación de bienes).

P.N. Vicente Panchón, La Nora del Río, año 1820. Caja 7670, sig. No se aprecia porque está rota la primera hoja. fol. 20-21 (inventario de bienes).

P.N. Vicente Panchón, La Nora del Río, año 1823. Caja 7670, sig. 2454. fol. 125-130 (inventario de bienes).

P.N. Vicente Panchón, Alija del Infantado, año 1827. Caja 7671, sig.2458 fol. 56 (inventario de bienes)

P.N. Vicente Panchón, Quintana del Marco, año 1827. Caja 7671, sig.2458 fol. 78 (avance de bienes).

\section{La Bañeza}

P.N. Miguel de las Heras, Jiménez de Jamuz, año 1825. Caja 7694, sig. 2566, fol. 9-11 (dote).

P.N. José Manuel Fernández, La Bañeza, año 1829. Caja 7704, sig. 2594, fol. 406-415 (inventario de bienes).

P.N. Miguel de las Heras, Requejo de la Vega, año 1839. Caja 7695, sig. 2570, fol.141147 (inventario, cuenta y división de bienes).

\section{Destriana}

P.N. Manuel Lorenzo, Destriana, año 1825. Caja 7723, sig. 2669, fol 29-30 (inventario de bienes).

P.N. Manuel Lorenzo, Destriana, año 1843. Caja 7724, sig. 2675, fol. 1-18 (inventario de bienes). 


\section{Castrocalbón}

P.N. Ramón Calabozo, Castrocalbón, año 1814. Caja 7632, sig. 2278, fol. 164-167 (inventario de bienes).

P.N. Matías Díez Hernández, Castrocalbón, año 1832. Caja 7721, sig. 2657, fol. 66-67 (inventario de bienes).

P.N. Matías Díez Hernández, Felechares, año 1836. Caja 7721, sig. 2658, fol. 54-55 (inventario de bienes).

P.N. Matías Díez Hernández, Felechares, año 1837. Caja 7722, sig. 2659, fol. 28-29 (inventario de bienes).

P.N. Matías Díez Hernández, San Feliz, año 1838. Caja 7722, sig. 2660, fol. No numeradas después del 77 una hoja (bienes que le tocaron de sus padres difuntos).

P.N. Matías Díez Hernández, Calzada, año 1838. Caja 7722, sig. 2660, fol. Idem va seguida dos hojas (inventario de bienes).

P.N. Matías Díez Hernández, Castrocalbón, año 1839. Caja 7722, sig. 2661, fol.29 (dote). 


\section{GLOSARIO DE TÉRMINOS}

\begin{tabular}{|c|c|c|c|}
\hline Palabra & Página & Palabra & Página \\
\hline Abanico & 92 & Apero & 255 \\
\hline Abregancias & 154 & Aposento & 467 \\
\hline Acabellado & 402 & Arado & 224 \\
\hline Aceitera & 122 & Arca & 198 \\
\hline Acerandar & 277 & Arcabuz & 398 \\
\hline Acribar & 277 & Argadillo & 371 \\
\hline Aderezo & 111 & Armador & 63 \\
\hline Afelpada & 362 & Armario & 197 \\
\hline Agujeta & 93 & Almilla & 62 \\
\hline Ajado & 473 & Arquetón & 199 \\
\hline Alabarda & 398 & Arracada & 112 \\
\hline Alacena & 194 & Arreos & 245 \\
\hline Alba & 421 & Arroba & 320 \\
\hline Albanega & 83 & Artesa & 164 \\
\hline Albarda & 244 & Arveja & 415 \\
\hline Albornía & 122 & Asador & 155 \\
\hline Alconcil & 111 & Asementar & 277 \\
\hline Alcuza & 123 & Aspa & 371 \\
\hline Aldabilla & 221 & Astudillo & 451 \\
\hline Aldabón & 221 & Ativa & 225 \\
\hline Alemanisco & 450 & Atropar & 278 \\
\hline Alepín & 337 & Avellana & 114 \\
\hline Alfiletero & 370 & Ávila & 451 \\
\hline Alfombra & 185 & Avinagrada & 403 \\
\hline Alforjas & 245 & Azabache & 114 \\
\hline Algodón & 330 & Azada & 256 \\
\hline Almagre & 444 & Azadón & 257 \\
\hline Almendrilla & 113 & Azafate & 283 \\
\hline Almirez & 160 & Azófar & 428 \\
\hline Almofía & 123 & Azuela & 503 \\
\hline Almohada & 169 & Azufrador & 180 \\
\hline Almohadón & 170 & Azumbre & 315 \\
\hline Altamía & 124 & Bacía & 125 \\
\hline Alzacuello & 94 & Badana & 434 \\
\hline Amantelado & 363 & Badil & 157 \\
\hline Amito & 421 & Baeza & 452 \\
\hline Andas & 425 & Balanza & 328 \\
\hline Angarilla & 230 & Balduque & 494 \\
\hline Angosto & 472 & Ballesta & 398 \\
\hline Anguarina & 57 & Banasta & 284 \\
\hline Anillo & 113 & Banca & 202 \\
\hline Anjeo & 451 & Banco & 201 \\
\hline Ansar & 393 & Bandeja & 161 \\
\hline Anteojo & 94 & Baranda & 165 \\
\hline Anzuelo & 477 & Barbecho & 464 \\
\hline Añino & 337 & Barbilla & 415 \\
\hline Añino & 390 & Bardino & 403 \\
\hline Aparador & 195 & Barragán & 338 \\
\hline Apañar & 277 & Barreño & 125 \\
\hline Aparejo & 472 & Barreñón & 126 \\
\hline
\end{tabular}




\begin{tabular}{|c|c|c|c|}
\hline$\underline{\text { Palabra }}$ & $\underline{\text { Página }}$ & Palabra & $\underline{\text { Página }}$ \\
\hline Barril & 127 & Calabaza & 130 \\
\hline Barrila & 127 & Calabozo & 259 \\
\hline Barro & 446 & Calabria & 452 \\
\hline Basquiña & 74 & Calamaco & 339 \\
\hline Bastidor & 186 & Calcetas & 50 \\
\hline Bastón & 95 & Caldera & 143 \\
\hline Batidora & 162 & Caldero & 297 \\
\hline Batiente & 509 & Calentador & 159 \\
\hline Baúl & 199 & Calesa & 493 \\
\hline Bayeta & 338 & Calzón & 50 \\
\hline Beatilla & 332 & Calzón & 404 \\
\hline Becerro & 380 & Calzoncillo & 51 \\
\hline Beldar & 278 & Cama & 213 \\
\hline Bielda & 258 & Camastro & 215 \\
\hline Bieldo & 258 & Camba & 231 \\
\hline Blonda & 95 & Cambar & 231 \\
\hline Bocado & 246 & Cambray & 452 \\
\hline Bolsa & 478 & Camelote & 340 \\
\hline Bordado & 363 & Camilla & 214 \\
\hline Borrego & 390 & Camisa & 52 \\
\hline Bota & 106 & Campano & 252 \\
\hline Bota & 299 & Canasta & 284 \\
\hline Bote & 128 & Canastillo & 285 \\
\hline Botella & 129 & Cancilla & 481 \\
\hline Botija & 129 & Candado & 482 \\
\hline Botín & 107 & Candelero & 190 \\
\hline Botón & 96 & Candil & 190 \\
\hline Braga & 49 & Cántara & 297 \\
\hline Bragado & 403 & Cántara & 325 \\
\hline Brasero & 158 & Cantarera & 195 \\
\hline Brazuelo & 230 & Cántaro & 297 \\
\hline Breviario & 423 & Cántaro & 326 \\
\hline Brial & 75 & Cantonera & 221 \\
\hline Brocado & 364 & Cantuda & 415 \\
\hline Brocatel & 443 & Cañamina & 444 \\
\hline Buey & 379 & Cáñamo & 349 \\
\hline Bufete & 209 & Cáñamo & 443 \\
\hline Bujía & 190 & Cañizo & 232 \\
\hline Burato & 339 & Capa & 58 \\
\hline Burro & 383 & Caparrosa & 365 \\
\hline Cabeza & 394 & Caparrosa & 404 \\
\hline Cabezada & 246 & Capero & 195 \\
\hline Cabezal & 172 & Capillo & 84 \\
\hline Cabijal & 226 & Capote & 59 \\
\hline Cabra & 389 & Capotillo & 59 \\
\hline Cabrito & 389 & Cardino & 404 \\
\hline Caceta & 153 & Carga & 316 \\
\hline Cacharro & 142 & Carmesí & 404 \\
\hline Cachivache & 480 & Carnero & 390 \\
\hline Cacho & 488 & Carpeta & 219 \\
\hline Cadena & 493 & Carpontes & 469 \\
\hline Caja & 478 & Carranca & 254 \\
\hline Cajón & 218 & Carreta & 232 \\
\hline
\end{tabular}




\begin{tabular}{|c|c|c|c|}
\hline Palabra & $\underline{\text { Página }}$ & Palabra & $\underline{\text { Página }}$ \\
\hline Carro & 233 & Chupa & 60 \\
\hline Carro de oro & 340 & Chupín & 67 \\
\hline Cartera & 96 & Сhuzo & 399 \\
\hline Carvonera & 130 & Cigüeñal & 311 \\
\hline Casaca & 63 & Cincha & 246 \\
\hline Casero & 473 & Cíngulo & 422 \\
\hline Castaño & 405 & Clavera & 308 \\
\hline Castradera & 259 & Claveteado & 310 \\
\hline Castrón & 389 & Clavetero & 310 \\
\hline Catalufa & 341 & Clavija & 225 \\
\hline Catre & 214 & Clavo & 309 \\
\hline Cazo & 143 & Cobertera & 145 \\
\hline Cazuela & 144 & Cobertor & 172 \\
\hline Cebada & 395 & Cobertor & 238 \\
\hline Cebada & 416 & Cobre & 429 \\
\hline Cedazo & 260 & Cochinilla & 405 \\
\hline Celemín & 317 & Cofia & 85 \\
\hline Celestre & 365 & Cofre & 200 \\
\hline Celestre & 405 & Coladera & 163 \\
\hline Cenador & 202 & Colaño & 234 \\
\hline Cencerro & 253 & Colcha & 173 \\
\hline Centenal & 464 & Colchón & 176 \\
\hline Ceñidor & 96 & Colgadura & 179 \\
\hline Cepillo & 97 & Collar & 115 \\
\hline Cepillo & 304 & Collar & 254 \\
\hline Cera & 445 & Collera & 254 \\
\hline Ceranda & 261 & Colmenar & 464 \\
\hline Cerandón & 262 & Colonia & 97 \\
\hline Cerdo & 386 & Colonia & 453 \\
\hline Cernadero & 181 & Colorado & 406 \\
\hline Cerrado & 60 & Comedera & 250 \\
\hline Cerrado & 395 & Cómoda & 201 \\
\hline Cerradura & 222 & Contray & 453 \\
\hline Cerrojo & 223 & Copera & 200 \\
\hline Cerrón & 349 & Copero & 196 \\
\hline Cespedero/a & 262 & Coral & 115 \\
\hline Cesta & 285 & Cordel & 216 \\
\hline Cesto & 286 & Cordellate & 341 \\
\hline Chaleco & 65 & Cordero & 391 \\
\hline Chalón & 341 & Córdoba & 454 \\
\hline Chamberga & 64 & Cordón & 495 \\
\hline Chambergo & 84 & Cornal & 238 \\
\hline Chambra & 65 & Cornalina & 116 \\
\hline Chapín & 107 & Согписоріа & 191 \\
\hline Chaqueta & 66 & Corral & 464 \\
\hline Charpa & 399 & Corsé & 53 \\
\hline Chaveta & 494 & Cortadillo & 137 \\
\hline China & 453 & Cortina & 179 \\
\hline Chinela & 108 & Corza & 234 \\
\hline Chisme & 480 & Coscojo & 247 \\
\hline Chivo & 389 & Costal & 293 \\
\hline Chocolatera & 130 & Costana & 235 \\
\hline Chuchería & 480 & Cotón & 331 \\
\hline
\end{tabular}




\begin{tabular}{|c|c|c|c|}
\hline$\underline{\text { Palabra }}$ & $\underline{\text { Página }}$ & Palabra & $\underline{\text { Página }}$ \\
\hline Cotonía & 331 & Ermilla & 69 \\
\hline Crespón & 356 & Escalera & 485 \\
\hline Cribo & 263 & Escalfador & 156 \\
\hline Cristal & 445 & Escañil & 203 \\
\hline Cruceta & 117 & Escaño & 204 \\
\hline Crucifijo & 426 & Escaparate & 196 \\
\hline Cruz & 116 & Escapulario & 424 \\
\hline Cuadro & 186 & Escarlatín & 342 \\
\hline Cuarta & 317 & Escarpia & 485 \\
\hline Cuartadero & 239 & Escarpidor & 99 \\
\hline Cuartal & 318 & Escarpín & 108 \\
\hline Cuarterón & 327 & Esclavina & 423 \\
\hline Cuartillo & 318 & Escoba & 264 \\
\hline Cuba & 299 & Escopeta & 400 \\
\hline Cubeto & 300 & Escoplo & 311 \\
\hline Cubierto & 150 & Escribanía & 210 \\
\hline Cubo & 298 & Escriño & 288 \\
\hline Cuchara & 151 & Escritorio & 211 \\
\hline Cuchillo & 152 & Escudilla & 124 \\
\hline Cuello & 98 & Escusabaraja & 288 \\
\hline Cuelmo & 288 & Espada & 400 \\
\hline Cuelmo & 444 & Espadar & 373 \\
\hline Сиепсо & 131 & Espadilla & 373 \\
\hline Cuero & 435 & Esparragón & 357 \\
\hline Сuerpo & 66 & Esparto & 444 \\
\hline Cuerpo & 66 & Espejo & 219 \\
\hline Сиегро & 466 & Espetera & 164 \\
\hline Cueva & 467 & Espinazo & 418 \\
\hline Daga & 400 & Espita & 337 \\
\hline Damasco & 454 & Espliego & 416 \\
\hline Dengue & 68 & Espolinado & 357 \\
\hline Dentudo & 226 & Espumadera & 153 \\
\hline Desbagar & 278 & Espumilla & 358 \\
\hline Desbaratado & 474 & Espurrir & 279 \\
\hline Desborcillado & 474 & Esquilón & 253 \\
\hline Devanadera & 372 & Estameña & 342 \\
\hline Devanar & 372 & Estampa & 426 \\
\hline Devantal & 80 & Estante & 212 \\
\hline Dije & 98 & Estera & 350 \\
\hline Dogal & 247 & Estercar & 279 \\
\hline Dosel & 426 & Esterquera & 264 \\
\hline Droguete & 342 & Estopa & 350 \\
\hline Ejecutoria & 482 & Estopilla & 351 \\
\hline Embarrar & 495 & Estoque & 401 \\
\hline Embudo & 163 & Estribo & 247 \\
\hline Enaguas & 53 & Estuche & 479 \\
\hline Enarcar & 300 & Estufa & 159 \\
\hline Encaje & 332 & Evangelio & 424 \\
\hline Encaño & 249 & Facerón & 491 \\
\hline Encarnado & 406 & Facha & 99 \\
\hline Encorado & 435 & Faja & 99 \\
\hline Encordeladura & 216 & Faltriquera & 100 \\
\hline Encubridor & 174 & Fanega & 318 \\
\hline
\end{tabular}




\begin{tabular}{|c|c|c|c|}
\hline$\underline{\text { Palabra }}$ & $\underline{\text { Página }}$ & Palabra & $\underline{\text { Página }}$ \\
\hline Fardel & 294 & Gorro & 85 \\
\hline Fardela & 294 & Guadamecil & 435 \\
\hline Farol & 191 & Guadaña & 265 \\
\hline Felpa & 333 & Guante & 100 \\
\hline Felpo & 496 & Guardapiés & 76 \\
\hline Ferreruelo & 69 & Guardapolvos & 180 \\
\hline Fiambrera & 131 & Guarnición & 101 \\
\hline Filigrana & 365 & Gubia & 306 \\
\hline Filoseda & 358 & Gubilete & 132 \\
\hline Fitera & 373 & Gusanillo & 367 \\
\hline Fleco & 366 & Hebilla & 101 \\
\hline Forca & 264 & Hechura & 496 \\
\hline Forcada & 265 & Hemina & 319 \\
\hline Foro & 482 & Herrada & 328 \\
\hline Fosco & 408 & Herrado & 497 \\
\hline Frac & 75 & Herradura & 498 \\
\hline Fragua & 160 & Herraje & 498 \\
\hline Frailengo & 409 & Hierro & 430 \\
\hline Franela & 333 & Hilaza & 368 \\
\hline Frasco & 492 & Hilo & 375 \\
\hline Frechilla & 455 & Hojalata & 431 \\
\hline Fréjol & 416 & Holanda & 456 \\
\hline Freno & 248 & Horma & 470 \\
\hline Frisa & 60 & Horno & 498 \\
\hline Frisa & 343 & Horqueta & 499 \\
\hline Frontal & 470 & $\mathrm{Hoz}$ & 266 \\
\hline Frutero & 137 & Humero & 437 \\
\hline Frutero/a & 138 & India & 456 \\
\hline Fuelle & 159 & Inglés & 456 \\
\hline Fuente & 138 & Jarra & 132 \\
\hline Funda & 175 & Jarro & 133 \\
\hline Fusa & 374 & Jato & 380 \\
\hline Fuso & 374 & Jaula & 499 \\
\hline Fustán & 334 & Jerga & 344 \\
\hline Fustera & 162 & Jergón & 176 \\
\hline Gabardina & 61 & Jerguilla & 345 \\
\hline Gabucha & 108 & Jeringa & 487 \\
\hline Gacho & 396 & Jícara & 134 \\
\hline Gajo & 486 & Joya & 118 \\
\hline Gallego & 455 & Joyel & 118 \\
\hline Gallina & 393 & Jubón & 69 \\
\hline Galocha & 109 & Justillo & 70 \\
\hline Galón & 366 & Labrado & 364 \\
\hline Garabito & 311 & Labranza & 279 \\
\hline Garapiña & 367 & Lagar & 301 \\
\hline Garapiñera & 132 & Lámina & 187 \\
\hline Garduñera & 496 & Lámpara & 192 \\
\hline Garfio & 486 & Lamparilla & 345 \\
\hline Garganta & 227 & Lana & 345 \\
\hline Gargantilla & 117 & Lanar & 391 \\
\hline Garlopa & 305 & Lata & 491 \\
\hline Gato & 305 & Latón & 431 \\
\hline Gaza & 249 & Lavadero & 500 \\
\hline
\end{tabular}




\begin{tabular}{|c|c|c|c|}
\hline$\underline{\text { Palabra }}$ & $\underline{\text { Página }}$ & Palabra & $\underline{\text { Página }}$ \\
\hline Lavativa & 487 & Marra & 257 \\
\hline Lecho & 215 & Marrano & 388 \\
\hline Lechón & 387 & Martillo & 312 \\
\hline Lechuza & 396 & Mascarilla & 502 \\
\hline Legajo & 483 & Masera & 165 \\
\hline Leña & 491 & Maserón & 166 \\
\hline Levita & 71 & Mazo & 313 \\
\hline Lezna & 312 & Mazorca & 376 \\
\hline Libra & 321 & Medalla & 118 \\
\hline Libro & 483 & Media & 54 \\
\hline Lienzo & 352 & Mediano & 267 \\
\hline Liga & 54 & Mela & 255 \\
\hline Limiste & 457 & Melado & 447 \\
\hline Linaza & 417 & Melena & 240 \\
\hline Lino & 353 & Melonera & 417 \\
\hline Linterna & 192 & Menudo & 419 \\
\hline Lista & 102 & Merino & 346 \\
\hline Llábana & 448 & Mesa & 207 \\
\hline Longaniza & 417 & Meúl & 235 \\
\hline Lumbral & 470 & Mimbre & 439 \\
\hline Machado & 306 & Misal & 425 \\
\hline Macheta & 307 & Mitán & 354 \\
\hline Macho & 384 & Mocho & 474 \\
\hline Madeja & 375 & Moer & 358 \\
\hline Madera & 438 & Mohíno & 397 \\
\hline Madero & 439 & Molinillo & 166 \\
\hline Madrid & 457 & Monfort & 458 \\
\hline Magüeto & 381 & Montera & 88 \\
\hline Majadera & 267 & Morado & 410 \\
\hline Majar & 280 & Morcajo & 418 \\
\hline Maleta & 502 & Moreno & 410 \\
\hline Mamón & 396 & Morillo & 158 \\
\hline Manada & 324 & Morlés & 458 \\
\hline Mancera & 227 & Mortero & 161 \\
\hline Mancerina & 138 & Moscovia & 458 \\
\hline Manchester & 457 & Mosquera & 217 \\
\hline Mandil & 80 & Mula & 384 \\
\hline Mangas & 82 & Muladar & 465 \\
\hline Manguito & 102 & Mular & 384 \\
\hline Manizo & 375 & Mullida & 241 \\
\hline Manta & 177 & Munición & 401 \\
\hline Manteca & 419 & Muselina & 358 \\
\hline Mantel & 182 & Naspa & 376 \\
\hline Mantellina & 86 & Navaja & 152 \\
\hline Manteo & 77 & Naveta & 212 \\
\hline Mantilla & 86 & Negrillo & 440 \\
\hline Mantillín & 72 & Negro & 410 \\
\hline Manto & 72 & Nogal & 441 \\
\hline Mantón & 73 & Novillo & 381 \\
\hline Maragato/a & 54 & Olla & 146 \\
\hline Marco & 187 & Omero & 441 \\
\hline Marmota & 87 & Onza & 322 \\
\hline Maroma & 267 & Ordenanzas & 484 \\
\hline
\end{tabular}




\begin{tabular}{|c|c|c|c|}
\hline$\underline{\text { Palabra }}$ & $\underline{\text { Página }}$ & Palabra & $\underline{\text { Página }}$ \\
\hline Ordinario & 475 & Percal & 334 \\
\hline Orejera & 103 & Pereruela & 459 \\
\hline Orinal & 490 & Pernil & 419 \\
\hline Ormesí & 359 & Pernilla & 236 \\
\hline Oro & 432 & Perol & 147 \\
\hline Orona & 289 & Pesa & 329 \\
\hline Orza & 134 & Pesebre & 250 \\
\hline Oveja & 392 & Pesebrera & 251 \\
\hline Ovejuno & 392 & Peso & 329 \\
\hline Ovillo & 377 & Peto & 270 \\
\hline Pabellón & 179 & Petral & 248 \\
\hline Pabilo & 354 & $P e z$ & 445 \\
\hline Pajar & 467 & Picador & 166 \\
\hline Pajizo & 411 & Pichonera & 291 \\
\hline Pajizo & 444 & Picote & 360 \\
\hline Pala & 268 & Pie & 503 \\
\hline Palanca & 502 & Piedra & 448 \\
\hline Palangana & 490 & Piel & 436 \\
\hline Palanquilla & 503 & Pieza & 489 \\
\hline Palencia & 459 & Pila & 425 \\
\hline Palero & 441 & Pila & 500 \\
\hline Paleta & 157 & Pilón & 251 \\
\hline Palmatoria & 192 & Pina & 236 \\
\hline Palmilla & 346 & Pintura & 188 \\
\hline Palmo & 325 & Piñuela & 360 \\
\hline Palo & 237 & Piqué & 335 \\
\hline Palomo & 393 & Pistola & 401 \\
\hline Pana & 334 & Plancha & 501 \\
\hline Pandero & 503 & Planchada & 501 \\
\hline Panera & 295 & Planchón & 313 \\
\hline Pantalón & 78 & Plata & 433 \\
\hline Paño & 347 & Plato & 139 \\
\hline Pañuelo & 89 & Plomada & 314 \\
\hline Papelera & 213 & Pluma & 171 \\
\hline Pardillo & 355 & Podadera & 271 \\
\hline Pardo & 355 & Poíno & 302 \\
\hline Pardo & 412 & Polainas & 104 \\
\hline Parlamenta & 61 & Polla & 394 \\
\hline Parrilla & 156 & Pollino & 385 \\
\hline Pasal & 485 & Poltrona & 204 \\
\hline Pasamanos & 368 & Polvo & 210 \\
\hline Pato & 394 & Pólvora & 401 \\
\hline Pechador & 103 & Pomo & 492 \\
\hline Pedazo & 488 & Portugal & 460 \\
\hline Peinador & 103 & Poste & 504 \\
\hline Peine & 377 & Pote & 147 \\
\hline Peiza & 135 & Potro & 249 \\
\hline Pellejo & 302 & Potro & 385 \\
\hline Pellejo & 436 & Pozal & 298 \\
\hline Pelliza & 61 & Prádanos & 460 \\
\hline Peltre & 432 & Prender & 280 \\
\hline Pendiente & 119 & Pretina & 104 \\
\hline Peñera & 269 & Prisión & 252 \\
\hline
\end{tabular}




\begin{tabular}{|c|c|c|c|}
\hline$\underline{\text { Palabra }}$ & $\underline{\text { Página }}$ & Palabra & Página \\
\hline Puchera & 148 & Rubio & 414 \\
\hline Puchero & 147 & Rueda & 505 \\
\hline Pujavante & 314 & Sábana & 178 \\
\hline Puntas & 369 & Saca & 291 \\
\hline Quebrado & 475 & Sacho & 273 \\
\hline Quilma & 296 & Salero & 140 \\
\hline Quiñón & 468 & Salostrero & 303 \\
\hline Quitasol & 104 & Salsera & 140 \\
\hline Rajadillo & 272 & Salvadera & 210 \\
\hline Rallador & 164 & Sanguino & 414 \\
\hline Randa & 370 & Sarta & 119 \\
\hline Raposo & 437 & Sartén & 148 \\
\hline Rasa & 217 & Saya & 79 \\
\hline Rastra & 271 & Sayo & 79 \\
\hline Rastrillar & 281 & Sayuelo & 74 \\
\hline Rastrillo & 271 & Seda & 360 \\
\hline Rastro & 272 & Sedal & 478 \\
\hline Ratina & 348 & Segovia & 461 \\
\hline Real & 504 & Segundera & 237 \\
\hline Rebociño & 90 & Semanilla & 425 \\
\hline Red & 477 & Sembrar & 281 \\
\hline Redoma & 135 & Sempiterna & 348 \\
\hline Refolleta & 477 & Serafina & 349 \\
\hline Regadera & 273 & Serón & 297 \\
\hline Regla & 308 & Servilla & 149 \\
\hline Regla & 424 & Servilleta & 183 \\
\hline Regular & 476 & Sevilla & 461 \\
\hline Reja & 228 & Sierra & 314 \\
\hline Relicario & 427 & Silla & 205 \\
\hline Reliquia & 427 & Silleta & 205 \\
\hline Repostero & 189 & Sobeo & 241 \\
\hline Res & 397 & Sobeyuelo & 242 \\
\hline Resma & 325 & Sobrecama & 175 \\
\hline Respaldo & 220 & Sobredorado & 434 \\
\hline Retazo & 490 & Sobremesa & 184 \\
\hline Rienda & 249 & Soga & 506 \\
\hline Roble & 442 & Solideo & 422 \\
\hline Rocadero & 105 & Sombrerera & 223 \\
\hline Rodador & 273 & Sombrero & 90 \\
\hline Rodao & 78 & Somonte & 355 \\
\hline Rodapisa & 183 & Sortija & 120 \\
\hline Rodezno & 505 & Sotana & 423 \\
\hline Rojo & 407 & Tabla & 507 \\
\hline Roldo & 505 & Tablado & 509 \\
\hline Romana & 329 & Tablilla & 120 \\
\hline Romano & 310 & Tablizo & 509 \\
\hline Ropa & 178 & Taburete & 206 \\
\hline Ropero & 197 & Tachuela & 510 \\
\hline Ropilla & 73 & Tafetán & 361 \\
\hline Roquete & 422 & Tajadera & 167 \\
\hline Rosario & 427 & Tajador & 167 \\
\hline Roto & 476 & Tajo & 168 \\
\hline Ruan & 460 & Talavera & 461 \\
\hline
\end{tabular}




\begin{tabular}{|c|c|c|c|}
\hline$\underline{\text { Palabra }}$ & $\underline{\text { Página }}$ & Palabra & $\underline{\text { Página }}$ \\
\hline Talega & 291 & Trigal & 469 \\
\hline Talego & 292 & Trilla & 282 \\
\hline Talegón & 292 & Trillar & 283 \\
\hline Tapapié & 81 & Trillo & 275 \\
\hline Tapete & 223 & Trona & 207 \\
\hline Tapiz & 189 & Trosa & 276 \\
\hline Tarazona & 462 & Unto & 420 \\
\hline Tarima & 217 & Urdidor & 379 \\
\hline Tartera & 150 & Vaca & 383 \\
\hline Taza & 141 & Valón & 55 \\
\hline Tela & 335 & Valona & 56 \\
\hline Telar & 378 & Vaqueta & 437 \\
\hline Telera & 228 & Vara & 238 \\
\hline Tenada & 465 & Vara & 323 \\
\hline Tenaza & 315 & Vara & 511 \\
\hline Tenedor & 152 & Varal & 511 \\
\hline Tercia & 323 & Vareta & 370 \\
\hline Tercial & 308 & Varilla & 260 \\
\hline Terciopelo & 362 & Vasar & 196 \\
\hline Terliz & 336 & Vasija & 137 \\
\hline Ternero & 382 & Vasija & 303 \\
\hline Terrón & 471 & Vaso & 141 \\
\hline Tiesto & 480 & Velador & 193 \\
\hline Tijera & 510 & Vellón & 511 \\
\hline Timón & 229 & Velón & 193 \\
\hline Tinaja & 135 & Vestido & 81 \\
\hline Tino & 136 & Verbión & 238 \\
\hline Tintero & 211 & Vidrio & 446 \\
\hline Tiradero & 229 & Viga & 471 \\
\hline Toalla & 184 & Vigada & 471 \\
\hline Toca & 91 & Vinagrera & 142 \\
\hline Tocinera & 169 & Vinco & 121 \\
\hline Tocino & 420 & Viña & 469 \\
\hline Toledo & 462 & Vistas & 92 \\
\hline Tonel & 303 & Volvedera & 154 \\
\hline Toquilla & 91 & Vuelta & 105 \\
\hline Tornadera & 274 & Vuelta & 121 \\
\hline Tornear & 281 & Yеgиа & 386 \\
\hline Torno & 378 & Yugo & 243 \\
\hline Trabuco & 402 & Zagalejo & 56 \\
\hline Trascorral & 468 & Zamorano & 463 \\
\hline Trasga & 242 & Zapa & 449 \\
\hline Trasquilar & 282 & Zapato & 109 \\
\hline Trasto & 481 & Zaraza & 336 \\
\hline Travesero & 220 & Zarcillo & 121 \\
\hline Trébede & 155 & Zиесо & 110 \\
\hline
\end{tabular}




\section{ANEXO DOCUMENTAL}

Los anexos que figuran a continuación son una muestra de los inventarios recogidos durante el trabajo de campo. Esta muestra se ha hecho seleccionando épocas y lugares. Los que aparecen como muestra del S. XVII son un inventario de Coomonte de la Vega y otro de La Bañeza, seleccionando así núcleo rural y urbano, este último no figura en el repertorio de fotografías pero se ha seleccionado porque se recogen los objetos de una tienda lo que hace que se trate de un inventario con cierto interés lexicográfico. Del s. XVIII se han seleccionado cuatro inventarios puesto que es el siglo en el que más inventarios se consultaron en la fase inicial, uno de La Bañeza (núcleo urbano) y tres del núcleo rural pero correspondientes a distintas zonas: Valduerna, Valdejamuz y Páramo. Del S.XIX se han seleccionado dos inventarios, uno de Destriana que no aparece en la muestra fotográfica pero que he seleccionado para que figure en los anexos puesto que se trata de un inventario muy completo que además muestra los objetos que se van relacionando siguiendo el orden de enseres que aparecen en cada una de las dependencias de la casa, el otro es de la zona de Castrocalbón, es decir de la Valdería, quedando así representadas todas las comarcas que comprende el Partido Judicial de La Bañeza: Bajo Órbigo (Coomonte), La Bañeza, Valdería (Castrocalbón), Páramo (Laguna de Negrillos), Valdejamuz (Villanueva) y Valduerna (Robledo de la Valduerna). 
Título: Inventario de los bienes Roque Martínez llevó al matrimonio con Beatriz de

\section{Figueruela}

Tipo: inédito

Carácter: particular

Procedencia: Archivo Histórico Provincial de León

Signatura Caja 7034, 397

Folios: 303- 309

Año: 1645

Lugar: Coomonte de la Vega

Provincia: Zamora

País: España

(Fol. 303r.) En el lugar de Comonte, aldea y juridiçión /

de la villa de Alixa, a treynta días del mes de novienbre de /

mil y seiszientos y quarenta y zinco años, ante mí Martín /

García escribano de la dicha villa de Alixa y su juridiçión, y ante los testigos /

ynfraescriptos, parezieron presentes Roque Martínez Pego y /

Beatriz de Figueruela su muger vezinos de dicho lugar y dixeron /

que ellos estaban casados y belados en "faz eclesie" de la sancta /

madre Yglesia, el uno con el otro y que cada uno /

dellos tenía al tienpo y quando se casaron cantidad /

de bienes y açienda en ganados, axaraes y otras /

cosas de que querían haçer ynuentario y ponerlo todo /

por quenta y raçón, para que sienpre se sepa lo que cada uno /

tenía y que los dichos uienes y hacienda se tasen por su justo /

precio y balor por si se consumen, gastan o destruyen /

y que para este efeto auían nonbrado por tasadores e yn-/

ventariadores, anuos de conformidad, a Bartolomé Ló-/

pez y a Pedro Martínez Pego, vecinos de dicho lugar de Comonte, que /

presentes estauan. Los quales dichos Pedro Martínez y Barto-/

lomé López hacetaron el dicho oficio y luego fueron /

haciendo inuentario y tasación de /

los uienes y hacienda que tenía el /

dicho Roque Martínez suyos propios quan-/

do casó con la sobredicha y de aquellos mis-/

mos que la dicha Beatriz de Figueruela /

confesó ser suyos propios del dicho /

Roque Martínez y tenerlos quando casó con ella /

en la forma y manera siguiente: /

Primeramente pusieron por ynbentario una lechona /

buena cebada tasada en doçe ducados. I

Yten más una lechona y un lechón medianos tasados /

en catorçe ducados. I

Yten más un burro pardo bueno de quatro años tasado /

en catorce ducados/

(Fol. 303v.) más vn exe de carro nuebo de faya en tres reales /

y medio. /

Más, un costal de pauilos que hará seis heminas hu- / 
sado tasado en nuebe reales. /

Más unas escaleras de treçe pasales husadas tasadas / en quatro reales. /

Más un poste de negrillo bueno en quatro reales. /

Más vn banco de palero biexo en quatro cuartos. /

Más vn moyl biexo que fue banco en quatro cuartos. /

Más vn carretón de hechar estiércol pequeño con una / rueda tasado en dos reales. I

Más vna puerta pequeña de álamo tasada en çinco / reales. I

Más vnos esquilones con collares de raposo buenos en / ocho reales. I

Más dos mantas buenas con listas negras a diez y seis / reales cada una. /

Más dos cabezales de lana buenos con listas negras ta-/ sados en treynta y seis reales. /

Más vn repostero de lana con listas negras husado / tasado en beynte reales. /

Más otra manta de lana con listas negras husada / tasada en doçe reales. /

Yten más otra manta de lana biexa en ocho reales. / Más otra manta de lana husada tasada en diez reales. /

Más vn cabezal de lana con listas negras husado ta-/ sado en diez reales. I

Más otra manta de lana pequeña biexa tasada en / ocho reales. I

Otra manta biexa tasada en ocho reales /

digo en siete reales. /

Más vn cabezal biexo con listas negras tasado en / cuatro reales. /

Otro cabezal muy biexo de lana con listas negras / tasado en dos reales. /

Más otro cabezal de lana biexo con listas negras ta- / sado en dos reales. I

Más un arado con su rexa y cabixa en onçe reales. /

Más otros dos arados buenos con sus rexas, cabixas / y tiriguelas de yerro tasados en beynte y dos reales. /

(Fol. 304r.) Yten más un yugo bueno con sus cornales y / melenas, trasga y sobeyuelo todo bueno tasado en do-/ çe reales. I

Más otro yugo con sus cornales y melenas husado tasa-/ do en seis reales. /

Más vn cabezal de lana blanca con listas negras bueno / tasado en diez y ocho reales. /

Más otro cabezal de lana pintado bueno tasado en beyn- / te y tres reales. I

Más otro cabezal de lana pintado husado tasado en diez / reales. I

Más otro cabezal de lana con listas negras husado tasa-/ 
do en beynte y tres reales. I

Yten más otro cabezal de lana con listas negras husado tasa-/

do en beynte y tres reales. I

Más dos cabezales de lana pintados buenos tasados en /

cinquenta reales. /

Más vna manta nueba de lana con listas negras /

tasada en beynte y quatro reales. I

Otra manta buena con listas negras tasada en beyn- /

te y dos reales. I

Más un repostero de lana con listas negras tasado /

en beynte y dos reales. /

Más vna carpeta biexa pintada tasada en tres reales. I

Más vna caxa de cobre con treçe reales de a ocho en plata que tiene /

dentro. I

Más tres digo çinco bueltas de corales con beynte alcon-/

ciles y dos sortixas de plata tasadas en ciento y diez reales. /

Más vna chruzeta de plata con una hechura de un San-/

to Cristo tasada en diez y seis reales. /

Más otra chruzeta de plata con otra hechura de un Santo /

Cristo tasada en catorçe reales. /

Más otra chruzeta pequeña de plata con otra hechura /

tasada en diez reales. /

Más un zuelico de plata pequeño tasado en catorçe rea-/

les. /

Más vna cestica de ofreçer de binbre blanca tasada /

en un real. I

(Fol. 304v.) Más, otra çestica de ofreçer nueba en vn real. /

Más, vn Christo de plata pequeño tasado en tres reales. /

Más vna capa de pardo nueba aforrado el quello en fus-/ tán tasada en beynte y seis reales. /

Más otra capa de pardo casero husada tasada en beynte / y ocho reales. /

Más, vn sayuelo de contray husado tasado en quinze / reales. I

Más, otro sayuelo de contray con ribetes de terçiope-/

lo husado tasado en catorçe reales./

Más vnos cuerpos berdes nuebos con ribetes de contray / tasado en doçe reales. /

Más, vna saya azul biexa tasada en doçe reales. /

Más vna mantilla clara husada de paño azul tasada

en diez y seis reales. /

Más otra mantilla azul husada tasada en catorçe /

reales. I

Más vnos cuerpos berdes con ribetes de contray tasados /

en doçe reales. I

Más, vn sayuelo azul con ribetes de contray /

husado en diez y seis reales. /

Más vna mantilla de contray husada tasada en dos / 
ducados. I

Más otra mantilla de contray buena tasada /

en cuarenta reales. /

Más otra mantilla de paño de color husada tasada en / beynte y dos reales. /

Más vnos cuerpos de grana con ribetes de terçiopelo / husados tasados en treynta reales. /

Más tres quartas de estameña [...] tasada en /

dos reales. I

Más vnos cuerpos berdes digo azules biexos tasados / en dos reales. I

Más una saya berde husada tasada en quarenta / y quatro reales. I

Más vna saya de blanqueta nueba tasada en beyn-/ te y dos reales. /

Más, vna mantilla de çeñir de lana negra buena / tasada en siete reales. /

Más otra mantilla de çeñir negra tasada en siete / reales. I

(Fol. 305r.) Más vn mandil çamorano con listas bueno tasado / en seis reales. /

Más un cuerpo de camisa con sus mangas labradas de / blanco tasado en seis reales. /

Más vn paño de manos de ruan labrado de capa-/

rrosa tasado en seis reales, husado. /

Más otro paño de ruan bueno labrado de caparrosa / y seda negra tasado en doçe reales. /

Más vna almoada husada labrada de caparrosa / tasada en cuatro reales. /

Más, otro paño husado de lienzo labrado de blanco / tasado en diez reales. /

Más otro paño de lienzo nuevo labrado de çilestre ta-/ sado en beinte y cuatro reales. I

Más otro paño bueno labrado de lo mismo tasado / en treynta reales. /

Más vna sábana de tres lienzos buena tasada en treyn-I ta reales. /

Más otra sábana de dos lienzos husada tasada en /

dos reales /

digo tasada en diez reales. /

Más, vnos manteles de alimanisco husados tasa-/

dos en doçe reales. I

Más, otros manteles pequeños de alimanisco buenos / tasados en nuebe reales. I

Más, otros manteles pequeños de alimanisco de bara / y media tasados en seis reales. /

Más otros manteles angostos de lo mismo tasados en nue-/ be reales. I

Más otros manteles angostos pequeños de alimanisco / 
husados, buenos tasados en diez reales. /

Más cuatro baras y media de serbilletas nuebas de tres /

cuartas de ancho tasadas en quinçe reales. I

Más cuatro serbilletas de alimanisco buenas tasa-/

das en diez y seis reales. I

Más, vna saya de blanqueta nueba tasada en dos /

ducados. I

Más dos sábanas de lienço husadas de dos lienzos /

tasadas en vente reales. /

Más vn sayuelo de pardo husado con ribete de terçio-/

pelo tasado en ocho reales. I

(Fol. 305v.) Yten más, vna mantilla de cubrir de pardo bue-/ na tasada en catorçe reales. /

Más, otra mantilla de pardo buena de cubrir ta-/ sada en catorçe reales. I

Más otras dos mantillas de cubrir husadas tasa-/ das en diez y seis reales. I

Más vna saya de pardo nueba tasada en quinze / reales. I

Más vna arca mediana con su çerradura, llabe y / cantoneras todo nuebo tasada en tres ducados. /

Más otra arca mediana husada con su çerradura / ya biexa tasada en ocho reales. /

Más otra arca grande buena sin çerradura tasa-/ da en doçe reales. I

Más otra arca de pies biexa con su çerradura y lla-/ be tasada en siete reales. I

Más otra arca pequeña biexa sin çerradura tasa-/ da en dos reales./

Más otra arca de pies biexas sin çerradura tasa-/ das en çinco reales. /

Más, vn sobeo biexo tasado en cuatro reales. /

Yten más vn machado bueno tasado en ocho reales. /

Más vna garlopa y un çepillo tasado en tres reales. /

Más vnos balones de pasamanos de estameña fray-/

lenga tasados en ocho reales. I

Más otros balones de estameña negra buenos tasa-/

dos en nuebe reales. /

Más dos escoplos y una gubia todo de yerro tasado en /

dos reales y medio. /

Más cuatro espitas y un taladrico desbocado todo /

de yerro tasado en dos reales y medio. I

Más vnas tenaçicas de arrancar tasadas en dos reales. /

Más una zuela buena tasada en quatro reales y /

medio. I

Más vn machado biexo tasado en tres reales. /

Más vn açadón de monte tasado en seis reales y medio. /

Más vna açada de cabar biñas tasada en seis reales. / 
(Fol. 306r.) Yten pusieron por ynbentario cinco cazos de cobre, los çinco, digo/ los cuatro de cobre y el otro de azófar tasados en beynte y çinco reales / todos biexos y rotos. I

Más otro cazo de cobre pequeño biexo tasado en tres reales. /

Más dos asadores de gaxos buenos tasados en ocho reales. /

Más cuatro asadores el uno de gaxos y el otro sin ellos medianos / tasados en ocho reales. /

Más seis platos de Talabera fina pintados los çinco buenos y el otro / desborçillado tasado en onçe reales. /

Más vna tazica de Talabera de beber tasada en un real. /

Más dos candeleros de azófar buenos tasados en doçe reales. /

Más otro candelero de azófar mediano tasado en quatro reales. /

Más tres cazetas la una buena y dos biexas tasadas en dos reales. I

Más dos castraderas de yerro buenas tasadas en dos reales. /

Más vn peso de garfios con una pesa de dos libras y otra de medio quar-/

terón tasado en dos reales. I

Más dos basos de bidrio tasados en vn real. /

Yten más vnas tixeras lanales biexas y otras tixeras pequeñas de /

costurera tasadas en un real. /

Más dos tiriguelas de yerro de arados tasadas en dos reales. /

Más vna paleta de yerro de enbarrar tasada en un real. /

Más dos asadores de yerro vno de gaxos y otro sin ellos en tres reales. /

Más vn açiguñal de vna rueda de herrero en quatro reales. /

Más un martillo de orexas de yerro tasado en tres reales. /

Más vn [...] de una gixada de quero tasada en dos reales. /

Más vn xaxo de yerro pequeño tasado en un real. /

Más vn quero bueno que haçe dos cántaras de uino tasado en seis reales.

Más vna bota que haçe media azumbre tasada en un real. /

Más vn restrillo bueno tasado en siete reales. /

Más una cazeta de yerro buena tasada en un real. /

Más dos talegas buenas de binbre blanca tasadas en tres reales. /

Más otra talega negra buena en un real. /

Más una olla çamorana con cosa de quatro libras de manteca de /

lechón que tiene dentro tasada en siete reales. /

Más vna xarra de Talabera fina con el pie quebrado y un barril de /

barro colorado tasado en un real y medio. /

Más una botixa melada que ará dos libras de aceyte tasada en /

un real. /

Más vn pandero de tañer en dos reales. /

Más vna sartén de yerro buena tasada en quatro reales. /

Más otra sartén más pequeña buena en tres reales. /

(Fol. 306v.) Más vn pedaço de yerro en barras tasado en çinquenta y tres reales. /

Más vnos çuecos buenos tasados en ocho reales. I

Más vna caldera de cobre mediana buena tasada en beynte y dos /

reales. I

Más otra caldera de cobre mediana con aguxero en el ondo ta-/

sada en beynte reales./

Más otra caldera de cobre pequeña tasada en nuebe reales. /

Más cuatro piñeras usadas tasadas en seis reales. / 
Más dos hormas de haçer adobes en vn real. /

Más vn argadillo con su pie tasado en vn real digo en dos. /

Más vna pala de horno a medio serbir en vn real. /

Más vn haçadón çespedero biexo tasado en tres reales. /

Más dos haçadas de cabar biñas buenas en diez reales. /

Más vn banco de quatro pies de un madero de peral en vn /

real. I

Más vna mesa pequeña de castaño tasada en cinco reales. /

Más vnos manteles de torzillos husados tasados en quatro reales. /

Más un cazo de cobre usado tasado en quatro reales. I

Más cincuenta manizos de lino a dos reales cada uno. /

Más vna çerradura con su llabe pasada buena tasada en ocho / reales. I

Más vna cobertera de yerro buena en tres reales. /

Más vna sierra de mano pequeña tasada en cuatro reales. /

Más vna espada biexa tasada en tres reales. /

Más vna mascarilla de alambre buena tasada en qua-/

tro reales. I

Más seis heminas de linaza a ocho reales cada una. /

Más vn banquito pequeño de quatro pies en quatro quartos. /

Más vn poste de negrillo de dos baras de largo en tres reales. /

Más dos palas esterqueras biexas con cinco [...] tasa-/

das en doçe quartos. I

Más vn timón nuebo de bedul tasado en dos reales. I

Más vna masera buena tasada en beynte y quatro reales. /

Más vn yugo con sus melenas y una cornal en seis reales. /

Más vnos esquilones buenos con collares de perro en ocho reales. /

Más dos xarricos de barro colorado en çinco quartos. /

Más se tasó tres talegas pequeñas de tapiar en doçe quartos. /

Más vn cubeto que hará doçe cántaras bueno tasado en beynte /

reales. I

Más otro cubeto de siete cántaras tasado en seis reales. /

Otro cubetico biexo que hará çinco cántaras tasado en dos reales. /

Más otro cubeto que hará catorçe cántaras tasado en ca- /

torçe reales. I

Más vna cubeta nueba que hará treynta y dos cántaras poco /

más o menos tasada en sesenta y seis reales. /

Más vn peso de garfios bueno sin pesas tasado en doçe reales. I

Más vna olla grande de barro çamorano tasada en dos reales. /

(Fol. 307r.) Yten más otra olla çamorana más pequeña tasada en / vn real. /

Más vn barreñón pegado con pez de barro colorado en vn /

real. I

Más vn banco de palero en quatro cuartos. /

Más cuatro cañiços buenos en tres reales. /

Más vna masera biexa tasada en quatro reales. /

Más vna arroba de lana negra tasada en beynte y quatro /

reales. I

Más dos arrobas de lana blanca tasadas en beynte digo / 
en treynta y dos reales. /

Más arroba y media de añinos negros y blancos tasados en treynta y seis reales. /

Más vna pila de piedra de grano grande en doçe reales. /

Más vna cuba que hará sesenta cántaras tasada en /

sesenta reales. /

Más vna cinta de bimbre en dos reales. /

Más diez talegones buenos tasados en beynte reales. /

Más vn torno de torçer ylo con su pie en quatro reales. /

Más dos carros de estacas en treynta y tres reales. /

Más vn rodezno de molino pequeño tasado en doçe reales. /

Más cuarenta cántaras de vino tasadas a quatro reales /

la cántara que son çiento y cuarenta reales. I

Más seis pelexos de obexas y carneros en seis reales. /

Más vn braço biexo de negrillo sin barafuneras tasa-/

do en ocho reales. I

Más tres bigas de álamo tasadas en diez reales. /

Más ocho pesebreras de palero en quatro reales. /

Más unas brigancias de yerro medianas en nuebe reales. /

Más vna saca de lana blanca tasada en catorçe ducados. /

Más diez y seis gallinas y un gallo tasadas en treynta y tres reales. /

Más cuatro patas y un pato anexas tasadas en quinçe reales. /

Más diez y siete colmenas de pared, a dos ducados cada una. /

Más doçe libras de çera a medio ducado cada una. /

Más çinco azumbres de miel a seis reales la azumbre. /

Más dos montones de yerba a quinçe reales cada montón. /

Más vna gadaña biexa de segar en quatro reales. /

Más dos platos de Talabera fina tasados en dos reales. /

Más vna olla grande de barro çamorano en tres reales. /

Más otras dos ollas más pequeñas tasadas en tres reales. /

Más otra olla mediana tanbién çamorana en un real. /

Más tres fuentes de medio baño tasadas en tres reales. /

Más dos talegas blancas buenas en dos reales. /

Más çinco hoçes de segar buenas en siete reales. /

(Fol. 307v.) Más una clabera de once garabatos tasada en dos reales. /

Más siete platos de medio baño a dos quartos cada uno. /

Más ocho platos de medio baño buenos en tres reales y medio. /

Más nuebe baras de lienzo a dos reales cada una. /

Más vna emina biexa con su rasero en dos reales. /

Más tres palas esterqueras nuebas en tres reales. /

Más ocho tornaderas pequeñas en tres reales. /

Más ocho bildos en otros tres reales. /

Más dos hoçes buenas tasadas en tres reales. /

Más dos doçenas de latas de humero en dos reales. /

Más tres manos de derripar en dos reales. /

Más tres tiraderos con sus yerros buenos en quatro reales /

y medio. /

Más vn carro bueno con sus armaduras y berbixones /

tasado en seis ducados. / 
Más dos trillos biexos a seis reales cada uno. /

Más unas costanas esterqueras en un real. /

Más unas sogas de meter paxa en dos reales biexas. /

Más vna emina con su rasero herrada buena tasada en /

diez y seis reales. I

Más dos labancas y un labanco tasados en seis reales.

Más vna fragua con su yunque fuelles, [...] y todos los /

demás aparexos en tresçientos y treynta y tres reales. /

Más otra cuba de setenta cántaras tasada en siete ducados. /

Más vn restrillo bueno tasado en ocho reales. /

Más dos mantas nuebas por pisar tasadas en quarenta /

y dos reales. /

Más zinquenta tablas de álamo en setenta y cinco reales. /

Más vna rastra y una bilda de bildar paxa en dos reales. /

Más vn cazo de azófar pequeño en tres reales. /

Más una masera biexa tasada en doçe reales. /

Vn cazo de cobre biexo en dos reales. /

Más vna tabla redonda con unos garfios en catorçe /

cuartos y medio. I

Más vn caxoncico de madera pequeño tasado en dos reales. /

Vn cubetico biexo en dos reales. I

Más vna mesa con un caxón tasada en seis reales. /

Más vna horona grande que hará dos cargas tasada /

en catorçe reales. /

(Fol. 308r.) Más una rodadera del dicho Roque Martínez que/

se tasó en zinco reales./

Más una azuela viexa de martillo que se tasó en /

treçe reales. I

Más unos mediales de tapiar con sus aparexos que se ta- / saron en doçe reales. /

Más unas puertas de tapiar con sus aparexos a medio /

servir que se tasaron en veynte y cuatro reales. /

Yten más una arca panera grande que ará seis arcas de pan / que se tasó en beynte y dos reales. /

Más un rastrillo biexo que se tasó en quatro reales. /

Más dos çerandas usadas que se tasaron anbas en tres reales. I

Más tres cribos buenos que se tasaron en seis reales. /

Más dos perniles de tozino salado en [...] y secos que /

pesarían beynte y seis libras poco más o menos y los ta- /

saron en cuarenta reales. I

Más diez y ocho libras de lana ylada la mitad blanca /

y la otra mitad negra que se tasaron en cuarenta reales. /

Más una hoxa de sierra grande buena que tiene una yun-/

ta quebrada que se tasó en quatro reales. /

Más dos canbas y un dentudo nuebos en tres reales. /

Más una pesebrera de palero en real y medio. /

Más un caldero de yerro tasado en ocho reales. /

Yten más declararon que tenía dicho Roque Martínez cier-/

tas prendas enpeñadas en su poder en cantidad de / 
[....] cantidad dixo ser lo siguiente./

Una saya de paño berde de Domingo becino del lugar de /

Fresno en sesenta y dos reales. /

Más otra saya berde buena de [...] becino de Fresno en /

prezio de sesenta y seis reales. I

Más una mantilla de contray de [...] de Valdería /

enpeñada en diez y ocho reales. I

Más una tablilla de plata y una sábana de tres lienzos [...]

(Fol. 308v.) pañico de manos que todo es de Pedro Parrado y que está /

enpeñado en quarenta y dos reales. /

Más un paño de manos que dixo ser de Mariana Gon-/

çález muger de Andrés Çapatero bezino de Altobar y está en- $/$

peñado en dos reales. I

Los quales dichas prendas dixeron estar enpeñadas en poder del susodicho /

por la dicha cantidad. /

Más es declaración que la dicha Beatriz de Figueruela deuía /

al dicho Roque Martínez treynta y tres reales en dinero que le auía /

prestado antes que con él se casase. /

Más declararon que deuía la susodicha Beatriz de Figueruela al /

dicho Roque Martínez veynte y tres eminas de trigo que le /

avía prestado a ella estando biuda y ella lo confesó ansí. /

Yten más declararon que de la sementera que tenía hecha /

el dicho Roque Martínez quando casó con la dicha Beatriz de /

Figueruela se coxió este berano deste año de quarenta /

y zinco quarenta y ocho cargas y media de trigo orras de /

diezmo; y doçe cargas y nuebe heminas de zenteno orras /

de diezmo.

Yde zebada coxió diez y nueve cargas menos una emina /

orras de diezmo /

Yten más pusieron por ynbentario onçe cargas de trigo /

anexo que tiene el dicho Roque Martínez el día de oy /

y otras onçe cargas que se cobraron ese verano que las te-/

nía prestadas. /

Y más declararon tener el dicho Roque Martínez tres car-/

gas de zenteno anexo y nuebe heminas de zebada a-/

nexa en ser. /

Yten declararon que quando se casaron los dichos Roque /

Martínez y su muger, que fue por el mes de março des-/

te dicho año, desde entonçes acá, demás de el pan que /

dicho es, se gastó diez cargas de trigo en grano del dicho Ro-/

que Martínez y que se molió para el sustento de ellos y de sus /

yxos y criados; y más declararron aber bendido /

desde que se casaron asta oy diez cargas de zebada /

de la que el dicho Roque Martínez tenía quando se casa-/

ron, demás de la que ya ba ynbentariada y que se /

auía bendido para el sustento de la casa. /

(Fol. 309r.) Yten más declararon que al dicho Roque Martínez le están deuien-/ do el día de oy diez cargas y ocho heminas de trigo que había prestado / 
antes de que se casase con la susodicha lo qual deuían las personas siguientes / Santos Parrado bezino de Comonte carga y media de trigo, Jussepe Hidalgo y / más el dicho Santos Parrado y los erederos de Juan Asensio por otra parte / zinco cargas de trigo por obligación ante mí, el pressente escriuano; y Jorxe Martínez, / bezino del dicho lugar, deue ocho eminas de trigo de resto de una obligaçión / de mayor quantía, Francisco Gonçález Moço ocho meninas, Francisca González, / biuda, media carga de trigo, Bartolomé Alonso Ferrero de Rabalde diez / cargas y quatro heminas. I

Y más se declararon que de esto se ha de rebaxar las rentas y fueros y de-/ pósitos que tiene en su poder dicho Roque Martínez y deuió pa- / gar la coxeta deste año dicho que es lo siguiente: /

A la yglesia deue nueve cargas y diez eminas de trigo que en él están depositadas / de renta de palaçio; pagó de su parte tres cargas y siete eminas / de pan mediado trigo y zenteno. I

A don Juan de Uilla Gutiérrez, capellán de la capilla de don Rodrigo, le pagó / quinze eminas de zenteno y una fanega de trigo y dos eminas de zevada / por el fuero deste año que, aunque deuía más, lo demás se descontó por / auerlo pagado antemano para el susidio de mayo de dicha capilla. / Más pago Dña Francisca de Aguilar, biuda de Francisco de Aguilar, bezina de / La Banieza, media carga de trigo y otra media de çebada que deuía de / renta deste año. /

Y más pago a los frayles de Nogales seis eminas y un zelemín de trigo y qua-/ tro eminas de zevada y quatro eminas de zenteno de fuero deste año. /

Y más pago a Diego Ramos bezino de Redelga quatro eminas de ze-/ bada del caballaxe de una yegua. /

Todo lo qual declaro auerse de baxar de dicha sementera por auerlo pagado / todo ezepto las nueue cargas y diez eminas de trigo que debe / a la dich $a$ iglesia como dicho es. I Y más declararon que al dicho Roque Martínez le estaban deuiendo el día / de oy mucha cantidad de dinero que dixeron ser lo siguiente: / El concexo del dicho lugar le deue beynte y zinco ducados poco más / o menos porque para el alcançe que le yzo en las quentas que le / tomaron ante mí el escriuano no le an pagado más de diez eminas de trigo / a la tasa y ansí se le deue lo dicho. I

Yten más declararon que Bartolomé Garzía bezino de dicho lugar le / deuía al dicho Roque Martínez ocho ducados en dinero de un conçierto / dexazión de unas tierras de apréstamo. /

(Fol. 309v.) Más declararon que el dicho Bartolomé le deuía al dicho / Roque Martínez veynte y quatro ducados por una obligación an-/ te mí el escriuano. /

Y se declara que al herrero y al barbero les auía pagado ante-/ mano dicho Roque Martínez. I

Yten más declararon que el dicho Roque Martínez deuía a los / erederos de Baltasar Ydalgo, el uiexo, vezino que /

fue de Comonte quinze eminas de pan terziado trigo, zen-/ teno y zebada, y esto de a de baxar. /

Todos los quales dichos uienes y ha- /

cienda en este ynventario contenidos y de-/

clarados, que está escrito en ocho foxas de papel de sello quarto, / 
con esta en que esto se se escriue, confesó la dicha Beatriz de Figueruela ser propios del dicho Roque Martínez, su marido, y auerlos lleuado / él al matrimonio quando con él se casó. Y ella y él dixeron / y declararon ser cierto y berdadero el dicho ynuentario con / las declaraciones y adbertencias de deudas y otras cosas que / en él se hace minción y que, como tal, querían que se le diesse fee y / crédito en xuicio y fuera dél para que ualga por tal.

Y los dichos /

Pedro Martínez y Bartolomé López, tasadores e ynuentariadores / declararon auer fecho uien y fielmente / la tasación y ebaluación de todos los dichos uienes / en este dicho ynuentario contenidos, a lo que /

Dios nuestro señor les dio a entender y sus juy-/ cios y entendimientos auían alcançado y que en / ello no auía auido fraude, parcialidad, amistad ni enemis-/ tad ni en pro ni en contra de ninguna de las partes.

Y an-l

sí lo declararon y le dieron por bueno y bien fecho. /

Y no lo firmaron porque dixeron no sauer. /

Siendo testigos a ello presentes Juan Martínez y Bartolomé García / Jusepe Hidalgo y Santos Parrado vezinos del dicho lugar y los otorgantes, / aquien yo el escriuano doy fe que conozco, lo firmó el dicho Roque Martínez y por / la dicha su mujer, que dixo no saber, lo firmo vn testigo a su ruego.

Roque Martínez (firma), Jusepe Hidalgo (firma)

Passó ante mí Martín García (firma y rúbrica) 
Título: Inventario de los bienes de Francisco Martínez y Beatriz Escudero, de los que cada uno trajo al matrimonio.

Tipo: inédito

Carácter: particular

Procedencia: Archivo Histórico Provincial de León

Signatura Caja 7029, 385

Folios: $145-150$

Año: 1643

Lugar: La Bañeza

Provincia: León

País: España

(Fol. 145r.) Ynbentario de los bienes de Francisco /

Martínez y Beatriz Escudero, su muger, /

de los que cada vno trajo al matrimonio. /

En la billa de La Banieza, a veynte y quatro días /

del mes de março de mill y seiscientos y quarenta y tres años, en /

presencia y por ante mí Diego de Castillo de la Concha, scribano /

del número y ayuntamiento desta dicha billa, y testigos, /

parezieron Francisco Martínez de la Bega y Beatriz de Escudero, /

su muger, vecinos de la dicha villa y dijeron que, por quanto /

ellos se an cassado y belado en faz de la santa madre yglesia, /

y porque anbos dos tienen hijos de otros matrimonios, para /

que en todo tienpo aya quenta y raçón de los bienes que cada /

vno trajo al matrimonio, para lo qual quieren azer yn-/

bentario y tassación jurídica dello y, para el dicho efecto, anbos /

a dos, a vna conformidad, nonbraron por ynbentariador /

y tassador dellos a Pedro de Vrueña, vezino desta billa, el qual, /

estando pressente, lo açeptó y juró a Dios y vna cruz en forma de açer-/

lo vien y fielmente a lo que Dios le diere a entender y, /

en esta conformidad, se enpeçó a azer el ynbentario de los /

vienes que traxo la dicha Beatriz de Escudero en la manera siguiente: /

Primeramente...

(Fol. 145v.) Yten se tassó otro quadro digo dos pequeñicos en /

doze reales. I

Yten se tasaron otros tres quadros pequeños en /

doçe reales. I

Yten se tassó vna echura del Niño Jesús con su peana /

en çinquenta reales. /

Yten se tassó un escritorico pequeños con vn velador /

en que está en quarenta reales. /

Yten vn banco de nogal en doze reales. /

Yten se tasó vn arca vieja sin zerradura en /

seis reales. I

Yten se tassó un escaño de álamo en diez y seis reales. /

Yten vn aparador viejo de nogal tassado en /

treinta reales. I

Yten vn bufetico con sus caxones tassado en /

veynte reales. I

Yten vnos morrillos de yerro con sus tenaçes en / 
treynta reales. /

Yten se tassó vn cofre encorado bueno en seis / ducados. I

Yten vna cama entera de nogal con pasamanos y / cielo de lienço con sus fluecos tassada en zien reales. / Yten vna colcha de lienço colchada tassada / en diez ducados. I

Yten seis mantas fraçadas vssadas tassadas en / nuebe ducados. I

Yten tres colchones vssados tasados en ochenta reales. / Yten diez sábanas las quatro de lienço y las seis de / estopa tasadas en doze ducados. I

Yten vn brasero con sus caja en treynta reales. / Yten vn calentador biejo en doce reales. /

Yten vn quadro de la Anunciación tassado en / diez y seis reales. I

Yten vn quadro de San Antonio en diez y seis reales. / Yten vn quadro pequeño del Descendimiento de la Cruz / en seis ducados. I

Vna ymagen de Nuestra Señora cuya echura se tassó en / mill marabedís. /

(Fol. 146r.) Yten vna caldera vieja en seis reales. / Yten seis cabezales de pabilos en quarentayocho / reales. I

Yten vna caldera grande sin assa en diez y seis / reales. I

Yten vn tapete verde con su flueco ussado tasado / en tres ducados. I

Yten se tassó vna alonbra en çinco ducados. /

Yten quatro tapices muy viejos tassados digo que / no se tasan por no baler nada. /

Yten vn almirez con su mano grande que se tasó en / tres ducados. I

Yten dos cazos pequeños vno de azófar y el otro de / cobre en diez reales. I

Yten catorze baras de serbilletas en veinte y ocho reales. I

Yten tres tablas de manteles de gusanillo vssadas en / tres ducados. I

Yten ciento y treynta y nuebe reales en dinero. /

Por manera que suma y monta todos /

los vienes contenidos y declarados en este /

ynbentario duzientas y /

diez mill treszientos y tre-/

ynta y ocho marabedís como /

de las dichas partidas atrás /

contenidas consta según /

iban tassadas y apreciadas /

por el dicho Pedro de Vrueña /

tassador nonbrado por an- $/$ 
bas partes y todos los vie-/

nes contenidos y declarados en /

este dicho ynbentario con fessó /

de dicho Francisco Martínez los /

tenía la dicha Beatriz Escudero su mu-/

ger y que están en su poder y en /

la forma que ba declarada se fe-/

nezió y acabó el dicho ynbentario de los /

bienes de la dicha Beatriz Escudero y se-/

pezó a azer el del dicho Francisco Martínez /

en la forma y manera siguiente: /

(Fol. 146v.) Luego yncontinenti en la dicha billa dichos /

día, mes y año el dicho Pedro de Vrueña tasa el susodicho /

en birtud de dicho nombramiento y pasa a ler el ynbentario /

de los vienes que tassó el dicho Francisco Martínez lo fue /

aziendo en la forma y manera siguiente.

Primeramente ducientos y quarenta y quatro /

reales en dinero de contado que le pagó Juan de /

Aguilar vezino desta villa por otros tantos que /

le avía prestado en la ciudad de Balladolid /

Yten cien reales que le pagó Pedro de Vrueña /

tasador por tantos que le abía prestado /

Yten veynte reales que cobró de Gaspar de Luna /

vezino desta villa que le abía prestado. I

Yten siete cientos reales que cobró de Manuel /

García vecino desta billa por tantos que le abía /

prestado. I

Yten mill y ochocientos y ochenta y tres reales /

que cobró del presente escribano por abérselos presta-/

do en Balladolid. /

Yten seiscientos y veinte y seis reales que cobró de /

Mateo Fernández vezino desta billa por abér-/

selos prestado. I

Yten tres mill duzientos y honçe reales que le debe /

el dicho Mateo Fernández mercader por çédula fir-/

mada de su nonbre de vnos [...] que le abía /

bendido. I

Yten sesenta y quatro reales que cobró del licen-/

çiado Bustos médico desta villa por abérselos prestado. /

Yten seis sillas de respaldar negras de baqueta /

de moscobia nuebas en trescientos reales. /

Yten cuatro [...] de esparto tassados en catorce /

reales. I

Yten ducientos y setenta y cinco reales que le en-/ tregó en dineros Mateo Fernández y mercader des-/

ta villa por tantos que se abrá prestado./

Yten diez y nuebe pieças de damasquillos finos de /

tornay anchos con veynte y siete baras cada pieça /

que açen quinientas y treçe baras a honze reales / 
la bara que montan cinco mill seiscientos y quarenta / y tres reales. I

Yten cinco piezas de catalufa fina dobles que tienen / a treinta y tres baras cada pieza y catorçe baras en un pedaço a- I çen todas ciento y setenta y nuebe baras que se tassan /

(Fol. 147r.) a doze reales cada bara que montan dos mill / ciento y quarenta y ocho reales. / Yten tres dozenas y media de pares de medias / de Ynglaterra tasadas a quinze reales cada par / que azen seiscientos y treynta reales. /

Yten setenta y dos gruessos de botones de seda / entorchados negros y colores a cinco reales / y medio la gruessa montan trescientos y nobenta / y seis reales. I

Yten cinco dozenas de belduques a quatro reales / y medio la pieza de los entreanchos montan / ducientos y setenta reales. I

Yten dos dozenas de belduques finos anchos / de la calidad de los de arriba a zinco reales / y medio la pieza que montan ziento y treinta / y dos reales. I

Yten vn escaño grande de nogal con barras de / yerro tassado en veinte y quatro reales. /

Yten seis piezas de berlinbaos de lana con / treynta y tres baras cada pieza que son ciento / y nobenta y ocho baras tassado a seis reales / y medio que montan mill y duzientos y / ochenta reales y medio. I

Yten en otra pieça vn pedaço de ber-/ linbao de treynta y quatro baras en la dicha pieza / y pedaço a seis reales la bara que monta / duzientos y quatro reales. I

Yten dos piezas de catalufas de ylo y lana / de colores con veinte y cinco baras cada pieza / tasado a siete reales la bara que monta trezientos / y cinquenta reales. /

Yten ocho piezas de pasamanos de Santa Yssa-/ bel negros y colores con mill sietecientos / y ocho baras tasadosa veinte marabedís cada bara / que monta mill y seis reales. I

Yten otra pieça de pasamanos de pesso real-/ çados negros y de color con doze honzas y media / a cinco reales la honza tasado que monta se-/ senta y dos reales y medio. I

Yten sesenta baras de angeos a dos reales y medio / la bara que monta a ciento y cinquenta reales. / Yten vn candado grande herrado tassado con / su llabe en diez y seis reales. I

(Fol. 147v.) Yten vna resma de papel en veynte / 
y dos reales. /

Yten quinze cajas de chocolate tassadas a tre-/ ze reales cada vna que monta ziento y /

çinco reales. I

Yten doze platos de echura de plata de estaño / fino a libra cada vno tassados a seis reales / cada vno que monta setenta y dos reales. / Yten tres fuentes grandes y dos platos me-/ dianos de dicho estaño que pessan diez y seis li-/ bras tassados a seis reales la libra que / monta nobenta y seis reales. I

Yten vnos estribos de azófar tassados en / treynta y seis reales. /

Yten vn macho color pardo con sus adreços / Tassado en ochozientos reales. /

Yten dos mantos finos con recados para / bender pieza tassado en trescientos y ocho / reales. I

Yten vn cofre grande negro encorado y ta-/ chonado tassado en quarenta y quatro reales. I Yten vnas mangas de tela fina nuebas / de honbre tassadas en sessenta reales. / Yten vna pieza de gurato negro golpeado / con setenta y cinco baras tasada a siete reales / cada bara que monta quinientos y veinte / y cinco reales. /

Yten tres piezas de picotes de seda y lana / en cordonçillo blancos y negros y leonado y ne-/ gro con ziento y ochenta y vna baras a qua-/ tro reales y tres quartillos la bara que / monta nobecientos y diez y nuebe reales y medio. I Yten se tassó veinte baras de dichos picotes en vn / pedaço a cinco reales la bara que monta zien / reales. I

Yten veynte y dos baras y media de burato ne-/ gro golpeado a siete reales la bara que monta / ciento y cinquenta y siete reales y medio. / Yten trece baras de tafetán negro a cinco reales / y medio bara monta setenta y un real y medio. /

(Fol. 148 r.) Yten se tassó siete piezas de zintas de plata / y seda con decientas baras a real cada bara / que monta duzientos reales. I

Yten nuebe pares de medias de seda de muger ojete-/ adas de colores tassadas a treynta y dos reales / cada par monta duzientos y ochenta y ocho / reales. I

Yten vn jarro y salero y un salpimentero / y un azucarero y quatro cuchares todo / de plata que pessó cinquenta y siete onzas y / 
de echuras y premio se tassó todo en seis cientos /

y quarenta y quatro reales. I

Yten vn escritorio guarnezido de marfil /

mediano con otro escritorio de nogal por pie ta-/

ssados en duzientos reales. /

Yten vn calentador nuevo de cobre con una /

canpanilla de bronze tasado en veinte y ocho reales. I

Yten treynta y quatro libras de azafrán ta- $/$

ssado a zinquenta reales la libra que monta mill /

y sietecientos reales. /

Yten dos pieças de cordonzillos de lana blan-/

cos y negros de Valladolid con ziento y quarenta /

$\mathrm{y}$ tres baras a tres reales la bara que monta quatro /

cientos y veinte y nuebe reales. /

Yten dos piezas de dichos picotes lissos con lienzo /

y setenta y una baras tassados a dos reales y me-/

dio cada bara que monta cuatrocientos y veinte /

y siete reales y medio. /

Yten veinte y seis pares de calzetas de ylo de paño /

torillo tassados a quatro reales cada par que monta /

ciento y quatro reales. I

Yten seiscientos y veinte reales en dineros que /

cobró. I

Yten vn ferreruelo de gurato tasado en ve-/

ynte reales. /

Yten vn manto de gurate echo nuebo tassado /

en ochenta y ocho reales. /

Yten vn bestido de hombre de bayeta con /

ferreruelo todo con pestaña de rasso tassado /

en duzientos y tres reales. /

(Fol. 148v.) Yten dos pares de medias de seda negras de honbre /

tassadas a quarenta reales que monta /

ochenta reales. I

Yten dos pares de ligas en zinquenta y dos reales. /

Yten vn bestido de tafetán doble con fe-/

rreruelo de gurato aforrado en bayeta y guar-/

nezido de esparragón tasado en trescientos /

y quarenta y ocho reales. I

Yten vn calçón y ropilla de terciopelo /

fondo en riza con mangas sueltas tasado /

en quatrocientos y sesenta y dos reales. /

Yten vn sombrero y toquilla nueba en /

veinte y dos reales. I

Yten dos golillas vna de tela y otra de ter-/

ciopelo tassadas en veinte y seis reales. /

Yten quatro adereços de balonas de honbre ta-/

ssados en veinte y quatro reales. I

Yten vn adereço de espada y daga en zinquenta /

reales. I 
Yten un jubón de tela de oro fina tassado / en ziento y setenta y quatro reales. I

Yten vnas mangas de damasco negro en zin-/ quenta y tres reales. /

Yten dos pares de zapatos en veinte reales. /

Yten vn par de chapines y colonia seis reales. /

Otro par de chapines con hevillas de plata en /

sesenta y vn reales. I

Y sendos pares de zapatos con colonias en /

diez y ocho reales. /

Dos pares de medias finas de Ynglaterra en /

treynta y seis reales. /

Y sendos pares de calzetas finas de ylo tasadas /

en diez y seis reales. /

Yten vn par de ligas en ocho reales. /

Yten quatro tocas con puntas tasadas en /

quarenta y tres reales. I

Yten tres papeles de alfileres en ocho reales. I

Yten dos piezas de de zintas de seda en treynta /

y dos reales. I

Yten tres pares de guantes en doze reales. /

(Fol. 149 r.) Yten dos rosarios el vno de coral fino / gordo tasados en ziento y treynta reales. /

Yten otros quatro tocados treynta reales. /

Yten tres balonas de puntas grandes tasa- $/$

das en quarenta y seis reales. I

Yten vna estopilla fyna en /

veinte y dos reales. I

Yten vna nuz de San Francisco y Santa Te-/

ressa çerco de azero en veynte y quatro /

reales. I

Yten otra echura de Santa Teresa en caja de /

hébano y cerco de oro en veinte y seis reales. /

Yten quatro sortijas de oro y vna [...] de /

oro y una cruz de oro con piedras que pessó tre-/

cientos y sesenta y cinco reales con echu-/

ras y premio se tassó en quatroçientos y /

nobenta y seis reales. I

De vna esmeralda treynta reales. /

Yten vn tafetán berde de tres quartas /

con rapaçejos de oro en ocho reales. /

Yten quatro abanicos finos en veynte /

y quatro reales. /

Yten vn ábito de estameña entero tassado /

en çiento y cinquenta y un reales. I

Vn faldellín de damasco azul con nuebe /

guarniziones de oro fino tasado en quinientos /

y diez reales. I

Yten vn paño de manos con puntas y ca-/ 
denetas en treynta reales. /

Yten otro paño nuevo labrado y bordado de /

colores en zinquenta reales. /

Yten otro paño labrado con puntas blancas /

y de color tassado en treynta reales. /

Otro paño nuevo con puntas blancas /

en veinte y quatro reales. I

Yten otro paño con puntas blancas y labrado /

las cabezeras tassado en veinte y quatro reales. /

Yten vna caja de siete cuchillos de Palermo /

tasados en diez y ocho reales. I

Cinco pares de tijeras de Ledesma las qua-/

tro de despabilar y tres pares de yerros todo /

tasado en veinte y quatro reales. /

(Fol. 149 v.) Yten vn paño frutero de quadros tasado /

en doçe reales. /

Yten otro paño de bara y quarta con puntas /

tassado en doçe reales. /

Más vn arca grande con su llabe tasada en /

diez y ocho reales. /

Yten vna pintura de Nuestro Señor /

con la cruz a questas en veinte y quatro reales. I

Yten vna escopeta de çinco palmos ta-/

ssada en duzientos reales. I

Yten vn espexo con marco dorado y la-/

brado tasado en çinquenta reales. I

Yten veinte y quatro libras de azúcar a quatro /

reales la libra monta nobenta y seis reales. I

Yten vna sobremesa de terçiopelo de colo-/

res con las caydas de brocatel ya forrada /

en olandilla tasada en trezientos y cinquenta /

reales. I

Más vna colcha de damasco carmesí con /

flueco de seda tassada en quatrocientos /

y cinquenta reales. /

Yten seis tafetanes listados de colgar /

con tres baras y quarta de cayda los cinco de /

a seis piernas y uno de tres azen ciento /

y siete baras y media tasados a cinco reales /

y medio cada bara monta quinientos y no-/

benta reales. I

Vnas enaguas de damasco de lana con ri-/

betón de oro fino tasado en ziento y ochen-/

ta reales. /

Yten vn jubón y ropa de damasco negro de /

seda guarneçido con passamanos de [...]/

batillo tassado en quatrocientos quarenta /

reales con botones de bronze. /

Yten otro bestido de muger, ropa, jubón y bas-/ 
quina de tafetán doble negro guarneçido de / esparragón con botones de bidrio tasado en / quatrocientos y setenta reales. /

(Fol. 150r.) Yten vn jubón y basquiña de picote de seda / guarneçido con pasamanos de Santa Yssa-l bel tasado en çiento y quarenta y ocho reales. I Yten vna ropa de damasco de lana negra / con guarnición de lo mesmo tassado en noben-/ ta y quatro reales. I

Yten vnas enaguas y justillo de Cataluña / de algodón de colores fina con guarniçión / de oro fino tassado en trezientos y quarenta / reales. I

Yten vn manto fino de Sebilla con recados / y echura en ciento y sessenta reales. /

Vn reboçiño negro de bayeta negra tasada / en honze reales. /

Vnas enaguas de bayeta con galón tasada / en cinquenta y cinco reales. /

Yten vn reboziño con tres pasamanos de oro / fino terciopelo lisso negro aforrado con / tafetán en duzientos y nobenta y seis reales. / Por manera que suman y montan todos los / vienes contenidos en este dicho ynbentario con-/ forme a la tasación que ba fecha treynta / y cinco mill duzientos y nobenta y nuebe reales / como consta de las partidas de atrás con lo / qual se fenezió y acabó el dicho ynbentario / y se declara que además de los vienes que / aquí ban puestos el dicho Fran-/ cisco Martínez tiene más cantidad en la ziudad de / Balladolid donde residía que por no los tener en esta / villa no se pueden tasar ni ynbentariar por / lo qual la dicha Beatriz Escudero consiente que el dicho / Pedro de Vrueña baya a la dicha ziudad de Balladolid en / su nombre y los tasse, bea y ponga por ynbentario / que desde luego de su parte lo consiente y todos los / vienes que aquí ban puestos confiessa que el dicho Fran-/ cisco Martínez los a traydo a su poder y ansí lo / otorgaron según ba dicho y lo firmaron el dicho / Pedro de Vrueña ansí mismo lo firmó sien-/ do a todo ello testigos Antonio García maestro / de niños desta dicha villa y Alonso de /

(Fol. 150 v.) [...] y Andrés Bázquez vezino del / lugar de Priaranza y estante en / esta villa y los otorgantes que yo el / escribano doy fé conozco lo firmaron / ba emendado pan balga / 
Francisco Martínez (rúbrica), Pedro de Vrueña (rúbrica), Beatriz Escudero (rúbrica) 


\section{Título: Obligación de pago de Francisco de Navia}

Tipo: inédito

Carácter: particular

Procedencia: Archivo Histórico Provincial de León

Signatura: Caja 7353, 1251

Folios: 201-203

Año: 1712

Lugar: La Bañeza

Provincia: León

País: España

(Fol. 201v.) La Bañeza, julio catorze de mil setezientos y doze años.

Digo yo Francisco de Navia vezino desta villa, que me obligo por este papel de pa-/ gar a Manuel de Prado vecino deella, duszientos y veinte reales, en dos pagas /

por metad la primera para el día de San Juan de Navidad, que vienes des-/ te presente año y la otra para el día de San Juan de Junio del año de / setezientos y treze en la qual cantidad me arrendó dicho Manuel de Pra-/ do una casa que tiene en la calle de La madera y se advierte que / dicho Manuel de Prado no sea obligado a repararla cosa alguna y que si / la demoliese antes del día de San Juan de Junio, se aya de rebajar / la porrata de los días que faltasen asta este día y no los días que entre / en ella después del $\mathrm{S}$. Juan de setezientos y doze y a las dichas pagas se obliga Matías Cauezón vecino desta villa como mi fiador el qual lo / firmo y firmé en dicha villa = Francisco Fernández de Navia.

\section{Mathias Cabezón (rúbrica)}

Reziuí lo que contiene este papel de mano de la escriba/ nía de arguillo y lo firmé en La Bañeza y octubre 16 días.

Manuel de Prado (rúbrica)

(Fol. 202r.) Primeramente de las alajas, dinero y otras cosas que / boy gastando con mi hijo Francisco Fernández de Nauia / a quenta de las lexítimas paterna y materna auiendo / quedado de hedad de nuebe años quando mu-I rió su padre es como se sigue /

Lo primero e gastado con dicho mi hijo Francisco des-/ de la muerte de dicho su padre asta que se casó / de hedad de veinte y zinco años es escuela, bestir y / calzar, curazión de enfermedades, alimen-/ tos y enseñanza de ofizio quatrozientos / ducados y aun quedó corta / y quando se casó le di lo siguiente Lo primero la madera de una cama con sus cor- $/$ deles en nuebe reales. I Vn jergón en veinte reales. / Vn colchón en zinquenta reales. / Dos sáuanas de lienzo nuebas en ochenta reales. / Vn cobertor y una manta en treinta reales. / 
Vna colcha en veinte reales. I

Otra colcha de color en veinte reales. /

Dos almoadas con lana en doze reales. I

Quatro taburetes de madera en veinte y quatro reales. I

Vna arca mediana en doze reales. /

Vna mesa de goznes en doze reales. I

Una mesa nueba en seis reales. /

Vn banco largo en treze reales. I

Vn cazo de azófar en seis reales. I

Vna sartén y un asador en ocho reales. I

Vn cazo pequeño y una cuchar en seis reales. /

(Fol. 202v.) Vn asador en diez reales. /

Vna fanega de zeuada en nuebe reales. I

Vn millar de clauo de zapato en seis reales. I

Medio millar de clauo de a o chavo en doze reales. I

Medio millar de clauo de errar en diez reales. /

Una @ de pez en zinco reales. I

Media @ de almagre en un real. /

Vn peso de balanzas y dos libras en pesas en doze reales. /

Medio ziento de baras y una dozena de sogas en seis reales. I

Medio ziento de clauo de media naranja en diez reales. I

Medio ziento de clauo de escañil en siete reales. I

Medio millar de tachuelas en tres reales. /

Ocho palas de yerro en treinta y dos reales. I

Más otra arca nueba en diez reales. I

Más otra sáuana de lienzo delgado en qua-/

renta reales. I

Quatro tablas de manteles y doze seruilletas /

en ochenta reales. /

Treinta baras de lienzo a quatro reales. /

Más duzientos y veinte reales que pagué a Manuel /

de Prado de la renta de la casa en que bibió /

vn año. /

Más de siete años que le tube en mi casa des-/

pués de casado que no hizo bida con su mu-/

jer, de comida, bestido y demás gastos /

que tubo, azen quarenta ducados cada año /

en quatro años que crie a su hijo Lucas desde que /

nazió asta que murió con amas y demás /

(Fol. 203r.) gastos de alimentos, curazión de la enferme-/

dad que murió y entierro a duzientos reales cada /

año. I

De los gastos del entierro de dicho Franzisco mi hijo /

que fue doble, y misas y áuito treszientos reales y /

aún gasté más./

Que todo ymporta diez mill doscientos y sesen-/

ta i un reales de vellón salboyerro; y de ser así y /

aún quedo corta, en caso necesario los ju-/ 
ro a Dios y una cruz y no lo firmo por no / sauer. / 


\section{Título: Inventario de los bienes de Don Alonso Ramírez}

Tipo: inédito

Carácter: particular

Procedencia: Archivo Histórico Provincial de León

Signatura Caja 7370, 1471

Folios: 132-139

Año: 1734

Lugar: Laguna de Negrillos

Provincia: León

País: España

(Fol. 132r.) En la villa de Laguna de Negrillos a doze días del mes de Abrill de mill/ setezientos y treinta y quatro años El señor Don Gerónimo Velázquez /

correxidor deesta villa y su jurisdizión dijo que por quanto Don Alonso Ramí-/

rez Bezino que fue della a muerto y pasado deesta pressente vida y por ha- $/$ ver dejado hijos menores y que aia quenta y razón de sus vienes para hazer im-/ ventario dellos y para hazerlo con la solegnidad que se requiere nombraba y nom-/ bró por inventariadores y tasadores dellos a Francisco Benteno y Manuel Cazón / bezinos della a quienes se les notifique lo hazeten y juren pena de apremio / y lo firmó su merced y firmé

Ladrón de Guebara (rúbrica) Gerónimo Cepeda (rúbrica)

En la dicha villa de Laguna el dicho mes y año por los dichos imbentaria-/ dores y con assitenzia de dicho señor corregidor y por ante mí el escribano pasaron / a hazer el dicho imbentario en la forma siguiente Lo primero las casas que quedaron del dicho difunto que están en la calle de Astorga/

(Fol. 132v.) Cascos de esta villa tejadas con todas las serbidumbres que les corresponden /

que lindan con casas de Tomás de Balenzia y casas de herederos de Don Bearolo-/ fredo y calles de conzejo /

Una bodega con su lagar y aparejos sin bassija con un guerto con algunos ár- $/$ voles en la misma calle que lindan con casas de Matheo Crespo y Pedro Zente-/ no vezinos della y sale a la misma calle de Astorga con sus puertas /

Y en la cozina prinzipal se hallaron los vienes siguientes. /

Lo primero un calentador mediano en ocho reales. /

Más siete cazos de açófar los seis y el uno de cobre tasado en quarenta y dos reales / todos. I

Un perol de azófar roto tasado en ocho reales. /

Más tres candeleros y una palmatoria en diez reales todos /

Zinco asadores el uno de gajos y los demás llanos en diez reales. I

Tres sartenes de ierro medianos en seis reales. /

Una caldera de azófar en ocho reales. /

Unas parrillas y dos pares de tréuedes las unas quebradas en seis reales. /

Dos chocolateras en diez reales. /

Una gubiletera con unas tijeras deespabilar todo en dos reales y medio. /

Dos candiles con sus crisuelos en dos reales. /

Una cuchar de ierro de la olla en un rial. /

Dos coberteras de ierro en dos reales. / 
Dos morrillos grandes de yerro en zinquenta reales. /

Un escaño grande que está a la lumbre en seis reales. /

Una dozena de platos y escudillas media dozena en zinco reales todos. /

Cuios vienes se hallaron en la cozina y en la sala principal los siguientes

Lo primero un escañil bueno de encaje en ocho reales. /

Una mesa de nogal pequeña en seis reales /

Un bufete de nogal pequeño con su escritorio enzima con sus nabetas en

sin llave y un San Antonio enzima del escriptorio en zinquenta reales. /

Un bufete grande con dos cajones, zerraduras y llaues tasado en sesen- /

ta y siete reales. I

Un cofre con su forro, zerradura y llabe en quinze reales. I

y en él se halló lo siguiente $=$ seis camisas del difunto buenas y usadas y /

quatro pares de calzonzillos, dos pares de armillas y tres pares de calzetas /

tasado todo en quatro ducados. /

(Fol. 133r.) Otro cofre de la misma calidad que el antezedente, zerradura y llave / y en el no se alló más que ropa de las niñas. /

Una silla bieja en quatro reales. /

Un taurete con sus tornillos en quatro reales. /

Un espejo grande bueno en quinze reales. /

Seis quadros y dos láminas digo tres láminas en doze reales todo. /

Dos cortinas azules con sus barillas de ierro en doze reales. /

Un alcabuz con su llaue en dos ducados. I

Y en la sala de más adentro se alló lo siguiente. /

Dos quadros pequeños con el marco dorados en doze ambos /

Otro quadro de San Francisco dorado en veinte y quatro reales. I

Otro quadro de San Antonio con su marco negro grande en veinte reales.

Otros dos quadros pequeños y tres láminas en ocho reales. /

Un bufetillo con su contador y un escritorio pequeño y un Niño Jesús /

enzima tasado y su dosel de lienzo pintado en sessenta reales todo. I

Quatro sillas de uaqueta viejas en doze reales todas. I

Un escañil de nogal bueno en quinze reales. I

Otros dos escañiles pequeños en ocho reales. /

Un cofrezito pequeño clabeteado en ocho reales. /

y en ellos se hallaron zintas y pañuelos de las niñas. /

Un arca de nogal con su zerradura y llaue, aldabones y visagras en zinquenta. I

Dos sábanas de lienzo buenas en veinte y quatro reales. /

Una colcha de lienzo pintada en treinta reales. /

Dos tablas de manteles usados en diez reales. /

Un zernadero de estopa en quatro reales. /

Otro cofre pequeño con su herraje en doze reales con zerradura y llaue /

y en él un capote de camellón con su forro encarnado, unos calzones de /

paño, casaca y chupa del mismo paño tasado en doszientos reales todo. I

Tres colchones con sus gergones tasado todo en ziento y cinquenta reales. /

Una colcha de lana de color azul manchega aforrada en estameña /

azul en quinze reales. I

Un cobertor de estameña azul con su fleco en treinta reales. /

Dos mantas digo quatro mantas la una de Palenzia y las tres caseras /

Un cobertor azul y otro verde usados en veinte reales ambos. /

Tres almoadas con su lana en siete reales. / 
Una cortina con su barilla de ierro en diez reales. /

Dos capas usadas la una vieja y una casaca, chupa, calzón de paño /

hordinario usado en sessenta reales. I

(Fol. 133v.) Y en el quarto que está junto a la sala de adentro un gergón y dos /

mantas la una pintada todo en veinte y quatro reales. /

Un bufete de nogal con sus balaustres en veinte reales. /

Un arca pequeña en siete reales. /

$\mathrm{Y}$ en el quarto questa en la sala principal se halló lo siguiente

Dos arcas pequeñas con sus zerraduras y llaues en quinze reales. /

Dos tauretes torniados en diez reales. /

Una cama con su colchón y gergón en zinco ducados. I

Y en el quarto donde murió el difunto se halló lo siguiente. /

Una cama con sus balaustres de nogal buena en treinta y tres reales. /

Un gergón bueno en siete ducados. I

Dos sábanas y una colcha de gusanillo en setenta reales. /

Una manta y un cobertor buenos en quarenta reales. I

Un cobertor verde en quinze reales. I

Otra cama con sus valaustres de nogal y cordeles en quinze reales. I

Un bufete de pino pequeño en seis reales. I

Una silla de tabla vieja en dos reales. I

Un arca de nogal con sus cantoneras, zerradura y llaue en veinte reales. I

Tres mantas caseras buenas en quatro ducados. I

Y en el quarto de guardar se alló lo siguiente. /

Seis pajizas biejas en siete reales. /

Un peso de garfios con onze libras de yerro en quinze. /

Unos garfios de ierro de pozo en seis reales. I

Zinco quilmas dos deestopa y tres de lana en veinte y quatro todas. /

Tres piñeras y dos zerandas en ocho reales. /

Una carga de zenteno y otra de trigo=no se le da tasazión. /

Dos marras y dos azadones y una azada en veinte reales. /

Una orca de ierro con dos dientes en tres reales. I

Media dozena de sábanas seis de lienzo y dos deestopa que son ocho en ziento /

y por ser tarde se zesó dicho ynbentario con protesta de prosegir asta su con-/

clusión y lo firmo su merced y firmé

(Fol. 134r.) En la dicha villa de Laguna a treze días del dicho mes y año dicho señor correxi-/

dor y con asistenzia de dichos ymbentariadores i por ante mí el escribano prosigió /

en el dicho ymbentario en la forma siguiente

Más tres tablas de manteles buenos y una dozena de servilletas tasa-/

do todo en sessenta reales. /

Tres arrobas de tozino y una de zezina en ocho ducados. I

Un almirez con su mano en veinte y quatro reales. /

Dos escañiles en diez reales. /

Una cuba número primero que hará trescientas y zinquenta cántaras. /

Otra número segundo que ará lo mismo. /

Otra número terzero que hará diez cántaras sin bino. /

Otra número quarto que hará zien cántaras sin bino. /

Otra número quinto sin bino que hará quinientas cántaras/ 
Otra número sexto llena de vino remostado que ará ziento y veinte cántaras. /

Otra número séptimo que ará diez cántaras sin bino. /

Otra número nobeno llena de vino tinto que ará cien cántaras. /

Otra que ará seis cántaras llena de vino blanco en el cuerpo de la bodega. /

Dos cubetos sin vino que arán sessenta cántaras digo treinta. /

Dos tinajas pequeñas de barro que arán catorze cántaras. /

Un pozal que ará seis cántaras. /

Un arco de ierro con su llave./

Una caldera grande usada $=$ otras dos calderas una bieja /

y otra mediana la grande no tiene asa ni beros tasada la grande /

en quinze reales y la otra mediana en quinze y la bieja en seis. /

Otra caldera pequeña en ocho reales. /

Una carreta buena errada en doscientos reales. /

Dos maseras buenas usadas tasadas en treinta reales. /

Otra carreta pequeña sin herrar en treinta reales. I

Una mula moína de doze años en quatrozientos reales. /

(Fol. 134v.) Una iegua color negra de diez y ocho años en ziento y veinte reales. / Una pollina color negra moína en quarenta y quatro reales. I

Más quarenta y dos cabezas de ganado obejuno las veinte y seis con cor-/

deros a treze reales y las de sin corderos a diez reales. I

Una marrana buena en quarenta reales. I

Tres cucharas de plata en quarenta y zinco reales. /

Un bufete de castaño pequeño en seis reales. /

Más treinta cargas de cestos buenos y malos y seis talegas noventa y seis /

Más como cosa de carga i media sembrada que lo que no se diese dello se pon-/

drá a continuazión. /

Unas barillas de zernir en dos reales. /

Dos negrillos pequeños en quatro reales. /

Unas gallinas y un gallo en zinco reales. /

Y por oy dicho dia se zessó en dicho ynuentario por ser tarde con protesta de / proseguirle asta su conclusión y lo firmo su merced y firme yo el escribano y /

los dichos ynventariadores no lo firmaron por no saver en la dicha villa de Laguna / a treze días del dicho mes de abril de mil setezientos y trein-/

ta y quatro años.

Ladrón de Guebara (rúbrica) Gerónimo Espada (rúbrica) 
Título: Inventario de los bienes que quedaron de D. Gerónimo Natera cura que fue de dicho lugar de Robledo.

Tipo: inédito

Carácter: particular

Procedencia: Archivo Histórico Provincial de León

Signatura Caja 7426, 1471

Folios: 60-70

Año: 1726

Lugar: Robledo de la Valduerna

Provincia: León

País: España

(Fol. 60v.) Ynbentario de los bienes que que-/

daron de D. Gerónimo Natera /

Cura que fue del lugar de Robledo.

En el lugar de Robledo jurisdicción de la villa de Palazios de /

la Balduerna a veinte y tres días del mes de Julio /

año de mil setecientos y veinte y seis su merced el Sr.licenciado Don /

Manuel Meléndez abogado de los Rs consejos, alcalde nuestro /

de dicha villa y su jurisdicción por ante mí el escribano dijo que me-/

diante $[. .$.$] le consta que D. Gerónimo de Na-l$

tera cura proprio que fue deste dicho lugar a muerto /

y pasado de esta terrestre bida a la eterna y que deste dicho /

an quedado aquellos bienes muebles y raízes para que es-/

tos se pongan en recobro y que con quenta y razón /

se entreguen a quien legítimamente los aia de auer man- $/$

daba y mandó azer este ymbentario con tasazión de to-/

dos los dichos bienes y para que se haga dicho ymbentario en/

la forma y orden, mediante allarse en este dicho lugar/

Don Thomás Velasco vezino de la villa de la Bañeza.

(Fol. 61r.) Luego incontinentemente los dichos ymbentaria-/

dores y tasadores yzieron ymbentario y tassación/

de los bienes que quedaron de dicho Don Gerónimo /

de Natera en la forma y manera siguientes. /

Primeramente, vna arca en la sala baja de nogal con /

zerradura, aldabones y cantoneras tasada /

en sesenta reales./

Vn bufete de nogal con sus trabeseros de lo /

mismo tasado en ochenta reales. I

Vn zenador de nogal tasado en doze reales. /

Vn escañil de álamo y otro de nogal tassados /

en diez y seis reales. I

Vna mesa de nogal de dos tablas en veinte reales. I

Dos uronas grandes en quinze reales. I

Seis países biejos con sus marcos en quarenta reales. I

Pasose a la sala alta y en ella se allaron diez /

quadros de diferentes ymágenes pintura de /

Balenzia con marcos cortados a diez y ocho ca-/ 
da uno que inporta ziento y ochenta. /

Vn quadro de San Antonio con su marco y en él /

quatro tarjetas doradas en sesenta./

Vna lámina de Nuestra Señora de las Angustias con /

marquito de ébano en zinquenta reales. /

La pintura del nazimiento de San Juan pequeña /

con marco negro y el filete dorado en veinte reales. /

Dos quadros el uno con la pintura de San Phelipe de/

Neri y marco dorado y el otro con la de San Bizente /

y el marco viejo en ochenta reales. I

Otro de Nuestra Señora de Belén pintura ordinaria /

en seis reales. I

(Fol. 61v.) Vn bufete forrado en baqueta en beinte reales. /

Vn scriptorio fábrica de Salamanca con el pie y /

herraje y nabetas doradas en novecientos reales. /

La echura de vn cruzifijo de marfil con la cruz /

y peana de ébano en ziento y zinquenta reales. /

Dos escaparates pequeños forrados en terziope-/

lo con diferentes echuras de zera en treinta reales. /

Vn escritorio con seis nauetas y vidrios a la fron-/

tera en quarenta reales. I

Otro con seis nauetas de concha viejo en /

zinquenta reales. /

Dos bufetillos forrados en terziopelo biejos con /

trabeseros de yerro en sesenta reales. I

Seis sillas de baqueta de moscobia de al-/

muadilla a beinte y quatro cada una que ynporta /

ziento y quarenta y quatro. I

Seis cortinas con sus zenefas de tafetán car-/

mesí en treszientos reales./

Vn escribidor de lo mismo en treinta reales. /

Vna sobremesa de Damasco vieja en sessenta reales. I

Vnas mangas de estaño de oro en sessenta reales. /

Vna almilla de felpa berde vieja en treinta. /

Diez y seis baras digo un hábito largo de tafetán /

en ziento y zinquenta reales. /

(Fol. 62r.) Vna sotana de lo mismo en sesenta. /

Vna capa de lo mismo en setenta. /

Vna casaca chupa y calzón de paño limiste negro /

en duzentos y quarenta reales. I

Vna casaca de terziopelo negro chupa y calzón /

de lo mismo mui usado en duzientos reales. /

Vna ropilla de paño con mangas de rizo en quarenta reales. /

Otra de bareta vieja sin mangas en seis. I

Vna ropilla de bareta nueba sin mangas en quinze. /

Vnos calzones de paño de Segouia viejos en quinze./

Vna chupa de grana con botonzillos de plata en ochenta. /

Vn jubón de ante con galones de plata en treinta. / 
Otro de lo mismo usado en veinte y quatro. I

Vn jubón de raso berde espolinado sin mangas /

en quarenta reales. I

Otro de ormesí biejo en diez y ocho. /

Vnos calzones viejos de nobleza en ocho reales. I

Dos alzaquellos vno de Damasco y otro de tafe-/

tán y vn solideo en ocho reales. I

Vn gorro de punto negro y blanco en siete reales. I

Vn manguito de onbre en diez reales. I

Tres pares de medias de seda viejas en quarenta reales. I

Otros tres pares de lana biejas en veinte. /

Vn sombrero de castor para abate y un chanbergo. /

(Fol. 62v.) en quarenta /

Vn capote de carro de oro mui usado con bueltas de /

nobleza en ochenta reales./

Dos ziñidores de seda en treinta y dos reales. /

Vna mantilla y tapa fundas biejas de felpa en /

veinte reales. /

Vna bata de damasco carmesí forrada en tafe-/

tán doble en duzientos reales. /

Seis camisas de morlés buenas en noventa reales. /

Seis pares de calzetas buenas en treinta reales. I

Seis camisas de lienzo vsadas a doze reales cada una yn-/

porta sesenta y dos./

Dos pares de calzonzillos de morlés en quinze reales. /

Otros tres pares de calzoncillos de lienzo nuebos en /

veinte reales. I

Otros quatro vsados en beinte y dos reales. /

Dos almillas de lienzo nuebas en doze reales. /

Otras dos de lo mismo usadas en nuebe reales. /

Vnos calzonzillos y dos almillas de bareta biejas /

en diez reales. I

Dos pañuelos de Canbrai vsados en diez /

Vna dozena de cuellos en ocho reales. /

Beinte y una libras de ylo casero curado a seis /

reales libra ynporta ziento y veinte y seis reales. /

Catorze sábanas de lienzo casero buenas a tre-/

inta reales cada una ynporta quatrozientos y beinte./

Quatro dozenas de serbilletas de gusanillo buenas /

a dos reales y medio cada una ynportan /

(Fol. 63r.) ziento y beinte reales. /

Beinte y dos seruilletas de Alemanisco ta- /

sadas a lo mismo ynporta zinquenta y zinco./

Doze paños de manos de gusanillo en treinta y seis. /

Vna tabla de manteles de gusanillo en doze reales. /

Dos tablas de Alemanisco en veinte y quatro. /

Dos tablas de morlés en ochenta reales. I

Una alba con su amito de encajes en ziento / 
y ochenta reales. /

Vn zíngulo de seda encarnada en zinquenta reales. I

Vna pelliza de Cambrai ussada en quarenta y zinco. /

Otra de morlés con su amito en treinta. /

Una manga de punto para meter las pellizas /

en seis reales. /

Siete almoadas de lienzo en veinte y ocho.

Siete tomos de a folio Istoria de los anales de /

Aragón con su ýndize en ziento y veinte reales. /

Otro tomo de a folio Ystoria de las guerras ziui-/

les de Franzia en quarenta y zinco reales. /

Otro tomo de a folio espejo de las cristalinas a-/

guas en quinze reales. I

Más otro de a folio práctica de ventas reales en /

quinze reales. I

Ystoria de Mariana en un tomo en seis reales. /

Folio Istoria de Méjico en quinze. I

Agricultura de Herrera en doze reales. I

Escripturas de millones en doze reales. /

(Fol. 63v.) Para dar luz a los biuos en quinze./

Bocavulario eclesiástico en doze reales. I

Suma de Fray Luis de San Juan en diez y ocho. /

Corella Práctica de confesores, tres tomos, uno de /

folio y los dos de quarto en veinte reales. /

Moncada Comunión Spiritual en diez reales. /

Opúsculos de oro birtudes morales y cristianas /

de Calderón en diez reales. I

Dominica del Padre Carantes; dos tomos en doze. /

Larraga añadido y otros tres pequeños de octauo /

en doze reales. I

[...] Cartilla Moral en seis. /

Fuero de la conzienzia en ocho reales. I

Obras de [...] dos tomos de quarto en veinte reales. /

Corona gótica en ocho reales. I

Obras de Góngora en ocho. I

Parnaso de Quebedo vn tomo en pasta de quarto /

en diez reales./

Novelas tomo de quarto en seis. /

Ignozienzia mendicada un tomo seis. /

Dos tomezillos Nobleza española y genología de la / casa Leiba en quatro. /

(Fol. 64r.) Canto llano dos tomos en quatro reales. I

Los quinze cantos de la numantina en seis. /

Bidas y teología digo [...] seis reales. /

Autos de Calderón quatro. I

D. Alejo Piamontes quatro reales. /

Garcilaso de La Uega en dos. I

Dichos y echos de Don [...] Segundo en dos. / 
Manual de confesores de Uillalobos tres /

Conjuros de Remijio tres reales. I

Definiziones morales de Aguirre en ocho reales. /

Antorcha moral en dos. I

Santo Thomás en tres. /

Salazar dos tomos en quatro. I

Ordenantes vn real. /

Bustamante de Rúbricas dos reales. /

Entremeses vn real. /

Floresta Española tres. /

El diablo cojuelo un real. /

Thriunfo del rosario dos reales. /

Doctrina cristiana vn real. /

[...] de Alfonso un real. /

Secretos de Naturaleza un real. /

(Fol. 64v.) Especulum Granati Corum dos reales. /

Gerónimo de [...] un real. /

Barias questiones morales dos tomos quatro reales. /

Dos concilios seis reales. /

Quatro cuerpos de brebiarios buenos en /

duzientos reales. I

Otro brebiario pequeño de todo el año en quarenta reales. /

Dos divinos en veinte. /

Dos semanas santas en treinta reales. I

Vn quadernillo dos reales. I

Más treinta baras de lienzo gallego ancho en /

ziento y zinco reales. I

Veinte y dos baras de lienzo digo zinquenta y /

nuebe baras de lo mismo en duzientos y seis reales y un. /

Beinte y dos baras de lienzo casero en ochen-/

ta y ocho reales. I

Más beinte y siete baras de lo mismo en ziento /

y ocho reales. I

Catorze baras de lienzo gallego en quarenta y nuebe. /

Dieziocho baras de lienzo casero ordinario en /

zinquenta y quatro reales. I

Más diez y seis baras y media de zerrón en /

beinte y quatro reales. I

Beinte y seis baras de estopa en treinta y /

nuebe reales. I

Quarenta y nuebe baras y media de terliz en no-/

benta reales. I

(Fol. 65r.) Dos sábanas de estopa nuebas en veinte /

y quatro reales. I

Treze sábanas de lienzo nuebas en treszientos y /

nouenta reales. I

Vna arca de nogal con sus cantoneras en /

setenta reales. I 
Vn bufete de nogal con sus zerrojos bueno en /

zien reales. /

Vn bufete de castaño con su cajón pequeño /

en veinte y quatro reales. /

Vna papelera con su zerradura y pie de pino en /

quinze. I

Dos taburetes chiquitos en ocho reales. /

Vn brasero de cobre con caja de nogal en /

veinte y quatro reales. I

Vn lienzo con la pintura de Nuestra Señora de la Sole-/

dad en veinte y quatro. /

Vna artesa de amasar con sus barillas en /

zinco. /

Vnos morillos pequeños de yerro en nuebe. /

Tres tarimas en treinta reales. I

Otra tarima que sirbe de antepara en ocho. /

Vna alazena de álamo en veinte reales. /

Otra uieja en ocho. /

Otras dos tarimas en veinte reales. /

Quatro escopetas largas tassadas en quatrozientos y diez reales. I

(Fol. 65v.) Dos pares de pistolas vnas de arrón y otras /

de faltriquera en ziento y veinte reales. /

Vn trabuco y una charpa en setenta. /

Dos espadas anchas en duzientos reales. /

Vn espadín de puño de ojalata en ziento y ochenta reales. /

Dos cuchillos de monte en treinta reales. /

Dos estoques y dos dagas en sesenta reales. /

Dos frascos vno de macho i otro de gan $a$ do en /

treinta y seis reales. I

Dos pretinas de golilla en siete reales. /

Vn dosel de damasco encarnado en ocho. /

Tres dozenas de platos finos en dieziocho reales. /

Vna dozena de escudillas en quatro. /

Seis cazos grandes y pequeños en treinta. /

Ocho ollas grandes y pequeñas en quatro reales. /

Vna media luna de picar carne en dos reales. /

Vna emina herrada en diez reales. I

Vn azadón y dos azadas viejas en ocho reales. /

Dos sajos de guerta en dos reales. I

Vna pala en un real. /

Setenta y ocho libras de cobre en diferentes piezas en tres-/

zientos y doze reales. /

(Fol. 66r.) Vna garapinera de estaño grande en veinte /

y zinco reales. I

Dos candeleros de alquima en ocho. /

Más diez libras de alquima vieja /

en quarenta reales. I

Más setenta y zinco libras de yerro bie-/ 
jo en setenta reales. /

Vna barra de yerro de diez y siete libras /

en diez y siete reales. I

Vna garduñera buena en quinze reales. /

Tres cazos viejos y uno nuebo de azófar en /

veinte y quatro reales. I

Diez y siete barillas de yerro en diez /

y siete reales. I

Zinco azadones grandes y pequeños en seis reales. I

Vnas parrillas biejas en dos reales. I

Vn herrage de carro en zinquenta y zinco reales. I

Quatro sartenes en diez reales. I

Un escalfador de cobre bueno en quinze. /

Vn perol y una caldereta de azófar en doze. /

Vn almirez con su mano en veinte y quatro. /

Dos barreñones bidriados en ocho reales. /

(Fol. 66v.) Beinte y dos libras de plata labrada a /

diez y seis reales la onza ynporta zinco mil seis-/

zientos y treinta y dos reales. I

Tres cargas y tres fanegas de trigo en ziento /

y beinte y quatro reales. I

Ocho cargas de zenteno en duzientos y quarenta reales. /

Tres arrobas de lana negra en nobenta reales. /

Dos arrobas de lana blanca en quarenta y ocho. /

Media arroba de añinos negros en diez y

ocho reales. I

Nuebe libras y media de ylo calzetero en /

sesenta y seis reales. I

Diez y ocho libras de ylaza casera en zinquenta /

y quatro reales. I

Beinte y dos libras de estopa cozida en

quarenta y quatro reales. I

Diez pellejos de azer bino quatro buenos y /

seis biejos en zien reales. /

Treinta arrobas de lino fabricado en no-/

bezientos reales. I

Doze sábanas de estopa biejas en sessenta. /

Quatro sábanas de lino biejas en treinta /

y dos reales. I

Diez y seis almoadas de lino biejas en tre-/

inta y dos reales. /

Dos colchas de cotonía mui biejas en /

veinte y quatro reales. I

(Fol. 67r.) Otras dos colchas de gusanillo de cáñamo /

biejas en veinte y quatro reales. I

Vna colgadura de cama de bratillarista /

en sesenta reales. I

Vn cobertor de paño verde biejo en / 
quinze reales. I

Otro de escarlatín biejo en veinte y quatro /

Vn sobre cama de serafina con roda-/

piés usada en quarenta reales. I

Vna colgadura de cama de jerguilla en- /

carnada en ochenta reales. I

Diez colchones de terliz buenos en quini-/

entos reales. I

Quatro biejos de lo mismo y dos en blancos en /

duzientos reales. I

Seis cobertores vsados en setenta y dos. I

Otros dos viejos en diez y seis. /

Dos mantas fábrica de esta tierra en veinte y /

quatro reales. I

Dos gergones biejos en quinze reales. /

Quatro mantones de pauilos en veinte /

y quatro reales. I

Otro viejo en quatro reales. I

Diez y ocho quilmas biejas en treinta /

y seis reales. I

Quatro tablas de manteles usados en quarenta reales. I

(Fol. 67v.) Tres dozenas de servilletas vsadas en / setenta y dos reales. I

Siete paños de manos vsados en veinte /

y dos reales. I

Dos peinadores de tela con sus encajes en /

treinta reales. I

Dos romanas vna pequeña y otra grande en be- /

ynte reales. I

Seis cortinas de bareta encarnada bi-/

ejas con sus zenefas en sesenta. /

Quatro cortinas de gerguilla en quarenta reales. /

Otras quatro de bareta verde en zinquenta. /

Vna bata de coton en quarenta y zinco. /

Siete cofres en ziento y quarenta reales. /

Seis camas zinco rasas y vna de ar- /

mar en setenta reales. /

Dos juncos uno con puño de plata en /

quarenta y zinco reales. I

Vn ábito largo de bareta usado en en ziento; y /

zinquenta reales. I

Vna casaca de carro de oro vieja en zinquenta reales. /

(Fol. 68r.) Otra de paño de Segouia vieja en quarenta reales. /

Vna chupa de paño de Segouia usada en /

quarenta reales. I

Otra de lo dicho uieja en veinte y quatro reales. /

Otra casaca de lamparilla vieja en veinte y seis reales. I

Vnos botines de paño negro en siete reales. I 
Vna calesa vieja con dos almoadones uno / de serafina y otro de baqueta en duzientos / y quarenta reales. I

Tres zerdas de zeba y seis de cría en treszientos y se-/ senta reales. I

Vna caja de cuchillos con zinco y un tene-/ dor en diez reales. /

Vn casacón de paño basto usado en zin-/ quenta reales. I

Dos pares de calzones de ante biejos en veinte / y quatro reales. I

Vn capote de barragán forrado en cochi-/ nilla viejo en quarenta reales. /

Vna capa de paño de chinchón en sessenta. / Treinta y nuebe baras de gusanillo en pieza en / ziento y diez y siete reales. I

(Fol. 68v.) Diez baras de Alemanisco en treinta reales. / Beinte baras de lienzo mediano en sesenta reales. I

Quarenta baras de lienzo gordo en ziento y / veinte reales. I

Dos arcas de pino en quarenta reales. / Quatro tapizes viejos en ziento y veinte reales. /

Vna yegua grande vieja en ochenta reales. I

Dos sillas de briza, dos albardones y dos / frenos en ziento y treinta reales. I

Vna cruz y dos relicarios de plata y un / par de botones de lo mismo en zien reales. / Vn anillo y una sortija de oro con piedras / falsas en zinquenta reales. I

Vn estuche de zapa guarnezido de plata / en ziento y veinte reales. I

Otro stuche viejo de concha perdidas las / piezas en diez reales. /

Vna muestra de relox descompuesta / con caja de plata con fábrica de Franzia con / sobrecaja de zapa en sesenta reales. I Vna caja de vidrio azul con zerquillo de / plata en veinte reales. I

Otra caja de concha en veinte reales. / Vn alfiletero de azero en nuebe reales. / Vna guerta en el casco deste lugar zercada al ba- /

(Fol. 69r.) rrio de Arriba con sus árboles frutales que / ará dos eminas de zenteno y linda azia Portugal calle / de concejo y para auajo con guerto y casas de Thomé Car-l nizero vezino deste lugar tasada en mil / y duzientos reales. I

Otro guerto zercado más auajo que ará me-/ dia emina de zenteno linda azia auajo con casa / 
de Gaspar Morán y azia arriba con guerta de Bea- /

triz Lendero en duzientos reales. I

Vn colmenar con quarenta pies do llaman /

los matos que linda todo alrededor con cam-/

po de concejo bien notorio en setezientos reales. /

Más un corral en el monte deste lugar do lla-/

man el balle de Astorga que linda azia /

Astorga con corral de Joseph Morán /

y que las demás lindes con campo de concejo ta- /

sado en ziento y veinte reales. I

Vn pajar que está pegado a la casa de Curato /

cubierto de teja que linda azia Portu-/

gal y parte de auajo con calle de concejo y que las de-/

más partes con dicha casa de Curato tasado en /

treszientos reales. I

Más se allaron en dinero efectivo quini-/

entos y quarenta y zinco reales. I

Más quinze tierras y un prado en terreno de /

[...] que todo aze de sembradura zinquenta y

(Fol. 69v.) tres eminas y constan de zinco bentas otor-/

gadas a fauor de Antonio Baez vezino que fue /

de La Bañeza y recaieron en dicho D. Gerónimo /

Natera por auerle hecho en ellas pago /

la [...] demás que dicho Báez le estaba /

teniendo y la tasaron en mil reales. I

Todos los quales dichos vienes del tasados di-/

jeron ser y auer quedado dicho Don Gerónimo Na-/

tera lo que a su uer y entender no ai otros algunos /

y que siempre y quando a su noticia llegue los ay con-/

parezerán ante su [...] a tasarlos $=\mathrm{y}$ asimis- /

mo dijeron que los frutos que están por coger y que /

pertenezen por razón de [...] al dicho Don /

Gerónimo Natera durante el año de su /

falleszimiento los regulan y aprezian en tres mil /

y quinientos reales arreglándose a las [...]

y a los balores de granos y frutos /

que $[\ldots]$ corren

Y la dicha Dña Isauel María de Berastegui /

Declaró que en el terreno de este lugar dejó /

por suias dicho Don Gerónimo Natera tres guertas /

un prado y diez tierras que todo ará de sembradura /

(Fol. 70r.) y Dn Joseph Cadórniga vezino de las personas que / tienen conozimiento para hazer dicha tassación; /

los nonbraba y nombró por inbentariadores y tasadores de dichos /

bienes a quienes se les aga sauer; y por este auto /

que firmó así lo procuró y mandó y doy fe. 
Manuel Meléndez (rúbrica) y Manuel Fernández Barral (rúbrica) 
Título: Dote a favor de Francisca Fernández mujer de Lorenzo del Villar

Tipo: inédito

Carácter: particular

Procedencia: Archivo Histórico Provincial de León

Signatura 1112

Caja 7306

Folios: 338-339

Año: 1704

Lugar: Villanueva de Valdejamuz

Provincia: León

País: España

(Fol. 338r.) En la villa de Villanueba de Valdejamuz a beinte y nue-/ be días deel mes de Novienbre deel año de mill setezientos y quatro / em presenzia de mí el scribano y testigos que parecieron presentes Santiago Fu-/ ertes vezino de esta dicha villa de la una parte y Lorenzo del Billar vezino / deella y dijeron que el dicho Lorenzo del Billar está casado / "ym faz eclesie" con Francisca Fernández hija de Gaspar Fernández / difunto y Cathalina Maio su muger que al presente lo es deel dicho / Santiago Fuertes y que de la dicha Francisca Fernández a sido tutor y cura- $/$ dor de su persona y bienes el dicho Santiago Fuertes y de la renta de / su hazienda y soldadas que a ganado con dicho su curador aquí / en abía serbido, le abía tomado quenta amigablemente por on- $/$ bres nonbrados que lo abían sido Francisco deel Billar vezino dees-/ ta billa y Joseph Pérez vezino deel lugar de Nabianos de la Bega / que abían tasado y moderado las dichas rentas y soldadas reua-/ jadas las crías de dicha menor bestido y calzado que le abían da-/ do en zinquenta ducados de bellón y beinte y vna heminas / de zenteno y paxa en pago destas cantidades y para ayuda / de sustentar las cargas deel matrimonio. El dicho Santiago Fuertes / abía dado y entregado al dicho Lorenzo deel Billar diferentes / bienes que abían tasado y moderado los dichos Francisco deel Bi-/ llar y Joseph Pérez que los que eran y sus tasaziones constaua / de vna memoria que abía escripto el lizenziado Manuel de Astor-/ ga presbítero vezino deesta uilla que escribieron a mí el / escribano para que ynserte en esta escriptura los bienes / que refiere y sus tasaziones la qual contiene los siguientes / Una casa thejada y pajiza en esta billa donde bibió y mu-/

(Fol. 338v.) rió Lázaro Maio que linda azia el sol salir con casa de Fer-/ nando Rodríguez y hazia la yglesia con casa de Joseph Fer-/ nández vezinos deesta billa y azia el monte con calle Pública / tasada en seiscientos y beinte reales liure de foro, zenso ni otra car- $/$ ga maior ni menor porque el zenso de quinientos reales de prin-/ zipal que está cargado soure dicha casa le a de redimir y quitar / el dicho Santiago Fuertes dentro de dos años y a ello a de ser confe-/ rido y apremiado por todo rigor de derecho contador dichos dos / años desde oy día de la fecha y a ello se obligó en forma el suso / dicho y de dicho zenso a de sacar a par y a salbo yndegne a los dichos / Lorenzo deel Billar y Francisca Fernández su muger y a sus hijos / 
y herederos. /

Vn buey castaño de zinco a seis años en duzientos reales. /

Una baca del mismo color y tienpo en duzientos reales. /

Vn arca mediana de álamo con zerradura y cantoneras /

en diez y ocho reales. I

Un escaño bueno en veinte reales. I

Una mesa pequeña en dos reales. /

Dos mantas caseras nuebas en ochenta y dos reales. /

Un cabezal de lana bueno con su pluma en treinta y tres reales. /

Vn paño labrado de zilestre y caparrosa y puntas en quinze reales. I

Una sáuana de lienzo nueba de dos pierrnas en beinte reales. I

Vnos manteles de alemanisco nuebos en veinte y seis reales. I

Una marrana de media cría en beinte y dos reales. /

Vna saia de paño de Cuenca de color de yielo vsada en zinquenta y zinco reales. I

Unos cuerpos de grana con sus morinillos y barras de terziopelo en /

zinquenta reales. /

Vna mantilla de contray nueba en quarenta y ocho reales. /

Otros cuerpos de media grana usados en diez y ocho reales. /

Otra mantilla de cubrir de frechilla nueba en diez y ocho reales. /

Una atiua con su reja y tiriguela de yerro en quinze reales. /

Un trillo usado en doze reales. /

(Fol. 339r.) Un yugo con todos sus aparejos en quinze reales. /

Vna camisa de lienzo labrada con lanilla negra en beinte reales. /

Un mandil de listas en ocho reales. /

Vna mantilla de zeñir nueba en diez reales. /

Una zeranda y una piñera en tres reales. I

Dos asadores en tres reales. /

Dos platos finos blancos en dos reales. /

Dos gallinas y vn gallo en seis reales. /

Diez y siete ouejas de bientre a quinze reales cada una azen duzientos y/

zinquenta y zinco reales. I

Siete bazias a onze reales cada vna setenta y siete reales. /

Un carnero para el día de la boda en quinze reales. /

Yten tres cargas de sementera en las tierras siguientes: Un arroto /

de la merindad de San Juan de Torres de carga y media de senbradura. /

Otro arroto de catorze heminas al balle de descuerna bueies, otra /

tierra quiñón de conzejo de dos heminas a torredillos; otra tierra /

al camino de la falgada de dos heminas y las beinte y vna /

heminas de zenteno que le deue de la renta de la tierra de dicha me- /

nor se quedan por el aramio de dicha sementera y a de pagar el dicho /

Lorenzo del Villar dos cargas de pan de la renta de dichas tierras /

y además de lo referido fue tasada la dicha sementera en ziento y zin-/

quenta reales. /

Los quales dichos vienes conthenía la dicha memoria que se [...] ymporta /

en presencia de las dichas partes que sus tasaziones ynportan dos mill /

y treinta y ocho reales de vellón salvo yerro los quinientos [...]/

de las soldadas que debengó la dicha Francisca Fernández en el tiempo que /

sirbió al dicho Santiago Fuertes y los vn mil quatrozientos y ochenta y /

ocho reales restantes se los dio el dicho Santiago Fuertes a la dicha Francisca / 
Fernández a quenta de lo que a de auer de la erenzia de la dicha Cathalina / Mayo su madre y se obligó en forma que los vienes que ban menzio-/ nados serán seguros a la dicha su entenada y a sus hijos y herede-/ ros y no quitados por persona alguna .....

(Fol. 339v.) Estos tan buenos vienes con las costas y daños que le cau-/ sasen y tanbién se obligó de que dentro de dos años contados desde / oy dicho día redimirá el dicho zenso que está cargado sobre dicha casa / y deel sacara a par y a saluo yndegna a los dichos Lorenzo deel Billar y su mu-/ jer y a ello quiere ser conpelido por todo rigor y en el ynterim que aze dicha / redeniption pagar a sus reditos y el dicho Lorenzo deel Billar confesó aber / reziuido dichos bienes y porque su entrega de presente no pareze renun- $/$ zio sus leies y la eszezión deel dolo engaño y más deeste caso como en / ellas se contiene los quales y vna tierra centenal que tiene susodicha en terreno / de esta dicha uilla a do llaman La Salgada que ará media / carga de senbradura linda azia el monte con tierra de Lorenzo Ramos / muger de Miguel de la Cuesta y azia Nuestra Señora de [...] con tierra de / Juan de las y azia Santa Elena fronta en tierra de Don Santiago Fernández de / Arraualde cura de la Verdenosa los rezibe por bienes dotales de la dicha Francisca Fernández su muger y se obligó y a sus bienes de que cada y quando / que el matrimonio entre los dos sea disuelto por muerte, diborzio, y en otra / forma la bolviere o a quien su poder y derecho tubiere los dichos bienes tales y / tan buenos como los reziba pagando la quiebra de los que vbiere en ser / y por los consumidos las cantidades de sus tasaziones y quiere que en todo / tienpo gozen del priuilexio de bienes dotales y que en lo más bien / parado de su hazienda este dote y dicho referido quiere ser conpelido / y apremiado por todo rigor y a pagar las costas y daños que se causasen / y anbas partes para cumplir cada uno con lo que ba obligado dieron poder a las / xustizias de su [...] de su fuero y xurisdizión y lo rezibieron por sentenzia defini-/ tiba pasada en cosa juzgada renunziaron las leies de su fabor con la xeneral / del derecho en forma y así lo otorgaron en pressenzia de mí siendo testigos Thoribio $[\ldots] /$ bezino deel lugar de Roperuelos del Páramo, Francisco Sánchez vezino desta villa [...] / escribiente residente en ella y los otorgadores a quienes doi fe, conozco, firma el que / supo y por el que no un testigo a su ruego.

Lorenzo Villar (Rúbrica) 
Título: Inventario de los bienes muebles y raíces que quedaron al fallecimiento del Sr. Don Felipe Corchado presbítero de esta villa.

Tipo: inédito

Carácter: particular

Procedencia: Archivo Histórico Provincial de León

Signatura Caja 7724, sign. 2675

Folios: 1-18

Año: 1843

Lugar: Destriana

Provincia: León

País: España

(Fol. 1r.) En la villa de Destriana a veinte y ocho días del mes de / septiembre de mil ochocientos cuarenta y tres; D. Manuel José Ber-/ ciano vecino de la misma y D. Eusebio Cansado López que lo es de / la de Laguna de Negrillos ymbentariadores, contador, partidores / y divisores nombrados por el Sr. D. Felipe Cordiado Caballero del / hávito de Santiago, presbítero prior cura párroco de ella: en su tes-/ tamento otorgado en diez y ocho de agosto último, vajo del cual / fallesció en veinte y tres del corriente cuyo encargo aceptamos por me-/ dio de este escrito presentado a el Sr. Alcalde Constitucional, suplicando la inivición del conocimiento de este ymbentario que así lo estimó por au-/ to que proveyó a continuación haciendo uso de la facultad que se / nos ha conferido por dicho señor y cumpliendo con el encargo damos / principio a la formación del ymbentario por los vienes muebles / comprendidos en la casa donde vivió y murió con distinción de ellos / y nota de las havitaciones donde se hallan colocados arcas, vaúles /

(Fol. 1v.) Cajones, escritorios y navetas con los que estos contenían, vajo / de sus respectivas llaves que con distinción es como sigue.

Sala principal

Un relox con sobre caja de nogal vidrieras / con máquina ynglesa de metal con diario, con / todos sus pertrechos en vuen uso, tasado trescien-/ tos veinte reales. /

Cuatro láminas con marco negro con sus cristales / que contienen la historia del hijo pródigo tasadas en / veinte y cuatro reales. / Un cuadro marco dorado con el busto de nuestro / obispo, tasado en diez reales. /

Unas cortinas de lienzo pintadas usadas con sus co-/ rras y varillas de yerro, tasadas en doce reales. / Una mesa de chopo pequeña sin cajón tasada / en doce reales. I

Otra mesa de chopo más larga con su cajón sin lla-/ ve tasada en veinte reales./

Otra mesa nogal con imbutidos dos cajones con / sus cerraduras y llave tasada en ciento sesenta reales. / 
Otra mesa de la misma figura que sirve de vaúl / con cerradura y llave tasada en lo mismo./

Otra mesa nogal lisa con cuatro cajoncitos cerra-/ duras y llave tasada en ciento veinte./

(Fol. 2 r.)

Ropa que contenía la mesa baúl

Un levita de paño fino negro en vuen uso, votones / de pasta vueltas de tafetán, cuello de terciopelo / tasada en ciento diez reales. I

Un chaleco de seda negra en veinte y cuatro reales. /

Un pantalón paño azul obscuro fino en vuen /

uso tasado en sesenta reales. I

Una capa paño azul en vuen uso con embozos de / terciopelo y muletillas de seda tasada en ciento se-/ senta reales. I

Una manta de alepín forrada en estameña fina / con su cruz de seda tasada en veinte reales. / Un manteo de coro de estameña fina en vuen u-/ so con su cola tasado en cuarenta reales./

Una sotana tela de carro usada forrada en ale-/ pín tasada en cuarenta reales./

Tres sillas asiento de paja en vuen uso tasadas a / cinco reales cada una ymportan sesenta y cinco reales./

\section{Gavinete}

Un relox sin caja antiguo máquina de madera /

(Fol. 2v.) y metal con sus arreos sin uso tasada en cien reales. /

Cuatro láminas marco negro con sus cristales que /

contienen la historia de [...] tasadas en vein-/

te y cuatro reales. I

Un par de cortinas lienzo pintado usadas con sus /

corras y varilla de yerro en doce reales. I

Otro par de cortinas lo mismo en otros doces reales. /

Una cortina grande de valcón estopilla con sus co-/

rras de yerro en treinta reales. I

Un estante de nogal pequeño con tres tablas de /

servicio tasado en veinte reales. /

Libros que en él se hallan

Tres tomos de la orden Militar de Santiago tasada / en veinte reales. I

Un tomo Constitución del año doce en tres reales. /

Un Misal nuevo con vroches de metal sin perjuicio / que corresponda o no a la Yglesia tasado en / ciento ochenta reales. / 
Un tomo de sermones en ocho reales. /

Siete cuadernos, oraciones fúnebres, cartas pastorales y es-/

posiciones tasados en siete reales. /

Cinco reglamentos y órdenes para diferentes cosas tasa-/

dos en diez reales. I

Tres tomos teología moral de [...] en treinta reales. /

Un tomo Antonio Pérez de jurisdición en cuatro reales. /

(Fol. 3r.) Seis tomos obra del [...] tasados en cuarenta reales. / Un tomo de elementos mecánicos en francés con láminas tasa-/ do en cuatro reales. I

Un tomo de [...] Moral en veinte reales. /

Catecismo de Poquet cuatro tomos en cuarenta reales. I

Dos tomos de la Curia Filípica en diez y seis reales. /

Un tomo arte esplicado en catorze reales. /

Diez y siete tomos compendio del Bufón con láminas en /

doscientos reales. I

Tres tomos Ynstruciones Doctrinales en diez y seis reales. /

Un tomo del Cavalari en diez reales. I

Un tomo breviario particular en ocho reales. I

Dos tomos indiferentes en cuatro reales. /

Una paloma de Talavera en dos reales. /

Seis votes de ojadelata grandes y chicos de tabaco de /

tape tasados en seis reales. I

Una cómoda madera de chopo pintada con guarni-/

ciones de metal dorado con tres cajones grandes dos /

con cerradura y llave y uno sin ella deteriorada ta- $/$

sada en cuarenta reales. /

(Fol. 3v.) Cuatro cubiertos de plata del peso de diez y ocho / onzas tasados en doscientos setenta reales. /

Un cuchillo mango de plata en treinta reales. /

Unos anteojos con caja de cartón en ocho reales. /

Otros sin caja descompuestos en dos reales. /

Un cepillo para limpiar ropa en cuatro reales. /

Un breviario completo en vuen uso en sesenta reales. I

Una semanilla con vroches de metal en diez y seis reales. /

Una mesa de nogal que hace de funciones de escriva-/

nía con reservas para papeles, clavos romanos con /

cuatro cajones sus cerraduras y llave tasada en dos-/

cientos cuarenta reales. /

Una escribanía de Talavera, tintero y salvadera/

tasada en dos reales. I

Un tintero grande de piedra en cuatro reales. /

Otro de asta pequeño en dos reales. /

Una caja para tavaco en cuatro reales. I

Un sofá de cuatro asientos con colchoncillo de tela /

en vuen uso tasado en sesenta reales. I

Diez sillas asiento de paja en vuen uso tasadas a /

cinco reales cada una importan cinquenta reales. / 
Otra silla del mismo asiento figura poltrona más / usada en diez reales. I

Alcova de gavinete

Un catre de nogal antiguo con encordeladura /

(Fol. 4r.) tres clavos romanos con imvertido figurando la / cruz de Santiago tasado en ciento veinte reales. /

Un colchón en vuen uso en cien reales. I

Otro lo mismo en cien reales. I

Otro de terliz vastante deteriorado en sesenta reales. /

Una sávana vuena de lienzo de tres piernas tasa-/

da en cuarenta reales. I

Otra tela vuena de dos piernas y media con /

guarnición de muselina en sesenta reales. /

Un cobertor encarnado de Palencia ya usado y /

raído tasado en veinte reales. /

Una colcha de lana afelpada azul usada vas-/

tante en ciento veinte reales. I

Un almoadón de tela con su guarnición de mu-/

selina tasado en veinte reales. I

Otro almoadón igual en otros veinte reales. /

Una funda de lana vieja en seis reales. /

Un sombrero de copa alta usado en treinta reales. /

Un baúl de cuatro varras grande con cerradura. /

(Fol. $4 \boldsymbol{v}$.) y llave, cantoneras de yerro usado tasado en / cinquenta reales. /

Otro baúl lo mismo con una copera para des-/ canso de un sombrero en otros cinquenta reales. I

Unos pies formados para sostener los dos vaúles /

tasados en seis reales. I

Un arca de nogal regular con sus aldabones de /

yerro, cerradura y llave en ochenta y cinco reales. /

Ropas que contienen los /

dos baúles y arca

Un paño y sobre paño de afeitar vastante usa-/

dos tasados en ocho reales. I

Otro paño y sobre pagno de lo mismo finos de coto-/

nía con sus guarniciones en veinte reales. /

Tres pares de calzoncillos de lienzo fino u-/

sados tasados en treinta reales. I

Otros tres pares de calzoncillos más usados y repa-/

sados tasados en veinte reales. I

Cuatro camisas vuenas de lienzo fino que se /

hallan en vuen uso tasadas en noventa y seis /

reales. I 
Otra camisa más vasta en veinte reales. /

Otra camisa vieja en cuatro reales. I

Una sávana vuena usada en veinte y cinco reales. /

(Fol. 5r.) Otra sávana deteriorada y rota tasada en diez / y seis reales. /

Otra mejor remendada en diez y ocho reales. I

Una almoada nueva sin guarnición en seis reales. /

Otra lo mismo con guarnición de percal en ocho reales. /

Otra sávana mediana rota en doce reales. /

Otra vastante usada en veinta reales. /

Otra fina de tela nueva en treinta y cinco reales. /

Otra sávana de lienzo nueva sin estrenar de dos /

piernas y media tasada en cuarenta reales. I

Otra lo mismo en otros cuarenta reales. I

Otra lo mismo en otros cuarenta reales. I

Otra lo mismo en otros cuarenta reales. /

Otra lo mismo en otros cuarenta reales. /

Un roquete de tela vastante usado en cuatro reales. I

Otro más usado en tres reales. I

Una tabla de manteles grandes finos de gusanillo /

muy usados en cuarenta reales. I

Otra tabla de manteles nuevos vastos sin estrenar /

tasados en cuarenta reales. /

(Fol. 5v.) Otra tabla de manteles sin estrenar vastos tasados /

en cuarenta reales. I

Otra lo mismo en otros cuarenta reales. /

Otra también nueva muy chica en veinte reales. /

Otra tavla de manteles usada y rota en diez reales. /

Otra tabla de menteles de uso común en veinte reales. /

Cuatro paños de mano nuevos sin estrenar /

tasados en treinta reales. I

Otro paño de manos nuevo más fino en diez reales. /

Un par de medias negras finas en diez reales. /

Otro par lo mismo en otros diez reales. /

Otro par algo mejores en doce reales. /

Tres pares de calcetas vastante usadas en quince reales. /

Cuatro almohadones nuevos de lienzo con /

guarnición de muselina en cuarenta reales. /

Una almoada fina vuena con guarnición en /

ocho reales. I

Otra más usada con guarnición en cuatro reales. /

Un paño de manos fino usado en diez reales. /

Otro algo más vasto en ocho reales. /

Ocho servilletas vuenas tasadas en sesenta y cua-/

tro reales a razón de ocho cada una./

Cuatro de uso común en diez y seis reales. /

(Fol. 6r.) Una colcha blanca amartelada vastante usada / 
tasada en cuarenta reales. I

Un sombrero de teja fino en cuarenta reales. /

Un alzacuello de paño de seda nuevo en ocho reales. /

Unas votas de calzar en vuen uso en veinte reales. /

Un chaleco de sarga viejo en seis reales. /

Otro de terciopelo viejo en seis reales. /

Otro de paño viejo interior viejo seis reales. /

Otro también viejo paño rojo en seis reales. /

Unos calzoncillos de vayeta pagiza en doce reales. /

Una chaqueta interior de bombari en ocho reales. /

Un levita viejo de paño negro en veinte reales. /

Una capa vieja embozos de terciopelo rota pa-/

ño rojo tasada en treinta reales. /

Un pantalón paño negro viejo en doce reales. /

Un vastón puño de plata con regatón de metal /

tasado en treinta reales. /

Una almoada con guarnición de percal en /

ocho reales. /

\section{Cuarto de las criadas}

Un arca de nogal con cerradura y llave sin /

aldavones tasada en setenta reales. I

(Fol. 6v.) Una cama rasa compuesta de pies y tablas tasa-/ da en doce reales. I

Otra cama rasa con encordeladura en otros doce reales. I

Un gergón usado de estopa en doce reales. /

Un mantón de lana viejo en veinte reales. /

Un cobertor de Palencia viejo en ocho reales. /

Una sávana vieja gorda en seis reales. /

Otra sávana mejor en catorce reales. /

Una funda de lona vieja en cuatro reales. /

Una silla de madera para un servicio con su /

puertecilla en doce reales. /

Un servicio grande de barro vidriado en seis reales. I

Un orinal de Talavera vlanco en tres reales. /

Cinco felpos en vuen uso en veinte reales. /

\section{Panerica}

Una tinaja de tener aceyte tasada en ocho reales. /

Una orza grande con dos asas vidriada también /

de tener aceyte en cuatro reales. I

Un maletón de baqueta viejo en veinte reales. /

Una maleta de baqueta con sus corras muy vie-/

ja en cuatro reales. I

Una fiambrera rota de madera en un real. /

(Fol. 7r.) Una olla grande zamorana con dos asas tasada en / 
doce reales. I

Una tinaja rota de lo mismo en dos reales. /

Una sobresilla azul vieja en seis reales. /

Unas alforjas vuenas sin tapas en treinta reales. /

Una escriña para sal en tres reales. I

Una tinaja grande de doce cántaras rota en ocho reales. /

Un brasero de yerro y paleta de lo mismo tasa-/

dos en veinte reales. I

Una caja para brasero de chopo vieja en seis reales. /

Una tabla de manteles vastos en diez y seis reales. /

Una colcha de ilo afelpada vuena en cien reales. I

Una escusavaraja sin asa en un real. /

Otra lo mismo en otro real. /

Un banquillo de dos pies en dos reales. /

Una alquitara pequeña en vuen uso tasa- $/$

da en ciento sesenta reales. I

Un cajón de chopo en tres reales. /

Un arquetón de lo mismo sin cerradura en /

ocho reales. I

Unos estrivos de madera con corras de yerro en ocho reales. /

(Fol.7v.) Una silla de montar con todos sus talages, estrivos /

de yerro y sus acciones tasada en cien reales. /

Un potro de madera con sus pies en ocho reales. /

Diferentes tiestos y otras cosas de madera de poco /

uso y valor en doce reales. /

Cuarto del común

Una tarima de pino con traviesas tasada en cua- $/$

tro reales. I

Un jergón de estopa viejo en diez reales. /

Una sávana buena de dos piernas en veinte reales. /

Otra sávana vieja y rota en seis reales. /

Una manta vieja en diez y seis reales. /

Una jaula de mimbre grande en cuatro reales. /

Unos (pies) de madera de una camilla en seis reales. /

Unos trastos viejos de poca consideración en cuatro reales. /

Pasillo

Una mesa sin cajón de castaño tasada en /

veinte reales. I

Un escañil vueno de chopo en diez y seis reales. /

Otro lo mismo en otros diez y seis reales. /

Unas alacenas de chopo con cuatro puertas y /

dos celosías con cerraduras y llave en cincuenta reales. I

Otras de chopo con dos puertas más pequeñas. /

(Fol. $8 \boldsymbol{r}$.) tasadas en treinta reales. / 


\section{Cuarto de la cocina}

Un catre de nogal antiguo con la cavecera im-/ butido en cuadro con la cruz de Santiago con su / encordeladura tasado en cien reales. I

Un jergón de estopa vueno en diez y seis reales. /

Un colchón de lona viejo en treinta reales. /

Una sávana de lienzo vuena en treinta reales. /

Otra fina con guarnición en cuarenta y ocho reales. /

Un cobertor de Palencia raso en diez y ocho reales. I

Una colcha lana azul afelpada usada en ciento /

veinte reales. /

Un almoadón con guarnición en ocho reales. /

Otro lo mismo en otros ocho reales. I

Una funda de lona vieja en cuatro reales. /

Otra lo mismo en otros cuatro reales. /

Un paño de manos nuevo en diez reales. /

Otro más usado en ocho reales. I

Un colchón de terliz viejo en treinta reales. /

Ocho sillas buenas y malas en treinta y dos reales. I

(Fol. 8v.) Una mesa de nogal las tablas y pies de chopo / tasada en diez y seis reales. I

Seis vasos de cristal labrados en quince reales. /

Otros seis pequeños lo mismo en nueve reales. /

Otros cuatro pequeños dorados en ocho reales. I

Otros dos cortadillos lisos en tres reales. /

Otros cuatro grandes lisos en ocho reales. /

Seis copas de cristal lisas en doce reales. /

Unas vinagreras de cristal de roca con su ca /

ja de caova en treinta reales. I

Una botella cristal de roca labrada con sus ta-/

pa rota en doce reales. I

Otra mayor con tapa lisa en diez reales. /

Otra lo mismo más pequeña en ocho reales. I

Seis botellas vidrio vasto en doce reales. /

Dos saleros de China floreados en diez reales. /

Una jarra de piedra rota floreada de azul en /

ocho reales. I

Otra blanca [...] en seis reales. /

Una escusavaraja grande vuena en cinco reales. /

Una bandeja achalorada fondo negro en ocho reales. /

Otra lo mismo pero mayor en doce reales. I

Un frasco vidrio grande en doce reales. I

Otro más pequeño cuadrado en ocho reales. /

Dos cajas madera para conducir pasas de media arro / va en cuatro reales. /

(Fol. 9r.) Doce platos de listas y flores azules tasados en / doce reales. I 
Doze platos finos y vastos desmejorados en doce reales. I

Siete platos más finos en siete reales. /

Una fustera de piedra en cuatro reales. /

Una fuente de lo mismo vuena en seis reales. /

Seis medias fuentes vastas en seis reales. /

Una salsera con su platillo en tres reales. /

Seis jícaras de Talavera en cuatro reales. /

Dos jarras vastas de Talavera en cuatro reales. /

\section{Cocina de lumbre}

Un escaño de chopo grande con respaldo ta-/ sado en treinta reales. I

Una caldera grande, usada, rota y muy delgada / tasada en ochenta reales. I

Una cantarera con siete [...] y los pies rotos / tasada en seis reales. I

Tres cántaros vuenos en un real. /

Una espetera con doce perchas en doce reales. I

Un caldero de azófar usado en veinte reales. /

(Fol. 9v.) Una sartén pequeña vuena en cinco reales. /

Un cazo de azófar pequeño en siete reales. /

Una caceta regular en un real. /

Un candil de cobre en cinco reales. /

Un sartén regular en ocho reales. I

Una tartera de cobre grande en doce reales. /

Un cazo de azófar más grande remendado en ocho reales. I

Un belón grande vueno con pantalla, espavila /

deras, tigeras, calderilla y tapadera en cuarenta reales. /

Un caldero de azófar viejo y remendado en diez reales. I

Dos cacillas pequeñas en un real. /

Una aceytera grande de ojadelata con su cola-/

dera vuena en seis reales. I

Una cobertera de ojadelata grande con su asa /

en un real. I

Otra de yerro regular en otro real. /

Una cafetera de ojadelata en dos reales. I

Un candelero de metal vueno en diez reales. /

Una chocolatera de azófar regular con su /

molinillo y tapa en catorce reales. I

Otra más pequeña en siete reales. I

Un belón de bara alta usado sin pantalla y sus /

espaviladeras de yerro en diez y seis reales. /

Una mesa de chopo con su cajón en diez y seis reales. /

(Fol. 10r.) Dos banquillos en dos reales. /

Un baral de cuatro separaciones madera de casta-/

ño tasado en doce reales. I

Una regadera de ojadelata vieja en cinco reales. / 
Una linterna sin cristal en un real. /

Una fuente de Talavera en tres reales. I

Una media fuente de piedra en seis reales. /

Una taza grande en un real. /

Una jarrica morada en un real. /

Dos embudos de ojadelata uno grande y otro chi-/

co en un real./

Tres coberteras de yerro muy ruines en un real. /

Tres jícaras de uso común en dos reales. /

Dos saleros pequeños en un real. I

Ocho platos vastos y finos de uso común en ocho reales. I

Un almirez con su mano vuena en doce reales. I

Tres tarteras de varro vidriadas regulares en un real. /

Dos cuencos grandes de lo mismo en un real. /

Tres fuentes madera grandes y chicas en dos reales. I

Una caldera grande vieja en veinte y cinco reales. /

Otra caldera más chica pero mejor en treinta reales. I

(Fol. 10v.) Una artesa mediana de madera en un real. /

Un tajo de encina vueno en dos reales. /

Un mortero con su mano en un real. /

Dos cuchillos grandes con el mango de hueso en cuatro reales. /

Cuatro ollas regulares de uso común en dos reales. /

De cazuelas, cántaros y otros tiestos de cocina de poca /

consideración y de uso común en cinco reales. /

Cuatro cazuelas zamoranas grandes y chicas de /

guisar en dos reales. /

Un escañil de chopo usado en ocho reales. /

Dos gallos de yerro para sostener pucheros en cuatro reales. I

Una paleta de yerro grande de la lumbre en /

cuatro reales. I

Otra pequeña de lo mismo en dos reales. I

Unas tenazas regulares pequeñas en cuatro reales. /

Unas trévedes de gallo pequeñas en cuatro reales. /

Otras pequeñas triangulares de tres pies en dos reales. /

Un fuelle de la lumbre en vuen uso en seis reales. /

Unas bregancias de yerro en diez y seis reales. I

Un pote de yerro con tres pies en treinta reales. /

Dos candiles de yerro medianos en cuatro reales. /

Un belón pequeño sin vara vastante usado en /

ocho reales. I

Una cesta pequeña de costana en un real. /

(Fol. 11r.) Tres canestillos medianos en dos reales. /

Un sartén pequeño en dos reales. /

Una espumadera regular en un real. /

Una palancana de peltre rota en ocho reales. / 


\section{Escalera}

Un arca de chopo vuena con su cerradura y lla-/

ve tasada en veinte y cuatro reales. /

Panera

Una estera grande de cinco paños que servía para la sala principal tasada en treinta reales. I

Un poco de cal viva en ocho reales. I

Un poco de yeso de [...] en seis reales. /

Corral delantero

Una pila de piedra vuena tasada en veinte reales. /

Otra pequeña en seis reales. /

Dispensa

Un cavezón de sarrete tasado en cuatro reales. /

Una caldera vien grande vuena tasada en dos-/

cientos reales. /

(Fol. 11r.) Tres orzas de tener manteca en dos reales. /

Una romana grande con su pilón tasada /

en cuarenta y cinco reales. /

Una oronica sin ondón en dos reales. /

Un tablón de poner los tocinos en sal en cuatro reales. /

Un tunel con arcos de madera para vinagre en /

ocho reales. I

Dos pellejos de tener vino el uno roto y otro en /

vuen uso tasados en diez y ocho reales. I

Un banco de matar los cerdos en cuatro reales. /

Un picadero de madera para carne en doce reales. /

Un barreñón grande para adovar en seis reales. /

Unas escaleras de mano en cuatro reales. /

Un cajón grande de tablas en dos reales. /

Cuatro quilmas viejas en doce reales. /

Una emina herrada con su rasero tasada /

en diez y seis reales. I

Una yegua pelo rojo y cavos negros cerrada /

con defecto en los pies tasada en cuatrocientos reales. /

Unas sobreventanas vidrieras en el cuarto junto a /

la cocina con sus cristales algunos de ellos partidos /

con sus marcos tasados en veinte y cuatro reales. /

Otras en la misma cocina de lumbre con sus mar-/ cos y los cristales también algunos de ellos partidos / tasados en otros veinte y cuatro reales. /

(Fol. 12r.) Los ymbentariados nombrados para el mayor / 
acto cumplimiento de su encargo, han deliverado asociar-/ se para la tasación de la casa con los maestros ala-/ rifes Manuel López y Manuel Lovoso, que actual-/ mente residen en esta villa, ocupados en el trabajo de / obras de edificios; y para las demás posesiones con Anto-/ nio Falagán y Francisco Vidales López de esta vecin-/ dad como labradores e inteligentes lo que así se ano-/ ta para que en todo tiempo conste $=$ Una casa en el casco de esta villa de Destriana do-/ Llaman Los Castros, se compone de puertas principa-/ les, portada, cuadros, cuarto havitación, panerica / Palomar, panera grande por alto, sala alta, pa- $/$ jares todo doblado, corral y un huertecito de nueba / y vuena construcción de piedra que linda oeste con / terreno de la [...] encomienda de esta villa, mediodía / quiñón y palomar de D. Manuel José Berciano po-/ niente casa de José Balderrey y norte pajar de Agus-/ tín Lozano y casa de Francisco Falagán tasada en / trece mil doscientos reales. I Una huerta de pared de piedra cercada en el mismo / casco sitio del Barrio de Abajo y es de regadío de ca /

(Fol. 12v.) vida de hemina y media de trigo poco más o menos / linda oeste [...] de la Encomienda, mediodía / y poniente Calleja y Calle de Concejo y casa de Alonso / Berciano y norte con camino que dirige a La Bañeza / tasada en mil y quinientos reales. / Un huerto término de esta misma villa do llaman / Las Heras de Bernavé de cavida de media hemi-/ na de trigo cercado de pared de piedra, linda oeste ca-/ sa de Victorio Fernández mediodía calle de Concejo, / poniente Calleja que va para Las Sajojas y pajar de / dicho Victorio y norte huerto del vínculo de Antonio / Alonso tasado en doscientos cuarenta reales. / Una tierra centenal de dicho término do llaman la / Previda hace hemina y media de centeno linda oeste con / Camino de la Previda y mediodía otra de Antonio A-/ lonso tasada en sesenta reales. /

Otra tierra en dicho término do llaman el Camino de las / Chinas hace dos heminas de centeno de ínfima Cali-/ dad, linda oeste otra de la Capellanía de S. Jerónimo, / mediodía otra de Blas Balderrey Berciano poniente tierra / de la Piedad de Villacís tasada en quince reales. / Otra tierra centenal en el mismo término do llaman / Los Meseros y Barrera pequeña hace tres heminas de / centeno de ínfima calidad, linda oeste con otra Ba-/ rrera, mediodía camino que atraviesa para los Me-/ seros y al poniente Mesero de Felipe Falagán tasada / en treinta reales. / 
Otra tierra linar regadía dicho término do llaman /

(Fol. 13r.) El Tejar que hace dos heminas de linaza de media-/ na calidad linda oeste otra de la Capellanía de /

Sta. Catalina, mediodía otra del Sr. Conde de Catay / y norte con quiñón su partija tasada en cien-/ to sesenta reales. /

(Continúan los bienes raíces hasta fol. 17 r.)

(Fol. 17r.) Deudas a favor

Primeramente debe a este caudal Baltasar Falagán de / esta vecindad, la venta de una tierra linar y una / huerta a los sitios del tejar y Barrio de Avajo, que / el mismo vendió a el fr. Felipe Corchado, con el / pacto de retrovendición por cinco años que han trans-/ currido según consta por escritura de venta otorgada / con legal forma, a razón de cinco heminas de linaza / por cada uno de cinco años: y otros cinco sembrados / de trigo, a razón de otras cinco heminas por cada / uno a precio de quince reales hemina las primeras y / a doce reales las segundas hacen la suma des seis-l cientos setenta y cinco reales. I

José Balderrey Berciano debe por razón del tres por / ciento del principal de doscientos ochenta y ocho reales / en que vendió su casa a el mismo señor con igual / pacto de retrovendición, en quince años que han trans-/

(Fol. 17v.) currido, según consta de escritura otorgada legalmente / importan ciento veinte y cinco reales. / El señor conde de Catay, por un aniversario que / anualmente paga, según cuenta ajustada y liqui-/ dada desde el año pasado de mil ochocientos trein-/ ta y seis hasta el de cuarenta y uno, trescientos / veinte y cuatro reales. I

Cristóbal Balderrey deve sesenta reales por renta de / dos años de la tierra linar camino de Lama, se-/ gún consta de obligación simple otorgada el 14 / de febrero de 1839. I Jacinto Vidales por dos años de la renta de la tierra / linar do llaman el Tejar, debe treinta y dos reales según / consta de obligación simple fecha 20 de marzo / de 1840. /

Francisco Travesí y sus hermanos deven por el subsi-/ dio [...] de la Capellanía de Sta. Catalnia que / disfrutan a nombre de su hermano D. Pedro Tra-/ vesí, según consta de cuenta ajustada, la can-/ tidad de ciento sesenta y dos reales. / Antonio Rodríguez vecino de Miñambres, deve / por esto del subsidio [...] de la Capellanía de /

S. Lucas a nombre de su hermano D. Pedro Rodrí-/ 
guez, doscientos cincuenta y tres reales. /

María Flórez por el entierro de José Ruvio /

su padre político, de quien fue heredera por su /

madre Teresa Pérez, debe noventa y tres reales. I

(Fol. 18r.) Blas Balderrey de esta vecindad, por el entierro /

de su muger difunta Micaela Chana, debe cien-/

to ochenta reales. /

Mil seiscientos cincuenta reales, que aproxima-/

damente sin perjuicio del más o menos que /

pueda corresponden a el Sr. Prior, por el servi-/

cio de Párroco, prestado en el corriente año por /

su dotación, cuya cantidad deverá reclamarse /

del Ayuntamiento constitucional de esta; u ofici-/

nas de la Hacienda Nacional./

Total ymbentario: 33.026

Ymportan las tasaciones de los vienes muebles y raí-/

ces que se hallaron a el fallescimiento del Presbítero /

D. Felipe Corchado, cavallero del Hávito de Santiago, /

Prior y Cura Párroco que fue en esta villa, la canti-/

dad de treinta y tres mil veinte y seis reales, salvo /

error, siendo los únicos que D. Manuel José Berciano /

y su esposa de esta vecindad, en cuya compañía vivie-/

ron en el día tenían noticia de ellos; vajo la protes- /

ta que hacían de incorporar en este ymbentario; cual-/

(Fol. 18v.) quiera otros que en lo sucesivo adquieran noticia de /

ellos; así lo declaran y aseguran y siendo necesario lo /

juran en legal forma; con lo cual se dio /

por finalizado este ymbentario que firmamos. Des- $/$

triana y octubre de tres de mil ochocientos y cuarenta y /

tres. $[\ldots]$

Manuel José Berciano (rúbrica), Eusevio Cansado López (rúbrica) 
Título: Inventario de los bienes que quedaron de Román Descosido

Tipo: inédito

Carácter: particular

Procedencia: Archivo Histórico Provincial de León

Signatura Caja 7632, sign. 2278

Folios: 164-167

Año: 1814

Lugar: Castrocalbón

Provincia: León

País: España

(Fol. 164v.) En la villa de Castrocalbón a ocho días del mes de ju / nio de mil ochocientos catorce años Diego Almanza y Juan /

Ravanedo vecinos della ynbentariadores y tasadores delos bie- /

nes que quedaron de Román Descosido difunto que fue desta /

vecindad en cumplimiento desu encargo por [........ pasa-/

ron a dar principio a dicho ymbentario poniendo en el con /

sus tasaciones por bienes propios del citado difunto los siguientes:

Vna arca vieja tasada en doce reales. I

Una caldera nueba en ciento y diez reales. /

Vn caldero mediano en veinte y cinco reales. /

Vna cazeta de azófar y un plato de madera en tres reales. /

Vn cántaro y una barrila en dos reales. I

Vna olla de periguela, una botija y una fiambrera en /

tres reales y medio. I

Vn pellejo de tener vino en diez reales. I

Dos jarros y un candil en tres reales. /

(Fol. 165r.) Vn escoplo grande y vna espita ynglesa en siete reales. /

Vn yugo sin arreos en ocho reales. I

Vn costal usado en nuebe reales. /

Otro y un cazo en onze reales. /

Un martillo y un cacho de planchón en cinco reales. /

Vn escañil viejo en seis reales. /

Un cacho de masera en tres reales. /

El lecho cotidiano con toda su ropa en ciento y ochenta reales. /

Una talega y un aro en tres reales y medio. /

Dos comederas en ocho reales. I

Dos argollas de yerro, dos gaxos, dos visagras y un /

candado en diez reales. I

Vn poco de yerro y una aldaba en ocho reales /

Una sartén en quatro reales. /

Dos libras de clabos de carro en seis reales. /

Una azada en de pino en seis reales. /

Tres ozes en seis reales. I

Un sobeo en zinco reales. /

Un peso de garfios en zinco reales. /

Una quilma vieja en tres reales. /

Un cesto y un paño viejo de ofrecer en quatro reales. I

Vna arca chica con zerradura y llabe en cincuenta reales. / 
Un mandil nuebo de pardo en veinte y dos reales. /

Vn chaleco de monfor azul en treinta reales. I

Una toca de tela con encajes en veinte reales. /

Tres baras de lienzo en veinte y quatro reales. /

Dos tocas de lienzo en veinte y cinco reales. /

Una mantilla pajiza en siete reales. /

Otra de serafina en veinte reales. /

Dos varas de pana negra en veinte y dos reales. /

Vnos manteles biejos con un poco de ylo blanco en ocho reales. I

Dos retazos de estameña azul en dos reales. /

Vn zadón de monte quebrado en cinco reales. /

Vn crivo y una palmatoria en ocho reales. I

Dos costales viejos en quinze reales. /

Un zesto tablizo y un banco en zinco reales. /

Una zesta de costura y un cesto en tres reales. /

Dos pañuelos de lienzo en quatro reales. /

Una camisa usada de mujer y otra vieja en onze reales. /

(Fol. 165v.) Una vara de lienzo y unas medias en once reales. /

Una camastra bieja y un zernadero en real y medio. /

Tres camisas viejas de hombre en nuebe reales. /

Dos camisas de muger en diez y seis reales. /

Otras dos de hombre en veinte y cinco reales. /

Una camastra nueba en cinco reales. I

Unas medias en tres reales. I

Dos fiteras y una espadilla en seis reales. /

Un talegón de mimbre en tres reales. I

Una mantilla de pardo en treinta y dos reales. /

Un poco de pardo en treinta y cuatro reales. /

Vna mantilla de astudillo en veinte y dos reales. /

Unas polaynas nuebas en doce reales. I

Vnos calzones nuebos en veinte y dos reales. /

Vna anguarina buena en sesenta reales. /

Vna capa de [...] en ciento y diez reales. /

Una mantilla usada y otra vieja en veinte y ocho reales. /

Tres costales usados en quarenta y cinco reales. /

Dos prisiones en seis reales. /

Una vilda en tres reales. I

Un pesebre y un pilonico en cuatro reales. /

Vna pala tornadera y un banquito en tres reales y medio. /

Un machado y una azuela en trece reales. /

Vn dogal nuevo en doze reales. I

Vna prisión en tres reales. I

Una arca de varillas y un vildo viejo en tres reales. I

Seis manizos de lino en ciento y veinte reales. I

Quatro palos para [...] en seis reales. I

Dos docenas de tablas de chopo en doscientos reales. I

Diez y seis tablas en sesenta y cuatro reales. I

Una porción de [...] en veinte reales. /

Una ceranda, digo dos jubones viejos y una anguarina / 
quinze reales./

(Fol. 166r.) Dos jubones en treinta reales. /

Tres armadores en diez y seis reales. /

Unos calzones usados en siete reales. /

Tres justillos de estameña en catorce reales. /

Unos calzones muy biejos y un talegón en cinco reales y medio. I

Vn batiente y dos tablas [...] en cinco reales. /

Un palo de roble y un pilón en dos reales. I

Ciento treinta y seis clabos de [...] en diez y seis reales. /

Cinco tablas en catorce reales. /

Vn pilón en tres reales. I

Vn trillo en veinte y cinco reales. /

Un roldo y dos palos de chopo en seis reales. /

Tres segunderas y dos palos de roble en doze reales. /

Vna viga de chopo en diez reales. I

Un azadón con reja en doze reales. /

Una porción de maderos que [...] que hay en el /

corral de la casa en veinte y dos reales. I

La leña y madera de los tenados en veinte y dos reales. /

Todo el abono que havía en la casa a la muerte del difunto /

en ochenta reales. I

Una emina de guisantes en veinte y dos reales. /

Ocho eminas de trigo en ochenta reales. I

Nuebe eminas de linaza a treinta y tres reales cada una. /

Un [...] viejo y un pilón chico en tres reales. /

Vna marrana mediana en ciento y treinta reales. I

Una mesa vieja en seis reales. /

Una quilma vieja y una cencerra en quatro reales. /

Quatro gallinas en treinta y dos reales. /

Ueinte libras de lana negra y blanca en sesenta reales. /

Ueinte libras de tocino en ochenta reales. /

(Fol. 166v.) Libra y media de manteca en dos reales. /

Libra y media de longaniza en siete reales y medio. /

Veinte libras de lino en ochenta reales. /

Un jato de dos años vendido en quinientos y cincuenta reales. /

Vnas ruedas nuevas de carro herradas en quinientos reales. /

Unas costanas de tabla en diez seis reales. /

Unas pernillas grandes en seis reales. /

Quatro maderos de encina y roble en diez reales. I

Seis cabezas de ganado cabrio incluida una cría en trescien- /

tos y diez reales. I

Ocho cabezas de ganado lanar con cinco crías a seis duca- /

dos cada cabeza son quinientos veinte y ocho reales. I

Una trasga de yerro quebrada con su cacho de sobeyuelo y un /

dogal en nuebe reales. I

Vn yugo con cornales y mullidas en veinte y dos reales. /

Vn arado con su rexa en diez y seis reales. I

Vna baca de quatro para cinco años en ochocientos reales. / 
Otra con su ternero en ochocientos reales. I

La mitad de tres roldos y una viga de chopo en /

cinquenta y cinco reales todo que son 7

Tres pies de chopo en la huerta de Manuel Descosido /

en veinte y ocho reales. /

Vn taburete en quatro reales. /

Vna orona grande con tapa en diez reales. /

Vn manteo de paño nuevo con rodapisa encarnada en /

sesenta y ocho reales. I

Vna mantilla de paño negro en cincuenta reales. /

Vn mandil de astudillo bordado con seda en veinte y seis reales. /

Vn jubón de pardo también bordado en veinte y dos reales. /

Vn justillo nuevo de [...] en veinte y dos reales. /

Vna montera de paño en ocho reales. /

Vna buelta de corales con quatro abellanas quatro al- /

conciles y su cruceta de plata en treinta y dos reales. /

Vna cruz de plata en veinte y ocho reales. I

Vn joel de plata en sesenta reales. I

Vnas arracadas, unas [...] y una sortija de plata /

en veinte y ocho reales. /

(Fol. 167r.) La casa de la habitación de dicho difunto que está en / casco de esta villa y barrio de [...] a la salida /

para la cuesta de [...] que se compone de cinco vigadas /

de alto cubiertas de teja sin piso lo alto, su [...] /

corredor, corral y puertas grandes de calle linda al /

norte tierra y casa de Josef Rebordinos, al poniente con /

huerta de Manuel Descosido, y frenta al mediodía en /

calle pública tasada en dos mil y setecientos reales /

Vna huerta que ha sido casa al sitio de la plaza, hará /

cinco celemines de trigo, linda al poniente con huerta de /

Manuel Descosido, al norte con calle que ba a la plaza, y /

frenta al norte en huerto de Don Antonio Mayo, cuya /

huerta es forera al mayorazgo de Melguero de la /

Bañeza a quien corresponde el derecho dominio y por /

su canon se le ha de pagar en cada año la sesta parte /

de ocho eminas y media de centeno, tasada en mil y cien reales /

Y por oy dicho ser tarde se cesó en este ymbentario /

con $[\ldots]$ de seguir en él siempre que combenga, firma- /

ronlo los ymbentariadores de que doy fe. /

Diego de Almanza (rúbrica), Juan Ravanedo (rúbrica), Ramón Calabozo (rúbrica) 
ANEXO DOCUMENTAL FOTOGRÁFICO 


\section{Inventario de La Bañeza, 1641}
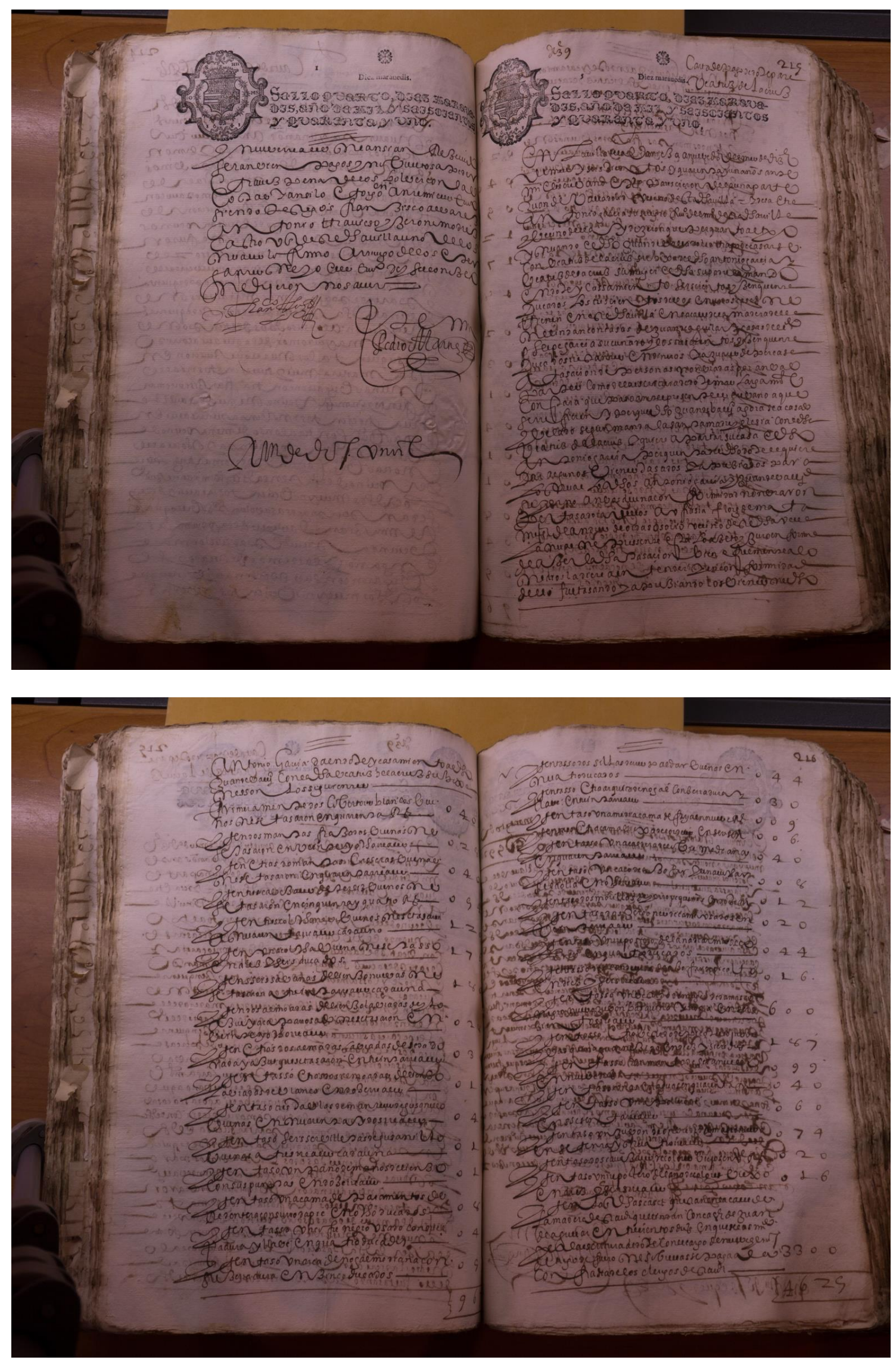


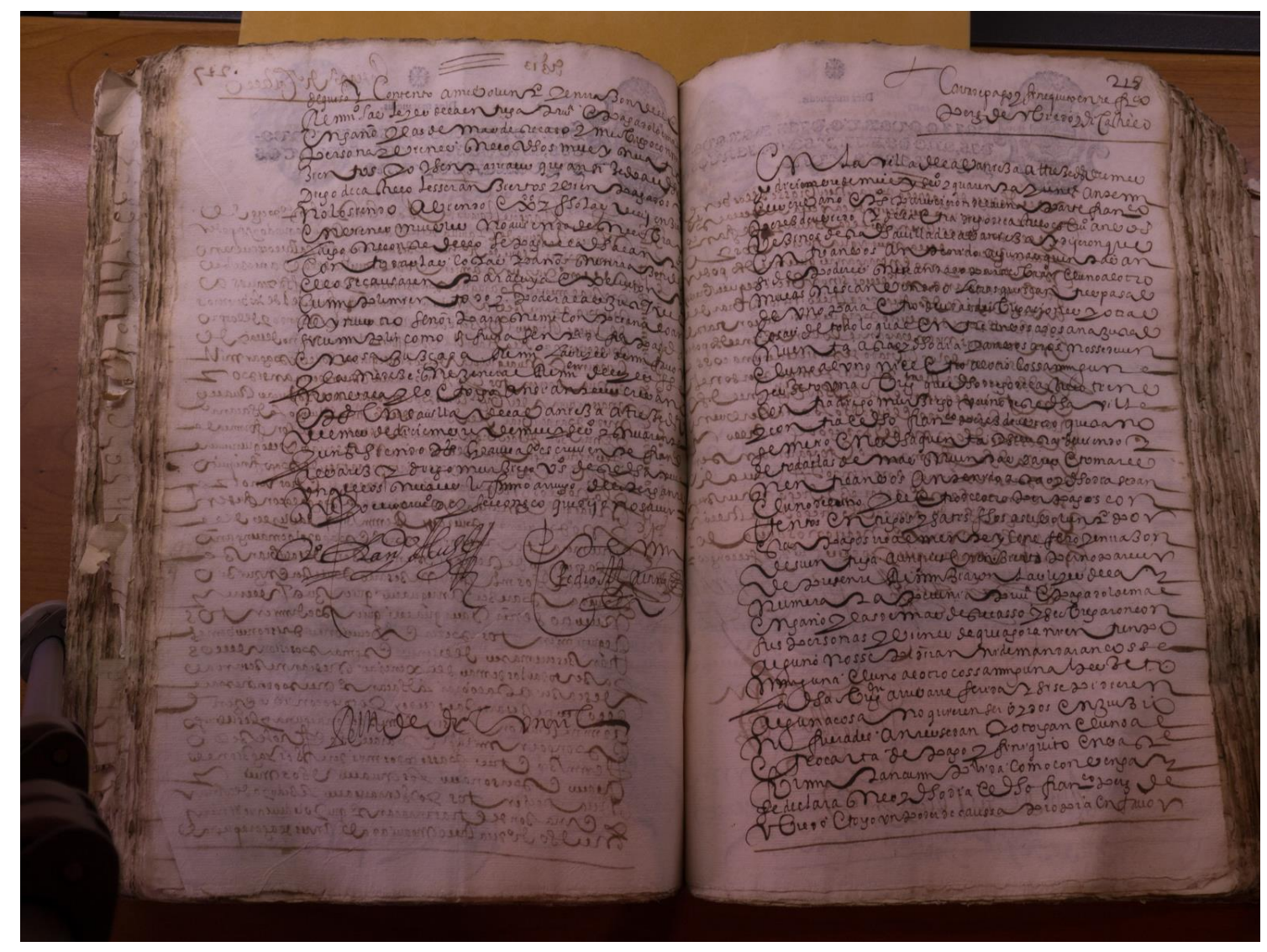


Inventario de Coomonte de la Vega, 1645
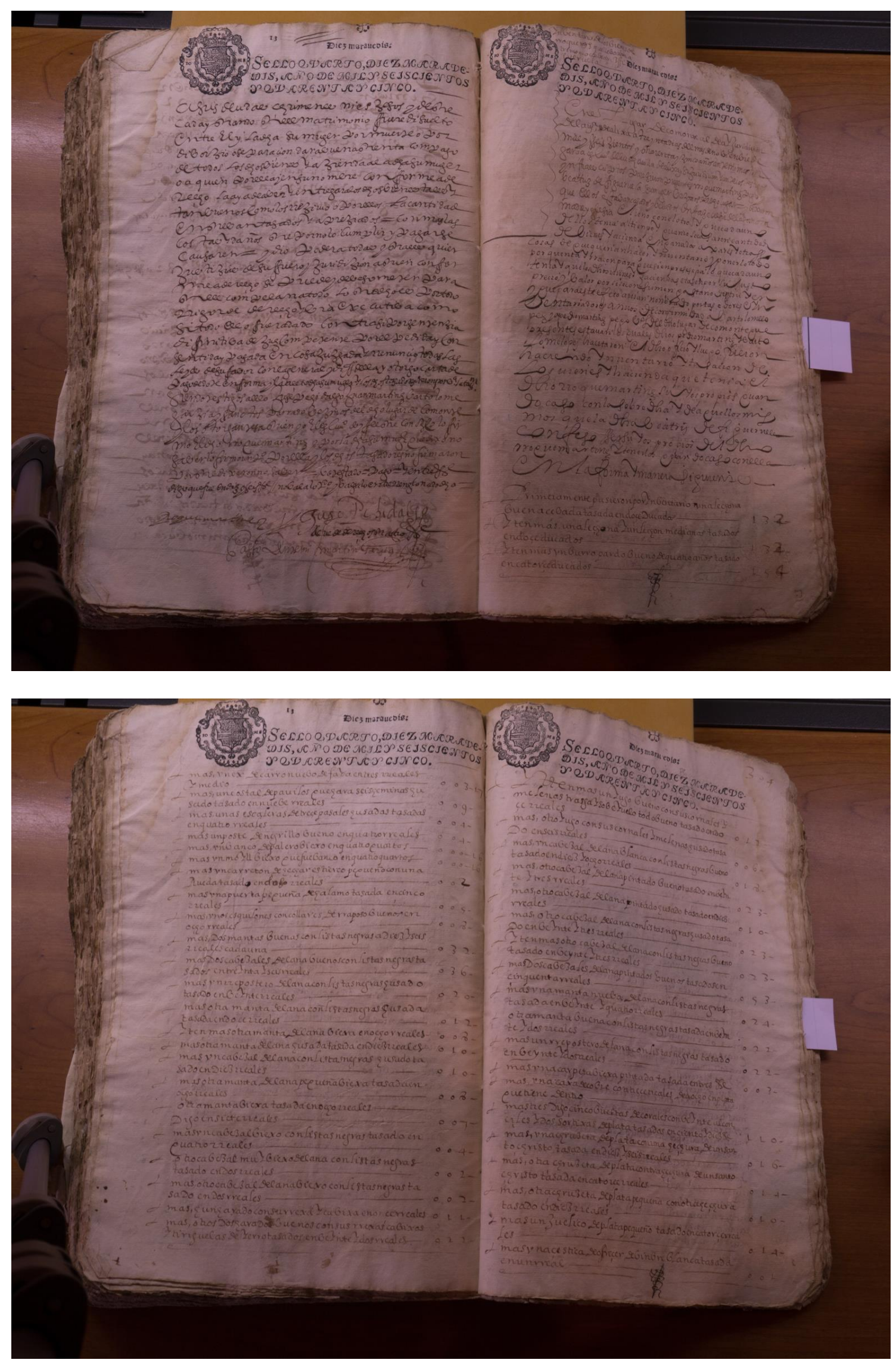

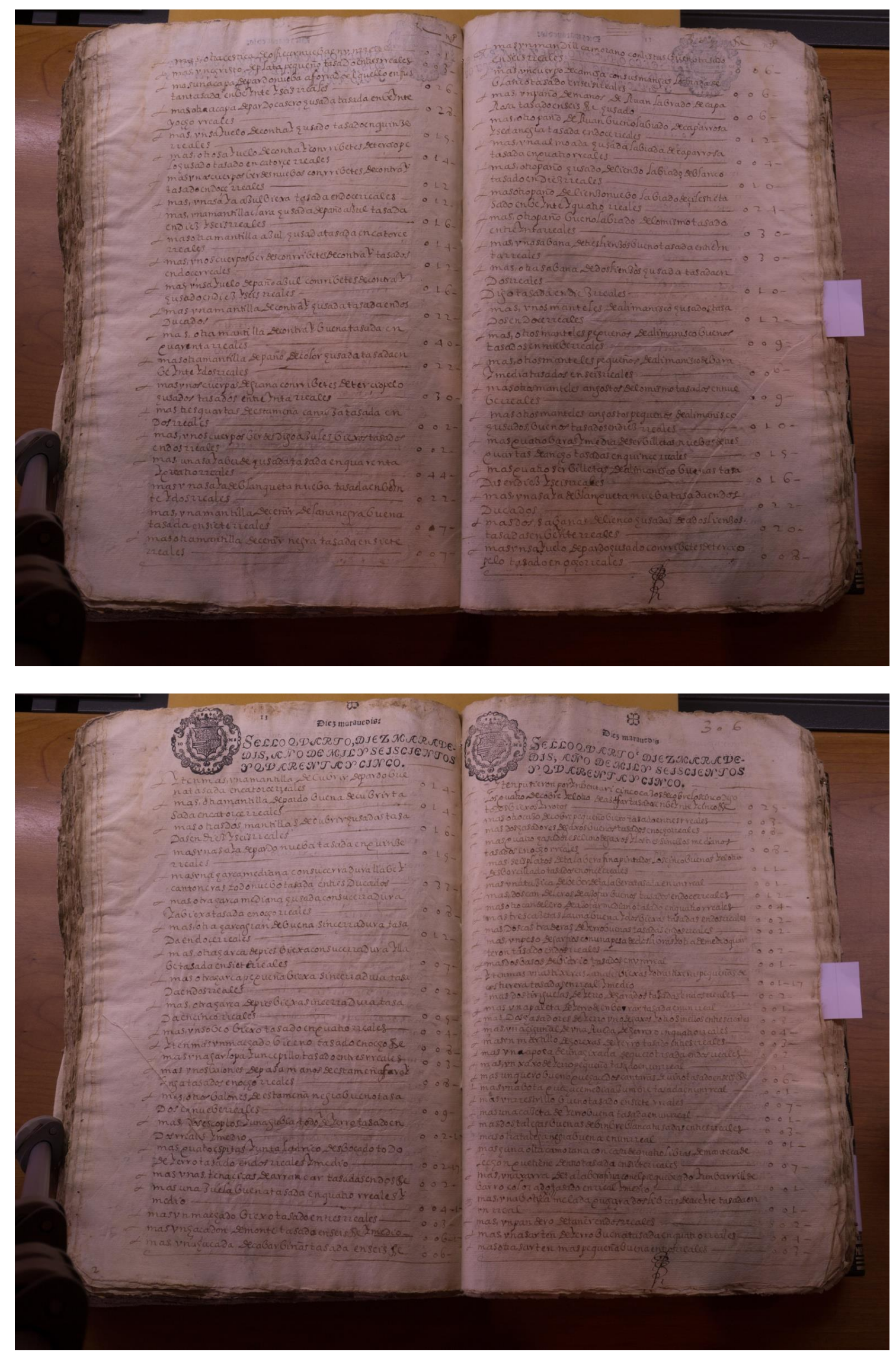

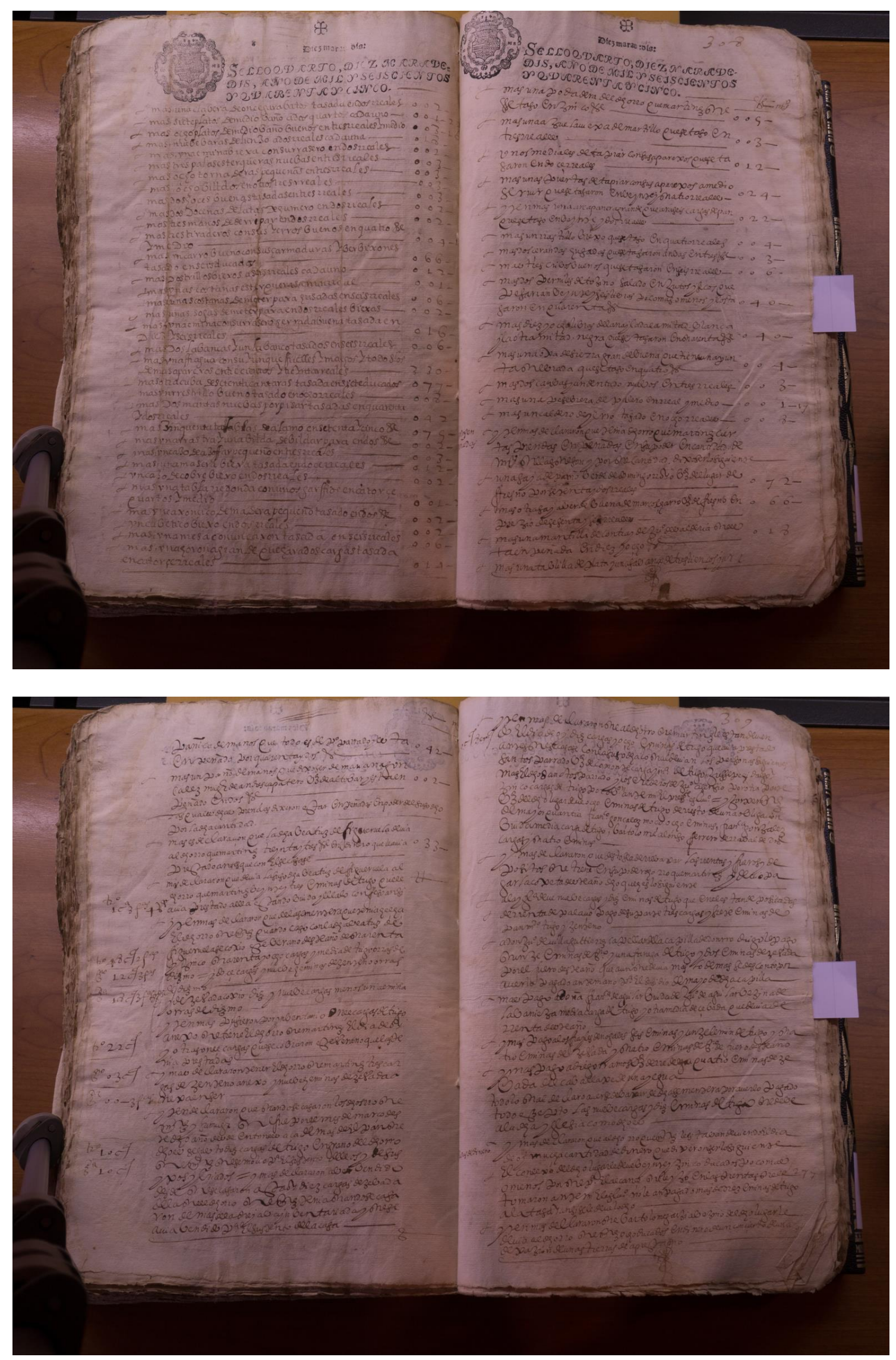


\section{Inventario de Valdejamuz, 1645}
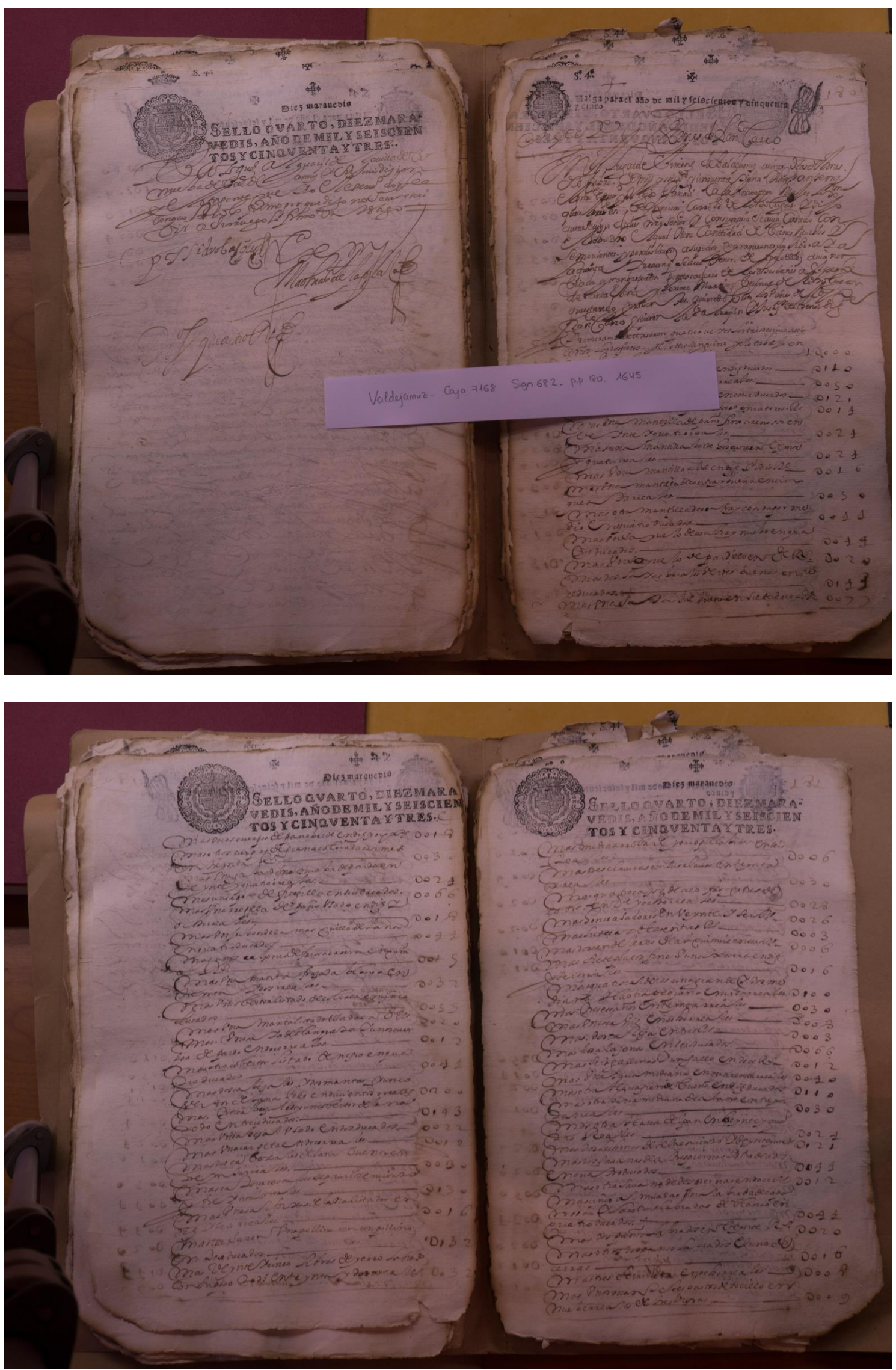


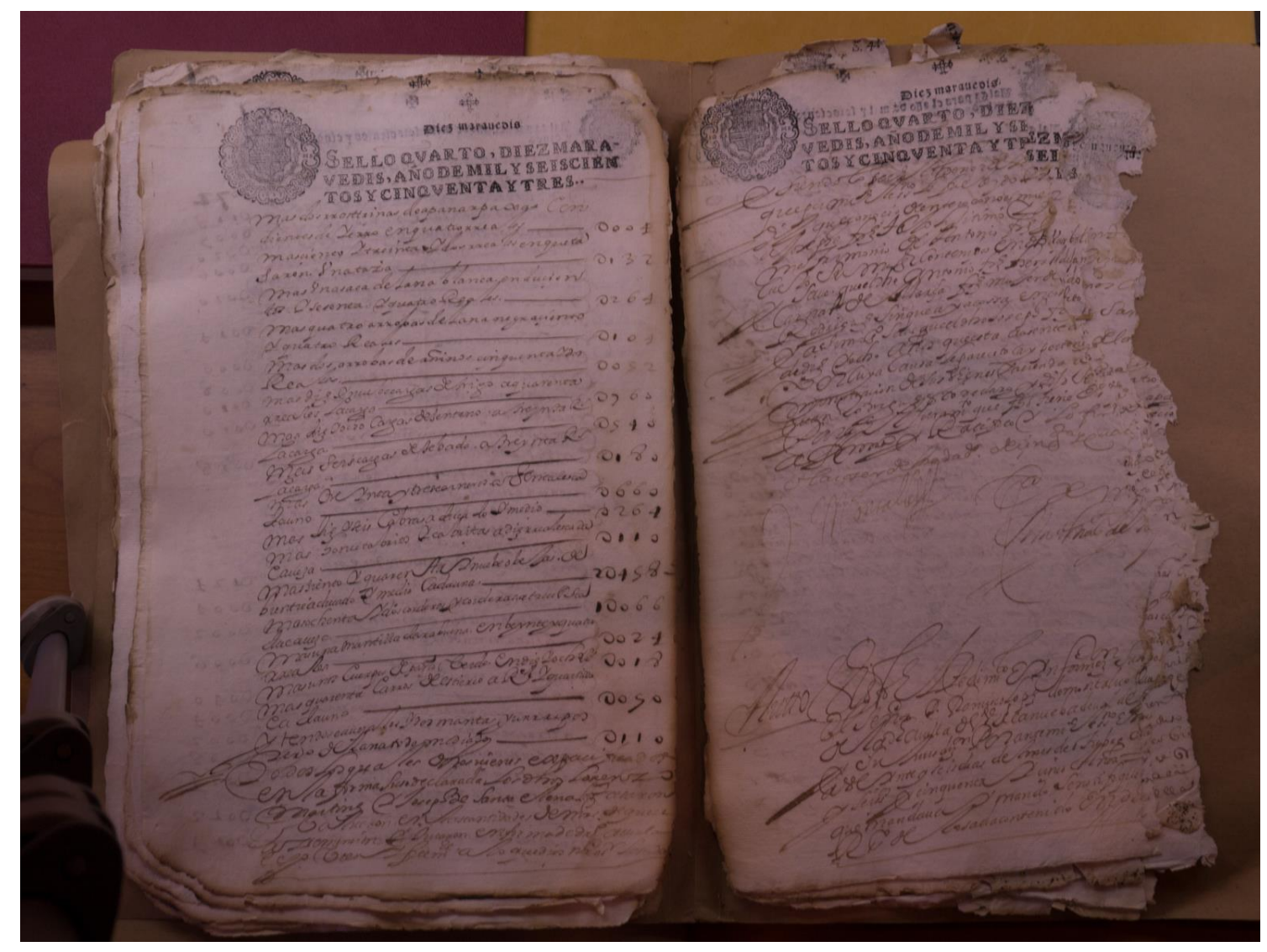




\section{Inventario de La Bañeza, 1712}
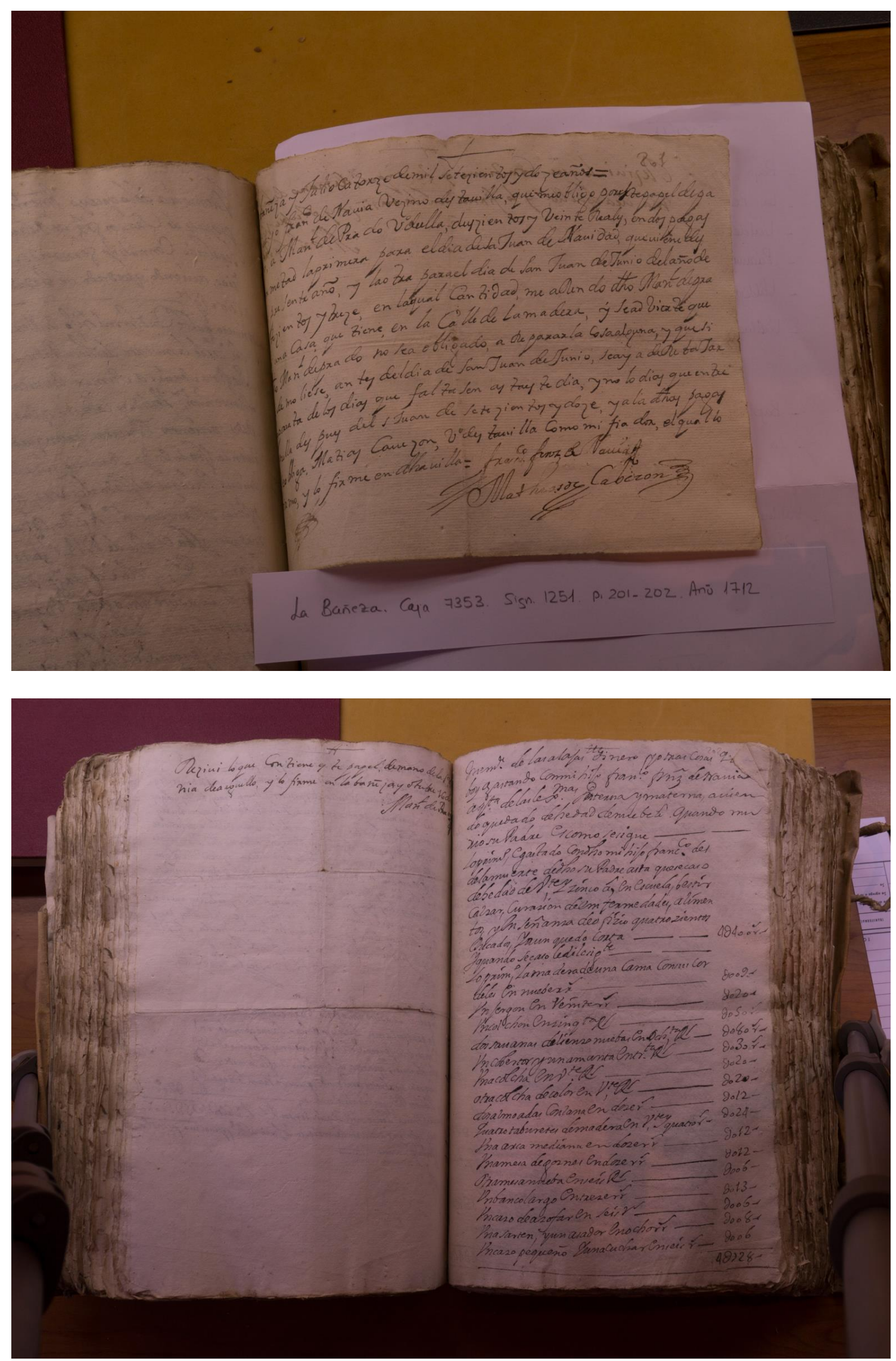


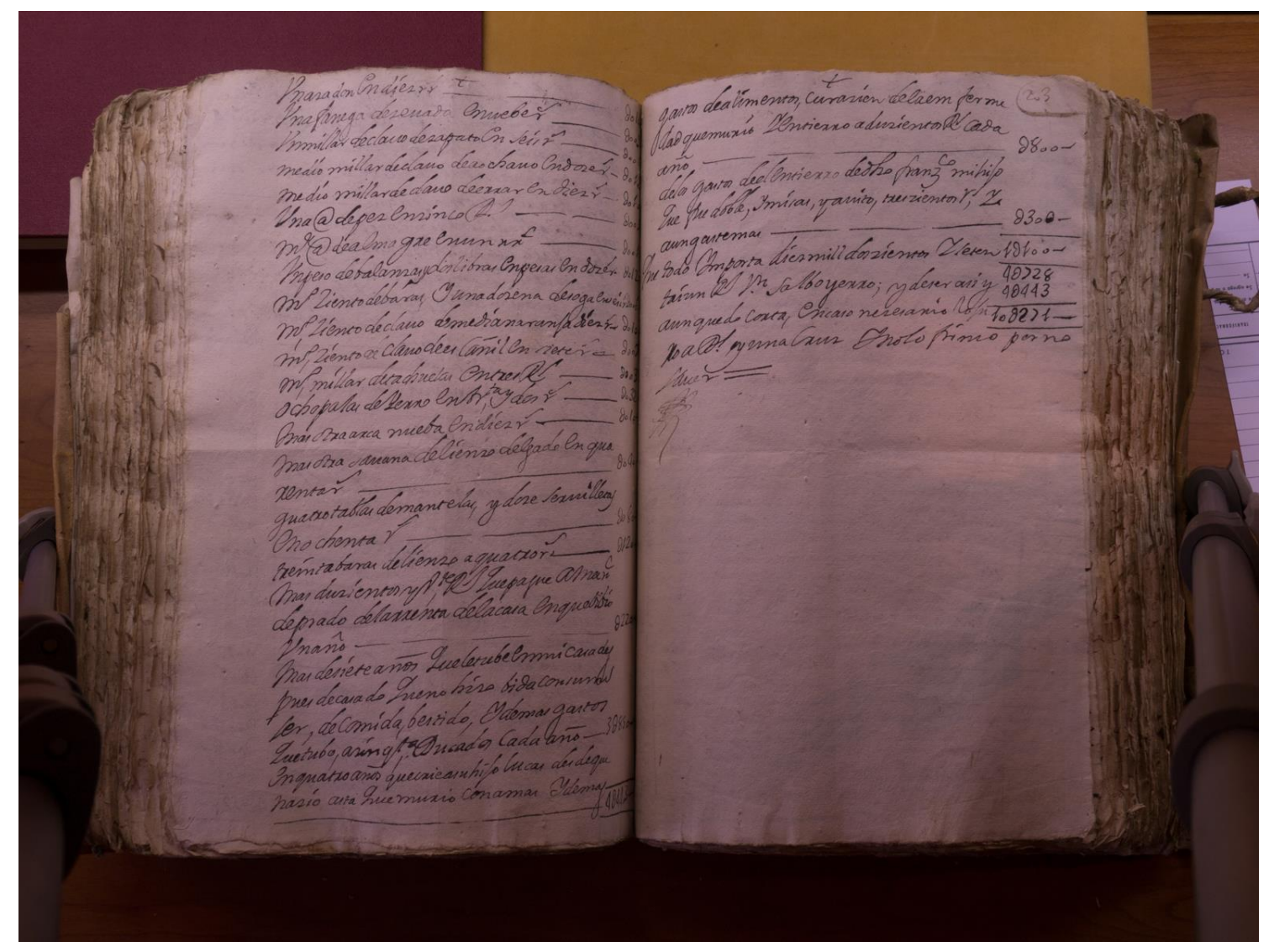


Inventario de Robledo de La Valduerna, 1726
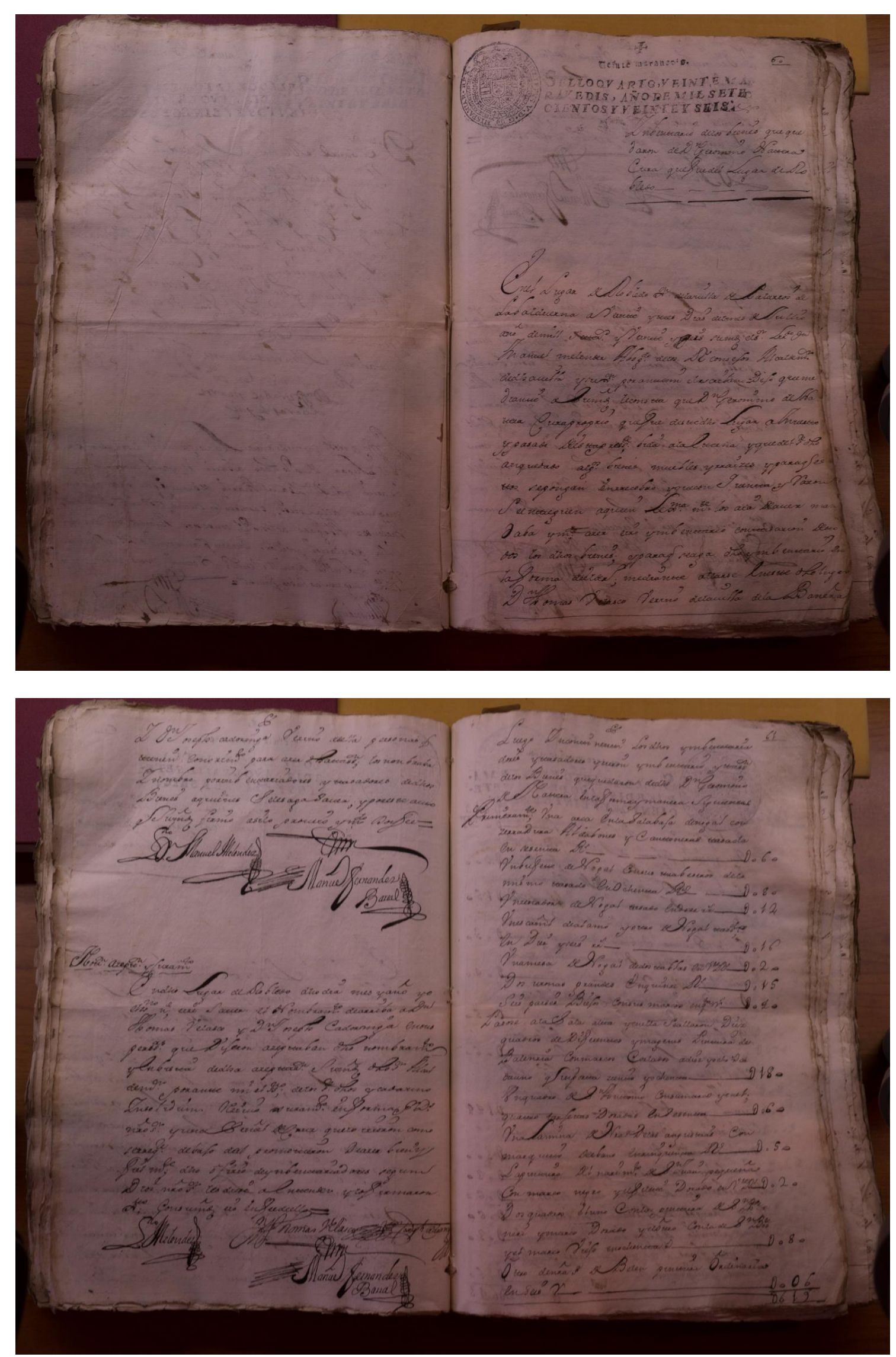

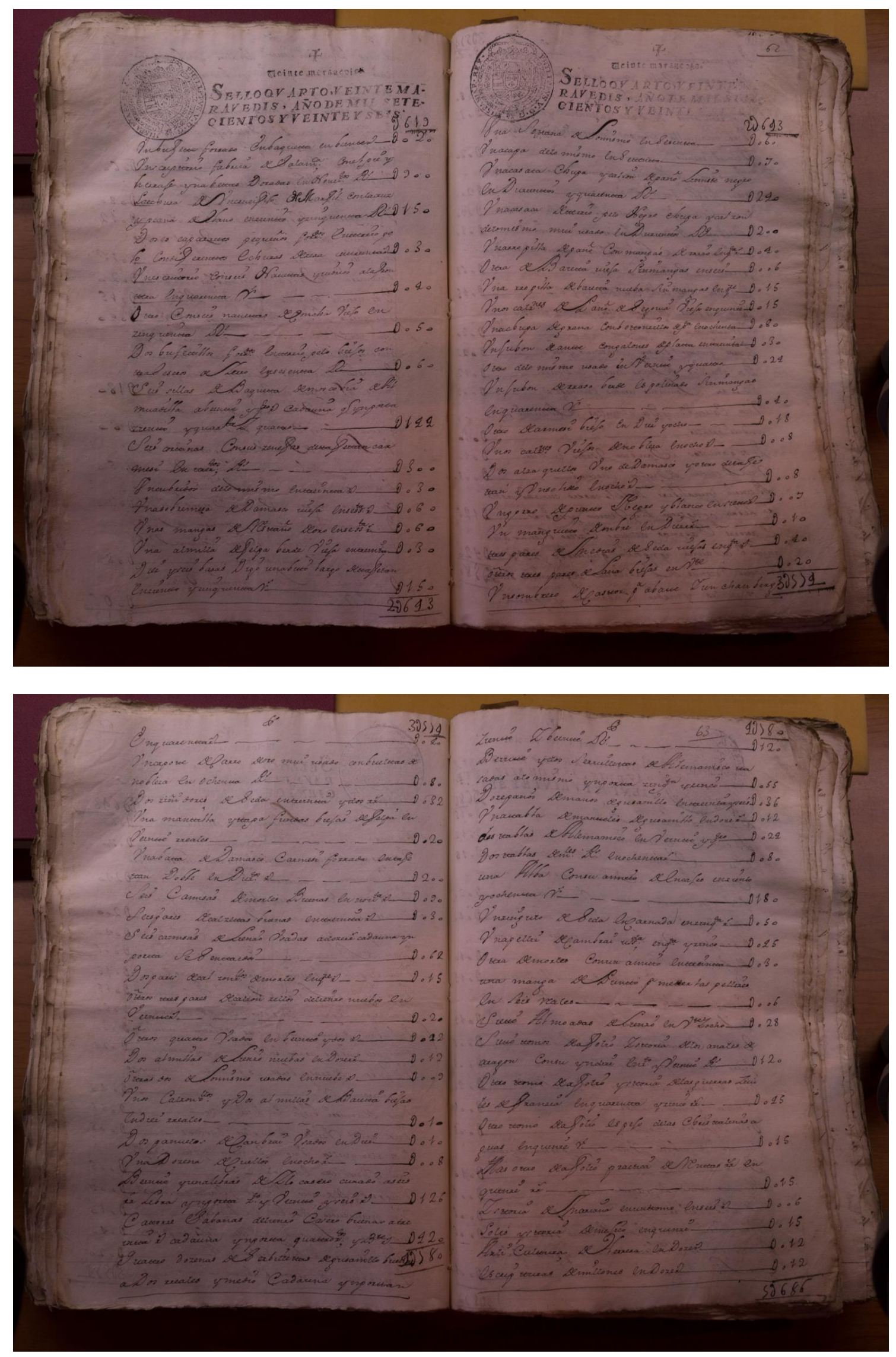

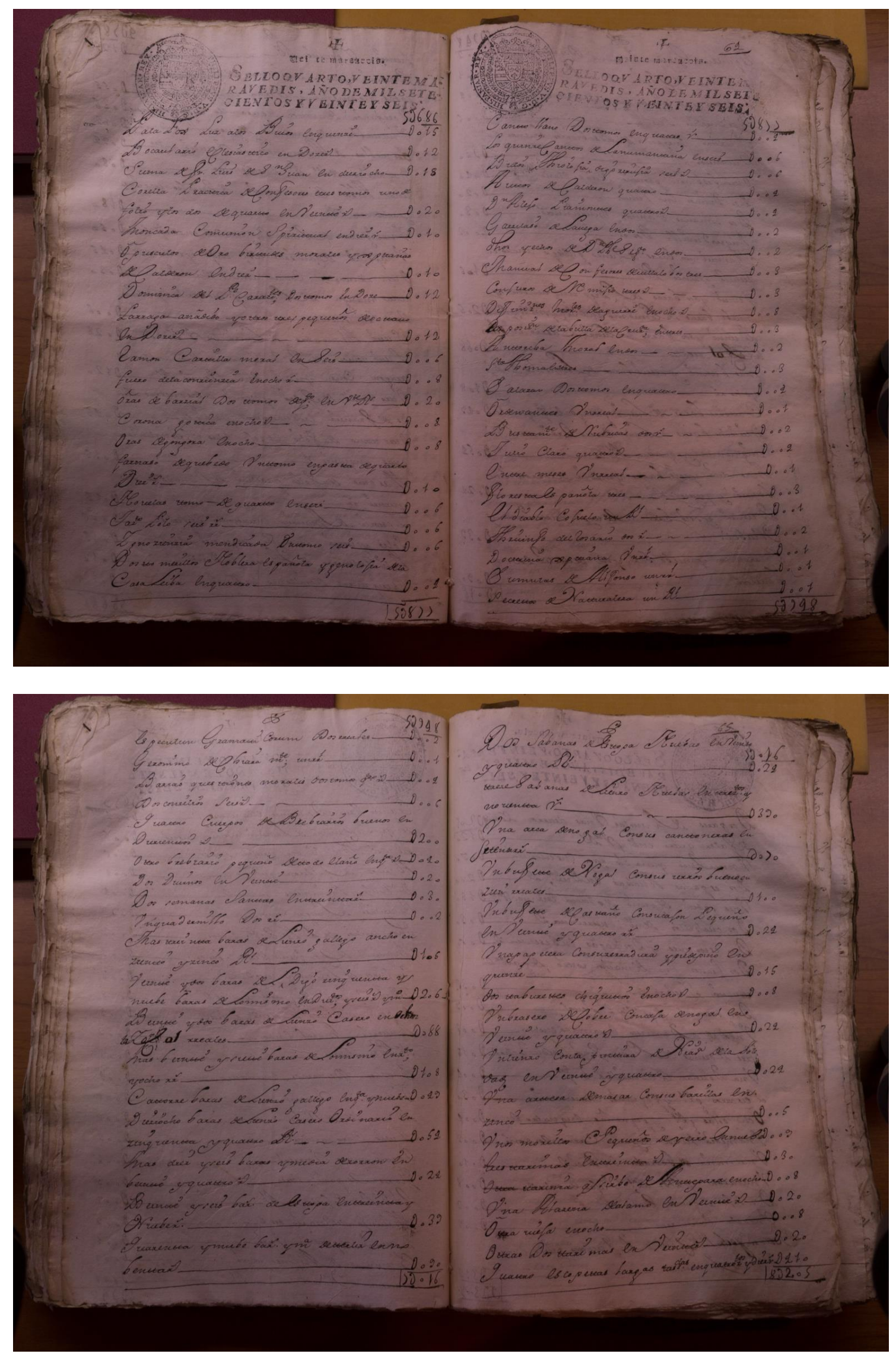

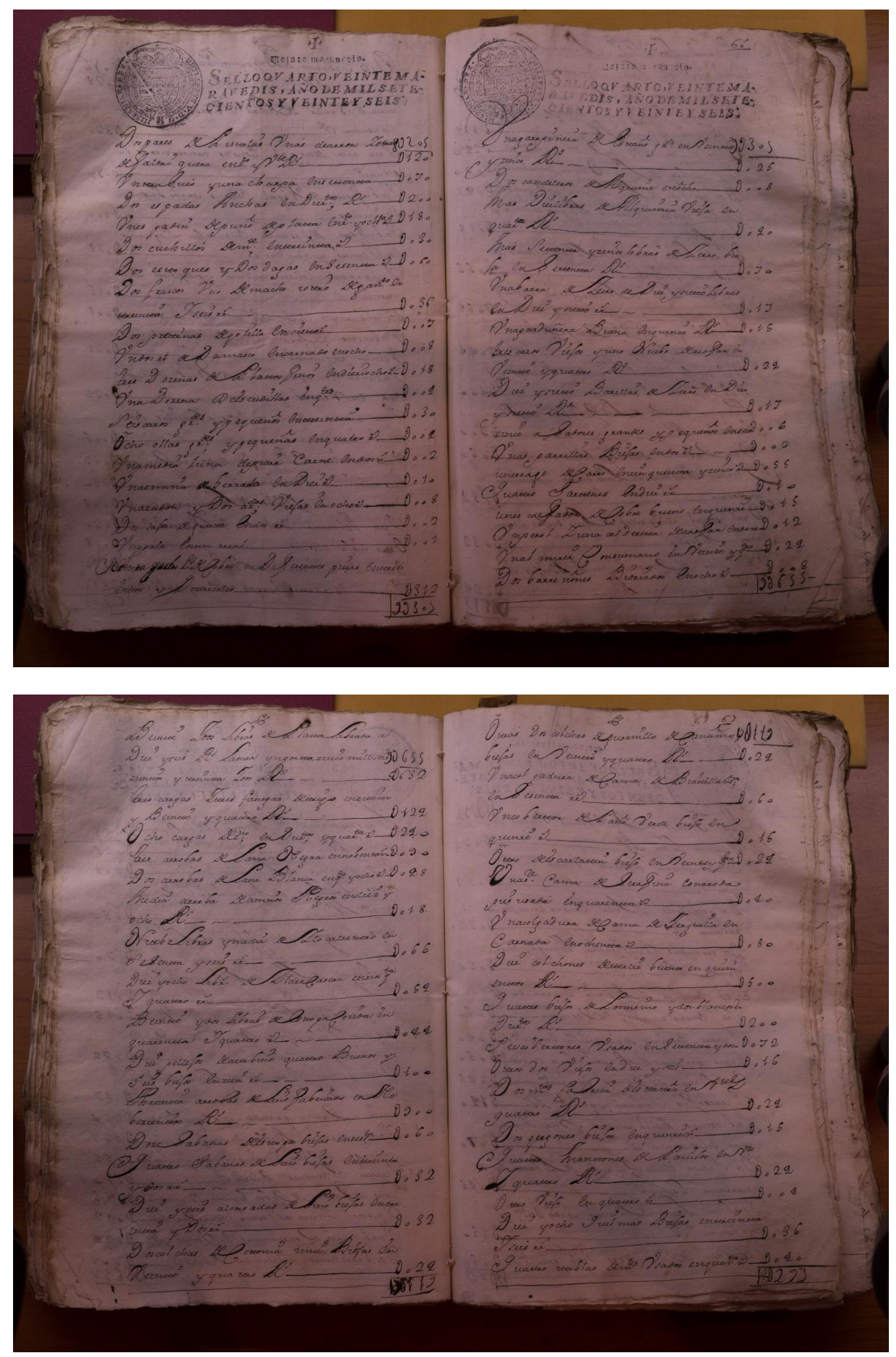

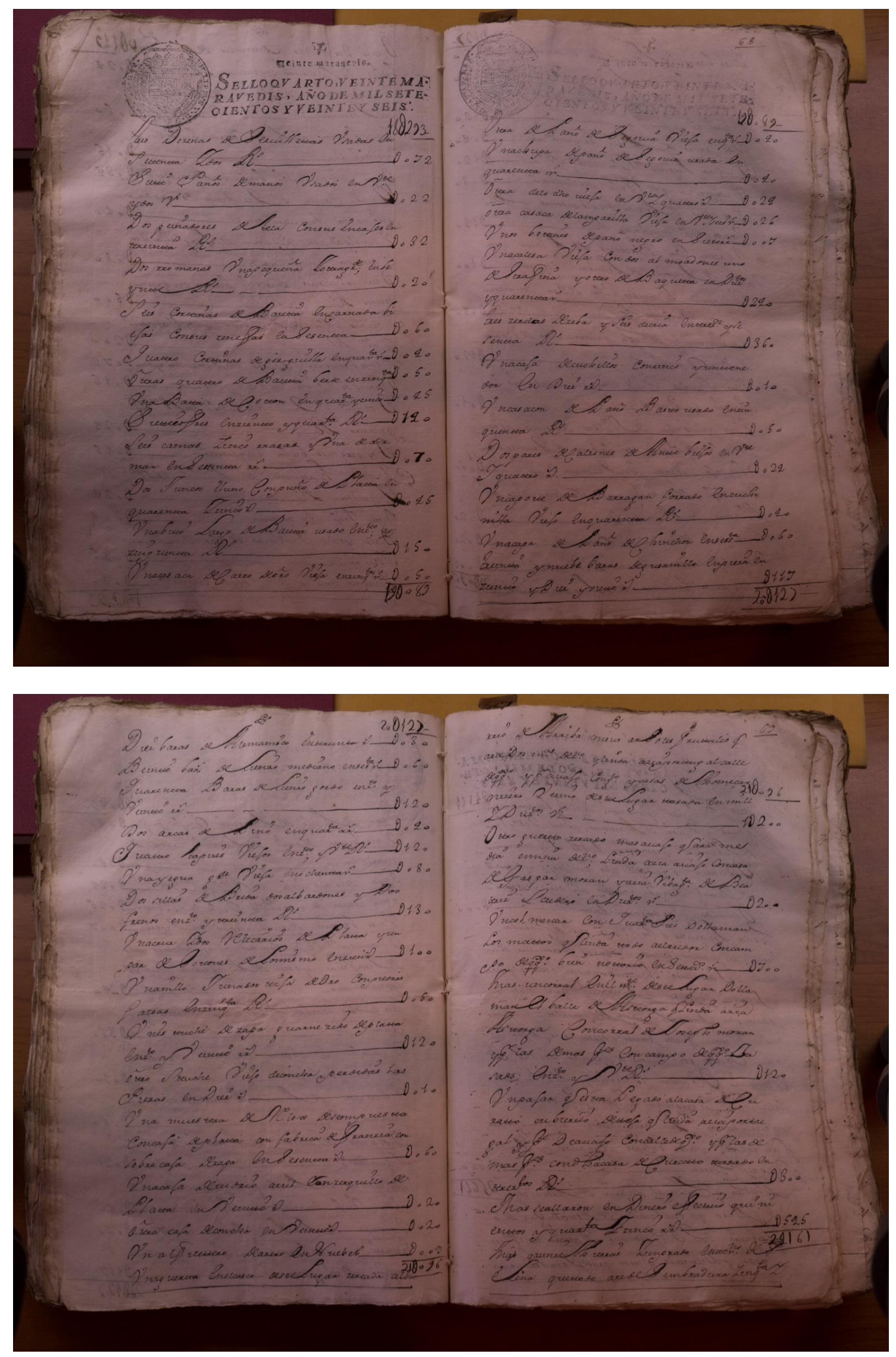

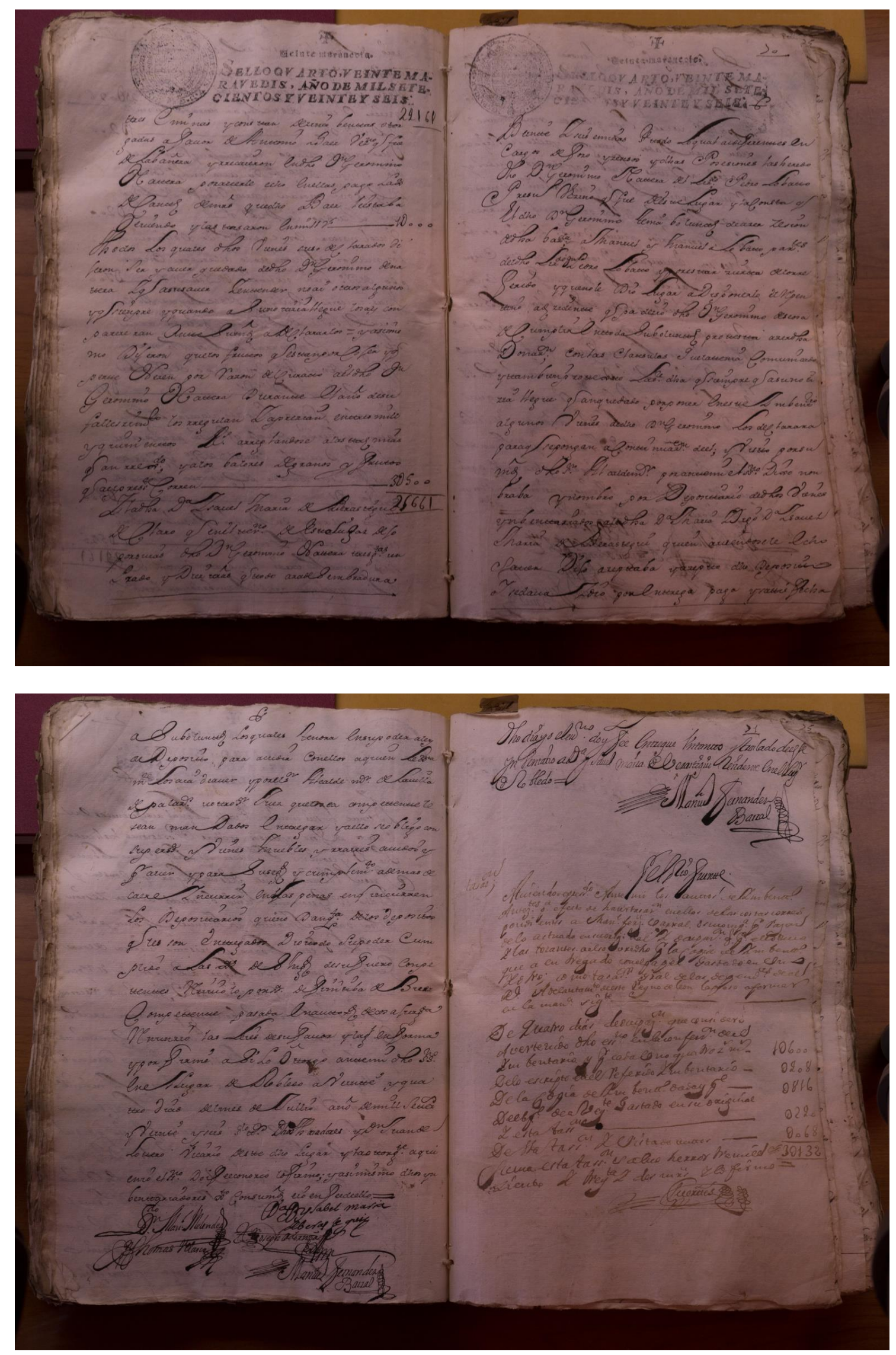
Inventario de Laguna de Negrillos, 1734
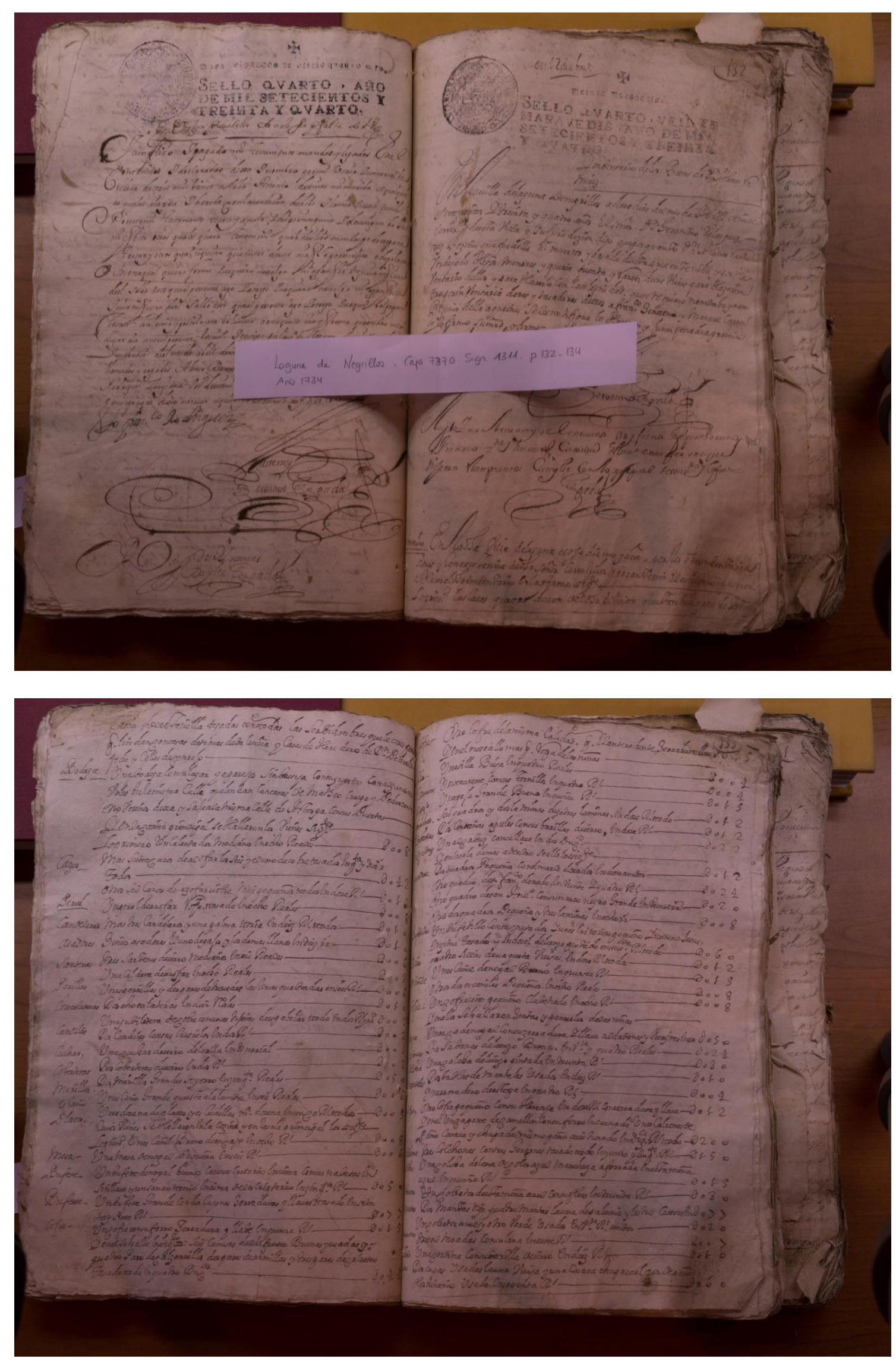

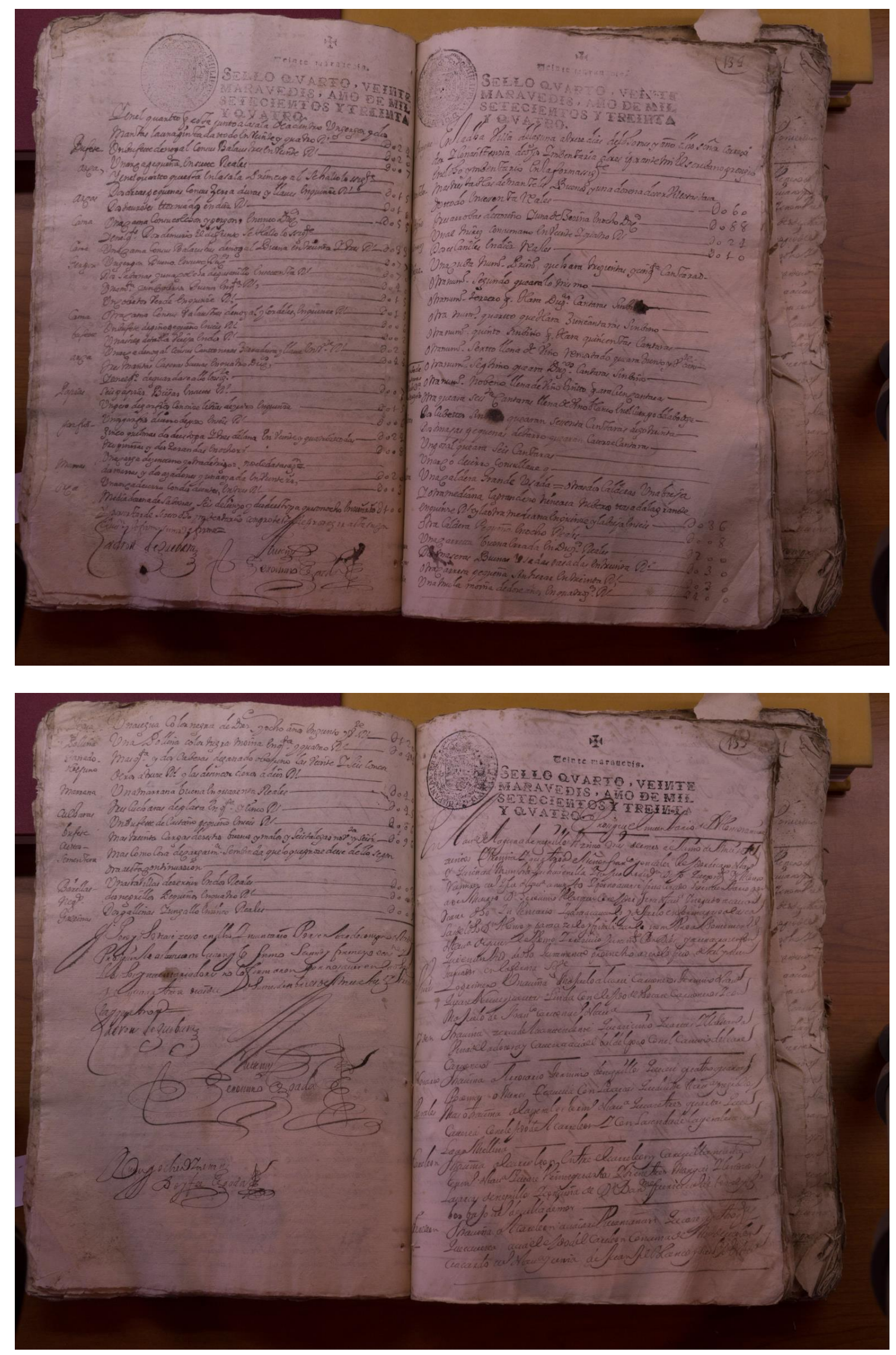
Inventario de Genestacio de la Vega, 1735
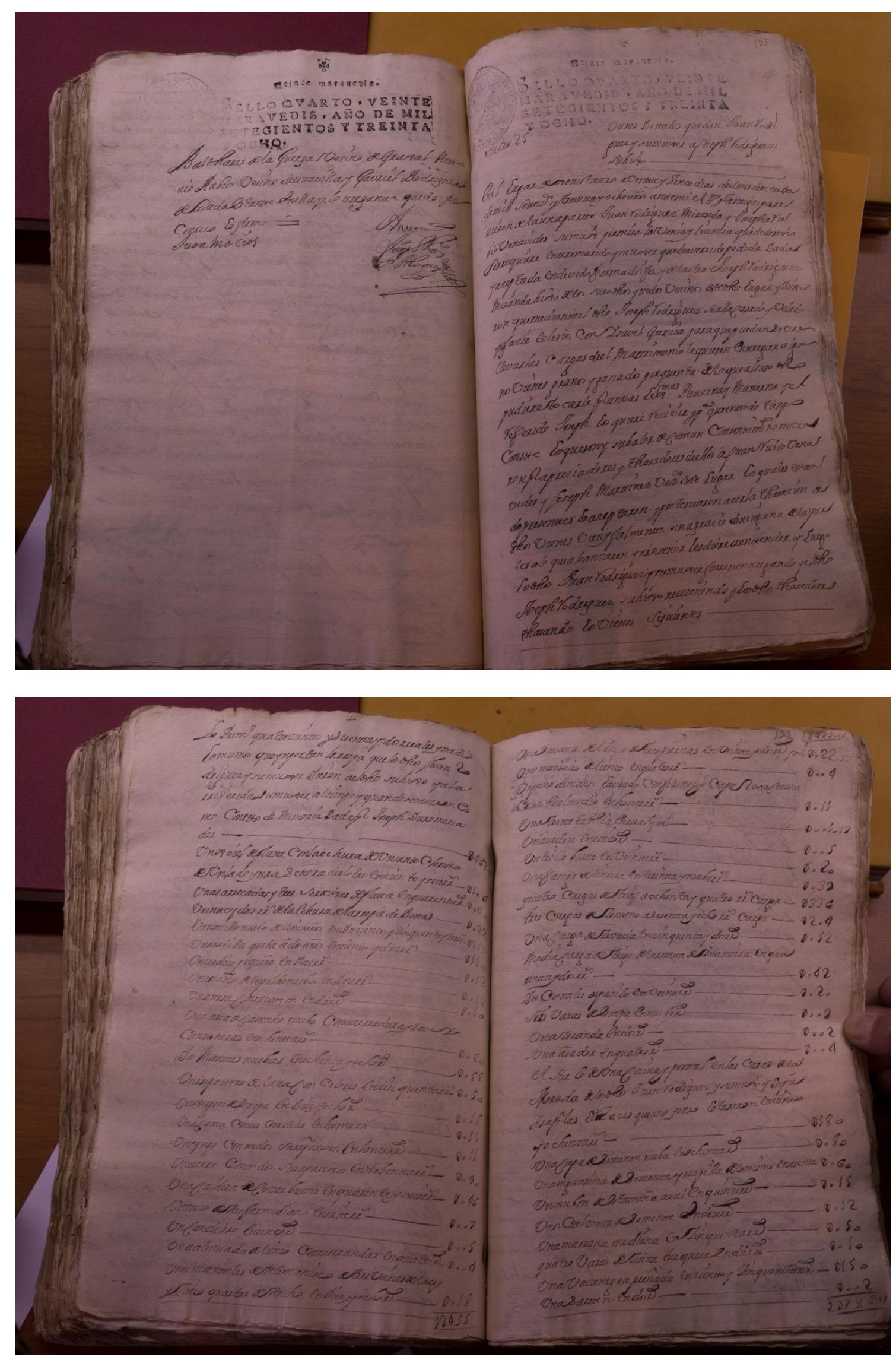

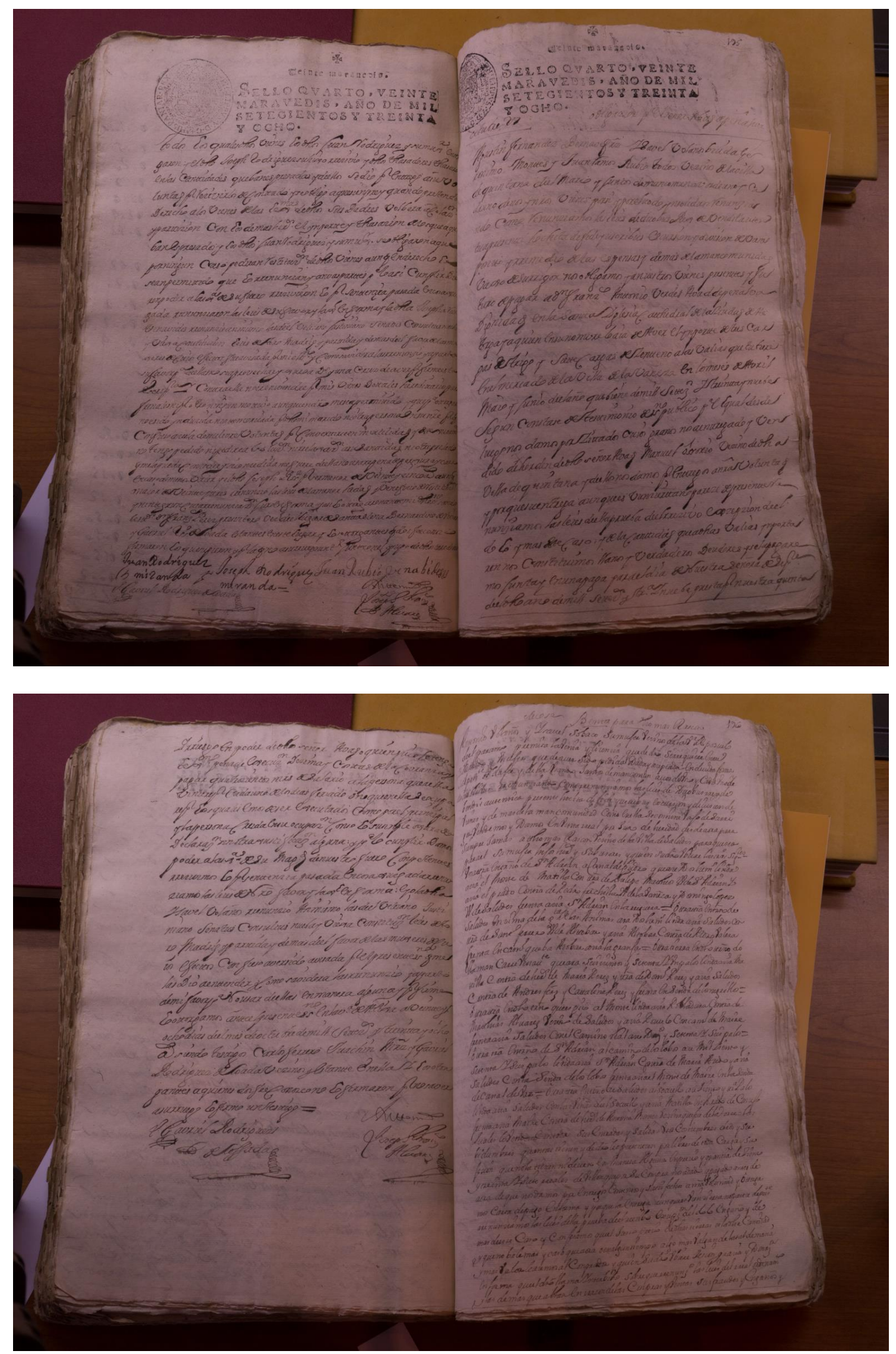
Inventario de Requejo de la Vega, 1839
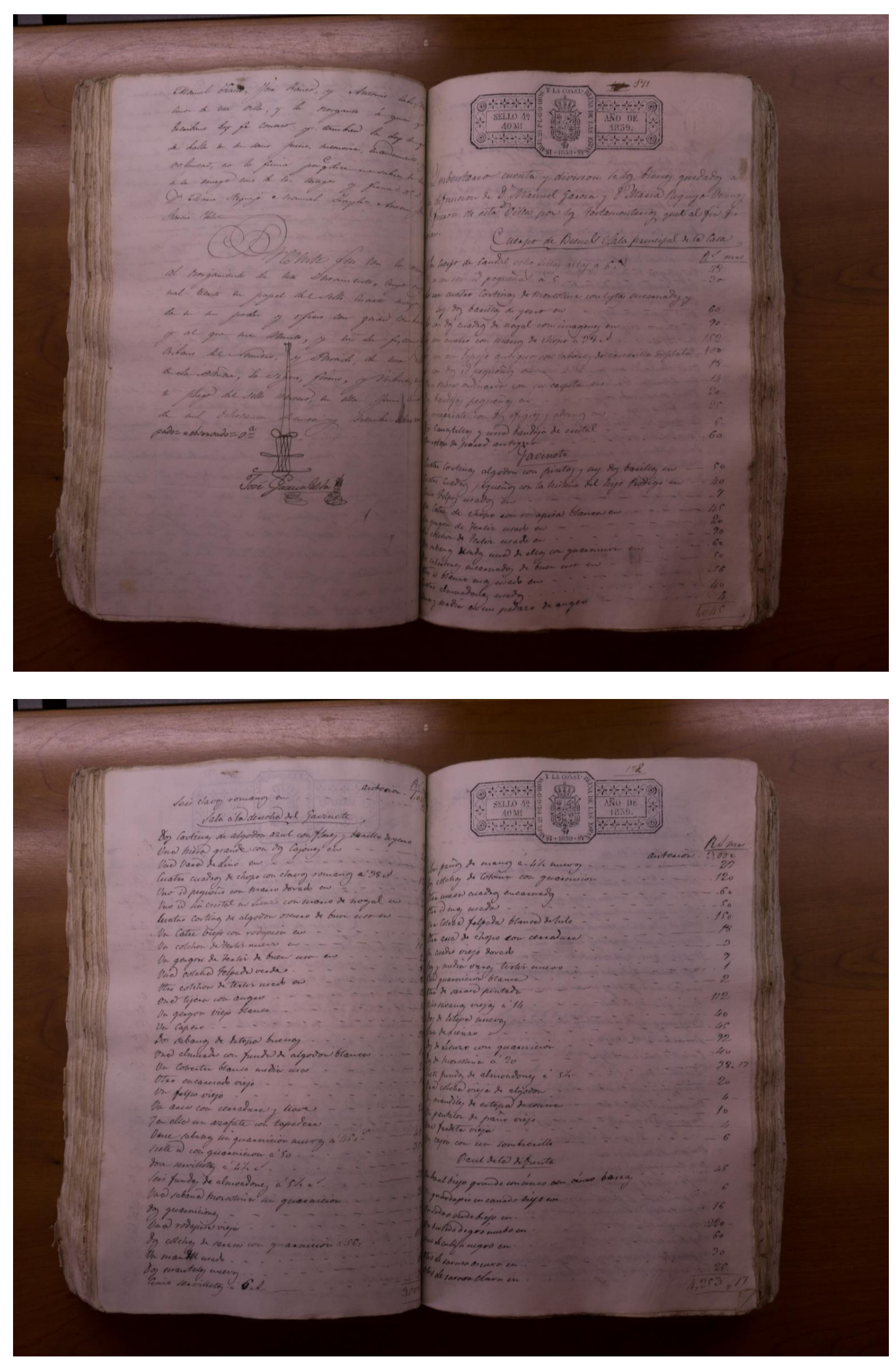

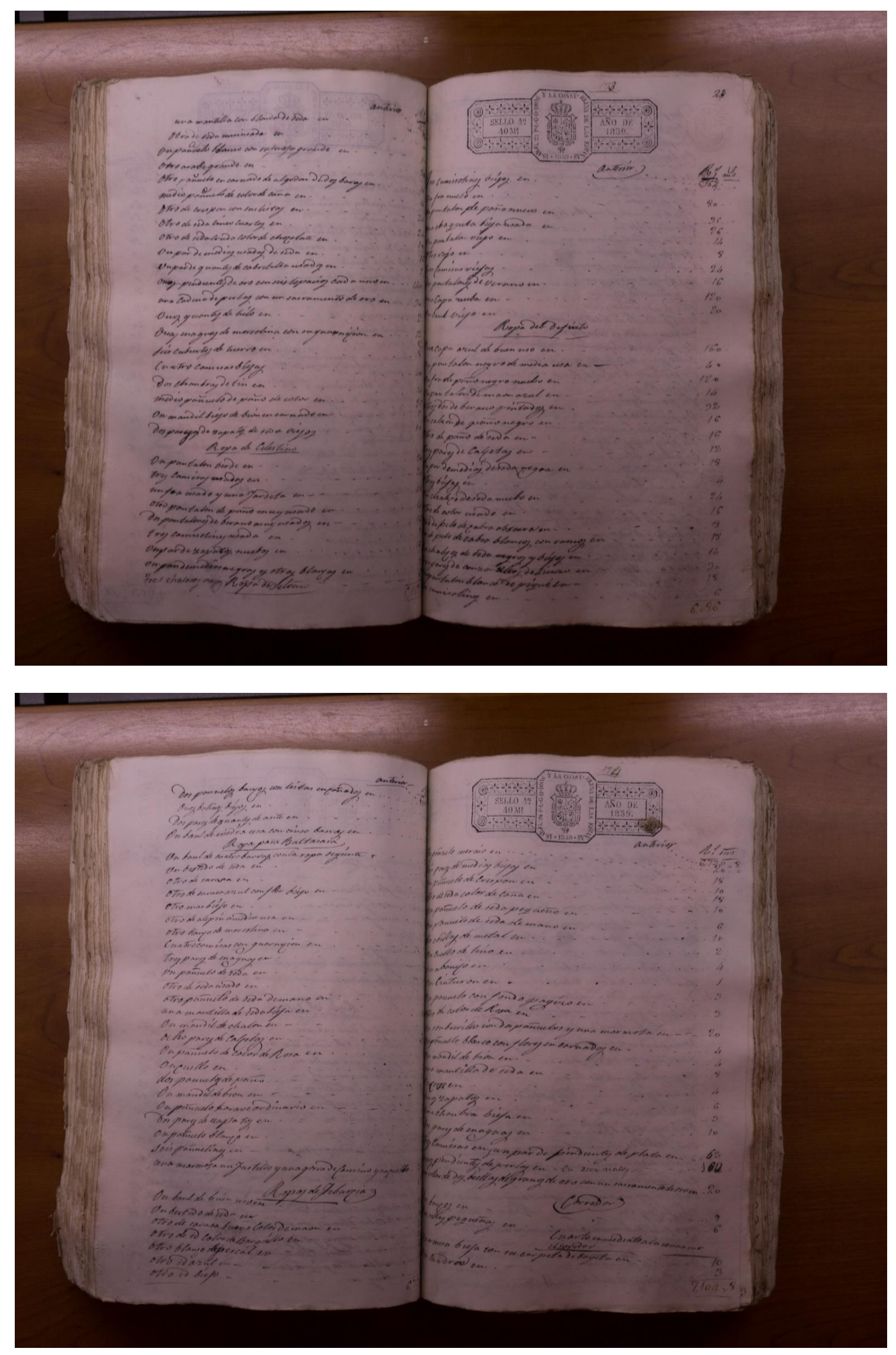

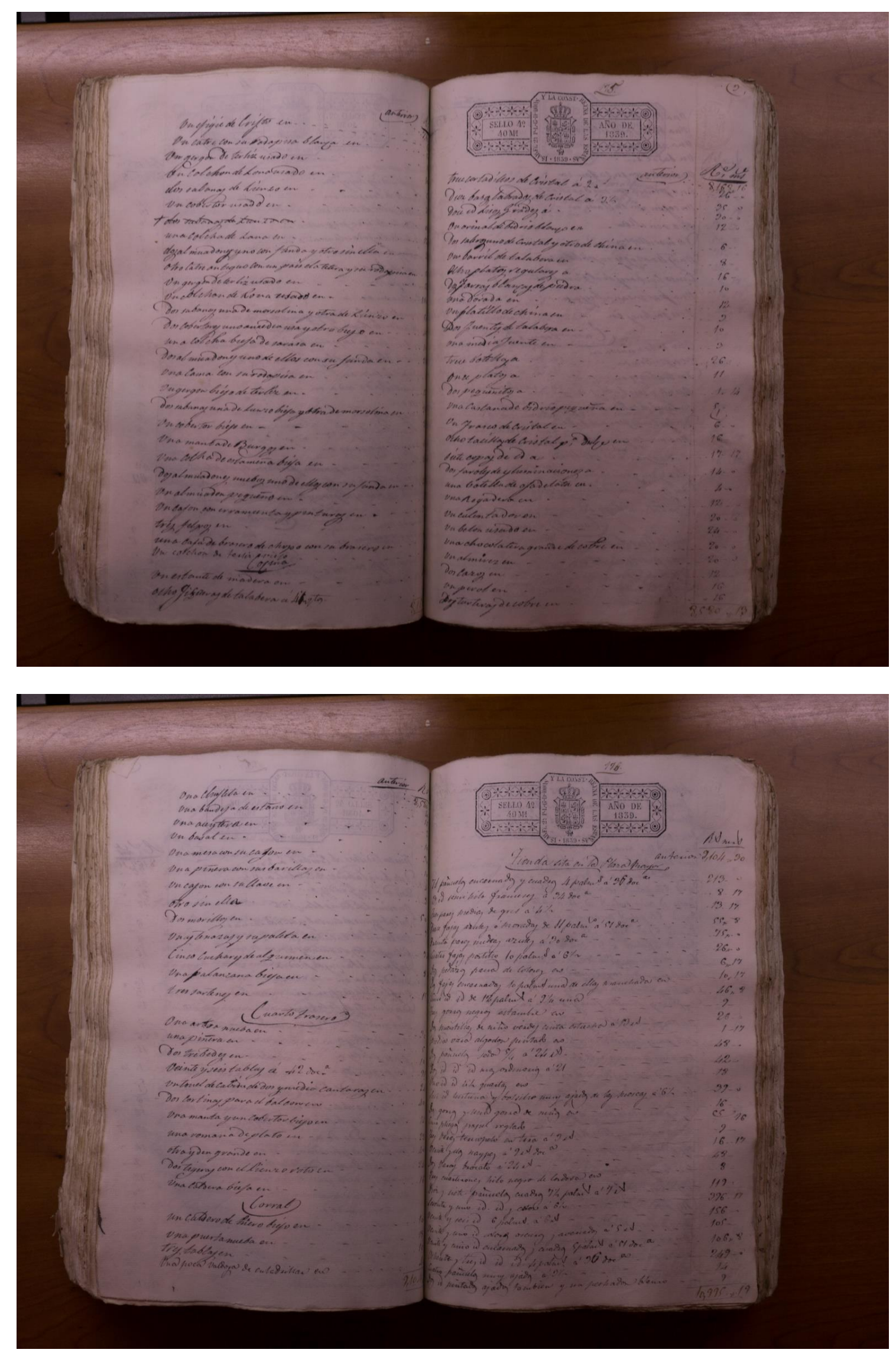

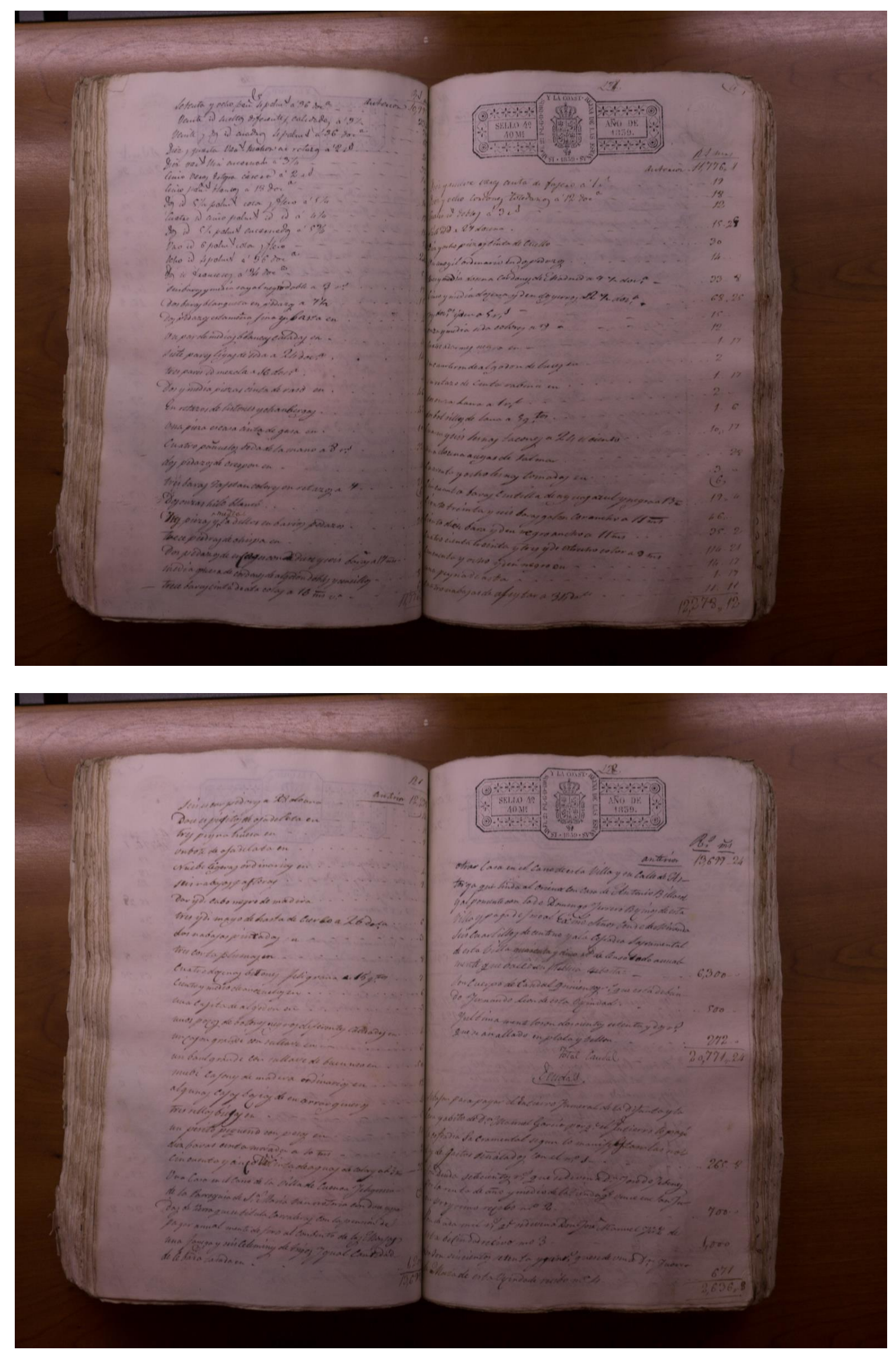

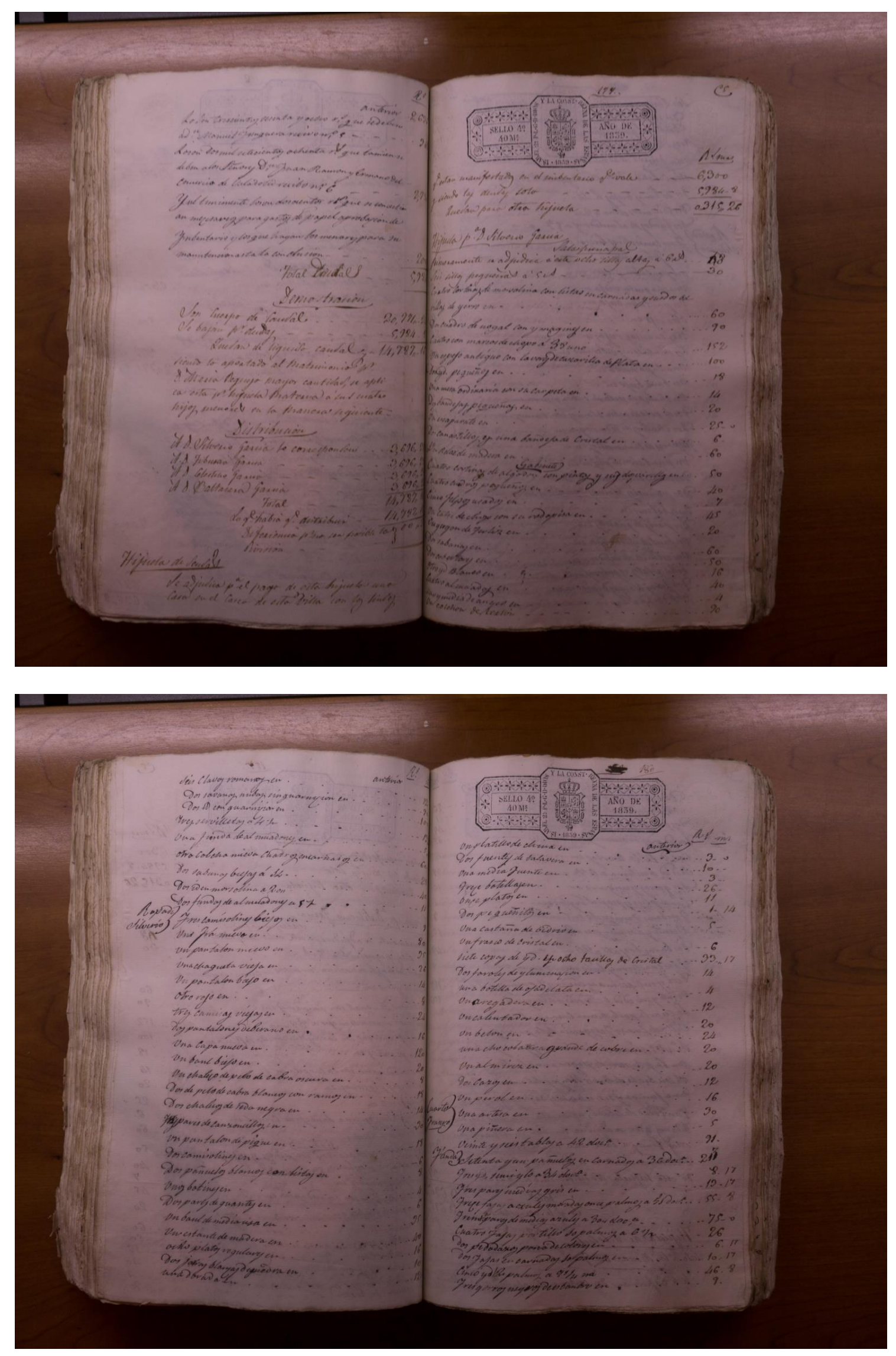

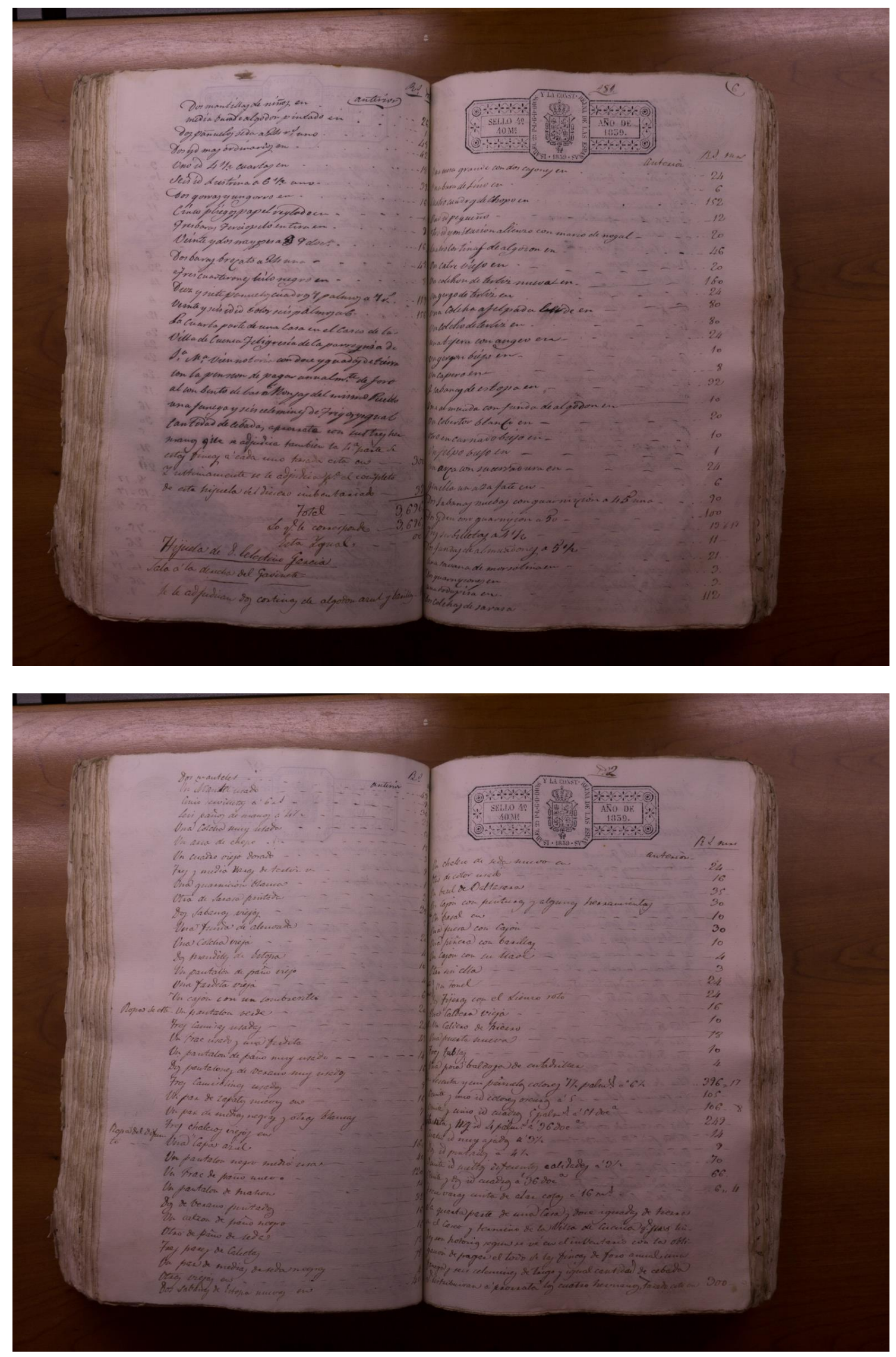

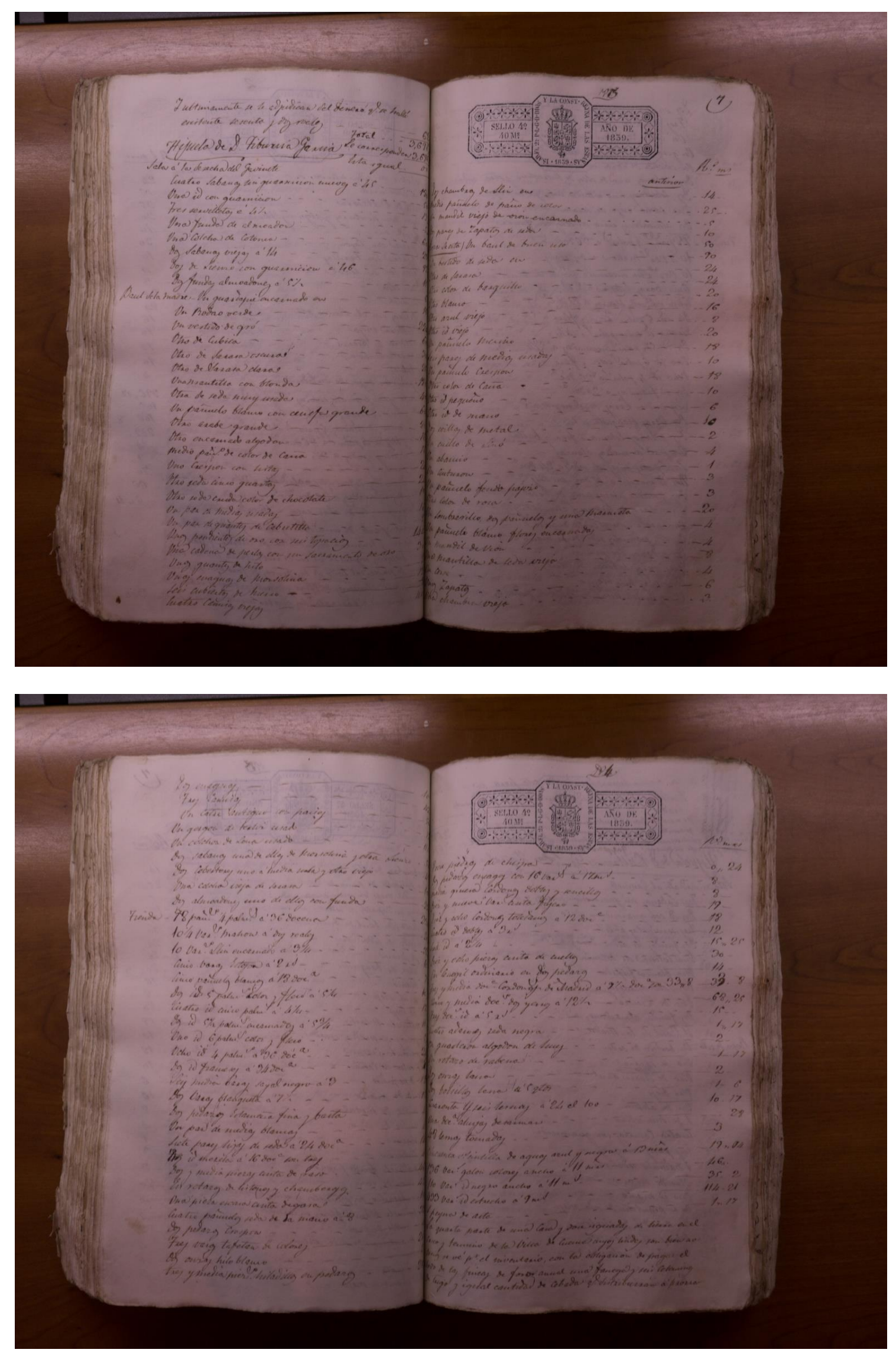

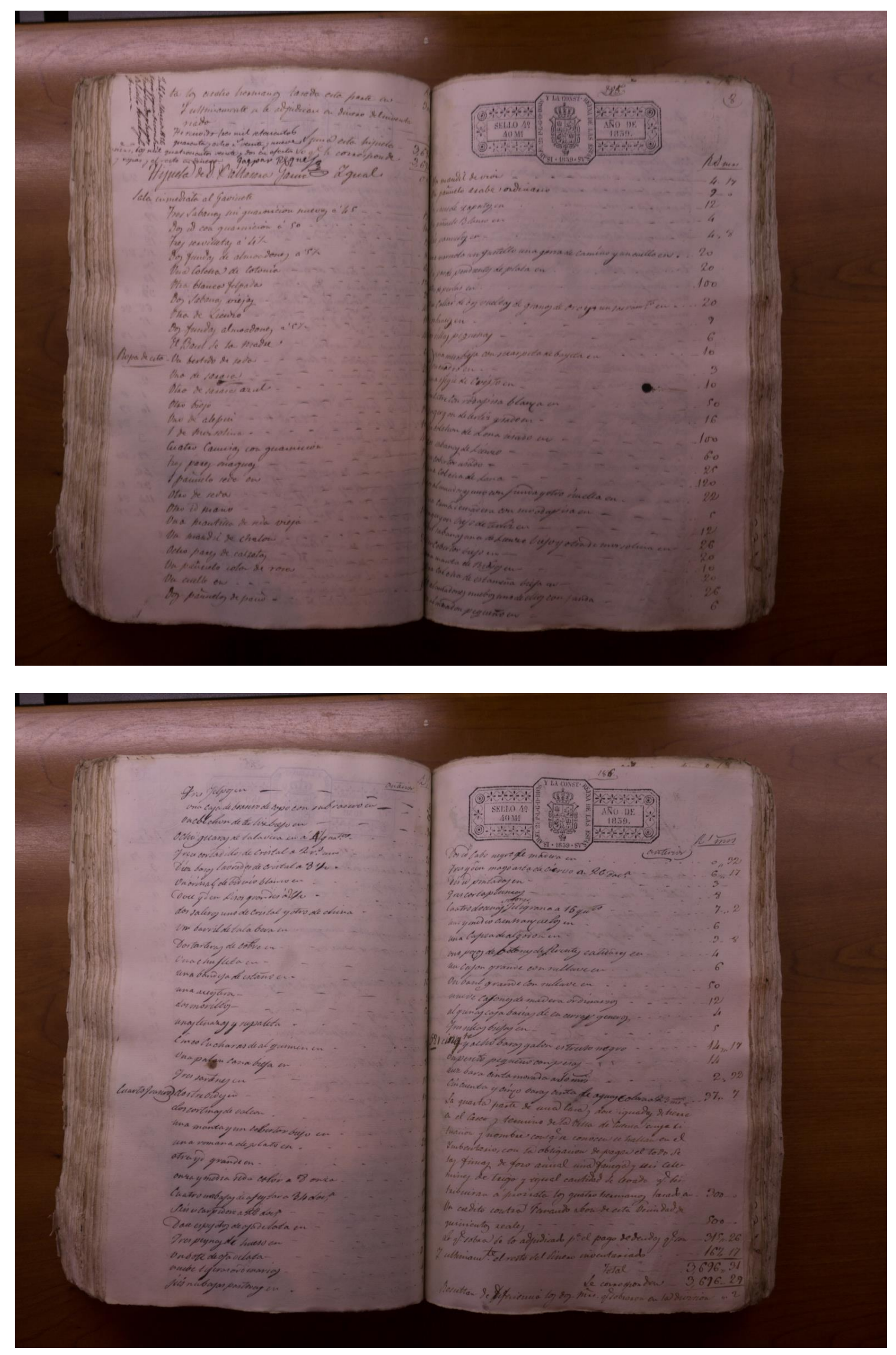


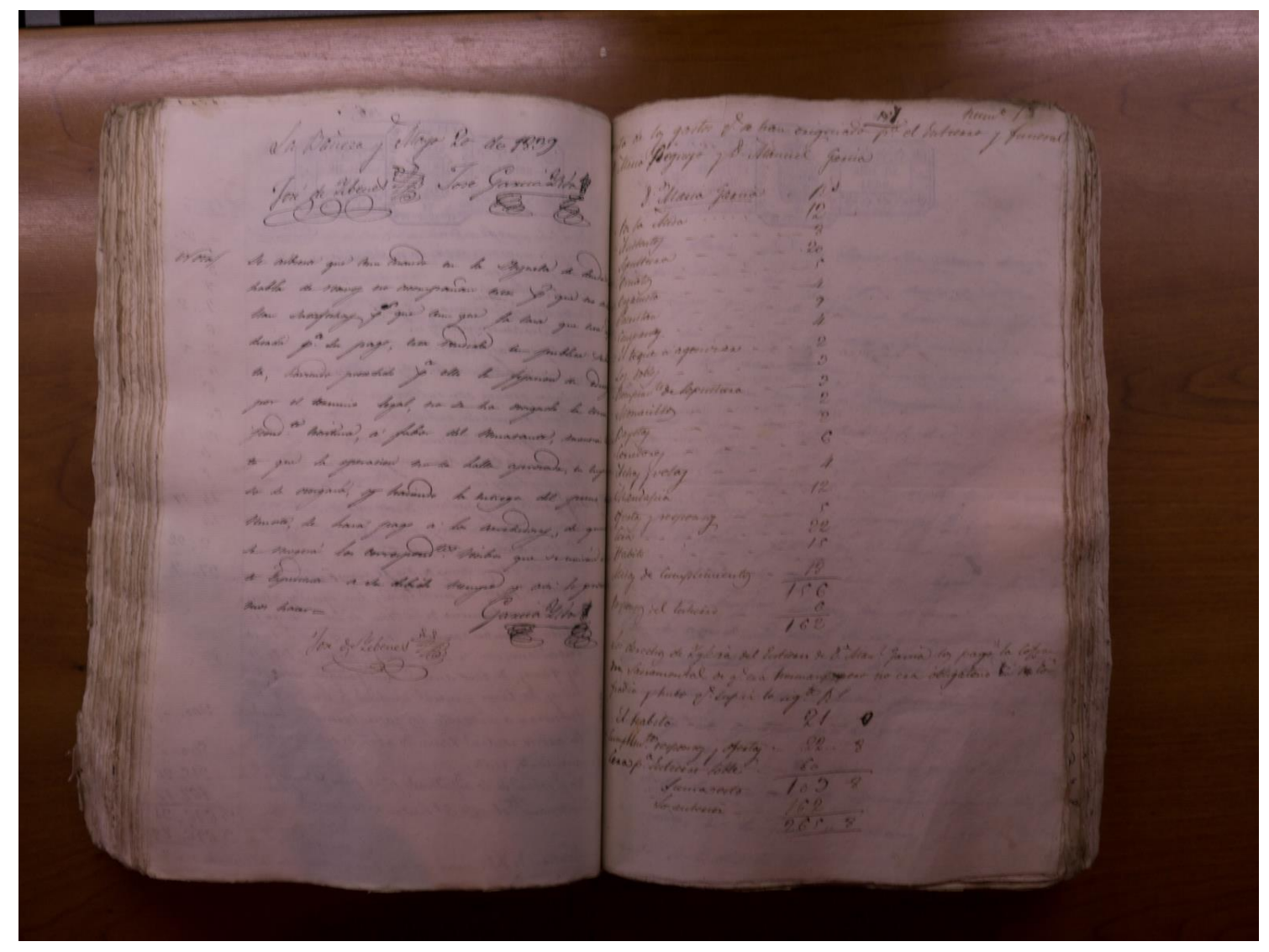

